\begin{abstract}
UNIVERSIDADE DE SÃO PAULO
FACULDADE DE FILOSOFIA, LETRAS E CIÊNCIAS HUMANAS

DEPARTAMENTO DE GEOGRAFIA

PROGRAMA DE PÓS-GRADUAÇÃO EM GEOGRAFIA HUMANA
\end{abstract}

A DIALÉTICA DA CONSTRUÇÃO DESTRUTIVA NA CONSAGRAÇÃO DO PATRIMÔNIO MUNDIAL: O CASO DE DIAMANTINA (MG)

EVERALDO BATISTA DA COSTA 


\begin{abstract}
UNIVERSIDADE DE SÃO PAULO
FACULDADE DE FILOSOFIA, LETRAS E CIÊNCIAS HUMANAS

DEPARTAMENTO DE GEOGRAFIA

PROGRAMA DE PÓS-GRADUAÇÃO EM GEOGRAFIA HUMANA
\end{abstract}

\title{
A DIALÉTICA DA CONSTRUÇÃO DESTRUTIVA NA CONSAGRAÇÃO DO PATRIMÔNIO MUNDIAL: O CASO DE DIAMANTINA (MG)
}

Dissertação apresentada ao Departamento de Geografia da Faculdade de Filosofia, Letras e Ciências Humanas da Universidade de São Paulo, para obtenção do título de Mestre em Geografia.

Área de concentração: Geografia Humana

Orientador: Prof. Dr. Francisco Capuano Scarlato 
AUTORIZO A REPRODUÇAO E DIVULGAÇÃO TOTAL OU PARCIAL DESTE TRABALHO, POR QUALQUER MEIO CONVENCINAL OU ELETRÔNICO, PARA FINS DE ESTUDO E PESQUISA, DESDE QUE CITADA A FONTE.

\section{Faculdade de Filosofia, Letras e Ciências Humanas}

Costa, Everaldo Batista da.

A dialética da construção destrutiva na consagração do Patrimônio Mundial: o caso de Diamantina (MG) / Everaldo Batista da Costa; orientador: Francisco Capuano Scarlato. São Paulo, 2009. 281 pp.

Dissertação (Mestrado - Programa de Pós-Graduação em Geografia Humana. Área de Concentração: Geografia Humana) - Faculdade de Filosofia, Letras e Ciências Humanas da Universidade de São Paulo.

1. Dialética da Construção Destrutiva. 2. Patrimônio Cultural da Humanidade. 3. Turismo.

4. Cidade Histórica. 5. Diamantina. 6. Gestão Participativa. 


\section{FOLHA DE APROVAÇÃO}

\section{Everaldo Batista da Costa}

A dialética da construção destrutiva na consagração do Patrimônio Mundial e seu papel na produção do espaço urbano em Diamantina - MG.

Dissertação apresentada ao Departamento de Geografia da Faculdade de Filosofia, Letras e Ciências Humanas da Universidade de São Paulo, para obtenção do título de Mestre em Geografia.

Aprovado em:

Banca Examinadora

Prof. Dr.

Instituição: Assinatura:

Profa. Dra.

Instituição: Assinatura:

Profa. Dra. Instituição: Assinatura: 
Dedico esta pesquisa a meu pai, Silvio (in memoriam), e a minha mãe, Isabel, com os quais aprendi, através da esperança e da perseverança, a enfrentar as dificuldades da vida.

Saudade. 


\section{AGRADECIMENTOS}

Agradeço, em primeiro lugar, a Deus, que opera, incondicionalmente, em minha vida.

Agradeço a todas as pessoas que, de alguma forma, contribuíram para a materialização desta pesquisa, em particular, deixo o mais sincero agradecimento a algumas delas, que tiveram uma importância que ultrapassou em muito o fundamental.

Ao meu orientador, Prof. Dr. Francisco Capuano Scarlato, agradeço pela grande e verdadeira amizade, pelo enorme carinho e pelos momentos alegres ao seu lado, mestre dos mais cativantes. Agradeço pela confiança depositada desde a graduação, pelo estímulo e comprometimento com a orientação desta pesquisa, agradeço pelo exemplo de dedicação às cidades históricas de Minas Gerais, as quais analisa há mais de três décadas, com os alunos da graduação da Universidade de São Paulo.

Agradeço a todos os professores que marcaram minha trajetória acadêmica, até o momento. Especialmente, à Profa. Dra. Bernadete Castro Oliveira, pela amizade, pela sensibilidade, pelo carinho, pela enorme confiança, pela disponibilidade e sugestões sempre muito pertinentes; à Profa. Dra. Amália Inés Geraiges Lemos, grande incentivadora da minha caminhada acadêmica, professora de grande estima e que também tenho como referência de uma vida dedicada à Geografia, meu muito obrigado. Ao Prof. Dr. Júlio César Suzuki, agradeço pela amizade e pelo incentivo dado para a conclusão desta pesquisa. Também agradeço, pelos diálogos sempre muito proveitosos e sugestões de leituras, aos professores: Profa. Dra. Rita de Cássia Ariza da Cruz, Prof. Dr. Antônio Carlos Robert Moraes, Prof. Dr. Mário de Biasi e Prof. Dr. José Bueno Conti.

Às funcionárias e funcionários do Departamento de Geografia da USP, da graduação e da pós-graduação, muito obrigado pela atenção e disponibilidade.

Deixo meus agradecimentos também aos funcionários das seguintes bibliotecas e arquivos: da FFLCH / USP; do IPHAN em Diamantina e em São João Del Rei (especialmente, ao caro amigo Jairo Braga Machado); do Monumenta / Diamantina; da Biblioteca Municipal de Diamantina e de São João Del Rei; da Universidade Federal dos Vales do Jequitinhonha e Mucuri (UFVJM); da Universidade Federal de São João Del Rei (UFSJ); do Instituto de Geociências da Universidade Federal de Minas Gerais (UFMG) e da Prefeitura Municipal de Diamantina. 
A todos os amigos que estiveram ao meu lado, neste momento singular de transição e de decisões que marcam, profundamente, minha história de vida, muito obrigado. Em especial, agradeço a Natália Zanetti que, com muito carinho e atenção, acompanhou-me, efetivamente, durante a elaboração desta pesquisa.

À Renata Levenstein, grande e inesquecível amiga, agradeço pelas palavras de motivação, elogios e incentivo; agradeço pela alegria contagiante com a qual me cercou no período final e mais "tenso" de elaboração da pesquisa; seu apoio foi essencial na formatação final deste trabalho.

Agradeço à colaboração direta e indireta dos colegas de pós-graduação; especialmente, ao Carlos Alberto Rizzi, pela ajuda na elaboração dos mapas temáticos apresentados nesta pesquisa e ao Jeferson Pacheco Rezende, pela disponibilidade em colaborar com os mesmos.

À Elenita Marins, agradeço pelo belo livro que me presenteou, o qual me apontou a universalidade e a genialidade das cidades históricas brasileiras consagradas como Patrimônio Cultural da Humanidade, direcionando-me para Diamantina, no norte de Minas Gerais, quando ainda idealizava esta pesquisa.

Agradeço, de forma muito especial, ao povo de Diamantina, cuja disponibilidade, hospitalidade e cordialidade, ainda não tinha presenciado, por todo estado de Minas Gerais; especialmente, agradeço à Luiza Almeida, moradora da cidade que, gentilmente, enviou-me algumas fotografias de Diamantina, enriquecendo nosso acervo construído ao longo dos trabalhos de campo. 
El movimiento dialéctico entre forma y contenido que preside el espacio, es igualmente el movimiento dialéctico del todo social, aprehendido en y a través de la realidad geográfica. Cada localización es, pues, un momento del inmenso movimiento del mundo, aprehendido em un punto geográfico, un lugar. Por eso mismo, gracias al movimiento social, cada lugar está siempre cambiando de significado: en cada intante las fracciones de la sociedad que incorpora no son las mismas.

Milton Santos

Espacio y Método 


\section{RESUMO}

COSTA, Everaldo Batista da. A dialética da construção destrutiva na consagração do Patrimônio Mundial: o caso de Diamantina (MG). Dissertação (Mestrado) - Departamento de Geografia, Faculdade de Filosofia, Letras e Ciências Humanas da Universidade de São Paulo. Orientador: Prof. Dr. Francisco Capuano Scarlato. São Paulo, 2009. 281 pp.

Esta Dissertação - cuja elaboração está focada em uma perspectiva histórico-dialética tem por objetivo analisar o processo de consagração do Patrimônio Cultural da Humanidade [UNESCO] e o Programa Monumenta [Municípios / Governo Federal / BID] a fim de identificar, em Diamantina - cidade histórica do sertão mineiro - através de uma análise crítica, como o par dialético "preservação" / mercantilização produz o espaço urbano em tela e como transforma a realidade e o imaginário do residente.

Denominamos essa contradição como dialética da construção destrutiva, que envolve os bens culturais do mundo, na contemporaneidade. Esta dialética estabelece-se no próprio percurso de consagração do Patrimônio Mundial, quando temos, por um lado, a UNESCO, que luta pela preservação inconteste dos bens culturais e naturais do mundo, em contraposição à tendência contemporânea de mercantilização, banalização e destruição dos espaços da história, da memória, da cultura, da natureza e da vida, quando da implantação de um turismo negligente com a sociedade e com o lugar. Dialética da construção destrutiva que rebate sobre o espaço urbano, a cidade histórica viva enquanto totalidade, ao ser reconhecida, simultaneamente, como símbolo de cultura e de mercadoria.

Assumimos uma postura crítica frente a simultaneidade da "preservação" e da mercantilização do patrimônio - um processo contraditório - dada a preponderância do caráter estético, fetichista, classista e de cenarização na apropriação das cidades históricas e na refuncionalização dos bens culturais, em detrimento ao seu valor de uso civilizatório. Analisamos esta realidade que se evidencia, incipientemente, em Diamantina (Patrimônio Mundial e mercadoria global), sobretudo, com a conquista da chancela da UNESCO e com a implantação do polêmico Programa Monumenta.

Veremos que a cidade histórica, ao ser tomada pela "indústria cultural" por via de um turismo descompromissado com a sociedade e com o lugar, é destituída de sua particularidade no fortalecimento do sentimento de pertencimento ao lugar e na edificação da cidadania.

Ante ao frénésie pela Lista do Patrimônio Mundial, que esboça a lógica mercantil que envolve os bens culturais, na atualidade, urge a implementação da gestão participativa dos lugares do patrimônio e o enfoque no planejamento da cidade histórica enquanto totalidade, não focado nos limites do núcleo tombado. Por fim, é no contexto da dialética entre o uso e a troca que se dá na apropriação do espaço urbano, e entre a "preservação" e a mercantilização do patrimônio cultural que direcionamos esta pesquisa, que identifica a fragmentação articulada propiciada pela dialética da construção destrutiva que impactua o território urbano de Diamantina, no sertão de Minas Gerais.

Palavras-chave: Dialética da Construção Destrutiva. Patrimônio Cultural da Humanidade. Turismo. Cidade Histórica. Diamantina. Gestão Participativa. 


\begin{abstract}
COSTA, Everaldo Batista da. The destructive dialectic of construction in consecration of the World' Heritage: the case of Diamantina (MG). Dissertation (Mestrado) - Departamento de Geografia, Faculdade de Filosofia, Letras e Ciências Humanas da Universidade de São Paulo. Orientador: Prof. Dr. Francisco Capuano Scarlato. São Paulo, 2009. XXX pp.

This dissertation - whose production is focused on a historical dialectic perspective - aims to analyze the process of consecration of the Cultural Heritage of Humanity [UNESCO] and Monumenta Program [Municipalities / Government / BID] to identify, in Diamantina historical city in Minas Gerais's backwoods - through a critical analysis, as the dialectical pair "preservation"/ merchandising produces the urban space on screen and how changes the reality and the resident imaginary.

We call this contradiction destructive dialectic of construction, which involves the cultural goods of the world, in the contemporary. This dialectic establishes itself in the path of the consecration of World Heritage, when we have, on the one hand, UNESCO, which fights for the preservation of cultural and natural world's goods, as opposed to the contemporary trend of commercialization, trivialization and destruction of space of history, memory, culture, nature and life, where the deployment of a tourism careless with society and with the place. Dialectic of destructive construction that swings on the urban space, the historic city living as a whole, to be recognized as both the symbol of culture and commodity.

We assume a critical posture in face of the simultaneity of the "preservation" and the commercialization of heritage - a contentious process - given the preponderance of the aesthetic character, fetishist, class and of giving background on ownership of historic towns and of giving refunction of cultural goods, rather than its value in civilization use. We analised this reality that there is, incipiently, in Diamantina (World Heritage and global commodity), especially with the conquest of the seal of UNESCO and with the deployment of the controversial Monumenta Program.

We will see that the historic town, when taken by the "culture industry" through a tourism uncompromised with society and the place, is devoid of its particularity in the strengthening of the feeling of belonging to place and the edifying of citizenship.

In face of the frénésie by the World's Heritage List, that outlines the commercial logic that envelops the cultural goods, in the present, urges the implementation of participatory management on places of the heritage and the approach of planning of the historical city as totality, not focused in the limits of the spot listed center. Finally, it is in the context of the dialectic between the use and exchange that occurs in the ownership of urban space, and between the "preservation" and the commercialization of cultural heritage that we directed this research, which identifies the articulated fragmentation provided by the dialectic of destructive construction that impacts the municipal area of Diamantina in the backwoods of Minas Gerais.
\end{abstract}

Keywords: Dialectic of Destructive Construction. World's Cultural Heritage. Tourism. Historical City. Diamantina. Participatory Management. 


\section{LISTA DE ILUSTRAÇÕES, GRÁFICOS, QUADROS E TABELAS}

\section{FOTOS}

Foto 01: Panorâmica da Igreja de N. Sra. do Amparo e Basílica, em Diamantina 54

Foto 02: Vista parcial do centro histórico de Ouro Preto 55

Foto 03: Santuário do Bom Jesus do Matosinhos, em Congonhas do Campo 55

Foto 04: Vista parcial da rua Direita em São João Del Rei 56

Foto 05: Rua da Câmara em Tiradentes

Foto 06: Igreja do Rosário dos Pretos, em Diamantina $\quad 109$

Foto 07: Rua Direita com três igrejas barrocas, em São João Del Rei 110

Foto 08: Foto aérea do centro histórico de Diamantina $\quad 115$

Foto 09: Alinhamento dos sobrados no Beco da Tecla, em Diamantina 124

Foto 10: Disciplina de fachadas, portas e janelas, na rua da Quitanda, em Diamantina 127

Foto 11: Rua Sto. Antônio, em São João Del Rei 128

Foto 12: Rua Direita, em Mariana $r$

Foto 13: Praça Joubert Guerra, em Diamantina $\quad 129$

Foto 14: Rua Direita, em Tiradentes $\quad 130$

Foto 15: Rua do Carmo, em rampa; traçado irregular em Diamantina 132

Foto 16: Núcleo urbano de Diamantina, na primeira metade do século XX 142

Foto 17: Núcleo urbano de Diamantina, na primeira década do século XXI 142

Foto 18: Fluxo de veículos no centro histórico de Diamantina $\quad 163$

Foto 19: Manifestação popular no centro histórico de Diamantina 169

Foto 20: Vesperata no centro histórico de Diamantina 211

Foto 21: Folia de Reis tocando para uma elite local de Diamantina 211

Foto 22: Panorâmica do centro histórico de Diamantina e seu arredor 225

Foto 23: Ocupação desordenada no Bairro Rio Grande, no entorno do centro histórico 235

Foto 24: Bairro Rio Grande, símbolo da negligência pública com o tecido urbano 236

Foto 25: Esgoto a céu aberto, no bairro Rio Grande 242

Foto 26: Descuido com o tecido urbano, no bairro Palha 243

Foto 27: Condições de vida precária, no bairro Bela Vista 243

Foto 28: Habitações precárias, entre as pedras, no bairro Rio Grande 245

Foto 29: Reivindicação popular por melhores condições de vida, no centro de Diamantina 246

\section{MAPAS E FIGURAS}

Mapa 01: Município de Diamantina $\quad 13$

Mapa 02: A geografia desigual do Patrimônio Mundial 63

Mapa 03: As Comarcas de Minas Gerais, em 1720

Mapa 04: Demarcação Diamantina, de 1731

Mapa 05: Planta de Diamantina, da primeira metade do século XVIII 122

Mapa 06: O Programa Monumenta e a "valorização do espaço" no centro histórico de 194

Diamantina

Mapa 07: A cidade histórica enquanto totalidade urbana 220

Figura 01: Localização do Município de Diamantina 12

Figura 02: Circuito dos Diamantes $\quad 169$ 


\section{GRÁFICOS}

Gráfico 01: Distribuição dos 851 Bens do Patrimônio Mundial por regiões geográficas 63

Gráfico 02: Moradores do Centro Histórico de Diamantina que já ouviram

falar no Monumenta

Gráfico 03: Moradores do Santo Inácio que já ouviram falar no Monumenta

Gráfico 04: Moradores do Rio Grande que já ouviram falar no Monumenta

Gráfico 05: Moradores do Bela Vista que já ouviram falar no Monumenta

Gráfico 06: Moradores entrevistados no centro que sabem do que se trata o IPHAN

199

Gráfico 07: Moradores entrevistados no Rio Grande que sabem do que se trata o IPHAN

Gráfico 08: População que sabe do que se trata o Monumenta

Gráfico 09: População que sabe do que se trata o IPHAN

Gráfico 10: Conhecimento da história de Diamantina entre os entrevistados

203

Gráfico 11: Entrevistados que consideram o centro histórico de Diamantina preservado

Gráfico 12: Principais festas realizadas no centro histórico, conforme os entrevistados

Gráfico 13: Problemas de infra-estrutura urbana nos bairros entrevistados

Gráfico 14: O centro histórico no imaginário da população

Gráfico 15: Movimentação de turista, em Diamantina, durante o ano, segundo residentes

\section{QUADROS}

Quadro 01: Vilas e cidades criadas, até 1720, no Brasil Colônia.

Quadro 02: Vilas criadas na zona do ouro e diamantes ao longo do Setecentos

Quadro 03: Bens de intervenção, na Área de Projeto, pelo Monumenta Diamantina

Quadro 04: Capacidade institucional das administrações municipais das cidades do Pólo

Turístico do Jequitinhonha

Quadro 05: Principais problemas urbanos identificados nos municípios do Vale do

Quadro 06: Principais problemas de esgotamento sanitário nos municípios selecionados do Pólo Turístico do Vale do Jequitinhonha

\section{TABELAS}

Tabela 01: Países com o maior número de bens do Patrimônio Mundial, até 2007 


\section{SUMÁRIO}

INTRODUÇÃO

Aporte teórico-metodológico: uma visão geográfica para a interpretação do fenômeno Métodos e técnicas da pesquisa

Os passos da pesquisa

Parte I - A consagração do Patrimônio Mundial 19

Capítulo 1.0 - A noção de Patrimônio Cultural 20

1.1. A concepção monumental do patrimônio 22

1.2. A ampliação da noção de patrimônio $\quad 25$

Capítulo 2.0 - A UNESCO e o Patrimônio Mundial: ações internacionais 37

2.1. O frénésie pela Lista do Patrimônio Mundial e as cidades brasileiras inscritas $\quad 45$

2.2. A geografia desigual do Patrimônio Mundial 60

Parte II - Diamantina. Da gênese colonial a Patrimônio Mundial 70

Capítulo 3.0 - Diamantina e as fases de produção do Patrimônio Cultural 71

brasileiro

3.1. Fase da gênese colonial do patrimônio e o urbanismo barroco 75

3.1.1 A mineração e a articulação do território colonial no século XVIII 75

3.1.2 A zona dos diamantes: um "enclave territorial" à parte 80

3.1.3 A mineração e a formação de uma rede urbana de um "tempo lento" 92

3.1.4 O urbanismo barroco das Gerais 101

3.2. Fase da produção simbólica do patrimônio 136

3.3. Fase da projeção inicial do patrimônio 144

3.4. Fase da "cenarização" progressiva do patrimônio 153

3.4.1. Diamantina: Patrimônio Mundial e mercadoria global 156

3.4.2. O Programa Monumenta e seu rebatimento sobre o território 173

3.4.3. O Programa Monumenta em Diamantina e a "valorização do espaço" 191

Parte III - Diamantina. Da valorização do espaço à 219 fragmentação articulada do território urbano

Capítulo 4.0 - A dualidade da "valorização" do centro histórico frente à "precarização" da periferia como fator de transformação da realidade e do imaginário do diamantinense: uma questão de produção socioespacial capitalística

4.1. Do imaginário do residente à urgência da gestão participativa para o 251

Patrimônio Mundial

À guisa de uma conclusão: as contradições do processo de "preservação" I "mercantilização" do patrimônio cultural como produtos da "dialética da 264 construção destrutiva"

REFERÊNCIA BIBLIOGRÁFICA 270

ANEXO $01 \quad 281$ 


\section{INTRODUÇÃO}

Inquieta-nos o entendimento de que algumas cidades históricas brasileiras estão passando por um sério processo de reapropriação estratégica de seu patrimônio cultural, enquanto materialidade de significativo valor histórico-cultural por representar as relações socioeconômicas que promoveram a conquista dos "fundos territoriais" (MORAES, 2002) e da formação do território brasileiro. Agentes públicos e privados somam forças no acelerado processo de mercantilização desse patrimônio, de forma imediatista, classista, descompromissada e não participativa, desconsiderando as diretrizes das cartas patrimoniais de preservação dos bens culturais, sobretudo, no que diz respeito ao Patrimônio Cultural da Humanidade, consagrado por meio da Convenção Relativa à Proteção do Patrimônio Mundial Cultural e Natural, adotada em 1972, pela UNESCO $^{1}$, que reconhece o valor excepcional universal dos bens culturais do mundo.

Entendendo que a refuncionalização ${ }^{2}$ do patrimônio, nas cidades históricas, o faz adquirir valor de mercado, acreditamos que pode ocorrer um descompromisso com o passado, com o lugar e com as pessoas, através da nova tendência global que estabelece a mundialização dos lugares, de todos os valores, relações e da própria cultura, transformando-a em um novo gênero de mercadoria. Essa dinâmica deve ser apreendida para além do mero olhar, mas próxima da observação pertinente e coerentemente crítica, uma vez que a gestão das cidades históricas vem ocorrendo de forma unilateral, imediatista e descompromissada pelos agentes públicos e privados, que desconsideram a importância da participação popular na tomada de decisões sobre as ações que envolvem a refuncionalização do patrimônio.

O patrimônio cultural estabelecido no espaço e refuncionalizado para novas atividades, sejam elas turísticas ou comerciais locais/regionais, representa, hoje, matéria de discussão dentro da análise geográfica das novas dinâmicas urbanas, uma vez que sua reapropriação vem atendendo às necessidades do mercado mundializado. Observamse intervenções de caráter eminentemente cenográfico, descompromissadas em revelar

\footnotetext{
${ }^{1}$ Organização das Nações Unidas para a Educação, a Ciência e a Cultura.

${ }^{2}$ Concordamos com Luchiari (2005, p. 96) ao enfatizar que a apropriação dos bens culturais vem seguindo a conduta de transformação do patrimônio cultural em mercadoria, assim como a sua refuncionalização vem servindo, agora, à ideologia do consumo e não mais às práticas culturais representativas do sentimento de pertencimento das culturas e populações locais.
} 
os reais valores histórico-culturais dos conjuntos, como é o caso do Programa Monumenta, no nosso entender. Segundo Motta (2000), aplica-se ao patrimônio cultural espacializado um desenvolvimento "sustentável", cuja apropriação criteriosa objetiva o repasse aos interesses privados.

Há a inserção do patrimônio cultural no circuito das comunicações, do consumo de massa e da "indústria" do turismo, o que favorece o enobrecimento de espaços urbanos dotados destas materialidades, pois se acentua o processo de especulação imobiliária com a chegada de novos agentes, permitindo que se estabeleçam usos específicos que tiram partido do potencial paisagístico do espaço constituído (Motta, 2000).

Concordamos com Luchiari (2005, p. 96) ao enfatizar que a apropriação dos bens culturais vem seguindo a conduta de transformação do patrimônio cultural em mercadoria, assim como a sua refuncionalização vem servindo, agora, à ideologia do consumo e não mais às práticas culturais representativas do sentimento de pertencimento das culturas e populações locais. A cidade, natureza transformada e artificializada pela ação social, acumula nos seus artefatos o tempo humano. A mudança de postura ideológica da sociedade em relação ao seu patrimônio cultural revela novos universos simbólicos que perfazem um processo contínuo de alterações de valores (LUCHIARI, 2005).

Logo, ampliando o escopo das pesquisas que tratam da mercantilização de patrimônio nas cidades históricas, de forma focada nas transformações do núcleo tombado, nos fluxos advindos da refuncionalização do patrimônio, nas novas territorialidades que se formam no centro histórico ou na revaloração dos bens culturais, apresentamos uma análise que propõe o entendimento da cidade histórica enquanto totalidade urbana, ou seja, uma cidade histórica que transcende o núcleo tombado, além de inserida em um contexto global de reprodução do capitalismo. Nesse sentido, o tema desta Dissertação é a análise do processo de consagração do Patrimônio Mundial frente à tendência fetichizante da chamada "indústria cultural", processo que denominamos dialética da construção destrutiva, que opera na totalidade do espaço urbano de Diamantina, nosso objeto empírico. É uma simultaneidade da "construção" / "desconstrução" vivenciada pela cidade, de forma mais intensa ao integrar a Lista do Patrimônio Mundial, em 1999, e da implantação do Programa Monumenta, no ano de 
2001; ou seja, nosso tema está ligado à análise crítica da mercantilização do patrimônio cultural que se dá através das novas políticas de preservação, um processo dialético que rebate sobre a organização do espaço urbano como um todo e revalora o patrimônio na cidade de Diamantina - MG (Patrimônio Mundial), transformando a realidade e o imaginário dos diferentes grupos sociais locais.

Estabelece-se, nos núcleos urbanos tombados, uma relação entre antigas formas e velhos usos, com novas formas e funções, perfazendo a interação do lugar com o mundo que o atravessa com novos costumes, mercadorias, valores, hábitos e relações; são ações que recriam a identidade do lugar e produzem um espaço social diversificado, onde, dialeticamente, o velho e o novo são fundidos, dando lugar a uma nova organização socioespacial em Diamantina, um núcleo urbano singular no bojo da "formação socioespacial" (SANTOS, 2004) brasileira.

Nesse sentido e adotando uma postura crítica, esclarecemos que o fio condutor de nossa análise reside em duas problemáticas centrais: 1) A inclusão de Diamantina na Lista do Patrimônio Mundial [UNESCO] e a posterior implantação do Programa Monumenta [Prefeitura Municipal / Governo Federal / BID] perdem o papel principal de valorização cultural, memorial e identitária para se estabelecerem como processos que têm na "valorização do espaço" (MORAES e COSTA, 1996) um adendo para a especulação econômica e imobiliária na cidade. 2) Os dois "eventos" (SANTOS, 2002, p. 143) ${ }^{3}$ supracitados redundam em uma política de patrimônio que desvia a atenção pública e recursos de problemas mais amplos, sobretudo, fora do núcleo tombado, o que vem afetando as condições de vida da população local, ressignificando "valores" e produzindo uma cidade caracterizada, dialeticamente, por uma fragmentação articulada.

Relacionado às nossas problemáticas, o objetivo geral da pesquisa é analisar o processo de consagração do Patrimônio Cultural da Humanidade [UNESCO] e o Programa Monumenta [Municípios / Governo Federal / BID] a fim de identificar, em Diamantina - MG, através de uma análise crítica, como o par dialético "preservação" I

\footnotetext{
${ }^{3}$ Consideramos o conceito de “evento” proposto por Milton Santos. Para o autor, um evento é, simultaneamente, a matriz do tempo e do espaço; um evento não se repete, são, pois, todos novos. Na verdade, os eventos mudam as coisas, transformam os objetos, dando-lhes, ali mesmo onde estão, novas características. "Os eventos são idéias e não apenas fatos. Uma inovação é um caso especial de evento, caracterizada pelo aporte a um dado ponto, no tempo e no espaço, de um dado que nele renova um modo de fazer, de organizar ou de entender a realidade”.
} 
"mercantilização" produz o espaço urbano em tela e como transforma a realidade e o imaginário do residente.

"Preservação" e mercantilização, valor de uso e valor de troca, cultura e mercadoria, dialeticamente; preserva-se, hoje, para a venda; vende-se o inalienável. É nessa dialética que buscamos entender o jogo de forças dos agentes que produzem o espaço urbano em Diamantina negligenciando a massa da população local, ao se evidenciar uma cidade dual, com um centro em vias de banalização pela "cenarização" progressiva e uma periferia em processo de intensa "precarização".

Acreditamos que a maior contribuição desta pesquisa esteja no esclarecimento que ela trás para a melhor compreensão da cidade histórica como espacialidade total formada e perpassada pela dialética da construção destrutiva que ronda os bens culturais da humanidade. Essa dialética envolve a simultaneidade contraditória da "preservação" / mercantilização regida pela operacionalização do capital sobre os territórios urbanos, o que fragmenta e pulveriza a sociedade e o lugar por sua lógica contraditória preponderante, uma vez que não são consideradas as reais necessidades e primeiros desejos da população local. A análise do caso específico poderá endossar, na Geografia, a reflexão crítica sobre as novas estratégias do planejamento urbano que se estabelece, historicamente, das elites para as elites - em que somam força o Estado e o mercado - que buscam na "valorização do espaço" a transformação da cultura em um novo gênero de mercadoria, lógica que encerra a busca da chancela da UNESCO pelos países e o polêmico Programa Monumenta.

\section{APORTE TEÓRICO-METODOLÓGICO: UMA VISÃO GEOGRÁFICA PARA INTERPRETAÇÃO DO FENÔMENO}

Nas ciências em geral e em especial nas ciências humanas, são criadas palavras e expressões para dar sentido a categorias e conceitos abstratos que passam a fazer parte do repertório apropriado para a produção do conhecimento nas mais variadas áreas. Aqui, interessa-nos a Geografia, que cria uma linguagem científica específica que vai caracterizá-la. Devemos considerar que essa criação não é desordenada ou descompromissada com os verdadeiros sentidos dos termos. Assim, reconhecendo que a 
categoria central da reflexão feita em nossa disciplina é o espaço geográfico, sua definição, no tempo atual, vai estruturar nossa discussão. Nesse sentido, delimitaremos a noção da categoria de análise "espaço" e também o conceito "território", empregados largamente pela geografia e que podem nos auxiliar a compreender as novas dinâmicas que envolvem os núcleos urbanos tombados; dinâmicas, hoje, catalisadas pela chamada "indústria cultural", enquanto processo de intensa mercantilização das formas culturais.

A escolha exata de um método fornece elementos para a elaboração de um plano de trabalho e seu encaminhamento. Segundo Moraes e Costa (1996), propicia um critério de relevância na seleção dos temas a serem abordados nas condições de repensar a geografia à luz de um parâmetro sólido, sustentado numa interpretação da realidade que transcende e engloba a própria geografia.

Como assumimos uma postura crítica, concordamos que é na dialética da negação e da assimilação, que a crítica válida é a que introduz a nova afirmação (MORAES e COSTA, 1996), onde o método fornece o próprio balizamento da discussão, pois introduz categorias que nos ajudam a compreender a realidade, no tocante às relações e às práticas sociais.

É nesse contexto que introduzimos um aporte teórico-metodológico para a compreensão das novas dinâmicas que favorecem a produção capitalista do patrimônio cultural junto aos núcleos urbanos tombados brasileiros, onde o movimento entre a categoria "espaço" e o conceito "território" permeia toda nossa análise. Logo, o aporte teórico-metodológico do qual nos valemos, que é a base de reflexão da pesquisa é, principalmente, a análise marxista desenvolvida por David Harvey e pelo geógrafo brasileiro Milton Santos em algumas de suas obras, além de trabalhos de outros estudiosos, como os geógrafos Antônio Carlos Robert Moraes e Francisco Capuano Scarlato. Além das teorias, sobretudo, desses geógrafos, os conceitos de outras disciplinas, associados às suas respectivas teorias, serão incorporados na análise e adaptados para a Geografia, a compor a explicação.

Como o patrimônio cultural, hoje, no Brasil, vem sendo transformado em um produto econômico, uma nova mercadoria que entra no circuito internacional da "indústria cultural", uma mercadoria consumida por platéias cada vez maiores, revestida por uma embalagem e um conteúdo adequados para a venda, acreditamos que a crítica à sua mercantilização deve se fundamentar em um posicionamento metodológico que 
envolva a lógica dialética dos pares opostos (uso / troca) e ("preservação" / mercantilização). A análise geográfica do processo de transformação do uso em troca, dessa maneira, obriga-nos a discorrer sobre a "produção" e "valorização do espaço" (MORAES, 2005; SANTOS, 2002), de acordo com a atual dinâmica do capitalismo. Ainda, como nossa análise é direcionada ao urbano, cabe considerar a proposta de Scarlato (2005), para quem há de se trabalhar a cidade não somente no plano de sua materialidade, mas também no da subjetividade; quer dizer, a sociedade não só produz, historicamente, formas espaciais, condições de sobrevivência, mas também reproduz, no seu imaginário, as representações simbólicas da cidade. Consideramos, assim, o fenômeno urbano numa concepção histórico-dialética, ao longo do trabalho, para, ao final, fecharmos com uma noção idealista do mesmo, através da análise do imaginário do residente sobre seu espaço de vivência, sua percepção do espaço vivido.

Dessa maneira, nossa pesquisa prevê, metodologicamente, analisar as transformações do espaço urbano - fruto de um longo processo histórico (SANTOS, 2002) - a partir do movimento dialético do uso e da troca, reconhecendo os processos de "valorização do espaço" (MORAES, 1996, 2005) que criam critérios de especialidade, singularidade, originalidade e autenticidade em Diamantina, de forma seletiva e pontual em relação à totalidade; "valorização do espaço" que coloca em evidência as contradições das ações que permeiam a sociedade contemporânea de um mundo globalizado. Assim, nossa abordagem vincula-se a uma crítica marxista, pois temos uma materialidade histórica - a cidade patrimônio cultural - envolvida pela unidade dialética indissolúvel dos opostos: "preservação" / mercantilização, que envolve os bens culturais do mundo; uma particularidade ligada às dinâmicas universais do próprio capitalismo.

Logo, sobre o método adotado nesta pesquisa, posicionamo-nos com Kosik (1976), para quem a dialética trata da "coisa em si". Mas a "coisa em si" não se manifesta imediatamente ao homem, segundo o autor. Para chegar à sua compreensão, é necessário fazer não só um certo esforço, mas também um détour. Por este motivo o pensamento dialético distingue entre representação e conceito da coisa, com isso não pretendendo apenas distinguir duas formas e dois graus e conhecimento da realidade, mas especialmente e sobretudo sobre a práxis humana. A atitude primordial e imediata do homem, em face da realidade, não é a de um abstrato sujeito cognoscente, mas de uma mente pensante que examina a realidade especulativamente, porém a de um ser que age 
objetiva e praticamente, de um indivíduo histórico que exerce a sua atividade prática no trato com a natureza e com os outros homens, buscando atender a consecução dos próprios fins e interesses dentro de um conjunto de relações sociais (KOSíK, 1976).

Assim, partimos, teoricamente, do entendimento de que a geografia humana é uma ciência social comprometida com a análise da apropriação da natureza e conseqüente produção do espaço social pelo homem. Para Moraes (2000), esse processo é passível de ser identificado num corte ontológico do real, ou seja, manifesta-se na realidade com determinações específicas, atuando como um elemento particularizador. A produção do espaço é um processo que resulta do trabalho humano, que é um ato de incorporação e criação de valor, de acordo com Moraes (2000), concluindo que a formulação categorial mais precisa para expressá-lo, na geografia, deva ser a da "valorização do espaço".

Para Smith (1976 apud Harvey, 1980, p.131), a palavra valor tem dois significados diferentes; algumas vezes expressa a utilidade de algum objeto particular, e outras, o poder de compra de outros bens que a posse daquele objeto transmite. $\mathrm{O}$ primeiro, "valor de uso", o segundo, "valor de troca". O autor esclarece que as coisas de grande valor de uso têm, freqüentemente, pequeno ou nenhum valor de troca; e ao contrário, as de grande valor de troca têm, freqüentemente, pequeno ou nenhum valor de uso. Para nós, a palavra "valor" suscita não dois, conforme referencia Smith (op. cit.), mas três significados. Consideraremos um terceiro sentido dessa palavra, o simbólico, o qual aparecerá ao longo desta pesquisa; valor simbólico que atribuímos aos objetos, algumas vezes com o sincero objetivo de preservação de nossa identidade ou da memória, outras com o objetivo de se agregar valor econômico ao objeto via avultamento do próprio valor simbólico, o que muitas das vezes acaba por metamorfosear seu real simbolismo. Demonstramos, com isso, a importância de não nos atermos a uma abordagem materialista da cidade (SCARLATO, 2005), mas tentaremos entender como a criação de um "capital simbólico" contribui para a "ultravaloração" econômica do espaço urbano, ou seja, a dialética do valor de uso e do valor de troca tem na valorização simbólica um adendo para se produzir marcos de distinção, novas mercadorias para a "indústria cultural".

Retomando nossas considerações sobre a categoria espaço, para esta pesquisa, sabendo que não encontramos uma definição única para tal categoria no âmbito 
das ciências, cabe aqui, inicialmente, frisarmos que tratamos de um espaço do homem, de um espaço social, ou seja, do espaço geográfico, que segundo Santos (2004a), deve ser considerado como um conjunto de relações sociais realizadas através de formas que se apresentam como testemunho de uma história escrita por processos do passado e do presente, ou seja, o espaço se define como um conjunto de formas que representam relações sociais do passado e atuais, e por uma estrutura representada por relações sociais que estão acontecendo "diante de nossos olhos" e que se manifestam por processos e funções. "O espaço é, então, um verdadeiro campo de forças cuja aceleração é desigual" (SANTOS, 2004, p.153).

Dessa forma, reconhecemos a categoria espaço como uma instância da sociedade, ao mesmo tempo em que a instância econômica e a instância cultural ideológica, de acordo com Santos (1986). O autor deixa claro que o espaço contém essas instâncias e essas instâncias o contém. Nos dizeres de Santos (1986, p.05),

La economia está en el espacio, así como el espacio está en la economía. Lo mismo ocure com lo político-institucional y con lo cultural-ideológico. Eso quiere decir que la esencia del espacio es social. En esse caso, el espacio no puede essar formado unicamente por las cosas, los objetos geográfico, naturales o artificiales, cuyo conjunto nos ofrece la naturaleza. El espacio es todo eso más la sociedad: cada fraccíon de la naturaleza abriga una fraccíon de la sociedad actual. (grifos nossos).

Já que a "essência do espaço é social", podemos considerar as formas espaciais como produtos históricos, trabalhados pela ação humana sobre a superfície terrestre, expressando as relações sociais que lhes deram origem (MORAES, 1996a). Para esse autor, objetos fixados ao solo exprimem a espacialidade de organizações sociopolíticas pretéritas, que se articulam sempre numa funcionalidade do presente, o que se aplica em nossa análise, ao tratarmos das novas espacialidades sociais produzidas em Diamantina, um dos significativos núcleos urbanos tombados brasileiros que ainda guarda as características de um urbanismo barroco singular da época da mineração.

Nesse sentido, o que analisamos são as relações pelas quais a sociedade se estabelece no seu espaço, ou seja, analisamos a sociedade a partir da dimensão espacial, quer dizer, identificamos a produção e o que denominamos "dialética da construção destrutiva" no espaço através das espacialidades da vida social, que em Diamantina são representadas pelo antagonismo das ações dirigidas ao centro histórico em contraposição 
aos bairros mais carentes da cidade, ações que revaloram seus bens culturais. Isso nos leva a crer que a análise geográfica da produção socioespacial de Diamantina, hoje, representa o que Milton Santos denominou para o espaço como "acumulação desigual dos tempos", onde a divisão territorial e social do trabalho continua sendo a força estruturante e organizadora de Diamantina que, no passado, representou o território dos diamantes da metrópole portuguesa, com características únicas de controle territorial, atualmente, como um novo "enclave territorial" alcançado pela "indústria cultural" por meio do turismo.

Sobre a atividade do turismo, consideramos que, em Diamantina, cumpre o importante papel de articulá-la com o mundo, considerando-o um fenômeno complexo que envolve outros fenômenos sociais, culturais e econômicos da sociedade contemporânea. Cruz (2003) deixa claro que os usos determinantes de dados territórios pelo turismo, acarretam diferentes tipos de fluxos de capitais, informações e pessoas; fluxos determinados fora do lugar, por pontes entre o local e global, que dinamizam o espaço. Silveira (1997) também considera uma nova lógica de fluxos numa nova era econômica mundial, que produz o turismo, onde novas formas de circulação dos bens, do dinheiro, das idéias, dos comandos, das modas e novas formas de consumo acabam por gerar novas formas de produção. "No período técnico-científico-informacional, as formas de consumo não-material e, entre elas, o lazer, aumentam e se disseminam no território. Esse parece ser, hoje, o contexto da produção do turismo." (SILVEIRA, 1997); contexto da atual dinâmica econômica de Diamantina, que se dá pela refuncionalização das formas do passado que integram o espaço urbano.

Formas do passado, estruturas socioespaciais pretéritas, hoje no espaço, são tratadas por Santos (2002) como "rugosidades"; forma, espaço construído ou paisagem "o que resta do processo de supressão, acumulação, superposição, com que as coisas se substituem e acumulam em todos os lugares" (p.140). Essas rugosidades podem se apresentar de maneira isolada ou em forma de arranjos, sistematizadas, constituindo o espaço geográfico; podemos dizer que elas representam ideais, valores e formas de organizações sociais, econômicas e políticas pretéritas, materializadas no espaço, ou de acordo com Santos "as rugosidades nos trazem os restos de divisões do trabalho já passadas, os restos dos tipos de capital utilizados e suas combinações técnicas e sociais com o trabalho" (2002, p.140). Essas "rugosidades" são muito bem representadas pela 
materialidade presente no centro histórico de Diamantina, enquanto patrimônio material que também carrega uma imaterialidade - ressignificado pela "indústria cultural".

Assim, entendemos que um espaço produzido historicamente, herança que condiciona a apropriação e os usos dos lugares, pode representar uma reserva de valor ao propiciar uma refuncionalização, novas relações e práticas sociais, permeadas por novos desejos e necessidades que acabam por dar continuidade histórica, formal e estrutural ao espaço, bem como a permanência da sociedade, processo que, em Diamantina, ocorre com a refuncionalização do patrimônio pela atividade turística.

É nessa perspectiva sobre o espaço e o território, baseada em uma teoria geográfica, que procuramos fazer, ao longo da pesquisa, um esforço constante de corelação entre o particular e o universal, a parte e o todo, nosso objeto empírico e o contexto total que o cerca, uma vez que para o método dialético, os fatos isolados são abstrações, são momentos artificiosamente separados do todo, os quais só quando inseridos no todo correspondente adquirem verdade e concreticidade. Do mesmo modo, o todo de que não foram diferenciados e determinados os momentos é um todo abstrato e vazio.

Logo, concordamos com Kosik (1976, p. 51-52), para quem a totalidade concreta como concepção dialético-materialista do conhecimento real significa, portanto, um processo indivisível, cujos momentos são: 1) a destruição da pseudoconcreticidade, isto é, da fetichista e aparente objetividade do fenômeno, e o conhecimento da sua autêntica objetividade; 2) em segundo lugar, conhecimento do caráter histórico do fenômeno, no qual se manifesta de modo característico a dialética do individual e do humano em geral; 3) por fim, o conhecimento do conteúdo objetivo e do significado do fenômeno, da sua função objetiva e do lugar histórico que ele ocupa no seio do corpo social. Por fim, consideramos que se não descobrirmos, por baixo da aparente objetividade do fenômeno, sua autêntica objetividade histórica, podemos confundir a pseudoconcreticidade (aparência) com a concreticidade do fenômeno (essência), tornando-nos "prisioneiros da intuição fetichista, cujo produto é a má totalidade", conforme Kosik (1976). Daí a importância da análise do processo histórico que envolve a consagração do Patrimônio Cultural da Humanidade, no qual está inserida Diamantina, para escaparmos da ilusão de realidade que nos causa a pretensa e aparente objetividade. 


\section{MÉTODOS E TÉCNICAS DA PESQUISA}

Visando o encaminhamento dessa pesquisa, buscou-se uma ampla pesquisa bibliográfica, que se estendeu por todo o processo de estudo. Uma primeira e ampla fase de pesquisa bibliográfica, leituras e confecção de fichamentos teve início mesmo antes de nosso ingresso no curso de pós-graduação, por ocasião da elaboração do projeto de pesquisa, quando já realizamos os primeiros trabalhos de campo em Diamantina.

O material coletado e apresentado nesta pesquisa sintetiza-se da seguinte forma:

1) acervo bibliográfico. Foi levantado todo o acervo bibliográfico possível, acerca de nosso tema, publicado em periódicos nacionais e internacionais, livros, dissertações, teses, dentre outros. ${ }^{4}$

2) registros fotográficos e cartográficos dos séculos $X V I I I, X I X, X X$ e atuais, que nos serviram de subsídio para traçarmos um panorama da evolução urbana de Diamantina.

3) levantamentos de campo (estado de preservação do patrimônio; dinâmica no centro histórico e realidade da periferia - comércio, turismo e principais problemáticas urbanas, em um contexto que extrapola o núcleo tombado).

\section{4) realização de entrevistas e aplicação de questionários \\ 5) elaboração de gráficos e mapas temáticos a partir dos dados colhidos em campo}

Através das pesquisas de campo realizadas, pudemos colher documentação referente à organização socioespacial pretérita e atual da cidade (Monumenta, IPHAN, Prefeitura) [mapa da Demarcação Diamantina, planta antiga do Arraial, mapa de ocupação e usos do solo atual, em arquivo]. Também conhecemos quatro dos dez Distritos de Diamantina, que a "orbitam" historicamente, como: Guinda, Mendanha, Sopa e Extração. Essa visita possibilitou-nos a observação e coleta de dados para analisar as problemáticas socioespaciais desses lugarejos e verificar as causas que configuram na centralidade de Diamantina para a região. A figura 01 e o mapa do Município de Diamantina, que se seguem, dão-nos a localização de nosso objeto empírico e dos diversos distritos

\footnotetext{
${ }^{4}$ As pesquisas foram realizadas em arquivos, bibliotecas e universidades em Diamantina - MG: Universidade Federal do Vale do Jequitinhonha e Mucuri (UFVJM), Prefeitura Municipal, Secretaria de Cultura e Turismo, IPHAN, Escritório do Projeto Monumenta e Biblioteca Municipal; São João Del Rei -MG: Universidade Federal de São João Del Rei, IPHAN, Biblioteca Municipal; Belo Horizonte: Instituto de Geociências da UFMG (Universidade Federal de Minas Gerais); São Paulo: na Biblioteca da FFLCH - USP (Universidade de São Paulo).
} 
pertencentes ao município. Diamantina, encravada no Vale do Jequitinhonha, encontra-se a 300 Km de Belo Horizonte, 750 Km do Rio de Janeiro, 890 Km de São Paulo, 730 Km de Brasília e a $1150 \mathrm{Km}$ de Salvador.

\section{LOCALIZAÇÃO DE DIAMANTINA}

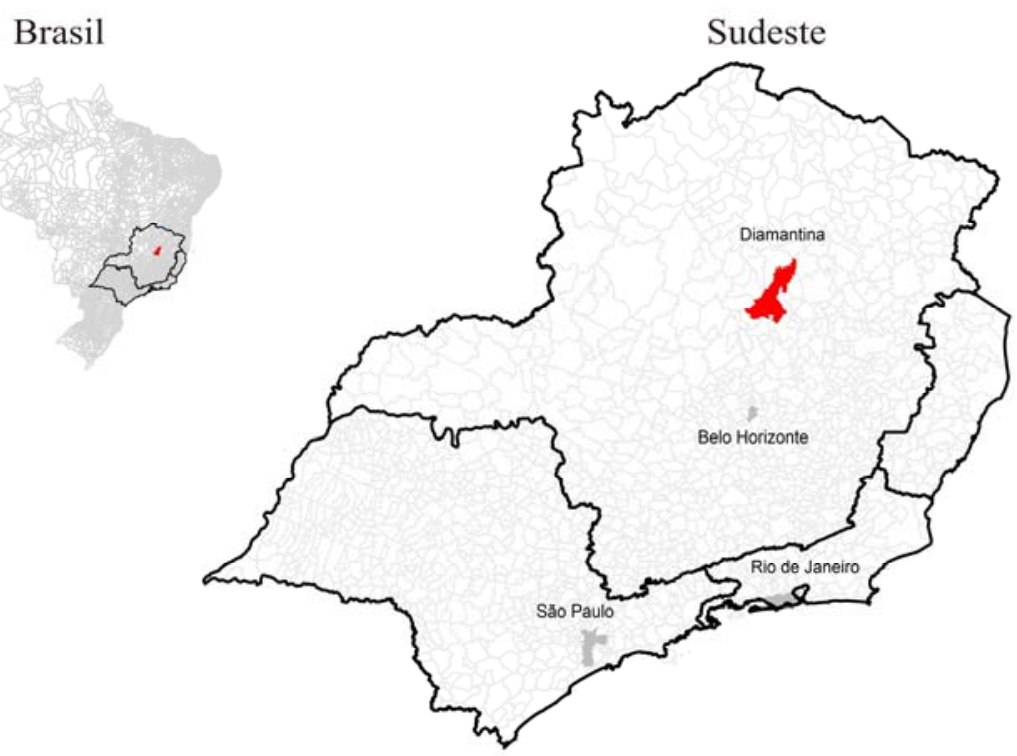

Município de Diamantina

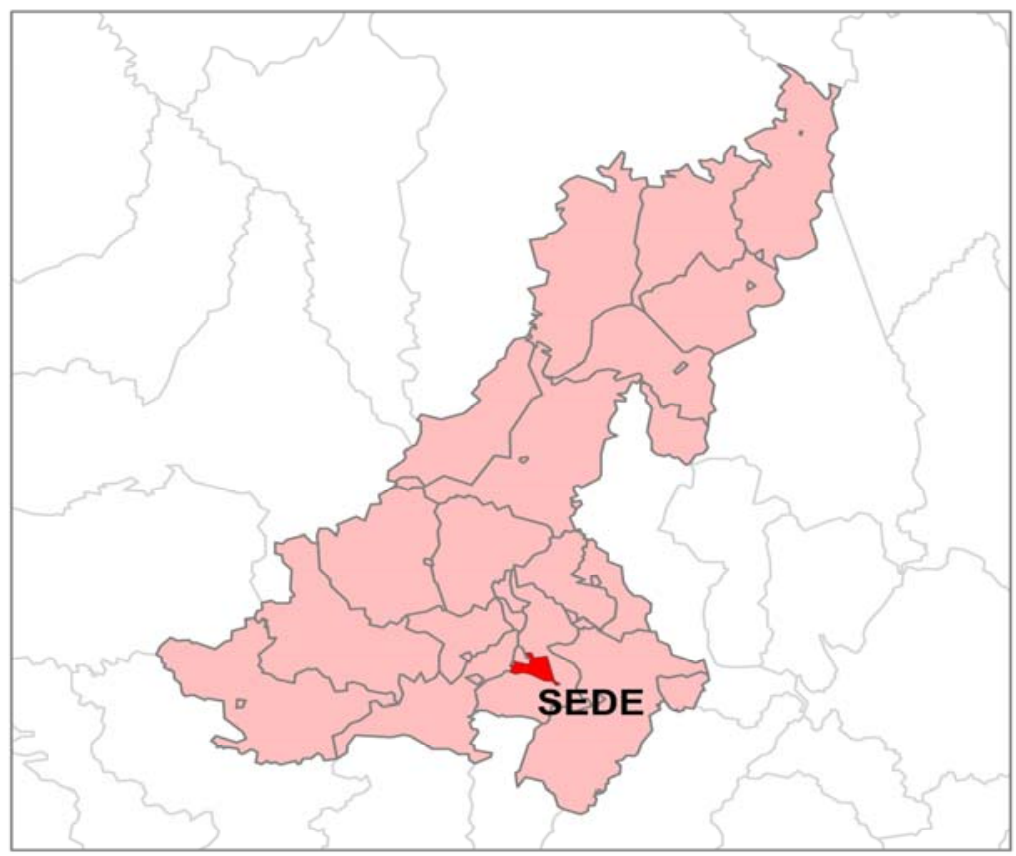

Org: Everaldo B. Costa; Carlos A. Rizzi 
MUNICÍPIO DE DIAMANTINA

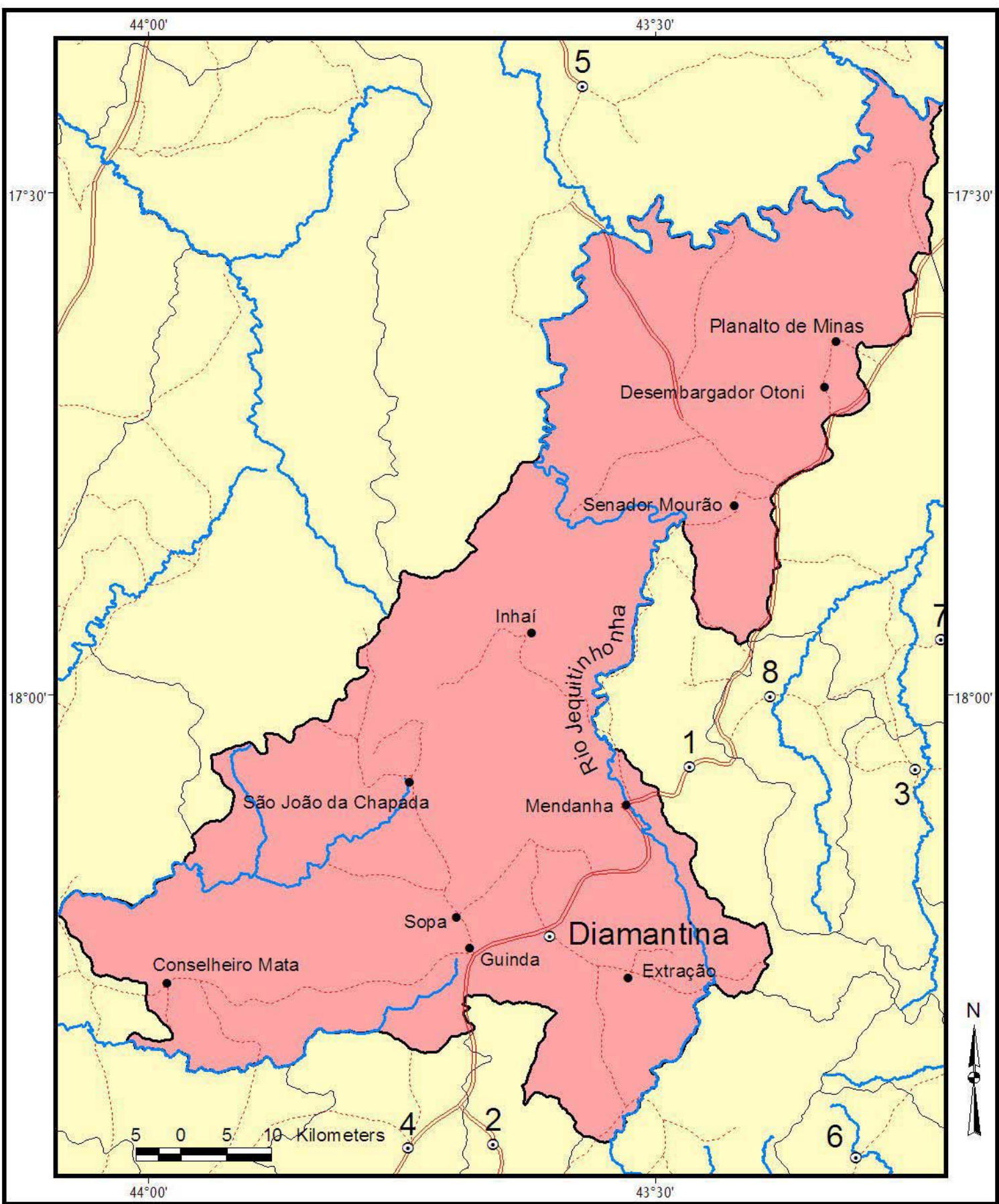

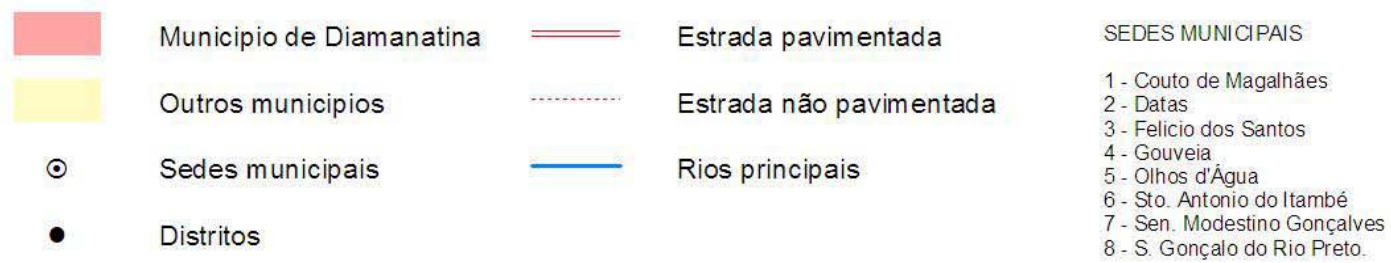

Fonte: Kelly (2006). 
O caminho trilhado para atingirmos nosso objetivo principal, ou seja, nosso percurso metodológico para compreendermos a realidade socioespacial a que nos propomos, não se encerra na articulação da pesquisa bibliográfica seguida de fichamentos, registros fotográficos / cartográficos e levantamentos de campo, mas, sobretudo, tem grande relevo em nossa pesquisa as entrevistas semi-estruturadas realizadas com agentes públicos e o questionário aplicado junto à população residente.

Para compreender, através de uma análise crítica, as contradições do processo de "preservação" / mercantilização do patrimônio cultural e seu reflexo sobre a produção socioespacial, na cidade de Diamantina (nosso objetivo de pesquisa), além da bibliografia especializada, julgamos necessário reconhecer, por um lado, as atuais ações de organização e valorização do espaço, através da pesquisa empírica e da fala dos principais agentes públicos da cidade, e por outro lado, identificar, junto à população de bairros da periferia, a realidade socioespacial vivida pelo diamantinense, através da aplicação do questionário (ANEXO 1), com uma amostragem de cento e quarenta pessoas, com abordagem a homens e mulheres acima de dezoito anos, exclusivamente residentes nos quatro bairros entrevistados.

Não nos abstemos de entrevistar apenas os residentes do Centro Histórico, julgamos pertinente ouvir moradores de outros três bairros da cidade, pois, nossa análise, não se atém à produção socioespacial do núcleo tombado, mas às conseqüências da mercantilização desse espaço central, que rebate na produção socioespacial da cidade como um todo, no nosso entender. Dessa maneira, as cento e quarenta pessoas abordadas dividem-se entre residentes do Centro Histórico, do Rio Grande, do Palha e do Bela Vista, os três últimos, bairros próximos ao centro, com evidentes problemáticas socioespaciais, bairros dos mais carentes de Diamantina. O resultado das entrevistas será representado em gráficos devidamente apresentados ao longo dos capítulos que tratam do estudo de caso, e através da citação da própria fala dos agentes públicos e da população.

Assim, nossa atitude concreta em relação ao fenômeno particular dar-se-á além do acervo bibliográfico analisado que nos possibilita compreender o processo histórico no qual se insere Diamantina enquanto Patrimônio Cultural da Humanidade com o confronto da tabulação dos dados colhidos por ocasião das entrevistas (retórica 
capitalista dos agentes públicos / clamor sublevado da população local), somados à nossa observação empírica nas pesquisas de campo. Esse procedimento pode nos oferecer uma dimensão da realidade socioespacial de Diamantina, no sertão mineiro, num momento em que esse núcleo urbano tombado é projetado mundialmente por via da "industria cultural", recriado como um "capital simbólico" excepcional e singular (HARVEY, 2005).

Princípio metodológico da investigação dialética da realidade social é o ponto de vista da totalidade concreta, que antes de tudo significa que cada fenômeno pode ser compreendido como momento do todo. Um fenômeno social é um fato histórico na medida em que é examinado como momento de um determinado todo; desempenha, portanto, uma função dupla, a única capaz de dele fazer efetivamente um fato histórico: de um lado definir a si mesmo, de outro, definir o todo; ser ao mesmo tempo produtor e produto; ser revelador e ao mesmo tempo determinado; ser revelador e ao mesmo tempo decifrar a si mesmo; conquistar o próprio significado autêntico e ao mesmo tempo conferir um sentido a algo mais. (KOSÍK, 1976, p. 40)

\section{OS PASSOS DA PESQUISA}

De acordo com Lefebvre (1975, p. 238), no mundo moderno, o exame e a análise mostram que as condições econômicas - a própria estrutura das forças produtivas industriais - criam as contradições entre grupos concorrentes, classes antagonistas, nações imperialistas etc. Logo, convêm estudar esse movimento, essa estrutura, suas exigências, com o objetivo de tentar resolver as contradições (em nossa análise a contradição entre a "preservação" e a mercantilização, que se operacionaliza simultaneamente, no processo de consagração dos bens culturais do mundo, o que denominamos dialética da construção destrutiva).

Para Lefebvre (1975), não existe, dialeticamente, a "contradição" em geral; existem contradições, cada qual com seu conteúdo concreto, com seu movimento próprio, que deve ser penetrado em suas conexões, em suas diferenças e semelhanças. Como as leis dialéticas (lei da interação universal, lei do movimento universal, lei da unidade dos contraditórios, transformação da quantidade em qualidade - lei dos saltos e lei do desenvolvimento em espiral - da superação) constituem, pura e simplesmente, uma análise do movimento, o movimento real, com efeito, implica essas diversas 
determinações: continuidade e descontinuidade; aparecimento e choque de contradições; saltos qualitativos e superação, conforme o autor.

Nesse sentido, dividimos a pesquisa em três partes, no intuito de desmantelar a pseudoconcreticidade do fenômeno que ronda as cidades históricas apropriadas pela "indústria cultural" por via do turismo, como Diamantina (onde opera sobre o território urbano a dialética da "preservação" e da mercantilização do patrimônio que busca lugares singulares e irreplicáveis para o estabelecimento de um "capital simbólico", segundo David Harvey). Contradição que forja não somente a ilusão da preservação, mas também de um futuro promissor para a coletividade, quando, em verdade, tem-se uma corrida particular em busca de benesses para uma classe determinada, onde o resultado é a precarização do território urbano e da situação de vida de pessoas menos esclarecidas e menos favorecidas social e espacialmente.

Na Parte I - A consagração do Patrimônio Mundial, que está dividida em dois capítulos e seus respectivos subcapítulos, apresentamos o contexto internacional e totalizador do qual Diamantina é parte integrante. Trata-se da consagração do Patrimônio Cultural da Humanidade partindo do processo histórico de ampliação da noção de patrimônio e dos significados atribuídos a essa materialidade ao longo do tempo, nas cidades, até se tornar uma mercadoria mundial (des)localizada. São relevantes para esse entendimento os seguintes documentos: Carta de Atenas (1931) Carta de Veneza (1964), a Carta de Quito (1967), a Convenção do Patrimônio Mundial (1972), a Declaração de Amsterdã (1975), a Recomendação de Nairóbi (1976) e o Memorando de Viena (2005). Busca-se, nesta primeira parte da pesquisa, compreender a idéia universal de patrimônio cultural, coroado pela conquista do título de Patrimônio Cultural da Humanidade, pelas cidades históricas espalhadas pelo mundo, caso de Diamantina, uma das oito cidades brasileiras intituladas Patrimônio Cultual da Humanidade. Será discutido o frénésie pela chancela da UNESCO, por parte dos países, esboçando uma geografia desigual do Patrimônio Mundial, ou seja, uma distribuição desequilibrada de cidades inscritas na Lista do Patrimônio Mundial, pelas distintas regiões geográficas do globo. Essa corrida caracteriza a dialética da construção destrutiva na consagração desse patrimônio, num contexto amplo de reprodução do capitalismo, em que a tentativa de inserção dos lugares no circuito do turismo internacional catalisa o processo. 
A Parte II - Diamantina. Da gênese colonial a Patrimônio Mundial, apresenta quatro fases consecutivas e distintas de produção do patrimônio no Brasil, as quais denominamos: gênese colonial do patrimônio, produção simbólica do patrimônio, projeção inicial do patrimônio e cenarização progressiva do patrimônio; para cada fase destinamos um subcapítulo. Essa parte discute a consagração do patrimônio, no Brasil, da gênese do urbanismo barroco no hinterland da Colônia à "cenarização" progressiva que cerca essa materialidade em nome do desenvolvimento do turismo, que representa um longo processo de valorização do espaço vinculado às práticas de patrimônio que se dão no plano internacional, ou seja, a dialética da construção destrutiva que envolve os bens culturais do mundo. Logo, a segunda parte da pesquisa torna-se fundamental para o entendimento da produção do patrimônio no Brasil e, em especial, facilita a compreensão da lógica que envolve Diamantina como Patrimônio Mundial e mercadoria global, dialeticamente. O último subcapítulo da segunda parte, denominado Fase da "cenarização" progressiva do patrimônio amarra a análise ao discutir, criticamente, o polêmico Programa Monumenta enquanto resultado do longo processo de produção e mercantilização de patrimônio, no Brasil.

\section{A Parte III - Diamantina. Da valorização do espaço à fragmentação} articulada do território urbano, a última da pesquisa, amarra nosso objetivo geral e dá resposta ao nosso problema, onde buscamos entender como a "preservação" de patrimônio cultural reflete na organização socioespacial de Diamantina, entendida como uma cidade histórica em sua totalidade. Por meio de uma abordagem crítica, busca-se entender a dualidade da "valorização" do centro histórico frente à "precarização" da periferia que transforma a realidade e o imaginário do diamantinense: uma questão de produção socioespacial capitalística. Verifica-se como o par dialético "preservação" I mercantilização favorece a produção de um território urbano dividido quando as ações do poder público voltam-se para o centro da cidade e negligenciam o processo de "precarização" vigente e ascendente na periferia, de acordo com nossa análise dos bairros Palha, Rio Grande e Bela Vista. Ao focar a cidade histórica enquanto totalidade urbana, essa parte da pesquisa discute um planejamento que não chega à periferia, que é feito das elites para as elites; apresenta um modelo segregacionista de planejamento urbano, quando deveria se constituir em um potencial instrumento de melhoria da qualidade de vida de toda população diamantinense. Logo, lançamos um olhar geográfico sobre 
Diamantina reconhecendo a dialética da fragmentação articulada instaurada no território urbano, pois a especulação do centro histórico parece estar dependendo da "precarização" da periferia; mesmo constituindo-se o centro em um lugar primaz na vida de todo diamantinense, a análise de seu imaginário aponta para a transformação dos significados que esse espaço para a população. No limite, essa análise fecha o que denominamos dialética da construção destrutiva na consagração do Patrimônio Mundial (simultaneamente, símbolo de cultura e de mercadoria; cultura urbana enquanto valor de uso civilizatório que é minimizada pela mercantilização que a recria e a maximiza como valor de troca), baseado na leitura de David Harvey, Milton Santos e Antônio Carlos Robert Moraes, principalmente, que nos legam uma crítica marxista que apresenta com propriedade e coerência a idéia de um desenvolvimento desigual e combinado da sociedade, argumentando que o capital constrói, destrói e reconstrói os lugares à sua lógica e semelhança. 


\section{PARTE I}

A consagração internacional do Patrimônio Mundial 


\section{Capítulo 1.0 - A noção de Patrimônio Cultural}

Bens culturais, patrimônio material e imaterial, objetos de culto tangíveis e intangíveis. Integrantes da cultura erudita e popular, material e imaterial, importa-nos entender que os bens culturais são social e historicamente produzidos e apropriados pelos homens, que Ihes dão forma, conteúdo, função e sentidos diversos, de acordo com as épocas e as necessidades do instante passageiro. O reconhecimento das formas de apropriação dos bens culturais é fundamental para se conhecer as operações humanas sobre o meio natural, o ambiente construído e para o entendimento da organização dos homens entre si; ou seja, a análise da apropriação da natureza ou dos objetos pretéritos ajuda-nos a compreender os momentos distintos da produção e "valorização do espaço" (MORAES e COSTA, 1996; MORAES, 2000), de acordo com cada momento histórico.

Segundo Meneses (1986), o estudo dos bens culturais precisa ir além do nível da corporeidade dos objetos. A cultura material ou imaterial, os artefatos ou as manifestações precisam ser entendidos como produtos e vetores de relações sociais; para o autor, a significação dos artefatos é oriunda de sua condição de trazerem embutidas propriedades que decorrem das formas segundo as quais os homens se organizam em sociedade, produzindo seus espaços, historicamente.

A palavra patrimônio é empregada com certa freqüência, no cotidiano. Choay (2006) esclarece que essa bela e antiga palavra estava, na origem, ligada às estruturas familiares, econômicas e jurídicas de uma sociedade estável, enraizada no espaço e no tempo, sendo requalificada, na atualidade, por diversos adjetivos (genético, natural, histórico, cultural etc.) que fizeram dela um conceito "nômade", seguindo, hoje, uma trajetória distinta e retumbante. Entretanto, tornou-se relevante, no âmbito das ciências humanas, a construção desse termo enquanto categoria de pensamento: "patrimônio" cultural, arquitetônico, histórico, artístico, natural e imaterial; além da recente consagração do chamado Patrimônio Cultural da Humanidade ou Patrimônio Mundial, considerado nesta pesquisa.

A categoria "patrimônio", tal como é concebida, na atualidade, nem sempre conheceu fronteiras bem delimitadas. Na concepção de Gonçalves (2003), a noção de patrimônio confunde-se com a de propriedade, apesar de, hoje, estar ligada a bens de natureza ideológica, moral, religiosa, política, jurídica, estética, psicológica e inclusive 
natural; são distintos valores atribuídos ao ambiente, aos objetos e às práticas sociais que, no limite, simbolizam a apropriação da natureza, a espacialização da sociedade ou a organização de espaços urbanos, ao longo da história.

Logo, por abranger a questão da produção do espaço, sobretudo, o urbano tanto pretérito quanto contemporâneo, e por ser envolvido pelo que consideramos uma dialética da construção destrutiva que pasteuriza a sociedade e o lugar por enredar simultaneamente "preservação" e "mercantilização" contraditoriamente, julgamos pertinente tratar da consagração do Patrimônio Mundial partindo do processo histórico de ampliação da noção de patrimônio e dos significados atribuídos a essa materialidade ao longo do tempo, nas cidades, até se tornar uma mercadoria mundial (des)localizada.

Quanto à dialética "preservação" x "mercantilização", que envolve "construção" x "desconstrução" e "uso" x "troca", que se operacionaliza nessa consagração, a qual analisaremos ao longo da pesquisa, veremos que se dá no movimento entre a tentativa de resgate, democratização, preservação e valorização dos bens culturais, no caso do Patrimônio Cultural da Humanidade, dirigido pela UNESCO, e a intensa mercantilização dos núcleos urbanos tombados, catalisada pela "indústria cultural" por via do turismo. A análise visa a entender Diamantina (Patrimônio Mundial) inserida na totalidade-mundo, onde a "indústria cultural" - através da atividade turística - contém e está contida em tal totalidade que rebate sobre o território urbano.

Martins (2006) chama-nos atenção para a importância de se caracterizar a relação singular-particular-universal no âmbito da investigação científica, afirmando-a como requisito para a compreensão do objeto em suas múltiplas relações e, acima de tudo, para superação de falsas dicotomias (do tipo indivíduo-sociedade), muito presente nas ciências humanas. De acordo com Martins (2006, p. 12), se preterida a função mediadora da particularidade, as relações acabam sendo consideradas na "centralidade de pólos aparentemente dicotômicos, perdendo-se de vista as formas pela qual ocorre a concretização da universalidade no vir-a-ser da singularidade, mediada pela particularidade".

Daí nossa análise inicial do processo histórico de consagração internacional do Patrimônio Mundial (universalidade), no qual Diamantina é inserida. 


\subsection{A concepção monumental do patrimônio}

Palavra de origem latina, "patrimoniun" significava entre os antigos romanos "tudo o que pertencia ao pai, 'pater' ou 'pater familia', pai de família" (FUNARI e PELEGRINI, 2006). Esse sentido de pertencimento mantem-se; o patrimônio continua sendo aquilo que pertence a alguém, individual ou coletivamente; entretanto, devemos considerar, na análise, o pertencimento ao grupo, à coletividade, à nação ou à humanidade, na construção identitária do país ou na configuração estrutural dos mais diversos espaços (COSTA, 2007). Contudo, nem sempre as materialidades antigas, símbolos de organização socioespacial pretérita que subsistem ao tempo, foram concebidas como patrimônio, patrimônio histórico ou, para usar o conceito mais recente, patrimônio cultural.

Daí buscarmos, de forma objetiva, a origem da noção de patrimônio. Vejamos, primeiramente, a idéia de monumento histórico. Sant'anna (2003) considera que o monumento histórico vincula-se a um saber e a uma sensibilidade que se enraízam no presente com vistas no passado. No Renascimento, essa idéia reportava-se aos edifícios da Antiguidade Clássica, vistos como exemplos de modelo de arte que deveria ser documentado mais para se conhecer e admirar, menos para se preservar, naquele momento. Assim, a noção de monumento estava ligada à contemplação da arte e da arquitetura sem a devida preocupação quanto à preservação. ${ }^{5}$

A seleção dos monumentos que, no Renascimento ${ }^{6}$, recaía sobre os objetos da Antiguidade Clássica, valorizando sistemas construtivos e estilos arquitetônicos greco-

\footnotetext{
${ }^{5}$ Le Goff (2003) nos dá indicações de que a memória coletiva aplica-se diretamente ao monumento como material; julga como principal característica do monumento o ligar-se ao poder de perpetuação, voluntária ou involuntária, das sociedades históricas - um legado à memória coletiva. "A palavra latina monumentum remete à raiz indo-européia men, que exprime uma das funções essenciais do espírito (mens), a memória (menimi). O verbo monere significa "fazer recordar”, de onde "avisar", "iluminar", "instruir”. O monumentum é um sinal do passado. Atendendo a suas origens filológicas, o monumento é tudo aquilo que pode evocar o passado, perpetuar a recordação (...) Mas, desde a Antiguidade romana, o monumentum tende a especializar-se em dois sentidos: 1) uma obra comemorativa de arquitetura ou de escultura: arco do triunfo, coluna, troféu, pórtico etc.; 2) um monumento funerário destinado a perpetuar a recordação de uma pessoa no domínio em que a memória é particularmente valorizada: a morte. O monumento tem como característica o ligar-se ao poder de perpetuação, voluntária ou involuntária, das sociedades históricas (é um legado à memória coletiva)” (LE GOFF, 2003, p. 526).

${ }^{6}$ Choay (2006, p.31) esclarece-nos que o nascimento do monumento se dá em Roma, por volta do ano 1420, quando um novo clima intelectual se desenvolve em torno das ruínas antigas, "que doravante falam da história e confirmam o passado fabuloso de Roma (...) Ver-se-á que o interesse intelectual e artístico atribuído por uma pequena elite do Quattrocento aos monumentos da Antiguidade era produto de uma longa maturação e tivera precedentes desde o último quartel do século XIV”.
} 
romanos admiráveis, se estende, após a Revolução Francesa, a edifícios do passado Medieval, quando se passa a valorizar obras de arte que testemunhavam o saber humano e processo histórico, obras que deveriam ser, então, preservadas. Nesse sentido, Sant'anna (2003) considera que, na França pós-revolucionária, os monumentos históricos estavam mais ligados ao campo da representação, sendo preservados com fins políticos para se unir grupos social e culturalmente heterogêneos, forjando uma identidade com vista a um projeto de nação ${ }^{7}$; política patrimonial que se estende, no início do século XX, ao Brasil, como veremos no terceiro capítulo desta pesquisa.

Entretanto, na França, berço do conceito "patrimônio", do final do século XIX aos dias de hoje, pouco a pouco, sua apreensão e significado evoluíram, passando da idéia de monumento histórico (isolado), para a preocupação com o tecido urbano, com o centro histórico das cidades, surgindo, assim, o conceito de patrimônio ambiental urbano, na atualidade, de acordo com Scifoni (2003). Isso nos indica que, apesar do termo "monumento" ainda ser empregado por muitos estudiosos, não podemos considerá-lo sinônimo de patrimônio cultural, nem conceitos formulados numa mesma época, "os monumentos históricos já não representam senão parte de uma herança que não pára de crescer com a inclusão de novos tipos de bens e com o alargamento do quadro cronológico e as áreas geográficas no interior das quais esses bens se inscrevem" (CHOAY, 2006, p. 12).

É sob a égide do ideário iluminista, durante a consolidação das grandes nações européias, que se fortifica a noção de patrimônio, quando a concepção de nação ainda se encontrava atrelada à idéia de posse de um território e também de uma cultura (e, conseqüentemente, dos seus bens representativos), como nos aponta Nigro (2001).

Em plena Revolução Francesa, em meio às violências e lutas civis, criava-se uma comissão encarregada da preservação dos monumentos nacionais ${ }^{9}$, com o objetivo

\footnotetext{
7“A expressão 'monumento histórico’ é assinalada em 1790 para designar tudo o que podia ilustrar a história nacional, arquitetural, estátuas e vitrais (...) e, de fato, algumas operações confirmam que o sentimento patrimonial aparece no fim do Antigo Regime.” (MOHEN, 1999, p. 279-280, tradução nossa).

8 “A denominação monumento, atualmente, é pouco utilizada, exceção feita aos bens já classificados no passado ou, para usar o termo, familiar entre nós, tombados. Essa denominação pode, também, induzir a pensarmos em escala de grandeza: seriam sempre artefatos gigantescos diante dos quais sentiríamos, ao contemplá-los, uma sensação de atordoamento, de pequenez ameaçada de esmagamento. Ora, existe uma coisa e outra. Ou seja, ao lado de conjuntos imponentes e monumentais, há peças pequenas, de proporções modestas.” (CAMARGO, 2002, p. 27).

${ }^{9}$ Segundo Choay (2006), quando se cria, na França, a primeira Comissão dos Monumentos Históricos, em 1837, as três grandes categorias dos bens eram constituídas pelos remanescentes da Antiguidade, os edifícios religiosos da Idade Média e alguns castelos. Há de se entender que foram as condições criadas pela Revolução Francesa que estabeleceram
} 
de proteger os bens que representavam a incipiente nação francesa e sua cultura (FUNARI e PELEGRINI, 2006). Esses autores apontam que a legislação protetora do patrimônio nacional francês tardaria ainda algumas décadas, pois a primeira lei data do fim do século XIX, tendo sido contemplada por uma legislação mais ampla no início do século $X X$. As disposições legais, na França, limitavam os direitos de propriedade privada, em benefício do patrimônio nacional, trajetória seguida por outros países, como o Brasil através do tombamento, conforme veremos no terceiro capítulo, com mais detalhes.

O patrimônio, naquele momento, passa a ser entendido como um bem material concreto; são edifícios, castelos, igrejas, objetos de alto valor material e simbólico para a nação (FUNARI e PELEGRINI, 2006). Isso indica que os valores passariam a ser compartilhados por todos, seriam comuns e se consubstanciariam em coisas concretas. Os bens determinados como patrimônio passam a ser os que simbolizam excepcionalidades, raridades e história viva, representantes da trajetória da nação em construção. São criadas, além das novas legislações que envolvem o patrimônio em âmbito francês, serviços de proteção ou instituições patrimoniais, formando uma administração patrimonial, no decorrer do século XIX, na França.

Mohen (1999) ao analisar L'aparition de la notion de patrimoine, faz uma crítica severa ao fato de os monumentos a serem preservados se resumirem a edifícios, estátuas, vitrais e vários outros objetos excepcionais que ilustravam e precisavam a história nacional, num contexto delimitado, na França revolucionária. Para o autor, desde aquele momento, deveria ter se pensado o sentido patrimonial num contexto mais amplo, de forma a reagrupar os fatos de civilizações e não somente os da história nacional. Contudo, há de se considerar que a formulação administrativa da noção de patrimônio progride lentamente e só teremos uma concepção de patrimônio representativo da humanidade, em meados do século $X X$, como veremos no item que se segue.

a necessidade da proteção legal dos bens materiais. Para Mayume (1999, apud Scifoni, 2003, p.3) como conseqüência da revolução, os bens confiscados da igreja, da coroa e da aristocracia passaram ao domínio do Estado. A conservação desses bens passa a ser um problema nacional, criando a necessidade de uma colaboração de toda a sociedade, forjando a idéia de um valor de nacionalidade, patrimônio coletivo, de interesse de todos. 
No entanto, é sobre o bem isolado, local, representante da construção de uma nacionalidade, que se canalizam os primeiros esforços em favor da preservação do patrimônio - hoje em dia tratado como patrimônio cultural ${ }^{10}$.

Pretendemos, neste item, deixar mostra de que a noção de patrimônio, como é entendida hoje, evoluiu lenta e gradualmente; parte da idéia de monumento enquanto objeto isolado a ser contemplado e preservado, até a concepção mais recente, que cobre de maneira complexa diversos bens, todos os tesouros do passado, materiais e imateriais. Fica claro, dessa maneira, que a expressão patrimônio cultural, enquanto conjunto do que é transmitido consciente e inconscientemente pelos homens, depois de seu aparecimento sobre a Terra, tem sua origem dans le Siècle des lumières, adquirindo força jurídica durante o XIXe siècle, enquanto patrimônios nacionais "criados" paralelamente à "construção" das nacionalidades de vários países europeus, "légitiment l'identité de ces pays et en symbolisent la richesse, l'originalité et la beuté." (MOHEN, 1999, p. 38).

\subsection{A ampliação da noção de patrimônio}

O processo de "monumentalização" que se dá através da tomada de elementos da paisagem, transforma-os em fetiches, objetos sacralizados, dotados de valores próprios como se fossem autônomos, imutáveis; independentes, também, do próprio contexto ambiental em que se inserem. De acordo com Meneses (1996, p.50), "o monumento é sempre algo que seu entorno não é". Dessa forma, ao se destacar, o monumento assume, isoladamente, significados dispersos no espaço do qual faz parte. É nesse sentido que entendemos como problemática a Carta de Atenas, no tocante à sua proposta de preservação do bem isolado.

Segundo Nigro (2001), a Carta de Atenas, de 1931, seguindo preceitos urbanísticos modernos, constitui o primeiro documento significativo que destaca a necessidade de se salvar monumentos de sua destruição. Contudo, elaborada no entre

\footnotetext{
10 Estabelecendo uma noção mais ampla do patrimônio histórico, as reavaliações dos conceitos e práticas preservacionistas colocaram em voga o uso do conceito de patrimônio cultural, dada a abrangência do que passa a ser considerado como cultural, nos dias de hoje.
} 
guerras $^{11}$, período de grande preocupação com os conflitos bélicos e com o rápido crescimento urbano, a Carta de Atenas apresenta um conceito de patrimônio extremamente restritivo e seletivo, ao tratar o monumento isolado em prejuízo ao conjunto urbano.

Fruto do $4^{\circ}$ Congresso Internacional de Arquitetura Moderna $(\mathrm{CIAM})^{12}$, o Congresso de Atenas - que dá origem à Carta - teve como tema a cidade funcional com a ocupação racional do solo urbano. Nos estudos de Funari e Pelegrini (2006), Silva (2003) e Telles (2000), fica claro que o referido congresso discutiu o estabelecimento de cidades que funcionassem para o conjunto de suas populações, distribuindo entre todos as possibilidades de bem estar decorrentes de avanços técnicos. Essa cidade funcional deveria atender a quatro necessidades do ser humano: habitação, lazer, trabalho e circulação; o que representa o reconhecimento da urgência de adoção de medidas socioespaciais de planejamento significativas para a época, na busca da cidadania.

Contudo, a Carta de Atenas põe em voga diretrizes (discutíveis) para a preservação de patrimônio. Nega-se, na Carta, o valor da manutenção dos centros históricos das cidades, dos conjuntos urbanos. Esse documento propunha a preservação de edifícios isolados, construções significativas, memória do passado, ao passo que quarteirões e edificações diferentes dos objetivados seriam devastados e suas áreas transformar-se-iam em campos verdes. Segundo Nigro (2001), o caráter monumentalista perdura como hegemônico até a disseminação das renovações urbanas, no pós-guerra, quando surge e se difunde a noção de preservação dos centros históricos das cidades, o que representa a valorização de lugares representativos de formações socioespaciais (SANTOS, 2004).

Ao desconsiderar o centro histórico como um todo, representatividade de um sistema de objetos pretéritos estabelecidos no espaço, e valorizar objetos isolados, o edifício "maior", fica claro que essa Carta tinha um caráter um tanto restritivo em termos de

\footnotetext{
11 “A ênfase no patrimônio nacional atinge seu ápice no período que vai de 1914 a 1945, quando duas guerras mundiais eclodem sob o impulso dos nacionalismos. Alguns exemplos (...) mostram como mesmo os vestígios mais distantes, no tempo e no espaço, podiam ser lidos como parte da construção da nacionalidade. (...) os italianos usavam os vestígios dos romanos para construírem uma identidade calcada nesse patrimônio, restaurado, glorificado, exaltado como exemplo do domínio do mundo pelos romanos e seus herdeiros, os italianos (...) Na Alemanha nazista (...) usavam-se vestígios dos germanos, considerados antepassados dos alemães, encontrados em territórios de outros países, como a Polônia, para justificar reivindicações territoriais e invasões militares.” (FUNARI e PELEGRINI, 2006, p. 21-22)

${ }_{12}$ Segundo Silva (2003), esses congressos eram instituídos por Lê Corbusier, expoente do Modernismo na arquitetura, e objetivavam reunir e sistematizar pesquisas de arquitetos internacionais.
} 
preservação e valorização da sociedade e do espaço (COSTA, 2007), que é representado por um sistema de objetos indissociável de um sistema de ações (SANTOS, 2002), não por objetos e ações humanas isoladas. Lamas (s.d.), ao tratar da Morfologia Urbana e Desenho da Cidade, estabelece um longo discurso sobre a Carta de Atenas, concluindo que a conservação integral de sítios históricos não é aflorada nem de leve no documento, restringindo-se à salvaguarda de edifícios isolados, ainda sob reserva de serem expressão de uma cultura anterior.

A Carta de Atenas evidencia, na década de 1930, um período amplo da construção do que apenas hoje nos é apresentado como patrimônio cultural, que se inicia com a formulação das primeiras diretrizes legislativas de preservação de monumentos, na França dos séculos XVIII e XIX, logo disseminadas para outros países, sobretudo, da Europa e das Américas.

Considerando que todas as dimensões do espaço citadino apresentam marcos da trajetória de uma sociedade que produz espacialidades notórias, significativas e representantes do longo processo de sua formação política, econômica e cultural, por que privilegiar a preservação de monumentos específicos isoladamente (por mais que tenham um valor simbólico irreplicável) em detrimento a todo o conjunto? Ao longo de séculos, tem-se ampliada a noção de monumento histórico para patrimônio histórico, por fim, patrimônio cultural (que envolve uma gama de objetos, ritos e significados, nos dias de hoje). Passa-se de um reducionismo objetivo a uma abrangência focalizada; identifica-se, pouco a pouco, no pós-guerra, a valorização da noção de conjunto e a superação da noção de arquitetura como obra de arte independente e isolada, dada a disseminação das renovações urbanas que se processam no período; integra-se o centro histórico na dinâmica da cidade. Consideramos que a partir do espaço urbano, em sua totalidade, podemos decifrar o mundo contemporâneo e sua complexidade. Para apreendermos as dinâmicas urbanas contemporâneas, faz-se mister considerar a totalidade da cidade inserida em um contexto global (esse é nosso grande esforço nesta pesquisa)

Choay (2006) acredita que a demora (quatro séculos entre a invenção do monumento histórico e a cidade histórica) para se inserir o espaço urbano (o centro histórico) na perspectiva da conservação (derrocada da concepção monumentalista de preservação) deve-se, de um lado, à questão da escala, à sua complexidade, à longa duração de uma mentalidade que identificava a cidade a um nome, a uma comunidade, a 
uma genealogia, e a uma história de certo modo pessoal, mas que era indiferente ao seu espaço; de outro lado, à ausência, antes do início do século XIX, de cadastros e documentos cartográficos confiáveis, à dificuldade em descobrir arquivos relativos aos modos de produção e às transformações do espaço urbano ao longo do tempo. ${ }^{13}$

Pelo forte caráter nacionalista, sagrado, prestigioso e elitista relativo à posse do patrimônio, coroado na Carta de Atenas, as noções de monumento histórico e patrimônio histórico começaram a sofrer duras críticas. A partir da década de 1960, surgiram vários questionamentos e reavaliações no campo preservacionista, segundo Nigro (2001). Nesse período, as reavaliações de conceitos e práticas de preservação se intensificam mundialmente, configurando no processo que Nigro (2001) denomina processo de democratização de patrimônio.

Esse processo desenvolve-se a partir de uma série de elementos que foram trazidos para junto dos debates e práticas preservacionistas do século $X X$, de forma a contestar a égide tradicional do patrimônio, ou seja, o caráter reducionista e elitista da preservação, também marcante no Brasil, como veremos, no terceiro capítulo deste estudo.

A principal razão do surgimento dessa série de contestações advém do grande distanciamento entre as instituições de preservação e os sujeitos sociais para as quais, teoricamente, suas atividades deveriam estar dirigidas: os habitantes. O primeiro aspecto corresponde à não participação direta $\mathrm{e}$ efetiva da população nas decisões promulgadas pelas instituições públicas preservacionistas (...) Já o segundo aspecto remete ao questionamento sobre quais bens culturais estão sendo selecionados pelas instituições públicas preservacionistas para 'representar' o patrimônio cultural da sociedade. (NIGRO, 2001, p.19)

Aparece como um divisor de águas entre a noção monumentalista e a de conjunto do patrimônio, a Carta de Veneza ${ }^{14}$. Esse documento enfatiza a possibilidade do patrimônio adquirir função útil à sociedade. A Carta inova ao esclarecer que os conjuntos

\footnotetext{
${ }^{13}$ Frente a essas dificuldades apresentadas por Choay (2006) que contribuíram, provavelmente, para o retardo na preservação do conjunto urbano histórico num todo, cabe lembrar que o progresso técnico modela nosso mundo, rearticula relações e reproduz o espaço geográfico, e é justamente devido a essa complexidade mutante que devemos considerar a análise conjunta dos processos históricos, estruturas estabelecidas, o movimento das formas e os conteúdos incorporados pelas materialidades ao longo do tempo, acarretando em novas funções, o que pode nos oferecer uma dimensão das transformações socioespaciais e a realidade da "valorização do espaço" através do trabalho humano, nas cidades históricas.

${ }^{14}$ UNESCO. La Charte de Venise - Charte Internationale Sur la Conservation et la Restauration des Monumentos et des Sites. Paris, 1965.
} 
urbanos históricos podem ser adaptados às "necessidades modernas", onde a revitalização do monumento propicia seu uso a despeito de sua função original, ou seja, permite sua refuncionalização (UNESCO, 1965) ${ }^{15}$.

Elaborada na década de 1960, a Carta de Veneza, conseqüência do II Congresso Internacional de Arquitetos e Técnicos de Monumentos Históricos, representa documento chave da atualidade em termos de ampliação da preservação de patrimônio. Em seu primeiro artigo, a Carta define o termo monumento e diz que ele se estende não somente às grandes criações mas, igualmente, às obras modestas que adquirem, com o tempo, um significado cultural (nesse ponto, o documento apresenta uma concepção mais ampla do que seria monumento).

A Carta compreende a criação arquitetônica isolada, mas também o sítio urbano ou rural que representam um testemunho de uma civilização particular, de uma trajetória significativa, ou de um acontecimento histórico (aqui, fica evidente a noção de conjunto). O patrimônio adquire, na Carta, dimensões temporal e espacial ao afirmar que o monumento é inseparável da história e do meio em que se situa. Quanto à necessidade de restauração ou apenas conservação, o documento coloca que a restauração deve ocorrer em caráter excepcional, e objetiva revelar o valor histórico e estético do bem; baseia-se no respeito à matéria antiga e a documento autêntico; a restauração deve parar quando começam as problemáticas, de acordo com o documento. Termina afirmando que as restaurações devem ser precedidas e acompanhadas por estudos históricos e arqueológicos do edifício. Quanto à preservação dos centros históricos, a Carta de Veneza reitera que esses devem ser objetos de cuidados especiais para salvaguardar sua integridade e assegurar seu saneamento, manutenção e valorização; essa vem em contraponto à Carta de Atenas, que desconsiderava a preservação dos centros históricos das cidades, valorizando monumentos isolados, numa visão reducionista do patrimônio.

Outro importante documento internacional que trata da temática é a Declaração de Amsterdã, elaborada em 1975, após o Congresso do Patrimônio Arquitetônico Europeu, organizado pelo Conselho da Europa. Segundo Funari e Pelegrini (2006), essa Declaração introduziu orientações para viabilizar a implantação de "políticas de conservação integrada", inaugurando uma abordagem pautada pela noção de

\footnotetext{
${ }^{15}$ A década de 1960, com a Carta de Veneza, representa o marco simbólico inicial do processo de mercantilização do patrimônio (abrangendo a preservação, conservação e mercantilização dos conjuntos), em nível mundial.
} 
integração do patrimônio à vida social e conferindo ao poder público municipal a responsabilidade de elaborar programas de conservação e aplicar os recursos financeiros angariados para esses fins. O documento recomendava, ainda, o envolvimento da população nos processos de preservação, "de modo a garantir maior observância dos valores ligados à identidade microlocal e a evitar a evasão dos habitantes em virtude de especulação" (FUNARI E PELEGRINI, 2006, p. 33), evidenciando a importância do processo de democratização do patrimônio. ${ }^{16}$ (Ao longo da pesquisa, veremos que as governanças urbanas pouco se valeram desses importantes documentos no que diz respeito à democratização dos usos bens culturais).

Assim, de acordo com os três documentos supracitados, aferimos que as novas orientações, que se dão em âmbito internacional, são marcantes para reconsiderar a prática de patrimônio que vinha sendo implementada, inclusive no Brasil, como abordaremos ao longo da pesquisa. Isso indica que os debates críticos sobre as políticas de patrimônio restritivas e elitistas impostas há décadas, contribuíram para a ampliação da noção de patrimônio e da sua preservação, ao ser considerado o valor do conjunto como um todo, o que simboliza a valorização do espaço urbano no qual se estabelecem os objetos a serem reconhecidos por seu valor histórico, artístico e, sobretudo, cultural. ${ }^{17}$

Paradoxalmente, é nesse momento de ampliação da noção de patrimônio e da tentativa de sua democratização (lenta e gradual, a partir da década de 1960), que ganha relevo a apropriação estratégica dos núcleos urbanos tombados brasileiros, como veremos no terceiro capítulo desta pesquisa. A partir daquele momento, algumas cidades históricas passam a viver a nova lógica de urbanização ligada à "indústria cultural", que

\footnotetext{
${ }^{16}$ Consideramos que a Declaração de Amsterdã representa um prelúdio às conseqüências advindas da apropriação desmedida dos núcleos urbanos tombados, ao esboçar uma das mais graves problemáticas oriundas da mercantilização desenfreada das cidades históricas: a expulsão do habitante do centro da cidade, com a valorização do espaço que acarreta em especulação econômica e imobiliária superiores ao nível de vida dos moradores do lugar.

${ }^{17}$ Nas décadas que sucedem às duas Grandes Guerras Mundiais, a transformação da noção de patrimônio se expande pelo mundo todo. Por exemplo, no Japão, a valorização de seu patrimônio se dá a partir da década de 1870, no contexto da abertura Meiji; os Estados Unidos foram os primeiros a proteger seu patrimônio natural, dando pouca importância em conservar o patrimônio edificado, cuja proteção é recente e começou por levar em consideração as residências individuais das grandes personalidades nacionais; a China, por sua vez, que ignorava esses valores, começou a abrir e a explorar sistematicamente o filão de seus bens culturais a partir de 1970 (CHOAY, 2006). A autora deixa claro que na primeira Conferência Internacional para Conservação dos Monumentos Históricos, que aconteceu em Atenas, em 1931, só participaram europeus. A segunda, em Veneza, em 1964, contou com a participação de três países não europeus: a Tunísia, o México e o Peru. Para quinze anos mais tarde, oitenta países dos cinco continentes terem assinado a Convenção do Patrimônio Mundial, sobre a qual discutiremos no capítulo seguinte.
} 
segundo Scarlato (2003), transforma o antigo em velho e o novo em modelo das virtudes do progresso.

É bom esclarecer que, apesar de focalizarmos, neste estudo, o patrimônio edificado, o domínio patrimonial não se limita mais a edifícios isolados ou apenas à "pedra e cal", como se convencionou chamar o patrimônio arquitetônico; os órgãos preservacionistas contam com uma legislação que reconhece aglomerados de edificações ou a malha urbana como um todo, dependendo de cada caso, além dos diversos tipos de manifestações populares, o chamado patrimônio imaterial ou patrimônio intangível. Existe uma dicotomia entre patrimônio material e imaterial que, ao nosso entender, minimiza o simbolismo da arte, da história e da cultura conjugadas, devemos tomá-los (bens materiais e imateriais) como complementares, faces de uma mesma moeda: a do patrimônio cultural. $^{18}$

No ocidente, o patrimônio, por longo tempo, esteve ligado à materialidade; a preservação foi vinculada à prática constituída de operações voltadas para seleção, proteção, guarda e conservação do patrimônio edificado. Só na segunda metade do século XX que as manifestações populares começaram, gradualmente, a serem vistas como bens patrimoniais em si, sem que objetos fossem convocados a reificá-las. É digno de nota, de acordo com Sant'anna (2003), que essa prática de preservação não tem origem primária na Europa, mas em países Asiáticos e no então chamado Terceiro Mundo, cujo patrimônio, em grande medida, é constituído das criações populares, menos importantes na materialidade, sendo vinculadas diretamente ao conhecimento popular, práticas populares e processos culturais. Fica claro que, no oriente, mais importante que conservar os objetos do passado, testemunhos de processos históricos e culturais pretéritos, é preservar e transmitir o saber que os produzem, buscando e permitindo a permanência desse savoir-faire no presente.

Contudo, ao tratarmos do patrimônio cultural, - uma noção atual, mais ampla de patrimônio, que abrange a superposição de conceitos e práticas culturais envolvidas

\footnotetext{
${ }^{18} \mathrm{O}$ ocidente só começou, verdadeiramente, a considerar a questão do patrimônio imaterial com a Convensão do Patrimônio Mundial, Cultural e Natural da Unesco, em 1972, onde países do chamado Terceiro Mundo reivindicaram a elaboração de estudos para a apropriação, em nível mundial, de um instrumento de proteção às manifestações populares de valor cultural. Assim, em 1989, uma resposta é dada a essa reivindicação, por meio da Recomendação sobre a Salvaguarda da Cultura Tradicional e Popular, aprovada em Conferência Geral da Unesco. No Brasil, o registro do patrimônio imaterial, se dá a partir do ano 2000, por meio do Decreto 3.551, de 04 de agosto do mesmo ano. (SANT'ANNA, 2003).
} 
na trajetória de sua "construção" ao longo do tempo - sobretudo, edificado, nossa análise não se desvencilha, por um lado, do mistério imaterial que o ronda, do invisível que o permeia, de sua força memorial, seu conteúdo significativo escondido em suas formas e, por outro lado, nossa análise também não se desvencilha das transformações do seu valor simbólico, dos novos sentidos a ele atribuído, através de sua apropriação estratégica pela "indústria cultural". 19

Logo, este item mostra que o século $X X$ é marcado pelo surgimento de questionamentos e mudanças instituídas internacionalmente no campo do patrimônio cultural, onde aparecem como significativos "eventos" (SANTOS, 2002) os Congressos que dão origem à Carta de Atenas (1931), à Carta de Veneza (1964) e à Declaração de Amsterdã (1975), três marcos referenciais da ampliação da noção de patrimônio em nível mundial, que se amplia progressivamente ao longo do século $X X .^{20}$ De monumento, a patrimônio histórico, centro histórico, patrimônio cultural, que por sua vez é reconhecido como material e imaterial ou mesmo patrimônio mundial; Choay (2006) oferece subsídios ao entendimento dessa ampliação progressiva do campo patrimonial, ao considerar três formas de ampliação do patrimônio (que amarra a discussão deste item): a tipológica, a cronológica e a geográfica.

Identificamos, ao longo das últimas décadas, uma tendência crescente de se instituir bens cada vez mais diversificados como patrimônio, conformando sua ampliação tipológica. A preservação não se restringe mais a edifícios religiosos, castelos e vitrais, mas se estende a obras da chamada arquitetura menor ou popular, às casas térreas, sobrados, bens ligados a práticas culturais, religiosas, de lazer, à etnologia rural e urbana.

As políticas preservacionistas não se limitam mais a objetos da Antiguidade Clássica ou da Idade Média, enquanto períodos significativos da história da humanidade, mas abarcam todos os períodos relevantes da formação territorial das nações, estabelecendo sua ampliação cronológica. Aqui, podemos dar como exemplo nossa capital federal, Brasília, datada da década de 1950, a primeira cidade moderna do planeta

\footnotetext{
${ }^{19}$ Devemos olhar para a arquitetura (formas), para a pedra e cal, resgatando, através dos registros existentes, as relações e práticas sociais de época (processo histórico), para assim termos uma verdadeira noção do papel atual do patrimônio cultural (conteúdo) na produção socioespacial contemporânea.

${ }^{20}$ Adiantamos que esses não são os únicos “eventos” que envolvem a preservação de patrimônio em nível internacional, mas são três expoentes da evolução da noção de patrimônio que traçam limites especiais do que deveria ou não ser preservado nos espaços urbanos produzidos por longo processo histórico. É de grande significado, em nossa análise, o reconhecimento do processo de consagração do patrimônio mundial, promovido pela UNESCO, o que demandou o estabelecimento de inúmeras diretrizes e encontros internacionais, também no pós-guerra, como veremos a seguir.
} 
inscrita na Lista do Patrimônio Mundial, onde o plano da cidade, idealizado por Lúcio Costa, segue os princípios básicos da Carta de Atenas de 1931 (SILVA, 2003). Consideramos outro bom exemplo de ampliação cronológica, a cidade histórica mineira São João Del Rei ${ }^{21}$, que apresenta, em seu núcleo urbano tombado, marcos de períodos históricos distintos da formação territorial brasileira, do Brasil Colônia à República Velha (mineração, Comércio de Abastecimento, expansão ferroviária e instalação de indústrias têxteis), de forma que essa cidade, diferentemente de outras cidades do ouro, apresenta um núcleo urbano tombado extremamente complexo, com arquitetura representada pelo auge do barroco em Minas (meados do século XVIII), seguida pelo rococó (fase terminal do barroco, no início do século XIX), e atingindo o estilo eclético e protomoderno (fim do século XIX e decorrer do XX). Distintos estilos preservados, datados de períodos históricos diversos, indo de encontro às diretrizes inicialmente impostas pelos órgãos preservacionistas brasileiros, que tinham apenas na arquitetura do período colonial (barroco) ${ }^{22}$ o símbolo da construção do "Brasil-nação" (COSTA, 2007).

Também identificamos, ao longo do século XX, a ampliação geográfica do patrimônio, onde as políticas preservacionistas apresentaram uma tendência crescente de discussão sobre a ambiência do bem tombado, em que se parte da preservação do objeto isolado (monumento), para a preservação do conjunto (bairros, vilarejos, cidades, sítios naturais e arqueológicos).

A ampliação geográfica do patrimônio não pode ser entendida apenas no tocante ao que deveria ser preservado localmente, se um objeto isolado ou o conjunto urbano como um todo. Julgamos pertinente dar uma outra dimensão para o entendimento dessa ampliação espacialmente consagrada.

\footnotetext{
${ }^{21}$ É bom lembrar que São João foi tombada no contexto de resgate do barroco mineiro pelo antigo Serviço do Patrimônio Histórico e Artístico Nacional (SPHAN), na busca de marcos significativos de nossa formação nacional, pelo governo de Getúlio Vargas, que considerou o barroco do período colonial brasileiro o símbolo máximo da formação da nação. O tombamento de áreas detentoras de parte da arquitetura eclética e proto-moderna, na cidade, deu-se ao longo do século XX, pelo Instituto Estadual do Patrimônio Histórico e Arquitetônico de Minas Gerais (IEPHA/MG) e pela Prefeitura Municipal, que vão consagrar o ecletismo representativo de São João. (COSTA, 2007, 2008).

22 “Trazido para o Brasil pelos jesuítas, instalou-se em Minas com a urbanização provocada pela mineração. Em território mineiro assumiu características peculiares, retratando no urbano o poder temporal, através das edificações civis-administrativas, e do poder religioso, com as igrejas representadas pelas ordens religiosas. Caracteriza-se por um estilo de formas exuberantes e 'pela pompa litúrgico-ornamental'.” (ÁVILA, 1980, p.33). Para Agnolin (2005) O objetivo de permear de espírito cristão a "razão de Estado" faz que a teoria da legitimidade da dissimulação seja sustentada por toda uma literatura política e religiosa, assumindo as características de elaborar um complexo de normas que deviam garantir a estabilidade e a defesa da ordem. Tortuosidade, ambigüidade, complicação do sentir e da expressão, como características do barroco, são instrumentos de ação que fazem do barroco uma verdadeira, uma suprema forma de arte, segundo o autor.
} 
Mencionamos, anteriormente, que a gênese inicial da noção de patrimônio esteve ligada à seleção de bens a serem preservados, cada vez mais, para um conjunto maior de pessoas, para se desenvolver o sentido de nacionalidade. Era preciso salvar os vestígios do passado ameaçado de desaparecimento; o patrimônio deveria ser protegido para todos os membros da "nação", onde a população poderia se reconhecer sob o formato do novo "Estado" resgatado nos objetos de culto; ou seja, consolidam-se nações, identidades nacionais, por meio do espaço conquistado ou produzido, onde os processos evolutivos das conquistas são simbolizados pelas "rugosidades" (SANTOS, 2002) que passam a representar essa nacionalidade, o que demonstra que as ações de preservação sempre tiveram um caráter espacialmente seletivo e político. ${ }^{23}$

Confronta-se essa idéia de bem coletivo nacional (de caráter particularista), que simboliza o processo de constituição da nação via símbolos de conquista e da "formação socioespacial", com a idéia de bem coletivo mundial. Abreu (2003) chama esse processo de vertente universalista do pensamento moderno ocidental, que, através do conceito de humanidade, confronta a idéia de bem coletivo nacional. Ou seja, além da "construção" de um patrimônio nacional, referência de cultura e identidade de um povo estabelecido no território, buscam-se marcos do que foi produzido pelos povos em diversos territórios espalhados pelo planeta, num longo processo histórico, e que passa a pertencer à humanidade como um todo. Forja-se, dessa maneira, a noção de patrimônio cultural da humanidade. ${ }^{24}$

\footnotetext{
${ }^{23}$ Segundo Meneses (1996 apud Scifoni, 2006), os valores do patrimônio podem ser atribuídos a partir de quatro categorias: valores cognitivos (bens como suporte do conhecimento histórico); valores formais (propriedades físicas dos objetos - técnicas arquitetônicas); valores afetivos e pragmáticos (resultam da relação afetiva que os grupos têm com os objetos e o valor de uso que esses objetos tenham; independente de seu valor cognitivo ou forma, representam um sentido e um significado social para determinados grupos). O autor considera que os dois últimos valores, que representam o valor social dos bens culturais, são os mais difíceis de serem aceitos no âmbito do Estado, pois isto implica numa postura mais democrática de reconhecimento da diversidade dos grupos sociais e de suas manifestações. Dessa maneira, o reconhecimento de valores tem, assim, uma dimensão política. Não trata apenas de uma atividade especulativa e cognitiva, mas concreta, prática e política. Fica claro que o núcleo de qualquer preocupação relativa ao patrimônio cultural (identificação, proteção, valorização) é político por natureza (MENESES, 1992, p. 189), hoje em dia, uma preocupação, demasiadamente, econômica.

${ }^{24}$ Silva (2003), ao tratar do patrimônio cultural da humanidade como tema de direito internacional público, considera humanidade um conceito aberto a todos os homens, povos e Estados, sem distinção de raça, sexo, religião ou ideologia; num sentido mais amplo, humanidade seria todo gênero humano que compreende a todos os homens. Essa noção de humanidade, na análise de Silva (2003), comporta, ainda, uma característica "atemporal", ao contemplar as pessoas de hoje e do futuro, diríamos, também, que do passado. "Disso resulta um liame entre os seres humanos da atual e da futura geração: os recursos do patrimônio comum da humanidade podem ser utilizados para atender às necessidades do presente, sem comprometer sua fruição pelas gerações vindouras, sob pena de extinção de toda a espécie humana." (SILVA, 2003, p.36).
} 
Ocorrem duas dimensões geográficas na "construção" do patrimônio cultural em seu longo processo histórico de formação. Uma particularista (nacionalista), que tem por base os bens representantes da produção do espaço como símbolos de identidade para a afirmação dos "Estados-nações". Outra universalista (mundialista), que tem na humanidade o viés para a integração das nações e o reconhecimento das diversidades culturais de todos os povos, onde a crença e o desejo de integração da humanidade dá sentido à consagração do patrimônio mundial, inicialmente e no plano teórico, como veremos no capítulo seguinte.

Nesse sentido, verifica-se que a "construção" do patrimônio sempre teve um caráter identitário, espacial e político. Primeiro, para afirmação dos "Estados-nações" via enaltecimento da produção territorial, depois, no extremo de sua ampliação, na tentativa de se afirmar a diversidade cultural dos povos e a integração das nações, através do conceito de humanidade.

Isso faz com que o patrimônio seja procurado e encontrado em todo o mundo, adquirindo uma visibilidade e importância inigualável na história, englobando tudo o que é dotado de significado cultural irreplicável. Cultura que se transforma em mercadoria na sociedade contemporânea, fazendo com que o patrimônio, cada vez menos, represente o ideal de "Estado-nação" ou de diversidade cultural dos povos, perdendo seu referencial de memória viva ao se tornar um produto em potencial do desenvolvimento turístico, que tem o poder de banalizar pela cenarização progressiva. A mercantilização desenfreada dos bens culturais faz com que os mesmos percam sua função primeira, que é a de esclarecimento, ligada ao valor cognitivo e mesmo afetivo, transformando-se num grande fetiche, "incorporado ao mundo do consumo e se tornando peça central da máquina reprodutiva do capitalismo" (NIGRO, 2001, p. 37).

Subtende-se ou não se entende o verdadeiro sentido da memória ${ }^{25}$, da tradição e da cultura que órgãos nacionais e internacionais lutam para preservar ${ }^{26}$. Os

\footnotetext{
${ }^{25}$ De acordo com Reis Filho (1992) a memória é a base para a construção da identidade, da consciência do indivíduo e dos grupos sociais, ela registra o processo de identificação dos sujeitos com o espaço que se inserem e com as conseqüentes relações que se vêm estabelecer a partir dessa identificação. Podemos compreender, dessa maneira, que a consciência política e a construção da identidade dependerão da forma de apropriação do espaço social; daí uma relação entre identidade e espaço.

${ }^{26}$ Trataremos, no segundo e terceiro capítulos, da atuação da UNESCO, enquanto a principal organização internacional responsável pela elaboração de diretrizes de preservação do patrimônio mundial, e do IPHAN (Instituto do Patrimônio Histórico e Artístico Nacional) enquanto um dos principais órgãos de preservação dos bens culturais brasileiros.
} 
bens culturais são destituídos de sua principal faceta, que é a de sua função social no fortalecimento do sentimento de pertencimento ao lugar e na edificação da cidadania.

Envolvido pela lógica dialética de uma construção destrutiva, os bens culturais do mundo têm seus sentidos metamorfoseados e esgotados em prol da "indústria cultural" por meio do turismo, essa é a mais nova noção que assume o patrimônio cultura através de um processo de mercantilização que redunda, de forma perversa, em contradições na produção socioespacial dos núcleos urbanos tombados, sejam nacionais ou mundiais, como Diamantina. Essa lógica de mercado contradiz as propostas estabelecidas pelas organizações nacionais e internacionais de preservação do patrimônio cultural, como veremos a partir de agora, com ênfase nas prescrições da Convenção Relativa à Proteção do Patrimônio Mundial Cultural e Natural, adotada em 1972 pela UNESCO, segundo a qual norteamos o capítulo que se segue.

O patrimônio (...) se enriquece, então, continuamente, como novos tesouros que não param de ser valorizados e explorados. A indústria patrimonial, enxertada em práticas com vocação pedagógica e democrática não lucrativa, foi lançada inicialmente a fundo perdido, na perspectiva e na problemática do desenvolvimento e do turismo. Ela representa hoje, de forma direta ou indireta, uma parte crescente do orçamento e da renda das nações. Para muitos Estados, regiões, municípios, ela significa a sobrevivência e o futuro econômico. E é exatamente por isso que a valorização do patrimônio (...) representa um empreendimento considerável (...) o empreendimento traz, no entanto, efeitos secundários, em geral perversos (...) Quando deixar de ser objeto de um culto irracional e de uma valorização incondicional (...) o reduto patrimonial poderá se tornar o terreno inestimável de uma lembrança de nós mesmos no futuro. (CHOAY, 2006, p. 225-226 e 257, grifos nossos) 


\section{Capítulo 2.0 - A UNESCO e o Patrimônio Mundial: ações internacionais}

Consideramos, inicialmente, que a ampliação da noção de patrimônio cultural foi e é favorecida pelos aparatos e dinamismos propiciados pela globalização, como a maior facilidade de contato entre lugares distantes do globo, a busca da constituição de uma comunidade internacional, os adventos técnicos e informacionais, um aporte científico amplo que contribui para diversas abordagens no campo do patrimônio, sobretudo, a partir das ciências humanas, além da onipresença da mídia que dá visibilidade inconteste aos bens culturais do mundo ${ }^{27}$. Esses são alguns poucos efeitos que fazem aproximar políticas culturais heterogêneas, multiétnicas e multirreligiosas que conformam a sociedade atual e redundam na consagração do Patrimônio Cultural da Humanidade ou Patrimônio Mundial.

Surge, nesse sentido, uma discussão sobre a ética de responsabilidade entre as diferentes gerações, baseada numa solidariedade internacional que também favorece o advento da categoria de Patrimônio Mundial. Nigro (2001) aponta-nos que essa idéia de Patrimônio da Humanidade supõe a valorização de certos bens culturais e naturais condizentes a todos os seres da Terra. Bens vistos como heranças transmissíveis entre as gerações, onde o coletivo torna-se (ou deveria se tornar) seu proprietário, o que consolida uma riqueza juridicamente comum, "por isso mesmo, a crescente difusão dessa nova categoria também ajudou a alavancar a compreensão do patrimônio como um direito social" (NIGRO, 2001, p. 29).

Nessa lógica, aparece como significante "evento" (SANTOS, 2002), que marca a consagração do Patrimônio Mundial, a criação da UNESCO, em um ambiente de busca de integração entre as nações, destacando-se a vertente universalista da noção de patrimônio cultural, que coloca em relação várias culturas nacionais (ABREU, 2003).

\footnotetext{
27 Nossa análise depende de um sério esforço de generalização e abrangência concomitante a um esforço de particularização e individualização, onde a generalização nos mostra os vetores externos possíveis de reestruturar relações humanas diversas; a particularização nos indica, hoje, como o lugar, o específico é entranhado por esses vetores, pela lógica "homogeneizadora” da globalização, que, contraditoriamente, acaba por fragmentar o espaço da sociedade. Na concepção de Santos (1993), a globalização constitui o estágio supremo da internacionalização, a introdução de todos os lugares e de todos os indivíduos no sistema mundo, ainda que em diferentes graus; a globalização aparece como uma nova fase da história humana que permite o surgimento de um conjunto de novas possibilidades concretas, que modifica os equilíbrios preexistentes e impõe sua lógica, "en esse sentido, con la unificación del planeta, la Tierra se convierte en un solo y único mundo y se asiste a una refundación de la Tierra como totalidad” (SANTOS, 1993, p. 69).
} 
Criada em 1945, a UNESCO definiu, naquele momento, no parágrafo I de sua constituição, as diretrizes para a preservação do patrimônio mundial ainda em "construção", conforme Mohen (1999, p. 284, tradução nossa):

c) Manter, desenvolver e difundir o conhecimento, assegurando (entre outras) a conservação e a proteção do patrimônio do mundo, os livros, as obras de arte e os monumentos da história e da ciência, e recomendar, às nações responsáveis, instituir as convenções internacionais necessárias. ${ }^{28}$

Contudo, apenas em 1972, a UNESCO, através da "idea de salvaguardar el patrimonio humano, la riqueza monumental de la humanidad" (BOSQUE, 1996, p.80), formaliza a defesa do Patrimônio Mundial. A mundialização dos valores e das referências ocidentais das práticas patrimoniais difundidas pelos aparatos globalizantes acarreta, dessa maneira, na Convenção Relativa à Proteção do Patrimônio Mundial Cultural e Natural, adotada em 1972, através da $17^{\text {a }}$ Conferência Geral da UNESCO ${ }^{29}$, consolidando a noção de Patrimônio Mundial. ${ }^{30}$

De acordo com Bosque (1996, p.80, tradução nossa) ${ }^{31}$, os objetivos do Comitê do Patrimônio Mundial, estabelecido pela Convenção são:

\footnotetext{
28 “c) Maintient, accroît et diffuse la connaissance; en assurant (entre autres) la conservation et la protection de l’héritage mondial des livres, des oeuvres d'art et des monuments de l'histoire et de la science, et em recommandant aux nations concernées d’établir les conventions internationales nécessaires”.

29 “As principais decisões são tomadas na Conferência-geral, constituída pelos representantes dos Estados-membros da Organização, que se reúne a cada dois anos (...) As convenções elaboradas sob o patrocínio da UNESCO são típicos tratados multilaterais.” (SILVA, 2003, p. 55-56).

30 “As instituições previstas na Convenção Relativa à Proteção do Patrimônio Mundial, Cultural e Natural, compõem a estrutura de uma autoridade internacional de proteção, cuja função principal é conferir plena execução à própria Convenção, promovendo a inscrição de bens culturais na Lista do Patrimônio Mundial ou na Lista do Patrimônio Mundial em Perigo e prestando assistência internacional.” (SILVA, 2003, p. 77). Essa autoridade internacional representa-se por meio de um órgão executivo permanente, o Comitê do Patrimônio Mundial, integrado por um Comitê consultivo composto por representantes do ICCROM (Centro Internacional de Estudos para Conservação e Restauração dos Bens Culturais, organização ligada à restauração dos bens culturais, criada pela UNESCO, em 1951, durante sua $6^{\mathrm{a}}$ Conferência-geral / ver: www.iccron.org) e do ICOMOS (Conselho Internacional de Monumentos e Lugares de Interesse Artístico e Histórico, organização não governamental fundada em 1965, fruto das diretrizes do Congresso de Veneza, de 1964; promove a teoria, a metodologia e a tecnologia aplicadas na conservação e proteção do patrimônio arquitetônico / ver: www.internationalicomos.org/e_statut.htm.). Ainda há um fundo internacional, paralelamente às ações do Comitê, para recolher e distribuir os recursos necessários para financiar as ações protetoras. A análise do original da Convenção esclarece-nos em seu Artigo 8 que, "le Comitê du patrimoine mondial (...) est composé de 15 Etats parties à la convention, élus par les Etats parties à la convention réunis em assemblée générale (...) Le nombre des Etats membres du Comitê será porté à 21 à compter de la session ordinaire de la Conférence générale qui suivra l'entrée em vigueur de la presente convention pour au moins 40 Etats.” (UNESCO, 1972, p. 04).

31 “1) identificar y proponer aquellos lugares de interes natural y cultural que deben ser protegidos por la Convención del Patrimonio Mundial, inscribiéndolos em la lista del patrimonio mundial; 2) difundir por todo el mundo la existencia de este patrimonio y procurar despertar em la opinión pública la conciencia de su responsabilidad, respecto a la salvaguardia de cada uno de los bienes que constituyen esa lista y 3) proporcionar ayuda técnica com cargo al fondo del
} 
1) identificar e propor os lugares de interesse natural e cultural que devem ser protegidos pela Convenção do Patrimônio Mundial, inscrevendo-os na Lista do Patrimônio Mundial;

2) difundir, por todo o mundo, a existência desse patrimônio e procurar despertar, na opinião pública, a consciência de sua responsabilidade, respeito à salvaguarda de cada um dos bens que constituem essa Lista;

3) proporcionar ajuda técnica ao fundo do patrimônio mundial para preservar, de todos os modos possíveis, aqueles bens, quando os recursos dos países integrantes são insuficientes.

Inaugurando um novo momento da política patrimonial em nível internacional, a Convenção amplia, sobremaneira, a noção de patrimônio cultural, considerando (UNESCO, 1972, p. 02, tradução nossa) ${ }^{32}$ :

- os monumentos: obras arquitetônicas, de escultura ou de pinturas monumentais, elementos ou estruturas de características arqueológicas, inscrições, grutas e grupos de elementos que tenham um valor universal excepcional do ponto de vista da história, da arte ou da ciência.

- os conjuntos: grupos de construções isoladas ou reunidas que, em razão de sua arquitetura, de sua unidade, ou de sua integração na paisagem, tenham um valor universal excepcional do ponto de vista da história, da arte ou da ciência.

- os sítios: obras do homem ou obras conjugadas do homem e da natureza, bem como as zonas de sítios arqueológicos que tenham um valor universal excepcional do ponto de vista histórico, estético, etnológico ou antropológico.

patrimonio mundial para preserva, de todos los modos posibles, aquellos bienes, cuando los recursos de los países que los vendan, esos bienes, son insuficientes.”

32 “ - les monuments: oeuvres architecturales, de sculpture ou de peinture monumentales, éléments ou structures de caractere archéologique, inscriptions, grottes et groupes d'éléments, qui ont une valeur universelle exceptionnelle du point de vue de l'histoire, de l'art ou de la science, - les ensembles: groupes de constructions isolées ou réunies, qui, em raison de leur architecture, de leur unité, ou de leur intégration dans le paysage, ont une valeur universelle exceptionnelle du point de vue de l'histoire, de l'art ou de la science, - les sites:oeuvres de l'homme ou oeuvres conjuguées de l'homme et de la nature, ainsi que les zones y compris les sites archéologiques qui ont une valeur universelle exceptionnelle du point de vue historique, esthétique, ethnologique ou anthropologique.” 
Outro importante conceito cunhado pela UNESCO (2005), em voga recentemente, é o de "paysage urbain historique", no contexto da ampliação da noção de patrimônio cultural. A Recomendação sobre a salvaguarda dos conjuntos históricos ou tradicionais e sua função na vida contemporânea, ou Recomendação de Nairóbi (UNESCO, 1976), já traçava diretrizes para as políticas de preservação a serem implantadas num momento de desenvolvimento tecnológico, de todas as formas de poluição, do avanço dos meios de transporte ou da "super-exploração" turística ${ }^{33}$. O texto refere-se não apenas à proteção de particularismos étnicos e locais, mas também discute o processo planetário de banalização e estandardização das sociedades e seus meios.

Reavaliando essa Recomendação, tratada em 1976, o conceito de paisagem urbana histórica é retomado em 2005, através do Memorando de Viena, que a considera como a expressão clara das evoluções sociais pretéritas e presentes que caracterizam a cidade histórica e urge ser preservada. ${ }^{34}$ Integram a paisagem urbana histórica, na concepção do Memorando do Viena: formas de ocupação do solo e sua afetação, a transformação do espaço, as relações visuais, a topografia e o relevo, a vegetação e todos os elementos de estrutura técnica, além de todos os detalhes das construções [calçadas, canaletas, iluminação, telhados, etc.] (UNESCO, 2005, p. 03, tradução nossa).

Fica claro que a classificação dada pela Convenção Relativa à Proteção do Patrimônio Mundial Cultural e Natural e mesmo o novo conceito de paisagem urbana histórica, reformulado no Memorando de Viena, referem-se às manifestações humanas por meio dos bens culturais imóveis, onde monumentos e conjuntos compreendem realizações próprias da ação humana sobre a Terra, e os sítios e a paisagem urbana histórica, à ação conjunta homem-natureza na produção do espaço. Tanto monumentos, conjuntos, sítios ou paisagem urbana histórica, na concepção da UNESCO, podem pertencer à categoria de Patrimônio Cultural da Humanidade ao esboçarem um valor universal excepcional.

\footnotetext{
${ }^{33}$ Choay (2006, p. 223) considera a Recomendação de Nairóbi a exposição de motivos e a argumentação mais complexa em favor de um tratamento não museal das malhas urbanas contemporâneas. Esse documento, para a autora, constitui também o texto mais lúcido sobre os perigos inerentes a essa política.

${ }^{34}$ O Memorando de Viena, estabelecido na $15^{\text {a }}$ Assembléia Geral dos Estados-partes na Convenção do Patrimônio Mundial, retoma cartas e recomendações internacionais anteriores, inclusive a Recomendação de Nairóbi, dada a ampla evolução da noção de patrimônio cultural e as novas dinâmicas que o envolve, que essas cartas não acompanharam ao longo das últimas décadas (UNESCO, 2005, p. 03, tradução nossa).
} 
O Comitê do Patrimônio Mundial, reunido em sua $31^{\text {a }}$ Sessão, na Nova Zelândia, em 2007, publicou a Discussion sur la valeur universelle exceptionnelle, que esclarece esse conceito. Por excepcional entendem-se os lugares naturais e culturais mais excepcionais do globo, por universal considera-se a importância do bem cultural para todas as pessoas do mundo, de forma que o valor universal excepcional dos bens não pode ser pensado numa perspectiva regional ou nacional (UNESCO, 2007, p. 32, tradução nossa). ${ }^{35}$ Logo, o conceito de valor universal excepcional implica em definir o valor de um bem em termos de sua importância mundial a partir de uma série de normas ou de critérios específicos, aplicados de maneira cuidadosa quando da inclusão na Lista do Patrimônio Mundial, como veremos. ${ }^{36}$

É importante ficar claro que o Comitê, ao longo dos anos, por meio de suas reuniões, formulou ou renovou conceitos para melhor caracterização dos bens culturais mundiais. Tudo indica que essas reformulações conceituais estão intimamente ligadas a um documento precursor, a Carta de Veneza (1964), que inaugurou uma nova fase, sobretudo, para os "conjuntos" urbanos, como vimos anteriormente. Os conjuntos, hoje, são classificados em cidades mortas, cidades históricas vivas e cidades novas do século $X X^{37}$, segundo Silva (2003, p. 88).

Nesse sentido, a partir do reconhecimento da importância da diversidade cultural mundial, a grande novidade estabelecida, após 1970, consistiu em considerar que os bens declarados como patrimônio da humanidade pertenceriam a todos os povos do planeta, ao serem inscritos na Lista do Patrimônio Mundial. Contudo, a corrida dos países

\footnotetext{
35 Podemos considerar que a UNESCO, por meio da Convenção do Patrimônio Mundial e da Lista do Patrimônio Mundial, promove a ampliação geográfica, cronológica e tipológica suprema do patrimônio cultural.

${ }^{36}$ Frente às novas dinâmicas que envolvem os bens culturais, às pressões vividas pelas cidades históricas e seus habitantes, sobretudo, através do turismo, o Comitê estabelece novas diretrizes para o planejamento desses lugares. Recomenda, atualmente, planos de gestão adaptados para explicitar e preservar os valores universais excepcionais do bem, de modo participativo (UNESCO, 2007b, tradução nossa), o que simboliza a tentativa de democratização do patrimônio cultural, em âmbito local, nacional e internacional. Devemos ter em mente que o patrimônio cultural inserese em um mundo criado pela globalização, onde um novo espaço geográfico se estrutura, estabelecem-se novas relações em que a eficácia das ações depende da localização, ou seja, a cidade histórica representa a possibilidade de reprodução do capitalismo, a partir da mundialização do capital. As novas técnicas favorecem novas lógicas, subvertendo o "antigo jogo de relações que se davam nos territórios” (SANTOS, 2000, p.79). É dessa maneira que o espaço se globaliza, mas não é mundial como um todo, senão como metáfora (SANTOS, 2002a), ou seja, todos os lugares são mundiais mas não há um espaço mundial, “quem se globaliza são as pessoas e os lugares” (SANTOS, 2002a, p. 16).

${ }^{37}$ Cidades mortas são cidades antigas que não possuem vida contemporânea, outrora habitadas por civilizações hoje desaparecidas, que nos legaram importantes vestígios dos períodos em que ali viveram. Cidades históricas vivas seriam as que possuem uma função contemporânea, sem perderem vestígios significativos de antigas civilizações, como Diamantina, Ouro Preto, Sabará, Tiradentes, São João Del Rei, Salvador e outras. Cidades novas do século XX não constavam do projeto da Convenção. Essa categoria foi concebida com base nas sessões do Comitê do Patrimônio Mundial, principalmente em razão da inscrição de Brasília na Lista do Patrimônio Mundial. (SILVA, 2003, p. 88).
} 
pela inscrição dos bens, na Lista, revela a faceta economicista das políticas patrimoniais que, com a atuação da "indústria cultural", produzem um "capital simbólico" (HARVEY, 2005), uma imagem invertida da cultura ao tornar mercadoria as "rugosidades" (SANTOS, 2002) espacializadas nos lugares "vendidos" como especiais, singulares, originais, autênticos e irreplicáveis, o que não nos parece ter sido o objetivo primeiro de preservação normatizado pela UNESCO. ${ }^{38}$

Até aqui, podemos dizer que apresentamos, no contexto do que denominamos dialética da construção destrutiva, ações que criaram o caminho para se consagrar o Patrimônio Mundial, que se dá em um longo processo histórico que estrutura e integra formas pretéritas de diversos territórios nacionais, no contexto de distintos momentos. Partimos do entendimento de monumento, passando pelas dinâmicas que enredaram os objetos de culto na França pós-revolucionária (berço do patrimônio) com o objetivo de se constituir uma nacionalidade (dinâmicas que se repetem em outros lugares do mundo, inclusive no Brasil do início do século $X X$ ), além do reconhecimento de documentos internacionais ${ }^{39}$ fundamentais que forjam a noção de patrimônio até meados do século $X X$, que colaboram para a consagração de um Patrimônio Mundial, na década de 1970.

A diversificação das ações voltadas ao patrimônio não finda na década de 1970 com a concepção do Patrimônio Cultural da Humanidade pela UNESCO, mas tem início, naquele momento, um novo período (apoiado na Carta de Veneza), com o frénésie pela inclusão de bens na Lista do Patrimônio Mundial, por parte de diversos países do mundo, como analisaremos no capítulo seguinte. A busca pela Lista é representante das muitas possibilidades de mercantilização e "turistificação" dos lugares ${ }^{40}$, que vai envolver as cidades históricas, gradativamente, a partir da década de 1970.

\footnotetext{
${ }^{38} \mathrm{Na}$ conjuntura atual que envolve os bens culturais, o Comitê do Patrimônio Mundial reconhece a necessidade da implantação de um Sistema de Gestão específico para cada lugar, para a proteção de seus valores patrimoniais e , em particular, de seu valor universal excepcional, em harmonia com os diversos problemas de desenvolvimento existentes e as necessidades legítimas das comunidades locais, para se assegurar a durabilidade do conjunto (UNESCO, 2007b, tradução nossa). Assim, os lugares do patrimônio destacam-se nas relações globais por meio do turismo. Num movimento conflituoso, o lugar do patrimônio e o global interagem. Quer dizer que a cidade histórica aparece como mediadora de agentes distintos e distantes, torna-se palco para os conflitos da lógica do turismo. Santos (1999) considera que caminhamos, ao longo dos séculos, da antiga comunhão individual dos lugares com o universo, para a comunhão, hoje, global; a interdependência universal dos lugares é a nova realidade da produção socioespacial.

${ }^{39}$ Carta de Atenas, Carta de Veneza, Declaração de Amsterdã, Convenção do Patrimônio Mundial, Recomendação de Nairóbi e o Memorando de Viena.

${ }^{40}$ Escolhemos o processo de consagração do Patrimônio Cultural da Humanidade, que se dá com a inclusão na Lista do Patrimônio Mundial, como símbolo de busca de valorização do espaço e mercantilização de patrimônio, por ser essa consagração uma realidade atual de Diamantina, incluída na Lista em 1999.
} 
Entendemos que é a partir da captura da cidade histórica pelo turismo que se passa a operar a simultaneidade relacional dialética de uma construção destrutiva dos bens culturais do mundo. No caso da consagração enquanto Patrimônio Mundial, como ocorreu com Diamantina, dando-Ihe visibilidade no cenário internacional, a cidade tende a se tornar um novo tesouro cada vez mais explorado na perspectiva do desenvolvimento e do turismo. A dialética da "preservação" x "mercantilização", da vitória da troca sobre os modos operantes do uso ${ }^{41}$ integram a construção destrutiva dos seus bens culturais, agora, envolvidos na mundialização dos lugares.

Esse processo relacional e contraditório que se inicia no plano teórico e de discussão da ampliação da noção de patrimônio, tem seu rebatimento no lugar, no plano do território. Logo, o que denominamos dialética da construção destrutiva do patrimônio deve ser considerado ao longo da pesquisa (passamos da construção à desconstrução do patrimônio, na análise, em vários momentos, de forma relacional), pois, consideramos a simultaneidade que nos exige a própria dialética, de afirmação e negação, da própria contradição que envolve o patrimônio hoje, ao simbolizar cultura e mercadoria; vende-se o inalienável, mercantiliza-se, descompromissada e particularmente, o que deveria ser preservado coletivamente. Esse jogo tende a forçar os territórios a uma compartimentação generalizada, onde se associam e se chocam o movimento geral da sociedade planetária e o movimento particular de cada lugar, ou seja, com a dinâmica desse processo, todo e qualquer pedaço da superfície da terra torna-se funcional às necessidades, usos e apetites de agentes do mercado, do Estado ou da associação de ambos, segundo Santos (2000). O autor considera que, até recentemente, a humanidade vivia o tempo da lentidão, no qual a prática de velocidades diferentes não separava os respectivos agentes; contudo, hoje, vivemos o mundo da fluidez e da rapidez possíveis através de novos sistemas

\footnotetext{
${ }^{41}$ A mercadoria vem ao mundo como valor de uso e só são mercadorias por sua duplicidade - objetos úteis e veículos de valor (MARX, 1982). De acordo com o autor, a mercadoria emana valor por ser expressão de uma mesma substância social, o trabalho humano; seu valor é apenas uma realidade social em que uma mercadoria é trocada por outra. Para nossa análise, é importante entendermos que, na abordagem marxiana, o valor de uso é um atributo do homem, o valor, um atributo das mercadorias. Segundo Marx (1982), um homem é rico e um diamante é valioso, o último tem valor como diamante, ou seja, valor, nesse sentido, implica necessariamente troca, riqueza não. O valor de uso independe de suas propriedades materiais, o valor, ao contrário, é materialmente um atributo das coisas. O valor de uso se realiza para as pessoas, sem troca, relação direta entre as pessoas e as coisas, já o valor só se realiza pela troca, por meio de um processo social (MARX, 1982). "Sem maior avanço nessa análise, limitamo-nos a ilustrar com mais alguns elementos o fetichismo da mercadoria. Se as mercadorias pudessem falar, diriam: Nosso valor-de-uso pode interessar aos homens. Não é nosso atributo material. O que nos pertence como nosso atributo material, é nosso valor. Isto é o que demonstra nosso intercâmbio como coisas mercantis. Só como valores-de-troca estabelecemos relações umas com as outras” (MARX, 1982, p. 92).
} 
técnicos; uma fluidez potencial, novas técnicas e meio informacional que aparecem no imaginário e na ideologia como se fossem bens ao alcance de todos, o que não se constitui na realidade.

Nunca a geografia foi uma disciplina tão central na posição do poder econômico e político. Nem a Economia nem a Sociologia explicam corretamente o comportamento da sociedade no território, pois a sociedade nacional é uma abstração se não a considerarmos a partir do território. $\boldsymbol{A}$ ação dos homens está sempre ditada pelas características dos lugares, pelas formas que os lugares têm. (SANTOS, 2003, p. 60, grifo nosso) 


\subsection{O frénésie pela Lista do Patrimônio Mundial e as cidades brasileiras inscritas}

Todo bem cultural pode ser inscrito na Lista do Patrimônio Mundial. Para isso, cada um dos 184 países signatários da Convenção, caso do Brasil, deve, na medida do possível, apresentar ao Comitê do Patrimônio Mundial um inventário dos bens do patrimônio cultural e natural situados em seu território que possam ser incluídos na Lista. A inclusão do bem não é feita sem o consentimento do Estado interessado (UNESCO, 1972, p. 05, tradução nossa).

O processo de inscrição do bem, na Lista do Patrimônio Mundial, exige duas etapas distintas. Na primeira, o Estado interessado inventaria o bem cultural e aplica as medidas necessárias à sua proteção, de acordo com a Convenção, o que fora feito, no plano teórico, por Diamantina, como veremos no terceiro capítulo, especificamente.

Cada um dos Estados-partes, na presente convenção, reconhece que the incumbe a obrigação de identificar, proteger, conservar, valorizar e transmitir às futuras gerações o patrimônio cultural e natural (...) situado em seu território (...) adotar uma política geral visando dar ao patrimônio cultural e natural uma função na vida da coletividade (...) instituir em seu território serviços de proteção, conservação e valorização do patrimônio cultural e natural (..) desenvolver estudos e pesquisas científicas e técnicas, aperfeiçoar os métodos de intervenção que permitam ao Estado fazer frente aos perigos que ameacem seu patrimônio cultural ou natural (...) estimular a pesquisa científica nesse campo. (UNESCO, 1972, p. 03, tradução nossa) ${ }^{42}$.

Num segundo momento, a solicitação da inscrição do bem cultural é submetida ao exame e à deliberação do Comitê do Patrimônio Mundial, que poderá deferir ou não a proposta de inscrição do bem. Segundo Silva (2003), a inscrição do patrimônio cultural de cidades brasileiras é proposta pelo Governo Federal por intermédio do Ministério das Relações Exteriores mediante dossiês encaminhados ao ICOMOS (Conselho Internacional

\footnotetext{
42 “Chacun des Etats parties à la presente Convention reconnaît que l’obligation d'assurer l'identification, la protection, la conservation, la mise em valeur et la transmission aux génerations futures du patrimoine cultural et natural (...) situe sur son territoire (...) d'adopter une politique générale visant à assigner une fonction au patrimoine culturel et naturel dans la vie collective (...) d'instituer sur leur territoire dans la mesure ou ils n1exisent pas, un ou plusierurs services de protection, de conservation et de mise en valeur du patrimoine culturel et naturel (...) de développer les études et les recherches scientifiques et techniques et perfectionner les méthodes d'intervention qui permettent à um Etat de faire face aus dangers qui menacent son patrimoine culturel ou naturel (...) d'encourager la recherche scientifique dans ce domaine.”
} 
de Monumentos e Lugares de Interesse Artístico e Histórico), instruídos com o nome do patrimônio e dos bens que o constituem, sua localização geográfica, as medidas de proteção e a justificativa de seu valor universal excepcional.

Fica evidente que para integrar a Lista, o bem necessita atender à concepção do valor universal excepcional, o qual a Convenção outorga ao Comitê a competência para defini-lo, além de sua autenticidade e comprovação de que o Estado interessado adotou medidas adequadas de proteção ao objeto de inscrição.

Os critérios de avaliação relativa ao valor universal excepcional dos bens nomeados sobre a Lista do Patrimônio Mundial evoluíram, conceitualmente, nas últimas décadas. De uma primeira versão, de 1976, tivemos, em 2005, a última redefinição dos critérios, a qual apresentamos a seguir (UNESCO, 2007, p. 04-05, tradução nossa):

- critério (i): representar uma obra prima do gênio criativo.

- critério (ii): testemunhar uma influência considerável, durante um período dado ou em uma área cultural determinada, sobre o desenvolvimento da arquitetura ou da tecnologia, das artes monumentais, do planejamento das cidades ou da criação de paisagens.

- critério (iii): representar um testemunho único, ou ao menos excepcional, de uma tradição cultural, uma civilização viva ou desaparecida.

- critério (iv): representar um exemplo excepcional de um tipo de construção ou de conjunto arquitetônico, ou tecnológico, ou paisagem ilustrativa de um ou mais períodos significativos da história humana.

- critério (v): ser um exemplo eminente do estabelecimento humano tradicional, da utilização tradicional do território ou do mar, que seja representativo de uma cultura (ou de culturas), ou da interação humana com o ambiente, especialmente quando esse se torna vulnerável sob o impacto de uma mutação irreversível.

- critério (vi): ser diretamente ou materialmente associado aos eventos ou às tradições vivas, das idéias, das crenças ou das 
obras artísticas ou literárias, adquirindo uma significação universal excepcional. (O Comitê considera que esse critério deve, preferencialmente, ser utilizado em conjunção com outros critérios).

É variável o número de critérios utilizados para cada bem incluído na Lista do Patrimônio Mundial. Identificamos na Discussion sur la valeur universelle exceptionnelle que, no contexto dos atuais 851 bens inscritos na Lista (UNESCO, 2007a, p. 03, tradução nossa), 14\% foram aceitos com adoção de apenas um critério; $42 \%$ com dois critérios (maioria), 30\% com três critérios; $10 \%$ dos bens foram eleitos com quatro critérios e apenas 4\% eleitos com cinco critérios ${ }^{43}$. Três casos dos 851 bens inscritos na Lista do Patrimônio Mundial foram eleitos com a consideração dos seis critérios, a saber: "Le Mont Taishan (Chine), les grottes de Moga (Chine) et Venise et sa Lagune (Italie)" (UNESCO, 2007).

Quanto ao critério autenticidade, Silva (2003) esclarece que os bens culturais considerados autênticos são aqueles que atendem à sua concepção original em "modelo, material, artesanato ou ambiente". O critério autenticidade privilegia o aspecto exterior do bem, torna-se secundário apurar se sua utilização é a mesma da época em que foi produzido. "Essa orientação segue os princípios da Carta de Veneza (1964) e foi consagrada como um dos princípios fundamentais que deveriam reger a proteção dos bens culturais imóveis durante os trabalhos preparatórios da Convenção. Trata-se de uma concepção européia de proteção que permeia a maioria das decisões do Comitê." (SILVA, 2003, p. 94).

O Brasil possui dezessete bens inscritos, atualmente, na Lista do Patrimônio Mundial. Desses, as Missões Jesuíticas dos Guaranis estabelece-se enquanto um bem transnacional (Brasil-Argentina), os outros dezesseis dividem-se entre os mundiais naturais e os mundiais culturais unicamente brasileiros.

São oito as cidades brasileiras inscritas, atualmente, na Lista do Patrimônio Mundial, Ouro Preto (MG), Olinda (PE), Salvador (BA), Congonhas (MG), Brasília (DF), São Luís (MA), Cidade de Goiás (GO) e, por fim, Diamantina (MG). As cidades foram

\footnotetext{
${ }^{43}$ Como exemplo de bens inscritos com a adoção de apenas um critério podemos mencionar o Campo de Concentração de Auschwitz, Polônia (1979) e o Memorial da Paz de Hiroshima, Japão (Cúpula de Gembaku) (1996), ambos eleitos com base no critério (vi). (UNESCO, 2007, p. 11).
} 
inscritas na Lista com base nos seguintes critérios, deferidos pelo Comitê do Patrimônio Mundial:

- Conjunto Arquitetônico e Urbanístico de Ouro Preto (1980): critérios (i) e (iii);

- Centro Histórico de Olinda (1982): critérios (ii) e (iv);

- Centro Histórico de Salvador (1985): critérios (iv) e (vi);

- Santuário de Bom Jesus de Matozinhos, Congonhas (1985): critérios (i) e (iv);

- Conjunto Urbanístico de Brasília (1987): critérios (i) e (iv);

- Centro Histórico de São Luís (1997): critérios (iii), (iv) e (v);

- Centro Histórico de Diamantina (1999): critérios (ii) e (iv); e

- Centro Histórico da Cidade de Goiás (2001): critérios (ii) e (iv).

À exceção de Brasília, uma "cidade nova do século XX", consideramos que as demais podem ser enquadradas no conceito de "cidades históricas vivas", por possuírem uma função contemporânea, sem perderem os vestígios pretéritos de nosso longo processo de colonização, conquista territorial e "formação socioespacial" (SANTOS, 2004). São consideradas cidades históricas vivas nos seguintes casos, de acordo com Silva (2003, p.89):

- cidades típicas de uma época ou de uma cultura, preservadas em quase toda sua integridade, pois não afetadas significativamente por qualquer desenvolvimento posterior. Assim, caracterizam-se pela identidade entre o bem inscrito e o conjunto da cidade, exigindo-se uma proteção integral; desconhecemos exemplos dessas cidades, no Brasil;

- cidades evolutivas cuja parte histórica é claramente delimitada em relação ao seu meio contemporâneo; caso de Diamantina, Cidade de Goiás, São Luís, Salvador, Olinda e Ouro Preto; 
- centros históricos cuja dimensão espacial abrange exatamente o perímetro da cidade antiga, atualmente englobada por uma cidade moderna; e

- setores, áreas ou unidades isoladas que representam um estado residual da antiga cidade desaparecida, mantendo, porém, as características que atestam sua origem daquela antiga cidade; a área e as construções testemunham claramente o conjunto desaparecido, caso do Santuário de Bom Jesus de Matozinhos, em Congonhas (MG).

A riqueza patrimonial dessas cidades é extraordinária e de uma variabilidade enorme. O conjunto das oito cidades brasileiras inscritas na Lista do Patrimônio Mundial (das quais, três estão no estado de Minas Gerais) representa bem essa variabilidade, sobretudo em relação aos momentos de constituição de cada uma, em distintas fases econômicas, políticas e culturais da conquista territorial e da "formação socioespacial" brasileira. Segundo Bosque (1996), a presença de Brasília, na Lista, revela que a visão sobre a excepcionalidade não se detém somente no passado remoto, atingindo os processos produtivos das cidades atuais.

(...) junto a isso, encontramos também o Santuário de Bom Jesus, em Congonhas - parece que podemos considerar essa obra excepcional pictórica como o 'Miguel Angelo brasileño' - e a seu lado riquezas naturais como o Parque Nacional do Iguaçu e o Parque Nacional da Serra da Capivara, um dos exemplos mais extraordinários de bosques de floresta tropical. (BOSQUE, 1996, p. 82, tradução nossa) ${ }^{44}$

Nessa diversidade implantada pelo reconhecimento do Patrimônio Cultural da Humanidade surge um sério dilema. É necessário deixar claro que a origem da Convenção Relativa à Proteção do Patrimônio Mundial Cultural e Natural de 1972, do Comitê e da Lista do Patrimônio Mundial foi extremamente conservadora. Não identificamos, na constituição da Convenção, a prioridade de que os bens da humanidade

\footnotetext{
44 “Junto a eso, se encuentran también el Santuario del Buen Jesús em Congonhas - parece que esta obra excepcional pictórica podríamos considerar com oel "Milguel Angel” brasileño - , y a su lado riquezas naturales como el Parque Nacional de Iguazú y el Parque Nacional de la Sierra de apibara, uno de los ejemplos más extraordinarios de bosques de floresta tropical.”
} 
devessem ser objetos fundamentais de atração turística, massa de manobra da "indústria cultural", ou seja, recursos mercadológicos; o que vem ocorrendo, especialmente, em Diamantina. ${ }^{45}$ A Convenção é clara, o objetivo primordial está na conservação, defesa, formação de uma opinião pública responsável de preservação e em sua divulgação para todos os povos (inclusive amarra contrapartidas para os casos de apropriação descabida dos bens inscritos, incluindo-os na Lista do Patrimônio Mundial em Perigo). Deve-se divulgar os bens, sobretudo, com o objetivo de se criar um "ambiente" conservador, de defesa do patrimônio cultural e natural de todo o planeta, representantes da evolução do homem e da produção do espaço, não apenas dos bens inscritos na Lista, mas de todos os bens estabelecidos nos territórios nacionais. De acordo com a Convenção, em seu quarto e décimo primeiro Artigos,

\begin{abstract}
Cada um dos Estados-partes na presente Convenção reconhece que a obrigação de identificar, proteger, conservar, valorizar e transmitir às gerações futuras o patrimônio cultural e natural (...) situado sobre seu território, Ihe incumbe primordialmente. Procurará tudo fazer para esse fim, tanto por seu próprio esforço, utilizando o máximo dos recursos disponíveis, quanto mediante a assistência e cooperação internacional de que possa se beneficiar, notadamente nos planos financeiros, científicos e técnicos (...) O Comitê organizará, manterá em dia e publicará, quando exigirem as circunstâncias, sob o título de "Lista do Patrimônio Mundial em Perigo", uma lista dos bens constantes da Lista do Patrimônio Mundial para cuja salvaguarda sejam necessários grandes trabalhos e para os quais tenha sido pedida assistência (...) Nessa Lista do Patrimônio Mundial em Perigo serão incluídos bens do patrimônio cultural e natural que estejam ameaçados de perigos sérios e concretos, tais como risco de desaparecimento devido à degradação acelerada, projetos de grandes obras públicas ou privadas, rápido desenvolvimento urbano e turístico, destruição propiciada por mudanças de utilização ou de propriedade da terra. (UNESCO, 2007a, p. 03 e 06, tradução e grifo nosso) ${ }^{46}$
\end{abstract}

\footnotetext{
${ }^{45}$ Consideramos que a atividade turística é catalisada e é portadora de caracteres da própria globalização que, segundo Santos (2000), representa “uma competitividade que destroça solidariedades”, freqüentemente horizontais, e que impõe uma solidariedade vertical, cujo epicentro é o capital especulativo e hegemônico, obediente aos interesses globais e indiferente ao lugar e seu entorno, como o próprio turismo. Para Santos (2000), as ações externas individualizantes não buscam sentido de benefícios para a vida local. Logo, a globalização cria a ilusão de que tudo tende a se assemelhar e a se tornar homogêneo, mero engano. A globalização que combina com integração e homogeneização, rima com o binômio diferenciação e fragmentação, apresenta-se enquanto uma "fábrica de perversidades” (SANTOS, 2000).

46 “Chacun des Etats parties à la presente Convention reconnaît que l'obligation d'assurer l'identification, la protection, la conservation, la mise em valeur et la transmission aux génerations futures du patrimoine cultural et natural (...) situe sur son territoire, lui incombe en premier chef. Il s'efforce d'agir à cet effet tant par son propre effort au maximum de sés ressources disponibles que, le cãs échéant, au moyen de l'assistance et de la coopération internationales dont il pourra bénéficier, notamment aux plans financier, artistique, scientifique et technique (...) Le Comitê établit, met à jour et diffuse, chaque fois que les circonstances l'exigent, sous le nom de 'liste du patrimoine mondial em péril', une liste des biens figurant sur la liste du patrimoine mondial pour la sauvegarde desquels de grands travaux sont nécessaires et pour lesquels une assistance à été demandée (...) Ne peuvent figurer sur cette liste que des biens du patrimoine culturel et
} 
Ainda, em seu vigésimo sétimo Artigo, a Convenção exige que os Estadospartes fortaleçam a apreciação e o respeito de seus povos pelo patrimônio cultural e natural, sobretudo, por meio de programas educativos, "obrigar-se-ão a informar amplamente ao público das ameaças que pesem sobre esse patrimônio". Essa diretriz aproxima-se da busca do desenvolvimento de valores afetivos da população local em relação aos seus bens culturais.

Não é por acaso que o Comitê recomendou a elaboração de um plano de reabilitação integral da parte histórica da cidade de Ouro Preto (MG), em razão dos danos causados pelo turismo, ou, no caso de Salvador (BA), o Comitê do Patrimônio Mundial estimulou a realização de grandes trabalhos para a restauração e revalorização do núcleo tombado, principalmente da área do Pelourinho, cuja definição de novas funções daquela área e o deslocamento de seus habitantes motivaram o Comitê a organizar um grupo formado por especialistas internacionais e por autoridades regionais e locais para debater esse dilema controverso, como nos aponta Silva (2003).

Nesse sentido, entendemos que, com a atual relativização do tempo e do espaço propiciada pelas possibilidades de comunicação e circulação contemporâneas, com a universalidade das técnicas e das formas, que tendem a uniformizar e a pasteurizar os estabelecimentos humanos, a preservação da paisagem urbana histórica pode contribuir como suporte para a investigação de valores culturais e sociais da construção de cada nação, favorecendo o uso sustentável e coletivo do patrimônio urbano. ${ }^{47}$ Mais recentemente, a própria UNESCO reconhece a conservação da paisagem urbana histórica como "uma das missões mais árduas de nossa época", dado o aumento exorbitante da população mundial viva em zonas urbanas e das previsões de aumento desse número, bem como a incapacidade dos políticos em reconhecer e em facilitar o uso sustentável dos bens patrimoniais, "les pressions sur les villes historiques vont continuer à augmenter" (UNESCO, 2007, p. 01).

naturel qui sont menacés de dangers graves et précis, tels que menace de disparition due à une dégradation accélérée, projets de grands travaux publics ou prives, rapide développement urbain et touristique, destruction due à des changements d'utilisation ou de propriété de terre.”

47 É no urbano que está mais evidente a tendência contemporânea à mundialização, ou segundo Carlos (1993), “é onde a fragmentação aparece com mais força” (p.306), seja para a produção, para o consumo, para a residência ou para o lazer. A totalidade nos coloca diante da mundialidade em constituição; o capitalismo, o estado e o lugar se mundializam, o mercado mundial permite perceber a convergência dos fluxos de informação e mercadorias. O capitalismo constitui-se em totalidade contornando, destruindo e absorvendo os obstáculos, de acordo com Carlos (1993, p. 306) 
Seja como for, o surgimento da noção de Patrimônio Cultural da Humanidade ou Patrimônio Mundial, contribui, de acordo com Nigro (2001), para uma imensa divulgação do patrimônio e para a consolidação de sua defesa como um direito fundamental do ser humano, que deve estimular diversos setores da sociedade civil à causa patrimonialista. Ao nosso ver, também é evidenciada uma "ultravaloração" do espaço quando esses bens da cultura, ao adquirirem o caráter nobre e soberano do título de reconhecimento internacional, são apropriados, estrategicamente, pela "indústria cultural", que ressignifica os núcleos urbanos tombados através da implantação, na maioria das vezes, de um turismo negligente com a sociedade e com o lugar, que revalora o patrimônio, produz novas espacialidades, novas distinções e relega os objetivos primordiais dos órgãos nacionais e internacionais de preservação, o que identificamos de forma perversa em Ouro Preto, Tiradentes e, incipientemente, em Diamantina.

Ao ser destituído de seus tradicionais conteúdos significativos com o advento de novos usos que o mercantiliza e banaliza, o patrimônio deixa de ser símbolo memorial local, nacional e mesmo mundial, é entregue ao bel sabor do mercado fluído, seu lugar passa a ser o mundo virtual, veloz e quantitativo da globalização. Há de se refletir sobre a força desse processo capaz de mercantilizar o inalienável, ou seja, os bens símbolos de passagem e permanência, desejos e medos, do espaço-tempo. ${ }^{48}$

Vê-se uma séria ambigüidade nos espaços dotados dos bens memoráveis da história humana. Preservados, inicialmente, com o objetivo de resgatar os símbolos de formação de territórios e de nações e, posteriormente, com o intuito de resguardar uma materialidade de significativo valor universal excepcional e autenticidade, o patrimônio cultural, em algumas cidades brasileiras, como Diamantina, hoje, é investido de valor de troca, torna-se uma mercadoria inserida no mercado global de competição entre as

\footnotetext{
${ }^{48}$ Acreditamos que algumas conseqüências da intensificação do processo de globalização, como a diminuição dos custos de transporte, a redução das barreiras espaciais para o movimento de bens, capital, pessoas e informação, contribuem para realçar a importância das qualidades dos lugares e fortalecer consideravelmente o vigor da concorrência interurbana para o desenvolvimento econômico local, onde a "indústria cultural” atua através do processo de "valorização do espaço”, como vem ocorrendo em Diamantina. Para Harvey (2005), a valorização de regiões urbanas degradadas, inovação cultural, melhoria física do ambiente urbano e atrações para o consumo e entretenimento se tornaram facetas proeminentes das estratégias para regeneração urbana; a cidade aparece como um lugar inovador, estimulante, criativo e seguro para se viver ou visitar, para se divertir ou investir; lógica “encarnada” em Diamantina e que a imprime novos sentidos ao ser consagrada como Patrimônio Mundial e contemplada com o Programa Monumenta. Festivais e eventos culturais também se tornam foco das atividades de investimento; de acordo com Harvey (2005), a cultura do "é possível fazer" torna-se essencial para o desenvolvimento do empreendimento cultural, onde as atividades culturais e as artes “podem ajudar a romper a espiral descendente da estagnação econômica nas cidades do interior” (p.176).
} 
cidades, onde o turismo aparece como a "indústria" vetora do processo (COSTA e CASTRO, 2008a).

A ambigüidade ganha força no instante em que, mundializado, convivendo com a nova lógica da relativização do espaço-tempo, com o avanço técnico, científico e informacional, os lugares do patrimônio, gradativamente, deixam de pertencer aos habitantes do local, apesar de mundializado, uma dramática contradição (é mundial e vem deixando de ser local?). A mercantilização dos núcleos propicia uma intensa "banalização pela cenarização" que acaba por "mascarar" o sentido dado inicialmente a esses bens, enquanto símbolos de identidade, cultura e memória das nações e dos povos da humanidade; infelizmente, não assumem uma função na vida da coletividade, atendem, sobretudo, aos anseios exclusivos de uma classe e não são, verdadeiramente, compartilhados e preservados para a posteridade e toda humanidade, de acordo com as diretrizes do Comitê do Patrimônio Mundial, via Convenção.

No estado de Minas Gerais (dedicamo-nos, nos últimos anos, à análise da apropriação estratégica dos núcleos urbanos tombados, nesse estado), enquanto Patrimônio Mundial, Diamantina (foto 01), Ouro Preto (foto 02) e Congonhas (foto 03) vivem essa lógica, cada qual à sua intensidade e contexto específico de cada lugar. Além de outras cidades que, apesar de não consagradas como Patrimônio Mundial, são tombadas pelo Instituto do Patrimônio Histórico e Artístico Nacional (IPHAN) e passam pela mesma dinâmica dos novos fluxos dirigidos pela implantação de um turismo desordenado e crescente, como é o caso de São João Del Rei (foto 04) e Tiradentes ${ }^{49}$ (foto 05).

\footnotetext{
${ }^{49}$ Para análise do turismo e produção do espaço em São João Del Rei e Tiradentes, ver Costa (2005, 2007 e 2008) e Costa e Castro (2008a).
} 


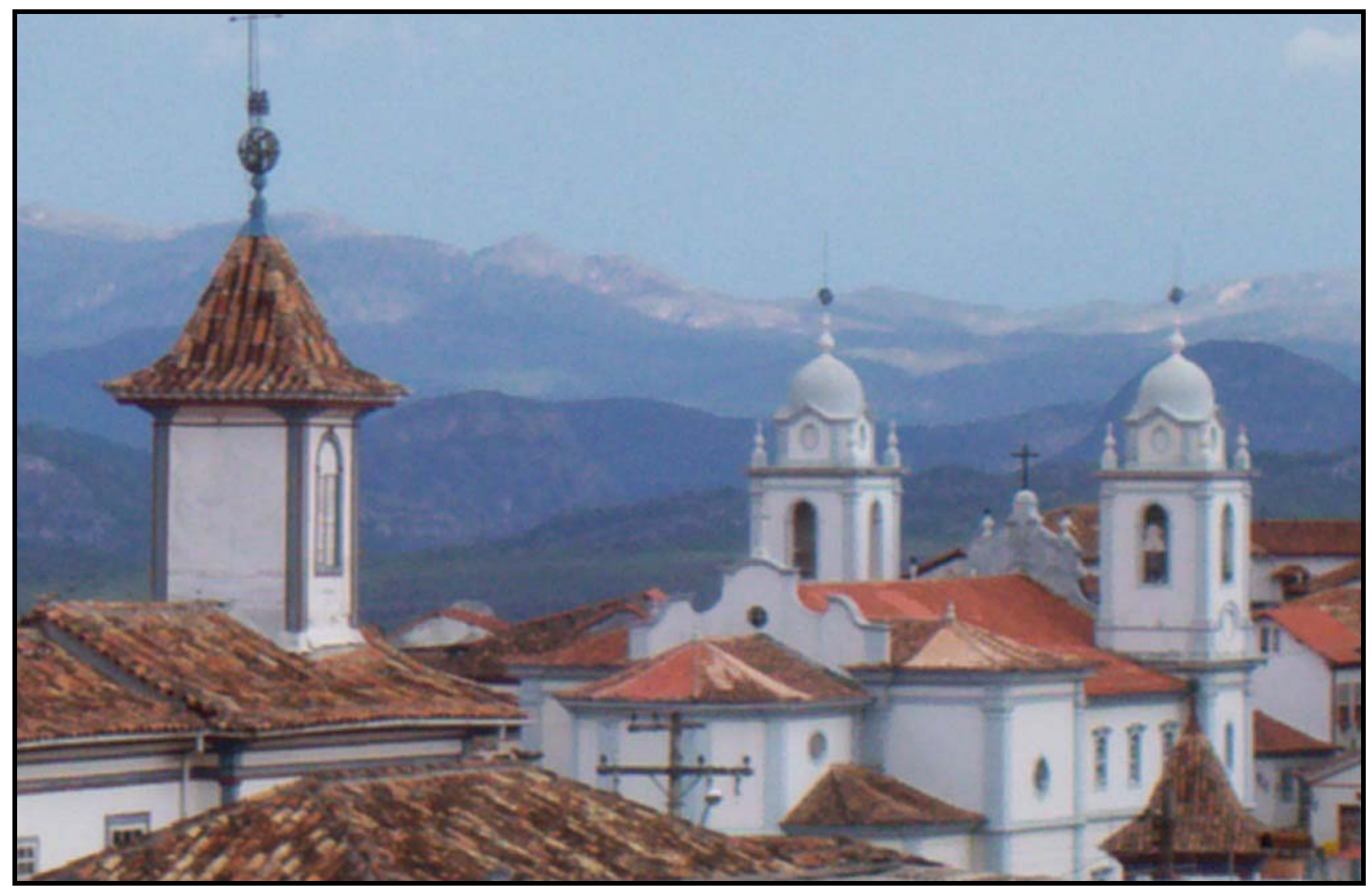

Foto 01: Igreja de Nossa Senhora do Amparo e Basílica, em Diamantina, no complexo do Espinhaço; está a $1400 \mathrm{~m}$ de altitude, ao norte de Minas Gerais, Brasil.

Foto do autor, jan/2008. 


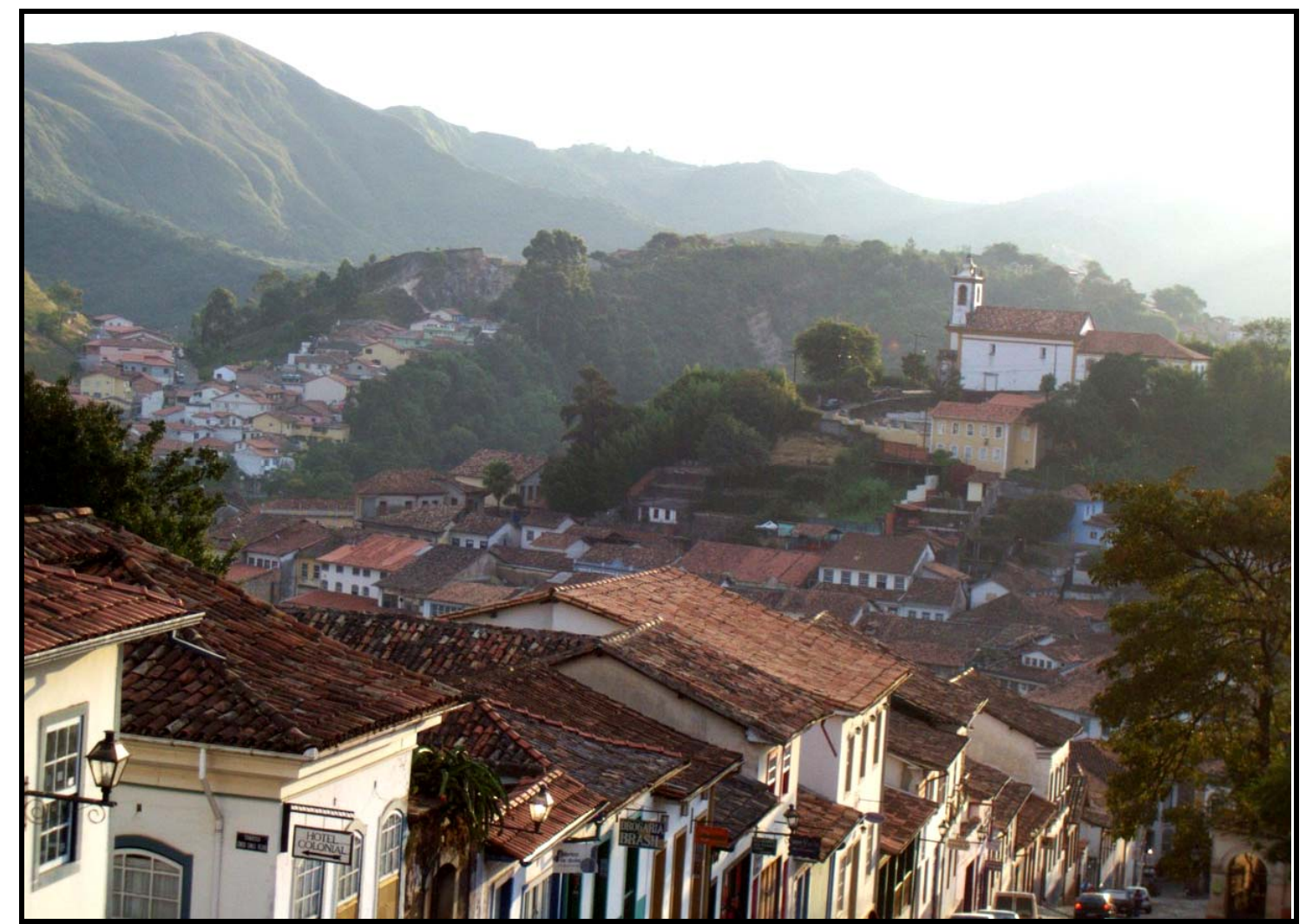

Foto 02: Vista parcial do centro histórico de Ouro Preto, MG, Brasil. Foto do autor, maio/2008.

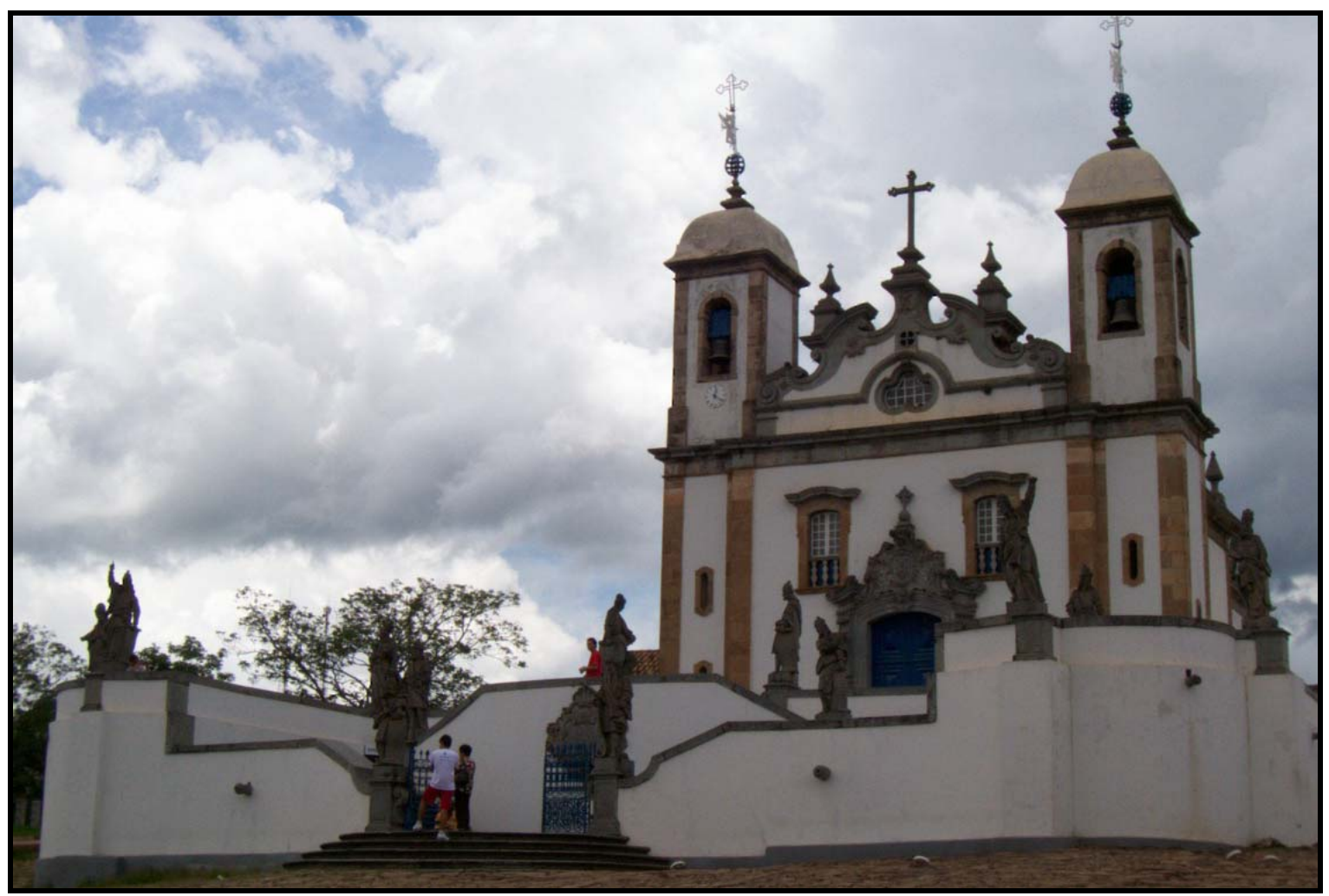

Foto 03: Santuário do Bom Jesus do Matozinhos, Congonhas do Campo, MG, Brasil. Foto do autor, jan/2008. 


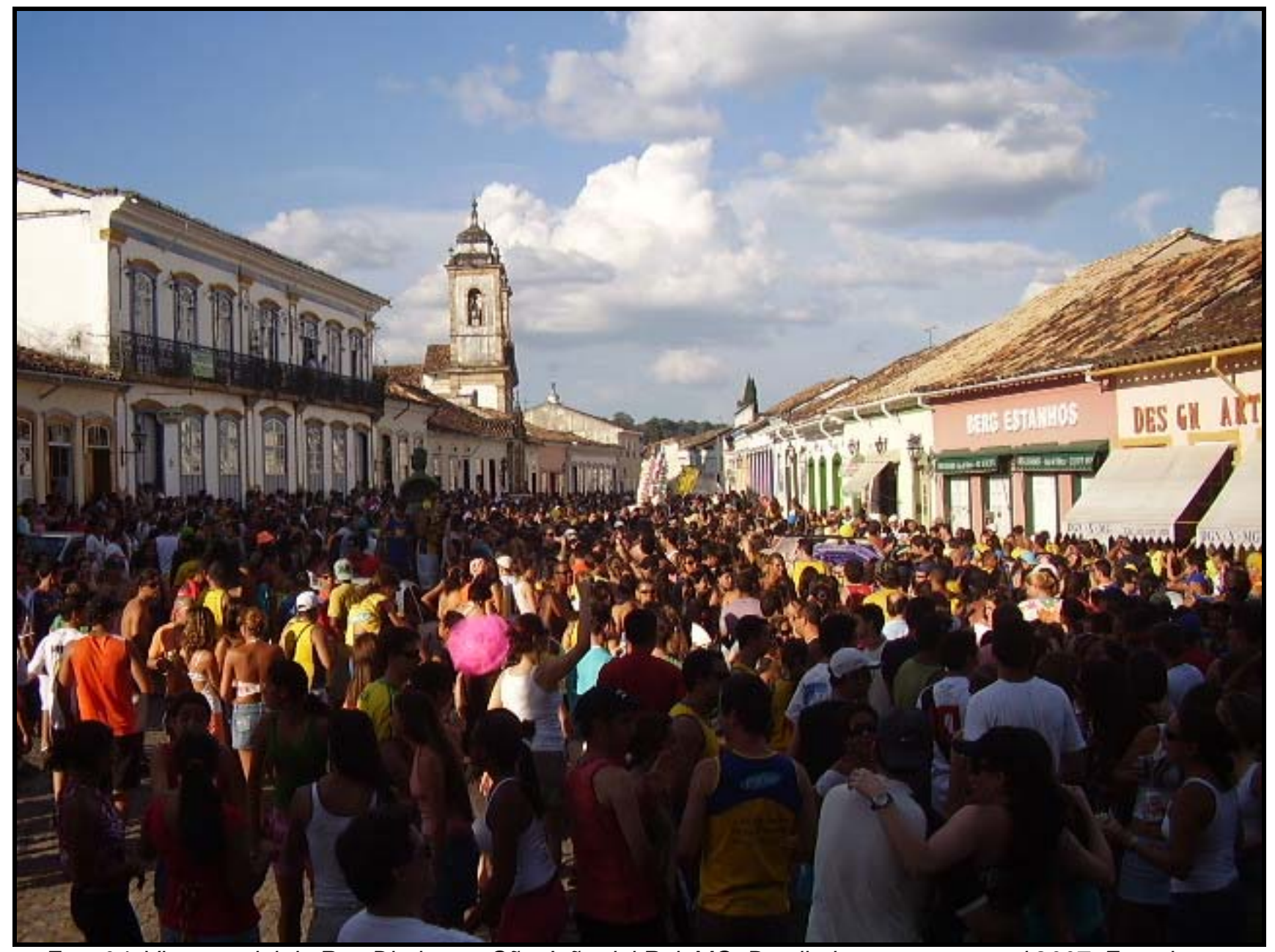

Foto 04: Vista parcial da Rua Direita em São João del Rei, MG, Brasil, durante o carnaval 2007. Foto do autor, jan/2007. 


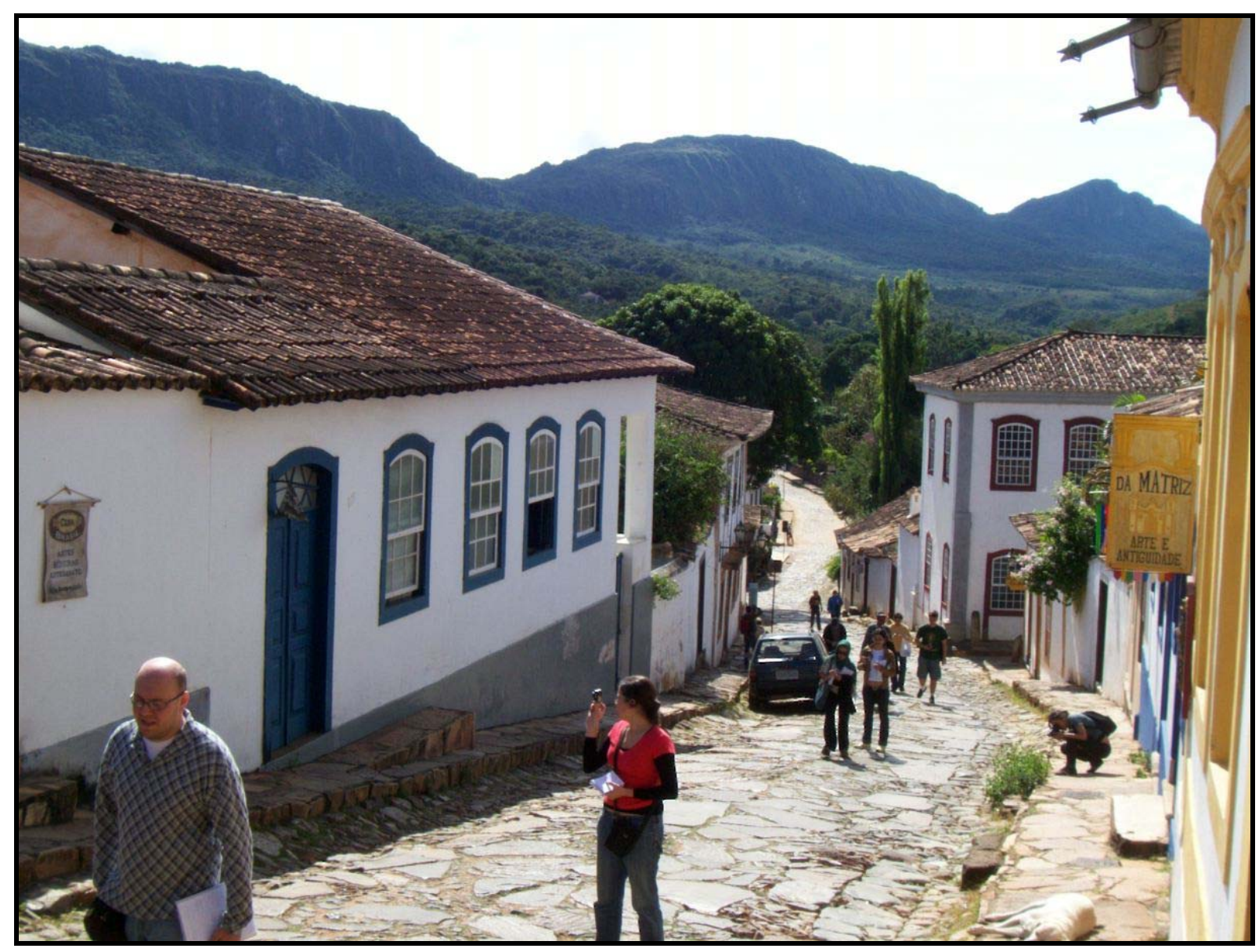

Foto 05: Rua da Câmara em Tiradentes; uma das ruas mais antigas, que integra o sítio original da cidade. Foto do autor / maio de 2008.

De acordo com nossa problemática, a inclusão de Diamantina na Lista do Patrimônio Mundial constitui-se no primeiro processo significativo contemporâneo de valorização do espaço urbano, contudo, uma valorização que caminha para uma política de patrimônio que desvia a atenção pública e recursos de problemas mais amplos, sobretudo, fora do núcleo tombado, produzindo uma cidade fragmentada também pela faceta mercantil da preservação de patrimônio, como atestamos em nossas análises de campo e apresentaremos na terceira parte desta pesquisa.

Logo, o recebimento da chancela da UNESCO, via Comitê do Patrimônio Mundial, dado o caráter ambicioso e imediatista de agentes públicos e de mercado de cada Estado-parte, torna-se o filão para a intensa e programada valorização simbólica dos bens culturais, que transforma a cultura num novo gênero de mercadoria, objetivo precípuo da "indústria cultural", pois é o estímulo a essa valorização simbólica que acarreta na valorização econômica dos bens culturais (vitória da troca sobre os modos de 
uso), contrariando as propostas primeiras da UNESCO ${ }^{50}$. Já afirmamos que a intensa e programada valorização simbólica ${ }^{51}$ dos bens culturais atribui-lhes valor de mercado, que na análise geográfica desse processo, significa a evidência do "valor do espaço"52.

Há uma vertiginosa corrida dos países pela inscrição de seus bens culturais na

Lista do Patrimônio Mundial, conformando numa geografia específica do Patrimônio Cultural da Humanidade. Essa corrida, que caracteriza um verdadeiro frénésie, produz desequilíbrios no tocante aos países e continentes contemplados na Lista, evidenciando nossa sociedade altamente complexa, fragmentada e extremamente desigual, o que se torna um paradoxo esboçar o conceito de humanidade vinculado na diversidade cultural dos povos e na busca de maior integração entre as nações. Essa realidade reflete uma "humanidade" híbrida, massificada, unificada, porém, não unida. Segundo Milton Santos, “nunca houve uma humanidade, agora que está havendo, essa que é a 'coisa', estamos fazendo ensaios do que será a humanidade."53

\begin{abstract}
Naturalmente, a declaração de bem do patrimônio da humanidade tem, do ponto de vista do turismo, limitações significativas. Como contrapartida, é indubitável e evidente que em quase todos os casos, praticamente em todos, os grupos interessados que promoveram a declaração foram movidos, ao menos em parte, pelo interesse turístico. Em último caso, a declaração de bem do patrimônio da humanidade cria uma imagem a nível mundial que atrai, que pode atrair uma série de visitantes, cria uma imagem que provoca curiosidade, no mínimo, e que cria interesses que podem ser científicos ou que podem ser puramente relacionados ao ócio. (BOSQUE, 1996, p. 84, tradução nossa)
\end{abstract}

Torna-se relevante frisarmos, desde já, nosso ponto de vista de que seja no turismo ou em qualquer outra "indústria" humana, o que se deve enfatizar não são apenas

\footnotetext{
${ }^{50}$ De acordo com Santos (1993, tradução nossa), as normas se estabelecem em diferentes níveis geográficos e políticos, mas levando em conta a competitividade numa escala global, as normas globais, induzidas por organismos supranacionais e pelo mercado, têm a tendência de configurar o resto dos objetos e a totalidade do espaço, onde todos os espaços mostram a presença simultânea das horizontalidades e verticalidades.

${ }^{51}$ Consideramos que se a valorização simbólica dos objetos não estiver comprometida, primeiramente, com o objetivo de preservação de nossa identidade ou da memória e sim com uma necessidade única e negligente de se agregar valor econômico aos bens culturais, corre-se o risco de se metamorfosear e perdermos um suporte espacial original, modos de vida e a visão que nossos antepassados tinham do mundo, através de suas representações e construções.

${ }^{52}$ Retomando nossa análise inicial, o "valor do espaço” é transferido no processo de trabalho para o produto "através das características próprias de cada lugar” (MORAES e COSTA, 1996, p.122), o que ocasiona uma heterogeneidade na produção e apropriação de subespaços, onde singularidades são estabelecidas através do trabalho humano; valores distintos são atribuídos a estruturas socioespaciais distintas. Essa valorização diferencial do espaço produz e reproduz ao mesmo tempo em que fragmenta e destrói, ocasionando disparidades socioespaciais, hoje, induzidas, também, pela criação de singularidades e excepcionalidades evidenciadas no espaço por meio de novas estratégias do capital.

53 Documentário: “Encontro com Milton Santos: ou o mundo global visto do lado de cá”, 2006.
} 
os bens, sentidos, valores, a permanência ou não da atividade em si, mas a relação estabelecida entre os homens. Seja qual for a atividade desenvolvida por grupos sociais, o que caracterizará a situação social geral, segregados e beneficiados, a democratização ou o império da mercantilização dos bens culturais, são os tipos de interações estabelecidas, julgadas coerentes, aceitáveis e cabíveis, essas sim, ditarão o padrão da sociedade instituída, a fragmentação ou não do mundo vivido, do lugar ou da humanidade. Nossa crítica dirige-se às ações, não aos meios encontrados para espacializá-las (a turistificação dos lugares, por exemplo), pois esses, em mãos de agentes verdadeiramente comprometidos com a promoção da gestão participativa dos núcleos urbanos tombados, na qual os residentes tenham a palavra final, podem servir para a edificação de uma sociedade justa, igualitária e de lugares não-fragmentados, espaços, primordialmente, dos cidadãos, que escapem da dialética da construção destrutiva que enreda a consagração dos bens culturais do mundo, transformando a realidade e o imaginário de populações locais, como identificamos em Diamantina e discorreremos na terceira parte desta pesquisa. $^{54}$

Ideal seria a implementação de projetos turísticos voltados, verdadeiramente, ao desenvolvimento local, onde a população residente, o turista e o turismo sejam, todos, beneficiados mutuamente. Tarefa um tanto difícil de ser realizada, dado o interesse imediatista de nossos representantes e o unilateralismo dos agentes de mercado. (COSTA, 2007, p.39)

\footnotetext{
${ }^{54} \mathrm{O}$ que denominamos dialética da construção destrutiva na consagração do patrimônio é representado pelo próprio processo longo, contínuo, simultâneo, relacional e contraditório de "preservação” x "mercantilização”, “construção” x “desconstrução", “valor de uso” x "valor de troca” que envolve instituições, organizações, agentes públicos e privados com ideologias e interesses, muitas das vezes, discordantes sobre os bens culturais, sobre a produção do espaço e sobre a cidade e sua funcionalidade. Enquanto que organismos internacionais como a UNESCO e instituições nacionais como o IPHAN são representantes dos verdadeiros "guardiões” dos bens culturais do mundo, a associação de agentes públicos e privados - descompromissados - aparece em contraponto, calcados na ideologia mercantil que enreda a "indústria cultural” dinamizada pelos novos instrumentos da globalização atual. Assim, essa dialética tem início no plano teórico e das ações dos organismos de preservação de patrimônio (construção) frente às novas "ideologias”, teorias e práticas estabelecidas nos lugares (desconstrução) tidos como especiais, singularidades, originais, autênticos e irreplicáveis por parte de agentes locais. Na prática, essa dialética rebate sobre o território urbano, estabelecendo espacialidades díspares que representam o descompromisso público-privado com a sociedade e com o lugar. Envolvendo essa lógica complexa, contraditória e relacional, as normas e diretrizes criadas por organismos compromissados com a preservação do patrimônio tornam-se instrumentos de poder nas mãos dos agentes da "engenharia patrimonial”, da mercantilização cultural.
} 


\title{
2.2. A geografia desigual do Patrimônio Mundial
}

Já afirmamos que o reconhecimento de valores, sobretudo no campo do patrimônio, tem uma dimensão política. As ações direcionadas para a "construção" do patrimônio cultural não representam apenas anseios simbólicos e cognitivos, mas, sobretudo, práticos e concretos. Meneses (1992. p. 189) também reconhece que a centralidade de qualquer preocupação relativa ao patrimônio cultural (identificação, proteção, valorização) é político por natureza, hoje em dia, uma preocupação política com o viés econômico predominante.

Isso implica em afirmar que a preservação do patrimônio adquire dupla funcionalidade, contraditoriamente; por um lado assume a busca da identidade, do saber, da história e da memória, que não podemos negar; por outro lado, o patrimônio adquire um caráter mercadológico, é um produto cultural fabricado, empacotado e vendido para platéias exclusivas; é uma dialética que envolve a questão patrimonial, hoje, mundialmente. Segundo Choay (2006, p. 211),

\begin{abstract}
A metamorfose de seu valor de uso em valor econômico ocorre graças à "engenharia cultural", vasto empreendimento público e privado, a serviço do qual trabalham grande número de animadores culturais, profissionais da comunicação, agentes de desenvolvimento, engenheiros, mediadores culturais. Sua tarefa consiste em explorar os monumentos por todos os meios, a fim de multiplicar indefinidamente o número de visitantes.
\end{abstract}

Devemos ter claro que o turismo urbano representa a quase totalidade dos fluxos turísticos mundiais, sendo que as cidades não são apenas núcleos emissores de turistas, mas também pólos receptores de intensos fluxos (CRUZ, 2003), o que se dá, em nosso entender, pelo fato de a incessante busca do lucro, ou da renda de monopólio, impor a procura ou o estabelecimento de critérios de especialidade, singularidade, originalidade e autenticidade nos lugares; daí Scifoni (2003, p. 08) afirmar que "a corrida para a inscrição na Lista do Patrimônio Mundial tem uma explicação: estar na Lista significa contar com um status internacional, prestígio e reconhecimento que é fundamental para o marketing do turismo."

Estar na Lista do Patrimônio Mundial representa, para muitos países, a inserção de seus bens culturais na mundialização dos lugares, no circuito global de 
cidades, através da atividade turística, que requer a acumulação e reafirmação tanto de um "capital simbólico" (HARVEY, 2005) como de marcos de distinção. O que se identifica é que a partir da inscrição na Lista, promove-se um bombardeio de imagens "valorativas" que produzem simulacros da história, da tradição e da cultura local, onde o marketing, a respeito de realizações artísticas relacionadas a esses valores, presta um apoio necessário à formulação desse processo de valorização espacial; coroa-se, dessa maneira, o encontro da economia com a cultura, da "mercantilização" e da "preservação", nos lugares, como se vê em Diamantina, inserida, atualmente, no circuito internacional do turismo.

A Lista do Patrimônio Mundial recebe, todos os anos, novas inscrições de bens dos países signatários da Convenção do Patrimônio Mundial. Com base na Liste des Etats parties la Convention du patrimoine mondial, Répartition des biens du patrimoine mondial dans les Etats parties et Composition du Comitê du patrimoine mondial depouis 1976, editado pela 16 ${ }^{\text {a }}$ Sessão da Assembléia Geral dos Estados-partes na Convenção do Patrimônio Mundial, no ano de 2007, identificamos a existência de 184 países signatários e nada menos que 851 bens ${ }^{55}$ incluídos na Lista e distribuídos entre 141 dos países, uma distribuição que se apresenta, geograficamente, desigual.

De acordo com Silva (2003), o Comitê do Patrimônio Mundial, desde sua primeira sessão, objetivou promover um modelo de Lista do Patrimônio Mundial que representasse um número equilibrado de bens culturais e naturais de todas as áreas do planeta, a partir da idéia de universalidade que envolve a Lista. "Espera-se que um dia a Lista tenha um caráter plenamente universal e que sirva de referência definitiva das obrasprimas da cultura e da natureza cujo destino concerne, hoje, a todos os países e a todos os homens" (ZARAGOZA, 1988, apud Silva, 2003, p. 91).

Bosque (1996), um tanto determinista, tenta justificar o que denominamos geografia desigual da Lista. Para ele, essa realidade é justificada pelas variações lógicas no desenvolvimento natural da história da Terra. O autor faz uma comparação entre o Brasil e a Espanha, onde o primeiro concentra maior número de riquezas naturais que o segundo, o que o faz ter maior número de bens naturais inscritos na Lista. Quanto aos bens culturais, a Espanha possuir, de acordo com Bosque (1996), maior diversidade monumental retratada que o Brasil justifica-se por sua história "mucho más larga y mucho

\footnotetext{
${ }^{55}$ Os 851 bens englobam 660 sítios culturais, 166 sítios naturais (patrimônio natural) e 25 bens mistos.
} 
más complicada", o que faz ser natural possuir maior número de bens inscritos. Para nós, essa geografia desigual da Lista deve ser encarada no plano da política e da economia mundial, ou seja, no próprio quadro das relações internacionais, na posição de cada país signatário, no cenário planetário, e não determinada pelo quadro natural ou histórico de cada país. Essa desigualdade está ligada, na verdade, ao poder de atuação/persuasão político-econômica de cada país signatário, uma vez que identificamos uma espacialização desequilibrada do Patrimônio Mundial, cuja distribuição dos bens esboça uma desigualdade perante uma humanidade que se diz e se quer constituída e integrada.

Nosso mapa representa a lógica geográfica desigual que identificamos na Lista (UNESCO, 2007a). Primeiramente, indagamos o seguinte: Qual o critério adotado para a classificação dos bens do Patrimônio Mundial por regiões? Pois, aparecem distribuídos em cinco grandes regiões do globo, de acordo com a Lista estabelecida pela Convenção, da seguinte forma:
1) Europa (inclusive Federação Russa) junto a toda América do Norte;
2) África;
3) Ásia e Pacífico;
4) Estados Árabes; e
5) América Latina e Caribe, conforme o mapa.

Nosso segundo questionamento diz respeito aos motivos que levam os países signatários a uma corrida vertiginosa pela inscrição de seus bens culturais e naturais na Lista, ocasionando um frénésie pela chancela da UNESCO.

O mapa (representação da Lista) remete-nos à velha concepção de um mundo bipolar, não no sentido do período da guerra-fria, do conflito entre capitalistas e comunistas (leste / oeste), mas, sobretudo, no contraste da hegemonia do "mundo do norte" sobre o "mundo do sul", envolvendo a ideologia do capital e da mais-valia. A junção Europa / América do Norte, na classificação dos bens do patrimônio mundial, dá ainda mais visibilidade aos principais destinos turísticos do mundo, localizados nos dois continentes do hemisfério norte. O desejo de maior "visibilidade" internacional orienta esse critério de "regionalização", em nosso ponto de vista, tendencioso e parcial. Precisamos reconhecer também que essa supremacia dos países do norte na Lista reflete um ideário 
de valores construídos e mundializados sob bases de uma hegemonia político-econômica construída no cenário internacional do pós-guerra, que demonstra um continuísmo cíclico da geopolítica mundial. 


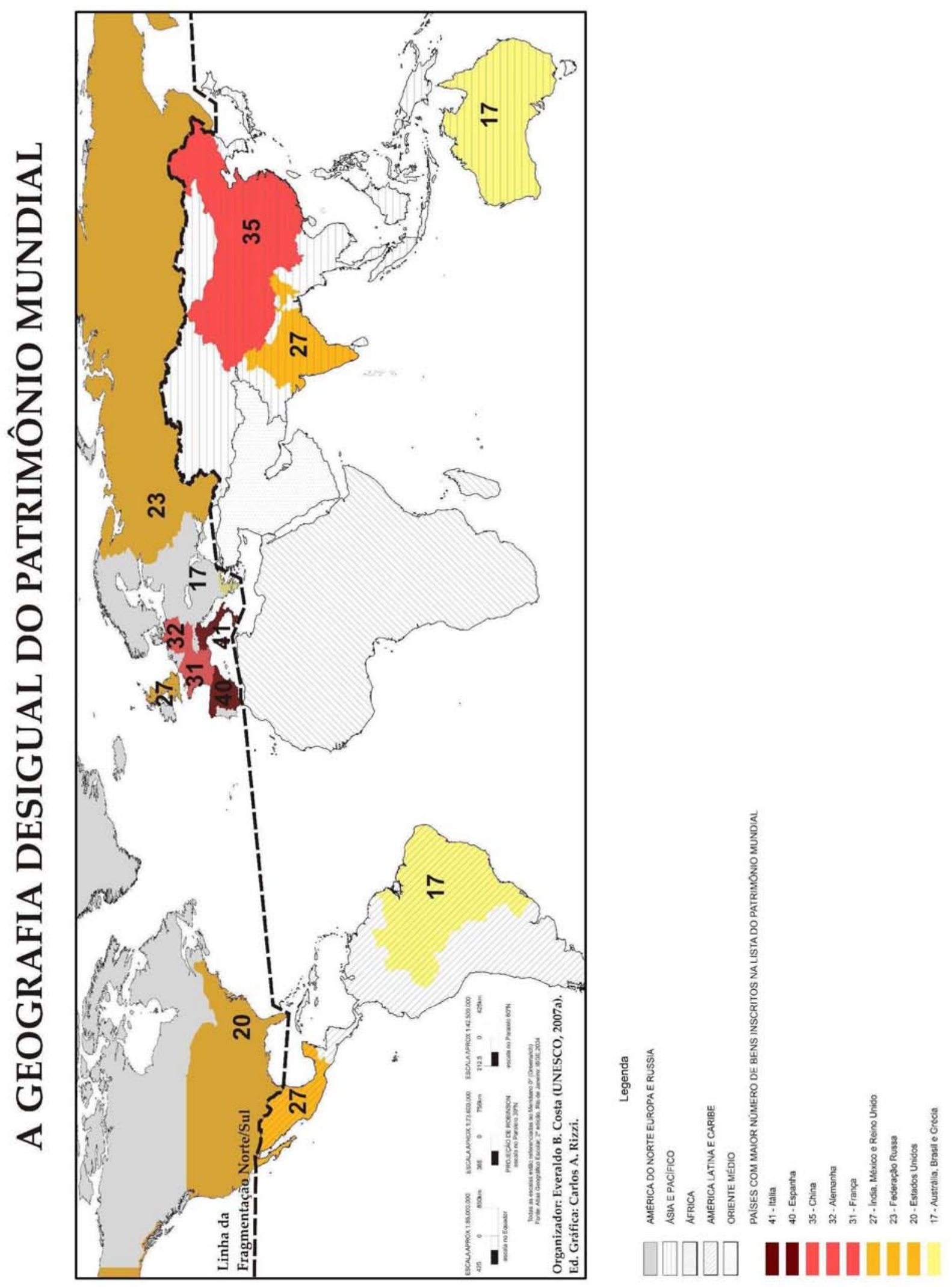


Nessa fragmentação norte / sul, fica evidente que mais da metade dos bens inscritos pertencem aos países do norte, como demonstramos no gráfico 01 abaixo e representamos, também, no mapa.

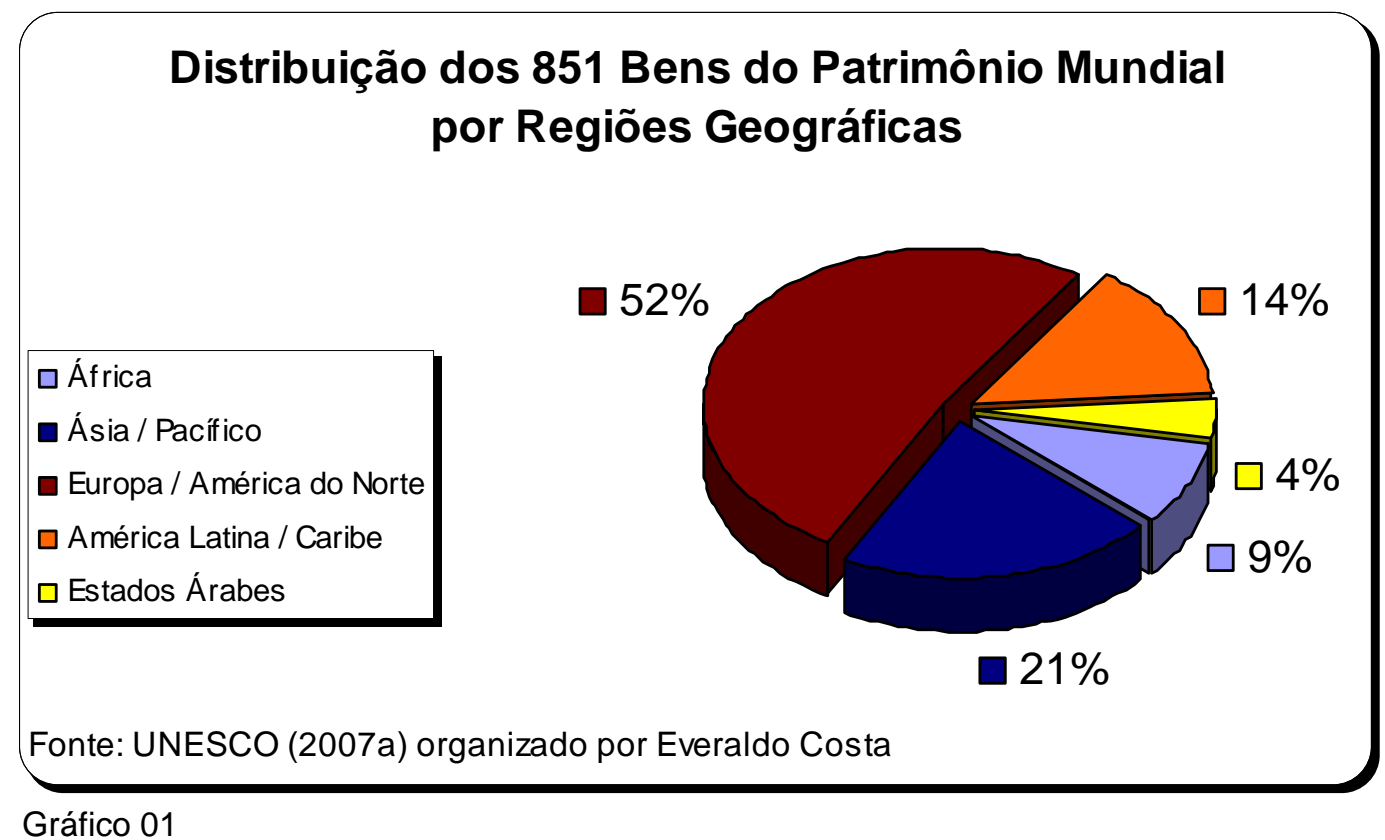

Encabeçam a Lista, a Europa e América do Norte, seguidas pela Ásia, depois América Latina, a África e por fim, os Estados Árabes. Afirmar que o desequilíbrio da Lista deve-se ao longo processo de produção territorial ou "formação socioespacial" dos países consagrados é, no mínimo, desenvolver a análise na ótica eurocêntrica, pois temos, na representação, por um lado, os Estados Unidos liderando junto à Europa na classificação dos bens inscritos da Lista, um país de formação territorial, relativamente, recente; por outro lado, temos os Estados Árabes, cuja produção de seus territórios e formações culturais datadas de milênios, como os relegados do processo, são pouco representativos na Lista (as guerras pelas quais passaram teriam devastado todo acervo cultural desses países?). A tendência da concentração da economia mundial nos países do norte persiste, agora, forjando-se uma nova mercadoria, o Patrimônio Cultural da Humanidade, consagrado, singularmente, pelo turismo, uma das "indústrias" que mais cresce em todo o mundo.

Apesar do desequilíbrio geográfico na distribuição dos bens mundiais, que identificamos através da Lista do Patrimônio Mundial, é necessário esclarecer que, em 
1994, o Comitê do Patrimônio Mundial lançou sua Stratégie globale pour une Lista du patrimoine mondial équilibrée, représentative et crédible (UNESCO, 2007), para responder à preponderância dos bens culturais sobre os bens naturais, na Lista, e também numa tentativa de deixar claro o próprio "desconforto" da Organização pelo fato de a maioria dos bens estarem situados nos países desenvolvidos, notadamente, na Europa. Decorridos 15 anos, o desequilíbrio permanece, a hegemonia do norte continua notória, conforme nosso mapa e gráfico 01.

A análise de Scifoni (2006) remete-nos à existência de um fervor "contemporâneo ao culto do passado", na Europa, de forma que a preservação do patrimônio atinge um estágio tal que se tornou um princípio primeiro, se generalizou como fundamental, alcançando um excesso de conservação, naquele continente. Jeudy (2005, apud Scifoni, 2006, p. 62) cita as evidências desse excesso: "a prioridade total nos centros históricos pela restauração de fachadas; o esgotamento da identificação e da proteção do patrimônio industrial; a expansão das pesquisas etnográficas que buscam identificar todas espécies de rito, de simbolismos; a preservação até mesmo a memória de catástrofes". De acordo com o autor, essa "obsessão" pelo patrimônio tem relação com a formação de uma consciência coletiva dos riscos da perda dos referenciais de memória e de identidade, que se desenvolveu nas últimas décadas.

Todavia, ao analisarmos os dados da UNESCO, fica claro que não é apenas a necessidade de se preservar a memória do passado que permeia a "obsessão" atual pelo patrimônio. Os bens culturais passam a desempenhar papel fundamental no desenvolvimento do turismo internacional, haja vista o número crescente de bens inscritos, nos últimos anos, pelos principais destinos turísticos do mundo, inclusive, fora da Europa. Vejamos a tabela 1, que traz a classificação, por ordem decrescente, dos bens do patrimônio mundial, "coincidentemente", alguns dos principais destinos do turismo internacional:

\begin{tabular}{|l|c|}
\hline \multicolumn{2}{|c|}{ PAÍSES COM O MAIOR NÚMERO DE BENS DO PATRIMÔNIO } \\
MUNDIAL ATÉ O ANO DE 2007 (ORDEM DECRESCENTE) \\
\hline \multicolumn{1}{|c|}{ PAÍS } & $N^{\circ}$ DE BENS NA LISTA \\
\hline \multicolumn{1}{|c|}{} & 41 \\
\hline Itália & 40 \\
\hline Espanha & \\
\hline
\end{tabular}




\begin{tabular}{|l|c|}
\hline China & 35 \\
\hline Alemanha & 32 \\
\hline França & 31 \\
\hline Índia & 27 \\
\hline México & 27 \\
\hline Reino Unido & 27 \\
\hline Federação Russa & 23 \\
\hline Estados Unidos & 20 \\
\hline Austrália & 17 \\
\hline BRASIL & 17 \\
\hline Grécia & 17 \\
\hline Tabela 1 / Fonte: UNESCO (2007) - organizado por Everaldo Costa
\end{tabular}

O turismo contribui para uma crescente busca do sentido estético das formas; formas que esvaziadas de seu conteúdo, conduzem à cumplicidade com o fetichismo, processo revelado pelos novos caminhos da pós-modernidade, segundo Lencione (1999). Para a autora, a valorização do aparente fez com que a estética se apresentasse como um novo e valorizado mito da sociedade. "Tanto quanto no lluminismo, quando o progresso aparecia como um mito; no momento atual, a estética se apresenta como mito e como tal paira acima do bem e do mal" (LENCIONE, 1999, p.182).

Essa valorização das formas, da estética, em detrimento ao conteúdo significativo, correlaciona-se ao que Harvey (2005) considera como a busca de singularidades e produção de um capital simbólico (que ocorre, sobretudo, no plano do lugar, no nosso entender), na perspectiva de se atingir a renda de monopólio e não apenas o lucro. O turismo contribui no alcance dessa meta; o que, no limite, explica a corrida vertiginosa dos países pela inscrição de seus bens culturais na Lista do Patrimônio Mundial, forjando uma irreplicabilidade fundamental para a expansão do capitalismo e a reprodução local do capital.

Torna-se premente questionar até que ponto o Patrimônio Mundial pode ou deve se constituir em uma razão turística e até que ponto o turismo pode conservar, transformar ou afetar seriamente esses bens. O que fica claro é que o Patrimônio Cultural da Humanidade revela-nos a riqueza histórica da mesma humanidade em constituição permanente, uma riqueza que, dialeticamente, vive um processo de "construção destrutiva", através das ações de preservação mediadas pelas necessidades de 
sobrevivência econômica da sociedade contemporânea (simultaneidade da preservação e da mercantilização), quer dizer, é uma preservação que se converte em mecanismo primeiro do desenvolvimento turístico, da mercantilização. ${ }^{56}$

O patrimônio é difundido, sobretudo, pelo desenvolvimento de uma lógica que ganha fôlego a partir da década de 1960, mundialmente, através da exploração turística via bens culturais, não pelas propostas primeiras das organizações de preservação. Para Nigro (2001), a exploração turística do patrimônio cultural vem ganhando destaque como instrumento de salvaguarda, viabilizando intervenções de restauro e conservação de bens culturais como ações de mercado; vê-se o amálgama das políticas de preservação com as ações interesseiras da "indústria cultural". A exploração turística do patrimônio acarreta, progressivamente, na sua intensa mercantilização e esgotamento, reduzindo-o a uma imagem-simulacro ao ser metamorfoseado seu conteúdo significativo, histórico e cultural. Nesse contexto, o Comitê do Patrimônio Mundial sugere, dado as ameaças que as cidades estão sofrendo com as novas dinâmicas do mercado, uma gestão do patrimônio que permita estabelecer a compreensão dos valores dos bens para os habitantes e o púbico em geral, e também sensibilizar a população da necessidade de proteção dos bens, dado seu valor educativo e seu potencial para o desenvolvimento social e econômico, nos lugares, de forma, sempre, participativa (UNESCO, 2007b, tradução nossa), o que pouco temos observado, no Brasil.

Assim, o patrimônio, o espetáculo e a exibição se transformam em símbolos de comunidades dinâmicas que têm na valorização simbólica aparato para a valorização do espaço e a conseqüente transformação da cultura em um novo gênero de mercadoria engendrada pela confusão entre a cultura e o lazer, na era da mundialização dos lugares. Segundo Arendt (1972, apud Mohen, 1999, p. 48),

(...) não quer dizer que a cultura se espalha pelas massas, mas que a cultura é destruída por engendrar o lazer. O resultado não é uma desintegração, mas a morte (..) O resultado não é sobre uma cultura de massa que, propriamente dita, não existe, mas um lazer de massa que se sustenta dos objetos culturais do mundo. Acreditar que uma tal sociedade seja cultivada com o tempo e o trabalho da educação é, acredito, um erro fatal. (tradução nossa).

\footnotetext{
${ }^{56}$ Os bens culturais do mundo são, hoje, cultura, mercadoria, dinheiro e “imagem mercadoria” dentro da fluidez contemporânea, das possibilidades de transparência advindas da técnica, da ciência e da informação.
} 
Nossa crítica é baseada no caráter meramente estético da apropriação do patrimônio via turismo cultural implantado, descompromissadamente, no espaço social, em sua fetichização e "banalização pela cenarização progressiva" que envolvem cidades históricas como Diamantina, Tiradentes e Ouro Preto. Essas cidades são tomadas pelo capital especulativo e hegemônico obediente aos interesses globais e indiferente ao lugar e seu entorno, retratando o que Santos (2000) reconhece como ações externas individualizantes que não buscam sentido de benefícios para a vida local.

A indústria patrimonial desenvolveu os recursos de embalagem que também permitem oferecer os centros e os bairros antigos como produtos para o consumo cultural. Estados e municípios a eles recorrem de forma reservada e discreta ou abertamente, em razão de suas opções sociais e políticas, mas sobretudo de acordo com a natureza (dimensões, caráter, recursos) do produto a ser lançado e segundo a importância relativa da renda que se espera obter (CHOAY, 2006, p. 224).

Fica claro para nós, dentro da perspectiva da consagração do Patrimônio Cultural da Humanidade, que Diamantina - apesar de contemplada pela Lista do Patrimônio Mundial dada sua formação urbano-ambiental que responde aos caracteres de universalidade, excepcionalidade e autenticidade exigidos pela UNESCO, apesar de representante inconteste de paisagem urbana histórica herdada para a humanidade - vem sendo apropriada e transformada no mais novo reduto do turismo cultural de Minas Gerais, através das alegações de singularidade e autenticidade, agora, (re)criadas pela influência de um novo discurso, o dos agentes públicos e privados ligados ao processo que resulta da intensa mercantilização das formas culturais, ou seja, à "indústria cultural", que a partir das "ideologias" enredadas pelo capital especulativo, tende a pasteurizar a sociedade e o lugar.

Em pleno "sertão" mineiro ${ }^{57}$, no Vale do Jequitinhonha, uma das áreas mais pobres do norte do estado, Diamantina não é mais protegida pela distância e pelo segredo de seu isolamento, as resultantes do processo de globalização (a própria "construção" do

\footnotetext{
${ }^{57}$ Chamamos essa parte do Vale do Jequitinhonha “sertão”, não por sua caracterização fitogeográfica, mas por ser uma região pouco povoada, ainda representando o vazio característico de um Brasil que teve em sua formação territorial o litoral como base de estabelecimento. Segundo o viajante francês Auguste de Saint-Hilaire "Os sertões em cada província são as partes mais desertas de cada uma, independendo do tipo de vegetação” (SAINT-HILAIRE, 1974, p. 209".
} 
patrimônio mundial) deixam a cidade histórica em evidência internacional, é exposta e revelada à luz de um turismo emergente e se torna acessível a "todo o mundo". Sua consagração como Patrimônio Cultural da Humanidade, ao nosso ver, constitui-se no primeiro processo significativo de valorização daquele espaço urbano, na contemporaneidade, contudo, uma valorização que acarreta em uma política de patrimônio que reproduz uma cidade fragmentada quando da dialética imperativa da troca e dos modos operantes dos usos. "Assim, acredita-se que o sucesso recente dos patrimônios deve-se mais à sua inclusão no mundo da mercadoria do que a uma questão de formação de consciência da importância da história e da natureza" (SCIFONI, 2006, p. 65).

A efervescência da lógica mercantil patrimonial que banaliza os lugares e seus habitantes, de forma evidente no âmbito de algumas cidades históricas mineiras, levounos a crer na importância da análise geográfica da noção de patrimônio, da consagração do Patrimônio Mundial, das especificidades, tendências e dinâmicas contemporâneas contraditórias que envolvem os bens culturais. A análise até aqui realizada fornece-nos subsídios para lançarmos um olhar crítico sobre as contradições inerentes à produção do espaço urbano, em Diamantina, o mais novo reduto do turismo cultural no Circuito das Cidades Históricas Mineiras, enquanto Patrimônio Cultural da Humanidade.

Visto o contexto internacional e totalizador no qual Diamantina é parte integrante como Patrimônio Mundial, cujo entendimento constitui o percurso metodológico adotado nesta pesquisa, partiremos para a análise do processo de valorização do espaço e formação territorial que desemboca no surgimento da cidade (conquista do hinterland no XVIII), constituindo-se numa representante singular do urbanismo barroco característico de Minas Gerais, sobre o qual oferecem-nos importantes análises: Azevedo (1956), Reis Filho (1997, 1998), Scarlato (2005a, 2008), Vasconcellos (1997), Machado (1973) e outros.

A compreensão da dinâmica socioespacial que promove a gênese da arquitetura colonial barroca na região das Geraes fornecer-nos-á suporte para justificar a inclusão de Diamantina na Lista do Patrimônio Mundial como um bem universal excepcional, para discorrer sobre sua posição na trajetória da reprodução do patrimônio cultural no Brasil, bem como facilitará o entendimento da atual política de patrimônio implantada, hoje, no distrito; uma das cidades brasileiras escolhidas para implantação do Programa Monumenta. 
Devemos considerar que a promoção de um lugar como singularidade ocorre através do apelo à tradição ou pela descrição direta de alguma característica notável local (a paisagem urbana histórica é colocada à venda). Na lógica da "indústria cultural", modos de distinção devem ser "criados" para se sustentar alegações e discursos que estabeleçam o aumento da renda por meio da diferenciação e do posterior consumo do lugar. É nesse sentido que identificamos o papel da mídia na dinamização da "indústria cultural", que metamorfosea o sentido da história, da arte e da cultura para que ocorra seu consumo, ou seja, esse processo fecha a jogo relacional, simultâneo e contraditório que denominamos dialética da construção destrutiva; consagra-se um Patrimônio Mundial a ser "preservado" para, no próprio processo de consagração, inseri-lo no mundo da mercadoria, como um produto embalado e pronto para o consumo turístico. Tem-se uma simultaneidade que existe apenas dessa forma, enquanto uma dialética necessária à produção do patrimônio-mercadoria. 


\section{PARTE II \\ Diamantina: da gênese colonial a Patrimônio Mundial}

Capítulo 3.0 - Diamantina e as fases de produção do Patrimônio Cultural brasileiro

Os estudos por nós realizados nos últimos anos, tratando da organização socioespacial e da mercantilização de patrimônio cultural nas cidades históricas de Minas Gerais (especialmente, São João Del Rei, Tiradentes, Ouro Preto e, nesta pesquisa, Diamantina), levam-nos a considerar quatro fases consecutivas e distintas de produção do patrimônio no Brasil, as quais denominamos: gênese colonial do patrimônio, produção 
simbólica do patrimônio, projeção inicial do patrimônio e cenarização progressiva do patrimônio. Essas fases são marcadas pela trajetória socioeconômica das cidades históricas em tela, representando momentos distintos de produção e valorização do espaço; ou seja, nesses momentos, há a produção de formas em determinadas estruturas que assumem funções distintas ao longo do processo histórico da "formação socioespacial" da zona do ouro (para adotar uma metodologia de análise do espaço geográfico proposta por Milton Santos e apresentada no início da pesquisa).

Veremos, neste capítulo, que a consagração do patrimônio, no Brasil, sofreu as influências das orientações postas no plano internacional, sobretudo, europeu, analisado anteriormente, de ampliação tipológica, cronológica e geográfica do patrimônio cultural (CHOAY, 2006), da própria ampliação da noção de patrimônio e da idéia de conjunto em detrimento ao bem isolado, nos espaços urbanos, dentro de um processo histórico contínuo que parte da gênese dessas materialidades quando da conquista, dominação e valorização de novos espaços, especificamente, no século XVIII brasileiro, momento da implantação dos núcleos urbanos das Geraes.

O entendimento dessas quatro fases distintas e consecutivas de produção da arquitetura colonial mineira - em especial, de Diamantina - não se desvincula do contexto global de consagração do Patrimônio Mundial apresentado anteriormente, muito menos da dialética da construção destrutiva que envolve os bens culturais do mundo, ao serem símbolos, ora de memória e identidade, ora de reprodução do capitalismo, simultaneamente, no movimento processual de mercantilização. Ao contrário, a análise do processo histórico que envolveu e envolve essas "rugosidades" cristalizadas no território (trajeto da gênese inicial às dinâmicas contemporâneas), remete-nos à consideração do valor universal excepcional que consagra Diamantina como um Patrimônio Cultural da Humanidade para, ao mesmo tempo, torná-la uma mercadoria para o desenvolvimento turístico; processo que corrobora para o entendimento do frénésie pela Lista do Patrimônio Mundial, bem como ao seu desequilíbrio. Logo, considerar, ao longo deste capítulo, a análise posta até o momento, torna-se fundamental para o entendimento da reprodução do patrimônio no Brasil e, em especial, facilitar a compreensão da lógica que envolve Diamantina como Patrimônio Mundial e mercadoria global.

Essas fases (gênese colonial do patrimônio, produção simbólica do patrimônio, projeção inicial do patrimônio e cenarização progressiva do patrimônio) representam 
distintos momentos da ampliação histórica da noção de patrimônio nas cidades históricas mineiras, em especial, Diamantina:

1) Gênese colonial do patrimônio: século XVIII - surgimento do então Arraial do Tijuco pela expansão territorial e busca de metais preciosos [logo após a conquista de fundos territoriais (MORAES, 2005) e da primeira valorização e dominação do espaço ${ }^{58}$, no hinterland brasileiro];

2) Produção simbólica do patrimônio: décadas de 1930-1950 - Diamantina, juntamente com as cidades da zona do ouro, torna-se referência na busca de símbolos capazes de registrar a trajetória de um novo "Estado-nação", momento em que o barroco mineiro é resgatado como expressão máxima de identidade nacional. A criação do Serviço do Patrimônio Histórico e Artístico Nacional (SPHAN) pelo governo de Getúlio Vargas busca cumprir essa finalidade [talvez essa fase seja assaz significativa do ponto de vista da incipiente valorização simbólica (THOMPSON, 1995) ${ }^{59}$ do patrimônio por parte do Estado, no Brasil];

3) Projeção inicial do patrimônio: décadas de 1960 a 1990 - Nessa fase, o patrimônio passa a ser reconsiderado, no contexto do planejamento urbano estratégico, enquanto vetor de mudanças socioeconômicas capaz de contribuir para o desenvolvimento local e regional [nesse momento, são consideradas as orientações da Carta de Veneza, que indica a possibilidade de valorização econômica dos núcleos urbanos tombados ${ }^{60}$ ]. As cidades históricas - algumas em franca decadência econômica - são evidenciadas com o incipiente turismo cultural; e

4) cenarização progressiva do patrimônio: fim do século $X X$ e início do século $X X I$ momento em que a atualidade da globalização, da mundialização dos lugares, da expansão do capitalismo e da seletividade do capital (MORAES, 2005 e HARVEY, 2005) favorecem a transformação da cultura em um novo gênero de mercadoria, nos lugares. Nesse momento de intensificação dos fluxos (SANTOS, 2002a), torna-se premente o que denominamos dialética da construção destrutiva na consagração do patrimônio, ora símbolo de cultura, ora de mercadoria, simultaneamente, no processo mercantil. Nessa fase, os bens culturais passam por uma reprodução ampliada, uma marcante valorização

\footnotetext{
${ }^{58}$ Sobre a teoria da valorização e dominação do espaço considerada nesta pesquisa, retomar o aporte teórico.

${ }^{59}$ Sobre nosso ponto de vista da valorização simbólica dos bens culturais, retomar o aporte teórico.

${ }^{60}$ Para a retomada das orientações da Carta de Veneza de 1964, que faz um contraponto à Carta de Atenas da década de 1930, reavaliar o primeiro capítulo da pesquisa.
} 
de mercado que ocasiona a transmutação dos valores a eles inicialmente atribuídos (de identidade, memória coletiva e cultura); momento em que se evidencia a vitória da troca sobre os modos operantes dos usos nas cidades coloniais barrocas das Geraes. No movimento do uso à troca, da preservação à mercantilização buscamos entender a produção socioespacial de Diamantina. ${ }^{61}$

Nesse contexto, podemos dizer que para a melhor compreensão do espaço geográfico não basta desvendarmos as suas múltiplas dimensões atuais, há que se investigar também o processo histórico do qual faz parte, pois aí estão, muitas vezes, os segredos de sua boa interpretação, como indica Abreu (1997, p. 240).

Também devemos considerar que a análise do processo histórico que desemboca na consagração de Diamantina como Patrimônio Cultural da Humanidade reflete uma das exigências de nosso método de pesquisa, pois para a dialética, as "coisas" não são analisadas na qualidade de objetos fixos, mas em movimento: nenhuma coisa está "pronta", "acabada", encontrando-se sempre em via de se transformar, desenvolver; de forma que o fim de um processo remete ao início de outro. Daí a importância deste capítulo para o entendimento da construção destrutiva que envolve Diamantina, hoje. Para Santos (2008, p. 103-104),

\begin{abstract}
A história é sem fim, está sempre se refazendo. O que hoje aparece como resultado é também um processo; um resultado hoje é, também, um processo que amanhã vai tornar-se uma outra situação. O processo é o permanente devir. Somente se pudéssemos parar a história é que teríamos um estado, uma situação permanente. Toda situação é, do ponto de vista estático, um resultado, e do ponto de vista dinâmico, um processo. Numa situação em movimento, os atores não têm o mesmo ritmo, movem-se segundo ritmos diversos. Portanto, se tomarmos apenas um momento, perderemos a noção do todo em movimento. Os cortes no tempo nos dão situações em um determinado momento. Não captam o movimento, são apenas uma fotografia. Já o movimento é diacrônico, e sem isso não há história. Não haveria dialética se o movimento dos elementos se desse de maneira sincrônica.
\end{abstract}

\footnotetext{
${ }^{61}$ A análise desta fase de intensa cenarização progressiva do patrimônio cultural torna-se salutar, pois amarrará a discussão que fazemos da própria dialética do uso e da troca, da preservação e da mercantilização que envolvem os bens culturais nas cidades históricas, transformando a realidade e o imaginário da população residente. Esta é a fase mercantil atual de Diamantina, encravada no sertão mineiro.
} 


\subsection{Fase da gênese colonial do patrimônio e o urbanismo barroco}

Segundo Moraes (2002, p. 89), a colonização expressa, talvez melhor que qualquer outro exemplo, momentos de ação da sociedade sobre o espaço, onde a partir do capital fixado no território colonial formam-se as bases de movimentos econômicos autocentrados, isto é, que perseguem objetivos próprios de realização e acumulação. Continua o autor, afirmando que a colonização pode ser equacionada como um processo 
de valorização do espaço, com suas modalidades de relação em que são apropriados os meios naturais, logo transformados em segunda natureza e, posteriormente, são apropriados esses meios naturais transformados, o que redunda na produção de formas espaciais e apropriação do espaço produzido.

Logo, a gênese do que hoje se constitui no surpreendente acervo arquitetônico das Geraes (primeira fase do patrimônio cultural brasileiro, de sua edificação propriamente dita) simboliza a própria ação da sociedade sobre o espaço, historicamente, de forma que o Brasil deve a maioria de suas cidades a grandes atos de vontade humana movidos pelo fascínio causado pela conquista. Adiantamos que não pretendemos complexizar na análise geohistórica do mote propulsor da gênese colonial do patrimônio mineiro (o que poderia ser abordado em outra pesquisa, na linha da geografia histórica, dada a profundidade da questão), mas considerar o contexto no qual é edificado, no cerne da ocupação dos "fundos territoriais" do Brasil Setecentista.

\subsubsection{A mineração e a articulação do território colonial no século XVIII}

Primeiramente, faz-se necessário salientar a importância da atuação dos paulistas no processo de formação do território brasileiro. Atuaram por vastas regiões da colônia, desmantelando quilombos, submetendo indígenas, e mesmo atacando assentamentos de holandeses e espanhóis, de acordo com Moraes (2000a, p. 395). Contudo, será com a descoberta do ouro, no hinterlad do território colonial, que se realiza o maior feito dos bandeirantes paulistas, na última década do século XVII. "A exploração (do ouro e diamantes) comandará a economia (e a formação territorial) brasileira ao longo de todo o século seguinte" (MORAES, 2000a, p. 395).

Há mesmo uma reorientação da economia colonial quando da consolidação da economia açucareira nas Antilhas, que concorre vantajosamente com as regiões produtoras do litoral nordestino brasileiro, episódio que criou as propícias condições para a mudança do pólo econômico do açúcar para a economia da mineração, que desloca o eixo do povoamento para outras regiões do território colonial brasileiro, como aponta Scarlato (1996, p. 124). A mineração do ouro, num primeiro momento, acompanhada pela dos diamantes, cerca de 30 anos depois de iniciada a aurífera, torna-se a saída para a crise da metrópole. 
(...) desde 1560, os paulistas já haviam descoberto ouro nas vizinhanças da vila de São Paulo, região do Jaraguá, e nos finais do século XVII já haviam chegado à região das Geraes (...) onde fundaram Sabará. Isso revela que, mesmo com a existência de toda uma legislação portuguesa que controlava as penetrações decorrentes de povoamento para o interior, os paulistas, transgredindo estas leis, expandiam as fronteiras do povoamento em várias direções do território, invadindo, inclusive, os territórios das colônias espanholas na América do Sul, delimitados, até então, pelo Tratado de Tordesilhas. (SCARLATO, 1996, p. 124)

A busca da riqueza mineral das Alterosas, nas regiões do Rio das Mortes, do Rio Doce e do Rio das Velhas ocasionou um grande fluxo migratório, que fez da zona do ouro e diamantes o pólo econômico central da estrutura colonial brasileira, no século XVIII. Segundo Celso Furtado, em Formação Econômica do Brasil, a economia mineira abriu um ciclo migratório europeu totalmente novo para a colônia. Por suas características, a mineração oferecia possibilidades a pessoas de recursos limitados, pois não se exploravam grandes minas - e sim o metal de aluvião que se encontrava depositado no fundo dos rios, que exigia parcos recursos ${ }^{62}$-, diferentemente da economia açucareira, que demandava um grande capital para implantação dos engenhos ${ }^{63}$. Portugal chegou a tomar medidas concretas com o objetivo de conter o fluxo migratório. Celso Furtado (1974, p. 74) afirma que a população colonial de origem européia decuplicou no correr do século da mineração:

a população do Brasil teria alcançado 100.000 habitantes em 1600, um máximo de 300.000 em 1700 e ao redor de 1.250 .000 em 1800. A população de origem européia seria de cerca de 30.000 em 1600 e dificilmente alcançaria 100.000 em 1700. Ignorando-se qualquer contribuição migratória européia ocorrida no século XVII, deduz-se que o crescimento vegetativo

\footnotetext{
${ }^{62}$ A técnica da mineração evoluiu no decorrer do século XVIII, embora sempre tenha se mantido atrasada, relativamente às possibilidades da época, o que não exigia grandes recursos iniciais na empreitada. Franco (1944, p. 84-5) considera que os paulistas apenas procuravam o ouro, não se preocupando em explorá-lo, de início. Utilizavam-se dos meios mais rudimentares, afastando o cascalho do leito ou das margens dos ribeirões e apurando-o em instrumentos toscos de emergência, “até nos próprios pratos de estanho”. Para o autor, o descobrimento efetivo das minas, o emprego da mãode-obra escrava e a fixação da população favoreceram o aperfeiçoamento dos métodos de trabalho. "A bateia, vasilha cônica de madeira, própria para separar o metal do cascalho, originária provavelmente da África, representou um passo importante, pela generalidade do seu uso. A exploração do ouro estava ligada à água. Dentro do leito dos ribeiros (ouro da água ou da madre), ou nas margens deles (ouro de taboleiro), mais longe, nas encostas das serranias (ouro de grupiara), era o metal retirado do cascalho, da piçarra e mesmo do desmonte de pedra com auxílio da água.”

63 Scarlato (2008) considera a sociedade formada pela mineração eminentemente promíscua do ponto de vista da coexistência das classes sociais no espaço urbano, um fato inédito na Colônia, bem como pela relativa mobilidade dos indivíduos entre as classes (notas de curso - Geografia Regional do Brasil II-Região Sudeste. Faculdade de Filosofia Letras e Ciências Humanas / Departamento de Geografia / USP).
} 
dessa população permitia no máximo que a mesma triplicasse no correr de um século. Se se admite esse ritmo de crescimento para o século seguinte, a população de origem européia deveria alcançar (ignorado o efeito migratório) cerca de 300.000 pessoas ao término do século XVIII. Como os dados de que se dispõe indicam para essa época uma população de origem européia de algo mais de um milhão, deduz-se que a emigração européia para o Brasil no século da mineração não terá sido inferior a 300.000 e poderá haver alcançado meio milhão. Como o grosso desses imigrantes eram lusitanos, cabe deduzir que Portugal contribuiu com um maior contingente de população para o Brasil do que a Espanha para todas as suas colônias da América.

A intensa imigração que a região mineradora propiciou ao Brasil pode ser considerada um rush de grandes proporções, que relativamente às condições da colônia, foi mais acentuado que o famoso rush californiano do século XIX, segundo Caio Prado, em História Econômica do Brasil. Esse fato contribuiu para uma rápida transformação socioespacial da colônia, propiciando um povoamento esparso e distribuído em pequenos núcleos separados entre si por enormes vazios; o que acabou caracterizando o povoamento do Brasil até nossos dias, notadamente em algumas áreas do centro-sul ${ }^{64}$ (PRADO JÚNIOR, 1983; DUARTE, 1995).

Consideração de suma relevância a ser feita é a de que a empresa mineira não permitia a ligação direta à terra, como ocorreu nas regiões açucareiras. Sendo a duração da lavra incerta, o capital fixo tornava-se reduzido e a atividade organizava-se, assim, de forma a poder se deslocar em tempo relativamente curto. Por outro lado, a grande lucratividade da extração favorecia concentrar na própria mineração os recursos adquiridos. Dessa maneira, a incerteza e correspondente mobilidade propiciada pela nova empresa, a alta lucratividade e correspondente especialização marcam a organização de toda a economia mineira (FURTADO, 1974, p. 76).

Para Caio Prado, em Formação do Brasil Contemporâneo, a indústria mineradora no Brasil nunca foi além de uma aventura passageira que mal tocava um

\footnotetext{
${ }^{64}$ Tomando como referência as rodovias BR - 040 e BR - 381, que ligam, respectivamente, Rio de Janeiro a Brasília e São Paulo a Belo Horizonte, além de rodovias estaduais de menor fluxo em Minas Gerais, como as que ligam Belo Horizonte ao Norte de Minas, passando por Diamantina, ou que liga Lavras a Barbacena, verificamos a constituição de grandes espaços vazios, tomados, ainda hoje, por pequenas (na maioria) e médias propriedades agrícolas. Além da grande distância entre as cidades, nesses trajetos, apresentam-se, ainda, em sua maioria, afastadas do eixo rodoviário atual, formando um rosário, o que simboliza, provavelmente, serem núcleos surgidos dos antigos caminhos que ligavam o litoral ao interior. Como exemplo desses núcleos podemos citar: Campanha, Carrancas, Nazareno, Madre de Deus, Prados, Rezende Costa, Marina, Conceição do Mato Dentro, Morro do Pilar, Santana do Pirapama, Gouveia, Serra Azul de Minas etc.
} 
ponto para abandoná-lo em seguida e passar adiante. Para o autor, essa é a causa principal que, apesar da riqueza produzida pela atividade, drenada toda para fora do país, deixou tão poucos vestígios, a não ser a marcada destruição de recursos naturais que semeou pelos distritos mineradores. Nesse ponto, fazemos uma ressalva, pois o território atual, no qual se estabeleceu a zona do ouro e dos diamantes, é representante do maior acervo barroco do país, considerando o conjunto das cidades coloniais mineiras ainda hoje preservadas.

O ouro e o diamante são símbolos da conquista espacial que emergiu como determinação principal de Portugal no Setecentos, ou como se refere Moraes (2002, p. 31), "como pecado original das colônias, na medida que a expansão territorial e o domínio de espaços se inscrevem como móveis básicos de sua objetivação". A conquista que acarreta na formação do território induz práticas sociais e relações humanas que se corporificam na estruturação do próprio espaço, dando forma específica ao processo de assentamento da sociedade na zona do ouro e dos diamantes, caracterizando-a singularmente.

Assim, há de ser destacado também o papel fundamental da mineração no tocante à articulação da zona do ouro e dos diamantes com outras partes do território colonial, sua característica sui generis. A população emigra em massa do planalto do Piratininga, recursos em forma de mão-de-obra escrava advém do Nordeste açucareiro "decadente" e em Portugal forma-se, ineditamente, uma corrente migratória com destino ao Brasil, como visto acima. Contudo, foi a própria dificuldade de assentamento em uma região tão distante do litoral (base do povoamento inicial da Colônia), e inóspita pelas condições naturais (solos pouco produtivos e topografia extremamente acidentada), junto ao desejo de enriquecimento rápido, que favoreceram a articulação do território das minas com o restante da colônia, em nosso entendimento.

Localizada a grande distância do litoral, espalhada e em região montanhosa, a população mineira dependia para tudo de um suficiente sistema de transportes. Segundo Furtado (1974, p. 76), a tropa de mulas constituiu autêntica infra-estrutura de todo sistema minerador. A análise desse autor indica-nos que a dificuldade de abastecimento de alimentos, a grande distância por terra que deviam percorrer todas as mercadorias importadas, a necessidade de vencer grandes caminhadas em região montanhosa para alcançar os locais de trabalho, tudo contribuía para que o sistema de transporte 
desempenhasse um papel básico no funcionamento da economia e favorecesse a articulação territorial, necessária para a sobrevivência da empresa.

A mineração propiciou o desenvolvimento de um grande mercado para animais de transporte e mesmo o fortalecimento da pecuária. Para Furtado (1974, p. 77), ao considerarmos em conjunto a procura de gado para corte e de muares para transporte, a economia mineira constituiu um mercado de proporções superiores ao que havia proporcionado a economia do açúcar, em sua etapa máxima de produção. Isso faz com que a economia sul-rio-grandense, onde a criação de mulas ocorreu em ampla escala, se integrasse à economia mineira e colonial.

As tropas de mula formaram um "corredor" de escoamento (não só de mulas e bovinos - vivos - mas também de charque) que partia do sul em direção ao Planalto de Piratininga e depois destinados, sobretudo, para a zona da mineração. Sobre essa articulação, Castro (1979, p.53) deixa-nos minuciosas indicações. Para o autor, o famoso negócio das "bestas de Viamão" (Sorocaba), não apenas propiciava um primeiro vínculo entre extremo sul e o resto da Colônia, mas também fornecia as rendas de que se nutria o importante registro de Curitiba. Esse comércio constituiu-se, por um tempo, na principal atividade econômica dos paulistas. O comércio de muares, dada sua própria natureza, superava o grande desafio enfrentado pela inserção econômica do sul no resto do país: a necessidade de cruzar a floresta densa que se extendia do sul de São Paulo aos campos sulinos. A mineração e suas exigências de transporte, tornam-se, pois, a mola propulsora do desenvolvimento dessa atividade do sul, articulando, ainda, São Paulo.

Não é difícil de se supor a importância de articulação territorial propiciada pela empresa mineradora ao considerarmos, ainda, que sua base geográfica compreendia a vasta área que integra o atual Estado de Minas, a região de Cuiabá, no Mato Grosso, Goiás, o próprio Nordeste, o atual estado de São Paulo e o Sul do país. Essa articulação fez-se pela necessidade do abastecimento da região mineira ${ }^{65}$, seja pela carência de

\footnotetext{
${ }^{65}$ De acordo com Zemella (1990, p. 169-189), o consumo nas Geraes variou conforme quatro fatores principais: 1) povoamento; 2) produção das minas; 3) sistematização das correntes de abastecimento; e 4) desenvolvimento dos núcleos locais de produção. Essa consideração da autora remete-nos à complexidade da própria empresa e das suas maiores necessidades, apontadas por ela como os seguintes gêneros: 1) cereais, açúcar, toucinho, a carne e o sal; 2) ferro, aço e pólvora; 3) vestimenta e calçados, móveis, arreios (material de lida); e 4) artigos de luxo para os novos ricos das Geraes. Mafalda considera a pinga e o tabaco como um grupo a parte, pois, “eram os suavizadores do rude trabalho das lavras (...) a aguardente era vital para os negros que permaneciam durante horas com o corpo mergulhado nos ribeiros, manejando a bateia (...) nessa época acreditava-se seriamente nas virtudes terapêuticas da pinga (...) os escravos
} 
produtos alimentícios (pouco produzidos nas primeiras décadas do século XVIII), seja pela urgência de animais de carga. ${ }^{66}$

Logo, a mineração foi o mote do desenvolvimento regional e a mola propulsora para a articulação de diferentes pontos da colônia, do Nordeste ao Centro-Sul, contribuindo, assim, para a integração do território brasileiro.

\subsubsection{A zona do diamante: um "enclave territorial" à parte}

Neste tópico da pesquisa, trataremos do surgimento de Diamantina, que representa um capítulo especial no contexto da expansão do território colonial que se deu pelo desenvolvimento da economia mineira e por seus efeitos indiretos (como vimos, a mineração favoreceu a articulação de distintas regiões e o estabelecimento de atividades paralelas, como a pecuária e a agricultura de subsistência que se desenvolveram ao longo do século XVIII e ganharam vulto no século XIX, em alguns pontos da zona do ouro e dos diamantes, refutando a tradicional análise historiográfica da crise que se generaliza com o declínio da mineração ${ }^{67}$ ).

podiam viver mal vestidos e mal alimentados, porém jamais poderiam passar sem uma dose diária de aguardente e sem um naco de fumo" (MAFALDA, 1990, p. 187).

66 Surge dessa dinâmica uma figura singular justamente lembrada por Deffontaines (1944, p. 08), o tropeiro. Segundo o geógrafo francês, houve durante muito tempo mais transportadores do que produtores, onde o ofício convinha à psicologia aventurosa da gente pobre, na qual não existia nenhum atavismo de sedentarismo camponês. "Através das solidões mais afastadas, esses tropeiros transmitiam as idéias, os hábitos, as novidades; eles se tornaram um dos principais agentes da unidade brasileira; desde o século XVIII eles penetraram em pleno Mato Grosso, onde tinham achado ouro; por caminhos de burro, as estradas, que eles tinham traçado, eles tinham previsto paradas, repousos, pousos que progressivamente se tornaram pequenas aglomerações”.

${ }^{67}$ Em trabalho anterior, apresentamos uma análise das atividades que acompanharam a mineração em alguns pontos específicos da zona do ouro, como na Comarca do Rio das Mortes. "São João Del Rei e outras vilas da Comarca do Rio das Mortes, como Barbacena e Pitangui, destacaram-se como áreas abastecedoras de alimentos para outros pontos, como a Província do Rio de Janeiro, desde as primeiras décadas do oitocentos, antes da estruturação da cafeicultura paulista, refutando uma tradicional visão da decadência de toda a economia mineira com a estagnação aurífera e que segundo esta visão, marcaram todo o oitocentos por uma agricultura de subsistência fragmentada e à margem da economia colonial. Não pretendemos afirmar que este comércio adquiriu um vulto que movimentasse toda a colônia, como o próprio ouro ou o açúcar, ou que representou a base da economia colonial como um grande ciclo, mas esclarecer a importância das atividades agrícolas e pecuárias desenvolvidas após a mineração, especificamente em São João Del Rei, pois, a decadência desta atividade que para muitas vilas representou, realmente, uma estagnação, uma parada no tempo, não teve efeito equivalente para São João, que segundo Gaio Sobrinho (1996), soube encontrar nas suas demais atividades, agrícolas, pecuaristas e comerciais, os recursos econômicos para prosseguir no seu desenvolvimento. Primeiramente, podemos reconhecer que a vinda da Corte para o Brasil consolidou, no oitocentos, a centralidade e emergência da região centro-sul, deslocada do Nordeste açucareiro há algumas décadas. Na visão de Campos (1998), esta região emergente destacou-se pela originalidade de estruturar uma produção voltada para o mercado interno e não exportadora, desenvolvendo atividades agropecuárias, produção de alimentos e comercialização. Secundariamente, a autora aponta 
Em sua Tese de Doutorado, Os negócios de diamante e os homens de fortuna na praça de Diamantina - MG: 1870-1930, Marcos Lobato Martins menciona a dificuldade em encontrar fontes historiográficas sobre Diamantina. "A despeito de sua importância histórica no contexto mineiro dos séculos XVIII e XIX, a região correspondente à antiga Demarcação Diamantina ainda hoje recebe pouca atenção dos historiadores. A literatura sobre Diamantina e seu entorno é bastante restrita, e concentrada em torno das temáticas relacionadas à extração de pedras preciosas e do ouro" (MARTINS, 2004, p. 37).

Não é diferente na geografia humana brasileira, onde são escassos os trabalhos monográficos sobre o norte mineiro, em especial sobre a região, ainda hoje, diamantífera. Dessa maneira, são substanciais para nossa breve análise da formação histórica do antigo Arraial do Tijuco, os trabalhos de Caio Prado Júnior - que faz uma curta menção à mineração do diamante e sobre suas características básicas; as minuciosas observações do naturalista francês Augusto de Saint-Hilaire, em Viagem pelo Distrito dos Diamantes e Litoral do Brasil, o significativo trabalho de Joaquim Felício dos Santos, Memórias do Distrito Diamantino da Comarca do Serro Frio; o trabalho de Aires da Mata Machado Filho, Arraial do Tijuco Cidade Diamantina, o estudo de José Moreira de

uma produção mercantil de exportação (...) Em sua Dissertação de Mestrado, Campos (1998) considera que as rotas de comércio da colônia se invertem. Há uma relativa alteração dos fluxos de mercadorias, que ao invés de irem do litoral para o interior das minas passam a ser direcionados do interior para o Rio de Janeiro, nas primeiras décadas do oitocentos; posiciona São João e Barbacena como passagem obrigatória entre a província e a Corte, onde se caracterizou uma sólida atividade comercial e pautaram-se como relevantes entrepostos. Segundo a autora, a Vila de São João Del Rei constituía-se no maior núcleo urbano da comarca, com uma infra-estrutura consolidada. Afirma que os viajantes que passaram por ela, em décadas diferentes do oitocentos, são minuciosos em relatar sobre seu aspecto progressista. A cidade é descrita pela variedade de lojas comerciais, com grande estoque de produtos diversos, entre eles muitos importados, outros mais grosseiros, fabricados na província, e grande carga de sal. 'Este comércio é mantido principalmente por meio de quatro tropas regulares, consistindo cada qual de cerca de cinqüenta burros que perfazem geralmente oito jornadas por ano" (LUCCOCK, 1975 apud CAMPOS, 1998). São João Del Rei era intermediadora de vilas do interior da província, as quais apresentavam uma enorme produção de víveres, como também do couro de Paracatu, o algodão da região de Minas Novas, ou o tabaco da região de Baependi, segundo Campos (1998). Verificamos, assim, o importante papel que assumem as tropas de mulas, o único meio de transporte, naquele momento, capaz de estabelecer as circulações e as comunicações entre os diferentes pontos do território que se constituía com a conquista dos novos espaços, através de rotas estabelecidas desde o início da exploração do ouro, subsidiando uma 'rede' relacional de significado econômico regional. Conforme Campos (1998), todas as quintas-feiras produtos eram comercializados numa grande feira que acontecia em São João. 'Era em São João que muitos produtores e comerciantes do interior se reuniam para negociar. Enviavam ou traziam seus produtos e era ali que adquiriam as mercadorias necessárias ao consumo de seus arraiais e vilas. Raramente negociavam diretamente com o Rio de Janeiro.' (1998, p. 42). Contudo, se partia de São João tropas transportando para o Rio de Janeiro toucinho, queijo, bovinos, suínos, aves, algodão, tabaco, açúcar, ouro e alguns manufaturados como chapéus, couros e panos de algodão, chegava do Rio de Janeiro para São João produtos importados (CAMPOS,1998); dentre os produtos importados que São João recebia destacaram-se os de origem portuguesa e inglesa como chitas, rendas, louças, panos, utensílios de ferro, vinhos, licores além de muito sal, talvez o principal produto de importação, pela necessidade e raridade, atingindo elevados preços.” (sobre a importância do Comércio de Abastecimento, símbolo do desenvolvimento da atividade agropecuária em Minas, ver (COSTA, 2007). 
Souza, Cidade: Momentos e processos. Serro e Diamantina na formação do Norte Mineiro no século XIX e a Tese de Doutorado de Marcos Lobato Martins.

As minas dividiram-se, até 1720, em três grandes Comarcas: do Rio das Velhas (Sede Sabará), do Rio das Mortes (Sede São João Del Rei) e de Vila Rica (Sede atual Ouro Preto). Após essa data, a capitania divide-se, definitivamente, para todo o período da dominação mercantil, em 4 comarcas, pois a Comarca do Rio das Velhas é repartida em duas: Comarca do Serro Frio - aonde vai se estabelecer o território dos diamantes - e a Comarca de Sabará. O mapa abaixo ilustra as divisões político administrativas mencionadas. ${ }^{68}$

\footnotetext{
68 “Possui legenda, indicando as representações de: cidades; vilas; paróquias; capelas; fazendas; registros, guardas e patrulhas de soldados; guardas de São Paulo; aldeias de gentio; e estradas. Apresenta escala de 40 léguas, de 18 léguas ao grau, e rosa-dos-ventos. Registra na rede de meridianos e paralelos, medidas de latitudes, de $12^{\circ}$ a $24^{\circ} \mathrm{S}$, e de longitudes, de $327^{\circ}$ a $337^{\circ}$, sem a designação do Meridiano de Origem [Ferros]. Localiza as Comarcas do Serro Frio, de Vila Rica, Rio das Mortes e de Sabará. Indica as capitanias limítrofes de Minas Gerais, especificadas a seguir: Pernambuco, Bahia, Espírito Santo, Rio de Janeiro, São Paulo e Goiás. Representa elementos da hidrografia e do relevo. Trata-se de uma representação considerada referência sobre o território mineiro e a cartografia produzida nos setecentos por militares cartógrafos. Nessa representação registra-se a configuração de Minas Gerais que perdurou da criação da Capitania, em 1720, até a incorporação, em 1816, dos julgados e freguesias do Araxá e do Desemboque (áreas correspondentes atualmente às regiões mineiras do Triângulo e do Alto Paranaíba), pertencentes à Capitania e Comarca de Goiás, à Comarca do Paracatu de Minas Gerais, criada em 1815. Nesse mapa são representados elementos do relevo e destacadamente os da hidrografia, a par de aspectos da organização do espaço, compreendendo as cidades, vilas, paróquias, capelas, fazendas, registros, guardas e patrulhas de soldados, aldeias de gentios e estradas. A distribuição geográfica desses aspectos demonstra a ocupação expressiva das áreas relativas à Bacia do São Francisco, particularmente na sua porção centro-meridional, e às das Sub-Bacias do Rio Grande e Jequitinhonha. Essa distribuição destaca também porções do território mineiro pouco conhecidas e basicamente intocadas pelos colonizadores, como a da Sub-Bacia do Rio Doce, ocupada pela população indígena, designada por gentio. O mapa faz parte de um conjunto de cinco documentos manuscritos aquarelados, elaborados por Joaquim José da Rocha e datados de 1778, que correspondem à representação do território da Capitania de Minas Gerais e de suas Comarcas. Todos esses documentos são descritos neste catálogo, destacando-se do conjunto referido para considerações ampliadas, além deste mapa, o da Comarca de Vila Rica. O autor dos mapas, nascido em Portugal, chegou em Minas entre 1763 a 1768, onde, como militar, serviu aos governantes até 1778. Nessa condição, trabalhou como cartógrafo e em outras atividades relacionadas à defesa da Capitania, tornando-se um profundo conhecedor do seu território. Esse conhecimento foi registrado em uma notável monografia ou memória, a Geografia Histórica da Capitania de Minas Gerais, dedicada ao Governador e Capitão-Geral das Minas Gerais D. Rodrigo José de Menezes, em 1780. Nesse trabalho encontram-se dados estatísticos, relativos às receitas tributárias da Capitania, dentre outros, que demonstram que o autor dispunha de muitas relações de prestígio na administração para ter acesso aos mesmos. Rocha esteve envolvido no episódio da Inconfidência Mineira, acusado de fornecer informações estratégicas ao Alferes Joaquim José da Silva Xavier, o Tiradentes, capazes de incentivar ou fundamentar razões para o levante, do qual foi inocentado. A par dos mapas e do manuscrito referido anteriormente, o autor produziu outros documentos cartográficos de interesse sobre Minas Gerais.” (Arquivo IGC / UFMG).
} 


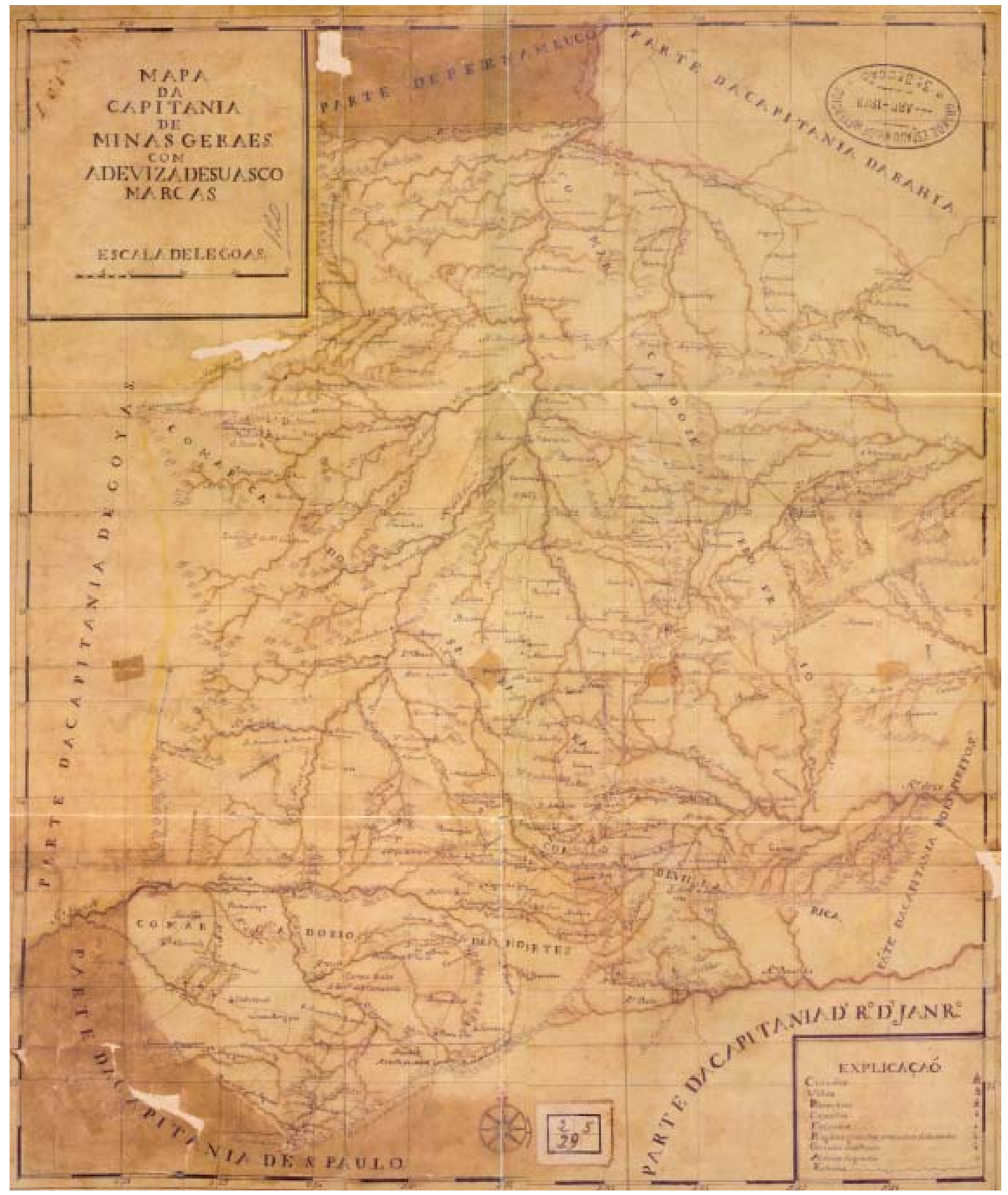

Fonte: Centro de Referência em Cartografia Histórica / IGC - UFMG. 
Segundo Joaquim Felício dos Santos, em Memórias do Distrito Diamantino da Comarca do Serro Frio, as lavras do Tijuco até 1729 foram puramente auríferas, logo, sujeitas ao regimento dos superintendentes e guardas-mores das terras minerais (do ouro). As cartas de data, na ocasião, eram distribuídas pelo Guarda-Mor da Vila do Príncipe (atual Serro), mediante pagamento dos direitos estabelecidos sobre as lavras auríferas. "É certo (...) que no ano de 1729 já os diamantes estavam descobertos e eram explorados, conquanto ainda não fossem bem conhecidos (...) D. Lourenço de Almeida, manda suspender todas as minerações de ouro nas terras diamantinas e anulando as cartas de datas obtidas do guarda-mor." (FELÍCIO DOS SANTOS, 1978, p. 49).

Assim, a história dos diamantes em Minas Gerais remonta à terceira década do Setecentos. Conforme Martins (2004, p. 63), a Vila do Príncipe, em cujos ribeirões houve significativa extração de ouro na primeira metade do século, foi o ponto de partida de uma série de expedições de mineradores rumo ao norte. Essas expedições descobriram depósitos aluvionares de ouro na base da Serra de Santo Antônio (o sítio original de Diamantina localiza-se na encosta frontal a essa serra), nas terras banhadas pelo Rio Grande. Felício dos Santos (1978) informa que os moradores do Arraial do Tijuco utilizavam grande quantidade de pedras brilhantes retiradas do Rio Grande para marcar pontos nos jogos de cartas, sem saber que eram o diamante. Ao chegar a notícia em Portugal da existência do produto, foram tomadas medidas draconianas de controle, jamais vistas em terras brasileiras.

Não descreveremos as minúcias dos sistemas adotados sucessivamente pela metrópole para a regulamentação da extração do diamante, porém, fica o registro de que foram três os sistemas impostos, com suas principais características: Livre Extração, Contratação e Real Extração, conforme Caio Prado (1969, p. 181).

Em 1730, a metrópole promulgou o primeiro regimento para os diamantes que declarava o produto como propriedade real. Segundo Martins (2004, p. 63), pelo regimento, era permitida a qualquer pessoa a pesquisa de diamantes, e estabelecia-se 0 regime de capitação para tributar os minerados; capitação que se elevava de ano a ano com o fim de controlar o volume de diamantes extraídos, de modo a não inundar as praças européias e evitar a queda dos preços da gema.

Em 1731, foi realizada a Demarcação do Distrito Diamantino, como medida significativa de controle da área diamantífera (ver mapa abaixo). Conforme Martins (2004), 
estabeleceu-se um quadrilátero dentro da Comarca do Serro Frio que circundava o Arraial do Tijuco, centro administrativo do Distrito, e incluía outros arraiais e povoados como Milho Verde, Gouveia, São Gonçalo, Chapada, Rio Manso, Picada e Pé do Morro ${ }^{69}$. Apesar dos cuidados da metrópole para que os preços das pedras não despencassem, o seu valor diminuiu em três quartos na Europa, o que forçou a Coroa a limitar a extração e a coibir o contrabando dos diamantes. Em 1740, chega o fim da Livre Extração.

\footnotetext{
69 “O mapa não apresenta referências sobre o posicionamento astronômico da área representada. Registra os limites da demarcação diamantina. Destaca elementos da hidrografia - o Jequitinhonha e seus afluentes - compreendidos no interior da área representada. Assinala pontes - passagens, nos rios Jequitinhonha e Paraúna . Indica a localização de povoações, identificando-as, entre as quais constam a Vila do Príncipe e os Arraiais do Tijuco, Milho Verde, São Gonçalo, Rio Manso, Inhaí, Gouveia e Paraúna. Representa pictoricamente elementos do relevo e da vegetação. Apresenta uma extensa nota explicativa, ao lado esquerdo do mapa, registrada a seguir: "A Villa do Príncipe Capital da Comarca do Serro do Frio, se fundou em 1714 no sítio das Lavras Velhas, descoberto por Lucas de Freitas. Ao Arrayal do Tijuco deu nome Jerônimo Correa natural da Bahia em 1713. O Arrayal do Milho Verde descobrio Manuel Rodrigues Milho Verde, natural da Província do Minho em 1713. O Arraial de São Gonçalo descobrio Domingos Barboza natural do Minho donde fundou huã Ermida a este Santo em 1729. Tomou nome o Arraial do Rio manço da mansidão com q'pello meyo delle corre o tal Rio, e delle foi o primeiro povoador Jozé de Godoy Passo Paulista em 1719. Descobrio Kaeté Mey [Caetémirim] Antônio Rapozo Paulista em 1714. Foy o 1o Situador do Arraial do Hynhah [Inhaí] e quem lhe deu o nome o Tapuyo Thome Ribeiro em 1716. De hua viuva chamada F(rancisca) de Gouvea n[atur]al, de Portugal houve nome e principio o Arraial de Gouvea em 1715. A povoação do Rio Parahuna foi principiada em 1713 por João Borges Delgado." O mapa da "Demarcaçam da Terra que produz Diamantes" faz parte do rico acervo em cartografia manuscrita do Brasil, pertencente ao Arquivo Histórico Ultramarino de Lisboa que guarda a documentação do Conselho Ultramarino. Trata-se de uma aquarela colorida de autoria desconhecida que representa um dos primeiros mapas do Distrito Diamantino, descoberto no início do século XVIII. Provavelmente fazia parte de uma correspondência oficial, dirigida ao Conselho Ultramarino. O mapa não apresenta graduação de latitudes ou longitudes, nem rosa de ventos. O conhecedor da geografia local observa que o norte do mapa está orientado para baixo. No seu canto inferior à esquerda consta uma escala gráfica (petipé) de 5 léguas. Nesse mapa, destaca-se a representação do alto Rio Jequitinhonha com seus principais afluentes e a das cabeceiras dos rios Pardo e Paraúna. O Distrito Diamantino está demarcado por uma linha pontilhada, tendo no centro o arraial de Tejuco. Seu diâmetro é de aproximadamente 15 léguas. A execução do desenho é do tipo de "art naïf", com arvores e igrejinhas desenhadas de maneira bastante singela. No lado esquerdo do mapa consta uma legenda que informa sobre os fundadores dos povoados e as respectivas datas de fundação: Vila do Príncipe em 1714, nas lavras velhas do Lucas de Freitas; Tijuco em 1713 pelo baiano Jerônimo Corrêa; Milho Verde por Manoel Rodrigues, natural do Minho/Portugal, em 1713; São Gonçalo por Domingos Barbosa, também natural do Minho, erigido em torno de uma ermida dedicada a este santo em 1729; Couto Magalhães, chamada na época de Rio Manso, pelo paulista José Godoy Passo em 1719; Caeté-Mirim em 1714 pelo paulista Antônio Raposo; Inhaí no ano de 1716 pelo índio tapuio Tomé Ribeiro; Gouveia em 1715 pela viúva F[rancisca] Gouvea, natural de Portugal; e o povoado de Rio Paraúna (hoje Andrequicé) por João Borges Delgado.” (Arquivo IGC / UFMG).
} 


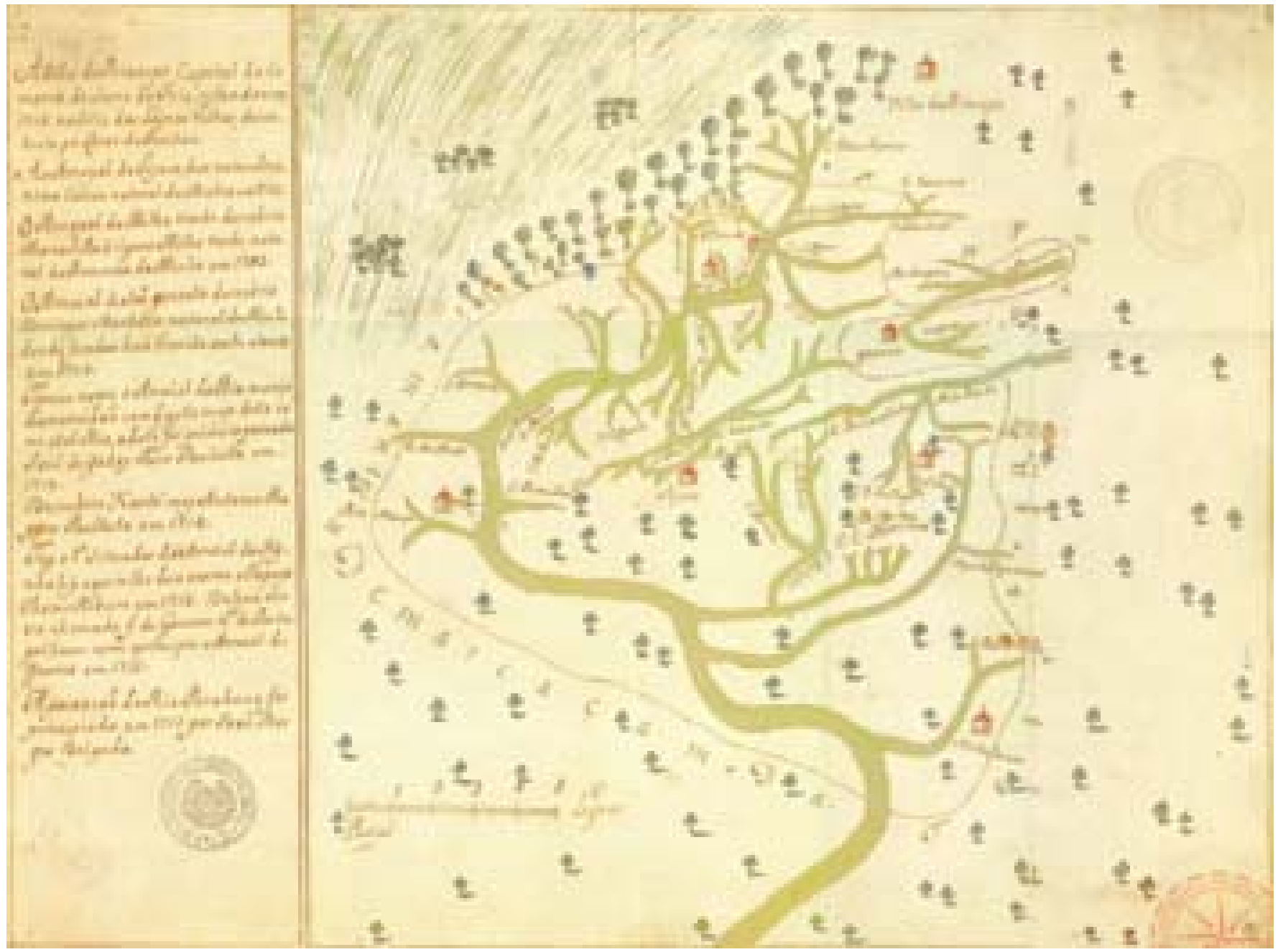

Fonte: Centro de Referência em Cartografia Histórica / IGC - UFMG.

Em 1740, a mineração de diamantes foi retomada sob o regime dos Contratos. Os contratadores, geralmente reinóis, arrematavam o direito de minerar diamantes e de cobrar impostos, ficando vedada a qualquer outra pessoa a possibilidade de manter lavras ou garimpos nas terras da Demarcação do Distrito Diamantino (MARTINS, 2004, p. 64). Esse sistema perdurou de 1740 a 1771 , sob comando de seis contratos sucessivos. ${ }^{70}$

\footnotetext{
${ }^{70}$ Martins (2004) aponta que embora as cláusulas dos contratos limitassem a 600 cativos a mão-de-obra que podia atuar nos serviços de mineração, o número de escravos que os contratadores empregaram na pesquisa e extração do diamante foi bem superior. Grande parte dos cativos que compunham as tropas dos contratadores era escravos de aluguel pertencentes a senhores da Demarcação. Continua o autor afirmando que, em 1745, na tentativa de controlar o fluxo populacional que se dirigia para a Demarcação, a Coroa impediu o livre acesso às terras diamantinas. As pessoas e mercadorias que iam para o Arraial do Tijuco precisavam de autorizações especiais, examinadas nos registros da Demarcação (Caeté-Mirim, Rabelo, Palheiro, Pé-do-Morro, Inhacica e Paraúna). Nesses registros também eram cobrados os direitos de entradas sobre o comércio dos diversos gêneros, inclusive de escravos.
} 
Insatisfeito com os descaminhos do diamante, em 1771, Portugal resolveu assumir diretamente a atividade de extração dos diamantes. Dentro da política pombalina, criou-se o monopólio real dos diamantes, conhecido como Real Extração. Surgiu a Real Intendência dos Diamantes, composta de um Intendente, um Fiscal e três Caixas. Edita-se o Regimento Diamantino, que integrava toda a legislação relativa ao Distrito e que ficou vastamente conhecido como Livro da Capa Verde, pois o exemplar do Regimento que chegou ao Tijuco era encapado com um pano verde. A Real Extração vigorou até a década de 1830. (MARTINS, 2004, p. 65)

$\mathrm{Na}$ descrição de Saint-Hilaire (1974, p. 13), o Distrito dos Diamantes foi submetido a uma administração particular, fechado não somente aos estrangeiros, mas ainda aos nacionais, formou um Estado à parte,

no meio do vasto império do Brasil (...) esse distrito, um dos mais elevados da Província de Minas, está encravado na comarca do Serro Frio; (...) faz parte da grande cadeia ocidental e compreende uma área, quase circular, de cerca de 12 léguas de circunferência. Rochedos sobranceiros, altas montanhas, terrenos arenosos e estéreis, irrigados por um grande número de riachos, sítios os mais bucólicos, uma vegetação tão curiosa quão variada, eis o que se nos apresenta no Distrito dos Diamantes. E é nesses lugares selvagens que a natureza se contenta em esconder a preciosa pedra que constitui para Portugal a fonte de tantas riquezas.

A bibliografia analisada aponta-nos que o Distrito dos Diamantes ficou como que "isolado do Universo", nos dizeres de Saint-Hilaire; para nós, um "enclave territorial" rigidamente vigiado. Situado em um país governado por um poder absoluto, o distrito foi submetido a um despotismo ainda mais absoluto; sob o sacrifício da própria sociedade assegurou-se à coroa a propriedade exclusiva dos diamantes. ${ }^{71}$

\footnotetext{
${ }^{71}$ Souza (1993, p. 36-7) faz uma análise interessante sobre o processo de extração dos diamantes. Ciente de que o diamante é artigo de luxo, enquanto tal, é valioso pela escassez, menciona a existência de uma política espacial necessária à extração diamantina, ensaiada por 60 anos com a Real Extração, após o período dos Contratos. O espaço dos diamantes deveria ser rigorosamente controlado para não inserir, no processo mercantil, livres relações de mercado, subvertendo relações entre os Estados. "Se o processo mercantil é inadequada às minas de ouro, na medida em que conflita com os 'reais interesses', estabelecendo a soberania do Estado civil sobre o Estado monárquico, ele o é muito mais para a exploração dos diamantes. Essa mercadoria não tem 'valor intrínseco', seu valor é simbólico, tal qual o ouro na fase em que se materializava em ídolos, imagens e jóias. Vivia-se a consciência de que as minas de ouro e de diamantes constituíram-se em espada de Dâmocles sobre o Estado monárquico e absolutista; qualquer passo em falso favorecia o aliado inconveniente, privatizando definitivamente todas as relações. Mas, principalmente, se o ouro pode circular livremente, desde que, com a devida precaução, se cuide de ressalvar os direitos reais, através do quinto, e se ele é posto exatamente para circular e através dessa circulação se reconhece o poder soberano do Estado, o diamante, ao assumir a posição de mercadoria, perde todo valor simbólico e sua descoberta, mais do que solução, cria o problema de como fazê-lo circular. Símbolo do luxo das cortes, o diamante não pode circular além delas. Desse modo, a extração e
} 
Conforme Caio Prado (1969, p. 182), o Distrito surge como um "verdadeiro corpo estranho enquistado na colônia", vivia isolado do resto do país e com uma organização peculiar; não havia governadores, câmaras municipais, juízes, repartições fiscais ou quaisquer outras autoridades ou órgãos administrativos. Havia apenas o Intendente e um corpo submisso de auxiliares, que eram tudo ao mesmo tempo, e que se guiavam, sobretudo, pelo Livro da Capa Verde - o Regimento -, que Ihes dava ilimitada competência. $^{72}$

Saint-Hilaire (1974) menciona a estruturação das atividades no Distrito. Além do Intendente e de seu corpo submisso de auxiliares, destaca o papel de alguns agentes. $\mathrm{O}$ trabalho relativo à extração dos diamantes era confiado a empregados denominados administradores particulares, cujo número variava de acordo com as necessidades do serviço - por serviço entendiam-se os lugares onde eram extraídos os diamantes, cada serviço teria um guarda-armazém e um moleiro, cargos da mesma categoria e do mesmo vencimento dos feitores, além dos carpinteiros e serralheiros, que também possuíam seus escravos. Cada administrador particular dirigia um certo número de escravos, cujo

comércio dos diamantes trazem embutidos em si, mais do que os do ouro, o desenvolvimento da consciência 'burguesa' em suas relações de transformação da nobreza fundiária e eclesiástica (...) Assim, entre os diferentes processos que se desenvolvem no Norte Mineiro: pecuária e extração aurífera, currais da Bahia e caminhos do sul, Minas do Norte, filiadas às de Jacobina e Minas Gerais, assume importância maior o exame das relações entre o espaço do ouro e dos diamantes, enquanto um, representado pela Vila do Príncipe, participa do processo geral de formação do espaço das minas: sejam as de Cuiabá, as dos Goitacases, as de Paranaguá, ou do Rio das Contas; o outro cria características especiais com amplas conseqüências para a formação do espaço das minas de ouro e, de modo especial, do Norte Mineiro.”

${ }^{72}$ É instituído o Regimento com o fim de coibir abusos, como menciona Machado Filho (1980). "Veio o decreto de 12 de agosto de 1771, que fez privativa da então Real Fazenda a extração dos diamantes, sob a direção de um Intendente e demais funcionários. Machado Filho transcreve o dito Regimento, do qual podemos dar como exemplos de sumo rigor e controle, alguns Parágrafos do Livro da Capa Verde; XII - "Mando que na conformidade do capítulo II do Regimento do Governador D. Lourenço de Almeida, (...) as penas acima estabelecidas, fiquem proibidos em todos os arraiais diamantinos (...) as negras de tabuleiro, como no Tijuco, as vendas por casas das negras e dos negros dentro das vendas e lojas ou a comprar ou a vender. XXII - A admissão ou segregação dos Administradores subalternos, feitores e mais empregados no serviço da Administração pertencerão privativamente ao Inspetor Geral e aos Caixas da Administração de Lisboa (...) XXIII - Todas as pessoas que houverem sido empregados no serviço da Administração e dela se despedirem ou forem despedidas pelos Administradores, serão logo mandadas sair, não só das Terras Diamantinas, mas de toda a comarca, por ordem do desembargador Intendente (...) XXXIII - Sendo informado que no arraial do Tijuco, na Vila do Príncipe e em vários outros lugares das Terras da Demarcação dos Diamantes, se tem aumentado a um número excessivo as lojas de fazendas secas, armazéns de molhados e vendas ou tavernas, tendo na maior parte delas por principal objeto muitos dos seus interessados comprarem diamantes extraviados debaixo do pretexto ou motivo de venda de seus gêneros, sou servido ordenar que o desembargador faça logo reduzir ao menor número possível assim no arraial do Tijuco como em todo os mais lugares das Terras da Demarcação, as sobreditas lojas (...) XXXVII - Nenhuma pessoa de qualquer estado, qualidade ou condição que seja poderá entrar na Terra da Demarcação sem licença do desembargador Intendente, a qual requererá por petição antes de entrar no Distrito Demarcado, fazendo certo por um Bilhete de Polícia ou das Justiças do lugar onde ouver saído, o negócio a quem vem e a que lugar se dirige, a distancia, e a diligencia que deve fazer (...)”. Assina o Regimento, no Palácio da Nossa Senhora da Ajuda, em 02 de agosto de 1771, o Rei de Portugal. 
agrupamento era chamado de tropa. Abaixo dos administradores particulares estavam os feitores, que faziam executar as ordens daqueles e que fiscalizavam os negros. Todos os escravos ocupados nos serviços pertenciam a particulares que os alugavam à administração, um negócio extremamente lucrativo. Também havia uma força militar à disposição do Intendente e da administração, composta de duas companhias de homens a pé, chamados pedestres, e de um destacamento do regimento da província contando 50 homens, inclusive oficiais. O destacamento de cavalaria ficava acantonado nas fronteiras do Distrito dos Diamantes a fim de impedir os contrabandos, o restante do destacamento ficava aquartelado no Tijuco e empregado no serviço de patrulhamento, na guarda das caixas, etc. A menção de Saint-Hilaire remete-nos à especificidade de Diamantina em relação às outras cidades da área da mineração, no que diz respeito ao controle imposto na Demarcação Diamantina, diretamente sobre os "olhos do rei".

Nessa breve análise histórica, pretendemos considerar a existência de duas principais zonas na área da mineração - zona do ouro e a zona do diamante - sendo essa última representante de um verdadeiro enclave territorial francamente vigiado por Portugal, quer seja pelo valor simbólico do diamante, quer seja por seu valor de mercado.

Apontamos também, que o Distrito Diamantino representa o último baluarte da mineração, abrangendo uma área relevante para a articulação do norte mineiro com o restante do país. Mais uma vez a mineração - agora do diamante, principalmente - vai ser fundamental no processo de formação do território brasileiro, ao integrar o longínquo e pouco conhecido norte mineiro às áreas mais dinâmicas do centro-sul do Brasil Colônia. ${ }^{73}$

Nesse sentido, Martins (2004, p. 62) considera que a importância econômica e social da mineração, no Alto Jequitinhonha, predominantemente praticada na forma de garimpo, acentuou-se ainda mais ao longo dos séculos XIX e XX, em razão do fato de que essa região acabou relativamente isolada das redes de comercialização que abrangiam Minas Gerais. "A região tornou-se marginal em relação aos centros dinâmicos da

\footnotetext{
${ }^{73}$ Moraes (2000a, p. 411) menciona que é a ocupação efetiva que qualifica a colônia, que a objetiva como espaço subordinado. Para o autor, o Brasil nasce e se desenvolve sob o julgo da conquista territorial, tratando-se da construção de uma sociedade e de um território, e mais, de uma sociedade que vai ter na montagem do território um de seus elementos básicos de coesão e identidade sociais. "Por isso, a dimensão espacial será uma das determinações fortes em sua formação histórica.” Nesse ponto, fazemos um gancho na análise de Moraes (2000a), pois as materialidades representantes da própria conquista territorial colonial mineira, cristalizadas nos núcleos urbanos das cidades históricas, foram resgatadas na década de 1930 como símbolo de identidade e cultura na constituição do "Brasil-nação”, como veremos; mais uma vez, a dimensão espacial faz-se determinante como símbolo de coesão e identidade de nossa sociedade.
} 
economia mineira, caminhando na direção da economia agro-pastoril de subsistência." No vastíssimo norte das Geraes, o processo mercantil limitou-se a produtos destinados à exportação: as pedras preciosas e o algodão, como aponta Martins. A exceção ficou por conta do Arraial do Tijuco, Cidade de Diamantina, centro dos negócios do diamante e do ouro, que a mantiveram conectada com outras partes de Minas Gerais e do Brasil.

Não pretendemos trazer minúcias da empresa da mineração no Brasil, mas mencionar algumas das principais características da atividade que representa o móvel da "formação socioespacial" da mineração - em especial dos diamantes, empresa que favorece a formação de uma primeira rede urbana na colônia, conforme Scarlato (2008).

Um dos critérios pelos quais Diamantina fora inscrita na Lista do Patrimônio Mundial foi o de "representar um exemplo excepcional de um tipo de construção ou de conjunto arquitetônico, ou tecnológico, ou paisagem ilustrativa de um ou mais períodos significativos da história humana" (ver capítulo 2.1); e sobre essa ilustração de um período significativo da história humana, não nos restam dúvidas de que, no período da mineração no Brasil Colônia, Diamantina encerra o reduto simbólico do absolutismo na América Portuguesa, seja através das práticas e relações sociais estabelecidas com a mineração, seja pela instituição das formas e conteúdos característicos do urbanismo barroco-rococó, que logo apresentaremos.

Um naturalista alemão que em princípio do século XIX visitou o Distrito, assim se refere a ele: 'Única na história esta idéia de isolar um território no qual todas as condições da vida civil de seus habitantes ficassem sujeitas à exploração de um bem da coroa'. (PRADO JUNIOR, 1983, p. 63) 


\subsubsection{A mineração e a formação de uma rede urbana de um tempo lento}

O que denominamos fase da gênese colonial do patrimônio está diretamente ligado à própria produção desses objetos através do processo de ocupação dos "fundos territoriais" (MORAES, 2002) pela colonização portuguesa. Partindo do litoral (ponto de estabelecimento inicial - século XVI), o colonizador ibérico conquista novos espaços em direção ao interior do território (ao longo dos séculos $X \mathrm{VII}^{74}$ e XVIII), marcando sua presença com a criação de novos arraiais, vilas e cidades, cuja materialidade atravessa o tempo e se estabelece no espaço como registro de um período simbólico da história brasileira - "rugosidades" (SANTOS, 2002) "permanentes".

Dessa maneira, o Brasil Colônia, que se pautava numa produção agrícola exportadora, cujos primeiros núcleos urbanos vinculados a essa atividade haviam se estabelecido, primordialmente, no litoral (Recife, Olinda, Salvador, São Luís, Rio de Janeiro), ocupando planícies e terraços, como nos esclarece Scarlato (2005), vê uma nova fase em sua dinâmica econômica e na conquista de novos espaços pelo interior do território, na busca pelo ouro e por diamantes.

Nesse contexto, o processo histórico singular de ocupação do interior movido pela mineração, com a formação de novos núcleos populacionais ao longo do século XVIII, gera o riquíssimo acervo arquitetônico das Geraes, representado por uma rede de cidades distribuídas pelos antigos caminhos do ouro, hoje integrando o que se denomina Circuito das Cidades Históricas Mineiras e mesmo de cidades dos estados de Goiás e do Mato Grosso.

A descoberta das minas de ouro e diamantes fornece ao território - que vinha se consolidando - um setor econômico dominante que vai polarizar as economias regionais já assentadas, animando-se com seu dinamismo e compelindo-as à expansão, como afirma Moraes (2000a, p. 415). Os fluxos de pessoas, animais e produtos diversos

\footnotetext{
${ }^{74}$ Segundo Moraes (2000a, p. 401), no final do século XVII as bases da formação territorial do Brasil estavam dadas, a soberania portuguesa estava reafirmada sobre uma grande porção do oriente sul-americano, abrangendo conjuntos regionais extensos, núcleos de colonização, enclaves e uma considerável zona de trânsito e visitação no hinterland designado sertão. Os holandeses foram expulsos com a reintegração da região pernambucana, o Estado afro-brasileiro dos Palmares destruído, as terras de Alagoas colonizadas, gerando uma zona de ocupação contínua entre Pernambuco e Bahia, a pecuária expandiu-se pelo sertão de dentro, definindo caminhos perenes que, da Bahia, demandavam as Geraes e o Maranhão, os campos Geraes e as vacarias do sul foram liberadas para a exploração portuguesa com o desalojamento das reduções jesuíticas dos espanhóis, além de, no extremo oeste, as bandeiras paulistas atingiam o piemonte dos Andes, “enfim, a conformação básica do futuro território brasileiro estava posta” (MORAES, 2000a, p. 402).
} 
propiciaram um padrão de ocupação e povoamento mais urbano, que adquire características próprias na zona do ouro e dos diamantes.

Em um clássico trabalho sobre Vilas e Cidades do Brasil Colonial, Aroldo de Azevedo registra as modificações substanciais no panorama urbano do Brasil ao longo do século XVIII. Segundo o autor, a obra de urbanização liberta-se de uma vez por todas da orla atlântica, dada a expansão povoadora e a conquista de larga porção do interior do território colonial e da própria Amazônia. O Bandeirismo, que penetra até a Chapada Diamantina e o vale médio do São Francisco, a expansão pastoril no sertão do Nordeste, a obra missionária na Amazônia, além da influência do "ciclo muar", são algumas facetas da produção de núcleos populacionais no Brasil de então.

Azevedo (1956, p. 35) considera duas áreas de maior relevância urbana, que apresentaram relativa continuidade: 1) a que pode ser denominada de região baianonordestina, que se estende desde a Baixada Maranhense até o baixo Mucuri, com maior penetração no sertão do Nordeste oriental e no trecho situado ao norte do Recôncavo Baiano; e 2) a que pode ser chamada de região paulista-mineiro-fluminense, que se estende desde a foz do Rio Doce até a ilha de São Francisco, com maior penetração no território áureo-diamantífero de Minas Gerais e no planalto paulista-paranaense ${ }^{75}$. Ao considerar os dados fornecidos por Aroldo de Azevedo, impressiona verificar que nada menos que 118 vilas foram criadas no século XVIII, de maneira particular no terceiro quartel do século. Segundo Fernando de Azevedo (apud Azevedo, 1956, p. 35),

\begin{abstract}
Se o século XVII, o das Bandeiras, foi o século da expansão territorial, da conquista e do povoamento, o século do ouro, o XVIII foi, com o declínio do patriarcalismo rural, no norte, e do movimento das Bandeiras, ao sul, o século do desenvolvimento das cidades, onde se formara e já ganhava corpo a nova classe burguesa, ansiosa de domínio, e já bastante forte para enfrentar o exclusivismo das famílias de donos de terras.
\end{abstract}

Com a mineração, a orla litorânea perde o privilégio de ser a notória concentradora populacional e de ser um espaço que caracteriza, paisagisticamente, o urbano. A zona do ouro e a zona dos diamantes agregam a primeira experiência

\footnotetext{
${ }^{75}$ Não poderia ser diferente, é esse grande geógrafo, dentre as fontes por nós consideradas, quem dá maior relevo à região diamantífera, ao Vale do Jequitinhonha e São Francisco, integrantes da saga urbanizadora do século da mineração. Como já nos referimos, o Norte de Minas é uma vasta área que, ainda hoje, permanece quase que esquecida pelos estudiosos das ciências humanas, em especial da geografia humana.
} 
tipicamente urbana do Brasil, considerando-se a complexidade que caracteriza essa formação, de apropriação e usos diversos de sentido urbano, de modos de vida verdadeiramente urbanos, segundo Scarlato (2008).

É nesse sentido que surgem diversos núcleos oriundos da mineração como atividade principal e de atividades subsidiárias a ela, como os deslocamentos dos tropeiros (tropas) e a própria pecuária. Ao ativar a circulação, a mineração exigia que a implantação dos núcleos se desse em sítios estrategicamente escolhidos, formando um rosário de povoados pelos principais caminhos que ligavam o litoral às minas mais distantes de Goiás, Mato Grosso e do Planalto de Diamantina.

Os geógrafos Pedro Pinchas Geiger, em Evolução da Rede Urbana Brasileira e Pierre Deffontaines, em Como se constituiu no Brasil a rede das cidades, são sumariamente relevantes para nossa análise. De acordo com Geiger (1963, p. 74), era comum, no período colonial, a implantação dos povoados ao longo dos rios, dado o maior papel que Ihes cabia na circulação. O autor se refere aos núcleos paulistas, do litoral e do vale do São Francisco, "por isso, é comum encontrar atualmente, à margem dos cursos de água, uma série de localidades tão estagnadas quanto estagnada se encontra a navegação fluvial". Acrescentamos que, na zona da mineração, essa escolha se dava, também, pela proximidade das áreas de extração nos leitos, nas grupiaras ou nos taboleiros. Outra observação de Geiger é a localização de cidades junto a cachoeiras dos cursos de água, principalmente as primeiras a partir da foz, onde se fazia mudança do transporte fluvial para a via terrestre. Esta é a razão, segundo o autor, de tantas cidades de nome Cachoeira, em geral pontos terminais de trechos navegáveis dos rios. "Extensas linhas de comunicação se estabeleceram (...) quando do desenvolvimento da mineração, que fez movimentar mercadorias, inclusive o gado. Longos trechos de rios eram aproveitados nessa circulação e alguns centros urbanos se localizaram nos extremos dos trechos navegáveis, como Itu ou Porto Feliz, em São Paulo."

Nas Geraes, verificamos que os núcleos envolvidos com a mineração, no século XVIII, encontram-se, na quase totalidade, localizados nas encostas de vales, próximos dos locais de garimpo, como observamos em Ouro Preto, São João Del Rei, Tiradentes, Diamantina, Sabará e Ouro Branco.

Indiretamente, ao ativar uma complexa circulação, a mineração propiciou o surgimento de outras cidades. É o caso de Sorocaba que se iniciou como feira de mulas 
que chegavam das campinas do sul e eram ali negociadas, seguindo depois para áreas onde seriam utilizados nos diversos transportes, como indica Geiger (1963).

O gado (intensamente movimentado pela mineração) também foi fator de abertura de caminhos e geração de aglomerados populacionais pelo interior da Colônia. "Tanto sobre os caminhos de gado, como sobre as linhas de circulação de viajantes e mercadorias, surgiram inúmeras localidades interioranas" (GEIGER, 1963, p. 75). Os pontos de pouso originaram localidades que revelam essa origem no próprio nome, como Pouso Alto, Pouso Alegre, Passo Fundo e Passa Quatro. Cidades que se denominam Registro eram pontos de cobrança de taxas sobre os caminhos. Cidades há que se desenvolveram de sedes de fazendas; outras nasceram ao longo dos caminhos das boiadas, como Curral del-Rei (primitivo nome de Belo Horizonte) e Malhadas, de acordo com Geiger.

Essas aglomerações, que se chamaram cidades de viajantes eram características, cheias de ranchos, cabanas-hangares para abrigar as caravanas, e estalagens; muitas vezes elas se prolongavam em uma só rua ao longo da estrada, como é o caso de Mogi Mirim, de Ouro Fino. Essa rua principal se chamava freqüentemente a rua direita, se bem que o seu traçado fosse em geral sinuoso. (DEFFONTAINES, 1944, p. 09, grifo nosso)

O quadro 01, a seguir, citado por Milton Santos em A Urbanização Brasileira, ao quantificar as vilas e cidades criadas no Brasil colônia do século XVI a 1720, representa, de forma fidedigna, a importância da mineração no desenvolvimento de novos aglomerados populacionais nas Geraes; não está computado o Arraial do Tijuco, que só é elevado à cidade no decorrer do século $\mathrm{XIX}^{76}$.

\footnotetext{
${ }^{76}$ De acordo com Felício dos Santos (1978, p. 246), em 1817, Diamantina já era a povoação mais importante da Capitania de Minas, pelo número de seus habitantes, riqueza, comércio e ilustração; possuía mais títulos a ser elevada a vila que muitas outras, que já o eram há muitos anos. Entretanto, quanto ao eclesiástico, esteve sempre dependente da Vila do Príncipe, e só foi erigida em paróquia no ano de 1819, pois, governado por uma Lei especial, não podia sair do estatuto de Arraial, seria incompatível com o sistema do poder despótico dos Intendentes; poder ilimitado, que não deveria ser partilhado por um Senado, e outras autoridades civis e criminais que se estabeleceriam com sua elevação à categoria de Vila. Assim, o Intendente reunia todos os poderes, administrativo, contencioso, criminal; só pertencia ao Juiz de Fora da Vila do Príncipe a jurisdição quanto a órfãos e ausentes. Mesmo a jurisdição eclesiástica, quanto ao espiritual, era exercida por delegados do vigário da Vila do Príncipe, quase independente. De Arraial do Tijuco é elevada à Cidade de Diamantina, em 1838, quando já tinha termo a Real Extração, sem ser Vila.
} 
Vilas e Cidades até 1720, no Brasil Colônia

\begin{tabular}{|c|c|c|c|}
\hline & $\begin{array}{l}\text { Séc } \\
\text { XVI }\end{array}$ & Séc XVII & Séc XVIII até 1720 \\
\hline Rio Grande do Norte & 1 & & \\
\hline Paraíba & 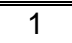 & & \\
\hline Pernambuco & 2 & 1 & 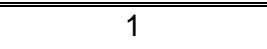 \\
\hline Sergipe & 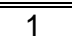 & 2 & \\
\hline Bahia & 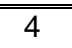 & 5 & $\overline{11}$ \\
\hline Espírito Santo & 2 & 1 & \\
\hline Rio de Janeiro & $\overline{11}$ & 6 & \\
\hline S São Paulo & 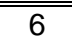 & 10 & 1 \\
\hline Pará & & 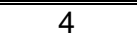 & \\
\hline Maranhão & & 2 & 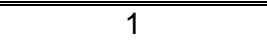 \\
\hline Alagoas & & 3 & \\
\hline Paraná & & 2 & \\
\hline Santa Catarina & & 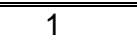 & 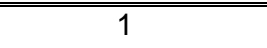 \\
\hline Piauí & & & 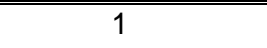 \\
\hline Ceará & & & 1 \\
\hline Minas Gerais & & & 8 \\
\hline
\end{tabular}

Quadro 01 - Fonte: Reis Filho (1968 apud Santos, 1994b).

Vê-se, no quadro citado por Milton Santos, que os primeiros vinte anos de exploração aurífera, no Brasil, foram suficientes para o surgimento de oito vilas na capitania mineira, deixando a criação de vilas em São Paulo e Rio de Janeiro para trás; dinamismo conseqüente de um novo fluxo de mercadorias, capital e pessoas proporcionado pela nova empreitada da mineração.

Considerando todo o século XVIII, a mineração promoveu o estabelecimento, apenas nas Geraes, de nada menos que 14 vilas - além dos arraiais constituídos -, distribuídas por toda capitania, de acordo com os dados fornecidos por Aroldo de Azevedo. Equiparando o quadro 02 que se segue ao que citamos de Milton Santos, identificamos que o Setecentos mineiro propiciou o surgimento proporcional de vilas, nas Geraes, aos duzentos anos anteriores de colonização do Nordeste açucareiro. O que demonstra a força urbanizadora da empresa aurífera do Brasil colonial. 
Vilas criadas na zona do ouro e diamantes ao longo do Setecentos

\begin{tabular}{|c|c|c|}
\hline Data de fundação & Ordem & Denominação \\
\hline 1711 & $1^{\mathrm{a}}$ & 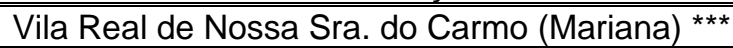 \\
\hline 1711 & $2^{\mathrm{a}}$ & 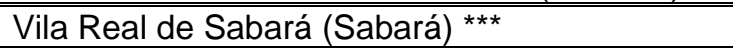 \\
\hline 1711 & $3^{\mathrm{a}}$ & 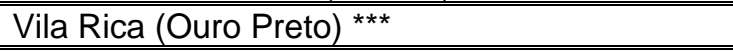 \\
\hline 1712 & $4^{\mathrm{a}}$ & 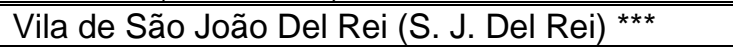 \\
\hline 1714 & $5^{\mathrm{a}}$ & 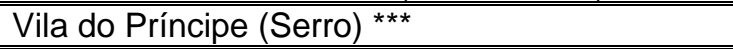 \\
\hline 1714 & $6^{\mathrm{a}}$ & $\begin{array}{l}\text { Vila Nova da Rainha do Caeté do Mato Dentro } \\
\text { (Caeté) }\end{array}$ \\
\hline 1715 & $7^{\mathrm{a}}$ & Vila Nova do Infante (Pitangui) \\
\hline 1718 & $8^{\mathrm{a}}$ & 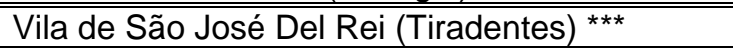 \\
\hline 1730 & $9^{a}$ & $\begin{array}{l}\text { Vila de N. Sra do Bom Sucesso das Minas do } \\
\text { Fanado (Minas Novas) }\end{array}$ \\
\hline 1789 & $10^{\mathrm{a}}$ & Vila de Itapecerica (Itapecerica) \\
\hline 1790 & $11^{\mathrm{a}}$ & 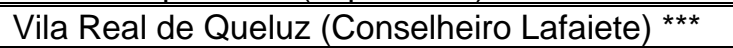 \\
\hline 1791 & $12^{\mathrm{a}}$ & Vila de Barbacena (Barbacena) *** \\
\hline 1798 & $13^{\mathrm{a}}$ & 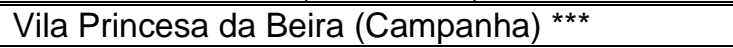 \\
\hline 1798 & $14^{\mathrm{a}}$ & Vila Paracatu do Príncipe (Paracatu) \\
\hline
\end{tabular}

Quadro 02 - Fonte: Aroldo de Azevedo (1956, p. 39-41). Organizado pelo autor.

*** Cidades analisadas, in loco, pelo autor, antes ou durante esta pesquisa (Tiradentes, Ouro Preto e São João Del Rei integraram nossas análises anteriores).

Também para Milton Santos, de modo geral, é a partir do século XVIII que a urbanização se desenvolve e a casa da cidade torna-se a residência mais importante do fazendeiro "ou do senhor de engenho, que só vai à sua propriedade rural no momento do corte e da moenda da cana" (BASTIDE, 1978, p. 56 apud SANTOS, 1994b, p. 21). É certo que essa análise diz respeito às cidades litorâneas do nordeste, que não acompanham, no nosso entender, o desenvolvimento de um modo de vida tipicamente urbano semelhante ao das Geraes, apesar da efemeridade da empresa mineradora, que se fez vultosa por pouco mais de meio século, mas que nos legou paisagens urbanas históricas irreplicáveis, características do urbanismo barroco das Geraes.

É claro que o grande número de vilas criadas deveriam ser regidas e ordenadas por um aparato burocrático-administrativo. De acordo com Moraes (2000a, p. 402), no que diz respeito à vida citadina e às funções urbanas, as cidades começaram a adquirir maior importância (já no XVII) no processo de ocupação e gestão do território brasileiro, fato que adveio da consolidação operada, mas sobretudo pela maior presença metropolitana em solo colonial. Moraes observa que os órgãos e cargos da administração reinol na colônia estabeleciam-se nos meios urbanos, e a hierarquia entre os núcleos se estabelecia em 
muito pela competência das instituições que abrigavam ${ }^{77}$. Essa situação, em conseqüência, diminuiu o âmbito do exercício de poder local também assentado nessas novas cidades, alocado nas câmaras municipais, os mais efetivos aparelhos de gestão da colônia. A análise de Moraes nos dá uma idéia da complexização que se processa, sobretudo, a partir do século XVIII, no tocante às nuanças da vida citadina e das problemáticas que envolviam a articulação entre os distintos e distantes lugares com o fim de formatar uma rede urbana de um "tempo lento", para usar uma expressão de Milton Santos (2002).

É bom relembrar que nem sempre o ouro e os diamantes foram os principais responsáveis pela organização e articulação de vilas e cidades da zona da mineração com outros pontos da Colônia, como sublinhamos no tópico anterior.

A Tese de Martins (2004) constitui-se em uma fonte singular que desmistifica a historiografia tradicional que atribui ao declínio da mineração uma miséria crescente na zona áureo-diamantífera. Ao contrário, verificamos que houve uma rearticulação do território colonial, formando redes urbanas de abastecimento inigualáveis na história da colônia, acompanhando, ou não, a atividade mineradora. O quadro que se esboça é o de uma economia com índices de produção agrícola e manufatureira que crescem, mesmo que a mineração enfrente - como realmente enfrentou, especialmente no caso do ouro momentos de declínio arrasador. Os estímulos do mercado interno em expansão, graças a uma população em contínua ampliação, transmitiram significativo dinamismo à diversificada economia mineira que se apresenta no século XIX.

Ao invés de se falar genericamente em 'involução' ou 'estagnação', de se aceitar apressadamente o modelo proverbial do boom and bust, matriz teórica da historiografia acadêmica pioneira, é melhor pensar em termos de um processo gradual e contínua diversificação produtiva, em uma economia que não estava nem em crescimento acelerado, nem em decadência absoluta, mas em processo de rearticulação interna. (MARTINS, 2001, p. 58).

O capital gerado pela mineração favoreceu a diversificação da base produtiva nas Minas Gerais do século XIX. A agropecuária e os setores de beneficiamento e transformação correspondentes estavam disseminados por quase todo o território, embora

\footnotetext{
${ }^{77}$ Reis Filho (1968) considera que esses núcleos formam, de início, bases para orientar a colonização, daí por diante, foram bases para o controle de diversas atividades na nova área de urbanização.
} 
houvesse áreas em que estas atividades encontravam-se mais desenvolvidas, como as áreas em torno de Pitangui, São João Del Rei e Barbacena, que abasteciam, principalmente, o mercado interno. (MARTINS, 2004 e COSTA, 2007)

O dinamismo do comércio estabelecido nas Geraes do XIX associava-se à existência de grande mercado interno criado pela empresa mineradora que se desarticulava. Porém, isso não quer dizer que Minas Gerais encontrava-se apartada de mercados "externos" (MARTINS, 2004, p. 59). As províncias do Rio de Janeiro e da Bahia recebiam quase todas as exportações mineiras: tabaco, algodão, bovinos, suínos, eqüinos, couros, queijos, toucinhos, ouro, diamantes, pedras preciosas e salitre. Identificamos a inversão dos fluxos, que agora ganham envergadura do hinterland para a orla atlântica. $^{78}$

Nesse quadro mais diversificado que desolador, a região de Diamantina possuía produção destacada de víveres, ouro, diamantes, pedras preciosas e siderurgia, como afirma Martins. Sua vinculação com o Rio de Janeiro, de onde recebia produtos importados, sobretudo da Inglaterra, era notória, mas a região também possuía relações mercantis com áreas vizinhas. De Minas Novas recebia víveres. Da região Mineradora Central Oeste recebia ferro. Da região Mineradora Central Leste importava víveres, trigo e algodão. Da Bahia chegavam produtos importados e escravos. Ainda segundo Martins, em termos de exportação, a região de Diamantina fornecia ferro para Minas Novas e ouro e diamante para o Rio de Janeiro. Esse é o quadro que vigora em alguns pontos específicos das Geraes até o terceiro quarto do século XIX, o que contraria a tradicional visão da pobreza mineira generalizada oriunda do declínio da mineração.

No contexto da constituição de uma primeira rede urbana na Colônia, que analisamos nesse tópico, é importante frisarmos que, independente das variadas causas que originaram os aglomerados (sedes de fazendas, pousos de tropas, locais de fiscalização - registros, pontos de transposição de quedas d'água, rota das mulas do sul, rotas de fuga dos registros, mineração, o comércio de abastecimento mencionados acima, etc.), tornou-se patente na escolha dos sítios urbanos a presença da água e a facilidade

\footnotetext{
${ }^{78}$ Clotilde Paiva (1996, apud Martins, 2004, p. 59) considera as regiões de alto nível de desenvolvimento as de Diamantina, Intermediária de Pitangui-Tamanduá, Mineradora Central Oeste e Leste. As regiões de médio desenvolvimento eram as de Araxá, Mata, Sul Central, Sudoeste, Mineradora Central Leste, Médio-Baixo Rio das Velhas e Vale Alto-Médio São Francisco. As de baixo desenvolvimento eram as do Extremo Oeste, Sertão, Minas Novas, Paracatu, Triângulo, Sertão do Alto São Francisco e Sertão do Rio Doce. Conforme Paiva, estes contrastes internos denotavam a existência de complexa divisão intra e inter-regional do trabalho nas Geraes.
} 
das comunicações, que foram dois elementos vitais para a existência e a sobrevivência dos aglomerados, conforme Aroldo de Azevedo, sem os quais dificilmente formaria-se essa rede.

Azevedo aponta que, no Brasil colonial, raro era o núcleo urbano que não se achava associado a um curso d'água, grande, médio ou pequeno. E muitas foram as causas dessa preferência: o fornecimento de água para o uso doméstico, a facilidade de obtenção de alimentos através da pesca, as vantagens oferecidas no que se refere aos contatos regionais e, no caso específico das áreas de mineração, a presença de ouro e de pedras preciosas no cascalho dos leitos fluviais, como indicamos acima. Não significa, porém, que hajam sido numerosos os verdadeiros aglomerados fluviais, aqueles que têm sua vida presidida pelos rios a que se acham ligados. Dada a vastidão que se tornava 0 território colonial, a facilidade das comunicações tornava-se quesito fundamental na implantação do sítio, daí a localização de aglomerados urbanos nas vias naturais de passagem e ao longo de precários trajetos, que as tropas de mulas, em penosas e longas caminhadas, sabiam aproveitar; tão penosos que as atuais rodovias, como a Fernão Dias, que liga São Paulo ao interior de Minas, esbarram apenas de leve e em alguns poucos pontos a antiga Estrada Real; mesmo as estradas estaduais, acompanham o antigo caminho apenas por alguns pontos, no interior do Estado ${ }^{79}$.

\begin{abstract}
Por isso mesmo, os caminhos coloniais constituíram a espinha dorsal da rede urbana, quer se dirigissem do litoral para os sertões do Nordeste ou para a Chapada Diamantina, quer procurassem atingir as áreas mineradoras de Minas Gerais, Goiás ou Mato Grosso, quer demandassem as regiões meridionais. Foram os pousos de viajantes, em conseqüência, o tipo comum de embriões de cidades em largo período de nossa vida colonial e, até mesmo, ao tempo do Império, o que lhes valeu o lugar de destaque que ocupam no relato da maioria dos viajantes estrangeiros do século XIX. (AZEVEDO, 1956, p. 71-2, grifos nossos)
\end{abstract}

Essa breve análise tem por fim enaltecer o papel da dinâmica propiciada pelo ouro, pelos diamantes e pelos diversos gêneros de abastecimento na formação de uma

\footnotetext{
${ }^{79}$ Identificamos, nas diversas idas a campo para o interior de Minas Gerais, que o antigo caminho dos tropeiros e viajantes, a Estrada Real - constituída do Caminho Velho, Caminho Novo, Caminho do Sabarabuçu e Caminho dos Diamantes - não coincide com os atuais eixos rodoviários que ligam o litoral ao interior, tocando-os em alguns eixos, como o que vai de Lavras a São João Del Rei e dessa a Ouro Preto. Para o Norte de Minas, até Diamantina, o último reduto da Estrada Real, as rodovias distanciam-se do antigo caminho, estando as atuais cidades fora das margens das rodovias, adentrando para o interior, como observado em campo.
} 
rede urbana de um tempo lento, ao longo dos séculos XVIII e XIX, dando a devida importância à mineração, um tanto subestimada no que diz respeito à articulação propiciada (SCARLATO, 2008). Uma rede intra e inter-regional, estrategicamente pensada, formou-se e favoreceu a produção de espaços simbólicos do ponto de vista da arte, da cultura e da memória de uma civilização criada pelas relações e fluxos advindos da mineração nas Alterosas. Constitui-se em um grande descaso geohistórico - e mesmo artístico - negligenciar a trama estratégica que envolveu o desenvolvimento desses núcleos, considerando-os obra do acaso, sem rigor, sem método ou providência, simbolizando abandono e desleixo, como abordou a historiografia tradicional.

\subsubsection{O urbanismo barroco das Geraes}

Diversa é a visão dos estudiosos sobre o tipo de urbanização implantada no Brasil colonial, onde se busca, como ponto de referência, o padrão de urbanização estabelecido pelos espanhóis, na América, na maioria das análises conhecidas. Essa diferença é analisada a partir da importância que davam os portugueses e os espanhóis aos núcleos urbanos como elementos de conquista dos espaços coloniais. "Mais do que diferença, uma oposição total entre as duas formas de construir e encarar as cidades" (TORRÃO FILHO, 2003, p. 52).

Sobre essa distinção entre o padrão de urbanização estabelecido pelos espanhóis e portugueses, Sérgio Buarque de Holanda, em Raízes do Brasil, tece uma análise que marca essa diferença e que, posteriormente, é seguida por uma série de cientistas sociais. Ao fazer menção à cidade espanhola na América, em contraponto à portuguesa estabelecida no Brasil, Holanda (1995) distingue "ladrilhadores e semeadores". Para ele, o espanhol estabelece-se como um "ladrilhador" que acentua o caráter da cidade como empresa da razão, contrária "à ordem natural", estabelecendo planos de edificações, de forma a valorizar o traçado em linha reta e buscando regiões interioranas, com o objetivo de estabelecer um prolongamento aprazível da metrópole. Enquanto os portugueses apresentam-se como "semeadores" de cidades irregulares, "nascidas e 
crescidas ao deus-dará, rebeldes à norma abstrata". Holanda (1995, p. 110) considera que,

A cidade que os portugueses construíram na América não é produto mental, não chega a contradizer o quadro da natureza, e sua silhueta se enlaça na linha da paisagem. Nenhum rigor, nenhum método, nenhuma providência, sempre esse significativo abandono que exprime a palavra 'desleixo'.

Para Holanda, "como um ato de vontade humana", o próprio traçado dos centros urbanos na América espanhola denuncia o grande esforço a vencer e retificar a "fantasia caprichosa da paisagem agreste". Nem a topografia irregular, nem as asperezas do solo seriam suficientes para evitar o estabelecimento dos traçados em linhas retas, respeitando o plano regular, que "não nasce, aqui, nem ao menos de uma idéia religiosa, como a que inspirou a construção das cidades do Lácio e mais tarde a das colônias romanas, de acordo com o rito etrusco; foi simplesmente um triunfo da aspiração de ordenar e dominar o mundo conquistado" (HOLANDA, 1995, p. 96).

Enaltecendo o plano urbanístico espanhol, Holanda descreve que a construção da cidade começaria pela chamada praça maior; no litoral, no lugar de desembarque do porto; no mediterrâneo, no centro da povoação, formando um quadrilátero onde a praça serviria de base para o traçado das ruas, as quatro principais sairiam do centro de cada face da praça; de cada ângulo, mais duas. Nos lugares frios as ruas seriam largas e nos quentes, estreitas. A povoação partiria, claramente, de um centro.

Já a obra portuguesa teve antes um caráter de feitorização que de colonização, buscava-se o lucro imediato, nada de obras para estabelecimentos duradouros; agarrados ao litoral, só se desprenderam dele no terceiro século de colonização, continua Holanda. Assim, ao contrário da colonização portuguesa que foi, inicialmente, litorânea e tropical, a espanhola fugiu da marinha, buscando o interior e os planaltos, só ocupariam o litoral em local de instalação de bons portos, para facilitar o comércio, a entrada e a defesa da terra.

Sobre a ocupação duradoura na orla marítima, Moraes (2000a, p. 307) considera que esse foi o padrão colonial lusitano em todas as partes do globo; um império 
"filiforme e talassocrático. Estranho seria a adoção de um novo comportamento na ocupação das terras brasileiras." Moraes lembra que, ao contrário dos espanhóis, os portugueses não se defrontaram com uma estrutura territorial já interiorizada, nem com uma rede urbana que induzisse uma instalação na hinterlândia. Quanto ao sul, já havia, na América portuguesa, uma relação mais regular entre a vida litorânea e o interior, onde os colonizadores apropriaram-se dos itinerários e dos caminhos indígenas pré-existentes.

Moraes vê um despropósito em se qualificar a instalação portuguesa por comparação à espanhola, como faz Sérgio Buarque de Holanda ao concluir que os espanhóis tinham uma ótica de domínio territorial, os portugueses se moviam por objetivos mais comerciais. Essa avaliação gera conclusões precipitadas como: "para os portugueses a colônia é simples lugar de passagem, ao passo que para os espanhóis seria um prolongamento do país" (MORAES, 2000a, p. 307).

Holanda (1995, p. 103) considera que somente o "evento" do descobrimento das minas, sobretudo, as minas de diamante, obrigou Portugal a "por um pouco mais de ordem em sua colônia, ordem mantida com artifício pela tirania dos que se interessavam em ter mobilizadas todas as forças econômicas do país para lhe desfrutarem, sem maior trabalho, dos benefícios". 80

Vários são outros estudiosos que traçam essa perspectiva comparativa e que também consideram pouco significativa a preocupação da Coroa quanto ao traçado das cidades, ou mesmo um total desleixo por parte de suas criações.

Ao se referir aos núcleos de "grande porte" estabelecidos nos sertões da Colônia, Duarte (1995, p. 33-4) considera-os cidades que se formam em desalinho e reveladoras de circunstâncias específicas de interesses de época, cidades que se apresentam tipicamente arquitetadas no ciclo do ouro, onde o luxo e o fausto estão mais para o interior das igrejas e ambientes domésticos, que para a rua; tornando-se pública apenas a arte religiosa através do barroco; estrutura-se um "urbanismo fruto da desordem pública", de acordo com o autor

Francisco Capuano Scarlato, em População e Urbanização Brasileira, também faz comparação entre a organização espacial das cidades espanholas, na América, e a organização citadina estabelecida pelos portugueses, no Brasil, e verifica uma marcante

\footnotetext{
${ }^{80}$ É bom lembrarmos que o diamante só foi descoberto na terceira década do século XVIII, quando a extração do ouro já se fazia em grande escala. Também já havia, nas Geraes, nove núcleos erigidos à vila por decisão de Governadores ou por ordem real, sem falar nos diversos arraiais espalhados, sob jurisdição de vilas.
} 
distinção nos dois processos de produção de espaços urbanos coloniais. Porém, coerentemente, esse autor não negligencia o ordenamento urbano das Geraes.

Scarlato (2005a) reconhece na tipologia urbana espanhola uma formação a partir da praça central, com edifícios públicos, igreja e quartel. Ocorria o estabelecimento de residências ao redor da "plaza mayor", orientadas pela posição social do residente; ruas cruzando em ângulos retos formavam grandes tabuleiros de xadrez. Logo, estabelecia-se um traçado em linhas retas das ruas e praças. "A cidade em tabuleiro de xadrez foi a expressão da necessidade de dominar o território conquistado."

Ao contrário da geometria adotada pelos espanhóis em suas cidades americanas, Scarlato (2005a) considera que as cidades brasileiras do período colonial cresceram desordenada e desalinhadamente, um "crescimento espontâneo". Para esse geógrafo, o alinhamento das ruas e das casas partia da iniciativa de seus moradores, onde ruas e praças deveriam ser adaptadas às irregularidades do relevo. $O$ autor conclui sua análise entendendo que, posteriormente, esses planos de produção do espaço urbano colonial transformaram-se num obstáculo à indústria, aos automóveis, aos transportes de massa e aos processos de modernização; o que é uma conseqüência lógica, uma vez que os homens daquele período não imaginavam o avanço que ocorreria em termos de comunicações e circulações, onde a sociedade passa a exigir novas espacialidades urbanas, novas formas para novas funções dentro de uma nova estrutura de relações.

Em 1956, Aroldo de Azevedo já alertava que estava, ainda, para ser feito um estudo analítico e circunstanciado da estrutura de nossas cidades coloniais e, de maneira particular, as características de seu plano urbanístico. Ao que tudo indica, ainda hoje, não fora realizado, no âmbito da geografia, um trabalho que se valha de registros capazes de direcionarmos a um consenso sobre a urbanística colonial, em especial das Geraes. Inicialmente, em sua análise, Azevedo (1956, p. 72) nos dá indicações de que os aglomerados que resultaram de um propósito deliberado das autoridades coloniais obedeciam, em suas origens, a um plano regular e geométrico, se bem que adaptado às características topográficas; é o que identificamos em Minas Gerais. No entanto, em seguida, Azevedo considera que "sem demora, porém, deixava-se de lado essa preocupação urbanística e a expansão passava a se realizar de maneira espontânea, sem obedecer a nenhuma diretriz, daí resultando a irregularidade no traçado das ruas, 
tortuosas quase sempre". O autor exemplifica com os casos específicos de Salvador, Recife e Rio de Janeiro.

Salvador possuía, em seu centro primitivo, na "Cidade Alta", certa regularidade e ruas que se cortavam em ângulo reto, constituindo um "verdadeiro tabuleiro de xadrez", bem ao contrário do que se observava no restante da cidade. $\mathrm{Na}$ observação de Azevedo, Recife resultou em uma cidade de disposição radiocêntrica, como a planejaram tornar, no futuro, os urbanistas dos Países Baixos. Sobre o Rio de Janeiro, no que tange aos aglomerados "espontâneos" ou "naturais", Azevedo afirma que a irregularidade do plano e o traçado tortuoso das ruas constituiam a regra geral, formando estruturas inorgânicas como as do núcleo primitivo da cidade de São Paulo. No fim de sua análise, Aroldo de Azevedo faz referência a Sérgio Buarque de Holanda (Raízes do Brasil) para assinalar seu ponto de vista sobre as vilas e cidades coloniais brasileiras, tornando-se mais um adepto da teoria que define nossas cidades coloniais como não sendo "produto mental" e mera expressão da palavra "desleixo".

A questão que fica para nós - e que a busca de sua resposta ultrapassa os limites desta pesquisa - é a seguinte: qual cidade colonial é analisada em vários estudos sobre a temática? Esse ponto, em muitas análises, não fica patente. A cidade do século XVI, XVII, XVIII ou início do XIX? Em cada época, dadas as necessidades de cada sociedade, em cada lugar, são produzidos e reproduzidos lugares através de uma valorização do espaço, como vimos no início da pesquisa. Logo, identificamos, em algumas análises, notória generalização sobre a cidade colonial do Brasil, ligando-as, sobretudo, ao "desleixo" ou à impropriedade "mental". Algumas dessas análises não delimitam o período nem a área estudada; muitas vezes, não fazem referência a fontes primárias ou arquivos ultramarinos, limitando-se a referenciar o vasto período colonial, que perdurou mais de três séculos. Para não nos alongarmos, fazemos uma referência a título de exemplo. "Imagem da desordem, da irracionalidade, ora da dependência em relação ao campo, ora da auto-suficiência, as cidades coloniais são também a imagem do vazio: são vazias de atividades, movimento, economia, construções e povo." (TORRÃO FILHO, 2003, p. 59)

Em seu artigo - Imagens de pitoresca confusão: a cidade colonial na América Portuguesa - o autor supracitado tem por objetivo entender como se constroem as imagens sobre as cidades portuguesas na América (tanto ordenadas quanto 
desordenadas), "não são as cidades reais meu objeto de estudo, mas sim as suas projeções", afirma o autor. Para tanto, o mesmo se vale das descrições de viajantes e naturalistas (que percorreram todo o Brasil, diga-se de passagem), além de fontes favoráveis à existência dos traçados regulares e, em oposição, dos traçados irregulares fruto do desleixo. Porém, enquadramos sua análise no grupo da generalização que, ao nosso ver, não permite apontar de qual cidade colonial trata; são cidades da "autosuficiência" ou do "vazio de atividades"? São cidades da "dependência em relação ao campo" ou despovoadas? São cidades do litoral ou cidades do interior? Todas essas são as cidades coloniais? Foram ordenadas ou criadas desordenadamente? Qual é a cidade colonial em tela, são todas, genericamente?

Para Geiger (1963, p. 69) os casos das cidades planejadas - Goiânia, Belo Horizonte e Brasília - não constituem fato novo na história brasileira. "Quando Tomé de Souza veio governar o Brasil, 30 anos após a Descoberta, trazia consigo os planos elaborados para a criação de uma cidade - Salvador. Trazia prontos os planos e os estatutos da que seria nossa primeira Capital." O autor faz certa reserva ao "antiurbanismo colonial".

A análise de Geiger nos é fundamental para uma crítica à generalização com a qual é tratada a cidade colonial. Para o autor, o problema se origina da maneira de abordagem da questão urbana, pois são comparados, segundo um mesmo conceito de cidade, centros urbanos dos séculos XVII, XVIII ou XIX, com centros urbanos do século $X X$, como se fossem da mesma categoria (espera-se dos construtores daquelas cidades a mesma noção de planejamento das cidades atuais). Em realidade esse problema desaparece se admitirmos tratar-se de duas estruturas urbanas completamente distintas, que Geiger contrapõe como "estrutura colonial" e "estrutura nacional"; fazemos, ainda, outra subdivisão em relação à "estrutura colonial": chamaríamos "estrutura colonial litorânea" e "estrutura colonial interiorana setecentista", que representam duas áreas cujas formas materiais, estruturas relacionais, processos históricos genéticos e funções sociais divergem por se constituírem em diferentes formações socioespaciais.

Desse ponto, partiremos para uma análise delimitada e, acrescentamos, também específica. Faremos uma abordagem - sumária - do urbanismo barroco das Geraes, "ordenado" com o desenvolvimento da mineração, pois é justamente desse urbanismo específico que se reproduz o acervo arquitetônico consagrado na 
contemporaneidade como Patrimônio Cultural Brasileiro, e em alguns casos - como Diamantina, Ouro Preto e Congonhas - Patrimônio Cultural da Humanidade, ou seja, esse urbanismo é resultante da gênese colonial do patrimônio, em Minas Gerais. ${ }^{81}$ Também, é bom dizer, partimos de fontes especializadas - uma bibliografia específica que dá conta da proposta de análise do urbanismo barroco, que tem espaço e tempo delimitados - e da observação empírica que fazemos já há alguns anos.

Assim, não trataremos da cidade colonial brasileira, genericamente, mas do urbanismo que se desenvolveu com o ouro e os diamantes, em Minas Gerais; poderíamos dizer que discorreremos sobre a cidade colonial mineira ou a estrutura urbana colonial interiorana setecentista, que resumimos como urbanismo barroco das Geraes (enquanto formação urbana específica desenvolvida no período de estabelecimento da arte barrocarococó $^{82}$ ), onde temos como referência, principalmente, Diamantina, além de Ouro Preto, São João Del Rei e Tiradentes.

Evidentemente, os primitivos arraiais, anteriores à grande mineração, foram acampamentos mesquinhos, concordando com Afonso Arinos de Melo Franco, em Desenvolvimento da Civilização Material no Brasil. "Talvez fossem choupanas com paredes de folhas, à moda indígena, talvez fossem de taipa mal acabada. Os arraiais do ouro, posteriores a esses, teriam naturalmente mais desenvolvimento." (FRANCO, 1944, p. 78). Porém, pela análise de Abreu (1997, p. 213-4), fica patente a necessidade e o desejo de ordenar os novos espaços que se desenvolviam com a mineração. ${ }^{83}$

\footnotetext{
${ }^{81}$ Gênese colonial que, no contexto do que denominamos dialética da construção destrutiva que envolve os bens patrimoniais na atualidade, representa a incipiente construção realizada no transcorrer de nossa "formação socioespacial” e formação territorial, quer dizer, essa gênese representa o próprio processo de valorização do espaço a partir do trabalho humano. Dessa forma, esse processo é um resultado do próprio trabalho humano, que é um ato de incorporação e criação de valor, de acordo com Moraes (2000) seria a representação da valorização do espaço.

${ }^{82}$ Para Amaral (1997, p. 60-61), na região diamantina, várias tendências se integram harmoniosamente sem a intenção de um estilo único (ou seja, não apenas o barroco), na arquitetura de barro e madeira, na pintura perspectivista em que domina o desenho construtivo, ou em que imperam os medalhões centrais de colorido vibrante, na douração com motivos rocaille dos altares, arcos-cruzeiros, retábulos e adornos de igrejas. Logo, dada a marcante presença da variante rococó em Diamantina, mencionaremos, quando a ocasião exigir, o urbanismo barroco-rococó. O autor critica a grande quantidade de autores que negligenciam a arte barroca-rococó da região diamantina, ao se restringirem à zona do ouro, "Por que essa produção em barro, madeira, dourados e cores dosadas de madeira fascinante em geral não interessa tanto aos especialistas?”, questiona Amaral. De acordo com Machado (1973), há noções simplistas, errôneas e de difícil erradicação, entre as quais, as que interpretam a fase final do barroco (a variante rococó) como fenômeno da decadência.

${ }^{83}$ Foram transplantadas para o Brasil as praxes metropolitanas de controle territorial, dentre as quais tomou vulto o sistema municipalista de base urbana e de raízes romanas, cujas manifestações materiais foram o arraial (ou povoado), a vila e a cidade, segundo Abreu. Dentre esses, apenas o arraial teve origem espontânea, resultando do agrupamento de famílias em algumas residências (fogos) com certa contigüidade e unidade formal. Os demais, surgiram da ação direta ou indireta do Estado. Assim, as vilas resultaram da decisão de donatários e governadores, que tinham poder para criálas, ou de ordem régia para que se elevasse a essa categoria algum arraial. A criação de cidades, entretanto, foi sempre
} 
Logo, o barroco implantado na zona do ouro e dos diamantes assumiu papel fundamental na morfologia dos núcleos criados, que ganham feição ao longo do século XVIII, dentro do processo de produção socioespacial das vilas.

Pelo fato das manifestações artísticas e arquitetônicas barrocas terem se apresentado num contexto histórico e espacial diferente do europeu, em Minas Gerais, acabou adquirindo configuração diversa, segundo Scarlato (1996, p. 132). Nesse sentido, para entendermos essa diferenciação, podemos analisar a ordenação dos núcleos urbanos das Geraes sob duas perspectivas de produção do espaço que, no nosso entender, se interagem e se complementam, tornando-se indissociáveis ao ocorrerem em um mesmo plano: sob a ótica dos espaços simbólicos do Estado absolutista (construções religiosas) e sob a ótica dos espaços simbólicos de uma nova burguesia comercial (construções civis), onde os primeiros impuseram, sob o símbolo do barroco, o ordenamento e o ritmo aos segundos, constituindo o urbanismo barroco das Geraes.

Lourival Gomes Machado, em seu referencial trabalho Barroco Mineiro, nos dá indicações preciosas da diferença entre o barroco europeu e o implantado em Minas. A começar pela edificação das igrejas, não sentiram "aquela fome espacial" que tantas vezes levou o barroco às expansões paisagísticas e panorâmicas, na Europa. Nas Geraes o problema se invertia: tratava-se de plantar a igreja na terra como uma afirmação e nunca se procurou responder ao padrão mais próximo o ritmo arquitetônico. Segundo Machado (1973, p. 187), em Minas, o templo não nasceu afogado pelo casario de cidades antigas, mas sempre teve à disposição todo o terreno que desejava. A observação atenta do ordenamento espacial dos núcleos tombados de cidades como Diamantina, Tiradentes, São João Del Rei e Ouro Preto, por exemplo, remete-nos à imposição das igrejas no traçado das cidades, sua localização panorâmica e privilegiada em relação ao conjunto, de

atributo específico da coroa. Abreu (1997, p. 214) deixa claro que a diferenciação entre vilas e cidades era de caráter jurisdicional e não hierárquico. As cidades, por serem da coroa, eram denominadas “cidades reais”, apesar de nem todas alcançarem o papel de comando que o título lhes conferia. No entanto, o caráter de vila não diminuía a importância de um centro urbano, vejamos o caso do Arraial do Tijuco, foi erigida à Cidade de Diamantina, sem ser vila e sem perder seu protagonismo no Norte de Minas. O autor esclarece que vilas e cidades diferenciavam-se bastante dos arraiais, pois, só nas primeiras estava a sede de um governo local. Ali, se dava a justiça em nome régio, prerrogativa que se materializava na paisagem urbana pela ereção do pelourinho; possuíam, também, um termo, ou área de jurisdição, dentro da qual se situavam arraiais e o patrimônio fundiário, terras do Conselho. Arraial do Tijuco estava sob jurisdição da Vila do Príncipe, atual Serro, como visto anteriormente. Almeida prossegue dizendo que havia os patrimônio municipais ou "rossio da vila", ou "rossio da câmara", situados nos termos da vila (municipalidade), essas terras eram inalienáveis, pois se destinavam à serventia do povo, para a pastagem do gado ou para "utilidade pública e proveito comum a toda vila, para madeira, lenha, canas, cipós...” (Abreu, 1997, p. 216-7). A análise do autor nos remete à ordenação espacial, à organização da nova sociedade colonial que se constituía em arraiais, vilas e cidades, na zona do ouro e dos diamantes. 
forma a se evidenciar no cenário urbano. No caso de Diamantina, as igrejas do Rosário, de São Francisco, de N. Sra do Amparo e de N. Sra das Mercês delimitam, quase nas extremidades, um conjunto quadrangular implantado em uma das encostas da elevação na qual foi edificado o arraial. Essas igrejas buscaram os lugares mais planos, visíveis e acessíveis ao mesmo (foto 06), dando mostra de um ordenamento espacial.

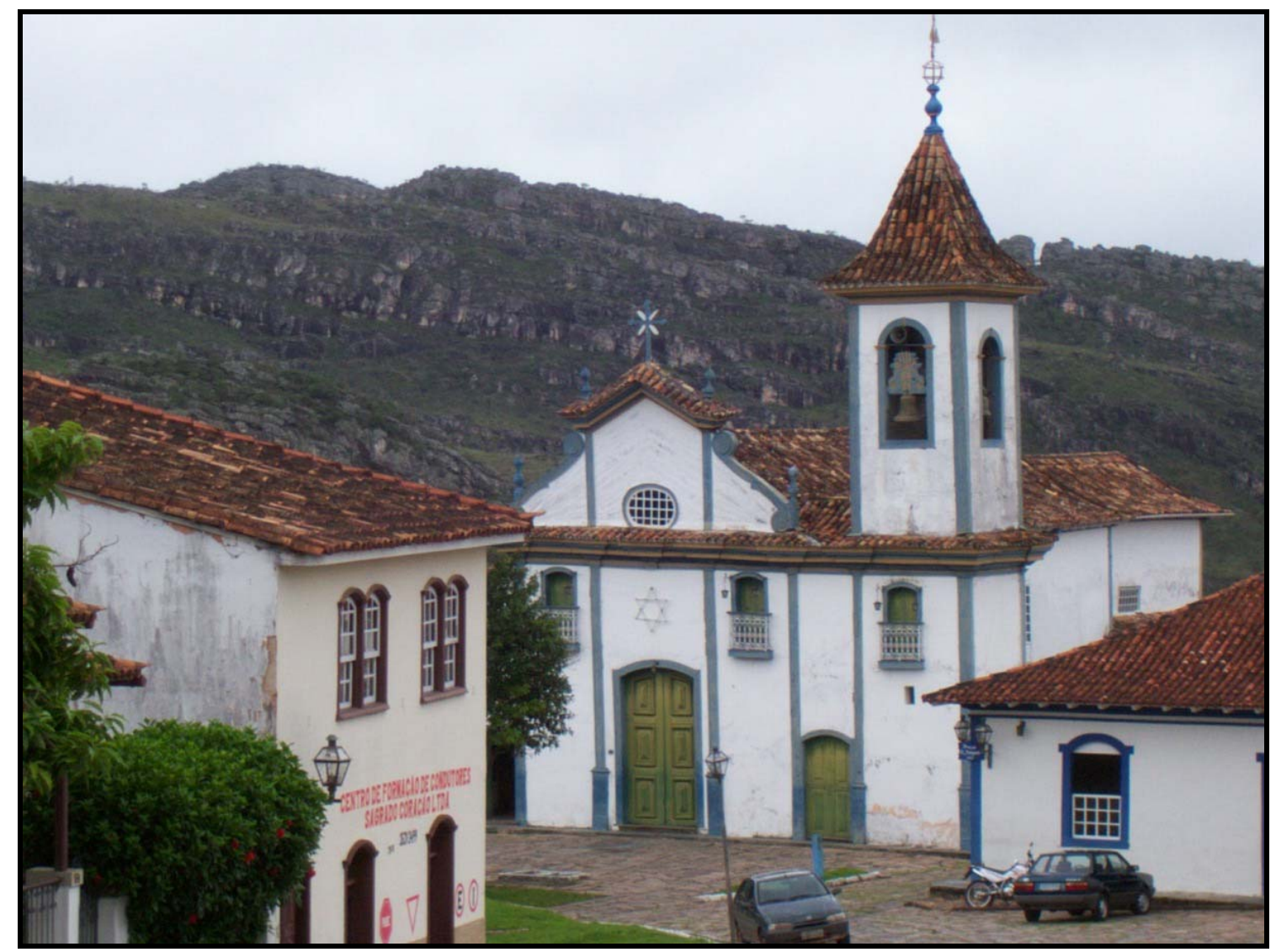

Foto 06 - Igreja do Rosário dos Pretos, em Diamantina, numa das extremidades do núcleo tombado, parecendo delimitá-lo. Foto do autor, jan / 07.

Também em São João as igrejas ocuparam os pontos estratégicos dentro da primitiva malha urbana, distribuídas pelos lugares principais de entroncamento e distribuição dos caminhos que chegavam ao núcleo. Verifica-se isso no posicionamento das Igrejas do Carmo, do Rosário e da Matriz do Pilar, todas na Rua Direita, de onde partiam e chegavam caminhos que levavam às minas nas encostas da Serra do Lenheiro (foto 07). A Igreja de São Francisco de Assis, no final da Rua da Prata, também se posiciona num ponto estratégico, numa área ocupada em segundo plano, servindo de balizamento para uma posterior ocupação, na margem direita do Córrego do Lenheiro, que atravessa o núcleo tombado. Em Tiradentes e Ouro Preto, pela topografia mais irregular, 
as igrejas foram implantadas em pontos de grande visibilidade e em espaços mais abertos, ganhando evidência no conjunto, como é o caso da Matriz de Santo Antônio e da Capela de São Francisco de Paula, em Tiradentes, e da Igreja de N. Sra do Carmo em Ouro Preto, posta em platô e defronte para o antigo Arraial de Ouro Preto, a dominar um amplo cenário da cidade.

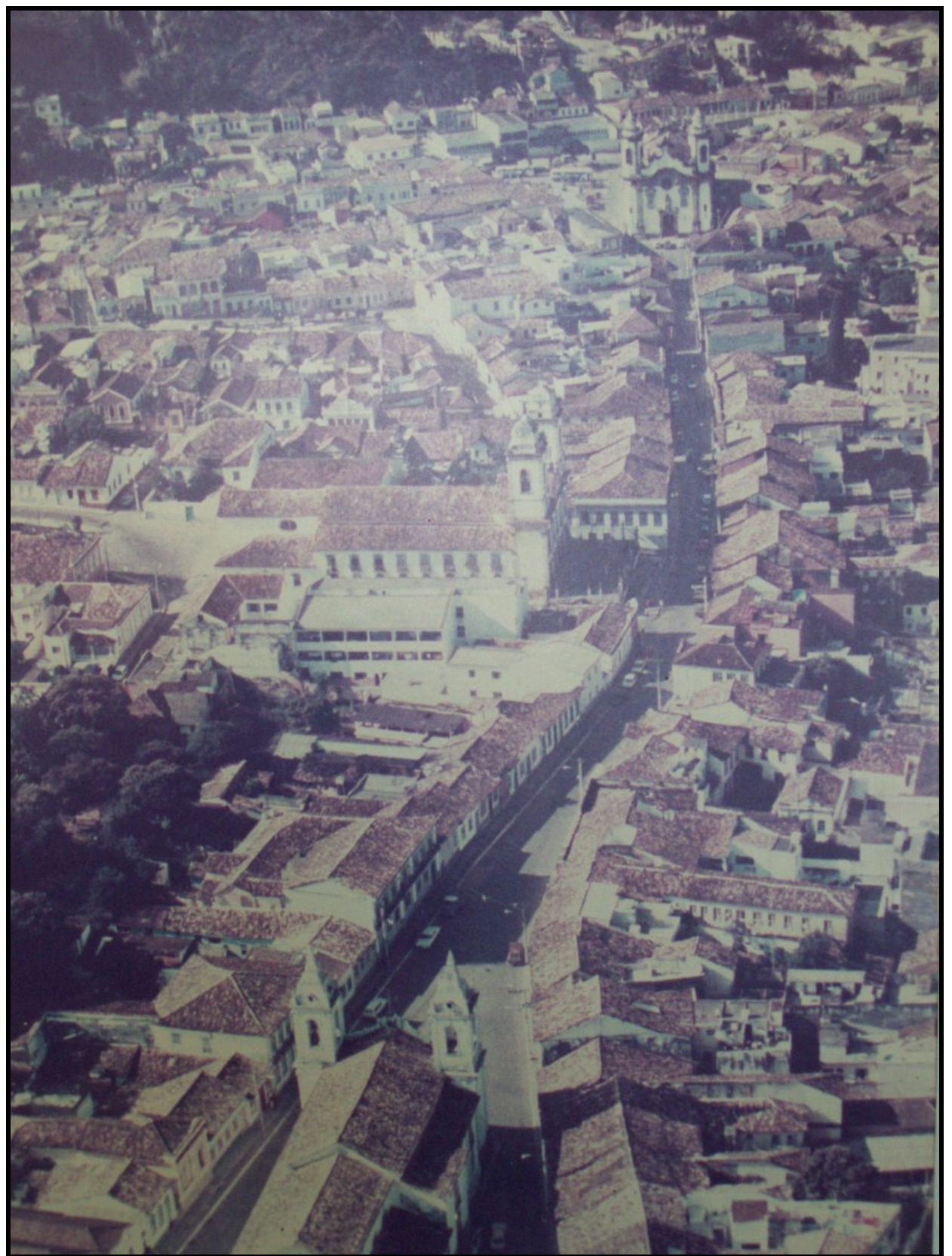

Foto 07 - Rua Direita, em São João Del Rei. A igreja abaixo é a de N. Sra. do Rosário dos Pretos, a central, voltada para o córrego do Lenheiro, é a Matriz de N. Sra. do Pilar e a que se encontra no fim da Rua Direita, acima, é a Igreja de N. Sra do Carmo. Salientamos que a rua Direita indica, não uma característica física, que por vezes desmentia o nome, porém o caminho mais direto entre referências maiores, quase sempre se não sempre em nossos primórdios, de cunho religioso, segundo Marx. Foto do IPHAN. 
Machado (1973, p. 104) considera que o barroco de Minas mostra-se claramente indiferente aos efeitos decorativos predominantes, aos recursos teatrais tão característicos nas grandes construções européias. As igrejas das Geraes, de maneira geral, tendem à "fachada limpa" e lisa (forma mais característica em Diamantina e Tiradentes, menos em Ouro Preto e São João Del Rei, muito mais carregadas nos ornamentos), caráter que embora abstrato, está "presente" mesmo nos casos em que a decoração recobre parte do muro plano e até quando há ondulação da própria fachada, o "decorativo das fachadas é mero complemento da arquitetura", o que se apresenta em contraponto ao padrão europeu. Se o barroco na Europa buscou expressar a "agitação sem fim" dos monumentos e ambiente exterior, aqui, essa agitação se expressa, determinantemente, no conjunto, ao nosso ver.

\begin{abstract}
A igreja da zona do ouro implanta-se diretamente na terra, sem ofertar preparativos cenográficos ao visitante, e, ainda quando apresenta adornos externos por vezes tão belos, sua determinante estética é a parede lisa e plana, em função da qual se conglomeram os demais elementos visuais. $\mathrm{Na}$ verdade, os monumentos, à medida em que avançamos nas datas, podem complicar sua feição anterior; contudo, mesmo quando chegamos às obras de auge, notamos que a maior grandiosidade expressiva não busca a agitação esplendorosa para exprimir virtuosismo ou para renegar a naturalidade, mas encaminha-se em sentido diverso, senão oposto. Lembraremos que o despojamento das fachadas só evidencia em contraposição ao modelo europeu, posto que a igreja mineira, quando comparada às suas ancestrais jesuíticas do litoral sul parecerá, pelo contrário, bem servida de embelezamentos externos. (MACHADO, 1973, p. 105)
\end{abstract}

Se a Coroa foi responsável pela organização do aparelho político-administrativo na zona do ouro e diamantes, as ordens terceiras e as irmandades (organizações laicas) diretamente ligadas ao Estado - assumiram a organização da vida civil, como também aponta Scarlato (1996, p. 134). Dessa maneira, mais que beleza estética materializada pela Igreja através do barroco na paisagem urbana histórica, ela assume papel relevante na organização da sociedade da mineração, junto ao poder público. Adquiriram importante papel no processo de estratificação da sociedade nos núcleos urbanos mineiros. Nada acontecia na vida social que não estivesse diretamente ligado à Igreja através das ordens religiosas ou irmandades, desde festas até o nascimento e óbito de pessoas, tudo era rigorosamente controlado pelas mesmas. Além disso, as pessoas, em razão de sua 
condição social, filiavam-se à irmandade condizente com sua classe, ou seja, essas irmandades organizavam os diferentes grupos da sociedade civil sob a invocação religiosa (irmandades de brancos - Santíssimo Sacramento e do Pilar, por exemplo, e irmandades de negros - como a do Rosário e de São Benedito). ${ }^{84}$

Deve ser destacado que em Minas inexistiram as grandes congregações (franciscanas, carmelitas e jesuíticas, por exemplo), que eram as responsáveis pela edificação da arquitetura religiosa do litoral brasileiro, bem como pela correspondência dessa arquitetura com o desenvolvimento e estratificação sociais da região, como aponta Vasconcellos (1997, p. 359). É interessante observar que se no litoral boa parte das igrejas eram erguidas por congregações que dispunham de recursos vultosos próprios, propiciados por suas matrizes na Europa, que também forneciam projetos, orientações e modelos, favorecendo construções rápidas impostas ao povo que delas não participava mais intimamente; nas Geraes, a inexistência dessas grandes congregações, proibidas por ordens metropolitanas, transferiu para o povo, de forma objetiva, a tarefa de edificar e ordenar os templos. Vasconcellos salienta que a composição das irmandades e ordens terceiras constituíram, em Minas, grupos que teriam de corresponder, naturalmente, aos agrupamentos sociais então existentes, sem maior assistência do clero e de Portugal. Essa tendência, diversa do litoral, marca a constituição social e espacial da zona do ouro e dos diamantes.

A arquitetura religiosa, dessa forma, especialmente em Minas, é representante de planos de construção ousados e suntuosos apoiados pela sociedade civil que se formava. Configura-se, nessa arquitetura e na decoração de seus interiores, o que se constitui em uma estética barroca que impressiona, exibe riqueza material e singularidade. Arte que não surge por mero acaso no interior do barroco, mas pela busca do desenvolvimento de armas da ideologia católica deflagradas com o movimento da ContraReforma. De acordo com Biancardi (2005, p. 46), a vontade de impressionar "pretendia agir sobre os sentidos, perturbar os hábitos, apelar para a afetividade e a imaginação,

\footnotetext{
${ }^{84}$ Logo, os grupos (homens brancos livres, mulatos e negros) filiavam-se a irmandades que reduziram os padres seculares a simples empregados e que se rivalizavam entre si, como é o caso de Diamantina e a longa peia entre os negros do Rosário e os mulatos da confraria das Mercês, como indica Colombo Filho (2005, p. 162). Podemos considerar que a Igreja em Minas, através das suas ordens terceiras, formaram corporações de classe da sociedade que se constituía. Contribuíam, informalmente, para a educação de uma população que o Estado demorou para assistir sob a forma de escolas, Casas de Misericórdia e garantiram assistência a menores e viúvas, segundo Frota apud Colombo Filho (2005).
} 
exatamente em oposição à postura do janseanismo [sic] protestante (...) ninguém poderia ficar impassível diante de uma obra de arte sacra".

É nessa linha que Scarlato (1996, p. 136) considera o barroco um movimento vitorioso no Brasil, pois enquanto manifestação artística e cultural - acrescentamos, espacial - da Contra-Reforma a arrebanhar os fiéis para o seio do catolicismo, a presença de cidades como Diamantina, Ouro Preto, São João Del Rei e Tiradentes (que aglomeram parte do irreplicável acervo arquitetônico barroco das Geraes) simboliza essa feita.

Fica patente a indissociabilidade entre o Estado e a religião no ordenamento da sociedade e dos núcleos que surgiram com a mineração, formando espaços simbólicos do absolutismo português, consciente da importância social dos signos faustosos e da demonstração de opulência, onde a determinação da estética de ostentação configura-se como arma de persuasão. Nessa perspectiva, a Igreja se serve da arte como um meio poderoso de persuadir, de conquistar os corações à fé pela admiração de uma beleza ofuscante, de acordo com Gregolin e Montanheiro (2005, p. 207). Após séculos no Brasil, o barroco continua sendo um poderoso instrumento de atração e persuasão, agora, com novo fim, de maneira que esse patrimônio é reproduzido para uma sociedade dita pósmoderna.

Nesse contexto de formação de um urbanismo barroco caracterizado pela marcante presença da Igreja, que teve na arte um instrumento poderosíssimo de controle social, há de se ficar claro que enquanto na Europa os edifícios religiosos precisavam se adaptar à uniformidade citadina e abria caso especial para si próprio (MACHADO, 1973), nas Geraes, a Igreja não se defronta com a imposição e a rivalidade do urbano, pois o antecede, o constitui e o domina. ${ }^{85}$ A observação e os melhores indícios apontam para a problemática de que na zona do ouro e dos diamantes as igrejas foram postas, inicialmente, em espaços amplos, abertos e vazios. Segundo Machado (1973), no caso de Ouro Preto, o casario que cerca suas principais igrejas não ousou encostar nas mesmas, respeitando a circulação livre a toda a volta, "quando isso não acontece e a construção civil vem confinar com a religiosa, o faz com toda a timidez e dificilmente encontramos

\footnotetext{
85 Carrato (1963, apud Gregolin e Montanheiro, 2005, p. 202) dá indicações das primeiras igrejas mineiras. “Os bandeirantes paulistas eram os verdadeiros arautos da fé: desde o princípio de suas andanças, pelas Minas, portavam seus oratórios de cedro ou de cabiúna e as imagens padroeiras, e depois que passaram a viajar em montarias, conduziam altares portáteis, que seus capelães armavam à sombra dos cruzeiros de baraúna chantados nas elevações ou dentro dos ranchos cobertos de colmo, de capim. Foram as primeiras igrejas mineiras.”
} 
mais de uma face de contato e, ainda assim, quase sempre a construção contígua é de emprego eclesiástico". Para o autor, fazendo referência a Ouro Preto, a igreja ficava solta no conjunto do burgo e, desde que as moradas começavam a cercá-la, mais adiante e mais acima haveria uma nova plataforma a espera da nova igreja, de forma que as datas de construção elevam-se com as cotas orográficas, conforme Machado (1973). Esse também é o caso das igrejas de Diamantina, todas datadas da segunda metade do século XVIII, de forma que as mais antigas - do Rosário e de São Francisco - localizam-se em dois extremos e nas partes mais baixas do conjunto.

Logo, a presença do catolicismo se fazia sentir pela maioria das ruas e esquinas dos núcleos, sobretudo nas íngremes colinas. Scarlato (1996) lembra-nos que além das grandiosas igrejas, ao longo dos tortuosos caminhos, em pontos estratégicos do emaranhado de vias, estavam sempre presentes enormes nichos como oratórios, onde se celebravam os atos da paixão, nas procissões e festas religiosas - os "passos" - que, para Scarlato $^{86}$, simbolizam o limite entre o sagrado e profano na urbe. Espalhados pelos aglomerados, os Passos da Paixão também representavam a presença da própria Igreja por todo o espaço e tempo, além de balizar o próprio crescimento dos núcleos, dando-os certo ordenamento.

Concordamos com Scarlato (1996, p. 136), pois se podemos associar as teorias do barroco e do absolutismo a manifestações isoladas das edificações produzidas nas Geraes (no caso das igrejas, símbolos da constituição de espaços de poder do Estado absolutista), dificilmente poderíamos fazer a mesma associação a uma teoria do urbanismo barroco, onde as grandes praças centrais emolduradas por um alinhamento de casarões com altimetria e volumetria rigidamente projetadas, desdobram-se em quarteirões com vias paralelas, seguindo sempre o plano da "praça central", estivessem presentes nas cidades de Minas. O autor afirma que esse padrão inexiste em Ouro Preto, tanto pelas razões de sua topografia como em razão da própria história da edificação da cidade, de forma que as únicas breves manifestações dessa forma de urbanismo podem ser encontradas na Praça Tiradentes e na volumetria do casario, seguindo sempre uma

\footnotetext{
${ }^{86}$ Essa análise foi desenvolvida in loco, em Tiradentes, analisando a trama espacial configurada pelos Passos da Paixão distribuídos pelas principais vias do núcleo urbano setecentista, quando do trabalho de campo para as cidades históricas de Minas Gerais, com os discentes do curso Geografia Regional do Brasil II - Sudeste do Departamento de Geografia da USP.
} 
mesma escala, alinhando-se ao longo das vias tortuosas e ladeiras, aproximando-se da plasticidade rígida do urbanismo barroco.

O que Scarlato (1996) identifica como a expressão de um urbanismo barroco em Ouro Preto, também identificamos em outras cidades históricas do estado, sobretudo, muito evidente em Diamantina, o que vem a caracterizá-la como um exemplo significativo do urbanismo barroco das Geraes. Na cidade, constituem-se em exemplos significativos de busca de ordenamento do urbano e valorização dos espaços públicos e de poder mesmo diante da acentuada irregularidade topográfica - as praças Barão de Guaicuí (onde se localiza o Mercado Velho) e Joubert Guerra (que concentra grandes sobrados de até três pavimentos e a imponente Matriz de Santo Antônio), conforme foto 08, abaixo.

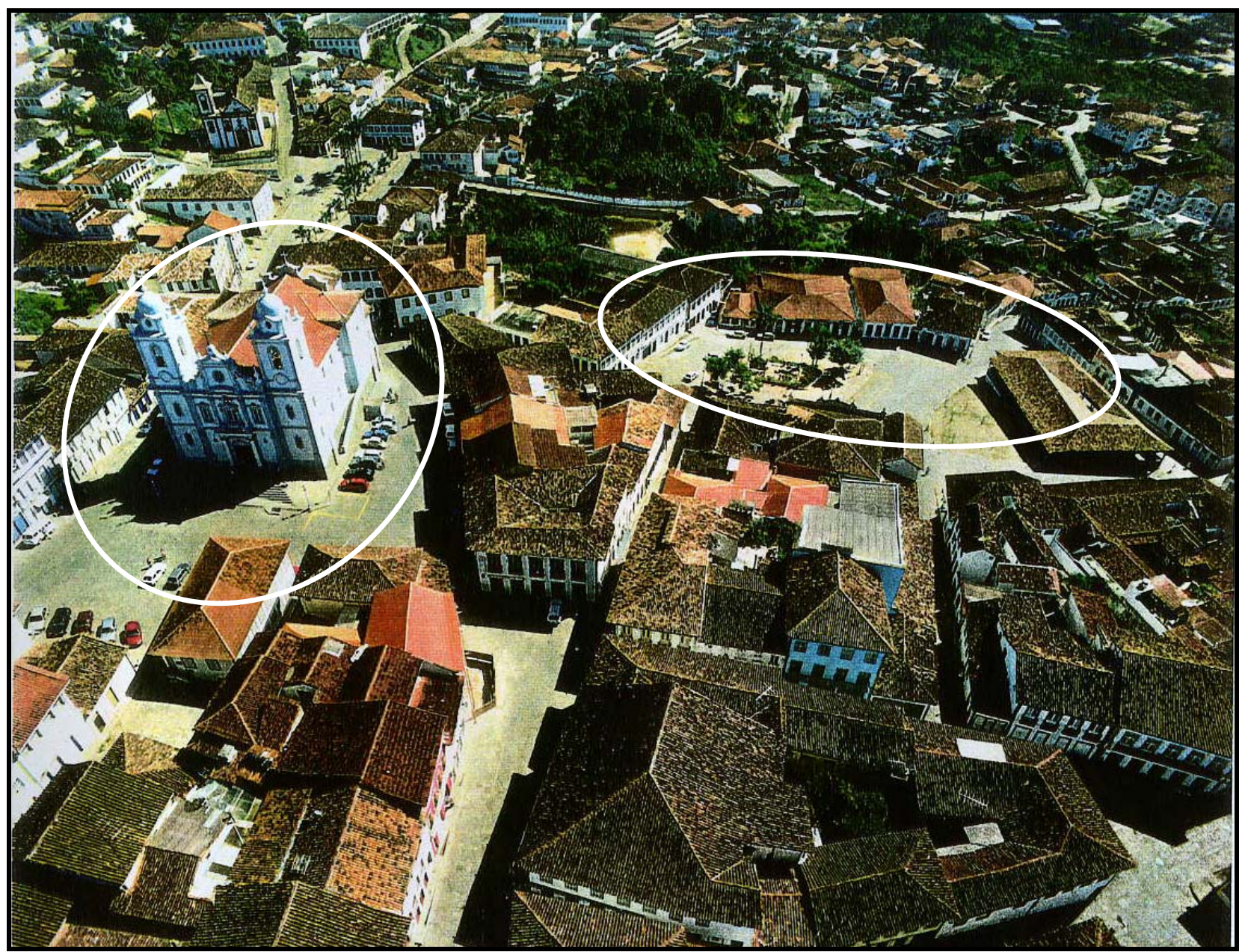

Foto 08 - Valorização das principais praças, no espaço urbano de Diamantina. Foto da PMMG / 06.

Retomando nosso ponto de vista esboçado anteriormente, sobre a análise da urbanística das Geraes - sob a ótica dos espaços simbólicos do Estado absolutista 
(construções religiosas) e sob a ótica dos espaços simbólicos de uma nova burguesia comercial (o próprio conjunto que agrega as construções civis), que se articulam - resta apontarmos algumas características dos conjuntos, que, como já afirmamos, sofreram imposições de um ordenamento balizado pela disposição das próprias igrejas barrocas estrategicamente localizadas, onde cada conjunto pode ser caracterizado pelo balanço, densidade, ritmo e volumetria de sua arquitetura ${ }^{87}$, conformando o urbanismo barroco das Geraes.

Para Nestor Goulart Reis Filho, em Notas sobre o urbanismo barroco no Brasil, a análise deve buscar as obras menos monumentais (casario, ruas e praças) examinadas no conjunto, pois, tomadas isoladamente, perdem expressão (diferentemente das obras simbólicas do Estado absolutista). Para o autor, esses conjuntos representados pelas obras menos monumentais nem sempre foram considerados como dignos de estudos e preservação, sendo, historicamente, destruídos.

Freqüentemente, quando se menciona o urbanismo barroco, há referências ao palácio de Versalhes, com seus parques (...) que podem ser relacionados com a multiplicidade de perspectivas da decoração das igrejas barrocas ibéricas e ibero-americanas. Mas é possível estabelecer uma outra referência para o urbanismo barroco: a das praças e conjuntos urbanos. No Brasil, tivemos alguns exemplos importantes dessa forma de urbanismo, que nunca foram devidamente valorizados. (REIS FILHO, 1997, p. 218)

Consideramos que a própria geografia da região das minas auxiliou na caracterização do urbanismo barroco implantado. Localizadas em um relevo extremamente acidentado do sudeste, seguindo os vales dos rios e encostas de onde se extraia o ouro e os diamantes, os portugueses não poderiam ter criado cidades diferentes das que encontramos hoje. ${ }^{88}$

\footnotetext{
${ }^{87}$ Bruno Zevi, em Saber ver a arquitetura, é taxativo quanto à necessidade do método para a análise dos conjuntos arquitetônicos. "Se (...) quisermos ensinar a saber ver a arquitetura, devemos, antes de mais, propor-nos a clareza de método” (ZEVI, 1978, p. 15). Assim, dentre os conceitos discutidos pelo autor, o balanço (ligado à altimetria proporcionada pela irregularidade topográfica e que influi, diretamente, na percepção do movimento do conjunto; na escala do edifício, representa seu equilíbrio, ou seja, massas equivalentes de um lado e outro da construção, a partir de um eixo central), a densidade (refere-se ao número de edificações, cuja percepção nos remete à escala do conjunto) $e o$ volume (diz respeito à própria volumetria dos edifícios) tornam-se fundamentais para a leitura dos espaços barrocos, em nosso entendimento, como também aponta Scarlato (2008).

${ }^{88}$ Não imaginamos que os espanhóis pudessem ter ladrilhado núcleos, em nossa zona do ouro e diamantes, diferentes de Diamantina e Ouro Preto; a busca de terrenos menos irregulares e distantes das áreas de extração colocaria em risco a própria empresa pelos descaminhos dos produtos, aumentando a dificuldade do controle régio, uma problemática.
} 
Na visão de Nestor Goulart Reis Filho (1968) em Contribuição ao Estudo da Evolução Urbana do Brasil. (1500/1720), em Minas, já no início do povoamento, havia preocupação entre os oficiais das Câmaras com questões urbanas. Apesar do povoamento recente, já se verificava a preocupação com o arruamento, abastecimento de água, abertura de ruas e estradas, calçamentos, alinhamento de residências e limpeza pública. Uma regularidade no traçado urbano que se evidencia nas "cidades novas" a partir do setecentos. Esse autor crê ter havido uma ordenação espacial dos núcleos urbanos edificados, sobretudo, a partir do setecentos, na região das minas.

A irregularidade topográfica associada às precárias técnicas de construção e a existência de agentes imediatistas, afoitos pelo enriquecimento com o ouro e diamantes abundantes, podem ter contribuído para o estabelecimento de núcleos desordenados, inicialmente, como nos referimos anteriormente.

As Câmaras Municipais, como órgãos locais de administração, eram as responsáveis pelo controle do crescimento urbano, apesar dos poucos recursos. Reis Filho (1968, p. 118) menciona que o contrato de homens que "particem terras da villa" e de arruadores representava um esforço das municipalidades para controlar as mudanças em sua organização espacial. Centros maiores com esquema administrativo mais evoluído contavam com presença de arquitetos e engenheiros. E é claro, se houve engenheiros militares e arquitetos, além de artistas mulatos consagrados na história urbana de Minas, como Antônio Francisco Lisboa (Aleijadinho), o mestre Manuel da Costa Ataíde e Manuel Victor de Jesus (em Tiradentes), por exemplo, houve também uma massa de negros que, por preconceitos raciais e negligência de classe foram esquecidos; artistas negros e mulatos que nos deixaram obras significativas do barroco e rococó brasileiros, presentes, ainda hoje, em inúmeras das chamadas cidades históricas vivas ${ }^{89}$ espalhadas pelo território, não apenas em Minas; caíram no ostracismo, como já nos referimos em um trabalho anterior (COSTA, 2008b, p.74). ${ }^{90}$

\footnotetext{
${ }^{89}$ Para rever esse conceito, retomar o capítulo 2.1. desta pesquisa.

${ }^{90}$ Reis Filho (1997, p. 234) considera que a produção arquitetônica brasileira do tempo de colônia há de ser entendida através da análise, não só de suas construções, mas também da formação de seus autores, sempre dependentes de uma técnica construtiva limitada aliada a uma precária fonte de informação advinda das imensas dificuldades de comunicação. Segundo o autor, a arquitetura oficial era exercida praticamente com exclusividade pelos engenheiros militares, sendo raros os mestres ou construtores civis trazidos pelas autoridades locais representantes do governo ultramarino. A arquitetura religiosa era repartida entre esses engenheiros militares e os mestres do risco ou artistas das várias ordens aqui sediadas, com Antônio Francisco Lisboa (Aleijadinho) e o mestre Ataíde. As construções civis residenciais ficavam à mercê da variadíssima gama de profissionais que iam desde altamente qualificados, o que era
} 
Vieram, sim, mestres de vários ofícios, oleiros, ferreiros, carpinteiros, sapateiros, homens de tradição íbero-mourisca, escultores, estatuários, artistas diversos, arquitetos, mestres-de-obra, etc., mas não foram as mãos delicadas de franceses, holandeses ou mesmo de portugueses que sobrepuseram pedra sobre pedra nos arraiais, vilas e cidades aqui instaladas. (COSTA, 2008b, p. 73-74)

Segundo Reis Filho (1968, p. 147), a aparência geral das ruas favorecia a colocação de edifícios de importância em frente ao término das mesmas, "no ponto de fuga da perspectiva", criando alguma variedade na paisagem urbana e ao mesmo tempo valorizando o edifício ali colocado. Refere-se à igreja de São Francisco em São Paulo, em frente à rua de São Bento, defronte à igreja de mesmo nome, e à Igreja do Rosário em Ouro Preto colocada em posição estratégica, dando idéia de profundidade; o posicionamento de edifícios oficiais e religiosos eram privilegiados na organização do espaço urbano colonial mineiro, como mencionamos acima sobre Diamantina, onde as igrejas fecham um espaço quadrangular parecendo delimitar e proteger o núcleo.

Se no início do XVIII as Câmaras Municipais exigiam apenas que as novas edificações respeitassem os termos dos alinhamentos fixados pela administração municipal, como pré-condição para aprovação das construções, no final do século, já impunham como pré-condição a apresentação dos desenhos que corresponderiam, ainda de maneira precária, aos atuais projetos, submetidos a aprovação da autoridade municipal, segundo Reis Filho em $A$ urbanização e o urbanismo nas regiões das Minas.

Nesse sentido, as construções comuns adquirem relevância na paisagem urbana e as normas para a sua regularização corresponderiam a um projeto de conjunto ou ao um modelo coletivamente aceito, que não poderia ser apenas imposto pela autoridade central da colônia mas teria que ser, necessariamente, resultado de uma disciplina coletiva, em atendimento a valores urbanos, burgueses, modernizadores, racionais, leigos e oficiosos mas não oficiais, que iam sendo introduzidos e difundidos com as idéias da llustração, segundo Reis Filho (1998, p. 02-03).

Não podemos desconsiderar que são os próprios objetos como as casas de câmaras e cadeias, pelourinhos, palácios, igrejas, sobrados, pontes de pedras, traçados das ruas, desenhos das praças e largos, que constituem e dão forma ao conjunto, que vão

raro, até humildes pedreiros, taipeiros e carpinteiros, que trabalhavam pelo país afora repetindo sempre as lições aprendidas através da observação das obras mais significativas. 
caracterizar a cidade colonial mineira, não seguindo à risca o ritmo em arquitetura. Instaladas em terrenos de topografia irregular e distantes do litoral, ainda, com todas as dificuldades de comunicação do século XVIII, essas cidades representam a vontade de conquista do colonizador, o momento da fixação à terra e a busca da adaptação socioespacial.

Coelho Netto (2007, p. 133) menciona que o ritmo tem a finalidade de pôr em prática três princípios muito caros ao pensamento renascentista: princípio de equilíbrio, princípio da continuidade e princípio da passagem do todo para as partes. Cita P. A. Michelis para completar o conceito; "o ritmo permite-nos adivinhar que vai seguir-se um golpe rítmico ou uma certa série de golpes, assim como mais ou menos o efeito segue a causa. Antes portanto que o golpe se produza nós já o esperamos, e quando ele acontece segue-se em nós uma sensação muito rápida de satisfação."

A partir desse entendimento do ritmo em arquitetura, podemos afirmar que a cidade colonial mineira não o respeita, fugindo da arte renascentista e adotando uma nova concepção de organização espacial que representa o próprio barroco. Nesse ponto, concordamos com Coelho Netto (2007), pois é justamente o "tortuoso" um dos elementos fundamentais para a animação de um espaço, para sua vitalização, para a eliminação do tédio do "habitar". Uma longa avenida em linha reta, com suas ruas paralelas e igualmente retas não nos deixam surpresas, não vão nos causar espanto e êxtase, não há reconhecimentos, não há intimidades, o ritmo indica o que virá depois. Ao contrário, é a própria tortuosidade e as estratégias construtivas imperante nas cidades coloniais de Minas que nos dão a impressão de haver sempre algo a conhecer, a descobrir, a viver; é essa irregularidade - que no nosso entender é a melhor expressão urbana possível, dadas as possibilidades locais e de época - o diferencial que dá sentido ao urbanismo barroco das Geraes; é essa irregularidade, a tortuosidade, a complicação do sentir e da expressão próprias do barroco que caracterizam esse urbanismo.

Levando ao extremo, poderíamos dizer que esse urbanismo representa o barroco em si, que buscou negar a forma linear e fechada da arte renascentista, cuja ordenação era capaz de produzir equilíbrio e ordem (AGNOLIN, 2005, p. 175). O urbanismo barroco das Geraes é assimétrico no que tange as condições de sua implantação em terrenos, por vezes, extremamente acidentados, o que oferece acentuado balanço aos conjuntos; por outro lado, o urbanismo barroco das Geraes buscou 
determinado padrão das formas que constituem os conjuntos, a contrabalançar a geografia física regional. ${ }^{91}$ Assim, temos, por um lado, os balanços e as paisagens pitorescas propiciadas pela topografia e pelas dificuldades técnicas que os construtores não temeram - que indica como desleixo o observador menos atento. Por outro lado, identificamos a busca da regularidade das formas, nos conjuntos; que nos dão importantes indicações Reis Filho (1968, 1992, 1997, 1998) e Scarlato (2008).

Reunidos de acordo com o desenho dos conjuntos urbanos barrocos, os edifícios mais simples dos particulares adquirem um caráter monumental, que até então fora privilégio das grandes construções e praças de caráter aristocrático, nas quais se instalavam as edificações públicas, as do clero e dos grandes comerciantes; "os conjuntos urbanos barrocos são a afirmação do Terceiro Estado e a glorificação do comércio", considera Reis Filho (1997, p. 221). Vasconcellos também nos remete à complexidade da sociedade da mineração, ao papel preponderante dessa sociedade que se constituía na produção do espaço urbano colonial setecentista, que necessitava ser ordenado.

Se o lugar progride, alguns se enriquecem, outros permanecem pobres, aparece um novo tipo de atividade e de gente: o comércio. Começam a se definir as classes sociais: pobres, ricos, trabalhadores braçais, comerciantes, administradores, brancos, pretos etc. A localidade tende a estabilizar-se, exigindo paróquia provida de vigário próprio. A classe de maior recurso, recém-constituída, trata de construir a matriz. (VASCONCELLOS, 1997, p. 360)

É bom lembrar que os procedimentos adotados pelo governo português no século XVIII, para fundação de vilas e cidades, no Brasil, foram consolidados no período pombalino, de forma a constituir uma linha de suporte técnico para uma sólida política urbanizadora. Reis Filho (1997, p.218) menciona que, no período, foram estabelecidos documentos que traçavam as diretrizes básicas para a organização territorial e políticoadministrativa na criação de vilas. Documentos que prescreviam normas para o traçado de ruas e praças, traçados de lotes dentro de quadras e fixava padrões de fachadas, que conduziam a uma sistemática padronização da própria arquitetura. Estabeleciam diretrizes

\footnotetext{
${ }^{91}$ Machado (1973, p. 109), ao se referir ao sítio da igreja mineira, por exemplo, considera que esse exclui a necessidade do enriquecimento da fachada, dado o próprio caráter da paisagem, ou seja, da irregularidade, da complexidade da implantação das igrejas e dos conjuntos. "De fato, a orografia característica da zona do ouro, que jamais o urbanismo ou a arquitetura coloniais buscaram contraditar, sempre acompanhando os caprichos da feição do terreno, e feita de surpresas, imprevistos e dificuldades, desenhando-se curvas fortíssimas quer vertical, quer horizontal”.
} 
para os padrões dos lotes e dos edifícios, visando a uniformização das fachadas dos prédios e sua integração em conjuntos maiores, em cada quadra. "No exemplo ideal, os edifícios tinham todos a mesma altura, as mesmas dimensões de portas e janelas e os mesmos tipos de ornamentos, como se fossem partes de um edifício maior."

Segundo Reis Filho (1998, p. 03), a disciplina urbanística do século XVII e da primeira metade do século XVIII era, sobretudo, uma disciplina de traçado, de regularidade de alinhamentos que só pode ser percebida em planta. Regulava basicamente as relações entre os espaços públicos e os espaços privados evitando a apropriação de parcelas dos primeiros pelos segundos e procurava assegurar a livre circulação de pessoas, animais e veículos, em condição de eficiência para a época.

Observando a planta de Diamantina, da primeira metade do século XVIII, podemos atestar a assertiva do autor supracitado. O Arraial apresentava um traçado regular, formando grandes quadras retangulares e ruas que buscaram a reta, em uma grande encosta, de acordo com a planta. Verificamos também o posicionamento das igrejas na malha urbana, postas a delimitar o conjunto que se formava, como nos referimos anteriormente. ${ }^{92}$

\footnotetext{
${ }^{92}$ Está transcrito abaixo da planta: "Contem este Arraial sete Templos, estes vaõ numerados nos seos lugares como adiante se mostra; contem mais 567 cazas, estas se mostraõ nos lugares escurecidos com pardo, e quazi todas inda no centro do mesmo Arraial, tem pateo, úas maior, otras menór conforme acomodidade de cadaúma; as linhas que semostraõ na planta são os muros que dividem os quintáes; os pontinhos saõ caminhos que saem domesmo Arraial. Este esta situado na descida de um morro, ese estende quazi até a afalda [sic], é toda estas acompanhada de um regato, que se intitula Rio de S. francisco, todos os lugares onde acompanha na sombra azul aúm risco prêto são valos com algúa agua, qe vão dar aomesmo Rio. Identifica os templos localizados na representação, após a nota transcrita anteriormente, nomeandos: Sto Antonio, Igreja Matriz; Snra do Rosario, Igreja dos Prêtos; Snr do Bonfim, Capelinha; S. Francisco de Paula, Igreja dos Terceiros do Carmo; Snra da Conceição, Igreja dos Terceiros Franciscanos, Snra do Amparo, Igreja dos Pardos; Sta Quitéria, Capelinha.”
} 

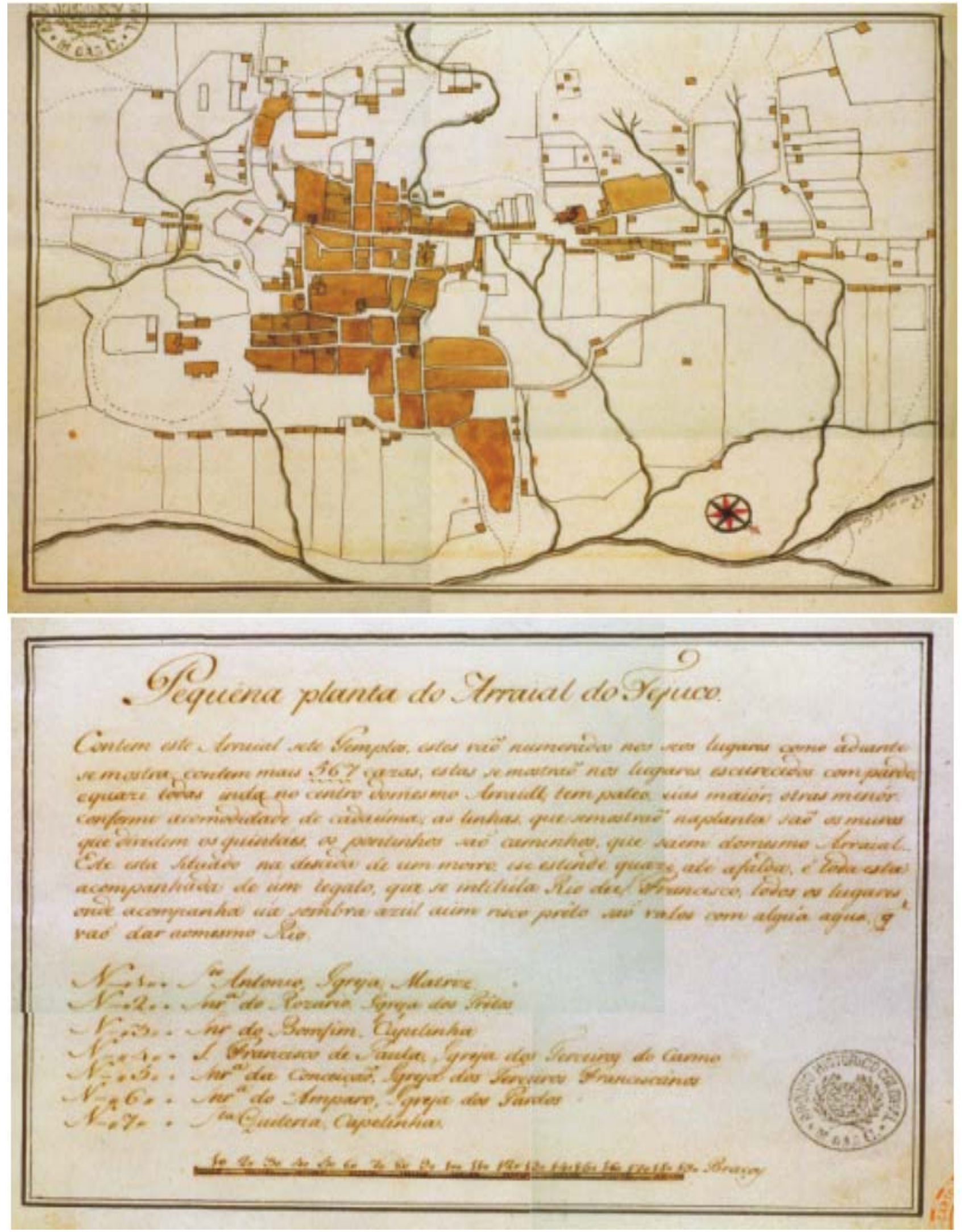

Fonte: Centro de Referência em Cartografia Histórica / IGC - UFMG. 
A partir da segunda metade do século XVIII, o urbanismo mineiro apresenta dimensões mais ambiciosas. Apresenta-se, segundo Reis Filho (1998), como parte de um projeto de criação de um cenário urbano, no qual as paisagens são definidas como conjuntos que resultam de uma disciplina imposta às construções comuns, cuja importância crescente vem colocá-las no primeiro plano da definição estética, cultural e política das vilas e cidades, correspondendo com as transformações sociais que estavam ocorrendo.

Torna-se fundamental para a análise favorável da existência do ordenamento dos núcleos das Geraes um posicionamento em relação aos sentidos da palavra regularidade. Quando os historiadores remetem o termo à comparação do urbanismo português e hispânico nas Américas, o fazem considerando regularidade como atributo do traçado geométrico, obedecendo à forma de xadrez. Porém, consideramos um sentido diferente para regularidade, que se aproxima do que Reis Filho (1998) considera como existência de repetições de determinadas características, quer seja em um núcleo, quer seja nos núcleos que surgem na zona da mineração, representando séries de eventos; o que nos leva a observar diferentes formas de disciplinas urbanísticas empregadas na zona do ouro e dos diamantes.

Reis Filho (1998, p. 04) apresenta como modalidades de disciplina urbanística os seguintes casos: alinhamento das casas junto às ruas; a largura das ruas; a ordem estabelecida das fachadas; a concentração das casas das câmaras e palácios, além dos sobrados dos homens mais ricos, nas principais praças públicas dos núcleos do século XVIII. O olhar atento sobre Diamantina e outras cidades da zona do ouro e dos diamantes revela-nos essas disciplinas urbanísticas empregadas em Minas Gerais.

A preocupação com o alinhamento das casas junto às ruas fica evidente em todas as vias do primitivo núcleo de Diamantina. Apesar de alguns autores considerarem essa disciplina como adoção de ruas retas, nem sempre foi assim, na realidade são duas formas distintas de disciplina, conforme Reis Filho. O alinhamento das casas era estabelecido por iniciativa do chamado arruador, que fixava a linha segundo a qual eram divididos os espaços públicos dos espaços privados. As ruas, na maioria das vezes, estabeleciam-se em curvas, em Minas, dada a irregularidade dos terrenos, de maneira que se procurava acompanhar as curvas de nível ou cruzá-las de forma suave, não admitindo que os terrenos avançassem sobre as ruas. "Curvas ou retas, as ruas deveriam 
ser definidas sempre por uma única linha contínua estabelecida pelo arruador (...) Nas ruas com aparência de curvas essa linha não era composta de uma sinuosidade contínua mas correspondia a um conjunto de pequenas retas que seccionavam em cada terreno a linha em curva, puramente imaginária de tal sorte que a cada lote correspondia, em principio, uma linha reta." Observando a foto 09, de Diamantina, verifica-se o alinhamento dos sobrados rente à rua, respeitando essa disciplina urbanística.

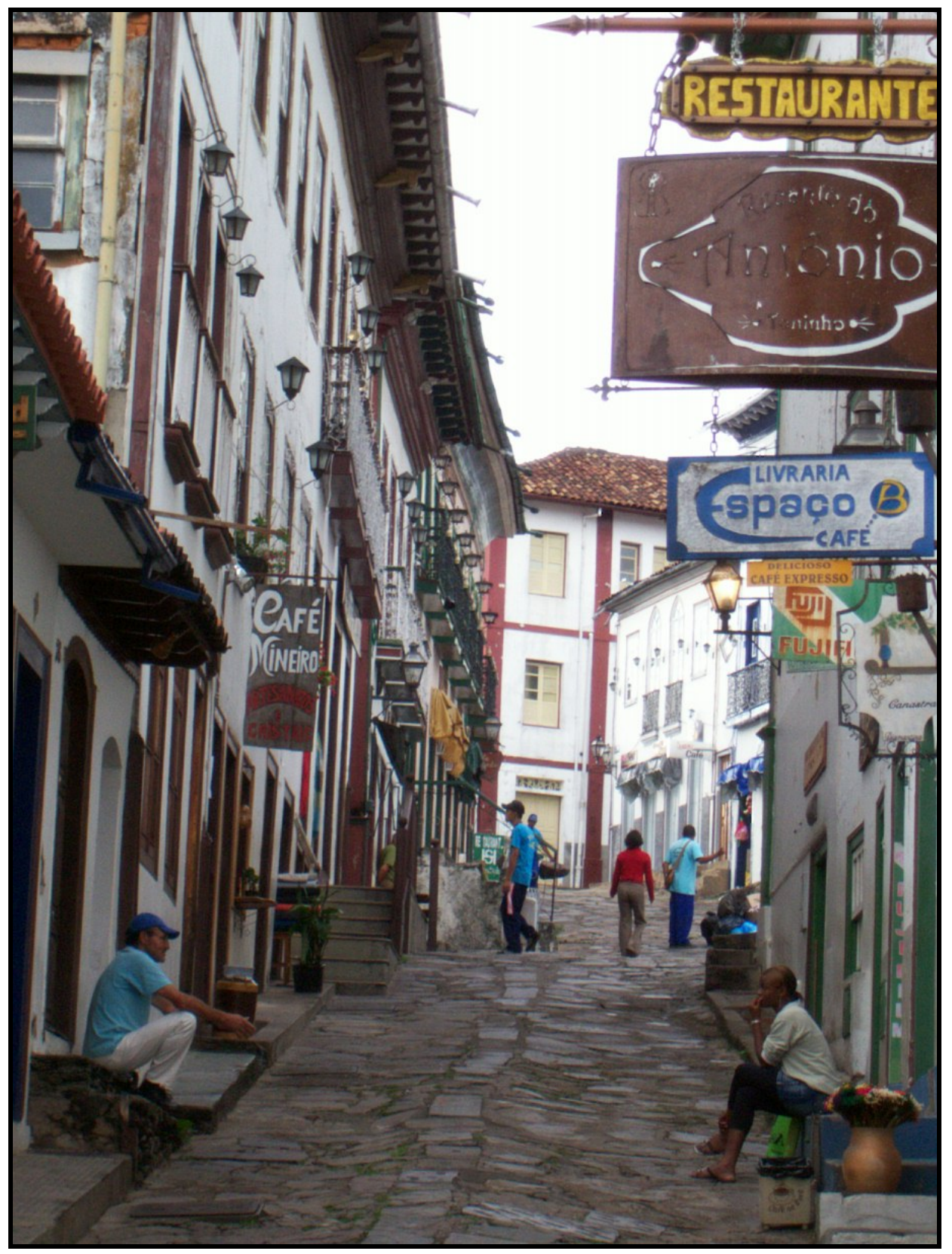

Foto 09 - Alinhamento dos sobrados no Beco da Tecla, em Diamantina. Foto do autor, fev / 08. 
Uma maior complexidade no trabalho do arruador se dava na manutenção da largura das vias púbicas. O alinhamento das ruas não correspondia necessariamente a uma largura constante. Em ruas retas ou ruas curvas, buscava-se, sempre, a uniformidade da largura, em obediência à determinação da câmara, em geral em atendimento aos padrões mínimos indicados pelas Ordenações do Reino. Contudo, o que identificamos in loco, apesar de algumas ruas tendentes à linearidade, quase nunca atingindo-a, é uma variação da largura das ruas. A Rua Direita em São João Del Rei, a Rua da Câmara em Tiradentes e a Rua Direita, em Diamantina, são exemplos da tentativa de manutenção da largura das ruas que, adaptando-se ao relevo, às curvas de nível, tiveram consideráveis variações. $^{93}$

De acordo com Marx em Cidade no Brasil em que termos?, o cuidado com o alinhamento e com o nivelamento persiste no pequeno rol de atenções das câmaras municipais, no que diz respeito à configuração do espaço urbano em geral, ao traçado viário e à disciplina devida pelos concessionários de data. Esse cuidado vai crescer com a expansão de determinadas vilas e cidades de vida urbana mais intensa, como é o caso de Diamantina, Ouro Preto e São João Del Rei. Dessa maneira, nas cidades do ouro e dos diamantes, o alinhar, fazer alinhamento ou simplesmente alinhamento foi sempre estabelecer fronteira entre o espaço público e o privado (MARX, 1999, p. 79; SCARLATO, 2008).

Buscou-se o ordenamento frente às agruras dos terrenos da região das minas. A primeira impressão do visitante que chega a Diamantina ou a Ouro Preto é a da mais pura desordem do espaço urbano. Só a análise apurada, mais longa e desprovida de préconceitos, oferece indícios da busca do alinhamento das ruas, de suas larguras e da proximidade das casas junto às vias, além da ordem das fachadas; é claro, a análise deve sempre relevar a escolha que se deu para a implantação dos sítios, nos vales e nas encostas mais íngremes e próximas dos locais de extração.

\footnotetext{
${ }^{93}$ Para fazer uma breve observação sobre os nomes das ruas, Marx esclarece que diziam respeito, ora aos tipos de gente habilitada a certos ofícios (do Sapateiro, dos Ourives, dos Saboeiros etc.), ora competindo com outros mais gerais, como rua da Praia, do Meio, de Cima, de Baixo, do Comércio pura e simplesmente, ou a freqüente e mais típica rua Direita. Aquelas a indicar uma situação topográfica relativa, indiretamente função ou funções, ou o conjunto de funções diferentes. A Direita a indicar não uma característica física, que por vezes desmentia o nome, porém o caminho mais direto entre referências maiores, quase sempre se não sempre em nossos primórdios, de cunho religioso. Assim, podemos considerar que as ruas representavam, de forma geral, a própria divisão social e territorial do trabalho que se processava nos novos centros urbanos das Geraes.
} 
Sobre a disciplina urbanística que se refere à ordem das fachadas, talvez se constitua na mais clara evidência da regularidade do urbanismo barroco das Geraes lembremos, regularidade no sentido de repetição de características.

Essa modalidade de disciplina escapa da planta da cidade e dá conformação padronizada ao conjunto de edifícios que se implantam, ou seja, à ordem estabelecida das fachadas, para controlar as formas e a aparência das edificações (de cada edificação e do conjunto) em cada trecho das ruas e das praças (REIS FILHO, 1998, p. 05). Essa disciplina determinava o espaçamento entre portas e janelas nas fachadas e a altura dessas aberturas bem como a altura de cada um dos pavimentos, incluindo regras para que os edifícios adquirissem uma linha dominante no conjunto (foto 10). "Desse modo, sem que as decisões fossem tomadas isoladamente por cada um dos proprietários, as casas de uma rua terminavam por formar um conjunto, como se fossem uma única obra de maior porte".

O que se mostra é a presença de diretrizes aplicadas às vilas do século XVIII, com distintos graus de complexidade urbanística que se apresentam nas paisagens urbanas históricas. De forma geral, nesse contexto de tentativa de ordenamento que se estabeleceu, é notório, como mencionado por Reis Filho, que, na paisagem urbana, os edifícios oficiais e religiosos, em geral isolados e destacados ou em praças centrais, representavam um verdadeiro espaço do poder, por isso, objetos de acabamento mais elaborados, de forma que até as casas maiores pertencentes aos moradores mais ricos e importantes situavam-se em locais destacados ou nas principais praças do núcleo, junto aos objetos representativos do poder absoluto. 


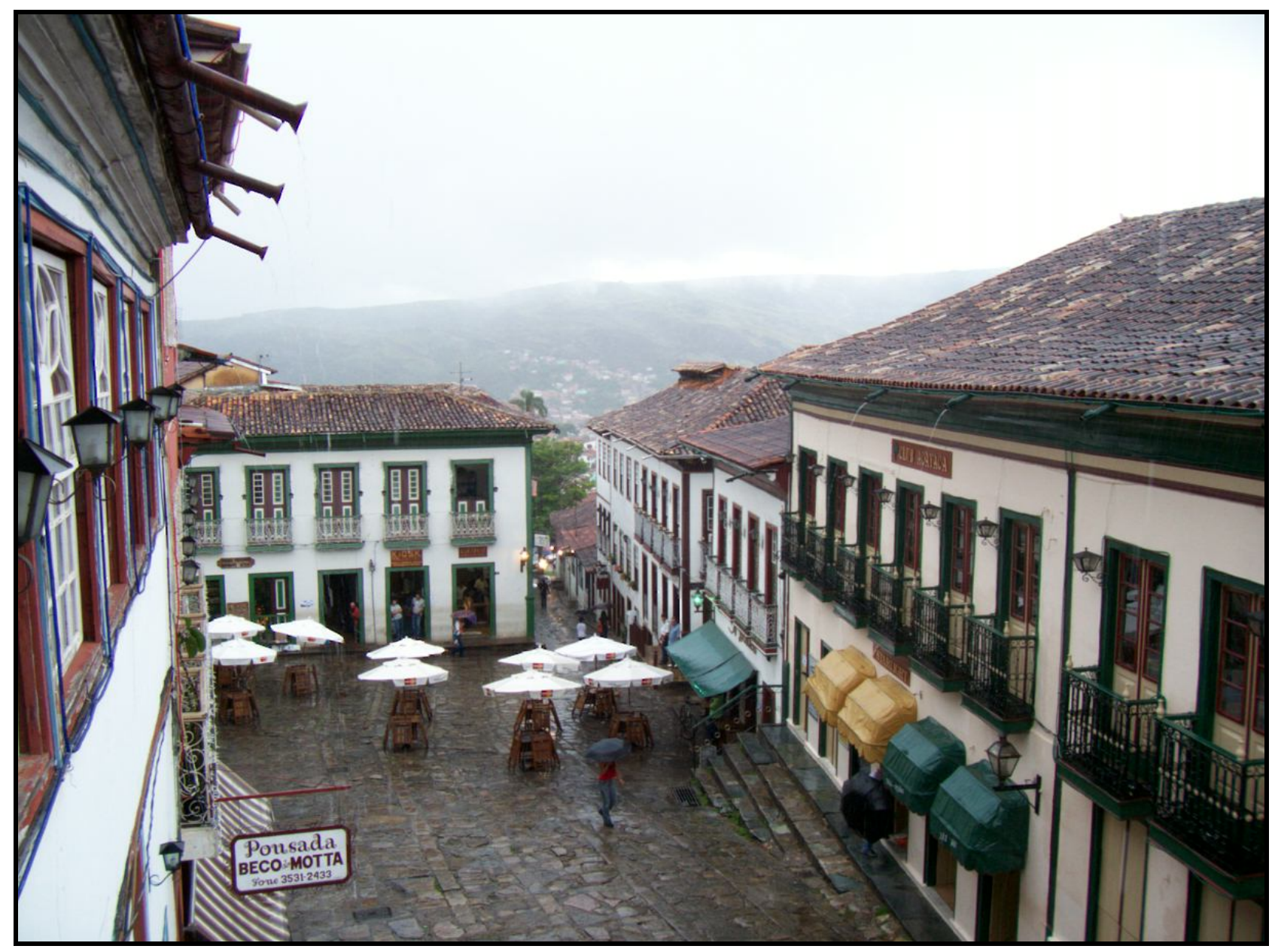

Foto 10 - Padronização da ordem das fachadas e alinhamento das portas e janelas, apesar da topografia extremamente irregular, na Rua da Quitanda, em Diamantina.Veremos, no decorrer da pesquisa, que este espaço configura-se como o "palco" das famosas Vesperatas de Diamantina, um espaço público em que o privado se apossa em detrimento a uma maioria local. Foto do autor, jan / 07.

Outra característica típica do urbanismo barroco das Geraes é a proximidade dos edifícios, agarrados uns aos outros, sem terrenos disponíveis para a necessária expansão que muito precariamente poderia aproveitar-se dos fundos, cada vez menos presentes, dificultando uma distribuição lógica e adequada das peças; só podiam lançarse ao alto as casas dos centros urbanos mais densos, como aponta Vasconcellos (1997). Surge o sobrado, nem sempre para atender a ampliação da moradia, mas, sobretudo, para abrigar dependências anexas indispensáveis à vida ou ao trabalho dos residentes. São dependências para animais, carros, arreios, mantimentos, senzalas, depósitos de utensílios e ferramentas, e, principalmente, para o comércio, que se localizava na parte inferior do sobrado. Moradia na parte superior e comércio embaixo. 
Sobre a proximidade dos edifícios, casas térreas e sobrados agarrados uns aos outros (exceção feita às igrejas e palácios de governo, que nunca as construções dos populares ousavam encostar), passando uma idéia, talvez falsa, do estabelecimento de relações cotidianas entrelaçadas, de compartilhamento de relações familiares entre moradores, Gilberto Freyre em Sobrados e Mucambos: decadência do patriarcado e desenvolvimento do urbano dá uma explicação psicológica para essa característica dos espaços urbanos coloniais; seria a desforra contra o silêncio opressivo dos largos espaços entre as cidades, uma reação contra as distâncias enormes, principalmente em Minas, mencionando os próprios sobrados grandes tão agarrados quanto as casas pequenas. Verificamos essa característica em São João Del Rei (foto 11), Mariana (foto 12), Diamantina (foto 13) e Tiradentes (foto 14), na seqüência abaixo.

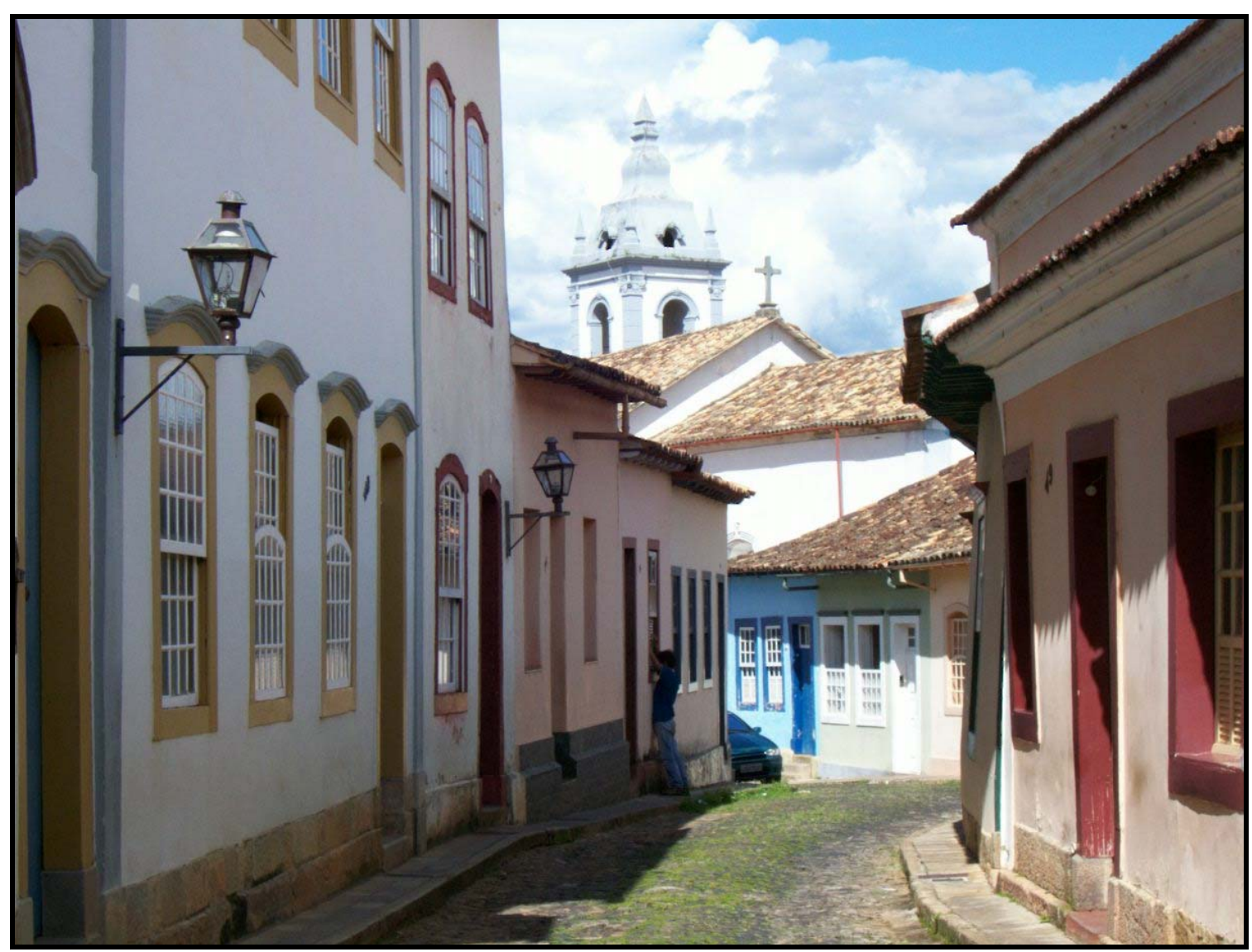

Foto 11 - Rua Sto. Antônio, que compõe o sítio original de São João Del Rei; observa-se a proximidade entre as edificações e a busca de seu alinhamento junto à rua, além das casas com a parede frontal inclinada (à direita da rua) que demonstra o relativo desenvolvimento técnico construtivo. Foto do autor / jan. 07 


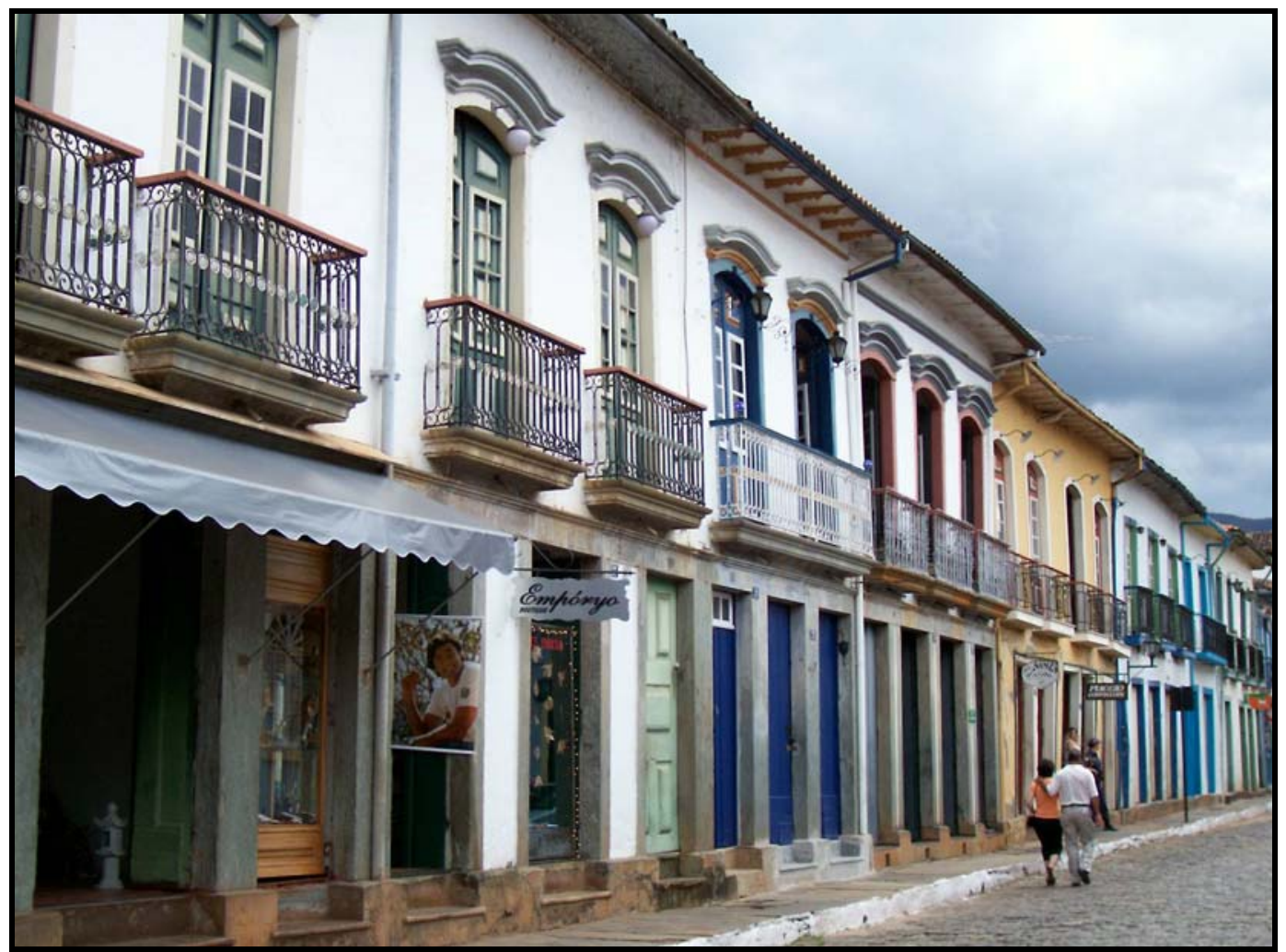

Foto 12 - Rua Direita, em Mariana. É notório o alinhamento e a grande proximidade dos sobrados, além do ritmo construtivo. Foto do autor / jan. 06

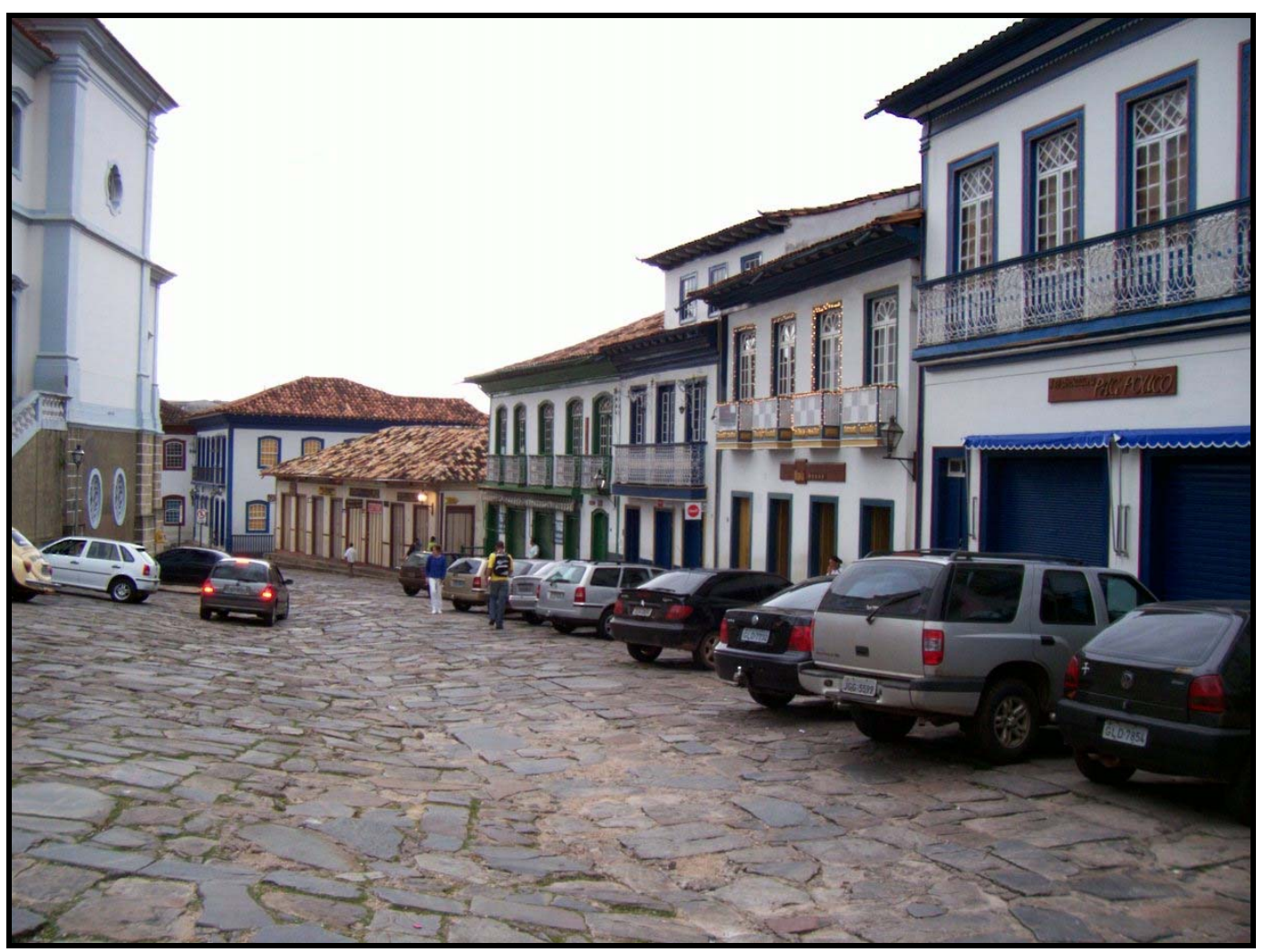

Foto 13 - Praça Joubert Guerra, em Diamantina, com sobrados alinhados e agarrados uns aos outros, além da disciplina entre portas e janelas. Foto do autor / jan. 08 


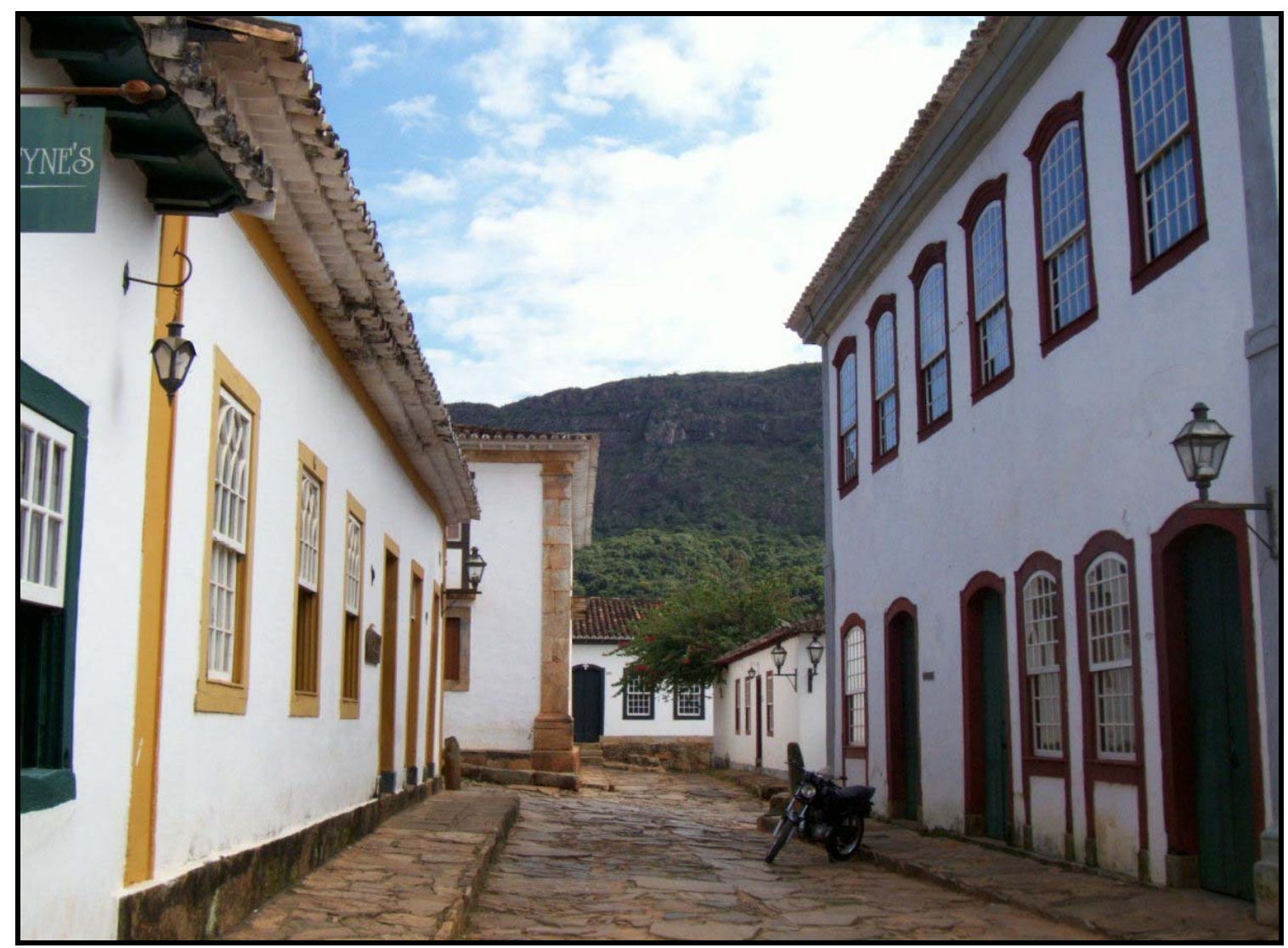

Foto 14 - Rua Direita, em Tiradentes, que guarda a maioria dos sobrados da cidade, alinhados e agarrados uns aos outros, mantendo o padrão construtivo das cidades históricas mineiras, caracterizando o urbanismo barroco das Geraes. Foto do autor / maio 08

Outra questão do urbanismo barroco das Geraes diz respeito à tipologia do sobrado. Em estudos analisados sobre Recife (PE), Olinda (PE) e São Luis (MA), e ainda no que pudemos constatar em visitas realizadas em Salvador (BA), Rio de Janeiro (RJ), São Sebastião (SP), Mariana, Tiradentes, Ouro Preto, Sabará, Santa Luzia, Congonhas, Diamantina e São João Del Rei, é notória a variação na tipologia dos sobrados de herança colonial, ao apresentarem construções acima de dois pavimentos, atingindo quatro,cinco ou seis, nas litorâneas; diferentemente dos conjuntos mineiros, que apresentam seus sobrados em dois pavimentos, muito raramente atingindo três ou quatro. "Inferioridade" que podemos justificar com Gilberto Freyre:

Não se alegue o simples fato da riqueza das Minas e dos mineiros, para explicar todo esse seu esplendor de vida e de idéias no século XVIII. Já nos referimos àqueles ricaços (...) morando pobremente em casebres de barro, quase em mucambos. Ausência de estímulo de ordem intelectual, ou de natureza psicológica, , que completasse o estimulo econômico (...) o sobrado (...) o requinte da moda, nem sempre corresponderam, no Brasil, à situação 
puramente econômica dos moradores. O determinismo econômico falha (...) do mesmo modo que o determinismo geográfico, quando pretende, isolado e puro, explicar fatos tão complexos e dinâmicos como os humanos. (2003, p. 444, grifos nossos).

É interessante notar que a arquitetura civil de Diamantina é uma referência especial dos conjuntos urbanos barrocos-rococós das Geraes, pois fica em destaque um grande conjunto de sobrados, muitos deles acima de dois pavimentos, e a quase ausência de casas térreas. Constituindo-se, o sobrado, em símbolo significativo da burguesia comercial crescente das Geraes, sua marcante presença indica a opulência econômica vivida por Diamantina, ou seja, são materialidades que indicam o complexo processo de formação do núcleo. Também é digno de nota a ausência de trabalhos de cantaria, sobressaindo o trabalho em madeira nos arremates dos telhados e das fachadas dos sobrados, em sua totalidade.

Diamantina também apresenta um traçado característico das demais povoações surgidas na zona do ouro, com ruas adaptadas à topografia acidentada do terreno, com edifícios públicos e igrejas balizando o desenvolvimento do núcleo, como já consideramos. Incrustada em uma vertente montanhosa, a cidade apresenta uma perspectiva pitoresca, gerada pelas diferentes alturas dos telhados e das torres das igrejas, marcando singularmente a paisagem urbana histórica (foto 15). O balanço, a densidade e o volume do conjunto urbano de Diamantina é incomparável às demais povoações mineiras, com ressalva à Ouro Preto, o maior conjunto urbano barroco brasileiro, segundo Scarlato (2008). O grande número de sobrados, a volumetria dos mesmos e o padrão das disciplinas urbanísticas já relatadas e que se aplicam ao conjunto, somados à topografia extremamente irregular do Planalto de Diamantina, caracterizam o conjunto que pode ser inteiramente visto da Serra dos Cristais, que o defronta. 


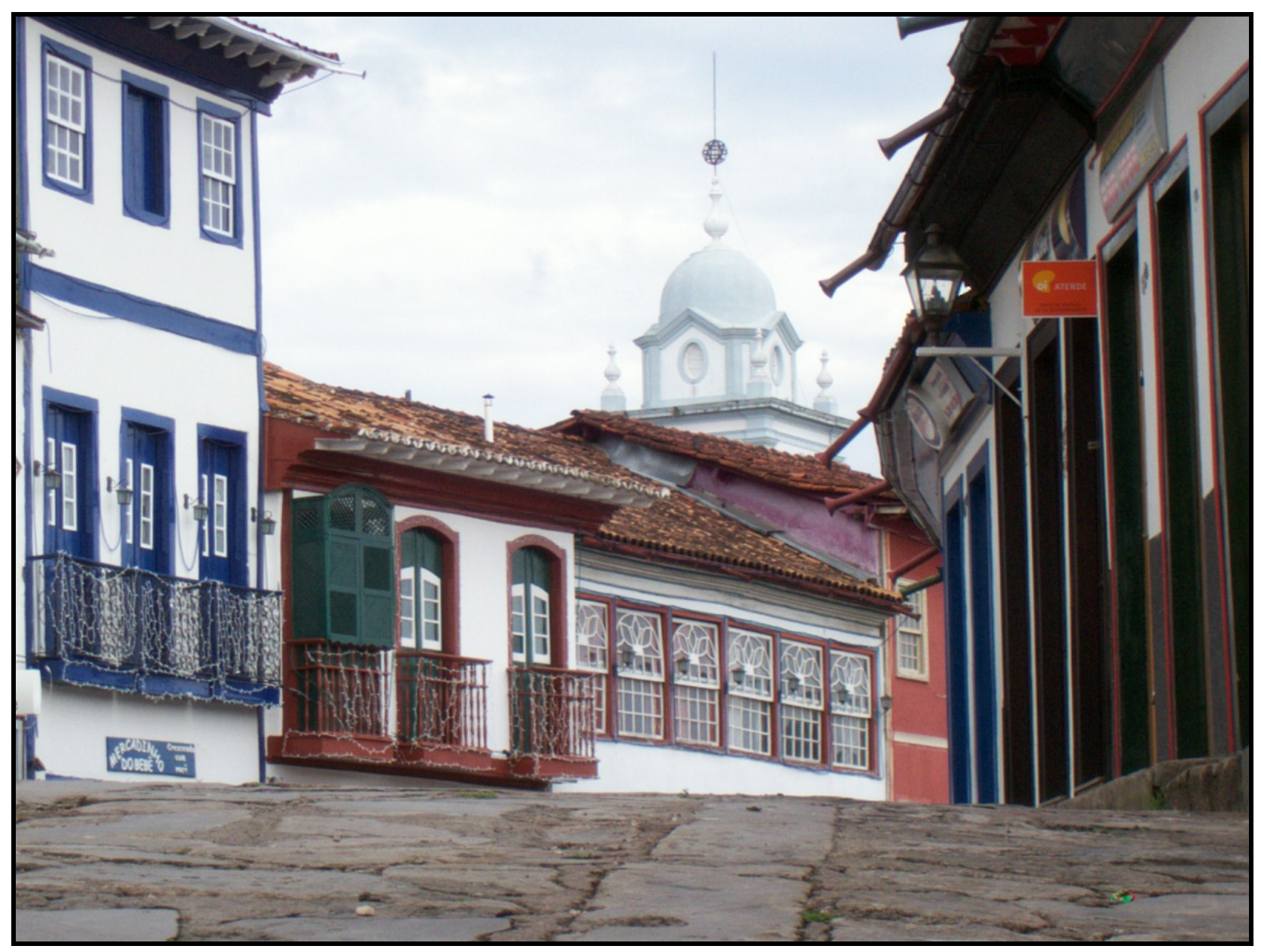

Foto 15 - Rua em rampa oferecendo uma perspectiva irregular do traçado, na Rua do Carmo, em Diamantina. Foto do autor / fev. 08.

Saint-Hilaire (1974, p. 27), no início do século XIX, registrou características memoráveis do então Arraial do Tijuco. Segundo o autor, naquele momento, possuía o Arraial em torno de 6000 almas e cerca de 800 fogos. O autor francês descreve o conjunto de maneira precisa. Suas ruas são largas, muito limpas, mas muito mal calçadas, ainda hoje, quase todas em rampa, não se identificando partes planas, a não ser nos locais estrategicamente escolhidos para as igrejas e praças, em pontos mais planos da encosta. Suas casas são construídas umas em barro e madeira, outras com adobes; são todas cobertas com telhas. Segundo o autor, as casas eram,

brancas por fora e geralmente bem cuidadas (...) A cercadura das portas e das janelas é pintada de diferentes cores, segundo o gosto dos proprietários e, em muitas casas as janelas têm vidraças. As rótulas que tornam tão tristes as casas de Vila Rica, são muito raras em Tijuco, e os telhados aqui não fazem abas tão grandes para fora 
das paredes. Quando fiz minhas visitas de despedida, tive ocasião de entrar nas principais casas do Tijuco e elas pareceram-me de extrema limpeza. As paredes das peças onde fui recebido estavam caiadas, os lambris e os rodapés pintados à imitação de mármore. Quanto aos móveis eram sempre em pequeno número, sendo em geral tamboretes cobertos de couro cru, cadeiras de grande espaldar, bancos e mesas. (SAINT-HILAIRE, 1974, p. 28)

Dos poucos trabalhos que fazem referência à Diamantina, como já afirmamos nessa pesquisa, também é digno de citação a análise de Renée Lefèvre e Sylvio de Vasconcellos em Minas: Cidades Barrocas. Os autores consideram, quase que poeticamente, que "barrocas e dramáticas são muitas das povoações mineiras. Rococó, apenas uma: Arraial do Tijuco, Cidade de Diamantina (...) Urbanisticamente, a povoação resolve-se em quadrilátero, com ruas em xadrez, como mandam as Leis das Índias. Definem-na as estradas que, aos quatro lados a tangenciam (...) Se Ouro Preto sugere óperas trágicas, Diamantina inspira operetas. Se Portugal é jardim da Europa à beira-mar plantado, Diamantina é a primavera eterna das Minas, no sertão florindo." (Lefèvre e Vasconcellos, 1968, p. 41-43).

Essa citação nos remete à singularidade, à universalidade e excepcionalidade de Diamantina, tanto no contexto do urbanismo barroco-rococó estabelecido com a mineração nas Geraes - dentro de um processo peculiar de formação histórica que estabelece uma forma urbana de acordo com uma ordem e regularidade de disciplinas urbanísticas - como no contexto de sua elevação a Patrimônio Cultural da Humanidade.

Assim, as cidades da zona do ouro e dos diamantes, em especial Diamantina, foram edificadas nas montanhas e delas tiraram partido. Praças, adros e ruas são estabelecidas em declives. A curva, a rampa as descidas, subidas, os becos, o fausto e a ostentação presentes nas formas cristalizadas dominam toda a organização urbanística, representam a estrutura social em que se edificaram os conjuntos para assumirem determinada função dentro do processo histórico de formação do território das Geraes. Degraus, curvas e rampas dominam o traçado de Diamantina; para usar de uma metáfora, podemos dizer que a própria topografia de seu sítio faz-se barroca. Para Machado (1973), a cidade da zona da mineração já nasceu barroca.

Examinando atentamente o acervo caracterizado pelo urbanismo barroco das Geraes, com características próprias, reconhecemos as condições particulares da gênese colonial do patrimônio mineiro, que se deu pouco mais que no transcorrer de um século. 
Segundo Rodrigo Mello Franco de Andrade apud Telles (1997, p. 255), são obras de literatura, de música, arquitetura, pintura, escultura e artes menores cujo conjunto constitui, particularmente, no domínio das artes visuais, testemunhos irrecusáveis de uma escola mineira, com traços próprios e bem vincados, que permitem identificá-los nas obras de feição erudita ou popular realizadas.

Acrescentamos que todo o acervo preservado representa, para uma análise geográfica histórica, o próprio processo de valorização do espaço e formação territorial do Brasil. De forma que a presença dos conjuntos urbanos das Geraes simboliza a produção do espaço como processo resultante do trabalho humano, que é um ato de incorporação e criação de valor, de acordo com a teoria apresentada no início da pesquisa.

Produz-se um espaço, ligado à trama da empresa mineradora, que não se desvincula de instâncias sociais, econômicas, culturais e ideológicas ao longo do tempo, ou seja, os conjuntos urbanos da zona do ouro e dos diamantes constituem-se em formas pretéritas que surgem com determinadas funções e que, ao longo dos séculos, adquirem novos conteúdos e usos. Isso representa a valorização do espaço pelas diferentes formas de trabalho humano, dada a evolução da sociedade que vê, na atualidade, a valorização simbólica como um adendo para a valorização econômica dos objetos culturais, como esclarecemos no início da pesquisa e identificaremos em Diamantina, mais a seguir.

Enfim, nesse item, tentamos dar conta do que chamamos fase da gênese colonial do patrimônio mineiro, que envolve o surgimento de Diamantina pela conquista dos fundos territoriais do Brasil colonial, que consagra, na região, a primeira valorização e dominação do espaço cristalizada na forma de um peculiar urbanismo barroco das Geraes, no qual se insere nosso objeto empírico. Nessa fase, a valorização do espaço representada remete-nos à preponderância do valor de uso civilizatório dos núcleos considerados, ou seja, na lógica do processo que denominamos dialética da construção destrutiva que envolve os bens culturais do mundo, constitui o momento da construção dos conjuntos capturados, contemporaneamente, por um processo dialético que impede “uma transcendência necessária na 'reconstrução imaginária' do século XVIII, sem a qual, todo (...) conjunto se resumirá simplesmente num amontoado de edificações de pouca significação" (SCARLATO, 1996, p. 140).

Passaremos, a seguir, ao que denominamos fase da produção simbólica do patrimônio, um segundo momento significativo na trajetória do patrimônio cultural 
brasileiro, no qual Diamantina, juntamente com as cidades da zona do ouro, torna-se referência - através do urbanismo barroco-rococó - na busca de símbolos capazes de registrar a trajetória de um novo "Estado-nação". Essa fase torna-se assaz significativa do ponto de vista da incipiente valorização simbólica do patrimônio cultural brasileiro, que, no nosso entendimento, constitui em um "evento" que projeta essas cidades no cenário nacional para o desenvolvimento do turismo. A fase que se segue é mais uma das facetas da universalidade na qual se insere Diamantina; são fases que se prendem por laços necessários e recíprocos, pois a construção do urbanismo barroco-rococó local é a condição primeira do simbolismo que vai representar para o novo "Estado-nação" emergente, no início do século XX, que por sua vez consagra um Patrimônio Mundial e, simultaneamente, uma nova mercadoria global no alvorecer do século $X X \mathrm{X}$; um processo contínuo, ininterrupto, relacional e contraditório que redunda na produção do espaço urbano de Diamantina. Segundo Santos (2004, p. 58)

O espaço não pode ser estudado como se os objetos materiais que formam a paisagem trouxessem neles mesmos sua própria explicação. Isto seria adotar uma metodologia puramente formal, espacista, ignorando os processos que ocasionaram as formas. 


\subsection{Fase da produção simbólica do patrimônio}

Inicialmente, retomemos as considerações feitas na primeira parte desta pesquisa, quando afirmamos que se confrontam duas idéias de bens coletivos: nacionais (de caráter particularista), que marca o processo de constituição das nações via símbolos de conquista e da formação territorial (cuja precursora foi a França), com a idéia de bem coletivo mundial (de caráter universalista). Quer dizer, além da consagração de um patrimônio nacional, referência de cultura e identidade de um povo estabelecido no território, buscam-se marcos do que foi produzido pelos povos em diversos territórios espalhados pelo planeta, num longo processo histórico, e que passa a pertencer à humanidade como um todo. Forja-se, dessa maneira, a noção de patrimônio cultural da humanidade, como já apresentado.

São duas dimensões geográficas na consagração do patrimônio cultural em seu longo processo histórico de formação. Nesse ponto da pesquisa, limitaremo-nos à noção particularista (nacionalista) de patrimônio, uma vez que já tratamos da trajetória para a consagração do Patrimônio Mundial, no nível internacional. A noção particularista, no caso brasileiro, tem por base os bens representantes da produção do espaço como símbolos de identidade para a afirmação do "Estado-nação" que se constituía no início do século $X X$, bens que, no limite, representaram para o Estado a formação do território brasileiro dentro de um caráter identitário, espacial e político.

Afirmar que as práticas de patrimônio no Brasil acompanham contextos sociais não significa dizer que a cultura no país é resultado de uma unicausalidade política, mas considerar, de acordo com Cohn (1987), que o termo "concepção oficial de cultura" se refere a práticas orientadas e voltadas para a sociedade nacional, em que o Estado foi referência institucional. No Brasil, as práticas de patrimônio surgem como iniciativa do próprio Estado e assumem um lugar de destaque na formulação de uma concepção oficial de cultura, voltada para a construção de uma idéia de nação, seguindo o modelo francês do século XIX, o qual apresentamos na primeira parte da pesquisa. Esse processo é contemporâneo da República Velha, cujo período representou uma confusa transição na política brasileira que culminou com a Revolução de 1930. De acordo com Leite (2004, p. 48), esse período foi marcado pelas tensões de um novo arranjo institucional e político e por um contexto econômico igualmente complexo pela implantação da mão-de-obra 
assalariada e início da industrialização do país. Esse período representou, na realidade, a reestruturação econômica, social e política do país, quando temos o deslocamento do eixo econômico do Nordeste açucareiro para a economia do café no Sudeste, com destaque para São Paulo.

De acordo com Leite (2004, p. 48), as transformações estruturais que caracterizam o período são acompanhadas por um intenso debate que se tornou clássico: Como pensar o Brasil-nação, sua identidade nacional e sua cultura, no contexto pósabolicionista, republicano e capitalista? Dessa forma, a relação entre cultura brasileira e identidade nacional tornou-se um dos eixos interpretativos sobre a sociedade brasileira, cuja busca de uma idéia de Brasil perpassou as principais matrizes do pensamento social brasileiro. De acordo com Leite, a emergência das práticas de patrimônio no Brasil é contemporânea a essa problemática, que se tornou corrente nas primeiras décadas do século XX: "mais do que uma nação em construção, em busca incessante do seu próprio conceito, essa preocupação refletiu a complexa realidade a partir da qual o Brasil se constitui historicamente". Quer dizer que pensar a nação seria construir uma síntese cultural em torno de uma identidade nacional que conferisse sentido às diferenças e desigualdades que lhe eram constitutivas.

Para Fenelon (1992), no Brasil, a noção de patrimônio nasce mesclada pelo autoritarismo do Estado Novo e pela "rebeldia" modernista, cristalizando elementos do nacionalismo autoritário e as boas intenções modernistas, na busca de recuperar um passado para alcançar uma definição de identidade nacional. E é na vanguarda dessa fase e movimento que se colocam os intelectuais que dão forma e conteúdo às políticas de preservação do SPHAN (Serviço do Patrimônio Histórico e Artístico Nacional), criado através do Decreto-Lei $n^{\circ} 25$ de 30 de dezembro de 1937. A política de preservação do SPHAN é o exemplo que marca, significativamente, a primeira intervenção do Estado na área cultural, na busca de uma memória e identidade brasileiras. Consideramos, nesse contexto, que foi o governo de Getúlio Vargas o responsável pela primeira produção simbólica do patrimônio cultural brasileiro, onde esses bens vão assumir a representação da trajetória social, econômica e política do país, mesmo que essa operação tenha ocorrido de forma restritiva e elitista.

Deve ser considerado, dessa forma, que o modernismo, junto ao SPHAN, propiciaram uma volta ao passado, à valorização intensa de formas de expressão 
consideradas tradicionais, naquele momento de construção da nação em que o barroco mineiro foi simbólico, considerado como a primeira manifestação cultural tipicamente brasileira, possuidor da aura da origem da cultura nacional.

A relação dos intelectuais do SPHAN e dos modernistas com Minas Gerais deve-se basicamente à busca dessa expressão tradicional da cultura. Minas já era considerada um pólo catalisador de idéias. As várias viagens que muitos intelectuais fizeram para a antiga zona do ouro e dos diamantes, dentre eles, Mário de Andrade, o arquiteto Lúcio Costa e o jornalista Rodrigo Melo Franco - primeiro diretor do SPHAN -, foram marcos do que Leite (2004) chama de "redescobrimento" do Brasil e de suas expressões culturais consideradas genuinamente nacionais. ${ }^{94}$

Não foi por acaso que a primeira iniciativa de preservação de patrimônio, no Brasil, antes mesmo da criação do SPHAN, deu-se exatamente na cidade de Ouro Preto, considerada berço do patrimônio barroco colonial, ficando claro, já naquele momento, quais eram os parâmetros arquitetônicos que representariam o ideário de nação. Logo, Ouro Preto tornou-se uma espécie de laboratório prático de referências conceituais que o SPHAN buscava construir, de acordo com Leite (2004). Mais do que isso, tornou-se um mito fundante, espécie de centro exemplar da própria idéia de Brasil, como aponta Arantes (1991, p. 236) "Esta cidade é um dos principais territórios onde se funda, oficialmente, a nacionalidade brasileira".

Dessa forma e de acordo com o capítulo 1.2 da pesquisa, verificamos que a política de preservação no Brasil, no entanto, não foi diferente de experiências de outros países, estando relacionada à consolidação de uma imagem política e cultural da nação, tendo o Estado como protagonista do processo. Embora o anteprojeto do Serviço do Patrimônio Artístico Nacional elaborado por Mário de Andrade, em 1936, contemplasse uma definição abrangente de "obras de arte patrimonial", a política de preservação do SPHAN (atual IPHAN / Instituto do Patrimônio Histórico e Artístico Nacional) dirigiu-se para a restauração arquitetônica de cunho fachadista dos bens imóveis de pedra e cal, cujos

\footnotetext{
${ }^{94}$ Segundo Khouri (2005, p. 250), o maravilhamento dos modernistas ante a herança barroca das Minas Gerais daria os seus frutos, chamaria a atenção dos próprios mineiros para os tesouros escancarados que possuíam. "Era como se os paulistas estivessem tentando recuperar para o Brasil um barroco maior, que a pobreza paulista dos séculos XVII e XVIII não permitira, a não ser em migalhas, à terra bandeirante, e também, como já fora referidos pelos Andrade, a memória de uma façanha paulista na área das Minas. Um Mário, antes, referia-se aos bandeirantes descobridores, um Oswald, após, poeticamente registra os fatos: Ide a São João del Rei de trem como os paulistas foram a pé de ferro”
} 
bens (na maioria, representantes do estilo barroco colonial mineiro) expressavam uma versão oficial do patrimônio.

Concordamos com Leite (2004), pois a predominância dos monumentos que reafirmam os poderes políticos, religiosos e militares não apenas reforçaria essa versão oficial da própria cultura brasileira como excluiria um conjunto diverso de minorias étnicas e culturais que demandam formas particulares de inserção e pertencimento à nação. As origens sociais da maioria dos tombamentos que marca a história da preservação do patrimônio cultural no Brasil, entre 1938 e 1981, referem-se, como destaca Leite (2004), à etnia branca, ao catolicismo, às classes dominantes e às edificações símbolos do poder estatal: fortes, casarios, mosteiros, igrejas e quartéis. ${ }^{95}$

Logo, a partir do Decreto-Lei $n^{\circ} 25$, de 1937, pode-se dizer que realmente surgiu a proteção cultural urbanística no Brasil, mesmo com um viés elitista. Enquanto diploma legal e aparato jurídico-institucional, é correto afirmar que, até o ano de 2000, o teor desse decreto-lei, que é um legado do Estado Novo, pouco havia se modificado, até ocorrer o registro do patrimônio imaterial, no ano 2000, por meio do Decreto 3.551, de 04 de agosto do mesmo ano. Cardoso (2007, p. 75) salienta que na base conceitual da legislação é possível destacar aspectos da política de mise-em-valeur, aonde a salvaguarda de monumentos era prioritária, não conotando ao seu entorno importância alguma; uma posição que salienta a concepção de patrimônio ou conjunto urbano histórico considerado pela Carta de Atenas, da década de 1930, que desconsiderava o entorno dos monumentos, como apontamos em capítulos anteriores. O surgimento da política de preservação de patrimônio no Brasil, é, nesse contexto, contemporânea da Carta de

\footnotetext{
95 Muito pouco se fala também da riqueza dos bens culturais móveis das Geraes, como a pintura, a escultura e os diversos tipos de móveis sacros e civis. De acordo com Wasth Rodrigues (apud Andrade, 1987, p. 79), "Formando-se um círculo, cujo centro seja Mariana e cuja linha de contorno passe por Sabará, teremos uma circunferência com umas 25 léguas de diâmetro, abrangendo a região mais antiga de Minas (...) Esta era (naturalmente também) a zona mais rica em móveis antigos, sobretudo de produção regional ou local (...) Das cidades, fazendas e povoados dessa zona saíram as camas, as arcas, os tamboretes, as mesas 'holandesas', as cadeiras de dobrar e outros móveis do mais belo e variado teor além de uma quantidade dos mais variados e surpreendentes objetos. (...) Outras regiões foram ricas desses bens, pois Minas antiga não era somente esse recanto primitivo. A região de Diamantina, como Serro Frio e Minas Novas, era (igualmente) abundantíssima de preciosidades. O mesmo ao sul (e ao oeste), como Campanha, São João Del Rei, Tiradentes, Queluz, e Baependi. E em cidades mais afastadas como Pitangui, Montes Claros, Paracatu... Os contratadores, os altos funcionários reinóis, (...) enfim os homens de posse ou de representação viveram naturalmente no conforto e, alguns, na opulência... Daí existirem, deixados por eles, móveis ricos, serviços de prata, jóias, sedas e veludos, porcelana da China, faiança portuguesa e, nos começos do século XIX, serviços ingleses. O escritor observa com indisfarçada gratidão, depois de descrever os interiores das velhas casas mineiras que visitou antes de 1920: 'Minas, como se cumprisse um desígnio secreto uma determinação do destino, para realizar uma função na história, Minas guardou tudo"”.
} 
Atenas, também esboçando o caráter restritivo da preservação da paisagem urbana histórica, ao eleger pontos isolados da malha constituída. Choay (2006, p. 201) afirma que precisamos reconhecer a dialética da arquitetura maior e seu entorno, onde "isolar ou destacar um bem é o mesmo que mutilá-lo. O entorno do monumento mantém com ele uma relação essencial".

A origem da política de preservação de patrimônio no Brasil está associada a uma consolidação da imagem política e cultural da nação, onde o Estado, através do SPHAN, é o agente que conduz essa busca. Contudo, há de se considerar que a escolha dos bens a serem preservados, naquela época, foi feita através de uma visão elitista de cultura, quando o tombamento se restringiu a monumentos que reafirmavam os poderes políticos (câmaras, cadeias), os religiosos (igrejas barrocas) e os militares (fortes, quartéis), excluindo, dessa maneira, um conjunto diverso de minorias éticas e culturais, como se o Brasil fosse uma expressão única de uma elite branca, relegando o conjunto da sociedade e os bens materiais e imateriais - representantes da cultura popular - ao esquecimento.

Nossa sociedade é constituída, dessa forma, por meio da formulação de conceitos restritivos e deformantes de cultura, de valores culturais, de bens culturais, que se projetam também num certo tipo específico de uso, restritivo e gerador de deformidades, ainda que representado como nobilitantes, mas, na realidade, desqualificador de outros usos e funções, como aponta Meneses (1999, p. 88).

O Brasil é um país preocupado, desde o fim do XIX, em ser moderno, onde a elite sempre teve os olhos voltados e ofuscados pela dinâmica e realidade européia, pela convergência do primeiro mundo. No Estado Novo, a modernidade era fugazmente perseguida. A busca da preservação, nesse sentido, reiterava e sacralizava a história do Estado como se fosse a história de todos os brasileiros. Erigiu-se, no plano simbólico, a unidade da nação capaz de ocultar as diferenças e os conflitos, segundo Cunha (1992, p. 09). Consideramos, nesta pesquisa, que o conceito, a noção de patrimônio não deve se reduzir a edificações e manchas urbanas, apesar de termos como objeto de estudo, Diamantina, que possui um núcleo urbano tombado; já nos posicionamos contra a dicotomia que enreda o patrimônio cultural material e imaterial, faces de uma mesma moeda. 
Entendemos que ao remetermo-nos ao patrimônio cultural vislumbramos a própria categoria de espaço geográfico, uma vez que pode ser entendido enquanto a indissociabilidade de formas, funções, estruturas e processos, de acordo com nosso aporte teórico-metodológico; não podemos desvincular a consagração do patrimônio da "valorização do espaço" e da formação do território. Os lugares do patrimônio integram o espaço da sociedade, ou seja, são portadores não apenas de formas, mas de conteúdos que só podem ser decifrados para além da corporeidade dos objetos, a partir da estrutura em que se inserem e do processo histórico que os geriram. Assim se justifica nosso tópico anterior, no qual tratamos das múltiplas relações sociais, políticas e econômicas históricas que produziram o urbanismo barroco das Geraes (um acervo refuncionalizado na atualidade, envolvido pela expansividade do capitalismo e pela seletividade do capital).

No contexto geral apresentado e de acordo com a importância histórica dos modernistas preocupados, num primeiro momento, com a atualização das Artes no Brasil, e em um segundo instante, voltando-se para a descoberta de um país quase desconhecido, olhando para o passado distante através da herança barroca, Diamantina é tombada ${ }^{96}$, em 1938.

Diamantina foi inscrita em apenas um dos livros do tombo, enquanto Conjunto arquitetônico e urbanístico da cidade de Diamantina, no Livro das Belas Artes, Volume I (Processo: 64-T-38; número de inscrição, 66; número da folha, 12; data: 16/05/1938). São quatro livros do tombo, nos quais podem ser feitas as inscrições dos bens culturais: Livro do Tombo Arqueológico, Etnográfico e Paisagístico; Livro do Tombo Histórico; Livro do Tombo das Belas-Artes e Livro do Tombo das Artes Aplicadas. Para efeito comparativo, mencionamos que Ouro Preto e Congonhas foram inscritas também no Livro do Tombo das Belas-Artes; Salvador, no Livro do Tombo Arqueológico, Etnográfico e Paisagístico; e Brasília, no Livro do Tombo Histórico.

Outra questão a ser frisada é que se admite a inscrição de bens no livro do tombo, separada ou agrupadamente, o que permite, no segundo caso, o tombamento de núcleos históricos, áreas, bairros ou até cidades inteiras, num dos quatro livros do tombo; é o que se denomina "tombamento do conjunto urbano". Assim, temos em Diamantina, como em outras cidades, o tombamento do conjunto e ainda de bens isolados

\footnotetext{
${ }^{96}$ De acordo com o Decreto-Lei n 25/1937, o tombamento é o instituto jurídico pelo qual se faz a proteção do patrimônio histórico e artístico, que se efetiva quando o bem é inscrito em um dos livros do tombo, segundo Silva (2003).
} 
pertencentes ao conjunto. Tombadas isoladamente, totalizam sete igrejas do século XVIII, a casa que guarda o Museu do Diamante (século XVIII) e o Mercado Velho (início do XIX). As fotos abaixo indicam o núcleo original, na encosta frontal ao Morro de Santo Antônio, bem como a produção do espaço que se deu ao longo do século $X X$, na área de entorno ao mesmo, demonstrando um relativo adensamento urbano em Diamantina.

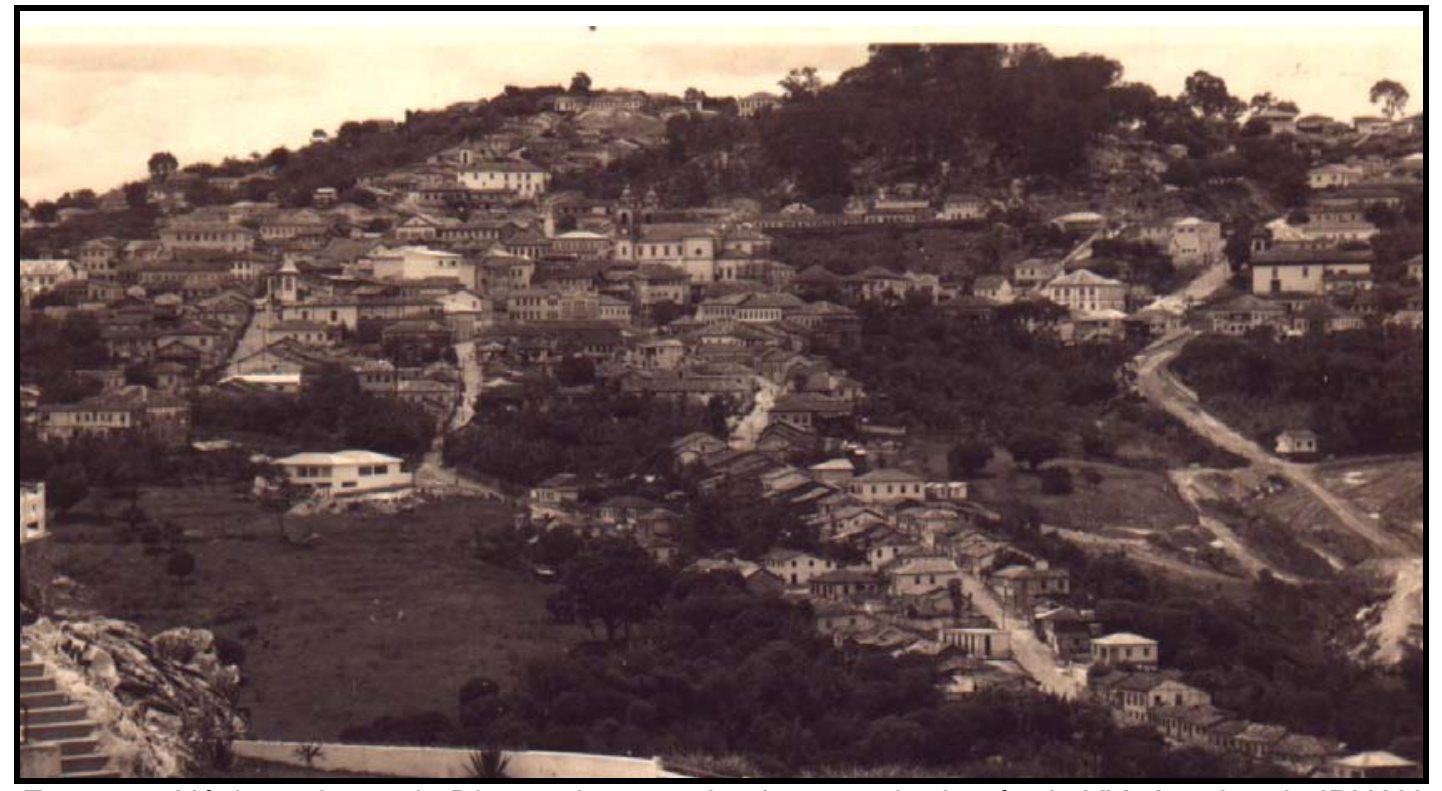

Foto 16 - Núcleo urbano de Diamantina na primeira metade do século XX. Arquivo do IPHAN.

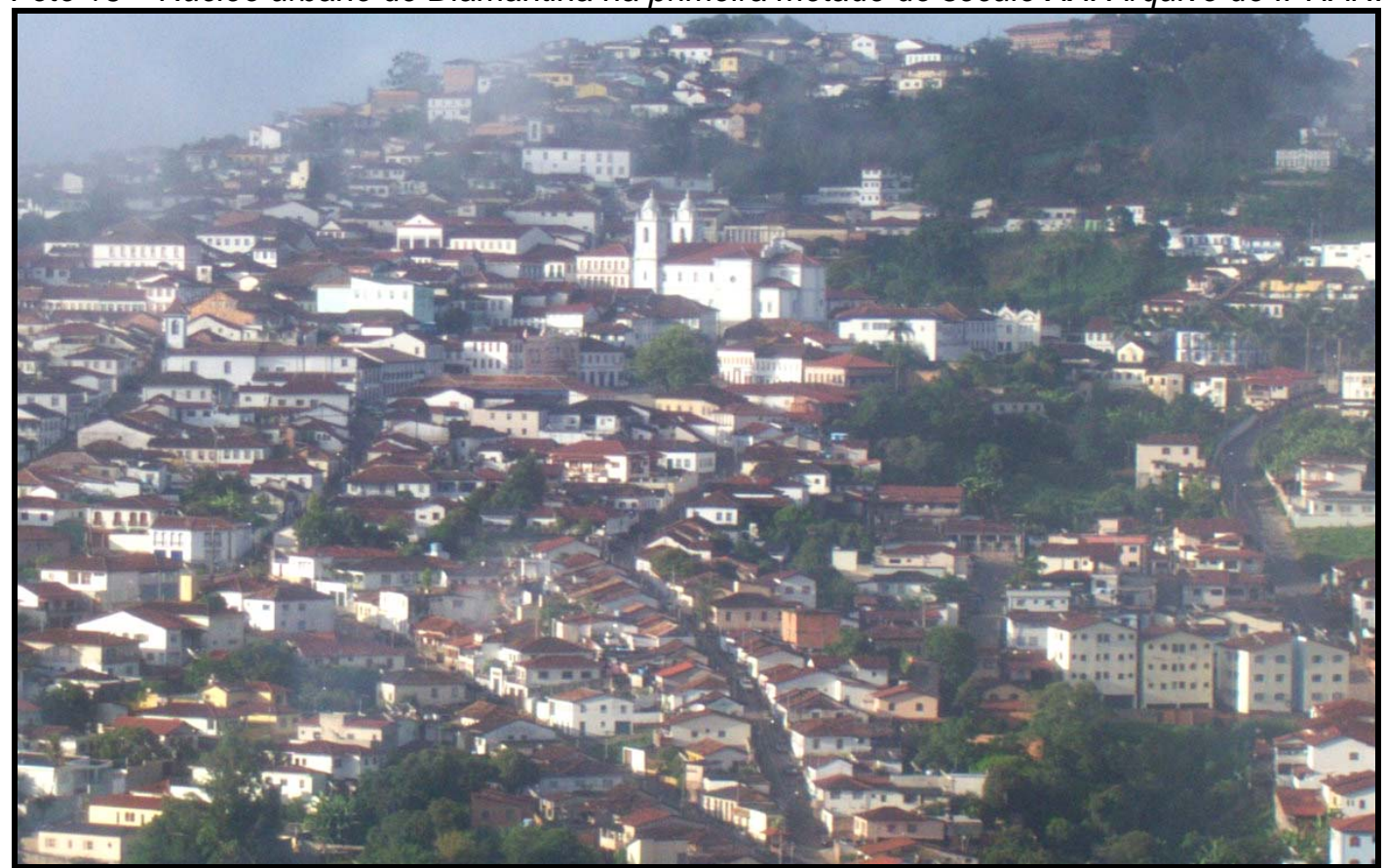

Foto 17 - Núcleo urbano de Diamantina na primeira década do século XXI. Foto do autor / jan. 2008. 
Referimo-nos, em nosso aporte teórico-metodológico, sobre a relação entre a valorização simbólica ${ }^{97}$ e a valorização econômica ${ }^{98}$ dos bens culturais. Para Thompson (1995), uma agregação de valor simbólico pode aumentar o valor econômico de um bem cultural. Mencionamos também que para a cultura ser transformada num novo gênero de mercadoria, objetivo precípuo da "indústria cultural”, há de se atribuir um valor simbólico a ações, manifestações verbais e objetos significativos de vários tipos, de forma que será o estímulo a essa valorização que acarretará na valorização econômica do patrimônio; ou seja, no limite, a valorização simbólica ${ }^{99}$ dos bens culturais atribui-Ihes valor de mercado, que na análise geográfica desse processo, significa a evidência do "valor do espaço"100.

Logo, o Estado assumiu, a partir da década de 1930, um papel extremamente relevante para uma primeira valorização simbólica das cidades históricas, em especial, Diamantina, que se torna uma das referências quando da busca de marcos capazes de registrar a trajetória do "Estado-nação" que emergia no início do século XX; momento em que o barroco mineiro é resgatado como expressão máxima de identidade nacional. Essa fase que denominamos produção simbólica do patrimônio cultural torna-se assaz significativa do ponto de vista da incipiente valorização simbólica (THOMPSON, 1995) do patrimônio por parte do Estado, no Brasil, que acarreta na posterior projeção inicial do patrimônio, com a valorização mercantil das cidades históricas por meio da atividade turística. A sorte estava lançada para um novo reduto criado pela expansão do capitalismo e seletividade do capital, no contexto da globalização política, econômica e cultural, que favorece uma terceira fase do patrimônio cultural no Brasil, sua projeção inicial no cenário nacional e internacional.

\footnotetext{
${ }^{97}$ Valorização simbólica: atribui-se às formas simbólicas um valor simbólico (modos pelos quais são estimados pelos indivíduos que os produzem e recebem).

${ }^{98}$ Valorização econômica: atribuí-se às formas simbólicas troca de mercado, no qual se constituem em mercadorias. As formas simbólicas mercantilizadas são os bens simbólicos.

${ }^{99}$ Como nos referimos no início da pesquisa, consideramos que se a valorização simbólica dos objetos não estiver comprometida, primeiramente, com o objetivo de preservação de nossa identidade ou da memória e sim com uma necessidade única e negligente de se agregar valor econômico aos bens culturais, corre-se o risco de se metamorfosear e perdermos um suporte espacial original, modos de vida e os símbolos de nossa "formação socioespacial”.

${ }^{100}$ Conforme nos posicionamos, torna-se relevante em nossa abordagem o "valor do espaço”, enquanto um valor que é transferido aos objetos durante sua criação ou enquanto um valor que é atribuído a objetos pré-existentes; o "valor do espaço" é transferido no processo de trabalho para o produto "através das características próprias de cada lugar” (MORAES e COSTA, 1996, p.122), o que ocasiona uma heterogeneidade na produção e apropriação de lugares, onde singularidades são estabelecidas através do trabalho humano; valores distintos são atribuídos a estruturas socioespaciais distintas. Essa valorização diferencial do espaço produz e reproduz ao mesmo tempo em que fragmenta e destrói, ocasionando disparidades socioespaciais, hoje, induzidas, também, pela criação de singularidades e excepcionalidades evidenciadas no espaço por meio de novas estratégias do capital.
} 


\subsection{Fase da projeção inicial do patrimônio cultural}

\section{Consideramos como terceira fase de produção do patrimônio cultural}

brasileiro o período entre as décadas de 60 e 90 do século XX, que denominamos fase de projeção inicial do patrimônio. Esse momento é representativo do ponto de vista em que as cidades históricas são evidenciadas com o incipiente turismo cultural, quando o patrimônio passa a ser reconsiderado, no contexto do planejamento urbano estratégico, enquanto vetor de mudanças socioeconômicas, ou seja, para o desenvolvimento local e regional.

Nessa fase em que a preservação e a valorização do patrimônio visam ao seu reconhecimento inicial para a "indústria" do turismo cultural, há uma transformação valorativa dos objetivos de preservação do acervo arquitetônico, respondendo-se aos anseios do mercado e do capital especulativo, incorporando a lógica da mercantilização dos espaços voltados às atividades do turismo. Porém, esse processo inicia-se lento e ganha fôlego a partir da década de 1990, no avançar do período técnico-científico e informacional (SANTOS, 2002).

A partir da segunda metade do século $X X$, o Brasil, que tinha significativa parcela da população no meio rural, torna-se, eminentemente, urbano. Esse boom urbano subverteu o modelo de cidade até então vigente. De acordo com Cardoso $(2007$, p. 75), problemas comuns a qualquer centro urbano que cresce sem planejamento passam a aterrorizar os administradores municipais. Surgem problemas relativos à sub-moradias (favelas, cortiços, ocupações desordenadas de encostas etc.), ao adensamento populacional de áreas centrais degradadas, ao crescimento desordenado de áreas periféricas desprovidas de infra-estruturas, enfim, desencadeia-se o esgotamento urbano em detrimento do crescimento desenfreado a ponto de, ao final da década de 1960, alguns urbanistas falarem na morte das cidades.

Cardoso (2007, p. 75) aponta que, contrastando com esse período de acentuadas mudanças citadinas, a legislação de preservação do IPHAN continuou inalterada, limitando-se, como antes, à conservação de monumentos que, no nosso entender, foram escolhidos a partir de critérios elitistas e exclusivistas de cultura.

Durante três décadas, o ideal democrático e mais abrangente da política de preservação de patrimônio proposto por Mário de Andrade ficou estagnado. O ideário 
nacionalista vigente à época adotou outras prioridades, como a "campanha do petróleo, a construção da capital federal, a caminhada do milagre econômico e, ao final, o enfrentamento do propenso 'perigo comunista'". (CARDOSO, 2007, p. 75).

Muito contraditória e exigente de uma pesquisa aprofundada, foi a política de patrimônio que se adotou durante a ditadura militar no Brasil. De acordo com Cardoso (2007), os ideais de Mário de Andrade somente foram postos em prática (acreditamos que em parte e atendendo aos interesses da ditadura) na década de 1960, criada pelo aparato técnico-burocrata da ditadura militar instaurada no país a partir de março de 1964. Para o autor supracitado, nessa época, o regime ditatorial, sentindo que poderia ocorrer um desgaste ideológico, iniciou uma aproximação do Brasil com os organismos internacionais dedicados à proteção do patrimônio cultural. O primeiro marco dessa aproximação foi a publicação da Carta de Veneza $(1964)^{101}$, a qual viria consolidar uma noção mais abrangente de "bem cultural", mais vinculada ao campo histórico e propondo normas jurídicas de proteção mais rígidas e modernas que as vigentes até então.

Novamente, em um contexto de regime político autoritário, o setor da cultura passa a ser componente estratégico de um discurso unificador, e a configuração políticoeconômica após 1964 trouxe consigo demandas de estrutura econômica que a estrutura tradicional do Ministério da Educação e Cultura não conseguiu suprir, de acordo com Tozi (2007, p. 34).

São iniciados, em 1965, os contatos com a UNESCO, produzindo documentos sobre a situação do patrimônio cultural no Brasil, dentre eles um relatório de acentuada importância elaborado por J. B. Perrin, denominado: Valorização dos Conjuntos e Locais Classificados no Brasil, Paris, Unesco, 1972. (CARDOSO, 2007, p. 76). Momento em que também tornamo-nos signatários da Convenção do Patrimônio Mundial.

Em 1967, o Brasil havia assinado a Carta de Quito, o primeiro documento nascido no âmbito interamericano, que além de conter os princípios mais relevantes da Carta de Veneza, procurava conciliar o desenvolvimento econômico e proteção do patrimônio cultural, propondo a todos os partícipes do evento que fizessem constar de

\footnotetext{
${ }^{101}$ A Carta de Veneza reitera que os bens culturais devem ser objetos de cuidados especiais para salvaguardar sua integridade e assegurar seu saneamento, manutenção e valorização; essa vem em contraponto à Carta de Atenas, que desconsiderava a preservação dos centros históricos das cidades, valorizando monumentos isolados, numa visão reducionista do patrimônio (ver capítulo 1.2 desta pesquisa)
} 
seus planos de desenvolvimento econômico as políticas preservacionistas, dando-lhes relevante importância.

Como vimos no tópico anterior, durante muitos anos, no Brasil, o paradigma da preservação de patrimônio esteve ancorado na idéia de construção de uma nacionalidade, contando, exclusivamente, com recursos públicos para as atividades de restauro e conservação dos bens culturais; enquanto responsável pelo desenvolvimento econômico e social, as políticas de patrimônio eram incontestavelmente função do Estado. Dessa maneira, a partir da década de 1970, no entanto, pela impossibilidade de o IPHAN manter, com recursos do governo federal, uma agenda atualizada de conservação e manutenção de todo o acervo nacional, inicia-se um processo de descentralização das políticas preservacionistas no Brasil, cujo resultado contribuiu, segundo Leite (2004, p. 53), para flexibilizar a difícil tarefa de atribuição de valor a certos bens que podiam ter relevância para estados e municípios, mas não para a genérica concepção do IPHAN a respeito de memória e identidade nacionais. Do ponto de vista operacional, essa descentralização se deve a três fatores básicos, de acordo com o autor: esgotamento das estruturas burocráticas tradicionais, a modernização administrativa do aparelho de Estado e a definição de uma nova divisão de tarefas entre União, Estados e Municípios.

Com essa descentralização, houve uma considerável expansão da política de preservação em vários programas e órgãos federais que resultou na divisão de responsabilidades do IPHAN entre esferas estaduais e municipais de preservação, surgindo novas estruturas e legislações em nível regional, propiciando mais uma vez a ampliação tipológica, cronológica e geográfica do patrimônio cultural, no nosso entender.

Importante frisar que o grande marco desse processo de descentralização da política de preservação de patrimônio, no Brasil, foram os Encontros de Governadores em Brasília (1970) e em Salvador (1971), nos quais foram traçadas novas estratégias de preservação com a participação dos estados. Segundo Leite (2004), foi proposto, nos encontros, o anteprojeto de lei para setores monumentais e paisagísticos, apresentado por Paulo Ormindo, no Encontro de Salvador, que propunha a criação do Plano Permanente de Preservação e Valorização (PPPV), que, segundo as recomendações da Carta de Veneza (1964) e do Encontro de Quito (1967), sugere a mesma estrutura de zonas de proteção das Normas de Quito, associando preservação do patrimônio e estratégias de planejamento urbano. Estava selado o processo simultâneo, relacional e contraditório de 
uma "preservação" para a "mercantilização" do patrimônio no Brasil, uma dialética da construção destrutiva necessária à reprodução do capital nas cidades históricas através do turismo.

Essas diretrizes foram fundamentais para a redefinição das práticas de preservação no país, na medida em que a idéia de "entorno" ampliou o âmbito de atuação dos órgãos de patrimônio para além das fachadas dos bens ressaltados como portadores de valor arquitetônico. Para Leite (2004, p. 54), a noção de ambiência circunscreve o bem, que no caso do patrimônio edificado das cidades se traduz, sobretudo, na prática de intervenção a partir do reconhecimento do valor urbanístico (e sua potencialidade comercial para o turismo) do bem ou conjunto a ser preservado.

As novas orientações de preservação do patrimônio, no Brasil, passam a seguir uma postura que assimilava as dimensões sociais e econômicas dos bens culturais, ultrapassando assim uma orientação corrente nas políticas de preservação até então vigentes, que privilegiavam aspectos predominantemente estilísticos. Dessa forma, os Encontros dos Governadores constituem-se em importantes "eventos" (SANTOS, 2002) que favorecem a mudança dos critérios e objetivos de preservação de patrimônio, em âmbito nacional.

Desses encontros e reuniões convocadas pelo Ministério da Cultura, na década de 1970, congregando governadores dos estados, prefeitos das cidades tombadas e dirigentes dos órgãos que, de alguma maneira, poderiam atuar no problema dos conjuntos urbanos, tais como a EMBRATUR (Empresa Brasileira de Turismo) e a SUDENE (Superintendência de Desenvolvimento do Nordeste), órgãos relacionados com a política urbana, originaram-se desde logo, nos âmbitos estaduais e municipais, órgãos específicos de preservação de bens culturais. Assim, em 1973, foi criado o Programa de Cidades Históricas (PCH), por iniciativa do ministro Reis Veloso, pela Secretaria do Planejamento da presidência da República e com a intervenção do IPHAN e da EMBRATUR. Segundo Telles (2000, p. 463), o PCH previa uma ação conjunta com estados e Municípios, os quais, provendo uma contrapartida de $20 \%$ de recursos, receberiam dotação suficiente para elaboração de projetos, execução das obras, equipamento e fiscalização. O Programa $(\mathrm{PCH})$ vigorou até 1979 , deixando resultados que, de acordo com Telles (2000), ainda aparecem em muitas localidades do Brasil, além de consolidar a iniciativa e a participação na preservação dos bens culturais, das 
administrações estaduais e municipais e a conscientização das comunidades nessa problemática.

Em face das dificuldades econômicas em conservar e restaurar o grande acervo patrimonial brasileiro, adotou-se uma política de valorização que permitia a integração das cidades buscando soluções "autofinanciáveis" a partir da "indústria" do turismo, ou seja, as cidades históricas seriam objetos de investimento para o desenvolvimento dessa atividade.

Para Leite (2004, p. 55), tal redefinição marca o início de um complexo percurso, iniciado no Encontro de Quito (1967), em que o patrimônio vai sendo incorporado às políticas urbanas e articulado ao desenvolvimento regional ao incremento do turismo. Nas Normas de Quito, encontra-se a seguinte consideração sobre a valorização econômica dos monumentos, citada por Leite (2004): "Partimos do pressuposto de que os monumentos (...) constituem também recursos econômicos da mesma forma que as riquezas naturais do país. Conseqüentemente, as medidas que levam à sua preservação e adequada utilização não só guardam relação com os planos de desenvolvimento, mas fazem ou devem fazer parte deles". Quer dizer que o entendimento do longo processo histórico de produção do patrimônio, no Brasil, torna-se assaz elucidativo da conformação de nosso território, sobre o entendimento da visão/atuação do Estado sobre a cultura na formação de uma nacionalidade, além de nos remeter à lógica que envolve a apropriação dos bens culturais para o desenvolvimento local e regional, de forma que o Estado e os agentes de mercado tornam-se os principais produtores do espaço do patrimônio.

Tem início um novo período de práticas de preservação no Brasil, associando ao patrimônio funções de desenvolvimento urbano. "Nesse sentido, a década de 70 representou o período de transição entre a antiga prática de preservação, fundamentada exclusivamente em critérios estilísticos, e uma nova prática em que os problemas inerentes à atividade de preservação eram compreendidos a partir da perspectiva integrada, e também abrangia critérios econômicos e sociais" (FREITAS apud, LEITE, 2004, p. 55).

Essa mudança de enfoque sobre os bens culturais é coroada, em 1972, em âmbito internacional, com a Convenção Relativa à Proteção do Patrimônio Mundial, Cultural e Natural, que apresentamos no segundo capítulo desta pesquisa, a qual 
consagra a existência de um Patrimônio Mundial. Em 30 de junho de 1977, através do Decreto Legislativo $\mathrm{n}^{\circ} 74$, o Brasil passa a signatário da Convenção, marcando seu engajamento na internacionalização das políticas preservacionistas.

Não era fato novo que a cidade estivesse associada à divisão social e territorial do trabalho, à acumulação do capital e à apropriação privada do solo urbano, mas a partir da década de 1960, identificamos a nova aura vigorante e caracterizadora de algumas cidades históricas brasileiras, como Diamantina, ao assumirem o status de mercadoria, de maneira a identificarmos a minimização de seu valor de uso civilizatório e a maximização de seu valor de troca com o desenvolvimento do turismo.

O patrimônio cultural começou a deixar, naquele momento, de ter o caráter exclusivo de esclarecimento - ligado ao valor cognitivo e mesmo afetivo - para se transformar, gradativamente, em grande fetiche, sendo incorporado ao mundo do consumo, da mercadoria e do valor de mercado - "peça da máquina reprodutora do capitalismo", como menciona Nigro (2001, p. 37).

A valorização simbólica do patrimônio propiciada pela política implementada pelo Estado Novo (que teve no barroco mineiro o símbolo representativo do "Estadonação") e as ações de descentralização da política de preservação de patrimônio no Brasil (entre União, Estados e Municípios), que acompanharam conceitos, normas e diretrizes internacionais, são "eventos" que, no limite, projetam as cidades históricas mineiras, em especial Diamantina, no cenário nacional e internacional para o turismo.

Estas novas diretrizes foram marcantes para a redefinição das práticas de preservação no país e, especificamente em Minas Gerais, na medida em que o estado e os municípios figuram-se como agentes interessados na preservação de seus bens. A manutenção dos sítios vai sendo incorporada às políticas urbanas e articulada ao desenvolvimento local e regional, com o incremento do turismo. A segunda metade do século XX é marco para a transformação valorativa dos objetivos de preservação do nosso acervo arquitetônico, num movimento que vai da busca de uma identidade nacional ao desenvolvimento da economia local.

Nessa nova fase, o Estado de Minas Gerais, através da Secretaria de Estado e da Cultura e do IEPHA/MG ${ }^{102}$ (fruto da descentralização), assume algumas

\footnotetext{
${ }^{102}$ Instituto Estadual do Patrimônio Histórico Arquitetônico de Minas Gerais.
} 
responsabilidades frente à nova política de preservação de patrimônio que está sendo implantada no país, segundo Carsalade (2000), adotando os princípios de:

- servir - prestar apoio incondicional à preservação, estimulando ações conjuntas e integradas de agentes sociais diversos, da comunidade e instituições públicas e privadas.

- responsabilidade compartilhada - estímulo do envolvimento pessoal com os bens a serem preservados.

- prevenção - inibir ações predatórias do homem, movidas por impulsos imediatistas e mesquinhos, bem como preservar o patrimônio de acidentes e ações do tempo.

- valorização do indivíduo e da sociedade, do fortalecimento da identidade de um povo e da qualificação da vida e do espaço urbano - são novos fundamentos da preservação do patrimônio e devem passar a nortear quaisquer ações que se façam em nome dos bens.

O Programa de Ações do IEPHA/MG, alicerçado nos princípios acima, trabalha sobre alguns conceitos de gestão do patrimônio que definem estratégias e ações como: integração do patrimônio ao cotidiano das pessoas; entendimento do Estado como incentivador e fomentador, orientando ações, agentes e diretrizes; entendimento da cultura como geradora de emprego, renda e qualificação profissional.

A partir desses princípios e programa de ações, verifica-se que são postas novas regras pelo estado de Minas, estabelecendo, em relação ao seu acervo, uma tentativa, ao menos no plano teórico, de viabilizar a preservação do patrimônio com uma maior integração de agentes sociais, tanto públicos como privados, buscando dar uma resposta econômica ao rico acervo do estado, sobretudo através do turismo cultural.

Segundo Carsalade (2000, p. 484), a política mineira de patrimônio, no decorrer das últimas décadas, reforça a responsabilidade e a participação da comunidade nas decisões, guarda e gestão do patrimônio, através dos conselhos municipais e estaduais, respaldando-a através de políticas públicas, apoio técnico e medidas de incentivo. Na realidade, fora do plano teórico, não é isso que identificamos em Diamantina (como veremos no decorrer do aprofundamento da análise de nosso estudo de caso), em São João Del Rei e em Tiradentes, por exemplo, que apresentam sérias problemáticas socioespaciais (ocupação desordenada do espaço urbano, precarização da periferia, cenarização do centro histórico, desemprego, concentração de renda, expulsão dos residentes do centro histórico etc.) catalisadas com o desenvolvimento de um turismo negligente com a sociedade e com o lugar, conforme nossas pesquisas anteriores 
revelaram. Segundo Becker (1996) o turismo bem planejado torna-se um instrumento criador de um potencial de desenvolvimento, gerador de empregos diretos e indiretos, de circulação de dinheiro, mercadorias e pessoas, mas, em contrapartida, na falta de um adequado planejamento espacial, propicia impactos perversos ao meio ambiente, ao espaço urbano ou mesmo, diretamente, ao meio social no qual se instala.

\begin{abstract}
O patrimônio (...) funciona como atrator (sic) de recursos de diversas fontes, os quais resultam em investimentos concretos, não apenas em edifícios isolados, mas também no conjunto urbano como um todo, com reflexos claros para as populações locais. A exemplo disso, citamos Ouro Preto, contemplado (sic) com recursos do projeto "Monumenta" e Diamantina, como aquela, também Patrimônio da Humanidade e que começa também a ser alvo de investimentos. Neste último caso, a cidade pode funcionar como indutor de desenvolvimento do Nordeste de Minas (CARSALADE, 2000, p. 486)
\end{abstract}

Mais uma vez lembramos que nosso ponto de vista é o de que seja no turismo ou em qualquer outra "indústria" humana, o que se deve enfatizar não são apenas os bens, sentidos, valores, a permanência ou não da atividade em si, mas a relação estabelecida entre os homens. Seja qual for a atividade desenvolvida por grupos sociais, o que caracterizará a situação social geral, segregados e beneficiados, a democratização ou o "império" da mercantilização dos bens culturais, são os tipos de interações estabelecidas, julgadas coerentes, aceitáveis e cabíveis, essas sim, ditarão o padrão da sociedade instituída, a fragmentação ou não do mundo vivido, do lugar ou da humanidade. Nossa crítica dirige-se às ações, não aos meios encontrados para espacializá-las (a turistificação dos lugares, por exemplo), pois esses, em mãos de agentes verdadeiramente comprometidos com a promoção da gestão participativa dos núcleos urbanos tombados, na qual os residentes tenham a palavra final, podem servir para a edificação de uma sociedade justa, igualitária e de lugares não-fragmentados, espaços, primordialmente, dos cidadãos, que escapem da dialética da construção destrutiva que enreda a consagração dos bens culturais do mundo, que transforma a realidade e o imaginário de populações locais.

Não temos dúvidas de que "não há turismo onde não há atratibilidade e o patrimônio é uma das principais fontes de atração turística", de que "um estado com o potencial turístico e com o acervo de Minas Gerais tem potencial para ser um dos três 
principais destinos turístico deste país", como se refere Carsalade (2000, p. 486). Porém, ainda não identificamos, no estado de Minas Gerais, políticas de patrimônio que respeitem, primordialmente, os lugares e as comunidades locais. Os representantes políticos das cidades históricas mineiras apropriadas pelo turismo chamado cultural, como é o caso de Diamantina (cuja produção do espaço urbano será especificada a partir do próximo tópico), descumprem suas atribuições de membros difusores, da "responsabilidade compartilhada", de "servir", de "prevenção", de "valorização do indivíduo e da sociedade, do fortalecimento da identidade de um povo e da qualificação da vida e do espaço urbano".

Diamantina entra na fase de cenarização progressiva do patrimônio (o que consideramos um quarto e atual momento do patrimônio cultural no Brasil, que apresentaremos no tópico que se segue) com a vitória da troca sobre os modos operantes dos usos, impactada pela dialética de uma construção destrutiva catalisada por sua consagração como Patrimônio Mundial e pela implantação do Programa Monumenta, ou seja, são dois "eventos" (SANTOS, 2002) que catalisam a o encontro da cultura com o processo mercantil urbano, da valorização simbólica com a valorização econômica, da "preservação" com a "mercantilização" do patrimônio, agravando, gradativamente, a oposição centro-periferia em Diamantina e produzindo uma cidade fragmentada. 


\subsection{Fase da "cenarização" progressiva do patrimônio}

Sabemos que, metodologicamente, o geógrafo precisa tratar dois espaços de forma simultânea, o lugar que ele estuda e aquele, mais amplo, onde esse lugar se insere, cujas relações se dão de forma centrípeta e centrífuga, vertical e horizontalmente, ou seja, tratar a parte e o todo em relação constante, considerar influências externas e o jogo de relações locais como partes integrantes de um único processo.

Nessa lógica, lançar um "olhar" geográfico sobre um espaço urbano em vias de mercantilização e identificar as contradições desse processo, exige-nos uma abordagem específica e complexa, pois, segundo Santos (1991), a geografia deve se preocupar com as relações presididas pela história corrente, onde o geógrafo pode se tornar um empiricista e está condenado a errar em suas análises se somente considerar o lugar, como se esse explicasse tudo por si mesmo.

Logo, nossa pesquisa exige-nos um sério esforço de generalização e abrangência concomitante a um esforço de particularização e individualização, como tentamos desenvolver até o momento. A generalização nos mostra os vetores externos possíveis de reestruturar relações humanas; a particularização nos indica, hoje, como o lugar, o específico é entranhado por esses vetores, pela lógica "homogeneizadora" da globalização, que, contraditoriamente, acaba por fragmentar o espaço da sociedade. Essa fragmentação (notória em Diamantina) diz respeito à intensificação da mercantilização de todas as esferas da vida, onde o uso estratégico da propriedade privada, da propriedade pública e dos bens culturais coletivos torna o espaço dividido em parcelas que passam a ser destinadas ao consumo, produzindo lugares submissos à dominação da troca. Ou seja, apreendemos o fenômeno a partir da simultaneidade, da universalidade e da particularidade.

Para a epistemologia materialista histórico dialética, a compreensão dos fenômenos em sua processualidade e totalidade encontra respaldo apenas na dialética entre singularidade, particularidade e universalidade (...) Ocorre que nenhum fenômeno se expressa somente em sua particularidade ou universalidade. Como opostos, se identificam, e a contínua tensão entre eles (particular-universal) se manifesta na configuração particular do fenômeno. Em sua particularidade ele assume as especificidades pelas quais a singularidade se constitui em dada realidade de modo determinado, porém não completo, não universal. Ainda, segundo Luckács, o particular 
representa para Marx a expressão lógica da categoria de mediação entre o específico (singular) e o geral (universal) que não podem ser compreendidos de modo isolado e por si mesmos. (MARTINS, 2006, p. 11)

Nesse procedimento de análise, para compreendermos a dialética da "preservação" / "mercantilização e o processo de cenarização progressiva incipiente em Diamantina, julgamos importante tratar nosso objeto empírico como o fizemos até agora e daremos continuidade. Quer dizer, universalmente, analisamos a existência de um Patrimônio Mundial no contexto da ampliação tipológica, cronológica e geográfica dos bens culturais, como o fizemos na primeira parte desta pesquisa; caminhando para nossa particularidade concreta, na segunda parte, analisamos o processo histórico de produção do patrimônio cultural das Geraes, no contexto da formação territorial brasileira, depois, com a constituição do novo "Estado-nação" que cria um valor simbólico sobre o barroco mineiro e, por fim, de acordo com a projeção inicial das cidades históricas que vêem em seu patrimônio edificado, na segunda metade do século $\mathrm{XX}$, um recurso para o desenvolvimento local e regional com o turismo. Esse é o contexto geral no qual Diamantina é inserida, de expansividade capitalista e seletividade do capital.

Da década de 90 aos dias de hoje, num quarto e último momento que denominamos fase de cenarização progressiva do patrimônio, os núcleos urbanos detentores de reconhecido acervo cultural vêm passando por um processo de produção ampliada (na atual dinâmica da globalização e do capitalismo), que ocasiona a transmutação dos valores a eles inicialmente atribuídos - símbolos de identidade e cultura na construção do novo "Estado-nação" -, dadas as novas relações mediadas pela dinamização dos meios de circulação e pela fluidez da informação, nas quais novos objetos e novas técnicas entremeiam os bens culturais para atender uma nova demanda externa, intensificando o processo de banalização pela cenarização progressiva que envolve as cidades históricas. O conhecer sobrepõe-se ao reconhecer; antigas e novas formas e conteúdos mesclam-se (re)produzindo um patrimônio que vem perdendo o sentido tradicional, a identidade, o significado de memória, enfim, são formas destituídas de um conteúdo social e histórico coletivo, o patrimônio é refuncionalizado para o desenvolvimento turístico.

Dessa maneira, verificamos que as três primeiras fases de produção do patrimônio cultural apresentadas (gênese colonial do patrimônio, produção simbólica do 
patrimônio e projeção inicial do patrimônio) são consecutivas e carregadas de relações, práticas e ideologias sociais distintas, o que não se difere desta última fase que estamos apresentando; são distintas fases de produção do espaço urbano. Da gênese do patrimônio, quando da produção dos espaços urbanos coloniais no interior do território (representantes de um valor de uso civilizatório), à fase de cenarização progressiva catalisada por novos modos operacionais do capital com o turismo (vitória da troca sobre os modos operantes do uso), verificam-se visões sociais de mundo distintas (por parte de agentes públicos, privados e sociedade civil), que redundam em ações que transformam o lugar, a cultura, a memória, a organização da sociedade e as condições de vida das populações locais.

Em síntese, lançamos um olhar sobre Diamantina considerando seu espaço urbano a partir da dialética do uso e da troca, de uma construção destrutiva, reconhecendo sua consagração como Patrimônio Mundial e a implantação do Programa Monumenta como processos que promovem a "valorização do espaço" ao criar critérios de especialidade, singularidade, originalidade e autenticidade, de forma seletiva e pontual em relação à totalidade; "valorização do espaço" que coloca em evidência as contradições das ações que permeiam a sociedade contemporânea de um mundo globalizado, o que transforma a realidade e o imaginário da população local, esboçando uma dialética no sentido que, hoje, Diamantina é envolvida pela unidade indissolúvel dos opostos: "preservação" / "mercantilização". 103

\footnotetext{
${ }^{103}$ Lembramos que nossas problemáticas são: 1) A inclusão de Diamantina na Lista do Patrimônio Mundial [UNESCO] e a posterior implantação do Programa Monumenta [Prefeitura Municipal / Governo Federal / BID] perdem seu papel principal de valorização cultural, memorial e identitária para se estabelecerem como processos que favorecem a intensa valorização do espaço urbano, a especulação econômica e imobiliária. 2) Os dois “eventos” supracitados redundam em uma política de patrimônio que desvia a atenção pública e recursos de problemas mais amplos, sobretudo, fora do núcleo tombado, o que vem afetando as condições de vida da população local, ressignificando "valores" e produzindo uma cidade fragmentada.
} 


\title{
3.4.1. Diamantina: Patrimônio Mundial e mercadoria global
}

\begin{abstract}
A partir de Deffontaines, (1944), Abreu (1982 e 1984), Martins (2004) e das pesquisas de campo (entrevistas e questionários aplicados) que realizamos em Diamantina, podemos afirmar que, frente ao relativo isolamento e possuindo uma economia cuja base sempre esteve voltada para o autoconsumo, o diamante representou, até as últimas décadas do século $X X$, a base econômica da vida regional. Diamantina sempre contou com sua posição fundamental em relação ao norte e nordeste mineiro, como elemento de articulação dos municípios da Zona da Mata e do Sertão do Rio das Velhas, garantindo-lhe certo papel como centro comercial e de serviços na estrutura urbana regional, ao longo de sua história.
\end{abstract}

Logo, a mineração e as atividades que se desenvolveram paralelamente (analisadas ao longo do capítulo 3.1) foram o carro chefe do processo de produção e valorização do espaço em Diamantina até o fim do século $X X$, quando a legislação ambiental impediu a atividade do garimpo na região (contudo, a atividade prossegue na clandestinidade, dada a carência de emprego na região). Entre as décadas de 1930 e 1970, Diamantina tornou-se uma cidade de funcionários públicos, cujos serviços polarizavam a área compreendida entre os municípios de Curvelo, ao sul, e Araçaí, ao norte. Uma espécie de compensação pela não-industrialização e pela perda da posição como principal centro de redistribuição de mercadorias do Norte de Minas (MARTINS, 2004).

Entre as décadas de 1930 e 1970, a cidade aparece também como local de moradia de proprietários de terras minerais que nela gastavam a renda que auferiam de seus garimpos, e de milhares de funcionários públicos que, com seus salários regulares, movimentavam a venda de mercadorias e serviços, para cuja oferta havia uma pulverizada rede de pequenos estabelecimentos diversos, como aponta Martins (2004) e pudemos observar através de pesquisa de campo, tanto antigos mineradores como uma significativa rede comercial e de serviços. Em torno dessas camadas, parte da população sobrevive de atividades ligadas aos trabalhos domésticos, às indústrias artesanais, ao comércio ambulante e às ações de caridade. Ainda, outra parte da cidade organiza-se em torno do atendimento ao comércio atacadista que atende à região, cujos estabelecimentos não têm mais a dimensão nem as pretensões hegemônicas do passado, ocupando-se apenas com 
o abastecimento de vendeiros que atuam nos distritos e nas pequenas cidades vizinhas a Diamantina, segundo Martins (2004).

Esse quadro vem mudando, gradativamente, nos últimos anos, devido às novas ações dirigidas ao centro histórico de Diamantina; considera-se a importância do seu patrimônio edificado para o desenvolvimento econômico local e regional por meio do turismo. Para Carsalade (2000), a cidade pode funcionar como indutora de desenvolvimento do Norte de Minas, considerando que o patrimônio cultural pode ser um atrativo de recursos de diversas fontes, com reflexos positivos para a população local, na concepção do autor.

É a partir da refuncionalização de seu patrimônio cultural ${ }^{104}$ que Diamantina embarca na fase que denominamos de cenarização progressiva. O processo que se desenrolou ao longo das fases que apresentamos é acelerado com sua inclusão na Lista do Patrimônio Mundial ${ }^{105}$, caracterizando, juntamente com a implementação do Programa Monumenta (que analisaremos no capítulo seguinte), "eventos" que promovem o intenso processo de valorização do espaço urbano de Diamantina, agora projetada no cenário internacional e envolvida pela lógica da "indústria cultural" por meio do turismo.

O interesse à candidatura a Patrimônio Cultural da Humanidade partiu da Prefeitura que teve no IPHAN, no IEPHA/MG, na Fundação CEBRAC (Centro Brasileiro de Referência e Apoio Cultural) e no Ministério da Cultura o apoio no processo que durou de 1997 a 1999, quando a cidade foi incluída na Lista do Patrimônio Mundial.

$\mathrm{Na}$ época, foi apresentado um quadro geral da arquitetura do conjunto, ou seja, as condições materiais do centro histórico, juntamente com as condições socioeconômicas apresentadas por Diamantina. Dentro do zoneamento estabelecido no planejamento urbano de Diamantina, o centro histórico é considerado como uma ZPR (Zona de Proteção Rigorosa), de forma que foram estipulados para o mesmo alguns

\footnotetext{
${ }^{104}$ Funções que se modificam, gradativamente, de acordo com as quatro fases apresentadas ao longo deste terceiro capítulo.

${ }^{105} \mathrm{O}$ procedimento de inscrição de um bem na lista do Patrimônio Mundial demanda duas fases distintas. Na primeira, o Estado interessado inventaria o bem cultural e aplica as medidas necessárias para sua proteção. Na segunda, a solicitação da inscrição do bem cultural é submetida ao exame e à deliberação do ICOMOS (Conselho Internacional de Monumentos e Lugares de Interesse Artístico e Histórico), cujo comitê defere ou rejeita a proposta de inscrição do bem (Silva, 2003). No caso de Diamantina, foi proposta pelo governo federal por intermédio do Ministério das Relações Exteriores mediante dossiês encaminhados ao ICOMOS, instruídos com o nome do patrimônio e dos bens que o constituem, sua localização geográfica, as medidas de proteção e a justificativa de seu "valor universal excepcional”, como apontamos no segundo capítulo deste estudo.
} 
critérios na determinação dos imóveis a serem cadastrados para a candidatura à Lista, que são eles: 1) construções do século XVIII e XIX; 2) o conjunto não estar descaracterizado radicalmente; 3 ) considerou-se o perímetro de tombamento federal, do IPHAN, ou seja, a paisagem mais antiga da cidade. (IPHAN, 1998).

Logo, esses critérios selecionados para a candidatura de Diamantina a Patrimônio Mundial serviram, posteriormente, como características fundamentais na busca de singularidades para o estabelecimento de uma renda para a cidade, em especial de uma "renda monopolista", sobre a qual discute Harvey (2005). O autor, na tentativa de esclarecer como a "indústria cultural", através dos processos contemporâneos de globalização econômica, se relaciona com as localidades e as formas culturais, busca subsídio no conceito de "renda monopolista" da economia política. Segundo Harvey, esse conceito pode propiciar interpretações valiosas sobre muitos dilemas práticos e pessoais resultantes do nexo entre globalização capitalista, desenvolvimentos político-econômicos locais e ampliação dos sentidos culturais e dos valores estéticos, como vem ocorrendo em Diamantina.

Toda renda se baseia no poder monopolista dos proprietários privados de determinadas porções do planeta. A renda monopolista surge porque os atores sociais podem aumentar seu fluxo de renda por muito tempo, em virtude do controle exclusivo sobre algum item direta ou indiretamente, comercializável, que é, em alguns aspectos, crucial, único, irreplicável. (HARVEY, 2005, p.222).

Assim, fica claro que para a renda monopolista se materializar, é preciso encontrar algum modo de conservar únicos e particulares as mercadorias ou os lugares, onde a vantagem monopolista se encontra numa economia mercantil e competitiva. A competição sempre tende para o monopólio ou oligopólio, pois a sobrevivência do mais apto, na guerra de todos contra todos, elimina os mais fracos (HARVEY, 2005).

O recente surto de globalização contribui na diminuição dos custos de transporte e com a redução das barreiras espaciais para o movimento de bens, capital, pessoas e informação (a implantação de um aeroporto em Diamantina, e o investimento em melhoria das estradas que a liga a cidades vizinhas e a Belo Horizonte, representa a diminuição dessas barreiras). No entanto, paradoxalmente, esses benefícios fazem por diminuir drasticamente a proteção monopolista conferida historicamente pelos altos custos 
de transporte, comunicação e pela existência de grandes barreiras comerciais, no passado. Contudo, Harvey (2005) afirma que o capitalismo não pode existir sem esses poderes monopolistas, e busca meios de reuni-los. O centro histórico de Diamantina é o meio de reprodução dessa renda para os agentes, dada sua distinção num contexto mais amplo de cidades.

Logo, a ordem do dia é como reunir os poderes monopolistas numa situação em que foram muito reduzidas, quando não eliminadas, as proteções proporcionadas pelos assim chamados "monopólios naturais" do espaço e da localização, assim como as proteções políticas das fronteiras nacionais (HARVEY, 2005).

A centralidade da análise de Harvey $(1980,2005)$ para nossa pesquisa encontra-se na afirmação de que a idéia de cultura está cada vez mais enredada com as tentativas de reassegurar tal poder monopolista, exatamente porque as alegações de singularidade e autenticidade podem ser melhor articuladas enquanto "alegações culturais distintivas e irreplicáveis (...) as alegações monopolistas são tanto uma influência do discurso, como resultado do empenho enquanto reflexão a respeito das qualidades do produto." (HARVEY, 2005, p. 228).

De um total de 418 imóveis inventariados para a inclusão na Lista, 140 são do século XVIII, a maior parte restante, do século XIX. Na época, foi constatado, de acordo com critérios do IPHAN, que $30 \%$ do conjunto apresentavam-se preservados com materiais e estética originais, $40 \%$ apresentou apenas a fachada conservada e $30 \%$ dos imóveis foram considerados descaracterizados. De acordo com a Proposta de Inscrição, a população colaborou demasiadamente, abrindo suas casas e prestando todas as informações possíveis para a efetivação do inventário. ${ }^{106}$

Interessante observar que 3 em cada 10 construções possuem dois ou três pavimentos; 1 em cada 4 construções possuem dois pavimentos; de forma que a maioria

\footnotetext{
${ }^{106}$ Impressiona-nos a disponibilidade e a hospitalidade do diamantinense. Por ocasião de nossas pesquisas de campo, em todos os contatos estabelecidos fomos muito bem recebidos e orientados, a ponto de oferecerem pouso e alimentação a um forasteiro; hospitalidade que não se assemelhou em Tiradentes, muito menos em São João Del Rei, por ocasião de nossas pesquisas anteriores. Saint-Hilaire (1974, p. 40), no início do século XIX, parece ter tido a mesma sensação que a nossa e comenta sobre o tratamento recebido quando do acidente que sofreu. "À minha chegada a Tijuco encontrei os principais moradores do lugar reunidos na casa em que me hospedei, e recebi as provas do mais tocante interesse. Essas provas continuaram durante todo o tempo em que estive sob tratamento e jamais falarei de Tijuco sem um sentimento de profundo reconhecimento. A população inteira tomou parte no acidente que sofri; pessoas mesmo que eu nunca vira vinham pedir notícias ao meu tropeiro e testemunhavam-lhe satisfação quando ficavam sabendo que haviam exagerado muito as conseqüências de minha queda (...) Durante minha estada no Distrito dos Diamantes deles recebi todas as delicadezas imagináveis; enquanto estive doente fui tratado como se estivesse na minha casa paterna, tantas foram as provas de carinho e amizade que recebi”.
} 
dos edifícios é térrea. Apesar de a paisagem urbana ser caracterizada pela horizontalidade, onde a altimetria varia em pontos especiais como praças, largos e algumas esquinas, impressiona a quantidade de sobrados e o ordenamento do espaço urbano colonial de Diamantina (urbanística analisada no capítulo 3.1.4), características que se somam à sua localização em uma encosta de topografia demasiadamente acidentada; o que a dá uma ambiência diferenciada em relação a Ouro Preto, São João Del Rei, Tiradentes, Sabará e Santa Luzia, por exemplo, cidades da zona do ouro, como vimos no capítulo 3.1, o que a dá notoriedade na antiga zona dos diamantes.

Como a incessante busca do lucro impõe a procura ou estabelecimento de critérios de especialidade, singularidade, originalidade e autenticidade nos lugares, buscou-se na irreplicabilidade da forma urbana e na história de Diamantina as justificativas para sua inclusão na Lista. ${ }^{107} \mathrm{~A}$ análise mostra-nos que se não for possível estabelecer a singularidade pelo apelo à tradição, ou pela descrição direta de alguma característica local, outros modos de distinção deverão ser "criados" para se estabelecer alegações e discursos que estabeleçam o aumento da renda e a distinção do lugar. Nesse sentido, tem grande relevo o papel da mídia na dinamização da "indústria cultural" para o desenvolvimento do turismo na cidade.

Ainda de acordo com a Proposta de Inscrição de Diamantina como Patrimônio Cultural da Humanidade, fica evidente a função comercial e de serviços que representa o centro histórico, a "área mais nobre e tradicional da cidade". Há uma distribuição desigual do comércio/serviços, sobretudo próximo às igrejas. É corrente a reclamação sobre o trânsito e a barulheira no centro histórico, carência de limpeza pública, opções de lazer e assistência de saúde, considerações que faremos nos capítulos seguintes com maior ênfase.

Não podemos desconsiderar que as tentativas de acumulação (no nosso entender a campanha para a inscrição de Diamantina na Lista do Patrimônio Mundial teve como primeiro objetivo o desenvolvimento do turismo, não a busca de um instrumento de

\footnotetext{
107 Conforme nosso capítulo 2, os critérios adotados pela UNESCO para a inclusão de Diamantina na Lista do Patrimônio Mundial foram: critério (ii) - testemunhar uma influência considerável, durante um período dado ou em uma área cultural determinada, sobre o desenvolvimento da arquitetura ou da tecnologia, das artes monumentais, do planejamento das cidades ou da criação de paisagens; critério (iv) - representar um exemplo excepcional de um tipo de construção ou de conjunto arquitetônico, ou tecnológico, ou paisagem ilustrativa de um ou mais períodos significativos da história humana.
} 
salvaguarda do patrimônio cultural) constroem e destroem, dialeticamente, o desenvolvimento social e a tradição cultural local. ${ }^{108}$ Há o interesse atual tanto na inovação cultural do lugar como na ressurreição e invenção de tradições locais, com o propósito de dinamizar a atividade turística. ${ }^{109}$

Se as alegações de singularidade, autenticidade, particularidade e especialidade sustentam a capacidade de conquistar rendas monopolistas, então sobre que melhor terreno é possível fazer tais alegações do que no campo dos artefatos e das práticas culturais historicamente constituídas, assim como no das características ambientais especiais (incluindo, é claro, os ambientes sociais e culturais construídos)? (HARVEY, 2005, p. 232, grifo nosso).

É interessante notar que a Proposta de Inscrição considerou que a principal atividade econômica de Diamantina no momento de sua elaboração, em 1998, era o garimpo (que se encontrava em declínio), seguido da agricultura de subsistência, de forma que o turismo não foi visto como aspiração prioritária da população (é bom notar que, naquele momento, o turismo já se encontrava em desenvolvimento), o que contraria os dados colhidos por nós nas atividades de campo, onde a população mostrou-se favorável ao desenvolvimento do turismo em Diamantina (identificamos - como veremos com detalhes na última parte da pesquisa - em campo, que o aparente [novos fluxos na cidade] torna-se o principal fator de transformação do imaginário do residente, que não compreende as contradições inerentes à própria reprodução do capitalismo e transformação socioespacial de Diamantina).

Outra questão a ser observada é que com o declínio da mineração no século XIX, a cidade pouco cresceu; a partir da década de 1950, aparecem manchas fora do sítio original; o Bom Jesus, Vila Operária, Fátima e Presidente.

Logo, como instrumento de preservação, a Proposta de Inscrição pontuou as zonas de proteção, a saber:

\footnotetext{
${ }^{108} \mathrm{O}$ investimento na área central da cidade em contraposição à periferia, a manutenção de edifícios específicos do centro histórico em detrimento ao conjunto, através do Programa Monumenta, as ações particularistas e mercantis do mesmo em prejuízo da coletividade, o estabelecimento de eventos voltados, sobretudo, para o desenvolvimento turístico - como, por exemplo, as Vesperatas que acontecem duas ou três vezes ao mês, de março a outubro e seu famoso carnaval - que se sobrepõem a eventos tradicionais como os religiosos, que se desintegram no imaginário do residente, representam essa dialética, espacialmente.

${ }^{109}$ Aprofundaremos nessa questão no quarto e quinto capítulos da pesquisa.
} 
- Zona de Proteção Rigorosa (ZPR) - entendida a partir do perímetro de tombamento feito pelo IPHAN em 1938, limitando o adensamento da ocupação.

- Zona de Proteção (Entorno da ZPR) - limitando altura das edificações e disposição de cores que não desconfigure o centro

- Zona de Proteção Paisagística (ZPP) - visa preservar a paisagem formada pela mancha urbana em conformação com a paisagem natural, formada em 4 pontos e grande área relativa

- Zona de Contenção de Ocupação de Encosta (ZCO) - controle emergencial da ocupação da vertente da Serra de Santo Antônio, visível da encosta onde está a cidade.

A partir da Proposta de Inscrição, foi elaborado, em 1999, o Plano Diretor de Diamantina, como última etapa da campanha iniciada em 1997 pela elevação da cidade a Patrimônio Mundial.

O Plano Diretor estabeleceu-se como um documento fundamental de orientação do poder público e da iniciativa privada. Consta como seus objetivos: 1) garantir as funções sociais da cidade e a propriedade imobiliária urbana; 2) melhorar a qualidade de vida dos habitantes, indicando áreas que devem receber especial atenção do município, minimizando desigualdades na distribuição dos equipamentos e serviços urbanos $^{110}$; 3) garantir a preservação do Patrimônio Arquitetônico e Urbanístico através de restrições à construção dentro das áreas oferecidas à UNESCO para Patrimônio Cultural da Humanidade e tombada pelo IPHAN, e da regulamentação de uso e ocupação fora desta área ${ }^{111}$; 4) conter a expansão da área ocupada de forma desordenada e imprópria, buscando alternativas para a ocupação indesejada. ${ }^{112}$

O Plano Diretor de 1999 previa diretrizes de proteção do patrimônio cultural e da memória que simboliza, priorizando o conjunto, a ambiência e os bens isolados,

\footnotetext{
${ }^{110}$ Esse objetivo traçado em 1999 não está sendo alcançado, ao contrário, agrava-se sobremaneira, em Diamantina, decorridos 9 anos. A periferia de Diamantina clama por melhores condições de vida, de acordo com nossos questionários.

${ }^{111}$ Observamos uma maior atenção destinada ao centro histórico em relação aos demais bairros ou Zonas de Preservação da cidade.

${ }^{112}$ Talvez essa ocupação desordenada seja mais indesejada pelos agentes sociais (que não vêem outra saída para sua sobrevivência, a não ser a ocupação de terrenos desocupados do espaço urbano) que a fizeram do que pelos responsável pelo planejamento urbano de Diamantina.
} 
protegendo os elementos paisagísticos e permitindo a visualização do panorama e a manutenção da paisagem em que estão inseridos. O Plano Diretor também priorizou disciplinar usos de comunicações visuais para resgate da paisagem urbana. Sobre as diretrizes do sistema viário e de transportes, frisou a garantia de condições de preservação do centro histórico com medidas disciplinadoras quanto à circulação dos veículos de grandes dimensões e peso, bem como redução dos veículos de passeio pela área tombada. Isso não vem ocorrendo na cidade (foto 18). Não podemos esquecer que o trânsito intenso nos núcleos urbanos tombados constitui-se em um dos mais graves problemas que assolam o patrimônio edificado.

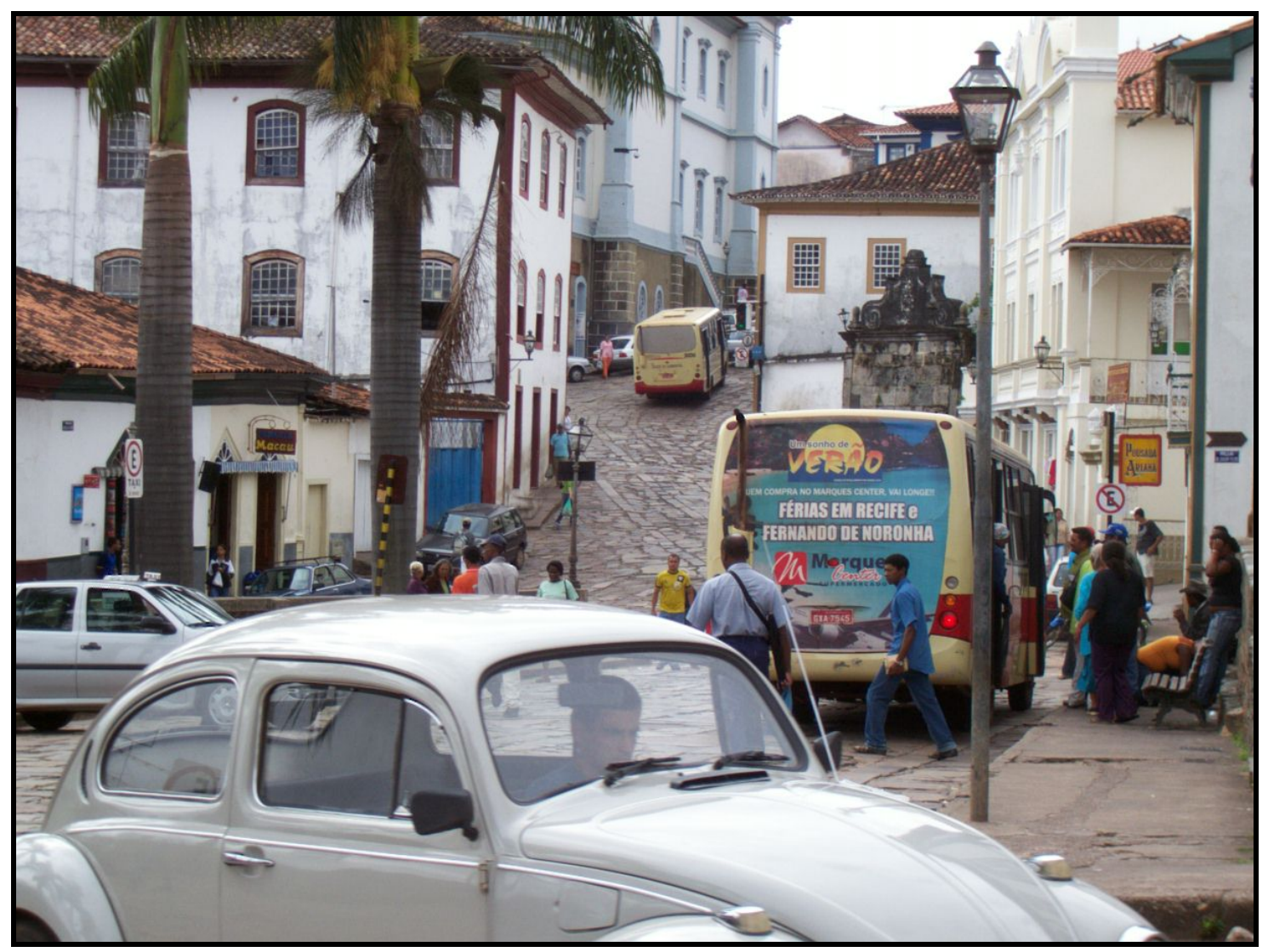

Foto 18 - O centro histórico de Diamantina ainda apresenta um intenso fluxo de veículos leves e pesados, o que caracteriza uma das grandes problemáticas que impactuam as cidades históricas no Brasil. Foto do autor / jan. 07.

A valorização do centro histórico de Diamantina mostra que o que é colocado em jogo é o poder do "capital simbólico coletivo" (HARVEY, 2005), a "valorização" da excepcionalidade, dos marcos de distinção e da autenticidade vinculados a lugares dotados de um poder de atração importante em relação aos fluxos de capital de modo 
mais geral. Esse "capital simbólico coletivo" vinculado a nomes e lugares especiais, como Diamantina, uma cidade estrategicamente alcançada pelo turismo via "indústria cultural", torna-se preponderante ao conferir à cidade vantagens econômicas em relação a outras. A globalização atual e a mundialização dos lugares favorecem o desenvolvimento desse processo.

Segundo Harvey (2005), a ascensão de uma cidade num sistema internacional de cidades requer uma firme acumulação tanto de "capital simbólico" como de marcos de distinção. Baseia-se o desenvolvimento desses atributos em bombardeios de imagens e "valorização" da história, da tradição e da cultura local, onde o marketing, a respeito de realizações artísticas relacionadas a esses valores, presta um apoio necessário à formulação desse processo. É nesse sentido que se estabelece uma avalanche de publicações, exibições e eventos culturais que subsidiam a atração do capital e valorizam o espaço (caso do atual carnaval e das Vesperatas, em Diamantina ${ }^{113}$ ). Vemos, assim, a cultura e a economia convergirem, correndo uma na direção da outra, dando a impressão de que a nova centralidade da cultura é econômica e a velha centralidade da economia tornou-se cultural (ARANTES, 2005).

Posicionamo-nos com Thompson (1995), para quem os produtos da "industria cultural" não são determinados por suas características intrínsecas como uma forma artística, mas pela lógica corporativa da produção de mercadorias e seu valor de troca, como é o caso das Vesperatas de Diamantina, que representam um novo produto atrativo de fluxos diversos e não um evento cultural para a comunidade local. A "indústria cultural" vende seu produto sem, contudo, entregá-lo ao consumidor, esse tem um encontro efêmero com a dita "cultura" singular ou "bem cultural" especial. Acreditamos que a idéia de Harvey (2005) sobre a "alegação de singularidades" para a distinção de um lugar, se dá através das imagens e representações emitidas por formas simbólicas que podem ou não ser fonte de reflexão, "objeto de identificação ou um referencial de interpretação" (THOMPSON, 1995, p. 136).

\footnotetext{
${ }^{113}$ Vesperatas são as exibições de bandas de música a partir das sacadas dos sobrados coloniais. Acontecem de março a outubro, duas ou três vezes a cada mês, com venda de mesas para turistas, que ocupam a parte interna do cordão de isolamento próprio para o evento. Discorreremos mais sobre esse evento e as problemáticas que causa, nos capítulos que se seguem, onde veremos que esse cordão é um símbolo marcante da limitação de acessos no centro histórico, que causa insatisfação generalizada à população residente, conforme o questionário aplicado. É uma das grandes contradições socioespaciais que identificamos na cidade, uma das facetas da transformação do uso em troca, em Diamantina.
} 
Nesse contexto, precisamos entender que Diamantina está sendo envolvida por um novo tipo de "imperialismo" que é o da mercadoria sobre a cultura ${ }^{114}$. Imposição que se dá numa dimensão inigualável na história da sociedade, onde a mídia aparece como catalisadora das ações geridas pela "indústria cultural" no seu processo mercantilizador, em que o patrimônio, principalmente, é envolvido pela dialética do uso e da troca, no espaço urbano, ao ser valorizado simbólica e economicamente. Hoje, sobretudo com a diversidade técnica e informacional, algo muito especial vem envolvendo esses objetos, produtos e os eventos culturais, resgatados ou recriados enquanto singularidades, sendo preciso pô-los à parte das mercadorias tradicionais, como bens de consumo duráveis e não duráveis; são produtos e eventos que estão num plano mais elevado de produção e da criatividade humana, diferente da produção industrial tradicional.

De acordo com lanni (2000), a mídia é uma poderosa técnica social, onde sobressai a televisão e diríamos também a rede mundial de computadores. Para o autor, ela se tornou um potente instrumento de virtualização e conversão que santifica e sataniza, constrói e destrói a realidade e o imaginário. Não é apenas uma rede prática integrada, mas um modo de articulação eficientíssimo que une o mundo inteiro. Na concepção de Said (2006), a mídia produz e articula cultura, economia e poder político, gera imagens transnacionais às vezes desproporcionais, que reorientam o discurso e as relações sociais locais, nacionais e internacionais.

A mediação interessada da mídia deturpa o conteúdo das mensagens e linguagens, numa verdadeira falsificação de discursos, lançando sombra sobre o entendimento dos fatos e prejudicando a formação e a informação da sociedade. Para Santos (1994a), a mídia é o grande veículo do processo ameaçador da integridade dos homens. Virtualmente possível, pelo uso adequado de tantos e tão sofisticados recursos técnicos, a percepção é mutilada, quando a mídia julga necessário captar a atenção do expectador através do sensacional e do medo. Segundo Santos (1994a) "estamos de volta

\footnotetext{
114 Consideraremos a concepção simbólica de cultura, enquanto um padrão de significados incorporados nas formas simbólicas, que inclui ações, manifestações verbais e objetos significativos de vários tipos, em virtude dos quais os indivíduos comunicam-se entre si e partilham suas experiências, concepções e crenças (THOMPSON, 1995). Assim, podemos considerar também que a cultura é mais que belas artes. É memória, história, política, cozinha, vestuário, religião, folclore, etc. Onde os seres humanos criam símbolos, valores, práticas, há cultura. Onde há o sentimento do tempo, do visível e do invisível, do belo e do feio, do doce e do amargo, do simples e do complexo, do popular e do erudito, da bondade e da maldade, aí há cultura (FENELON, 1992).
} 
ao mundo mágico, onde o fantasioso, o fantástico, o fantasmagórico prometem tomar o lugar do que é lógico e o engano pode apresentar-se como o verdadeiro (...) é preciso humanizar a técnica" (p. 21, 24).

Em nosso entender, o que dá notoriedade à construção da mídia é seu poder de transformar o sagrado em profano, mercadoria em ideologia e ideologia em mercadoria, o mercado em democracia, o social em individual, o consumismo em cultura popular e a cultura popular em um novo produto. A "indústria cultural” combina a produção cultural com a reprodução do capital, formando opiniões, imprimindo e vendendo idéias e ideologias no nível planetário, favorecendo, assim, o desenvolvimento da atividade turística. $^{115}$ A mídia promove Diamantina - um Patrimônio Mundial - como uma mercadoria global. Acessando a Internet, por exemplo, verificamos a divulgação efetuada pela CVC (uma grande agência de turismo e viagens do Brasil) que oferece Diamantina, junto a outras cidades dos circuitos do ouro e dos diamantes, embalada e pronta para o consumo; "charmosa (...) cheia de riquezas por todos os lados (...) a começar pelo nome (...) mais sossegada que Ouro Preto (...) orgulhosa por ser a cidade de Juscelino Kubitschek". 116

Fica claro para nós, dentro da perspectiva da consagração do Patrimônio Cultural da Humanidade, que Diamantina - apesar de contemplada pela Lista do Patrimônio Mundial dada sua formação urbano-ambiental que responde aos caracteres de universalidade, excepcionalidade e autenticidade exigidos pela UNESCO, apesar de representante inconteste de paisagem urbana histórica herdada para a humanidade - vem sendo apropriada e transformada no mais novo reduto do turismo cultural de Minas Gerais, através das alegações de singularidade e autenticidade, agora, (re)criadas pela influência de um novo discurso, o dos agentes públicos e privados ligados ao processo que resulta da intensa mercantilização das formas culturais, ou seja, à "indústria cultural", que a partir das "ideologias" enredadas pelo capital especulativo, tende a pasteurizar a sociedade e o lugar. Logo, a universalidade e excepcionalidade que serviram para a inscrição da cidade na Lista do Patrimônio Mundial, agora atendem à singularidade e à

\footnotetext{
${ }^{115}$ Há de se ficar claro que a mídia, enquanto aparato técnico e informacional ou conjunto dos meios de comunicação de massa, não age indiscriminadamente, são as ações humanas, os interesses dos agentes de mercado que manipulam e deturpam as imagens, daí Santos (1994a, op. cit) fazer referência à urgência da "humanização" da técnica, acreditamos. ${ }^{116}$ Ver site: www.cvc.com.br. Acessado em 09 de setembro de 2008.
} 
autenticidade que transformam o uso em troca, no espaço urbano, através da apropriação estratégica das formas e dos eventos culturais.

Entendemos que é a partir da captura da cidade histórica por um turismo descompromissado com a sociedade e o lugar é que se passa a operar a simultaneidade dialética de uma construção destrutiva. No caso da consagração enquanto Patrimônio Mundial, como ocorreu com Diamantina, dando-Ihe visibilidade no cenário internacional, a cidade tende a se tornar um novo tesouro cada vez mais explorado na perspectiva do desenvolvimento e do turismo, respondendo à reprodução do capitalismo. A dialética da "preservação" x "mercantilização", da vitória da troca sobre os modos operantes do uso integra a construção destrutiva dos seus bens culturais que embarcam na mundialização dos lugares. ${ }^{117}$

Ao receber a chancela da UNESCO, via Comitê do Patrimônio Mundial, dado o caráter ambicioso e imediatista de agentes públicos e de mercado, Diamantina passa por uma intensa e programada valorização simbólica dos bens culturais que, ao agregar valor de troca, transforma a cultura num novo gênero de mercadoria, objetivo precípuo da "indústria cultural", pois é o estímulo a essa valorização simbólica (misto de "cultura" e lazer) que acarreta na valorização econômica dos bens culturais (vitória da troca sobre os modos operantes de uso), contrariando as propostas primeiras da UNESCO, de salvaguarda dos bens culturais em benefício incondicional para a população local, conforme apresentado no segundo capítulo.

A "aura" que envolve o Patrimônio Cultural da Humanidade, analisada na primeira parte da pesquisa, paira sobre Diamantina, de forma que os principais agentes produtores do espaço - poder público e agentes privados - somam força na produção do

\footnotetext{
${ }^{117}$ Esse processo contraditório que se inicia no plano teórico e de discussão da ampliação da noção de patrimônio, tem seu rebatimento no lugar, no plano do território. Logo, o que denominamos dialética da construção destrutiva do patrimônio deve ser considerado ao longo da pesquisa (passamos da construção à desconstrução do patrimônio, na análise, em vários momentos), pois, consideramos a simultaneidade que nos exige a própria dialética, de afirmação e negação, da própria contradição que envolve o patrimônio hoje, ao simbolizar cultura e mercadoria; vende-se o inalienável, mercantiliza-se, descompromissada e particularmente, o que deveria ser preservado coletivamente. Esse jogo tende a forçar os territórios a uma compartimentação generalizada, onde se associam e se chocam o movimento geral da sociedade planetária e o movimento particular de cada lugar, ou seja, com a dinâmica desse processo, todo e qualquer pedaço da superfície da terra torna-se funcional às necessidades, usos e apetites de agentes do mercado, do Estado ou da associação de ambos, segundo Santos (2000). O autor considera que, até recentemente, a humanidade vivia o tempo da lentidão, no qual a prática de velocidades diferentes não separava os respectivos agentes; contudo, hoje, vivemos o mundo da fluidez e da rapidez possíveis através de novos sistemas técnicos; uma fluidez potencial, novas técnicas e meio informacional que aparecem no imaginário e na ideologia como se fossem bens ao alcance de todos, o que não se constitui na realidade.
} 
núcleo urbano tombado em prol do desenvolvimento turístico, com a implantação do Programa Monumenta.

Acreditamos que essa "aura" que envolve os bens culturais, hoje, está mais ligada a um processo de mercantilização que metamorfoseia identidades, culturas tradicionais e a memória do que a um processo de resgate e manutenção de valores culturais da sociedade.

A "indústria cultural" investe na visitação aos patrimônios sob pretexto de distração, entretenimento, lazer ou até mesmo para demonstrar status cultural e social. Para Scifoni (2006), na medida em que o patrimônio é permeado pela lógica do turismo cultural ou de massa, incorporado a roteiros, perde-se, aos poucos, sua maior riqueza, a sua função cognitiva, um representante simbólico de cultura e história passadas do lugar.

O universo da cultura transforma-se em entretenimento e lazer. O objetivo da visitação escapa do compromisso e do resgate de valores mais densos, os que nos permitem entender o mundo, as relações e as práticas sociais pretéritas numa perspectiva crítica. "A cultura se empobrece e é ameaçada a partir do momento em que é associada ao mercado e ao entretenimento das massas, pois o que a sociedade deseja, induzida ou não, é o entretenimento e não a cultura" (SCIFONI, 2006, p. 68).

Dessa forma, o patrimônio tornou-se um potencial instrumento não só de atração turística, mas também para a promoção das cidades no mercado global, "cultura como marketing territorial das cidades" (SCIFONI, 2006, p. 68). Diamantina Patrimônio Mundial torna-se uma mercadoria global.

A influência do discurso criado pelos agentes públicos e de mercado apresenta Diamantina como um híbrido de história, memória, cultura e lazer, enquanto nossa pesquisa empírica remete-nos ao desencadeamento de um processo de mercantilização das formas culturais sem uma devida valorização da sociedade. Diamantina torna-se centralidade no denominado Circuito dos Diamantes (ver figura abaixo); ora "preservação", ora "mercantilização", ora valor de uso, ora valor de troca, cultura e mercadoria; preserva-se, hoje, para a venda; vende-se o inalienável. É nessa dialética que buscamos entender o jogo de forças dos agentes que produzem o espaço urbano em Diamantina negligenciando a massa da população local, ao se reproduzir uma cidade dividida, com um centro em vias de banalização pela cenarização progressiva e 
uma periferia em processo de intensa "precarização" (ver foto 19). A relação entre a figura 02 e a foto 19, abaixo, sintetizam essa contradição.

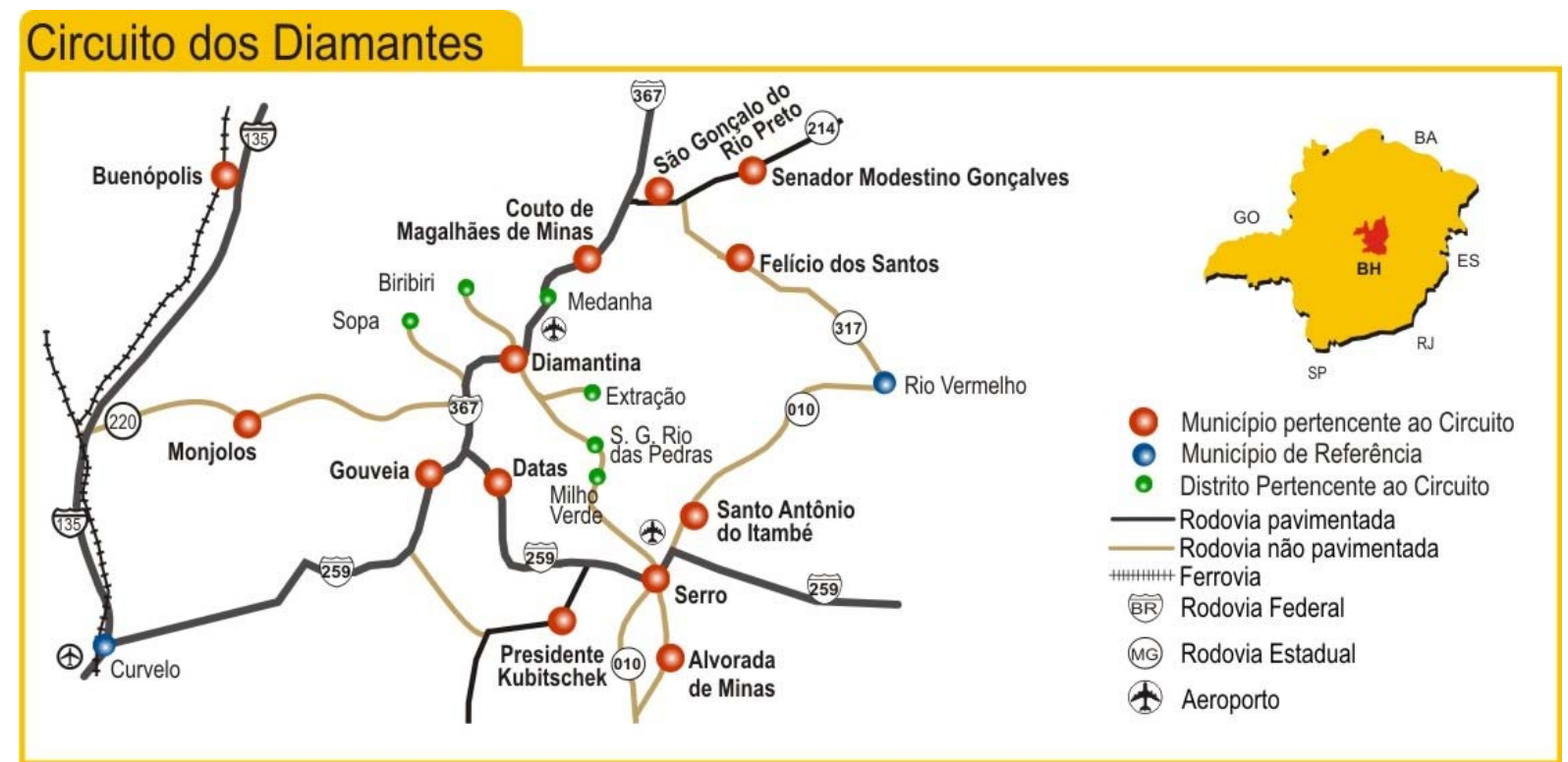

Figura 01 - O denominado Circuito dos Diamantes: o novo reduto do turismo em Minas Gerais. Fonte: www.circuitodosdiamantes.tur.br

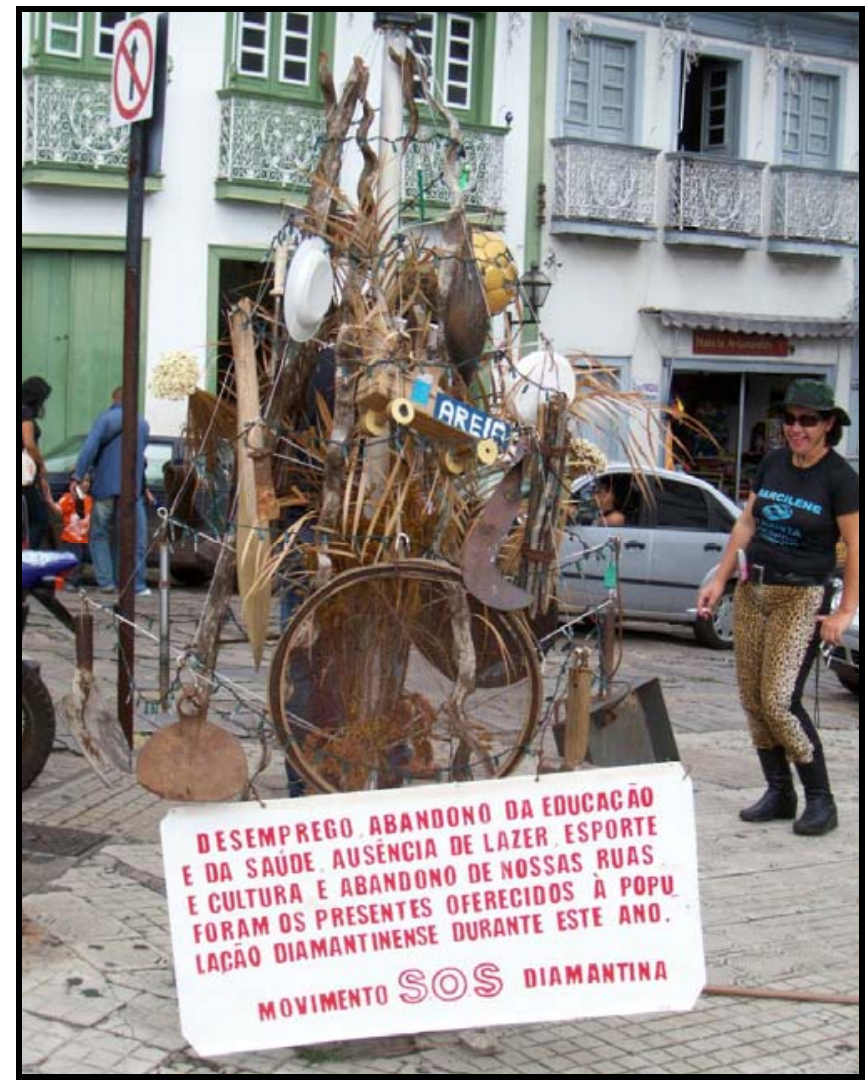

Foto 19 - Manifestação popular por melhores condições de vida, no centro histórico de Diamantina. Foto do autor / jan. 07. 
O discurso do atual secretário de turismo de Diamantina, Walter Cardoso França Júnior, sintetiza nossa análise e a dialética que consideramos. Ao ser questionado por nós sobre a situação do turismo na cidade com sua inclusão na Lista do Patrimônio Mundial, considerou que:

No fundo no fundo, se Diamantina configura-se hoje como uma cidade turística, ela sempre foi (...) é um foco do turismo totalmente diferente, o atual. Eu sou visitado porque existo. Se eu faço marketing e propaganda em cima disso, faço vir pessoas, começo a construir um PRODUTO em cima do que tem aqui dentro, começo a fazer a pessoa enxergar (sic) diferente um andar no Caminho dos Escravos ou um passeio no Parque das Sempre Viva, eu mudo o foco da visita, então tem pessoas aqui que não conseguem mais perceber a beleza de Diamantina, cada detalhe de sacada, de janela, porque é do dia a dia delas. Agora, quem vem de fora vem com essa visão, tenho que anunciar; o PRODUTO não é VENDIDO se ficar dentro de casa trancado, então eu acho que nosso caminho está certo, e acho realmente que a Secretaria de Cultura e Turismo conseguiu fazer o convencimento do setor político e do poder público de que este caminho daria certo. Nossa estrutura é pequena, mas com esforço nós conseguimos fazer Diamantina andar, enquanto um dos 65 destinos turísticos do país. ${ }^{118}$

O atual prefeito de Diamantina, Gustavo Botelho Júnior, apresenta uma retórica favorável à mercantilização do patrimônio, vendo no centro histórico de Diamantina um "produto" capaz de gerar renda e empregos na cidade.

Tivemos um problema no Governo Estadual de Milton Cardoso, quando ele mandou fechar o garimpo, pois este degradava muito o meio ambiente. Em função disto, a cidade começou a decair por completo e começavam a usar uma expressão numa cidade aqui perto 'visite a cidade vizinha antes que ela acabe'. Assim, em 1997, o prefeito resolveu encampar uma idéia que havia surgido de um visitante da cidade; de que ela deveria se tornar Patrimônio da Humanidade $e$ isso trouxe um ânimo novamente à cidade, os diamantinenses se entusiasmaram e daí começou a desenvolver o turismo. Esse turismo vinga justamente por causa da conservação do centro histórico; conservado através de imposição do IPHAN, pois ele que trouxe o

\footnotetext{
118 Entrevista do secretário de turismo de Diamantina, Walter Cardoso França Júnior, concedida ao autor em 13 de fevereiro de 2008.
} 
desenvolvimento a Diamantina. Então acho que o centro histórico é um fator importantíssimo ao desenvolvimento da cidade, pois isso que dá empregos, pois os mais beneficiados, é lógico, foram os proprietários, mas em segundo lugar a população mais carente. Com certeza a população carente é beneficiada porque o artesanato é desenvolvido por ela, as camareiras, cozinheiras, garçons todos são da periferia da cidade, enquanto dez pessoas da classe média alta trabalham, noventa são da periferia da cidade. ${ }^{119}$

A fala do secretário de turismo e do prefeito de Diamantina remetem-nos à dialética da construção destrutiva que apresentamos, de uma "preservação" para a "mercantilização" destinada aos detentores dos meios de troca. Busca-se construir uma imagem de Diamantina Patrimônio Mundial com a consciência de que o patrimônio cultural representa um produto capaz de gerar renda para o distrito, o que pode, realmente, ser positivo a partir de uma gestão participativa que prime pela manutenção de um espaço complexo de igualdades e de cidadania, onde a distribuição da renda auferida da atividade seja uma realidade (de acordo com os documentos internacionais analisados na primeira parte da pesquisa). Porém, essas falas consideram o descaso do próprio residente que não reconhece os valores culturais do patrimônio, suas formas e conteúdos, dado o costume e o cotidiano rotineiro (não há uma séria política de valorização cultural do patrimônio voltada para o esclarecimento do diamantinense); subtende-se que a visão do turista é a que deve ser desenvolvida e valorizada, o convencimento deve ser feito ao "setor político" e ao "poder público". Aprovar que para cada dez pessoas da classe média alta trabalhando há noventa da periferia significa concordar com a submissão de uma classe a outra em condições duvidosas de trabalho e de dignidade humana, como se dera no Brasil colonial escravocrata. O problema que se coloca é o de fazer do Patrimônio Mundial uma mercadoria global antes de se desenvolver com o residente o sentimento de pertencimento e reconhecimento do bem cultural que deveria ser coletivo, de forma que todas as classes sejam, igualmente, beneficiadas.

Não nos restam dúvidas, ao ser destituído de seus verdadeiros conteúdos significativos (os quais apresentamos no capítulo 3.1) com o advento de novos usos que o mercantilizam e banalizam, o patrimônio deixa de ser símbolo local, nacional e mesmo mundial, é entregue ao bel sabor do mercado; seu lugar passa a ser o mundo virtual, veloz

\footnotetext{
${ }^{119}$ Entrevista do prefeito de Diamantina, Gustavo Botelho Júnior, concedida ao autor em 14 de fevereiro de 2008.
} 
e quantitativo da globalização. Sendo o espaço-tempo coordenada básica dos diversos sistemas de representação, cabe à Geografia pensar essa problemática socioespacial da produção do patrimônio em tempos de globalização e do advento de novas técnicas e da informação. Não faz sentido o patrimônio cultural estar em todos os lugares, mundializado enquanto uma mercadoria a ser "consumida" e desaparecer para a comunidade de seu entorno, ser esvaziado de seu valor memorial, afetivo, cognitivo, histórico e cultural tradicional. Ora, é global mas não é local? Quem cuida melhor de um bem do que o próprio dono? Há de se desenvolver o sentimento de pertencimento ao lugar.

Conforme analisamos, o objetivo primordial dos órgãos de conservação e preservação não é o de dinamizar a "indústria" do turismo, mas de identificar, proteger, preservar, valorizar e transmitir às gerações futuras o patrimônio cultural e natural situado sobre o território das nações, com o fim primeiro de atender às necessidades dos habitantes locais, tanto no plano cognitivo e afetivo, como no plano econômico, se essa for a necessidade legítima das comunidades locais, onde a gestão participativa reine operante, com a última palavra a do habitante local, conforme demanda a Convenção do Patrimônio Mundial da UNESCO, suas recomendações e memorandos apresentados na primeira parte da pesquisa.

Buscamos, neste tópico, deixar claro nosso ponto de vista de que a consagração de Diamantina como Patrimônio Mundial está diretamente ligada à reprodução do capitalismo, onde a busca da singularidade e constituição de um "capital simbólico" favorecem o estabelecimento de uma renda diferencial ou da renda de monopólio, segundo Harvey (2005). Nesse sentido, Diamantina, enquanto um Patrimônio Cultural da Humanidade, representa uma forma cujas funções são alteradas dentro da estrutura do capitalismo, ao longo de seu processo histórico de formação. Diamantina assume a forma de uma nova mercadoria global, onde a análise da atuação de agentes públicos (representantes do Estado) e privados (capital financeiro), que trabalham um planejamento estratégico, de forma conjunta, para o estabelecimento do Programa Monumenta, dar-nos-á subsídios para essa afirmação.

Enquanto isso, o discurso novo do planejamento - novo mas só em aparência, porque carente de um conteúdo realmente novo - vale-se de acentos retóricos, como, por exemplo, a fastidiosa alusão à participação, coisa que, por falta de definição, não se pode reconhecer, e, por falta de uma 
vontade política, não pode ser definida nem implementada. (SANTOS, 2007, p. 159).

\subsubsection{O Programa Monumenta e seu rebatimento sobre o território}

Entendemos que o capitalismo representa uma lógica histórica da vida social, com a produção de mercadorias, onde o mercado atua a estruturar essa vida social. Possuidor de uma geografia específica, o capitalismo desponta em alguns espaços do globo, possui um centro geográfico. Será a própria expansão geográfica quem vai sustentar o capitalista, submetendo lugares, populações e países à economia mundializada. Um lugar é integrado a essa economia quando sua lógica operante responde à reprodução do capitalismo, dentro de um contexto mais amplo. ${ }^{120}$

Logo, a expansividade é um caráter da espacialidade do capitalismo, dando forma ao funcionamento da sociedade. Contudo, devemos considerar que essa expansividade ocorre de forma heterogênea no espaço e cria espacialidades distintas (HARVEY, 2005 e MORAES, 2005), como ocorre em Diamantina, hoje. É nesse contexto que Moraes (2005) considera que o capitalismo tem, em termos espaciais, a exaustão como meta, buscando submeter todos os lugares à sua lógica, modificando os gêneros de vida existentes antes de sua chegada a uma localidade. "Em temos espaciais, portanto, o capitalismo é - por natureza - exaustivo e universalizador (tanto que cria uma história universal e um espaço de relações globais)" (Moraes, 2005, p.149).

Ante o exposto, fica claro que o capital, entendido como relação social realizada através de objetos (MORAES, 2005), é seletivo em sua essência, não são todos os lugares escolhidos para sua instalação e concentração. ${ }^{121}$ Para Moraes (2005), a

\footnotetext{
${ }^{120}$ Essa análise foi discutida num debate, em aula proferida pelo Prof. Dr. Antônio Carlos Robert Moraes, aos alunos do Programa de Pós-Graduação em Geografia Humana, no Departamento de Geografia da USP, no dia 29 de outubro de 2007; disciplina: Formação Territorial e Teoria em Geografia Humana.

${ }^{121}$ A partir da leitura que Harvey (2005) faz de Marx, e da análise de Moraes (2005), fica claro que, no capitalismo, o crescimento econômico é um processo de contradições internas, que irrompe sob crises, de forma que um crescimento harmonioso ou equilibrado só pode ser acidental, devido à natureza caótica da produção de mercadorias sob o capitalismo competitivo; o normal é a ocorrência de tensões no processo de acumulação. A expansão da produção, sem levar em conta os limites do mercado, causa uma tensão no momento em que o capitalista expande o volume e o valor total das mercadorias para maximizar seu lucro, contudo, restringe o poder aquisitivo das massas, mantendo seus salários baixos (HARVEY, 2005). Nesse sentido, são simbólicas, no desenvolvimento do capitalismo, as grandes navegações. No século XVI, quando a Europa Ibérica alcança continentes “inexplorados”, tem-se início, gradativamente, um processo mais intenso de circulação e acumulação em nível mundial; plantas, minérios, pessoas, objetos e
} 
relação do capital com a superfície da Terra é oposta e combinada à do capitalismo, sendo marcada pela seletividade espacial, ou seja, pela seleção de áreas-eleitas de manifestação. "O capital está depositado em poucos lugares, enquanto a lógica capitalista impera nos diversos quadrantes do globo. Enfim, há lugares submetidos ao capitalismo com baixíssimo provimento de capital." (Moraes, 2005, p.140-150).

A lógica desse processo relacional entre a expansividade do capitalismo e a seletividade do capital força a criação de diferença entre os lugares, onde a combinação dessas diferenças aparece como alavanca da dinâmica do modo de produção capitalista, evidenciando nossa sociedade altamente diferenciada em termos políticos, econômicos e culturais, produzindo espacialidades ímpares, notórias e distintas, além de uma hierarquia dos lugares. Enquadramos Diamantina nesse contexto de expansão do capitalismo e seletividade do capital, ao se tornar uma referência de nível internacional para a atuação da "indústria cultural" por meio do turismo, lembrando que Diamantina é uma das oito cidades brasileiras inseridas na Lista do Patrimônio Mundial (que apresenta uma geografia desigual, como nos referimos no capítulo 2.2), uma das três de Minas Gerais ${ }^{122}$ e uma das 26 cidades escolhidas pelo Programa Monumenta.

Logo, consideramos o Programa Monumenta um paradigma no campo da política de patrimônio cultural fruto da operacionalização do capital sobre o território, tendo como principais agentes de produção do espaço: o Estado (esfera municipal, estadual e federal) conjuntamente aos agentes de mercado (cujo expoente é o Banco Interamericano de Desenvolvimento/BID, que financia o Programa). A partir dessa operacionalização, identificamos a fragmentação do espaço urbano ou o rebatimento do Programa sobre o

mercadorias diversas entram nesse "circuito mundo" que se desenvolve ainda mais com o passar dos séculos, segundo Santos (1999). De uma divergência concentradora passa-se a uma convergência dispersora, quer dizer, da busca de locais distantes para a acumulação e concentração, atinge-se a necessidade de uma nova dispersão para acumulação, fechando um ciclo infindável em nível mundial, tendendo à dita "homogeneização". Devemos considerar que em nenhum outro momento da história da humanidade, o modo de produção capitalista passou por tamanha difusão e generalização, mesmo que alguns pontos do globo não tenham sido selecionados para o intento da reprodução da maisvalia (Santos, 1999, p. 05, denomina esse processo de “modo de produção global”). É nesse sentido que talvez enveredemos em um equívoco de análise se considerarmos a globalização como um fenômeno atual. Harvey (2005) reconhece a questão da organização espacial, a questão da intensificação da atividade social, dos mercados e das pessoas, numa específica estrutura espacial, e a questão da expansão geográfica, como produtos necessários para o processo de acumulação. "Quanto mais difícil se torna a intensificação, mais importante é a expansão geográfica para sustentar a acumulação de capital.” (p.48). É nesse contexto que lançamos um olhar geográfico sobre a refuncionalização capitalística dos bens culturais do mundo.

${ }^{122}$ Lembremos as oito as cidades brasileiras inscritas, atualmente, na Lista do Patrimônio Mundial: Ouro Preto (MG), Olinda (PE), Salvador (BA), Congonhas (MG), Brasília (DF), São Luís (MA), Cidade de Goiás (GO) e, por fim, Diamantina (MG), inscritas na Lista com base em critérios específicos, deferidos pelo Comitê do Patrimônio Mundial, como já mencionamos. 
território, o que nos dá subsídios para a análise da dialética do uso e da troca, da "preservação" / "mercantilização" e da "construção destrutiva" que envolve os bens culturais do mundo, de forma particular em Diamantina. Passemos ao entendimento do Programa Monumenta, reconhecendo que o mesmo constitui-se em uma síntese da trajetória das fases de produção do patrimônio cultural no Brasil, apresentadas neste capítulo, da gênese colonial do patrimônio à sua cenarização progressiva contemporânea, fruto do avanço da globalização e da necessidade de reprodução do capital.

\section{Contexto histórico-econômico em que surge o Programa Monumenta}

A parceria público-privada foi a prática institucional do governo brasileiro na área cultural na década de 1990, representando o paradigma neoliberal como hegemonia da mentalidade política dos Estados Unidos no universo político do país. Há uma alteração do quadro de financiamento da cultura a partir da inserção da iniciativa privada como gestora dos recursos de fomento, o que demonstra uma transformação radical no papel do Estado na área cultural. Essa foi a fórmula adotada como paradigma de gestão pelo governo Fernando Henrique Cardoso (FHC), que tornou os processos de recuperação urbana associados ao universo de valorização da cultura como modelo principal, o que nos exige entender esse processo inserido no cenário da política globalizada, como aponta Tozi (2007).

Tozi (2007) afirma que o governo Fernando Henrique Cardoso (FHC) (19952002) foi o mais empenhado em estreitar as relações entre o Estado e a iniciativa privada, consolidando os preceitos de dissolução da estrutura tradicional do aparato estatal, característicos da proposta de gestão pública neoliberal. Esse modelo de gestão, voltado para a obtenção de "resultados", tem como premissa a eficiência administrativa, inspirada no universo empresarial, ou seja, o "sucesso" da gestão pública (enxugamento de gastos públicos sociais, privatização de empresas estatais para geração de divisas públicas, diminuição do controle do Estado sobre o mercado, e toda a verborragia neoliberal) fundese aos mecanismos do universo mercadológico.

Consideramos, nesse sentido, que o processo de reprodução do espaço, juntamente com a reprodução da sociedade, produz, no contexto neoliberalizante, novas contradições permeadas pela dialética do valor de uso e valor de troca, que envolve a 
cidade histórica ao ter revalorado seu patrimônio cultural no processo de mercantilização. Segundo Carlos (1999), as contradições são suscitadas pela extensão do capitalismo, aprofundando desigualdades e diferenciando apropriações - espaço público / espaço privado - espaço do consumo / consumo do espaço. Intensifica-se, assim, a busca de excepcionalidades espaciais, a construção de um "capital simbólico" (HARVEY, 2005) capaz de oferecer, por um lado, sustentabilidade econômica, por outro lado, favorece a mundialização dos lugares, seguida de sua fragmentação.

Esse processo mercadológico e de fragmentação casa com a proposta do governo de FHC, quando a cultura passa a ser o "produto" brasileiro exportado para o mercado internacional. Esse governo justificou suas ações no campo do patrimônio através da retórica de que a cultura brasileira atrairia divisas econômicas através do turismo, investimentos e empréstimos internacionais, assim como movimentaria a economia interna ao gerar novos postos de emprego. De acordo com Tozi (2007), a consolidação de um nicho de mercado cultural no governo FHC/Weffort (que foi o Ministro da Cultura durante a gestão) foi apoiada pela criação de um sistema financeiro da cultura calcado tanto no aprimoramento das leis de incentivo fiscal, como pelo apoio à difusão do marketing cultural entre as empresas, e pelo estabelecimento de acordos de empréstimos com o BID (Banco Interamericano de Desenvolvimento), cujos acordos tinham o objetivo de fortalecer a infra-estrutura turística, investindo na consolidação da importância do turismo cultural para a economia brasileira. Ou seja, temos, no fim do século $X X$, o coroamento da fusão entre a cultura e o mercado, onde a primeira é direcionada ou alcançada por agentes econômicos (às vezes associados ao poder público, como se dá com o Monumenta) que estabelecem estratégias de negócios que convergem a cultura tradicional à cultura do dinheiro e do poder, processo que Arantes (2005) denomina "culturalismo de mercado", a propósito do papel desempenhado pela cultura (imagem mercadoria) nas novas gestões urbanas.

Tozi (2007) considera que, assim como as metas do governo FHC, o governo Lula também teve na cultura o "produto" brasileiro por excelência de exportação, e o próprio ministro Gilberto Gil reforçou, por várias vezes, a importância da valorização econômica dos bens culturais brasileiros, assim como a profissionalização dos recursos humanos na área contribui para a construção de uma imagem positiva do país. O autor considera que a área de preservação do patrimônio, no Governo Lula, permaneceu como 
ponto estratégico, porém como principal elemento de sustentação da identidade nacional, a memória coletiva recebe uma nova abordagem para os investimentos e projetos do governo federal. Para o autor, a prioridade de preservação da cultura imaterial (valorização do saber popular) completou a noção de bem patrimonial que sustenta o discurso da identidade nacional brasileira. "Ou seja, por mais inserido no contexto de economias globalizadas que a gestão Lula esteja, seus esforços se concentram na valorização de uma identidade nacional (...) As identidades locais se constituem na base para a identidade nacional". No ponto de vista de Tozi, a diferença essencial no enfoque da gestão FHC para Lula, na área cultural, está em que o primeiro seguia à risca o modelo de retração das funções do Estado em detrimento da expansão do universo do mercado na esfera pública; o segundo, adota uma política de convivência da lógica mercadológica na esfera pública, porém, regulamentada pela intervenção estatal, que veste o papel de instituição política protetora dos interesses populares.

$\mathrm{Na}$ realidade, nossa análise in loco, em Diamantina, remete-nos ao continuísmo da prática mercadológica da "preservação" do patrimônio, o que já se inicia, em nosso entendimento, na fase que denominamos projeção inicial do patrimônio cultural, no Brasil, na década de 1970, quando o governo federal vê a necessidade da descentralização da responsabilidade preservacionista também entre estados e municípios. Assim, acreditamos que a partir do espaço urbano podemos decifrar o mundo contemporâneo e sua complexidade, pois é mediador e representante de uma "formação socioespacial" (SANTOS, 2004), de relações e práticas humanas que correspondem, hoje, à esfera da vida local dinamizadas pelos ditames do mundial, ou seja, o lugar aparece como fragmento do espaço, onde se pode apreender o mundo atual. Nos dizeres de Carlos (1993, p. 303), "o lugar se apresenta como ponto de articulação entre a mundialidade em constituição e o local enquanto especificidade concreta, enquanto momento. É no lugar que vão se manifestar desequilíbrios, as situações de conflito e as tendências da sociedade urbana".

Logo, no plano institucional, dentre as políticas oficiais de preservação de patrimônio cultural, no Brasil, celebra-se, em 1999, o maior acordo financeiro da história do país através de uma parceria entre a República Federativa (Ministério da Cultura) e o Banco Interamericano de Desenvolvimento (BID). Desse consórcio, assinado em Paris em março de 1999, que envolve também a participação de empresas nacionais, surge o 
Programa Monumenta/BID, cuja estratégia supera, obviamente, os aspectos arquitetônicos da preservação, conforme Leite (2004, p. 75), o que marca a produção do espaço em Diamantina e nas outras 25 cidades históricas brasileiras contempladas pelo Programa.

\section{Características do Programa Monumenta}

Neste item, apresentaremos as principais características do Programa, conforme as fontes do Ministério da Cultura (Regulamento Operativo), do Programa Monumenta/Diamantina (Carta Consulta para aprovação do Programa Monumenta em Diamantina; Parecer Técnico do IPHAN/Monumenta sobre a Carta Consulta; Perfil do Projeto de Diamantina), além de autores que realizaram uma análise sobre o Programa Monumenta (Tozi, 2007; Cifelli, 2005; Taddei Neto, 2003; Leite, 2004; Motta, 2000). As fontes documentais apresentam as características do Programa, logicamente, sem a devida apreciação crítica que alguns dos autores referenciados realizam e que pretendemos fazer.

Sobre a composição financeira do Programa, é constituída por recursos externos oriundos do empréstimo e por contrapartida, esta última proveniente de recursos da União, Municípios, Estados e da iniciativa privada. Os recursos do Projeto de cada cidade, especificamente, é constituído de 70\% de aporte federal, aí incluídos os valores referentes ao Contrato de Empréstimo junto ao BID, e 30\% de contrapartida municipal ou estadual (em Diamantina, a prefeitura entrou com os $30 \%$ dos recursos investidos em seu Projeto). ${ }^{123}$

O Programa Monumenta tem como objetivos de longo prazo, de acordo com o Regulamento Operativo (BRASIL, 2006, p. 10):

\footnotetext{
${ }^{123}$ O empréstimo do BID de US\$ 92 milhões, com taxa de 6,5\% ao ano, não é a ‘fundo perdido’ para a União (com prazo de pagamento para 20 anos). A outra parcela do montante que prevê a mobilização - somado o empréstimo atingirá aproximadamente US\$ 200 milhões, logo, parte do BID e parte do governo brasileiro (incluindo a participação dos estados e municípios). A participação dos municípios é condicionada à capacidade de fornecer a contrapartida de US\$ 20 milhões e de mobilização da iniciativa privada para sustentar a contrapartida que lhe confere o acordo (US\$ 12,5 milhões). Como crédito complementar, o Programa possui parceria com a Caixa Econômica Federal (para investimento em empreendimentos, aquisição de equipamentos e capital de giro para empresários das regiões selecionadas). A verba máxima destinada por Área de Projeto é de US\$ 8,5 milhões, na lógica de quem tem mais monumentos nacionais, tem mais verba e, portanto, mais impacto e visibilidade as intervenções propostas. A seleção da área de projeto e área de influência levou em consideração a lógica do "quanto maior a amplitude espacial da área a ser beneficiada, mais diluídos seriam os resultados de transformação urbana”, e por isso, optou-se por concentrar os bens, causando maior impacto na opinião pública. (TOZI, 2007).
} 
a) preservar áreas prioritárias do patrimônio histórico e artístico urbano sob proteção federal;

b) aumentar a conscientização da população brasileira acerca desse patrimônio; e

c) aperfeiçoar a gestão desse patrimônio e o estabelecimento de critérios para implementação de prioridades de conservação. O objetivo de curto prazo do Programa é aumentar a utilização econômica, cultural e social das Áreas de Projeto ${ }^{124}$.

O Programa alcançará seus fins quando as Áreas de Projeto mantiverem suas características restauradas sem necessidade de recursos federais adicionais para sua preservação; quando for observado um aumento no grau de conhecimento público e de atitude favorável em relação ao patrimônio cultural do país; ainda, terá alcançado seus objetivos quando a estratégia usada para desenvolver esse Programa for também usada para recuperar sítios nele não incluídos, independentemente da participação do BID no financiamento, de acordo com as fontes documentais analisadas.

A faceta mercadológica do Programa fica muito bem evidenciada nos documentos consultados. Enfatiza-se a necessidade de uma ação integrada em relação à preservação - diga-se de passagem que essa ação integrada refere-se mais à atuação de capitalistas e menos à integração popular efetiva. Essa ação integrada deve incluir, além dos investimentos em preservação e reabilitação de bens, os investimentos complementares para melhorar o seu entorno e assegurar seu uso "sustentável". "Os Projetos deverão incorporar a iniciativa privada desde a sua concepção, tanto na condição de potenciais operadores, como de parceiros em empreendimentos imobiliários e comerciais, com vistas ao esforço de revitalização das áreas de intervenção" (BRASIL, 2006, p. 36).

Logo, a Área de Projeto é o território no qual são aplicados os recursos do Programa, compreendendo imóveis públicos, $\operatorname{privados}^{125}$ e logradouros. No caso dos

\footnotetext{
${ }^{124}$ Por Área de Projeto entende-se parte ou o todo do Sítio Histórico Urbano Nacional (SHUN) ou de área que compreende Conjunto Urbano de Monumentos Nacionais, eleito pelo Programa como objeto de investimento. (BRASIL, 2006, p. 07)

${ }^{225}$ De acordo com o Monumenta (2006), os imóveis privados situados na Área de Projeto são financiáveis visando recuperar suas características históricas, artísticas e cênicas. Nesse componente, são beneficiários do Programa, pessoas físicas ou jurídicas proprietárias de imóveis situados na Área de Projeto, ou seus parceiros, formalmente constituídos, bem como promitentes compradores, inquilinos ou ainda aqueles que comprovem a utilização dos referidos imóveis para fins residenciais e/ou comerciais nos últimos cinco anos. Os proprietários, mediante edital público, são convidados a apresentar propostas que serão classificadas de acordo com: 1) proporção de contrapartida do proponente; 2) interesse do imóvel do ponto de vista histórico, artístico, cênico ou estratégico para os objetivos do Projeto (ou seja, refira-se a um potencial objeto para a atratividade, investimentos privados e acessibilidade); 3) estado de conservação do imóvel (que
} 
conjuntos tombados, o Monumenta (2006, p. 37) é categórico, o perímetro de intervenção deve possuir "o tamanho mínimo suficiente para assegurar a composição de um conjunto arquitetônico harmonioso e de um agregado sustentável de atividades econômicas".

Da análise estabelecida até o momento sobre o Monumenta, devemos considerar que a percepção humana e a sensibilidade do sujeito social não podem permanecer imunes às ações econômico-mercantís desestruturantes que nos cercam, à reprodução espacial acelerada e subvertida pelo capitalismo contemporâneo. Entendemos que são as ações humanas as responsáveis pelo processo desagregador vigente, importa-nos discutir a espécie de sociedade desejada e o tipo de espaço a ser produzido pela expansão do capitalismo e seletividade do capital - lógica que resulta no Monumenta e que rebate sobre o território. As problemáticas e contradições encontram-se no seio da sociedade, são produzidas por ela, para a partir daí transformar o espaço social. O espaço, o território ou mesmo a paisagem não são criados por si só (existem a partir da análise e da percepção humana), os homens os criam e transformam de acordo com a lógica de seu tempo, os estruturam conforme suas necessidades produtivas e reprodutivas. O espaço, por exemplo, é produzido na medida em que a sociedade vê a necessidade de auto-reprodução, dominando-o através dos objetos ${ }^{126}$ submetidos do uso à troca, como vem ocorrendo com a atuação do Monumenta, em nosso entendimento

O Monumenta (2006, p. 37) entende por "sustentabilidade" a geração permanente de receitas suficiente para garantir equilíbrio financeiro das atividades e manter conservados todos os imóveis da Área de Projeto, inclusive os bens cujas receitas sejam insuficientes para sua conservação. Tratando-se, via de regra, de áreas economicamente deprimidas, a "sustentabilidade" é tributária da intensificação do fluxo de freqüentadores e turistas à Área de Projeto, bem como da intensificação do uso de seus

também busca atender os princípios do Programa). O financiamento ao beneficiário é oneroso; seu retorno é, obrigatoriamente, depositado no Fundo Municipal de Preservação.

126 “A partir do reconhecimento dos objetos na paisagem, e no espaço, somos alertados para as relações que existem entre os lugares. Essas relações são respostas ao processo produtivo no sentido largo, incluindo desde a produção de mercadorias à produção simbólica (...) O enfoque geográfico supõe a existência dos objetos como sistemas e não apenas como coleções: sua utilidade atual, passada ou futura vem, exatamente, do seu uso combinado pelos grupos humanos que os criaram ou que os herdaram das gerações anteriores (...) Trata-se de reconhecer o valor social dos objetos, mediante um enfoque geográfico (...) As ações resultam de necessidades, naturais ou criadas. Essas necessidades: materiais, imateriais, econômicas, sociais, culturais, morais, afetivas, é que conduzem os homens a agir e levam a funções. Essas funções, de uma forma ou de outra, vão desembocar nos objetos (...) São as ações que , em última análise, definem os objetos, dando-lhes um sentido.” (SANTOS, 2002). 
imóveis. Para tanto, as intervenções devem enfocar a melhoria da acessibilidade e da atratividade da Área, segundo o próprio Programa.

Três são os conceitos básicos do Programa Monumenta e que mais nos chamaram a atenção para sua análise: participação privada, atratividade e acessibilidade. Conceitos que, na prática, favorecem a acumulação e a reprodução do capital (não fugindo de sua lógica contraditória) nas localidades selecionadas pelo Programa.

De acordo com o Ministério da Cultura (BRASIL, 2001), o Programa tem como um de seus princípios fundamentais a participação privada na recuperação de imóveis privados e públicos e no estímulo a ações de promoção de atividades econômicas, culturais e turísticas. A atratividade implica na seleção de ações que melhor contribuam para dinamizar os fluxos turísticos para a Área do Projeto. A acessibilidade refere-se a melhorias das condições de acesso à Área, incluindo sinalização, estacionamentos, operação do sistema viário, transporte coletivo, melhoria de calçadas e demais espaços para pedestres, a iluminação pública e segurança que produzam efeitos diretos sobre a Área de Projeto.

Os recursos gerados, direta ou indiretamente, pelo Projeto, conforme o Monumenta (2006), devem ser depositados em um fundo contábil criado pelo Município especialmente para esse fim; fundo que deve ser mantido pelo prazo mínimo de 20 anos. Os recursos depositados no Fundo de Preservação do município são oriundos de:

a) receitas diretas, que consistem em remunerações de capital, aluguéis, concessões de uso, bilheterias etc;

b) recursos de convênio;

c) contrapartidas;

d) receitas financeiras;

e) receitas de aluguel e arrendamento;

f) produto de alienação de imóveis; e

g) doações;

Pelo exposto, fica-nos claro que o Programa Monumenta tem, na sua origem, o objetivo de estabelecer uma recuperação "sustentável" do patrimônio urbano brasileiro sob tutela federal, resultante do contrato de empréstimo entre o BID e a República Federativa do Brasil. Objetiva, no plano teórico, a execução de obras de conservação e restauro e de medidas econômicas, institucionais e educativas para ampliar o retorno 
financeiro dos investimentos do Programa, aplicando-os permanentemente em sua conservação. Quase não são identificadas referências, nos documentos, sobre a importância da opinião das comunidades locais sobre esse processo mercantil ou sobre as ações voltadas para as mesmas ${ }^{127}$; colocam-se à "venda" bens coletivos e inalienáveis, os bens culturais do mundo, à revelia do sentido da história, da memória e da cultura.

Nessa perspectiva, devemos considerar que as pessoas recebem, de forma distinta, mensagens dos espaços construídos, ou seja, do tempo cristalizado, das formas corporificadas nos lugares, representantes das sociedades pretéritas, como é o caso do patrimônio cultural urbano, remanescente de outros períodos da história brasileira. Esse patrimônio "emite" informações que são apreendidas e reproduzidas por cada indivíduo de acordo com sua "visão social do mundo"; é nesse sentido que a análise de Harvey (1980) nos é favorável, por considerarmos, nessa pesquisa, o espaço enquanto uma produção histórico-social representante de relações e práticas sociais de época e contemporâneas (as quatro fases que apresentamos retrata a ampliação da noção de patrimônio e a transformação dos sentidos dos seus lugares ao longo da história), que assumem nova lógica, onde a valorização do espaço através do trabalho humano acarretou e acarreta na produção de territórios heterogêneos e fragmentados pelas novas ações estabelecidas no meio urbano. Entendemos que o Monumenta simboliza as ações hegemônicas globais que rebatem diretamente sobre o território urbano enquanto um espaço complexo de cidadania, neste momento de vertiginosa expansão do capitalismo mundial, dadas as distintas concepções dos agentes envolvidos em sua implementação.

(...) o capitalismo se esforça para criar uma paisagem social e física da sua própria imagem, e requisito para suas próprias necessidades em um instante específico do tempo, apenas para solapar, despedaçar e inclusive destruir essa paisagem num instante posterior do tempo. As contradições internas do capitalismo se expressam mediante a formação e a reformação (sic) incessantes das paisagens geográficas. Essa é a música pela qual a geografia histórica do capitalismo deve dançar sem cessar. (HARVEY, 2005, p.150)

\footnotetext{
${ }^{127}$ O Regulamento Operativo (BRASIL, 2006, p. 14) faz referência à importância da capacitação de artífices e de agentes locais de cultura e turismo, além de programas educativos sobre o patrimônio histórico, de forma objetiva. Veremos, no capítulo seguinte, que, em Diamantina, pouco se tem trabalhado nesse sentido, de acordo com a fala da população local.
} 
O Programa Monumenta foi implementado nas seguintes cidades: Alcântara (MA), Belém (PA), Cachoeira, Lençóis e Salvador (BA), Congonhas, Diamantina, Ouro Preto, Serro e Mariana (MG), Corumbá (MS), Goiás (GO), Icó (CE), São Cristóvão e Laranjeiras (SE), Manaus (AM), Natividade (TO), Oieiras (PI), Olinda e Recife (PE), Rio de Janeiro (RJ), Pelotas e Porto Alegre (RS), Penedo (AL), São Francisco do Sul (SC) e São Paulo (SP). Observemos que os estados da Bahia e de Minas Gerais foram contemplados, respectivamente, com três e cinco cidades; dois dos estados de maior fluxo oriundo do chamado turismo cultural do país.

Tozi (2007) diz que o Monumenta contemplou todos os sítios urbanos brasileiros inscritos na Lista do Patrimônio Mundial e que, de acordo com seus defensores, surgiu com a preocupação de promover a conscientização da importância do patrimônio cultural, não somente como símbolo de identidade da nação, mas como elemento de sustentabilidade econômica, inserido na dinâmica da vida cultural, social e econômica da população, promovendo, assim, o desenvolvimento social da comunidade, pois a "eficácia do Monumenta reside na demonstração de que uma política pública bem coordenada de recuperação do patrimônio associada à revitalização econômica e social dos espaços restaurados pode provocar mudanças de atitude na população, com efeito direto nos residentes do local recuperado".

Em primeiro lugar, o Monumenta não contemplou todas as cidades brasileiras inscritas na Lista do Patrimônio Mundial, como afirma Tozi, ficaram de fora: Brasília (DF) e São Luis (MA). Em segundo lugar, veremos que o Monumenta, especificamente em Diamantina, não buscou, efetivamente, preparar a população para a implantação do Projeto (o que demonstra a tendência da pouca participação e conhecimento das populações locais das políticas de patrimônio implantadas e do rumo que vêm tomando suas cidades históricas), o que se reflete no pouco conhecimento que a mesma tem do Programa, como atestamos em nossas atividades de campo e apresentaremos os dados no capítulo seguinte (a população é alienada sobre o sistema de ações estabelecido pela nova governança urbana em seu território).

Para Taddei Neto (2003, p. 106), diferentemente de outros bens culturais, o patrimônio edificado agrega a seu valor simbólico, inerente a todos os bens culturais, valor imobiliário, isto é, seu valor de mercado, que é eminentemente econômico (já afirmamos 
anteriormente que os agentes de mercado jogam com a valorização simbólica dos bens culturais com o objetivo de se agregar valor econômico aos mesmos). De acordo com Taddei, isso, somado a outros atributos dos bens imóveis, tais como a infungibilidade ${ }^{128} \mathrm{e}$ a durabilidade, torna esse patrimônio "bastante diferenciado no mercado". A posição de Taddei Neto é claramente favorável à mercantilização dos bens culturais coletivos. Segundo ele, "para conservar e perenizar nossas edificações históricas, dependemos de sua boa utilização social e, em contrapartida, da sua boa utilização econômica. Entretanto, esse patrimônio constitui-se de bens imóveis que podem a qualquer momento ser retirados do mercado, fechados, trancados, à espera de exploração econômica mais rentável".

Segundo Taddei Netto (2003, p. 109), forma-se um círculo vicioso, um problema crônico. Dispomos de um orçamento para a área da preservação de patrimônio incompatível com a dimensão de nosso acervo. O autor tem certeza, ainda, de que nenhum orçamento daria conta da manutenção permanente dos sítios já tombados e ainda da recuperação daqueles que passassem, ao longo do tempo, a integrar o patrimônio edificado. Nesse contexto, ele destaca como um aspecto relevante da política de cultura do governo Fernando Henrique Cardoso (FHC) a "valorização dos bens culturais representativos de todas as etnias, de todas as épocas e ciclos econômicos brasileiros, nas diferentes regiões do país", bem como a recorrência ao compartilhamento entre as várias esferas de governo e o setor privado na gestão das ações voltadas para a cultura, como forma de enfrentar o problema crônico da falta de verbas (esclarecemos que Taddei Neto é um arquiteto que esteve diretamente ligado à implantação do Monumenta, no governo FHC, como coordenador nacional do Programa).

Não acreditamos que a seleção das cidades para implantação do Monumenta tenha valorizado os bens representativos de "todas as etnias, de todas as épocas e ciclos econômicos das diferentes regiões do país". A relação das cidades escolhidas pelo Programa mostra que se constituem mais nos principais destinos do turismo cultural brasileiro do que na diversidade ora afirmada. Se a seleção dos bens culturais a representarem a formação de um novo "Estado-nação", no início do século XX, esteve

\footnotetext{
${ }^{128}$ São bens infungíveis aqueles que não são substituíveis por outros da mesma espécie, qualidade ou quantidade, ou seja, está ligada à irreplicabilidade, autenticidade e excepcionalidade das quais já fizemos referência. Os bens imóveis por exemplo, são legalmente considerados infungíveis, uma vez que possuem elementos diferenciais, de acordo com Taddei Neto (2003).
} 
ligada à preservação da cultura consagrada "branca, portuguesa e católica", onde as referidas cidades foram escolhidas, suas escolhas atuais pelo Programa reproduzem, novamente, essa seleção elitista, tendo Minas Gerais e Bahia como referenciais do Monumenta, como o foi com o barroco para o Estado, na década de 1930. Sendo 26 cidades as selecionadas pelo Monumenta, por que termos cinco em Minas, três na Bahia, duas em Sergipe, duas em Pernambuco, duas no Rio Grande do Sul e não uma cidade selecionada pelo Programa em cada estado da Federação? Se considerarmos, conforme propõe Taddei Neto, que a implementação do Monumenta constituiu um desafio graças ao "ineditismo de seus objetivos" - sustentabilidade, replicação ou reprodução dos projetos e diversificação do patrimônio protegido - vemos aí uma grande contradição que não responde a nossa questão.

\begin{abstract}
E, finalmente, atendendo a um dos princípios básicos da política cultural do governo, a priorização em proteger bens representativos de etnias, regiões e épocas da história pouco valorizadas foi incorporada como um dos objetivos do Monumenta (...) O Programa reúne (...) 26 cidades, em dezoito estados da Federação ${ }^{129}$ (...) Teve-se o cuidado de não restringir os projetos a cidades históricas que já são ícones, como Olinda, Ouro Preto ou Salvador. Cidades como Icó, no interior do Ceará, ou Oeiras, antiga capital do Piauí, representativas do Ciclo do Couro, ou ainda São Francisco do Sul, em Santa Catarina, também foram alcançadas, justamente para preencher as lacunas existentes em nosso patrimônio histórico protegido, atribuindo-lhe maior representatividade. (TADDEI NETTO, 2003, p. 112)
\end{abstract}

Fazendo uma análise do Programa Monumenta em Ouro Preto, Cifelli (2005), afirma que a grande maioria dos bens escolhidos concentra-se em locais de grandes fluxos de turistas - diga-se de passagem, como várias outras cidades contempladas pelo Programa, Ouro Preto não é uma cidade pouco valorizada na história do patrimônio no país, o que mostra a incoerência da tal diversidade contemplada pelo Programa. A autora observa também que a maioria dos tipos de intervenções que vem sendo efetuadas possui um caráter estético-paisagístico, envolvendo, edifícios, pontes e certas áreas do núcleo tombado de grande potencial turístico por sua imponência, beleza e pela relevância histórica que possuem. Nesse sentido, Cifelli considera que o conjunto de ações efetuadas pelo Programa demonstra a ênfase do poder público e das instâncias de preservação em

\footnotetext{
${ }^{129}$ Mereceria um estudo crítico e aprofundado sobre os motivos e justificativas que dariam respaldo ao Governo Federal por não contemplar com o Monumenta todos estados brasileiros, ao invés dos dezoito.
} 
consonância com a iniciativa privada de investir no potencial econômico do patrimônio cultural de Ouro Preto como forma de garantir sua preservação auto-sustentável.

$\mathrm{Na}$ realidade, precisamos ter claro que a efetivação de uma proposta "autosustentável" depende sim da parceria entre o poder público, incluindo a administração municipal e os órgãos de preservação, a iniciativa privada e, sobretudo e principalmente, a sociedade civil consciente do valor histórico e cultural de seu patrimônio tombado e dos seus deveres para com a preservação dessa materialidade pretérita. O que indica a relevância de uma educação patrimonial cuja função primeira seja de esclarecimento e ligada ao resgate do valor cognitivo e afetivo dos bens culturais, no âmbito do local e não a sua transformação em grande fetiche, em que o patrimônio passa a ser "incorporado ao mundo do consumo tornando-se peça central da máquina reprodutiva do capitalismo" (NIGRO, 2001, p. 37).

Leite (2004, p. 76) é taxativo e diz que a prioridade do Monumenta não é, portanto, a simples recuperação do patrimônio de valor histórico para determinados setores da população, mas prioritariamente a "revitalização" de áreas urbanas rentáveis, que possam fomentar a reaplicação econômica dos recursos envolvidos. Dessa maneira, nesse novo modelo de "gerenciamento" que rebate sobre o território das cidades históricas, Leite deixa duas questões: como assegurar recursos mínimos para a recuperação de monumentos que não tenham viabilidade econômica para o devido retorno dos investimentos? Que fundo rotativo se interessaria por uma área pouco atrativa para a necessária visibilidade do turismo cultural, mas de grande significação para a população local e para os usuários em geral? Por isso, a seleção das cidades já ícones, contrariando a afirmação de Taddei Neto, justifica-se; ou seja, as cidades selecionadas respondem ao investimento feito pela ação coordenada Estado / agentes de mercado; o que derruba a retórica apologética de agentes públicos e privados que tentam mascarar o caráter estético, fetichista, elitista e restritivo do Programa, em detrimento à diversidade cultural e aos interesses e necessidades dos habitantes locais.

Num primeiro instante, o princípio econômico do Monumenta sugere um retrocesso, para um país que tem uma política institucional de patrimônio que apenas há pouco tempo começou a reconhecer bens culturais relativos às minorias étnicas e religiosas. Para essas minorias, parece uma triste sina sair do "patronato do Estado para o mecenato do mercado": o primeiro, deixou-as à margem das políticas de patrimônio, 
porque se voltou para edificações simbólicas oficiais de uma idéia de nação branca e católica (através do barroco mineiro); o segundo, ávido pelo retorno de cada dólar investido, não se interessa nem mesmo por esses símbolos dominantes, caso não apresentem possibilidades imediatas de retorno de investimentos (LEITE, 2004, p. 77).

Consideramos que o Monumenta é representante, na verdade, das novas intervenções que tem como resultado a apropriação cenográfica do centro histórico sem a preocupação de considerar a cidade histórica como objeto socialmente construído e seu patrimônio como fonte de conhecimento coletivo. O que criticamos é a intervenção associada do poder público e dos agentes de mercado em sua dinâmica, pelo oferecimento do patrimônio cultural como mercadoria, igualando o bem coletivo aos produtos de consumo gerais; de forma excludente em relação à comunidade local.

É bom deixar claro que nosso objetivo não é apontar o mercado como um mal em si, uma vez que também é uma prática histórica e matriz geradora do processo cultural, como aponta Motta (2000, p. 258). Nossa crítica é dirigida ao papel que o Estado vem assumindo na seara da "preservação" do patrimônio cultural no Brasil, uma vez que deveria assumir responsabilidades - junto a uma sociedade consciente de seu papel na preservação de seus bens patrimoniais coletivos - evitando soluções simplificadoras ${ }^{130}$ de preservação das cidades históricas, equivocadas quanto a sustentabilidade dos núcleos tombados. Para Motta (2000, p. 260), o panorama das novas intervenções no patrimônio pode ser denominado como um modelo globalizado. "No modelo globalizado, o poder público situa-se como produtor de um valor que tira partido das transformações que vêm ocorrendo em virtude da globalização da economia e da cultural (...) No modelo globalizado, a opção do poder público é pelo consumo, pelo marketing cultural".

Esse novo modelo de intervenção nos núcleos urbanos tombados - de interesse do mercado internacionalizado - assumido pelo poder público em parceria com a iniciativa privada, investe pesadamente na mercantilização cultural. A implantação do Monumenta obedece ao capital privado e aos "tempos" estipulados pelo lucro. São desconsiderados ou negados os prazos necessários para o desenvolvimento de estudos adequados à complexidade dos sítios como fontes de conhecimento, de memória e de

\footnotetext{
${ }^{130}$ São escolhidos territórios, lugares e bens específicos para a preservação, de acordo com sua capacidade de oferecer um significativo retorno financeiro. Também representa solução simplificadora de preservação a falta de preocupação com a desalienação da população em relação às novas estratégias voltadas para o centro histórico e a ausência de uma política de educação patrimonial que atinja toda a cidade.
} 
identidades. "Ao invés do poder público cumprir seu dever de garantir ao cidadão o acesso à cultura, investindo no patrimônio como fonte de conhecimento, ele colabora para a construção de valores que interessam ao capital especulativo" (MOTTA, 2000, p. 263).

O público-alvo não é aquele que tem o patrimônio como fonte de identidade e história. O objetivo do novo modelo de intervenção (o Monumenta como típico exemplo) é atingir o consumidor que deve usar o bem cultural como mercadoria ou como um suporte para o consumo de outras mercadorias. Isso faz com que o cidadão não seja capaz de conhecer e de se reconhecer em sua própria história, especialmente como o mais importante agente de preservação (quem cuida melhor de um bem do que o próprio dono?); há a supressão e deslocamento de funções e relações históricas sempre que necessário o avultamento da lucratividade, em nome de um consumo certo.

Logo, o Programa Monumenta e as ações dirigidas à "preservação" de patrimônio com o fim de sua mercantilização não têm respeitado indicações, normas e diretrizes dos órgãos de preservação e organismos como a UNESCO. O Memorando de Viena (UNESCO, 2005, p. 3), resultado de uma conferência internacional que teve como tema O Patrimônio Mundial e a Arquitetura Contemporânea, tratando da paisagem urbana histórica, o qual tratamos na primeira parte da pesquisa, considera que as cidades históricas vivas, notadamente as cidades do patrimônio mundial, exigem uma política urbana de gestão que tenha na proteção o ponto chave da conservação do patrimônio cultural, de forma a não comprometer a autenticidade e a integridade das cidades históricas.

De acordo com o Memorando (UNESCO, 2005, p. 4), as intervenções materiais e funcionais nos núcleos tombados devem buscar a melhora da qualidade de vida e a eficiência dos investimentos em benefício do residente; melhorando as condições de vida, de trabalho, de lazer e adaptando os usos dos bens sem comprometer os valores existentes que decorrem da característica e do valor das formas no tecido urbano histórico.

Esse documento é uma expressão significativa de valorização da paisagem urbana histórica no quadro do que Motta (2000) denomina modelo globalizado de intervenção em áreas tombadas. Elementarmente, o planejamento urbano que envolve o patrimônio - que deveria fazer frente às ações contemporâneas extremas de mercantilização da paisagem urbana histórica - deve evitar todas as formas de concepção 
"pseudo-histórica" de valorização do lugar, na medida onde elas constituem a negação dos mesmos aspectos históricos. A visão histórica e identitária não devem ser suplantadas por outras, pois devem continuar legíveis, evitando-se a utilização da cultura nas intervenções que, descabidamente, têm em sua mercantilização o objetivo supremo. O Memorando finaliza dizendo que a arquitetura histórica constitui um atributo para as comunidades locais, que o patrimônio deve servir a objetivos educativos, recreativos e também turísticos, de forma a garantir todos os valores dos bens, inclusive sobre o mercado (UNESCO, 2005, p.4). Fica claro, no documento, a defesa da intervenção na paisagem urbana histórica respeitando os interesses e as opiniões dos habitantes locais, de forma que os bens culturais são considerados atributos das comunidades locais, servindo-lhes de fonte de educação, recreação e renda, de forma ampla.

Contudo, há a preocupação com as ameaças identificadas, internacionalmente, sobre o impacto que a mercantilização do patrimônio representa na fragmentação do espaço urbano, segundo o próprio Memorando de Viena que vê "Transformações socioeconômicas e crescimento que não respeitam a autenticidade e a integridade das cidades históricas, nem a paisagem urbana histórica e sua configuração"131.

Essa é a lógica do Programa Monumenta que rebate sobre o território urbano, que propicia a "valorização" dos bens culturais e desvaloriza o importante papel que poderia assumir a população local de forma integrada, no processo de "valorização", quer seja simbólica, quer seja econômica, pois representa peça fundamental no tocante à preservação. Carlos (2006) considera que a passagem da cidade produzida enquanto lugar da vida, para a cidade reproduzida sob os objetivos da realização do processo de valorização - momento em que o uso vira troca -, revela-nos o momento da produção de segregação. "Cria-se" uma cidade que passa a ter acessos extremamente desiguais, onde o habitante do lugar passa a viver precariamente. Para a autora, é o valor de troca como valorização do capital que torna o espaço produtivo em detrimento dos espaços improdutivos, que são aqueles do uso como condição de vida. ${ }^{132}$

\footnotetext{
131 “Reformes sócio-économiques et croissance qui ne respecteraient pas l'authenticité et l’intégrité des villes historiques ni leur paysage urbain hérité et as configuration.” (UNESCO, 2007c, p. 4)

${ }^{132}$ Nesse contexto, entendemos que para um proprietário uma mercadoria não tem nenhum valor de uso direto; o tem para outros, torna-se meio de troca para seu dono. O dinheiro entra nesse processo de troca convertendo o produto do trabalho (o objeto) em mercadoria. Esse é o contexto da lógica contemporânea que envolve o patrimônio cultural, pois a apropriação estratégica de um núcleo urbano, transformando-o em mercadoria, faz com que o espaço que agrega essas
} 
Isso representa a valorização do espaço ligada aos interesses do capital, de forma a tornar o homem estranho ao seu lugar, ao seu trabalho, à sua terra transformada em mercadoria. De acordo com Santos (2004a), vemos uma generalizada estandardização do espaço. Criam-se novos produtos a partir de objetos que são utilizados da melhor forma pelos atores hegemônicos, respondendo a necessidades do mercado, caso de Diamantina com sua elevação a Patrimônio Mundial e implantação do Programa Monumenta; "A arquitetura adaptou-se ao novo mundo dos negócios, à concentração e à estandardização na indústria da construção, à rigidez dos novos materiais e das novas máquinas" (SANTOS, 2004a, p.35).

Nesse sentido, entendemos que, no capitalismo, o valor contido na transformação da natureza e nas construções vai aparecer como valor agregado ao solo, que segundo Moraes (1993), aparece no seu uso produtivo ou na sua característica de valor de troca, o que nos obriga a analisar Diamantina na esfera da circulação do capital.

Por fim, não almejamos o entendimento de qualquer espaço urbano enquanto singularidade, mas sim de um espaço urbano que apresenta as especificidades das novas relações impostas pela valorização capitalística que o fragmenta. Integrando essa dinâmica e marcada por profundas contradições socioespaciais (intensa valorização do núcleo tombado em contraposição às problemáticas apresentadas pela periferia), Diamantina tem em seu centro histórico um "produto" que favorece a transformação do conjunto urbano e da cultura em novos gêneros de mercadorias; valorização que dá um novo rumo para a cidade. É sobre essas contradições socioespaciais - resultantes da dialética da construção destrutiva que enreda os bens culturais do mundo - que nos ateremos a partir de agora.

\footnotetext{
“rugosidades” (SANTOS, 2002) seja apropriado, sobretudo, por quem detém os meios de troca, ou seja, grande parte da população local não integra o processo, prevalecendo a vitória da troca sobre modos operantes de uso.
} 


\subsubsection{O Programa Monumenta em Diamantina e a "valorização do espaço"}

Para compreender, através de uma análise crítica, como o par dialético "preservação" / "mercantilização" (re)produz o espaço urbano em tela e como transforma a realidade e o imaginário do residente (nosso objetivo de pesquisa), além da análise que apresentamos até o momento - com enfoque histórico e dialético -, julgamos necessário reconhecer, por um lado, as atuais ações de organização e valorização do espaço, através de observação in loco e da fala dos principais agentes públicos da cidade, e por outro lado, identificar, junto à população de bairros da periferia, a realidade socioespacial vivida pelo diamantinense, através da aplicação de questionário com uma amostragem de cento e quarenta pessoas, com abordagem a homens e mulheres acima de dezoito anos, exclusivamente residentes nos quatro bairros entrevistados.

Não nos abstemos de entrevistar apenas os residentes do Centro Histórico (território inscrito na Lista do Patrimônio Mundial e de ação do Programa Monumenta), julgamos pertinente ouvir moradores de outros três bairros da cidade, pois nossa análise não se atém à produção socioespacial do núcleo tombado, mas buscamos identificar as conseqüências da mercantilização desse espaço central, que rebate na produção socioespacial da cidade como um todo, no nosso entender. Dessa maneira, as cento e quarenta pessoas abordadas dividem-se entre residentes do Centro Histórico, do Rio Grande, do Palha e Bela Vista, os três últimos, bairros periféricos dos mais carentes de Diamantina, com evidentes problemáticas socioespaciais.

Neste tópico, nos ateremos ao processo de "valorização do espaço" no centro histórico de Diamantina (contemplado pela Lista do Patrimônio Mundial e pelo Programa Monumenta) para, no capítulo que se segue, identificarmos como essa "valorização" do espaço central da cidade contribui para a transformação do território urbano de forma mais ampla.

De acordo com nosso aporte teórico-metodológico, consideramos a produção do espaço como um processo que resulta do trabalho humano, que é um ato de incorporação e criação de valor, de acordo com Moraes (2000), ao considerar que a formulação categorial mais precisa para expressá-lo, na Geografia, deva ser a da "valorização do espaço", enquanto um processo contínuo fruto do próprio trabalho. 
Já afirmamos também que tratamos de um espaço do homem, de um espaço social, que segundo Santos (2004a), deve ser considerado como um conjunto de relações sociais realizadas através de formas que se apresentam como testemunho de uma história escrita por processos do passado e do presente, ou seja, o espaço é considerado aqui como um conjunto de formas que representam relações sociais do passado e atuais, e por uma estrutura constituída de relações sociais que estão acontecendo "diante de nossos olhos" e que se manifestam por processos e funções. "O espaço é, então, um verdadeiro campo de forças cuja aceleração é desigual" (SANTOS, 2004, p.153). A partir dessa teoria, lançamos um olhar crítico sobre a transformação da realidade socioespacial de Diamantina, na contemporaneidade, pois entendemos que interpretar a transformação dos valores e a organização de um espaço dotado de objetos remanescentes de outros períodos históricos, exige-nos remontarmos ao início do processo de produção desse patrimônio (análise realizada ao longo do capítulo 3), que enquanto formas, assumiram distintas funções dentro de estruturas de épocas variadas, sendo refuncionalizados e reestruturados na contemporaneidade, para atenderem às necessidades de um turismo global.

Podemos afirmar que há uma valorização concentradora de objetos e ações em determinados pontos do território, processo que Moraes e Costa (1996) denominam "processo de concentração territorial do capital", que se dá em Diamantina inserida numa totalidade $^{133}$ e enquanto totalidade ${ }^{134}$. Áreas são geradas para representar a aglutinação de objetos do capital, que correspondem às necessidades de replicação e expansão do mesmo, ou seja, concentram-se indústrias, populações e transportes, criam-se singularidades, excepcionalidades, "autenticidades" etc., em locais rigorosamente selecionados pelos estrategistas do mercado. Na geopolítica do capitalismo, verifica-se

\footnotetext{
${ }^{133}$ Inserida numa totalidade, a cidade é escolhida para inclusão na Lista do Patrimônio Mundial, o que vem a favorecer, hoje, uma "concentração territorial do capital” quando passa a integrar o circuito internacional do turismo, dada sua reprodução midiática enquanto Patrimônio Cultural da Humanidade.

${ }^{134}$ Considerando a cidade em sua totalidade, não apenas seu centro histórico, identificamos ações público-privadas marcadamente concentradoras do capital, sobretudo a partir de sua consagração como Patrimônio Mundial e da implantação do Programa Monumenta; o problema da fragmentação urbana só é identificado quando da visão total da cidade e não focada em relação ao seu centro histórico, como se a cidade pudesse ser considerada exclusivamente por este. Acreditamos que a análise de uma cidade histórica que não leve em consideração a produção do espaço fora de seu núcleo tombado pode não dar conta do entendimento das novas dinâmicas propiciadas pelas "rugosidades” presentes no próprio centro, que favorecem novos fluxos capazes de transformar a realidade e o imaginário da população residente, não apenas no centro histórico; uma análise focada e compartimentada pode não dar conta da realidade multidimensional e em movimento da formação de novas espacialidades acarretadas pelas novas estratégias do planejamento urbano, no âmbito da Geografia.
} 
uma expansão que conquista e produz novos espaços, vai de encontro a ações humanas mediadas por interesses grupais e classistas, que produzem o "valor do espaço"135 que é transferido no processo de trabalho para o "produto através das características próprias de cada lugar" (MORAES e COSTA, 1996, p.122), formando centralidades "ultravaloradas", como o faz o Programa Monumenta.

Sendo os conceitos básicos do Monumenta a atratividade, a acessibilidade e a participação privada nas ações que envolvem a intervenção nas cidades históricas, não seria diferente em Diamantina. Na busca de se constituir um atrativo, selecionaram-se ações que melhor contribuiriam para esse fim, de forma a aumentar a eficiência da aplicação dos recursos do Programa na cidade (BRASIL, 2002, p. 4).

Nesse sentido, elegeu-se a Área de Projeto apoiada em trechos que abrangessem como foco principal (coincidentemente, estes são os bens culturais de maior valor simbólico de Diamantina, tombados no conjunto e isoladamente):

1) Igreja da Ordem Terceira de São Francisco de Assis;

2) Museu do Diamante;

3) Mercado Velho;

4) Igreja de Nossa Senhora do Carmo;

5) Igreja de Nosso Senhor do Bonfim dos Militares;

6) Igreja da Irmandade de Nossa Senhora do Rosário;

7) Capela Imperial de Nossa Senhora do Amparo;

Nessa Área de Projeto, elegeram-se, em 2002, como investimentos integrados: a revitalização do conjunto paisagístico da Praça Juscelino Kubitschek; a restauração arquitetônica e revitalização do Mercado Velho; a revitalização paisagística da Praça Barão de Guaicuí; a revitalização dos conjuntos paisagísticos das Praças D. Joaquim e Monsenhor Neves; revitalização do conjunto urbano constituído pela rua da Quitanda (palco de acontecimento das Vesperatas), e pelos becos do Alecrim, do Mota, da Tecla e da Pena; revitalização do conjunto edificado do Museu do Diamante e a Casa do Intendente com respectivo conjunto paisagístico.

Dessa maneira, o mapa a seguir espacializa as ações do Monumenta em Diamantina Hoje, decorridos sete anos da proposta inicial do Programa, onde os bens

135 O processo de valorização do espaço ocasiona uma heterogeneidade na produção e apropriação dos lugares, onde singularidades são estabelecidas através do trabalho humano; valores distintos são atribuídos a estruturas socioespaciais distintas. 
culturais, enquanto formas pretéritas simbólicas de um longo processo de valorização do espaço e formação do território, são "capturados" por uma nova estratégia urbana que visa, incondicionalmente, o desenvolvimento de um turismo capaz de gerar lucros e rendas. $^{136}$

O mapa traz a delimitação da Área de Projeto, feita em 2001, que por sua vez está inserida na delimitação da área de tombamento do IPHAN, elaborada na década de 1930, e na área delimitada para a inclusão do sítio na Lista do Patrimônio Mundial, realizada em 1999, o que mostra a busca de uma singularidade (capaz de agregar valor de troca ao espaço urbano) calcada em uma universalidade e excepcionalidade apontadas pelos órgãos de conservação e preservação (que deveriam cumprir, primordialmente, o papel de enaltecer o valor cognitivo e afetivo dos bens para a comunidade local) simultaneidade do novo jogo entre a economia e a cultura, entre o uso e a troca, da "construção destrutiva". O mapa traz, ainda, os imóveis privados beneficiados pelo Programa, bem como os bens tombados contemplados para investimento integrado. Vê-se que a intervenção atual difere da proposta inicial.

A tabela 02, abaixo, fornece-nos subsídios quantitativos para uma análise da dimensão socioespacial (qualitativa) e da intervenção que se processa através do Monumenta, no centro histórico de Diamantina. Verificamos, na tabela, que o Programa pretendia, em 2002, atuar em 110 imóveis dos 406 existentes na Área de Projeto, o que equivaleria a $27 \%$ do conjunto, o que não se processou na realidade, conforme podemos observar no mapa.

\footnotetext{
${ }^{136}$ Devemos lembrar que o fenômeno contemporâneo do turismo é contraditório, pois produz lugares ao mesmo tempo em que contribui para o seu consumo. Contudo, conforme Luchiari (1998) e Becker (1996), o turismo não pode ser tomado apenas do ponto de vista negativo, como um desestruturador de formas e funções sociais antigas, que destrói o velho e o substitui pelo novo. Para Becker (1996), o turismo pode se apresentar como um meio de desregulação socioespacial, na falta de um organizador do setor. Posicionamo-nos com a proposição das autoras, que consideram o turismo bem planejado um instrumento criador de um potencial de desenvolvimento, gerador de empregos diretos e indiretos, de circulação de dinheiro, mercadorias e pessoas, mas que em contrapartida, na falta de um adequado planejamento espacial, propicia impactos perversos ao meio ambiente, ao espaço urbano e mesmo diretamente ao meio social, nos quais se instala.
} 

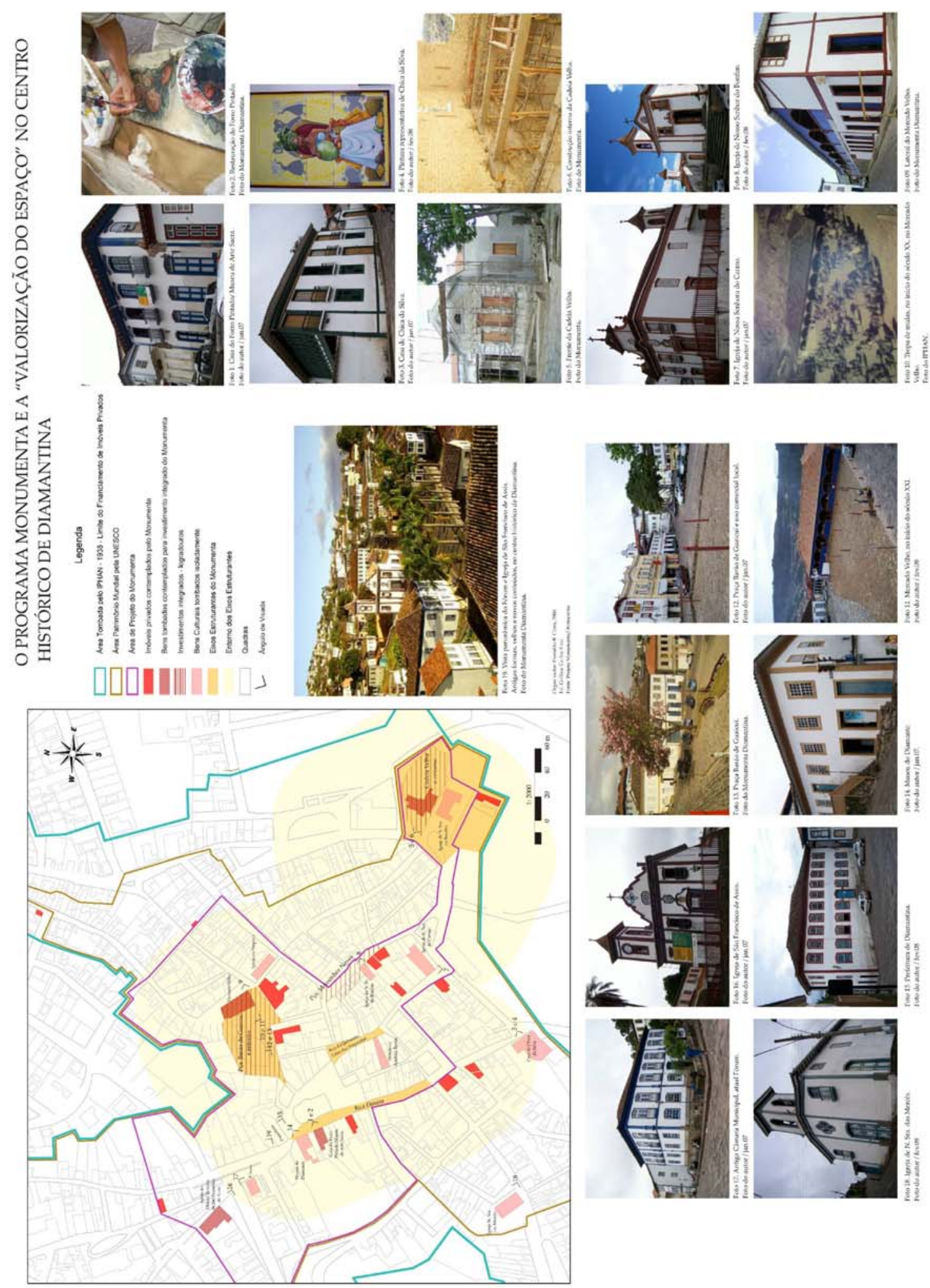


\begin{tabular}{|c|c|}
\hline USO DO IMÓVEL & NÚMERO DE CASOS \\
\hline \multicolumn{2}{|c|}{ TOTAL DE IMÓVEIS NA ÁREA DE PROJETO } \\
\hline Comercial + Serviços & 241 \\
\hline Residencial & 91 \\
\hline Misto & 71 \\
\hline Institucional & 2 \\
\hline Total & 406 \\
\hline USO DO IMÓVEL & NÚMERO DE CASOS \\
\hline \multicolumn{2}{|c|}{ INTERVENÇÃO DO MONUMENTA } \\
\hline Comercial + Serviços & 66 \\
\hline Residencial & 25 \\
\hline Misto & 19 \\
\hline Institucional & 1 \\
\hline Total & 110 \\
\hline USO DO IMÓVEL & NÚMERO DE CASOS \\
\hline \multicolumn{2}{|c|}{ SEM INTERVENÇÃO DO MONUMENTA } \\
\hline Comercial + Serviços & 176 \\
\hline Residencial & 67 \\
\hline Misto & 52 \\
\hline Institucional & 2 \\
\hline Total & 296 \\
\hline
\end{tabular}

Verificamos, a partir da tabela 02, a forte presença do uso comercial/serviços (voltado ao público local e ao turismo, de forma híbrida) no centro histórico de Diamantina, o que ainda representa a histórica importância da cidade enquanto pólo comercial e de serviços na região. Podemos considerar, ainda, um "privilégio" para Diamantina, manter um número razoável de residentes em seu centro histórico; característica singular frente a cidades históricas turísticas como Ouro Preto (CIFELLI, 2005) e Tiradentes (COSTA, 2008a), completamente refuncionalizadas para o turismo. A complexidade dos usos estabelecidos no centro histórico de Diamantina aproxima-se do que identificamos em São João Del Rei (COSTA, 2007), um centro histórico que ainda guarda suas diversas funções (moradia, comércio, serviços, poder religioso, poder político etc.). Contudo, após a conquista da chancela da UNESCO e a implementação do Programa Monumenta, no fim do século $X X$, Diamantina vem passando por uma lenta e gradual valorização de seu 
espaço central, de acordo com critérios de especialidade, singularidade, originalidade e autenticidade criados pelo turismo, que a insere no mercado global de competição entre cidades; o processo de mercantilização de patrimônio em Diamantina é incipiente e se mostra em franca ascensão; fato que possibilita uma intervenção mais compromissada, de imediato, por parte da comunidade local, a fim de se minimizar os impactos oriundos dessa prática.

Fica-nos claro que as ações do Monumenta, em Diamantina, foram previamente dirigidas a pontos específicos da malha urbana, numa tentativa de se agregar valor econômico aos bens cujo valor simbólico sobressaem no núcleo tombado, como é o caso do Mercado Velho, do Museu do Diamante, da Igreja de São Francisco de Assis e da Cadeia Velha, formando um trajeto obrigatório de visitação no centro histórico (ver mapa anterior). "Este conjunto de investimentos transformar-se-ão em ações contínuas e concêntricas, já que se acredita no centro da cidade como referência de cidadania de Diamantina pelo seu poder de atração e difusão de idéias" (BRASIL, 2002, p. 4). A questão que se coloca é de como essas ações concêntricas reestruturam o território urbano transformando a realidade e o imaginário do diamantinense.

A partir do entendimento de que o capital é extremamente seletivo do ponto de vista espacial, de que alguns espaços apresentam-se como "pontos luminosos" ou "enclaves territoriais" do capital, consideramos que a ação do Programa Monumenta (ação conjunta do Estado com o mercado), em Diamantina, em prol da "preservação" do patrimônio edificado, segue, primordialmente, a lógica do capital, apresentando ações restritivas ao eleger alguns bens e algumas áreas do centro histórico a serem preservadas pelo valor simbólico inerente capaz de agregar maior valor econômico, relegando outras áreas do centro para segundo plano, além de serem poucos os beneficiados no processo, até o momento ${ }^{137}$. O raso conhecimento da existência do Programa em Diamantina, por

\footnotetext{
137 Segundo Scifoni (2006, p. 13), é preciso reconhecer que a valorização do patrimônio no Brasil é um processo extremamente desigual, pois atinge, em geral, aqueles bens considerados monumentais ou aqueles para os quais o mercado turístico vê possibilidades de exploração. Conforme a autora, só no estado de São Paulo, para cada edifício monumental preservado na área central da capital, com recursos do Programa Monumenta, tem-se uma grande quantidade e diversidade de construções menores, de arquitetura mais modesta, espalhadas pelas cidades do interior e que estão se degradando à espera de investimentos públicos em conservação e restauração. "Pensar que os prédios restaurados na região da Luz, na capital paulista, simbolizam o quadro da situação do patrimônio tombado no Estado nos parece um equívoco. Assim sendo, a patrimonialização deve ser relativizada quando se trata da realidade brasileira.” (SCIFONI, 2006, p. 14). A questão não é diferente para Diamantina, onde os bens foram escolhidos estrategicamente para o restauro, visando à valorização do espaço urbano central e o desenvolvimento da atividade turística. São ações públicas e privadas que nos exigem uma análise socioespacial do centro histórico e outros três bairros da periferia da
} 
parte da população residente, de acordo com nosso questionário aplicado, atesta nossa afirmação (gráficos 02,03, 04 e 05, abaixo).

Diminui-se o conhecimento popular sobre a existência do Programa Monumenta, em Diamantina, na medida em que nos afastamos do centro histórico da cidade; mostra-se alienado em relação às ações que impactuam sua cidade. Ao contrário dos residentes do centro, onde $72 \%$ dos entrevistados pelo menos já ouviram falar do Programa, os moradores dos outros bairros entrevistados pouco sabem de sua existência; torna-se mais crítica a análise quando questionamos aos que sabem da sua existência qual a sua finalidade. Consideramos esse desconhecimento coletivo sobre o Programa uma das conseqüências do que estamos chamando "dialética da construção destrutiva" que envolve os bens culturais do mundo, de forma que a grande massa das populações residentes nas cidades históricas não é esclarecida dos benefícios e problemas oriundos dos processos mercantis em curso em seus hipotéticos espaços de cidadania, ou por negligência dos personagens centrais nas novas estratégias urbanas (planejadores e promotores culturais), como aponta Arantes (2002, p. 29), ou por descompromisso público-privado frente ao estabelecimento de uma gestão participativa séria dos bens culturais do mundo (da qual somos favoráveis), como prevê a Convenção do Patrimônio Mundial, que analisamos no capítulo 2 desta pesquisa.

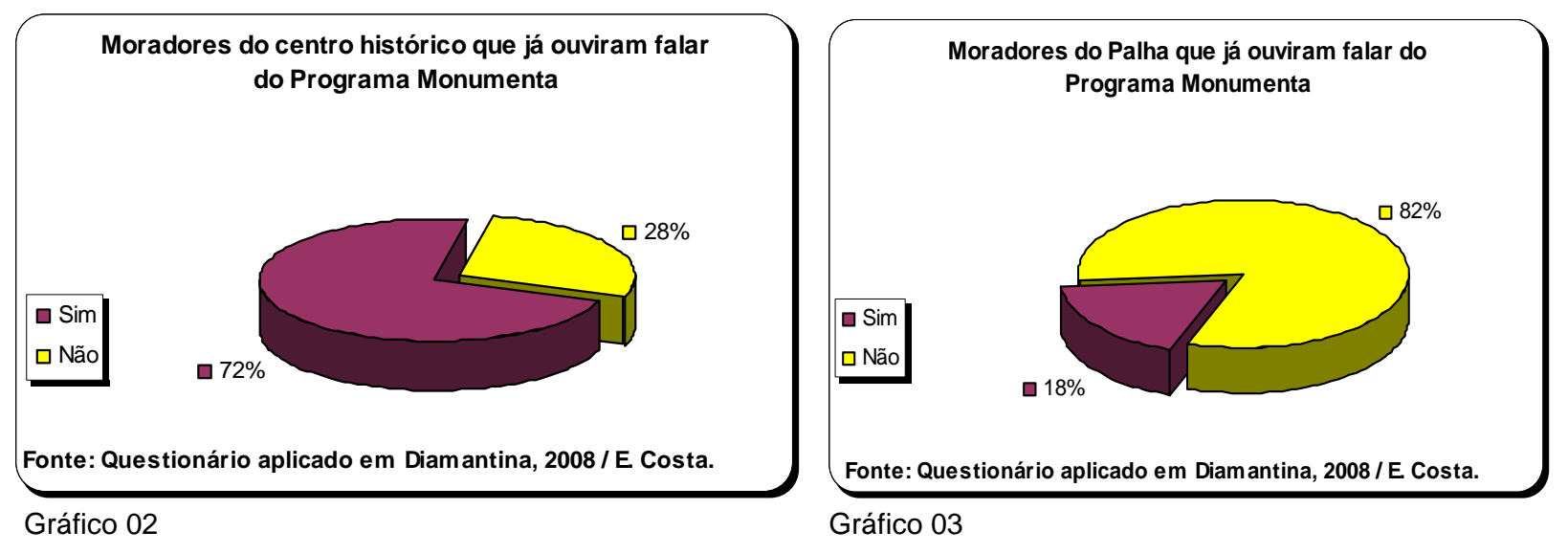

cidade, na tentativa de compreender os reflexos da mercantilização do patrimônio em Diamantina. O questionário aplicado já nos dá uma dimensão do restritivo beneficiamento da lógica mercantil do patrimônio na cidade, onde poucos são os residentes conhecedores do Programa Monumenta ou que se consideram beneficiados direta ou indiretamente por ele. 


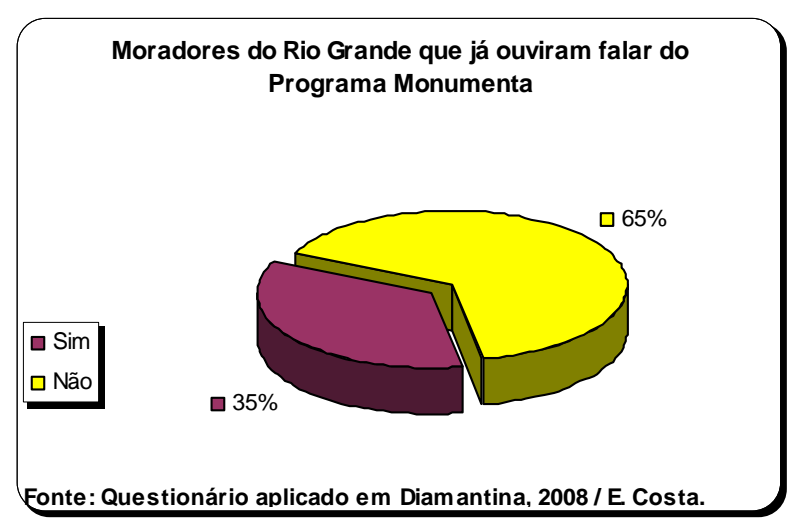

Gráfico 04

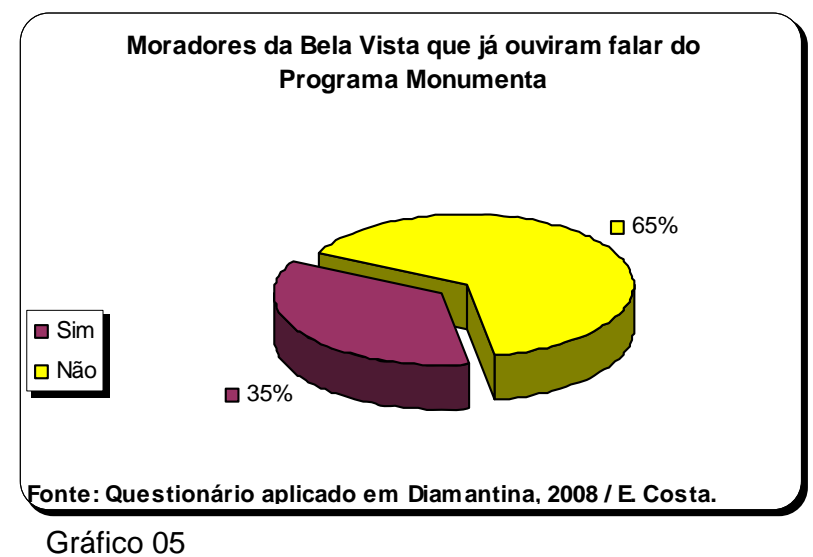

Gráfico 05

Ao questionarmos a população que já ouviu falar do Programa Monumenta ou do IPHAN se conhecem os objetivos de ambos, o quadro mostra-se mais grave, com exceção, novamente, para os residentes do centro histórico que apresentam um razoável conhecimento também dos objetivos do IPHAN. Esses dados revelam-nos que os maiores conhecedores do Programa e suas ações são aqueles envolvidos diretamente no processo mercantil, atingidos positiva ou negativamente pela valorização do solo urbano, quer sejam proprietários de imóveis e residentes no centro histórico (que se favorecem ou não da especulação imobiliária, onde o valor de troca dos bens beneficia os locadores impossibilitando ou diminuindo a permanência dos usos pelos locatários), quer sejam os próprios investidores dessa nova estratégia de "valorização" urbana. A fala do secretário de turismo da cidade, além de nossa análise in loco, revela-nos que a saída dos moradores do centro histórico de Diamantina - um dos mais graves problemas que consideramos nas cidades históricas - é um fenômeno em curso, onde alguns pontos específicos, como a rua da Quitanda, apresentam-se com raras residências. São pontos tomados pelo uso comercial e pelos serviços que atendem o público local e os turistas.

É muito interessante manter a identidade do povo, da cidade, é o que mais me preocupa, a perda da identidade, o povo que está se mudando. A rua da Quitanda, hoje, só tem três moradores. A saída do centro histórico, ainda, não é forte, mas em alguns pontos é, como na rua da Quitanda, por exemplo (local em que ocorrem as Vesperatas), a saída do centro se dá pelo falecimento, herdeiros que vendem para comerciantes etc. E perde-se o sentido do morar, o foco do comerciante é outro. ${ }^{138}$

\footnotetext{
${ }^{138}$ Entrevista do secretário de turismo de Diamantina, Walter Cardoso França Júnior, concedida ao autor em 13 de fevereiro de 2008 .
} 

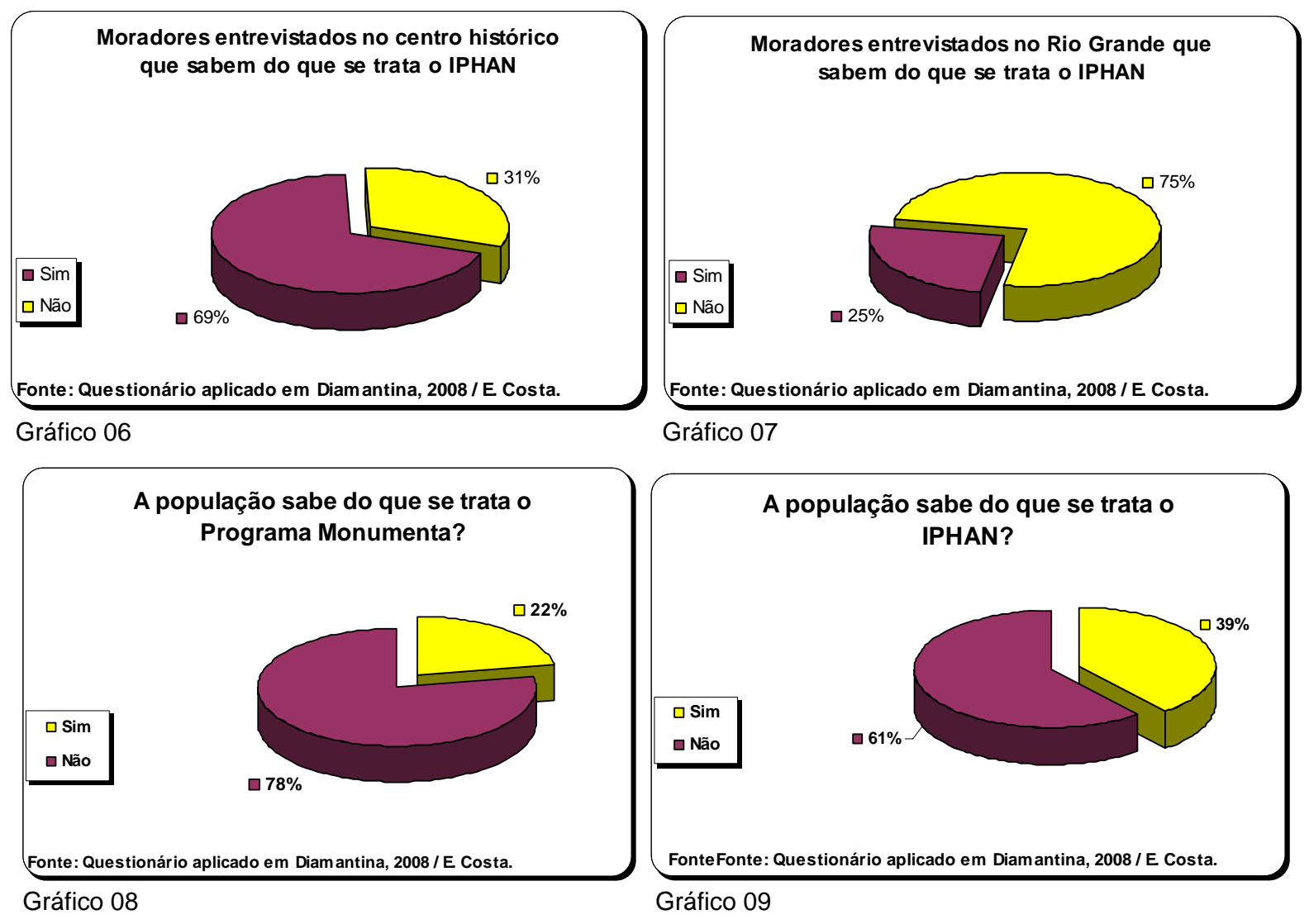

Gráfico 07

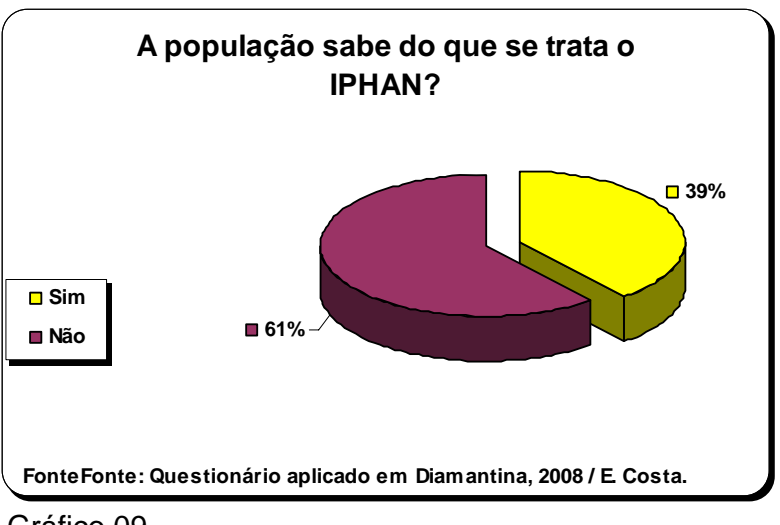

Os gráficos 08 e 09 (que abrangem o universo dos entrevistados nos quatro bairros) revelam-nos que urge, em Diamantina, o estabelecimento de uma séria política de educação patrimonial, de forma a se difundir a importância dos bens culturais para a comunidade local (tanto no que diz respeito ao seu valor cognitivo e afetivo, quanto ao seu potencial para geração de renda para todos), sobretudo, para a população residente fora do centro histórico da cidade. Mesmo o IPHAN, enquanto um importantíssimo órgão de preservação de patrimônio cultural em âmbito federal, implantado há anos em Diamantina, não apresenta, de acordo com nosso questionário, grande visibilidade. Ao contrário do que identificamos na fala da população da periferia, que pouco conhece o Monumenta, segundo o coordenador do Programa em Diamantina,

Em 2000 foi feita uma oficina com toda a população e ela opinou quais investimentos queria; dentre esses investimentos foi feita a viabilidade econômica, financeira, social e ambiental e concluímos os objetos a serem restaurados, os focos do projeto. A oficina aconteceu como ciclos de debates, votações, elaborou-se após, Carta Consulta, Perfil de Projeto e 
passamos para as obras. Isso foi feito de forma muito burocrática e democrática, com todas as associações, toda a população, inclusive da periferia. A população tem muito conhecimento do Programa. O Monumenta, em Diamantina, tem uma equipe de administração direta, que executa a obra, diferente de todas as outras cidades. Nós temos a última equipe de restauração do IPHAN no Brasil, outras existem em Tiradentes, mas é muito pequena, daqui são cinco pessoas mais um mestre de obras. O Monumenta tem 13 pessoas (equipe de obras). A população vê o monumenta pondo a mão na obra. ${ }^{139}$

De acordo com o Perfil do Projeto (BRASIL, 2002), os benefícios econômicos contabilizados a partir da implantação do projeto são:

- a valorização imobiliária dos bens da área de projeto (construções e áreas livres);

- a concessão de uso de espaços públicos à iniciativa privada ou de monumentos destacados pelo IPHAN para a exploração privada;

- a disposição a pagar do visitante pela preservação dos bens culturais, traduzida pelo valor estimado da cobrança pela visitação aos imóveis recuperados;

Isso comprova que, também em Diamantina, as novas estratégias de intervenção urbana visam ao patrimônio como "capital simbólico" (HARVEY, 2005), "cultura de mercado"; as cidades não podem deixar de constituir espaços complexos de cidadania, espaços verdadeiramente coletivos, para integrarem cidades representativas da lógica perversa do capital e da mercadoria. Para Carlos (1999), identificamos, nas cidades, a vitória do valor de troca sobre o valor de uso, onde o espaço se reproduz de acordo com a tendência que o transforma em mercadoria, o que limita seu uso às formas de apropriação privada. Essa prevalência da troca sobre os modos de uso, no espaço urbano, tende a anular o sentimento de pertencimento ao lugar, uma vez que "a imobilidade e a amnésia conduzem à alienação" (MENESES, 1992, p.194), à marginalização e à impossibilidade de construção da cidadania.

A prevalência da troca em detrimento ao uso vigora nas atuais ações voltadas ao centro histórico de Diamantina. Retomando o mapa anterior e de acordo com as

\footnotetext{
${ }^{139}$ Entrevista do coordenador do Programa Monumenta em Diamantina, Carlos Emanuel, concedida ao autor em 12 de fevereiro de 2008.
} 
informações do Perfil do Projeto (BRASIL, 2002), considerou-se a valorização imobiliária da área de projeto como o primeiro benefício econômico esperado pelo Monumenta. Forma-se, assim, uma espacialidade que tem em quatro eixos principais os objetos de intervenção do Programa, a fim de se avultar o valor econômico do solo urbano por meio do enaltecimento do valor simbólico do patrimônio cultural. A rua Direita (imóveis privados e bens culturais tombados restaurados); a Praça Barão de Guaicuí / Mercado Velho e entorno; a Cadeira Velha juntamente com a Igreja do Rosário e entorno e, ainda, a rua da Quitanda, que se constitui no palco do principal evento turístico de Diamantina (as Vesperatas que abordaremos a seguir) formam quatro "eixos estruturantes" principais do Monumenta, de acordo com nossa análise.

Observando o mapa, podemos concluir que a valorização imobiliária propiciada a partir dessa intervenção no centro histórico consegue cobrir boa parte da área do conjunto, tendo nos quatro "eixos estruturantes" principais da intervenção (área do Mercado, Rua Direita, Cadeia Velha e Rua da Quitanda) os elementos originários da valorização do espaço (valor simbólico adquirido por singularidades desencadeadas por processos históricos de produção do espaço) e da valorização do solo urbano (valor de mercado) no núcleo urbano tombado, ou seja, são ações e objetos estruturantes da materialização do que chamamos dialética da construção destrutiva na consagração dos bens culturais do mundo.

De acordo com o Perfil do Projeto (BRASIL, 2002), o segundo benefício econômico advindo com o Monumenta é a concessão de uso de espaços públicos à iniciativa privada, de maneira que para os edifícios públicos em áreas tombadas ou para os bens destacados pelo IPHAN dentre aqueles protegidos pelo Estado ou Município, considera-se a renda proveniente de aluguel ou uso do lugar (essa concessão de uso privado de bens públicos justifica nossa crítica à mercantilização descompromissada do patrimônio cultural, onde os bens culturais do mundo são "vendidos" a bel sabor dos agentes hegemônicos e à revelia da coletividade). Logo, segundo o Perfil do Projeto (BRASIL, 2002), as intervenções e os usos são os seguintes, de acordo com o quadro: 


\begin{tabular}{|c|c|c|}
\hline INTERVENÇÕES & USO ATUAL & USO FUTURO \\
\hline Casa do Intendente & Sem uso & Museu de Arte Sacra \\
\hline Mercado Velho & Mercado local & $\begin{array}{lll}\text { Mercado, } \quad \text { Centro } & \text { de } \\
\text { Artesanato e Museu Vivo } & \end{array}$ \\
\hline Museu do Diamante & Sem uso & $\begin{array}{l}\text { Pomar, café e lanchonete, } \\
\text { Arena de espetáculos }\end{array}$ \\
\hline Sobrado da Prefeitura & Prefeitura e Câmara Municipal & Prefeitura e Câmara Municipal \\
\hline Cadeia Velha & Sem uso & Teatro, Cinema e Café \\
\hline Praças & Praças & Praças \\
\hline Logradouros Públicos & Logradouros & Logradouros \\
\hline
\end{tabular}

Quadro 03 - Fonte: (BRASIL, 2002, p. 8)

Ao mesmo tempo em que o Programa destinará usos a bens que se encontram fechados (Casa do Intendente, o Museu do Diamante e a Cadeia Velha), o que é importante para a recuperação do patrimônio, ele implementará atividades destinadas, primordialmente, à exploração turística. Logo, dada a lógica dialética que enreda os bens culturais do mundo - do uso / troca; "preservação" / "mercantilização"; "construção destrutiva" - o Programa Monumenta favorece a transformação da cultura em um novo gênero de mercadoria, em pleno sertão mineiro; favorece a "turistificação" do lugar, criando-o ou recriando-o do uso à troca, desenvolvendo um turismo que representa mais do que uma atividade econômica, mas uma prática geradora de atividades econômicas, da mesma forma que a religião, o esporte e a guerra, segundo Hiernaux Nicolas (2001, p. 44).

No entanto, não podemos desconsiderar o papel do Monumenta no que diz respeito à recuperação estética dos bens, pois tanto a intervenção nos imóveis privados quanto nos bens tombados públicos e coletivos, favorece a melhoria visual da paisagem urbana histórica. O que questionamos é a pouca importância dada ao estabelecimento de uma séria política de educação patrimonial, o caráter eminentemente mercantil-estético desse processo que favorece uma "banalização pela cenarização progressiva" e a pouca participação e informação do residente, de maneira geral, sobre os valores históricoculturais que o conjunto representa (conforme gráfico 10). Uma séria política de educação patrimonial e de esclarecimento do potencial histórico, cultural e mesmo econômico dos bens culturais, poderia se constituir em um instrumento poderosíssimo - para o habitante local - de desenvolvimento do sentimento de pertencimento ao lugar e reconhecimento da 
cidade enquanto uma forma com funções múltiplas e complexas que começa a sofrer os impactos das novas ações que mercantiliza e banaliza o lugar; o esclarecimento dos residentes sobre os diversos valores que permeiam o patrimônio favoreceria o estímulo à exigências do residente perante o poder público.

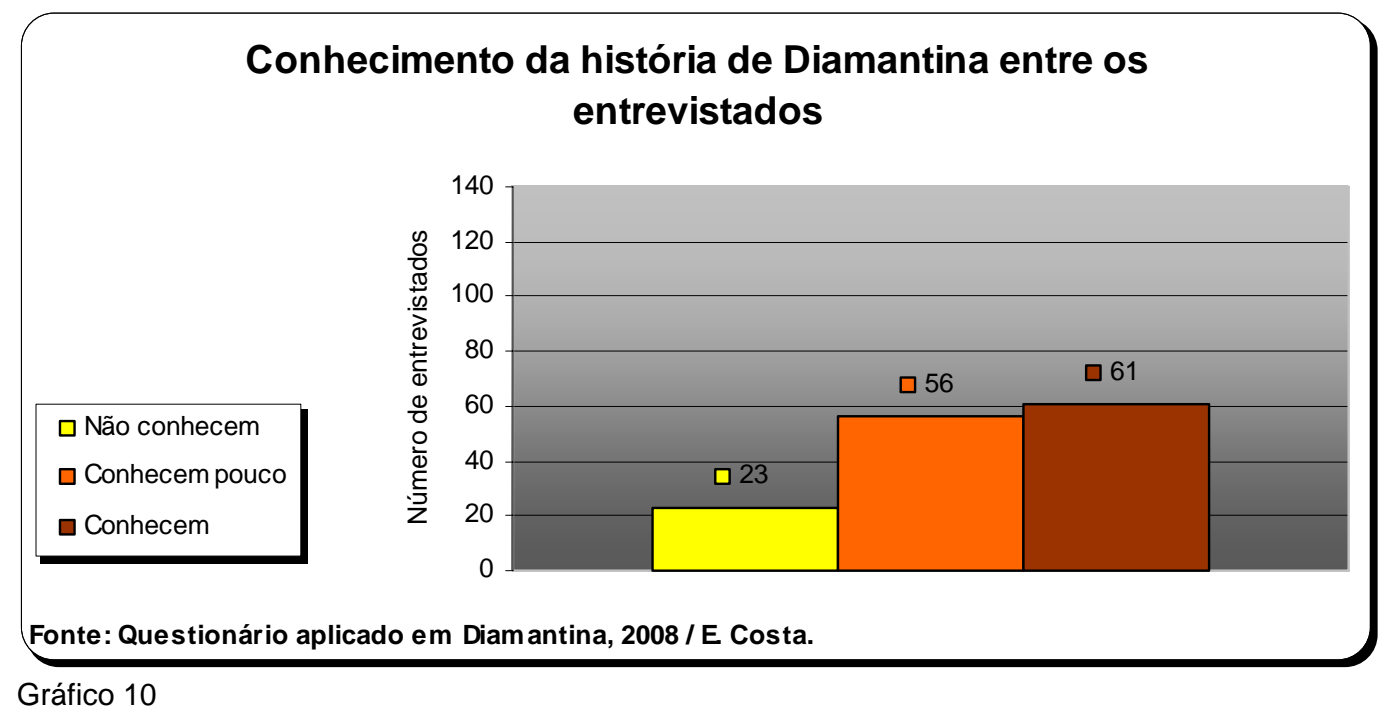

Isso reflete, como aponta Cruz (2007, p. 10), a mais importante contradição do modo de produção capitalista no que tange ao espaço: "mesmo sendo produzido socialmente, sua apropriação é privada", seria uma ingenuidade teórica acreditar que todos os indivíduos que habitam o planeta participam da mesma forma e com a mesma intensidade dos processos de produção do espaço. Há que se distinguir atores hegemônicos e não hegemônicos. Nesse sentido, o Monumenta nos é exemplar, quando tem como principais atores hegemônicos de produção do espaço o Estado e o mercado, onde o primeiro torna-se subserviente aos interesses do segundo, em relação ao Programa.

Apesar da fala dos residentes nos remeter ao seu pouco conhecimento sobre o IPHAN e o Monumenta, na cidade, a maior parte dos entrevistados consideram o centro histórico bem preservado (gráfico 11). Isso revela que, especialmente o IPHAN, ao longo dos anos, conseguiu cumprir, juntamente com os agentes envolvidos diretamente com os bens culturais (comunidade e agentes públicos), sua função na preservação do patrimônio cultural da cidade. Pode-se considerar também que a permanência das práticas religiosas, como se deu em Diamantina, através do catolicismo, constitui-se em um relevante 
instrumento de preservação do patrimônio, quando a comunidade local vê na conservação de suas igrejas e objetos de culto a perpetuação da própria prática, simultaneamente.

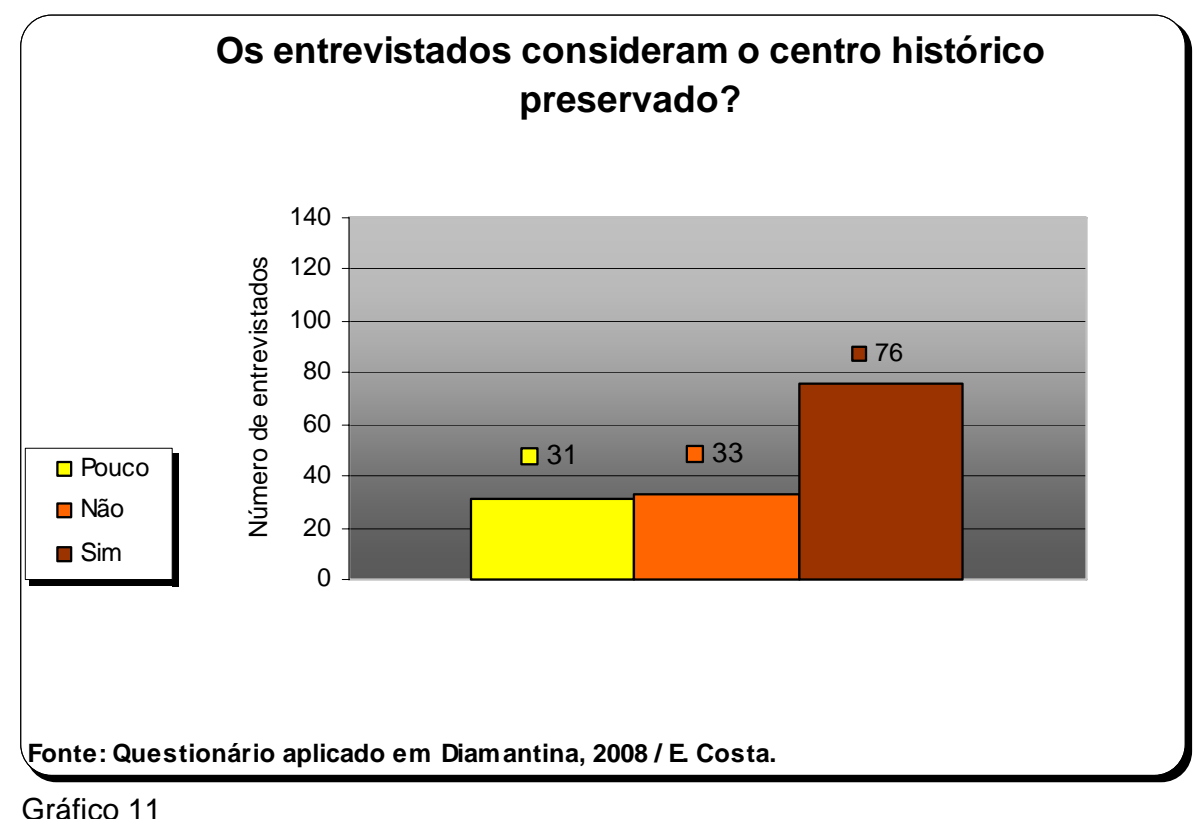

Logo, como a refuncionalização e a mercantilização de patrimônio constitui-se num processo incipiente em Diamantina, faz-se necessária uma resistência aos processos desestruturantes e fragmentários que se instalam. De acordo com Santos (1994), no plano do lugar, vêem-se, às vezes, pontos de resistência à nova lógica imposta pela voracidade do capital global; uma resistência que busca conhecer o oponente, sua força, artimanhas e vulnerabilidades. Compreender e se pautar na realidade que cerca o lugar torna-se a melhor estratégia para um contra-ataque às ações que fragmentam o mundo vivido. Para Santos (1994, p. 19), "graças aos milagres permitidos pela ciência, pela tecnologia e pela informação, as forças que criam a fragmentação podem, em outras circunstâncias, servir ao seu oposto" (rever foto 19).

A tendência atual é que os lugares se unam verticalmente e tudo é feito para isso, em toda parte. Créditos internacionais são postos à disposição dos países mais pobres para permitir que as redes se estabeleçam ao serviço do grande capital. Mas os lugares também se podem unir horizontalmente, reconstruindo aquela base de vida comum susceptível de criar normas locais, normas regionais (...) Na união vertical, os vetores de modernização são entrópicos. Eles trazem desordem às regiões onde se instalam porque a ordem que criam é em seu próprio, exclusivo e egoístico benefício. Se 
aumenta a coesão horizontal isso se dá ao serviço do mercado, mas tende a corroer a coesão horizontal que está a serviço da sociedade civil como um todo. (SANTOS, 1994, p. 19-20)

Por fim, o terceiro benefício econômico esperado pelo projeto, segundo o Perfil do Projeto (BRASIL, 2002), é a disposição a pagar do visitante pela preservação dos bens culturais na Área de Projeto. A cobrança de ingressos pela visitação aos imóveis que sofrerão intervenção do Monumenta será a variável que caracterizará o aumento do bem estar do visitante, ou seja, a cobrança refletirá a disposição a pagar do visitante. As ações implantadas foram observadas sob a ótica da viabilidade econômica e da "sustentabilidade" financeira, consideradas isoladamente e para o projeto como um todo (BRASIL, 2001).

Esses três "benefícios" econômicos esperados pelo Monumenta (mais particulares que coletivos) representam bem o que Arantes (2002, p. 29) considera como estratégias autodestrutivas; mesmo assim a corrida rumo ao desastre continua. São esperanças de benefícios que refletem a ilusão causada pela mundialização dos lugares a partir da dinâmica turística que tem no processo globalizante um suporte fundamental; processo globalizante que ganha força na contemporaneidade e que se manifesta não apenas no campo econômico, político e social, mas, sobretudo, no campo cultural, através de seu aparato técnico e informacional que contribui na transformação de cidades e da própria cultura em novos gêneros de mercadoria, respondendo às novas exigências do mercado globalizado, no qual se insere Diamantina Patrimônio Mundial e mercadoria global.

En cada época, nuevos objetos y nuevas acciones vienen a añadirse a los anteriores, modificando el todo, tanto formal como substancialmente. Actualmente, los objectos culturales tienen tendência a hacerce cada vez más técnicos y específicos, y son deliberadamente fabricados y localizados para responder mejor a unos objetivos previamente establecidos (SANTOS, 1993, p. 70).

Logo, o perfil da documentação consultada e a retórica dos agentes públicos locais, remetem-nos à homogeneidade do discurso sobre "preservação" associada à possibilidade de desenvolvimento econômico local e regional, que se afirma pelo uso de termos familiares ao vocabulário empresarial do universo teórico do planejamento urbano 
estratégico (aparecem, com freqüência, "valorização imobiliária", "estudo de mercado imobiliário", "valor dos imóveis", "viabilidade econômica", "concentrar investimentos", "envolvimento da iniciativa privada", "sustentabilidade financeira", "atratividade", "acessibilidade", "investimento privado", "financiamento", "estimativa de demanda" etc.) $)^{140}$.

$\mathrm{Na}$ expectativa de confirmar o caráter tipicamente mercantil do Programa, questionamos o coordenador do Monumenta, em Diamantina, se a população teria acesso livre aos bens culturais restaurados pelo Programa; sua resposta foi objetiva:

Não. Todo museu tem sua entrada, o residente terá acesso aos cursos técnicos que serão criados, infelizmente o residente não tem acesso livre nestes locais, o BID não faz nada tão de graça igual você está pensando, o próprio banco coloca regras, seria muito bom se isso acontecesse, mas a população passa a ter acesso a informações que ele nunca teve, no museu, por exemplo, pagando para entrar. Até mesmo porque há peças no museu que custam milhões, eu não posso abrir assim, então temos responsabilidade; precisa ser muito bem cuidado. A própria igreja de São Francisco, eu não tenho mais como soltar uma visitação aleatória na igreja, ela esta toda em ouro, tudo está restaurado, os altares... Lógico que o fiel tem a entrada livre, para sua oração. As igrejas de diamantinas são templos, não são como as de Ouro Preto que não são mais igrejas, são museus custeados, aqui todas as igrejas tem seus cultos. No mercado você entra sem ingresso. Não queremos congelar as igrejas, queremos as velinhas acesas, o nosso senhor exposto, pronta para ter uma missa e que a visitação turística não atrapalhe o cotidiano dela. Com o pagamento para entrada no museu de arte sacra, você ganha uma cartela para visitar todas as igrejas. O que será terceirizado é a Cadeia Velha, o Museu de Arte Sacra e frações de arrecadação das igrejas restauradas pelo monumenta, o caso é a igreja da São Francisco; o BID não dá dinheiro para ninguém ele é mercantilista, não te dá dinheiro sem saber, você paga para entrar na igreja e porcentagem disto vai para o fundo; batemos de frente com ele com a questão da sustentabilidade, como ter certeza de que as visitas surtirão a renda esperada? ${ }^{141}$

Nesse contexto particular, vemos que a ação do capital que rebate sobre o território urbano segue lógicas individuais entranhadas no próprio Estado, enquanto um dos promotores do Programa Monumenta, que responde a uma inteligência global, representada por um Governo Global (no caso, o BID, além do FMI e Banco Mundial), não nacional ou regional; Governo que escolhe lugares sendo cego; parece um paradoxo, é

\footnotetext{
${ }^{140}$ Os termos podem ser encontrados nos documentos nacionais citados e referenciados em nossa Bibliografia.

${ }^{141}$ Entrevista do coordenador do Programa Monumenta em Diamantina, Carlos Emanuel, concedida ao autor em 12 de fevereiro de 2008.
} 
cego para seu redor e lógico, preciso, determinado para seus interesses, como aponta Santos (1999, p. 11), "Cegos, sabem bem onde pisam, têm visão de mercado e de negócios".

Verificamos que se busca na estrutura urbana, na paisagem urbana histórica, a movimentação de investimentos de capital e a formação de um status de serviços terciários capazes de aumentar a atratividade dos bens culturais na área do projeto, na tentativa de se colocar Diamantina com maior evidência no cenário internacional com o turismo cultural. Verifica-se a fetichização das formas, seu "encantamento", a metamorfose de seu valor simbólico em valor econômico, de forma que o consumo estético dos bens culturais passam a ter mais valor do que seu uso social democrático, como aponta Luchiari (2005, p. 99). A municipalidade (com ideologia empresarial) passa a conceber o planejamento aos fragmentos, selecionando áreas que possam atrair o capital, esboçando o que Luchiari chama de "espetacularização do planejamento". A periferia é esquecida, como veremos.

Está em voga o privilégio de grupos seletos que usufruem de lugares (re)criados especialmente para os mesmos; excluem-se pessoas e suas territorialidades com o enobrecimento de áreas, pois os habitantes, mendigos, prostitutas e pobres são expulsos de seus espaços e de suas moradas, esboçando usos sociais seletivos de determinadas áreas. Para o arquiteto responsável pelo Escritório Técnico do IPHAN, em Diamantina, a "cenarização" implantada em Parati (RJ), por exemplo, é um fato "negativo", com ressalvas;

Negativo. Assim, há um lado de inevitável, mas virar loja, casa de paulista que nunca vai lá? Não é de todo negativo, mas acha que hoje teria sentido vermos ali gente pobre, vendedores de cachaça? Eles têm direito à cidade? Têm. Mas para entender a cidade como patrimônio nacional ... as pessoas que vão lá querem ver arquitetura colonial. O pelourinho, por exemplo, antes do tombamento, era o que? Era meretrício; era melhor? Hoje são lojas. Nesses lugares, há de ser lojas e restaurantes caros sim, mas têm que ter moradores. ${ }^{142}$

Segundo Luchiari (2005, p. 102), muda-se o conteúdo social dos bens tombados com a vocação turística. Concordamos com a autora ao considerar que as

\footnotetext{
${ }^{142}$ Entrevista do chefe do Escritório Técnico do IPHAN em Diamantina, Junno Marins da Matta, concedida ao autor em 13 de fevereiro de 2008.
} 
intervenções não são sempre negativas: o problema é dar suma importância às formas e atribuir-Ihes um valor econômico em detrimento de seu valor cultural original, destituindo destas paisagens as habitações, os usos pretéritos, o sentimento de pertencimento das populações locais e a sobrevivência das comunidades tradicionais, quando a lógica globalizante (aí entendidas as atividades de lazer e de turismo) organiza de forma específica os espaços dotados de patrimônios culturais, atendendo a demandas exclusivamente externa.

O fato é que temos com o Programa Monumenta - dirigido também por ações individualizantes externar - uma "segregação programada" que se realiza pela intervenção do Estado através de uma política urbana orientada pelas exigências da reprodução do capital na busca do desenvolvimento do turismo. Para Carlos (2006), o que identificamos, hoje, é a intervenção do Estado no espaço através de políticas urbanas que incentivam o deslocamento de atividades, transforma as funções dos lugares; isso gera um movimento que constrói e destrói, dialeticamente, os espaços da cidadania, da complexidade da vida representados pela cidade histórica envolvida pela simultaneidade do uso e da troca no processo de "revalorização".

Logo, a questão da "valorização" - objetivada pelo trabalho humano - implica criação e apropriação de valores, na produção do espaço geográfico. Esse movimento se dá através de riquezas naturais que são transformadas em objetos de uso e de consumo, que, enquanto formas construídas, se agregam ao solo sobre o qual estão erguidas, isto é, trabalho materializado na paisagem, valor depositado em lugares, conforme Moraes (2005). Esse autor aponta-nos que é em função disso que os lugares passam a se diferenciar por características humanas e não apenas por condições naturais variáveis. Ainda, vemos, sobretudo hoje, que a valorização espacial se aproxima da construção de um "capital simbólico" (HARVEY, 2005) sobre o "sistema de objetos" (SANTOS, 2002) espacial, que ganham novos sentidos, são revalorados, ocasionando novas espacialidades, novas distinções através da "ultravaloração" do espaço; forja-se o "valor do espaço" (MORAES e COSTA, 1996), teoria aplicável no caso da atual dinâmica que permeia a questão da apropriação estratégica de núcleos urbanos tombados, que ressignifica o patrimônio cultural, onde esse, através do simbolismo do qual é investido, torna-se matéria prima para a nova "indústria da cultura". No caso específico de Diamantina, sua consagração como Patrimônio Cultural da Humanidade (visto no capítulo 
2) figurou-se como instrumento primordial de valorização do espaço / valorização simbólica para, dialeticamente, ser agregado valor econômico à cidade-patrimônio (na busca de implementação da atividade turística), formando um território urbano revalorizado com a implantação do Programa Monumenta.

Pode-se dizer que a formação territorial é a manifestação empírica da valorização do espaço, da mesma maneira que a formação econômico-social manifesta o modo de produção numa expressão singular. Trata-se de níveis diferenciados de abstração e concreção: o modo de produção e a valorização do espaço referem-se ao plano da universalidade, enquanto as formações mencionadas voltam-se para a esfera da singularidade. A articulação de ambos objetiva a particularidade. (MORAES, 2000, p. 38)

\section{A valorização do espaço para a dinamização dos eventos e a intensificação dos}

\section{fluxos}

Aproveitando desse processo de valorização do espaço (onde o "valor do espaço" é transferido no processo de trabalho para o produto "através das características próprias de cada lugar", como propõe Moraes e Costa (2006)), o Programa Monumenta tem como estratégia para o alcance de seus objetivos ${ }^{143}$ a promoção de eventos que contribuam para a intensificação da circulação econômica, sobretudo, por meio do turismo com a atração de fluxos e refuncionalização dos imóveis nas Áreas de Projeto (BRASIL, 2006, p. 74).

De acordo com dados fornecidos pela prefeitura de Diamantina, dentre os tradicionais eventos responsáveis pela intensificação do fluxo de turistas, destacam-se: as Vesperatas, o Carnaval, a Semana Santa e o Festival de Inverno da UFMG. É sobre as Vesperatas que nos ateremos brevemente, por ser um evento simbólico da transformação da cultura em mercadoria e a principal atividade favorecedora da movimentação turística na cidade. Esse evento, além de gerar lucros e rendas, materializa o processo de segregação do residente em relação ao espaço central da cidade, ao deixar de ser uma atividade voltada para o habitante local para ser destinada, eminentemente, ao turista, conforme atesta a própria população. Mencionar as Vesperatas, neste ponto da pesquisa,

\footnotetext{
143 Sobre os objetivos do Programa, rever o item Característica do Programa Monumenta, no capítulo 3.4.2 desta pesquisa.
} 
em que tratamos do Programa Monumenta, justifica-se pelo seu caráter exclusivo mercantil, quando temos um rito tradicional local transformado em um novo produto turístico local. $^{144}$

Segundo Freitas (2008), devido às ações voltadas para a "preservação" de patrimônio empreendidas na última década do século $X X$, em Diamantina, observa-se o crescimento substancial do turismo, que coincide com a época de recebimento do título de Patrimônio Cultural da Humanidade. Nesse contexto, um importante acontecimento foi o resgate de tradições locais, a exemplo das serenatas, aspecto que possibilitou, segundo Freitas, a elaboração de um calendário de eventos encabeçado pela famosa Vesperata.

A origem da Vesperata remete-nos ao século XVIII, no Arraial do Tijuco, quando as irmandades incentivaram a formação de músicos como um ofício importante e seguro. A partir daí, todas as celebrações religiosas eram cantadas, a exemplo das festas e procissões, das ladainhas, alvoradas, novenas e missas. Em todas as ocasiões eram encomendadas músicas aos mestres de ofícios (FREITAS, 2008).

No início do século XX, a Vesperata foi resgatada por João Batista de Macedo, regente da banda do $4^{\circ}$ Corpo Militar de Diamantina, em uma das audições realizadas no coreto da praça. O regente, inspirado pela linha de composição da música apresentada, teve a idéia inovadora de posicionar os blocos de solistas nas sacadas e janelas dos casarões da antiga praça. Essa disposição dos músicos foi passada de maestro a maestro que assumia a regência da banda, até se consolidar, conforme aponta Freitas (2008). Em 1940, impulsionada pelos processos de urbanização e pelas novas opções de lazer, a prática perdeu força, desaparecendo. Somente em 1997, quando a cidade começava a se preparar para a busca da chancela da UNESCO é que a tradição ressurgiu, com a mesma forma, porém, com novo conteúdo. "Durante todos esses anos de contínuas apresentações, a Vesperata tem conseguido atrair, a cada realização, uma multidão de turistas que lotam os hotéis e restaurantes da cidade" (FREITAS, 2008, p. 227).

\footnotetext{
${ }^{144}$ Podemos mencionar um caso mais particular e pontual de transformação dos sentidos da cultura local, que esboça o processo em curso em Diamantina. Em um dos trabalhos de campo, tivemos a oportunidade de presenciar uma prática favorecedora da transformação da cultura em mercadoria. Fomos convidados, no mês de janeiro, para a apresentação de um grupo de Folia de Reis no Mercado Velho, que se apresentou para um grupo da CEMIG (Central Elétrica de Minas Gerais) e de empresários locais. Logo, a Folia apresentava-se para uma elite diamantinense, fora do contexto tradicional do ritual, que prima por percorrer as casas de alguns determinados bairros, onde são recebidos por seus moradores, onde tocam, cantam e recebem oferendas destinadas ao santo. Na ocasião, no Mercado Velho, verificamos que a Secretaria de Turismo e Cultura solicitou a apresentação para uma elite local, numa espécie de "show" para uma minoria que visava a enaltecer a obra então restaurada pelo Monumenta (foto 21).
} 
O evento integra o calendário turístico de Diamantina e os roteiros turísticos comercializados pelas agências Saint Germain e CVC, atraindo turistas de várias regiões do país. No acontecimento, a área de atendimento tem capacidade para 400 pessoas assentadas pagando. ${ }^{145}$

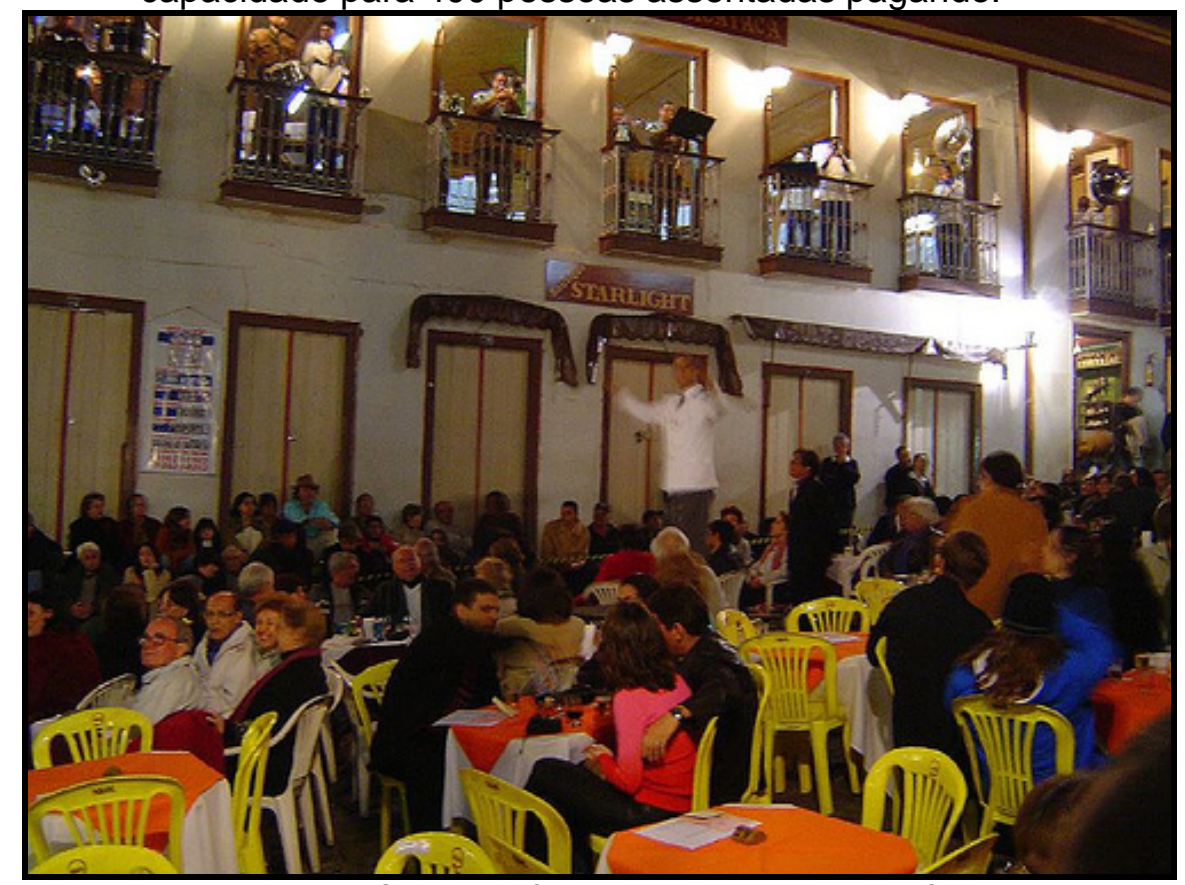

Foto 20: Vesperata no Centro Histórico de Diamantina, Rua da Quitanda. Fonte: www.google.com.br

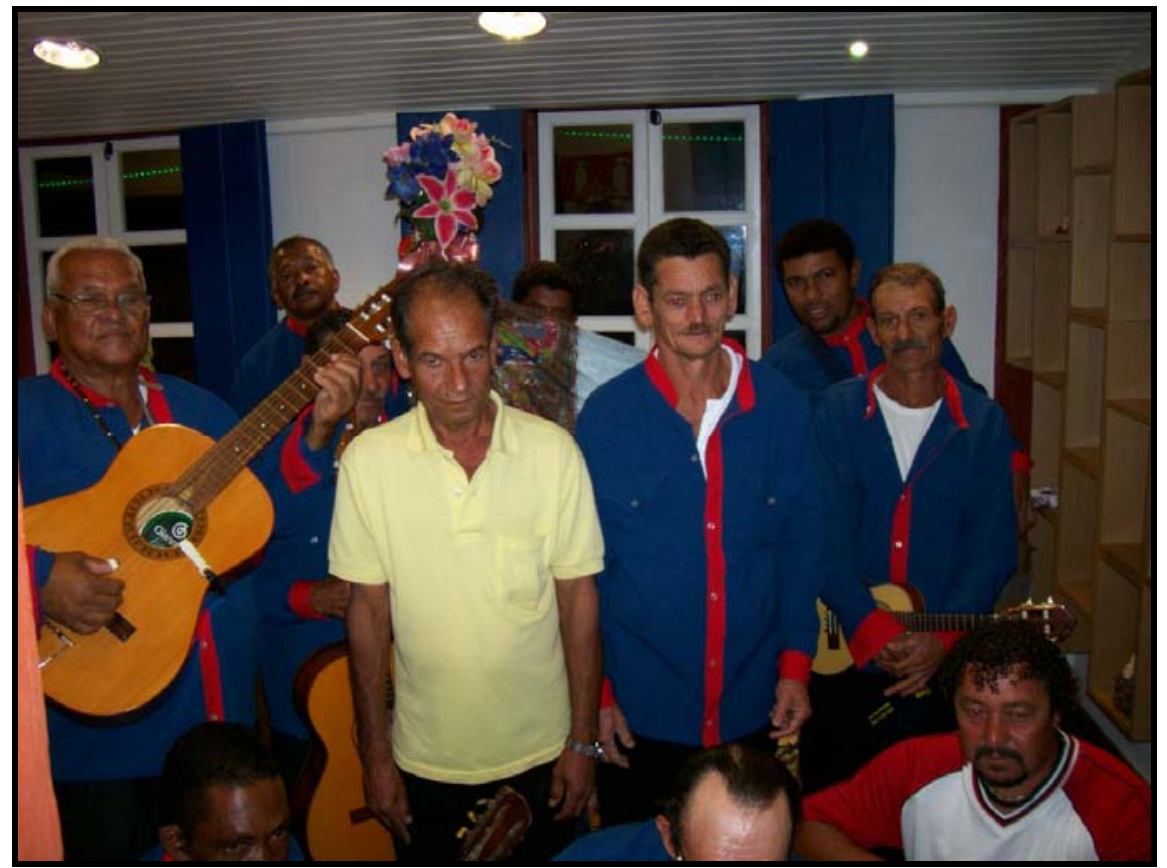

Foto 21: Folia de Reis convidada a tocar para uma elite local, no Mercado Velho de Diamantina. Foto do autor / fev. 08.

\footnotetext{
${ }^{145}$ Fundação João Pinheiro. Plano de Desenvolvimento Integrado do Turismo Sustentável. Pólo Turístico do Vale do Jequitinhonha. Belo Horizonte, 2005.
} 
Em sua tese de doutorado, Freitas (2008) deixa claro que a Vesperata é o produto principal dos fluxos de turismo para a cidade; "as operadoras e as agências (de turismo) não possuem o produto para a venda. O que tem sido distribuído no mercado é o destino Diamantina como cidade histórica e musical (Vesperata)". (FREITAS, 2008, p. 295).

Dada a importância do evento para a cidade (como um produto turístico), que acontece em uma média de 10 e 16 vezes ao ano, foi criada uma Comissão de Vesperata pelo decreto municipal $n^{\circ} 060$ de 24 de maio de 2004. Verificamos, em atividade de campo, que o diamantinense também já identifica o evento como um produto turístico e não como uma prática tradicional religiosa ou como um evento destinado aos habitantes locais. O gráfico 12 revela-nos que para o diamantinense as principais festas realizadas no centro histórico são as Vesperatas, as Festas Religiosas e o Carnaval. Consideramos um fator positivo o fato de o carnaval vir em terceiro plano no imaginário do residente, enquanto as festividades religiosas aparecem em segunda posição, o que revela a permanência das práticas católicas no pequeno centro histórico que concentra oito igrejas barrocas. Não podemos nos esquecer de que o intenso trânsito de veículos (grande quantidade de carros de passeio, ônibus e caminhões) compromete as estruturas dos conjuntos urbanísticos; outro problema já reconhecido e comprometedor é a prática do carnaval e grandes eventos (encontros, festivais, shows), que atraem centenas ou milhares de pessoas comprimidas nas estreitas ruas e becos dos centros históricos, o que ao menos aparentemente ultrapassa suas capacidades de carga, ou seja, o número de turistas que um lugar pode receber sem prejuízo físico e cultural local, segundo Knafou (2001), daí a necessidade de se repensar a prática do carnaval como um evento positivo para a cidade, dada a degradação que promove, se não muito bem planejado. 


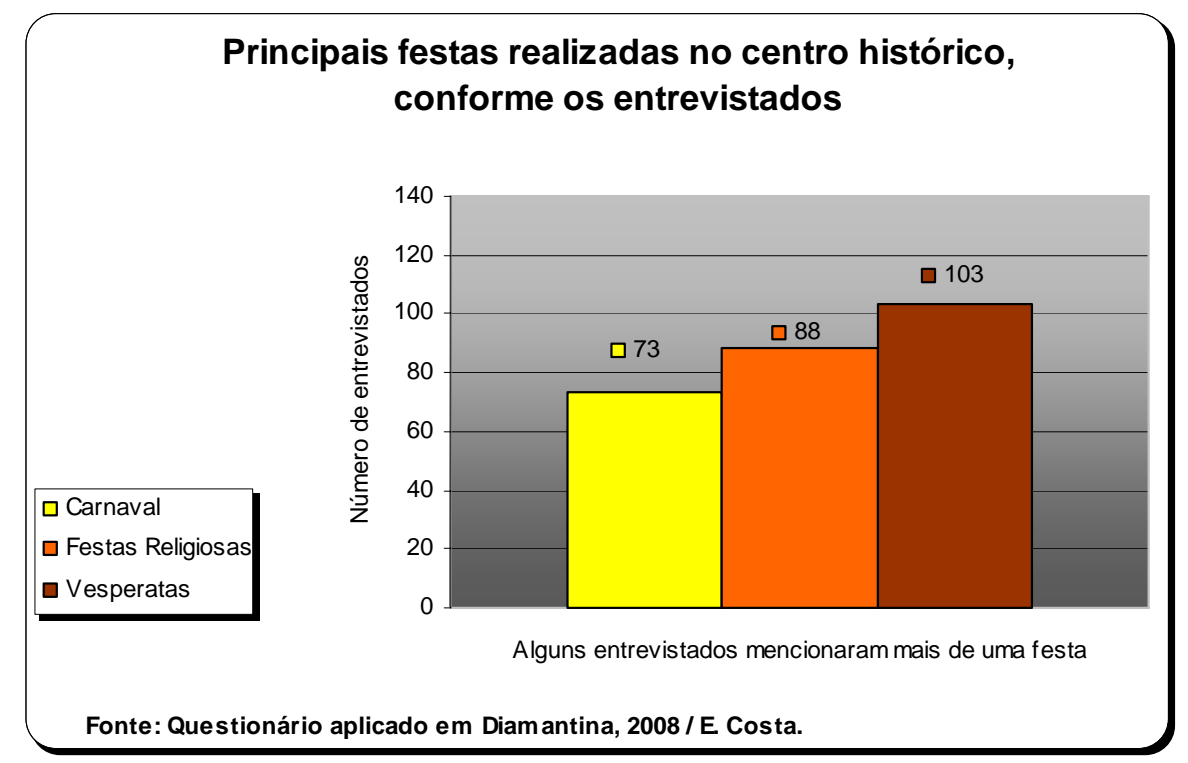

Gráfico 12

Apesar de ser um importante evento de atração turística e o habitante local reconhecê-lo como uma das principais festas realizadas no centro histórico, o mesmo habitante local vê-se excluído pela forma de realização do evento, que impossibilita a participação efetiva da classe menos favorecida da cidade, devido a colocação de um cordão de isolamento que impede a passagem do residente pelo local do evento e pelo alto preço das mesas.

Vemos um paradoxo. As Vesperatas acontecem na rua da Quitanda, em espaço público e aberto, de forma que a banda dispõe-se nas sacadas e os turistas, nas mesas, vendidas pelos hotéis, pousadas e restaurantes (ver mapa anterior, palco das Vesperatas). Ao residente, resta assistir do lado de fora do cordão de isolamento, dada a existência da barreira. Essa característica da disposição do evento, por mais comum que pareça, cria o sentimento de segregação nos habitantes que não têm condições financeiras de ocuparem as mesas e participarem do evento em comunhão com os turistas, no espaço público. Isso fica muito claro na fala da maioria dos entrevistados na periferia de Diamantina e mesmo de residentes do centro histórico, que consideram a Vesperata (uma prática tradicional da cidade) um evento voltado para a atração turística. Segundo Ana Angélica, residente no centro histórico de Diamantina, "o tratamento da população com a Vesperata é com muita falta de respeito"146.

\footnotetext{
${ }^{146}$ Entrevistada pelo autor no dia 12 de fevereiro de 2008.
} 
O atual prefeito de Diamantina, Gustavo Botelho Júnior, reconhece as Vesperatas como o mais importante produto turístico da cidade. Segundo ele,

\begin{abstract}
Aconteceu em 1997, na rua da Quitanda, das sacadas; para mim ela é um PRODUTO turístico, antes era um atrativo verdadeiramente cultural que acontecia de vez em quando, hoje ela é um produto turístico sustentável que gera renda para a cidade inteira. Se você perguntar para um artesão o que ele acha da Vesperata ele pode até dizer que não participa, mas que acha positiva por atrair turista. Hoje o turismo é uma das indústrias que menos polui e gera renda. O povo acha que beneficia só os comerciantes, mas não é verdade não é? O problema do turismo é a falta de entendimento da população da importância do turismo, apesar de empregar. A Vesperata não é de graça, né? Nós pagamos as sacadas, a locução, o som, os bares colocam as mesas, as bandas recebem um cachê, então fica em torno de 8 a 9 mil reais, daí é cobrado. Quando iniciou, em torno de 1997, era tudo de graça, por ocasião do 'tombamento internacional' (não há um tombamento internacional), e quem recebia os benefícios eram os hotéis e bares, no segundo momento o município conseguiu recursos do Ministério do Turismo para arcar com as despesas da Vesperata, que hoje ocorre quase quinzenalmente. A forma achada foi cobrar as mesas, daí os bares cobraram as mesas para quem quisesse assistir sentado e tomando sua cerveja, próximos às sacadas, parte deste dinheiro era para as despesas e a prefeitura completava o resto, hoje a prefeitura não paga mais nada, ela se tornou auto-sustentável, através da comercialização das mesas.
\end{abstract}

O prefeito prossegue caracterizando a organização espacial da Vesperata, ao questionarmos a não participação da população no evento. Ele comprova o elitismo do "espetáculo" que ocorre em espaço público e reconhece a insatisfação popular por ser destinado ao turista.

O que se fez foi para evitar não é? Porque tem as mesas, na praça, e o pessoal (o residente) começava a entrar no meio das mesas e atrapalhar as pessoas (os turistas), então coloca-se fita zebrada numa determinada parte para separar mesas e população; mas o povo fica assistindo em volta da fita zebrada. Por questão de segurança, também resolveu-se fazer um fechamento. O povo não gosta da fita zebrada, tentamos explicar, quem quer comprar as mesas fica dentro, quem não quer (não quer ou não pode?) fica de fora.

Logo, as Vesperatas simbolizam o processo mercantil em curso em Diamantina, que favorece a fragmentação da cidade histórica, onde temos, de um lado, residentes esperançosos pela melhoria das condições de vida local, de outro, turistas ávidos pelo consumo do espaço. Meneses (1999, p. 99) questiona como fazer conviver 
juntos turistas e residentes, mesclar ações grupais e individuais, em seus distintos ritmos culturais. "Como desfetichizar, no turismo, o universo cultural?". Para Meneses, a desterritorialização, a massificação, a identidade como mecanismos de segregação levam à fetichização.

Com seu sentido metamorfoseado, as Vesperatas simbolizam, hoje, a incessante busca do lucro e, principalmente, da renda de monopólio, que impõe a procura de critérios de especialidade e singularidade nos lugares. Difunde-se a irreplicabilidade através do apelo à tradição, ou pela descrição direta do patrimônio cultural (material e imaterial); invocam-se modos de distinção capazes de catalisar os fluxos locais por meio da atividade turística, mesmo que o preço pago seja muito alto para uma maioria que é atingida pela fragmentação socioespacial; (re)produz-se Diamantina Patrimônio Mundial como uma mercadoria global, na fase da cenarização progressiva do patrimônio cultural.

Assim, a questão que nos inquieta é a seguinte: Que significa Patrimônio Mundial quando ele, gradativamente, deixa de funcionar como patrimônio local, patrimônio municipal e patrimônio regional?

Busca-se tornar a cidade competitiva. Ela é inserida - como um nó - na rede mundial das cidades, enquanto "capital simbólico" e "cultura", valor de uso e valor de troca, um bem a ser "preservado" para ser "mercantilizado", tornando-se atraente ao capital nacional e internacional. Rentabilidade e patrimônio cultural se dão as mãos, no novo processo de revalorização urbana "- sempre, evidentemente, em nome de um alegado civismo (...) E para entrar neste universo dos negócios, a senha mais prestigiosa - a que ponto chegamos! (Sofisticação?) - é a cultura" (ARANTES, 2002, p. 31).

Enfatiza-se a história e a tradição locais - agora, metamorfoseadas -, 0 marketing a respeito de importantes festividades sagradas e profanas, bem como a singularidade e irreplicabilidade (baseadas na universalidade e excepcionalidade que consagram os bens inscritos na Lista do Patrimônio Mundial) da arquitetura colonial barroca, com o suporte de um bombardeio de propagandas imagéticas que exibem formas refuncionalizadas e tidas como irreplicáveis, únicas.

Esse processo perverso de mercantilização de todas as esferas da vida, de maneira geral, e do patrimônio, de forma específica, redundam na criminilização da pobreza (proteger turistas dos residentes), na precarização do trabalho (artesãos que se resumem a fabricantes de objetos, que não podem ter vida cultural ativa em seu próprio 
território), na desqualificação da vida, na precarização da periferia, na violabilidade dos espaços públicos (agora, privatizados) e na tomada capitalística inescrupulosa da cidade histórica - um símbolo do processo civilizatório, da formação socioespacial (SANTOS, 2004) e da constituição territorial do Brasil. Do uso à troca, da "preservação" à "mercantilização", Diamantina encerra o antagonismo dos elementos caracterizadores da dialética da construção destrutiva que envolve os bens culturais do mundo, onde a partir da síntese desses elementos contraditórios, temos algo novo: a fragmentação oriunda da valorização do espaço que objetiva a venda da cidade histórica.

Assim, confirmamos nossa primeira problemática de trabalho, sem restar dúvidas: a inclusão de Diamantina na Lista do Patrimônio Mundial [UNESCO] e a posterior implantação do Programa Monumenta [Prefeitura Municipal / Governo Federal / BID] não respondem, verdadeiramente, ao papel principal de valorização cultural, memorial e identitária; estabelecem-se, primeiramente, como processos que têm na "valorização do espaço" (MORAES e COSTA, 1996) um adendo para a especulação econômica, especulação imobiliária e para a exploração de uma maioria em benefício de uma classe.

Inserida em um mundo altamente competitivo, de forma que sua localização no sertão de Minas Gerais não representa um empecilho para a territorialização do capital, Diamantina é enredada pela luta resultante da acumulação de marcos de distinção e "capital simbólico coletivo" (HARVEY, 2005), onde a "valorização do espaço" (MORAES e COSTA, 1996) aparece como um motor que impulsiona a mercantilização das formas culturais nos lugares, favorecendo não apenas a acumulação territorial específica do capital, mas a localização seletiva dos equipamentos e infra-estruturas urbanas. Estado e agentes públicos unem-se (na corrida pela inscrição da cidade na Lista do Patrimônio Mundial e pela implantação do Programa Monumenta) com o propósito de se auferir renda de monopólio, favorecendo a constituição de uma cidade dividida, com um centro em via incipiente de "banalização" e uma periferia cujo processo de "precarização" apresenta-se acelerado. Não podemos perder de vista que a atual produção socioespacial de Diamantina segue a lógica contraditória de expansão do capitalismo e seletividade do capital, favorecendo a concentração territorial do dinheiro, do poder e do próprio capital.

Daí a importância da categoria espaço em nossa análise, como já apontamos, pois as transformações advindas com a tendência fragmentária do capitalismo redimensionam as relações e práticas sociais, exigindo um arcabouço teórico que 
acompanhe as novas transformações do lugar, dando suporte à análise da realidade multidimensional e em movimento; em nosso estudo, uma realidade socioespacial ressignificada. Mudanças que advém do redimensionamento do espaço-tempo, onde a produção não pode mais ser considerada meramente no sentido clássico, segundo Carlos (1996), por ser também reprodução das relações sociais contemporâneas, de forma que a reprodução do espaço social surge como condição necessária para a operacionalização do modo de produção capitalista. Isso faz com que o mundial torne-se referência como ponto de partida e de chegada dos novos vetores do capitalismo, o mundo se faz mundo nas partes, nos lugares, deixa para trás uma virtualidade desagregada e desagregante para assumir uma virtualidade agregada e que "agrega" (ou tenta agregar). Essas mudanças exigem um posicionamento claro sobre a formação socioespacial, ou seja, sobre o "estudo das sociedades humanas em sua obra de permanente reconstrução do espaço herdado das gerações precedentes, através das diversas instâncias da produção." (SANTOS, 2004, p. 240).

É nesse esforço que direcionamos esta pesquisa, que busca compreender a produção socioespacial de uma cidade herdada de gerações precedentes, uma cidade com características universais excepcionais, de acordo com os critérios da UNESCO, que hoje são tidas como "singulares" e "autênticas", de acordo com o discurso dos novos empreendedores urbanos (Estado, mercado, planejadores e promotores culturais) que visam a sua refuncionalização em nome de um capital que (re)produz uma cidade dual. Esse movimento do "universal excepcional" ao "singular autêntico" é uma das facetas do que chamamos dialética da construção destrutiva que envolve os bens culturais do mundo, em especial, Diamantina. Essa lógica dialética, hoje, mediada pelo Estado junto ao mercado, marcada por uma "preservação" em prol da mercantilização, representa muito bem uma proposição de Milton Santos em Metamorfoses do Espaço Habitado. Para o autor, a relação social, por mais parcial ou menor que pareça, contém parte das relações que são globais. A história que se passa, nesse instante, em qualquer lugarejo do planeta não se restringe aos limites desse lugarejo, ela vai muito além; para Milton, a história da produção de um fato desencadeia um processo bem mais abrangente, que insere o fenômeno em contextos cada vez mais amplos. No nosso entendimento, o desencadear dos processos históricos são acompanhados por contradições e jogos relacionais simultâneos frutos da necessidade de expansão do capitalismo, que rebatem sobre os 
territórios. Nesse sentido, a abordagem histórica e dialética adotada nesta pesquisa justifica-se por tentarmos identificar, no território urbano, as espacialidades resultantes da operação contraditória na busca de reprodução do capitalismo, que atinge as cidades históricas do interior brasileiro. Logo, essa pesquisa pode representar uma fonte de esclarecimento e informação para o embasamento crítico de uma população frágil e carente que tolera um sistema social e econômico por não perceber sua lógica perversa. No capítulo que se segue, analisaremos, dialeticamente, a situação da periferia de uma cidade em que os agentes públicos e privados somam forças e se voltam para a valorização de seu centro.

A uma situação sucedem outras: a situação representa uma instabilidade. Por trás da fotografia de uma situação há o movimento. O processo e a própria história, o movimento, a luta entre contrários, contrários que se chocam e criam uma nova realidade. Vamos aqui privilegiar apenas alguns elementos que participam desse processo dialético. O externo e o interno, o novo e o velho, o Estado e o mercado são três das grandes contradições de qualquer situação, são três pares dialéticos referentes ao fato geográfico. (SANTOS, 2008, p. 104) 


\section{Parte III}

Diamantina. Da valorização do espaço à fragmentação articulada do território urbano 


\section{Capítulo 4.0 - A dualidade da "valorização" do centro histórico frente à "precarização" da periferia como fator de transformação da realidade e do imaginário do diamantinense: uma questão de produção socioespacial capitalística}

Ao considerar uma maior porção do território urbano de Diamantina - a cidade enquanto totalidade inserida no contexto global - evidenciam-se, ainda mais, as ações público-privadas marcadamente concentradoras de capital, da estrutura urbana e de cuidados com o tecido urbano; essa concentração territorial do capital ganha relevo a partir de sua consagração como Patrimônio Mundial e da implantação do Programa Monumenta, "eventos" analisados anteriormente.

A análise geográfica da produção socioespacial de uma cidade histórica, hoje, deve abranger uma visão totalizadora da cidade e não focada em relação ao núcleo tombado enquanto espacialidade singular, como se o mesmo explicasse por si só a realidade vigorante a partir de suas formas pretéritas, de seus antigos e novos conteúdos. Acreditamos que a análise de uma cidade histórica que não leve em consideração a produção socioespacial fora de seu núcleo tombado pode não dar conta do entendimento das novas dinâmicas e relações propiciadas pelas "rugosidades" (SANTOS, 2002) presentes no próprio centro, que favorecem novos fluxos capazes de transformar a realidade e o imaginário da população residente, não apenas no centro histórico. Uma análise focada e desarticulada pode não dar conta da realidade multidimensional e em movimento da formação de novas espacialidades acarretadas pelas novas estratégias do planejamento dessas cidades do interior brasileiro, no âmbito da Geografia.

Logo, analisamos a produção socioespacial de Diamantina (ampla porção do território urbano cuja delimitação apresentaremos no mapa a seguir) a partir do entendimento de que a sociedade e sua dimensão espacial podem ser interpretadas através da espacialidade da política, da economia e da cultura, de maneira correlacional e dialética. Uma abordagem da espacialidade da economia (sobretudo, quando a cultura torna-se objeto de mercantilização, nas cidades) força-nos a discorrer sobre a "valorização do espaço"; a espacialidade da política, que remonta ao delineamento do poder, dirige a análise para a questão da "dominação do espaço"; já a espacialidade da cultura, que se estabelece enquanto espaço da consciência, exige uma abordagem sobre 
a "representação do espaço". Dessa maneira, seja através da valorização do espaço, da dominação do espaço ou da representação do espaço, o que pretendemos frisar é que esse contexto acaba por particularizar, exigindo um método de análise numa perspectiva histórica dialética que, no limite, redunda no reconhecimento da formação do território urbano, com uma ênfase política que articula valorização e representação (consideramos as três análises conjuntamente, representam uma simultaneidade contraditória). Logo, o entendimento da produção socioespacial de Diamantina não se restringe ao âmbito da política, da economia ou da cultura, mas na imbricação das três abordagens para o melhor entendimento das espacialidades sociais, de sua realidade no atual momento histórico. ${ }^{147}$

\begin{abstract}
Assim, enquanto a valorização do espaço aparece como o horizonte teórico genérico de indagações da geografia proposta, a formação territorial desenha-se como o objeto empírico da pesquisa, o ajuste de foco naquela ótica angular de captar o movimento histórico própria (sic) da geografia humana. Uma abordagem que busca apreender a valorização do espaço em manifestações únicas sincronicamente analisadas, logo, em processos de formação de territórios singulares. Transita-se, assim, da vaguidade da categoria "espaço" ao preciso e objetivo conceito de "território" (...) E nesse, ou melhor, em sua construção, às determinações mais especificamente econômicas se associam às injunções do universo da política e da cultura. (MORAES, 2000, p. 47).
\end{abstract}

Nesse contexto, valemo-nos da idéia de que o processo de produção do espaço é resultado exclusivo das ações e do trabalho humano, que incorpora e cria valor, valor no espaço e valor do espaço ${ }^{148}$, de acordo com Moras e Costa (1996) e Moraes (2000). Isso nos leva a crer que a análise geográfica da produção socioespacial de Diamantina, hoje, remete-nos ao que Milton Santos denominou para o espaço como uma

\footnotetext{
${ }^{147}$ Valorização, dominação e representação são bem exemplificadas pelo processo histórico de produção do território urbano, em Diamantina. Hoje, as ações destinadas à busca da chancela da UNESCO e à implantação do Programa Monumenta simbolizam a imbricação de ações políticas e interesses econômicos voltados para a mercantilização do patrimônio cultural, de forma que o urbano assume uma nova representação no imaginário do residente. Sobre essa relação imbricada, foi discutida, teoricamente, em aula proferida pelo Prof. Dr. Antônio Carlos Robert Moraes, aos alunos do Programa de Pós-Graduação em Geografia Humana, no Departamento de Geografia da USP, no dia 25 de setembro de 2007; disciplina: Formação Territorial e Teoria em Geografia Humana.

${ }^{148}$ Moraes e Costa (1996) e Moraes (2000) definem o "valor no espaço" como aquele criado pelo trabalho, onde o espaço torna-se o receptáculo da produção material, de forma que a diferenciação do trabalho acumulado sobre áreas distintas define o valor real. Assim, a produção instala-se no espaço valorizando nesse a localização e a distância; "é um valor criado", segundo os autores. Contudo, torna-se relevante em nossa abordagem o "valor do espaço”, enquanto um valor que é transferido aos objetos durante sua criação ou enquanto um valor que é atribuído a objetos pré-existentes; o "valor do espaço" é transferido no processo de trabalho para o produto "através das características próprias de cada lugar” (MORAES e COSTA, 1996, p.122), o que ocasiona uma heterogeneidade na produção e apropriação dos lugares, onde singularidades são estabelecidas através do trabalho humano; valores distintos são atribuídos a estruturas socioespaciais distintas.
} 
"acumulação desigual do tempo", onde a divisão territorial e a divisão social do trabalho são as forças capazes de criar novas formas e de dar novas funções a objetos que incorporam novos conteúdos. São forças reestruturantes e reorganizadoras de uma cidade que, no passado, representou o território dos diamantes da metrópole portuguesa, que adotou medidas drásticas de controle territorial (sem igual na história colonial) e que teve, ao longo de sua história, a extração de diamantes como principal atividade econômica; atualmente, a cidade é evidenciada como um novo "enclave territorial" alcançado pela "indústria cultural" por meio do turismo ${ }^{149}$.

Partindo da valorização do espaço - que representa uma análise mais abstrata das ações e relações capitalísticas inerentes ao processo mercantil que envolve a refuncionalização de patrimônio cultural ${ }^{150}$ - identificamos a fragmentação do território urbano (enquanto particularidade) quando temos os bairros de entorno ao centro com variados e sérios problemas socioespaciais, que vão desde infra-estrutura urbana, como iluminação pública, falta de água, esgoto, pavimentação, equipamentos de serviços diversos etc. até precárias moradias e elevado índice de desemprego, além da transformação do imaginário de seus residentes em relação ao seu patrimônio, à sua cultura e à sua cidade.

Não podemos perder de vista nossa segunda problemática de pesquisa, de que as ações voltadas ao centro histórico de Diamantina (em especial, após sua inclusão na Lista do Patrimônio Mundial e da implantação do Monumenta) constituem-se em "eventos" (SANTOS, 2002) que redundam em uma política de patrimônio que desvia a atenção pública e recursos de problemas mais amplos, sobretudo, fora do núcleo tombado, o que vem afetando as condições de vida da população local, ressignificando "valores" e produzindo um território urbano fragmentado. Adiantamos que identificamos,

\footnotetext{
149 Podemos considerar que o turismo em Diamantina cumpre o importante papel de articulá-la com o mundo, considerando-o um fenômeno complexo que envolve outros fenômenos sociais, culturais e econômicos da sociedade contemporânea. Cruz (2003) deixa claro que os usos determinantes de dados territórios pelo turismo, acarretam diferentes tipos de fluxos de capitais, informações e pessoas; fluxos determinados fora do lugar, por pontes entre o local e global, que dinamizam o espaço. Silveira (1997) também considera uma nova lógica de fluxos numa nova era econômica mundial, que produz o turismo, onde novas formas de circulação dos bens, do dinheiro, das idéias, dos comandos, das modas e novas formas de consumo acabam por gerar novas formas de produção. "No período técnicocientífico-informacional, as formas de consumo não-material e, entre elas, o lazer, aumentam e se disseminam no território. Esse parece ser, hoje, o contexto da produção do turismo.” (SILVEIRA, 1997); contexto da atual dinâmica econômica de Diamantina.

${ }^{150}$ Não esqueçamos que o centro histórico de Diamantina é envolvido por uma lógica que recria singularidades e irreplicabilidades em prol de se alcançar a renda de monopólio, analisada por Harvey (2005), num processo que se dá ante a cenarização progressiva do patrimônio.
} 
através das pesquisas de campo, uma população que clama pela ausência do poder público municipal na periferia, enquanto todas as ações estão voltadas para o centro da cidade, na atual gestão do município, o que demonstra limites e possibilidades do planejamento urbano de Diamantina e a confirmação de nossa segunda problemática de pesquisa.

Os gráficos elaborados (que serão apresentados) a partir da tabulação dos dados colhidos por ocasião das entrevistas (que apresentam uma clara contradição entre a retórica capitalística dos agentes públicos e o clamor sublevado dos habitantes locais), somados à nossa observação empírica, oferecem-nos uma dimensão da realidade socioespacial de Diamantina, no sertão mineiro, num momento em que a cidade é projetada mundialmente por via do turismo cultural e recriada como uma mercadoria singular e irreplicável. ${ }^{151}$

Açambarcado pela cenarização progressiva do patrimônio, já mostramos que o centro histórico de Diamantina vem sendo destinado à troca, cada vez mais seus modos operantes de usos são subordinados ao mercado, o patrimônio é condicionado à privatização e à lógica do neoliberalismo, ${ }^{152}$ o que se reflete na totalidade do território urbano, que configura uma cidade dual.

De acordo com Santos (2007, p. 79-80), no mundo de hoje, cada vez mais as pessoas se reúnem em áreas mais reduzidas, como se o habitat humano minguasse. Isso permite experimentar, através do espaço, a escassez. Para Milton, a ânsia de se utilizar, mercadologicamente, um dado território, não apenas divide como separa os homens, ainda que eles apareçam como se estivessem juntos. É essa fragmentação a identificada em Diamantina, onde as oposições [centro "valorizado" x periferia "precarizada"] e também [habitantes locais esperançosos por uma vida digna $x$ turistas ávidos pelo consumo do espaço] são agravadas pela correlação dos pares dialéticos uso / troca, "preservação" /

\footnotetext{
151 “A cidade, natureza transformada e artificializada pela ação social, acumula nos seus artefatos o tempo humano. A mudança de postura ideológica da sociedade em relação ao seu patrimônio cultural revela novos universos simbólicos que perfazem um processo contínuo de alterações de valores.” (LUCHIARI, 2005, p. 96).

152 Ao longo da pesquisa deixamos claro acreditar que a crítica à mercantilização do patrimônio cultural deve se fundamentar em um posicionamento que leve em consideração o movimento dialético entre o valor de uso e o valor de troca. Essa fundamentação teórico-metodológica baseia-se na crença de que, hoje, há a mercantilização total de um valor de uso civilizatório, que é a cidade (ARANTES, 2002), que desprende e pulveriza os laços do passado através de ações conscientes, programadas e equivocadas da parceria dos setores públicos e privados com o fim último de se estabelecer um espetáculo urbano de poucos personagens para selecionados expectadores, via mercantilização da cultura.
} 
mercantilização, e Estado / mercado; os últimos, constituindo-se como influência da eficácia de vetores hegemônicos externos que promovem políticas de produção do espaço urbano capazes de transformar a realidade e a representação do espaço para diferentes grupos sociais locais.

Devemos considerar que a forma de rebatimento da desigualdade no espaço construído da cidade, logo, depende de como este pode favorecer a acumulação do capital e tem sua geografia própria estabelecida dentro do processo histórico. Para Valença (2006), a cidade é, em diferentes formatos e intensidades, desigual, abrigando seletivamente ricos e pobres. Devemos considerar, ainda, que essa seletividade - que se traduz em segregação espacial, conforme Valença (2006) - também é a tradução no espaço de segregação social cuja natureza é tanto econômica, fruto de um desenvolvimento desigual e combinado, como de outras diferentes ordens. Tal segregação espacial, como no caso de Diamantina, quase sempre é muito fácil de verificar-se, trata-se de um fenômeno visível a olhos nus. "A cidade é repartida - toda ela - por delimitações tanto físicas quanto simbólicas" (VALENÇA, 2006, p. 185). Isso nos remete à questão de que a cidade torna-se cada vez mais importante para a acumulação de capital em geral - produção e consumo de mercadorias e reprodução da força de trabalho - como a produção do espaço urbano é parte nada desprezível dessa acumulação, que se mostra desigual no território. Logo, as ações dirigidas à cidade segue, cada vez mais, a lógica de sua transformação em mercadoria.

No capítulo precedente, já refletimos sobre algumas ações que atuam sobre o patrimônio edificado no centro histórico de Diamantina, que esboçam uma política de preservação que visa ao desenvolvimento de um "sistema simbólico" que se adapta às estruturas do sistema capitalista, de acordo com a dinâmica de consolidação de práticas e valores de consumo a partir da apropriação dos bens culturais metamorfoseados em "capital simbólico". Ao considerarmos o Programa Monumenta em Diamantina (Patrimônio Mundial e mercadoria global) vimos a dialética da "preservação" patrimonial que se dá simultaneamente às ações relativas à nova economia urbana capitalista (gerida pelo Estado e pelo mercado, no município), que reproduz o centro da cidade e rebate sobre o território urbano, num contexto mais amplo.

Resta-nos, neste capítulo, de acordo com nossa proposta inicial, a análise da produção socioespacial de três bairros periféricos da cidade, para identificarmos como o 
par dialético "preservação" / "mercantilização" favorece a produção do espaço urbano de maneira mais abrangente, ou seja, buscaremos compreender como as atuais ações públicas transformam a realidade (condições materiais) e o imaginário (consciência do espaço) do habitante local. Buscamos superar a enorme dificuldade encontrada na obtenção de dados oficiais sobre a periferia de Diamantina, por meio de nossa pesquisa empírica, onde nos valemos de nossos levantamentos de campo, com destaque para as entrevistas semi-estruturadas realizadas com agentes públicos e o questionário aplicado junto à população residente. A análise enfoca os bairros Palha, Rio Grande e Bela Vista (ver mapa a seguir), bairros periféricos dos mais carentes de Diamantina, com evidentes problemáticas socioespaciais, o que nos remete à dualidade da "valorização" do centro histórico frente à "precarização" da periferia como fator de transformação urbana e produção socioespacial capitalística. A foto 22, abaixo, indica-nos o sítio original de Diamantina e uma parte da mancha urbana que se desenvolve a partir do mesmo, espraiando-se de norte a sul e de leste a oeste; o que esboça a necessidade de se pensar a preservação de patrimônio em um contexto que incorpore o território urbano enquanto totalidade e não fragmentado.

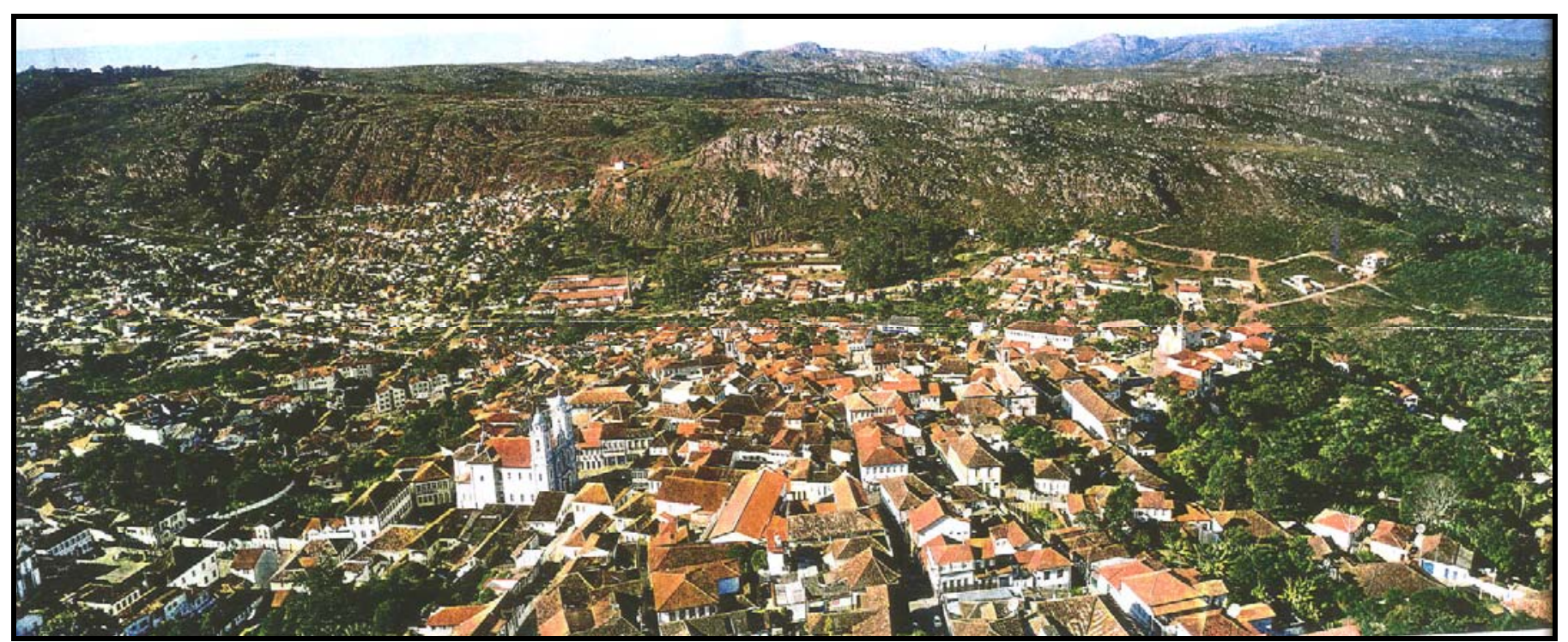

Foto 22: Panorâmica do centro histórico de Diamantina e seu arredor, a uma altitude de $1400 \mathrm{~m}$, na Serra do Espinhaço. Foto: PMMG.

Antes de lançarmos um olhar geográfico crítico sobre a periferia de Diamantina, retomemos algumas propostas do Plano Diretor, elaborado em 1999, que julgamos relevantes para nossa análise, pois nos oferecem uma dimensão da concepção que se tem de planejamento, na cidade, por parte da governança urbana. 


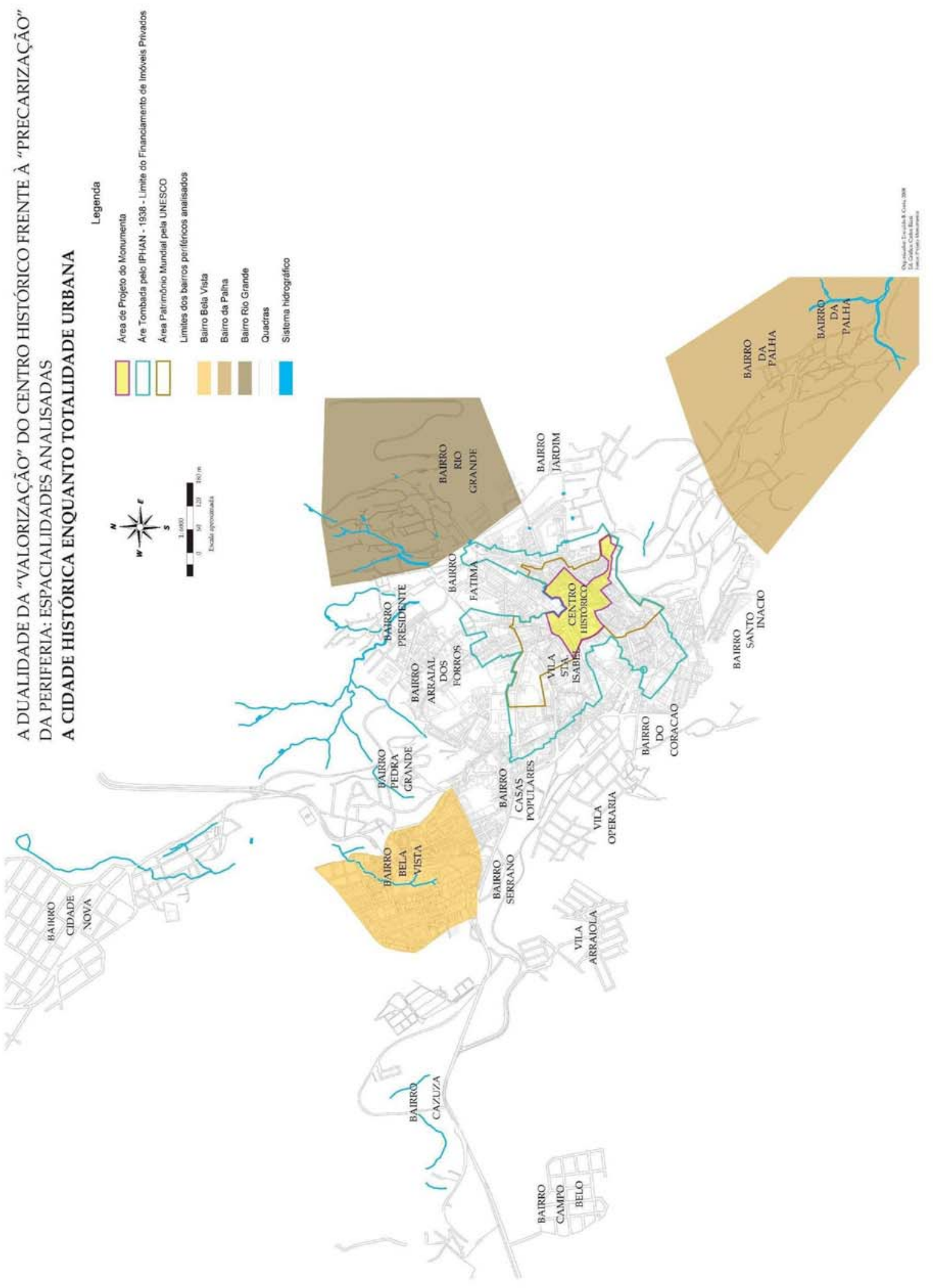


Os responsáveis pela elaboração do Plano Diretor de Diamantina, finalizado em 1999, assumem, em sua introdução, que o documento representa a última etapa da campanha iniciada em 1997 pela elevação da cidade a Patrimônio Cultural da Humanidade, onde "sintetiza o conjunto de medidas e normas que os poderes públicos e a comunidade, através de seus representantes na Câmara, comprometem-se a adotar para a preservação de nossas riquezas históricas, arquitetônicas e naturais e para o planejamento de nosso desenvolvimento urbano futuro" (PREFEITURA MUNICIPAL, 1999). Prossegue a introdução do documento,

Às vésperas de um novo século, um novo milênio, é com orgulho que a cidade de Diamantina está a um passo de conquistar o seu reconhecimento internacional pela UNESCO. Este título, arduamente buscado nos últimos anos, abrirá certamente novas perspectivas para o desenvolvimento econômico, cultural e social não só de Diamantina, mas do Vale do Jequitinhonha, de Minas Gerais e do Brasil. E em nome do povo de nosso município, a Câmara dos Vereadores mostrou o seu compromisso com estes objetivos maiores aprovando o Plano Diretor.

É notório, na introdução do documento, que a maior preocupação em sua elaboração estava na conquista da chancela da UNESCO e menos comprometida com um planejamento que atingisse, de forma objetiva e prática, a periferia da cidade, apesar de enfocar, teoricamente, a totalidade do território urbano. Mais uma vez, identificamos o comprometimento do Estado com as necessidades, sobretudo, de uma classe; o planejamento, historicamente, não chega à periferia, é feito das elites para as elites, o que temos são modelos segregacionistas de planejamento urbano, quando poderia se constituir em um potencial instrumento de melhoria da qualidade de vida de toda população local.

Fica claro que o Plano Diretor de Diamantina estabeleceu-se como um documento fundamental de orientação do poder público e da iniciativa privada, em especial, como um instrumento primaz para a inclusão da cidade na Lista do Patrimônio Mundial (o que é positivo para Diamantina [apesar de permanecer no plano teórico para a periferia], uma cidade de mais de 40.000 habitantes que adentraria o século XXI sem o mesmo). Consta como seus objetivos: 1) garantir as funções sociais da cidade e a propriedade imobiliária urbana; 2) melhorar a qualidade de vida dos habitantes, indicando áreas que devem receber especial atenção do município, minimizando desigualdades na 
distribuição dos equipamentos e serviços urbanos ${ }^{153}$; 3) garantir a preservação do Patrimônio Arquitetônico e Urbanístico através de restrições à construção dentro das áreas oferecidas à UNESCO para Patrimônio Cultural da Humanidade e tombada pelo IPHAN, e da regulamentação de uso e ocupação fora desta área ${ }^{154}$; 4) conter a expansão da área ocupada de forma desordenada e imprópria, buscando alternativas para a ocupação indesejada. ${ }^{155}$

O Plano prescreve a forma de ordenamento da ocupação e do uso do solo urbano, ações para a manutenção das funções sociais da propriedade, diretrizes para proteção da memória e do patrimônio cultural, diretrizes do sistema viário e de transportes, diretrizes relativas ao meio ambiente, diretrizes gerais da política de saneamento, diretrizes da política habitacional e diretrizes para a localização de equipamentos de grande porte e interesse social.

Sobre o zoneamento, que trata da ocupação e do uso do solo urbano, ele prescreve oito áreas a saber:

- Zona de Preservação Rigorosa - ZPR - que corresponde ao Perímetro de Tombamento do IPHAN, dentro do qual se insere perímetro oferecido a UNESCO para inscrição na Lista do Patrimônio Mundial;

- Zona de Preservação Complementar - PC - que corresponde às áreas que não apresentam grandes contrastes e discrepâncias com relação à $\mathrm{PR}$, integrando-se a imagem urbana do Centro Histórico;

- Zona de Proteção do Centro Histórico - ZPCH - que é constituída pelas áreas urbanizadas que envolvem o Centro Histórico, à nordeste;

\footnotetext{
153 Já afirmamos anteriormente que esse objetivo traçado em 1999 não está sendo alcançado, ao contrário, agrava-se sobremaneira, em Diamantina, decorridos 9 anos. A periferia de Diamantina clama por melhores condições de vida, de acordo com nossos questionários.

${ }^{154}$ Observamos uma maior atenção destinada ao centro histórico em relação aos demais bairros ou Zonas de Preservação da cidade.

${ }^{155}$ Como já afirmamos anteriormente, talvez essa ocupação desordenada seja mais indesejada pelos agentes sociais (que não vêem outra saída para sua sobrevivência, a não ser a ocupação de terrenos públicos) que a fizeram do que pelos responsáveis pelo planejamento urbano de Diamantina.
} 
- Zona Residencial - ZR - que abrange as áreas de tipologias residenciais consolidadas, confrontantes com a $\mathrm{ZPCH}$;

- Zona de Contenções das Ocupações - ZCO - que abrange as áreas de interferência visual indesejável na paisagem, que deverão ter sua expansão e adensamento contidos;

- Zona de Urbanização Prioritária - ZUP - que abrange diversas áreas descontínuas de urbanização precária, nas periferias do tecido urbano.

- Zona de Grandes Equipamentos - ZGE - que abrange uma faixa de 100 m de largura para cada lado, a partir do bordo da pista de rolamento da rodovia BR 367, da Reserva do Pau de Fruta até o trevo de Biribiri;

- Faixa de Reserva - FR - que abrange ambos os lados do Rio Grande e Ribeirão da Palha, e dos córregos da Prata e Pururuca, e é destinada à implantação de tratamento sanitário e paisagístico da calha dos referidos cursos d'água e à implantação de novas vias de circulação.

Notemos que o Plano, teoricamente, abrange a totalidade do território urbano de Diamantina (sobretudo as áreas de ocupação "indesejada") dando significativa ênfase ao centro histórico, de forma que a Zona de Preservação Rigorosa, a Zona de Preservação Complementar e a Zona de Proteção do Centro Histórico constituem, conjuntamente, áreas cujas diretrizes visam aos cuidados com o núcleo tombado. $\mathrm{Na}$ prática, a teoria é outra; decorridos nove anos, realmente, espera-se o momento ideal para que ocorra "o planejamento (...) do desenvolvimento urbano futuro da cidade"; espera-se, ainda, o momento certo para se contemplar com o planejamento todo o território e toda a população local. Logo, a elaboração do Plano Diretor elaborado em 1999, em Diamantina, aponta-nos para uma ação púbica que visa, inicialmente, a atender às necessidades de expansão do capitalismo e de reprodução do capital, com a refuncionalização dos bens culturais.

Para Castells (1975, p. 209), os problemas urbanos, isto é, os processos sociais de consumo coletivo, são, em muitos aspectos, dos problemas essenciais postos 
às sociedades industriais avançadas. Como, no fim das contas, o que está em jogo é a questão de se o sistema social é ou não capaz de absorver o ritmo das mudanças impostas, os problemas devem ser tratados por instituições público-administrativas, pelo Estado, e geridos em termos de previsão, com expectativas para um longo prazo. "A problemática do urbano coincide cada vez mais com a do planejamento urbano" (CASTELLS, 1975, p. 209).

A análise da organização espacial de Diamantina remete-nos a um complexo emaranhado de usos da terra justapostos entre si. Áreas são definidas pelos seus usos, como o centro histórico, local de lazer para o turismo, de comércio, de serviços e de gestão, apresentando, ainda hoje, funções múltiplas historicamente estabelecidas; o turismo e o turista é que, gradativamente, "ganham espaço", em relação às outras atividades e sujeitos sociais. O centro histórico de Diamantina constitui-se, ainda, em um espaço complexo de vivência referencial para o diamantinense (isso revela a incipiência do processo de mercantilização do patrimônio em Diamantina, o que confirma nossa problemática de que a "valorização do espaço" na cidade ganha relevo a partir de sua inclusão na Lista do Patrimônio Mundial e da implantação do Programa Monumenta, no início do século XXI, quando cidades como Ouro Preto e Tiradentes já estavam profundamente refuncionalizadas pela atividade turística (COSTA, 2008a)). A cidade também apresenta, de forma desconcentrada, pequenas indústrias e áreas residenciais diversas em termos de forma e conteúdo social (um olhar a partir da periferia), o que nos remete a um território urbano, dialeticamente, fragmentado e articulado.

Ao indagarmos o secretário de turismo de Diamantina, Walter Cardoso França Júnior, sobre o risco de a cidade, nos próximos anos, ver agravadas suas problemáticas socioespaciais, no que diz respeito à "cenarização" e segregação do residente, do centro, como identificamos em Tiradentes e Ouro Preto (COSTA, 2008a), o mesmo foi taxativo: "Acredito que sim, o risco é natural, isso ainda não é muito evidente, isso pode acontecer"156. Já o coordenador do Programa Monumenta, Carlos Emanuel considera que não é possível, devido ao grande fluxo diário de moradores para o centro da cidade. A postura contraditória de ambos agentes públicos revela-nos visões de mundo distintas e pontos de vista díspares sobre o que vem ocorrendo em Diamantina, mesmo sendo

\footnotetext{
${ }^{156}$ Entrevista do secretário de turismo de Diamantina, Walter Cardoso França Júnior, concedida ao autor em 13 de fevereiro de 2008.
} 
ambos diretamente envolvidos com a busca do desenvolvimento do turismo na cidade. $\mathrm{O}$ primeiro, com uma visão de longo prazo, crê na possibilidade do centro histórico de Diamantina tornar-se um cenário banal, onde o residente não tenha vínculo direto com território central da cidade, uma vez que já é evidente a saída de moradores do centro, como já apresentamos uma fala sua anteriormente; já o segundo, com uma visão mais imediatista, não crê nessa possibilidade, dada a complexidade da atual dinâmica que ronda o centro histórico.

\begin{abstract}
Não é possível, porque o cotidiano da população de Diamantina está ligada ao centro histórico, tanto que ali você tem um banco, uma transportadora, um forte comércio, você encontra com as pessoas nas ruas, caso diferente de Tiradentes, onde baixou Rio de Janeiro e São Paulo. Sobre reassentamento de residentes ou retorno da população para o centro histórico, no caso de Diamantina não tivemos nem desapropriação nem o reassentamento, com o Monumenta. Eu sei que há intervenções que há necessidade de retirar o pessoal, não é o caso de Diamantina. O comércio de Diamantina é antigo, não temos um centro histórico vazio, tem vida própria, tem uma movimentação cultural intensa, que a iniciativa parte da população e não somente pela prefeitura, o Monumenta foi assimilado por segmentos da prefeitura, pois a prefeitura não podia onerar seu quadro com arquiteto, engenheiro, economista, exclusivos para o Monumenta. ${ }^{157}$
\end{abstract}

Para Corrêa (2005, p. 07), o espaço urbano é simultaneamente fragmentado e articulado, de forma que cada uma de suas partes mantém relações espaciais com as demais, ainda que de intensidades desiguais; no entanto, a fala dos agentes públicos de Diamantina remete-nos à desarticulação das ações de organização do espaço; as mesmas não contemplam as transformações urbanas atuais de Diamantina, sobretudo, no que diz respeito à situação socioespacial da periferia da cidade; as atenções voltam-se para o centro histórico, de forma objetiva e pontual.

Em Diamantina, a articulação do território urbano, as relações socioespaciais, podem ser identificadas, empiricamente, através do intenso fluxo de veículos no pequeno centro histórico (o que se constitui em uma séria problemática), por meio do deslocamento cotidiano identificado nos bairros residenciais, da locomoção para os distintos locais de trabalho, visitas a parentes e amigos, busca de locais para o lazer, etc.

\footnotetext{
${ }^{157}$ Entrevista do coordenador do Programa Monumenta em Diamantina, Carlos Emanuel, concedida ao autor em 12 de fevereiro de 2008 .
} 
O centro histórico aparece também, conforme a função estabelecida por Corrêa (2005) para um centro urbano, como núcleo de articulação da cidade, o nó de uma pequena rede, de forma que as relações espaciais integram, diferentemente, as diversas partes da cidade, unindo-as em um conjunto articulado. Logo, podemos considerar, dialeticamente, o espaço urbano de Diamantina como fragmentado e articulado. Relembrando, consideramos em nossa segunda problemática que as atuais ações voltadas para o centro histórico de Diamantina redundam em uma política de patrimônio que desvia a atenção pública e recursos de problemas mais amplos, sobretudo, fora do núcleo tombado, o que vem afetando as condições de vida da população local, ressignificando "valores" e produzindo uma cidade altamente fragmentada, o que caracteriza a dialética da fragmentação articulada mencionada por Corrêa (2005).

\footnotetext{
O espaço da cidade capitalista é fortemente dividido em áreas residenciais segregadas, refletindo a complexa estrutura social em classes (...) é um reflexo tanto de ações que se realizam no presente como também daquelas que se realizaram no passado e que deixaram suas marcas impressas nas formas espaciais do presente (...) a desigualdade constitui-se em característica própria do espaço urbano capitalista (...) O espaço da cidade é assim, e também, o cenário e o objeto das lutas sociais, pois estas visam, afinal de contas, o direito à cidade, à cidadania plena e igual para todos. (CORRÊA, 2005, p. 08-09)
}

Nossa pesquisa de campo contribuiu para identificarmos, empiricamente, a vigente fragmentação articulada do território urbano, ao considerarmos, comparativamente, o centro histórico e os bairros Palha, Rio Grande e Bela Vista, os três últimos desprovidos de diversos equipamentos de infra-estrutura, saneamento básico e assistência pública, que aparecem concentradas no centro da cidade e seu entorno (o mapa apresentado anteriormente delimita esta área). A análise do gráfico 13 confirma nossa assertiva, quando temos a grande maioria dos entrevistados nos três bairros da periferia apontando variadas problemáticas socioespaciais em seus respectivos espaços de vivência, em contraponto à população residente no centro histórico, que demonstra maior satisfação com o planejamento da cidade. 


\section{Problemas de saneamento básico e infra-estrutura urbana nos bairros entrevistados}
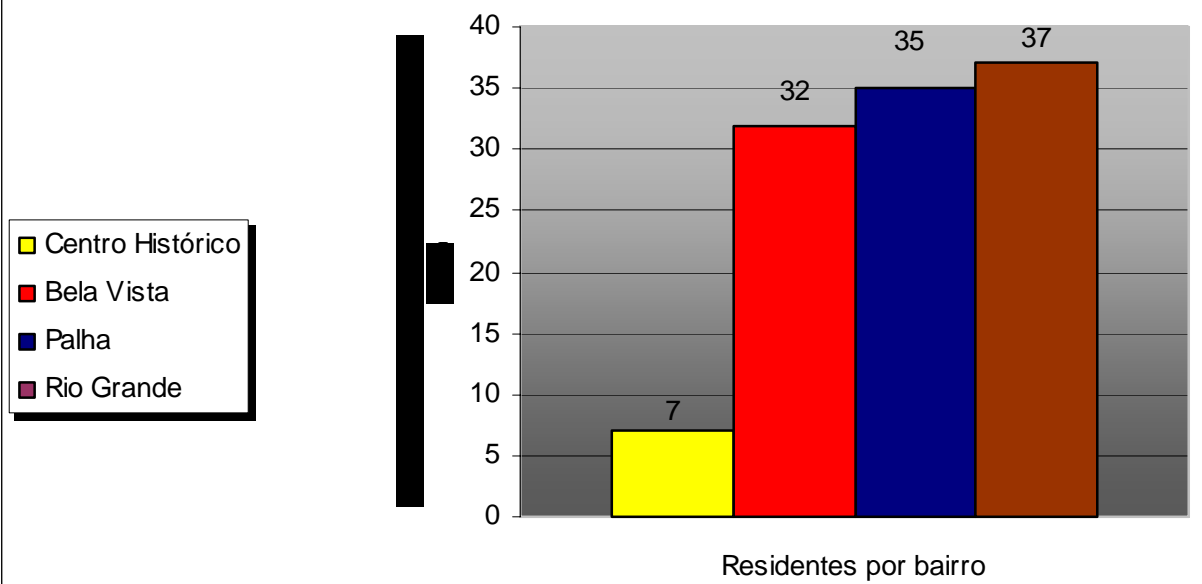

Fonte: Questionário aplicado em Diamantina, 2008 / E Costa.

Gráfico 13

Mais uma vez, fica notória a contradição existente em Diamantina entre a retórica capitalística dos agentes públicos e o clamor sublevado dos habitantes locais. Enquanto a população dos bairros Rio Grande, Palha e Bela Vista apontam a "precarização" de seu território pela negligência dos agentes públicos em relação aos seus espaços de vida, emerge uma retórica descabida por parte dos detentores do poder. De acordo com o atual Prefeito de Diamantina, Gustavo Botelho Júnior, quando o questionamos sobre sua análise dos principais problemas socioespaciais existentes na cidade e sobre a "turistificação" do centro histórico, diz-nos que,

Não temos nenhum problema [socioespacial], a administração falha por falta de planejamento [assume a falta de planejamento], principalmente agora, nestes últimos dois anos. Se você verificar a periferia, está toda asfaltada, e todas casas de alvenaria, inclusive casas boas; e quem trouxe isso foi o turismo, que deu emprego a estas pessoas que são oriundas do garimpo. A Universidade Federal, agora, de 2005 para cá, está em Diamantina, ajudando no desenvolvimento, criando. Por isso falo na falta de planejamento, agora que o turismo e a universidade juntos aumentaram muito a demanda, e não estávamos preparados para um desenvolvimento tão grande, e estávamos sem preparo do quadro técnico, e não estávamos estruturados para este desenvolvimento repentino, foi tão grande esse desenvolvimento, que transformou a vida da população. Diamantina é considerada pelo governo federal como Indutora do Turismo Internacional, Diamantina foi escolhida, em Minas Gerais juntamente com Ouro Preto e Tiradentes. Sobre o PRODETUR, a comunidade era chamada para participar 
de numa reunião; sobre uma das coisas que discutimos, percebi que havia uma divisão entre um grupo que considerava o centro histórico um atrativo turístico e outro grupo dizia que não é um atrativo porque não se pode vender. Com certeza absoluta deve-se vender, porque o município de Diamantina, desde sua origem, vivia da extração de diamantes e até pouco tempo atrás $70 \%$ da economia do município girava em torno da extração dos diamantes, hoje é o turismo. ${ }^{158}$

A fala do prefeito remete-nos à - utopia!? - de uma cidade que não apresenta problemas socioespaciais, a uma cidade que tem no turismo a atividade que vem favorecendo o ordenamento do espaço urbano por si só, bem como a melhoria da qualidade de vida da população local, sem planejamento (essa postura contraria nossas análises de campo e teórica). Contudo, a fala do atual secretário de turismo, Walter Cardoso França Júnior, contradiz o próprio prefeito, pois considera Diamantina, uma cidade com sérios problemas urbanos, o que o faz crer no potencial do turismo para a melhoria da qualidade de vida do diamantinense.

O pessoal que está no entorno de Diamantina, distritos ${ }^{159}$ e periferia, passam por muita dificuldade. Diamantina não tem muito que oferecer em termos de emprego. O turismo é uma nova chance e as pessoas começam a enxergar isso porque está dando dinheiro. Surgiu uma Vesperata com mil coisas que eu sou contra (já tratamos desse evento e das problemáticas que causa), bom, mas é um detalhe, mas é um produto que enche a cidade e se a enche, o hotel pode se manter, o que faz contratar mais, ele amplia espaço, o posto de gasolina vende mais, o artesanato vende mais, e isso vai aquecendo e fazendo aparecer a visão de que eu posso sobreviver disso. ${ }^{160}$

\footnotetext{
${ }^{158}$ Entrevista do prefeito de Diamantina, Gustavo Botelho Júnior, concedida ao autor em 14 de fevereiro de 2008.

${ }^{159}$ Visitamos Mendanha, Guinda, Sopa e Extração, na última atividade de campo, a fim de verificar a importância de Diamantina para esses distritos mais próximos à cidade. Identificamos que Mendanha não possui comércio, apenas uma escola, e todos os serviços são prestados por Diamantina, a cerca de $30 \mathrm{Km}$. Diamantina é central para a sobrevivência da população de Mendanha. Nesse local, os idosos vivem da aposentadoria do INSS e os jovens estudam e trabalham em outros locais (roças). Há apenas, atualmente, uma família que trabalha com a pecuária, próxima ao lugarejo. Distrito de Diamantina, Guinda sobrevive na órbita da primeira. Área de antigo Serviço, este lugarejo não possui agricultura nem pecuária própria, seguindo a característica de toda a região; distante de Diamantina cerca de 15 Km. Seguindo a mesma estrutura de Guinda e Mendanha, Sopa também é distrito de Diamantina, é um lugarejo pacato, que orbita Diamantina, distante desta cerca de $20 \mathrm{Km}$. A aproximadamente $8 \mathrm{Km}$ de Diamantina, Extração é outro lugarejo bem semelhante aos anteriores visitados, tanto na implantação do sítio como nas características sócio-econômicas. Com menos de 200 pessoas, a igreja é localizada numa praça central, com as casas no entorno e uma vida um tanto pacata. Diamantina é centralidade para as questões de saúde, compras, serviços diversos e emprego da população local. Segundo depoimento colhido em 17 de fevereiro de 2008, de Maria Aparecida, a residente mais antiga do Distrito, com 86 anos,

"Precisamos ir para Diamantina para resolver todo o problema. Antigamente, dava para viver da mineração, mas hoje tá difícil. As mulheres trabalha de doméstica em Diamantina, os homem novo estuda para concurso ou vai para Diamantina. Já saiu 48 família para outras cidade, hoje é numa média de 90 família. Aqui não tem criação de gado e nem plantação de mantimento. Eu só lamento que os mais antigos, como meu pai e minha mãe não verem o progresso aqui em Guinda (a entrevistada faz menção ao asfalto que chegou ao lugarejo), antes era tudo terra, a maior poeirada. Se você for em Sopa, vai ver a Igreja de lá mais antiga, a nossa é mais nova, foi reconstruída.”

${ }^{160}$ Entrevista do secretário de turismo de Diamantina, Walter Cardoso França Júnior, concedida ao autor em 13 de fevereiro de 2008.
} 
Ao ouvir os residentes nos bairros Palha, Rio Grande e Boa Vista, identificamos a lógica do ponto de vista do secretário de turismo de Diamantina, que reconhece o processo de "precarização" da periferia (foto 23), onde aparecem como principais problemáticas apontadas pelos moradores: a falta de água, sobretudo em períodos de grandes eventos; esgoto a céu aberto; precariedade das vias públicas; ausência de telefones públicos; ineficiência dos transportes públicos coletivos; falta de segurança pública, descaso com a limpeza de ruas e praças, além do grande desemprego (visivelmente, os bairros Rio Grande e Palha são dois dos bairros mais carentes de Diamantina). Também fica nítida a insatisfação dos moradores em relação à inexistência, por exemplo, de comércio e serviços em geral, em seus bairros, de forma a serem obrigados a se deslocarem, para diversos fins particulares, ao centro histórico e arredores, que ainda guarda suas funcionalidades. Fica nítida a insatisfação pelo ônus desse deslocamento, nesses bairros mais pobres.

De acordo com Haesbaert (2004, p. 315), a pobreza está associada à disponibilidade de recursos (em sua acepção mais ampla), o que inclui a própria dimensão espacial, ou seja, o território como "recurso", inerente á nossa reprodução social. O autor parte do pressuposto de que toda pobreza e, com mais razão ainda, toda "exclusão social", é também, em algum nível, "exclusão socioespacial" e, por extensão, "exclusão territorial", o que Haesbaert denomina "desterritorialização" em um sentido "forte", ou aquele que pode ser considerado o mais estrito, a desterritorialização como "exclusão, privação e lou precarização do território enquanto 'recurso' ou 'apropriação' (material e simbólica) indispensável à nossa participação efetiva como membros de uma sociedade". Para o autor, assim como não há uma situação completa de exclusão social, também não há a completa privação territorial, isto é, a desterritorialização num sentido absoluto, a não ser como espaços que são vedados à territorialização.

Haesbaert continua sua análise citando José de Souza Martins, que prefere utilizar o termo "inclusão precária", em vez de "exclusão social". Martins critica a noção de "exclusão" como um estado ou situação fixa, que "substitui a idéia sociológica de processos de segregação" e que ignora a "reação da vítima, isto é , sua participação transformativa no próprio interior da sociedade que exclui o que representa a sua concreta integração". Concordamos com o autor, daí considerarmos neste trabalho, o processo enquanto segregacionista. 


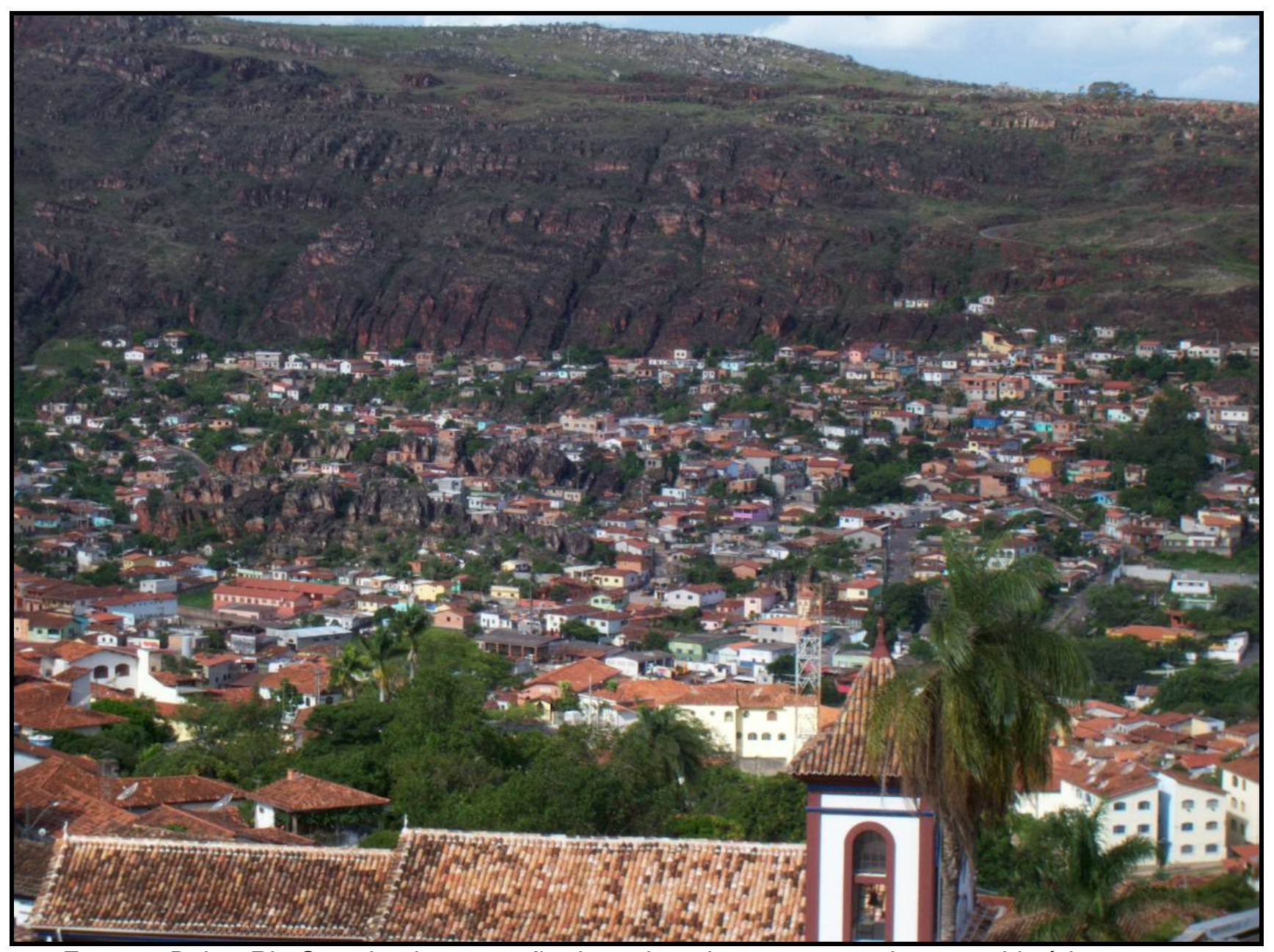

Foto 23: Bairro Rio Grande, de ocupação desordenada, no entorno do centro histórico, com gravíssimos problemas de infra-estrutura urbana. As casas foram construídas em meio às pedras. Foto do autor / fev. 2008. 


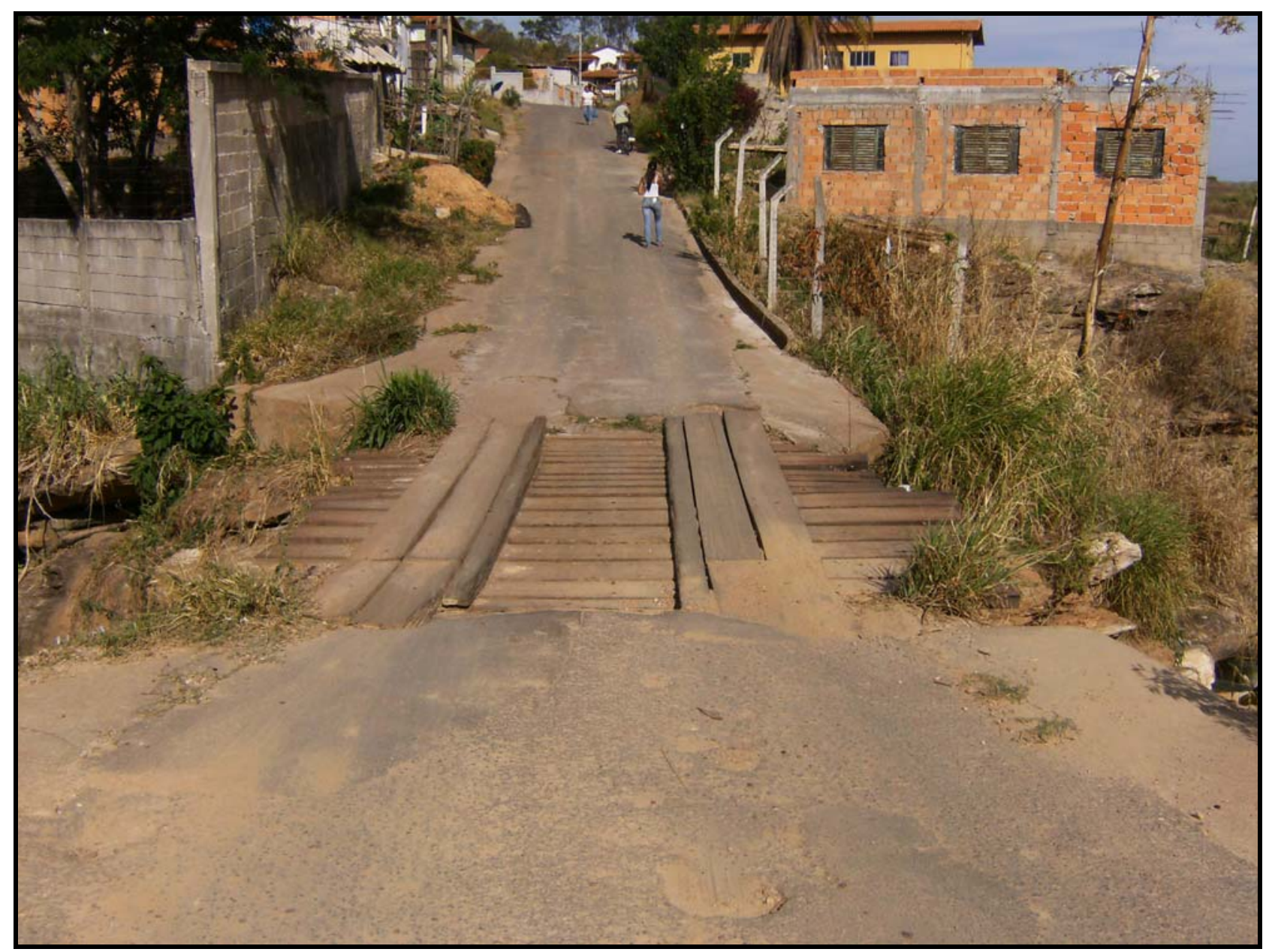

Foto 24: Bairro Rio Grande, símbolo da negligência pública com o tecido urbano e com a sociedade. Foto de Luiza Almeida (moradora de Diamantina) / set. 2008.

A atual política de patrimônio em Diamantina evidencia o negligenciamento do território, pois é tratado na ótica "econômica e economicista da atividade turística" (CRUZ, 2005). O Estado participa, ativamente, na transformação do espaço social em produto de consumo, com o Programa Monumenta. De acordo com Cruz (2005, p. 35), duas problemáticas afloram no tratamento do território para o turismo; a primeira diz respeito à própria negligência com a qual é tratado; a segunda está ligada ao insustentável discurso das diminuições das desigualdades regionais com a implementação da atividade, como se o turismo, uma atividade setorial, fosse capaz de reverter, por si só, desigualdades historicamente criadas. Logo, o turismo, por si só não é capaz de reverter as realidades históricas das desigualdades sócio-regionais. Segrega, ainda mais, um turismo sem um devido planejamento (CRUZ, 2005, p. 35). 
Precisamos considerar que a atividade do turismo tem algo de perverso em sua natureza, como aponta Cruz (2005). Só faz turismo quem tem condições para isso (expressa diferenças sociais) e não são todos os lugares escolhidos para o seu desenvolvimento. Já afirmamos que o capital é extremamente seletivo do ponto de vista espacial; para Cruz (2005), o é ainda mais quando atrelado ao turismo, uma vez que o espaço é seu objeto de consumo. Nesse sentido, a escolha dos lugares para o estabelecimento dessa atividade redunda em uso e também em negligenciamento do território, dialeticamente: "De um lado, enquanto se prioriza os territórios eleitos pelo turismo com obras e normalizações de uso, se negligencia outras porções do território, abandonadas à própria sorte" (CRUZ, 2005, p. 39), é o que identificamos na fragmentação articulada entre um centro em vias de "valorização" e uma periferia em processo de "precarização", em Diamantina.

Sendo o turismo uma atividade incipiente em Diamantina e considerando que seu planejamento urbano, na prática, está ligado às necessidades de uma classe específica voltada para um território pontual, torna-se mister a indicação de Campos Filho (1992, p. 47). Para o autor, hoje, há uma reivindicação crescente nas cidades, a de o poder público atender ao direito a uma vida segura, com estabilidade no emprego, e a um ganho correspondente estável, em que o progresso pessoal decorra de um jogo político limpo, em busca da apropriação da riqueza gerada (pode o diamantinense fazer frente ao poder público na exigência da implementação de políticas públicas que promovam a redistribuição da renda oriunda do turismo que vem se apropriando, privativamente, de um patrimônio mundial que é - ou deveria ser - apropriado de forma coletiva). Também, devese enaltecer o próprio direito de reivindicar e fazer greves gerais, o que ainda não é plenamente reconhecido. Deve-se reivindicar, ainda, os trabalhadores, o acesso à educação em todos os níveis. "A saúde tem de ser assegurada também e, para isso, é fundamental que a alimentação básica seja obtida através do trabalho em horário normal" (CAMPOS FILHO, 1992, p. 47).

Com a análise posta até o momento, sobre o território urbano de Diamantina, identificamos, mais uma vez, que o planejamento faz-se como um processo políticoideológico, que exprime anseios, desejos, angústias e visões de mundo dos agentes que o conduzem, daí vemos a rendição dos sujeitos aos pressupostos neoliberais, a centralização descentralizada, a negligência do espaço urbano em favor do mercado. 
Nesse sentido, o território urbano pode ser definido a partir de suas desigualdades, quando são estabelecidos "enclaves de prosperidade", nas cidades; processo que ocorre de forma desequilibrada, dado o despotismo do capital hegemônico que fragmenta o território urbano. Para Santos (1999), o capital torna-se cada vez mais autoritário, vestindo uma máscara da bondade e do equilíbrio, camufla suas contradições imanentes, transformando o território quando posto em ação.

As entrevistas com os agentes públicos de Diamantina (prefeito, secretário de turismo, coordenador do Programa Monumenta / Diamantina e com o chefe do Escritório Técnico do IPHAN / Diamantina) revelam uma retórica em que a cidade tem como norte o desenvolvimento do turismo, a geração de renda para o município e a melhoria do saneamento básico, num momento em que o garimpo deixa de ser a principal fonte de renda da população. Contudo, verificamos que as ações que buscam alcançar esses novos objetivos são estabelecidas desarticuladamente, o que dificulta, em nosso entendimento, a operacionalização da organização socioespacial urbana para o alcance dos mesmos. Segundo Corrêa (2003, p. 84) não é com remendos somente na organização espacial da cidade, que se resolve a questão das desigualdades socioespaciais postas historicamente. Há de se mudar a partir da prática e das relações daqueles que assumem o papel de agentes do destino de uma sociedade, de seu próprio destino e modeladores de seu espaço; há de se moldar o homem novo de uma sociedade que se retrata cada vez mais desigual.

$\mathrm{O}$ atendimento concreto da melhoria das condições de vida que deveria ser assegurada, nas cidades, é dificultado enormemente pela forma como está organizado o seu espaço, especialmente devido à especulação com a terra, segundo Campos Filho (1992). E é dificultado, também, pelas estruturas político-administrativas que impedem, ou não fazem a menor questão, de atender o direito do cidadão em participar da gestão da sua cidade (aqui defendemos, por exemplo, a gestão participativa da cidade, ou o Plano Diretor, verdadeiramente, participativo, que transcenda a retórica de agentes públicos inescrupulosos - é uma proposta que se faz clara na Convenção do Patrimônio Mundial, no Memorando de Viena, na Recomendação de Nairóbi e cartas analisadas no capítulo 2 desta pesquisa).

A questão da infra-estrutura urbana e do saneamento básico é muito séria em Diamantina. A Fundação João Pinheiro desenvolveu, em 2004, o Plano de 
Desenvolvimento Integrado do Turismo Sustentável do Pólo Turístico do Vale do Jequitinhonha que trás informações fundamentais sobre a capacidade institucional e municipal das cidades da região; informações que nos possibilitam enquadrar Diamantina no contexto regional e ratificar nossas observações de campo que nos levam a identificar uma cidade dual.

O quadro 04, abaixo, oferece-nos informações preciosas sobre a capacidade institucional das administrações municipais das cidades do Pólo Turístico do Jequitinhonha, do qual faz parte Diamantina. A situação geral dos municípios é calamitosa, onde o planejamento urbano e o provimento de infra-estrutura de obras e serviços apresentam-se com baixa capacidade para todo o Vale do Jequitinhonha. A maior contradição que identificamos no quadro, porém, encontra-se no descaso ao provimento de políticas culturais e de apoio ao turismo para todo o Pólo Turístico do Vale do Jequitinhonha (como se desenvolver um turismo sério, gerador de renda para a coletividade, sem o estabelecimento de tais políticas?). A análise qualitativa do quadro 04 demonstra uma desarticulação e a falta de critérios sociais no planejamento urbano dessas cidades do interior, onde, na esperança do lucro e de renda fáceis, as ações são pontuais e favorecedoras do estabelecimento de funções e formas espaciais distintas para sujeitos específicos; ações que promovem atividades e criam materialidades concentradas, o que favorece a dinamização espacial da segregação (as ações que acompanham o Monumenta, em Diamantina, são exemplares). Segundo o prefeito de Diamantina,

O desenvolvimento do turismo, a geração de renda e o saneamento básico são prioridades da prefeitura. No artesanato, por exemplo, sedemos uma parte da Secretaria de Cultura para um grupo de 17 artesãos; com 8 meses criaram uma associação e tinham 101 associados, o apoio da prefeitura foi oferecer o espaço físico e orientação via SEBRAE. Hoje temos vários projetos, mas continuamos dando o apoio a este projeto. Hoje a gente apóia pouco, não há necessidade, pois a associação já dá conta de se sustentar, os distritos também possuem esses grupos de artesãos que foram apoiados pela prefeitura. ${ }^{161}$

${ }^{161}$ Entrevista do prefeito de Diamantina, Gustavo Botelho Júnior, concedida ao autor em 14 de fevereiro de 2008. 
Capacidade institucional das administrações municipais dos municípios selecionados do Pólo Turístico do Vale do Jequitinhonha - Minas Gerais - 2003

\begin{tabular}{l|c|c|c}
\hline \multicolumn{1}{c|}{ CAPACIDADE INSTITUCIONAL } & $\begin{array}{c}\text { BAIXA } \\
(1-4)\end{array}$ & $\begin{array}{c}\text { MÉDIA } \\
(5-6)\end{array}$ & $\begin{array}{c}\text { ALTA } \\
(7-10)\end{array}$ \\
\hline a) Desenvolvimento institucional & $\mathrm{X}$ & \\
b) Finanças municipais & $\mathrm{X}$ & \\
c) Planejamento urbano e infra-estrutura de obras e serviços: & $\mathrm{X}$ & \\
- Politica urbana & & $\mathrm{X}$ \\
- Obras públicas & $\mathrm{X}$ & \\
- Política de transportes & & \\
d) Saneamento, preservação ambiental e saúde: & $\mathrm{X}$ & \\
- Saneamento & $\mathrm{X}$ & $\mathrm{X}$ \\
- Preservação ambiental & & \\
- Saúde & & $\mathrm{X}$ \\
e) Desenvolvimento e integração social: & & $\mathrm{X}$ \\
- Educação & $\mathrm{X}$ & \\
- Esporte e lazer & $\mathrm{X}$ & \\
- Politicas culturais e de apoio ao turismo: & $\mathrm{X}$ & \\
- Desenvolvimento e ação social & $\mathrm{X}$ & \\
- Infra-estrutura de abastecimento alimentar & & \\
f) Desenvolvimento econômico e do turismo &
\end{tabular}

Fonte: Prefeituras Municipais

Elaboração: Fundação João Pinheiro (FJP)

Quadro 04

O quadro 05, a seguir, também da Fundação João Pinheiro, trás os principais problemas urbanos identificados nos municípios do Vale do Jequitinhonha, o que nos revela um problema regional de gestão urbana que envolve a melhoria da qualidade de vida da população do norte de Minas Gerais. A fala dos moradores de Diamantina, juntamente com nossa observação em campo, faz-nos considerar o descaso municipal para com o saneamento básico e com a infra-estrutura urbana como sendo duas das principais problemáticas socioespaciais enfrentadas pelo diamantinense. A Fundação João Pinheiro ratifica, mais uma vez, nossa análise, ao trazer como os principais problemas urbanos da cidade os córregos sem canalização, a habitação e o saneamento, principalmente esgoto sanitário. Diamantina apresenta todos os problemas de esgotamento sanitário possíveis, de acordo com o quadro 06, que se sucede ao seguinte. De acordo com o prefeito,

O bairro Rio Grande foi ocupação desordenada; hoje, está sendo urbanizado, é um dos bairros que tem mais investimento em urbanização. Estamos investindo em praças, na captação de água da serra e na despoluição do córrego, porque la é onde recebe o 
esgoto, é uma das ações que estão sendo desenvolvidas, de saneamento. ${ }^{162}$

Principais problemas urbanos verificados nos municípios selecionados do Pólo Turístico do Vale do Jequitinhonha - Minas Gerais - 2003

\begin{tabular}{|c|c|}
\hline MUNICÍPIO & PRINCIPAIS PROBLEMAS URBANOS \\
\hline Capelinha & $\begin{array}{l}\text { Ocupação desordenada, destruição de matas, poluição de córregos e rios. } \\
\text { O município possui relevo bastante acidentado, ficando e o centro da sede } \\
\text { alagado no período das chuvas. }\end{array}$ \\
\hline Couto de Magalhães de Minas & $\begin{array}{l}\text { O turista reclama contra a existência chiqueiro na cidade e a falta de } \\
\text { açougues da data de validade nos queijos e de tratamento da água e do } \\
\text { esgoto na sede. }\end{array}$ \\
\hline Diamantina & $\begin{array}{l}\text { Córregos sem canalização, habitação e saneamento, principalmente esgoto } \\
\text { sanitário. }\end{array}$ \\
\hline Felício dos Santos & $\begin{array}{l}\text { Falta de saneamento básico, com a população resistindo à possibilidade de } \\
\text { concessão à COPASA. Falta de recursos para a elaboração do Plano } \\
\text { Diretor. }\end{array}$ \\
\hline Itamarandiba & Enchentes provocadas por lixo nas vias públicas. \\
\hline Minas Novas & $\begin{array}{l}\text { Loteamentos e desmembramentos irregulares, invasões, necessidade de } \\
\text { uma ETE e de redes de extensão de água. }\end{array}$ \\
\hline São Gonçalo do Rio Preto & Alinhamentos e traçado do sistema viário. \\
\hline Serro & $\begin{array}{l}\text { Os loteamentos da periferia são irregulares, impedindo a cobrança de IPTU. } \\
\text { Na periferia da sede e na zona rural, há incidência de doença de chagas. O } \\
\text { problema é agravado pela precariedade das habitações existentes. Há } \\
\text { necessidade de ampliação do sistema de abastecimento de água e } \\
\text { saneamento rural. }\end{array}$ \\
\hline Turmalina & $\begin{array}{l}\text { Crescimento desordenado e poluição ambiental. Falta de infra-estrutura, } \\
\text { principalmente rede de esgoto. Problemas urbanísticos de toda ordem. }\end{array}$ \\
\hline
\end{tabular}

Fonte: Prefeituras Municipais

Elaboração: Fundação João Pinheiro (FJP)

Nota: COPASA= Companhia de Saneamento de Minas Gerais; ETE= Estação de Tratamento de Esgoto; IPTU= Imposto Predial e Territorial Urbano.

Quadro 05

Há cidades, segundo Campos Filho (1992, p. 52), que pelo menos, num esforço gigantesco, procuram, com seus parcos recursos, levar a infra-estrutura de serviços urbanos e equipamentos comunitários à periferia; são cidades obrigadas a estendê-los muito mais do que seria necessário, caso não houvesse, ou houvesse, terrenos baldios em quantidade razoável. "Um governo urbano cada vez mais pobre, enfrentando cidades cada vez mais caras: essa é a realidade preocupante que nós, brasileiros, temos que enfrentar" (CAMPOS FILHO, 1992, p. 52).

\footnotetext{
${ }^{162}$ Entrevista do prefeito de Diamantina, Gustavo Botelho Júnior, concedida ao autor em 14 de fevereiro de 2008.
} 
Principais problemas de es gotamento sanitário nos municípios selecionados do Pólo Turístico do Vale do Jequitinhonha - Minas Gerais - 2003

\begin{tabular}{|c|c|}
\hline MUNICÍPIO & PRINCIPAIS PROBLEMAS DE ESGOTAMENTO SANITÁRIO \\
\hline Capelinha & $\begin{array}{l}\text { Poluição dos córregos e rios; necessidade de construção de fossas } \\
\text { sépticas nas fazendas e sítios. }\end{array}$ \\
\hline Couto de Magalhães de Minas & Tratamento de esgoto da sede. \\
\hline Diamantina & Todos os problemas. \\
\hline Felício dos Santos & Contaminação dos lençóis d'água pelo sistema de fossas. \\
\hline Itamarandiba & Todos os problemas. O município não dispõe de recurs os para resolver. \\
\hline Minas Novas & Poluição dos córregos e ausência de ETE na sede. \\
\hline São Gonçalo do Rio Preto & $\begin{array}{l}\text { O sistema de esgotamento sanitário implantado, inclusive com uma } \\
\text { ETE, atualmente desativada, não produziu os resultados e benefícios } \\
\text { esperados. }\end{array}$ \\
\hline Serro & $\begin{array}{l}\text { Necessidade de ampliação da rede de esgoto na sede, de construção } \\
\text { de interceptores na sede, ETE na sede; construção de rede com ETE } \\
\text { nos distritos, menos Pedro Lessa; saneamento de povoados e } \\
\text { população rural com fossas cépticas individuais e coletivas. }\end{array}$ \\
\hline Turmalina & Poluição do rio Araçuaí. \\
\hline
\end{tabular}

Fonte: Prefeituras Municipais

Elaboração: Fundação João Pinheiro (FJP)

Nota: ETE = Estação de Tratamento de Esgoto

Quadro 06

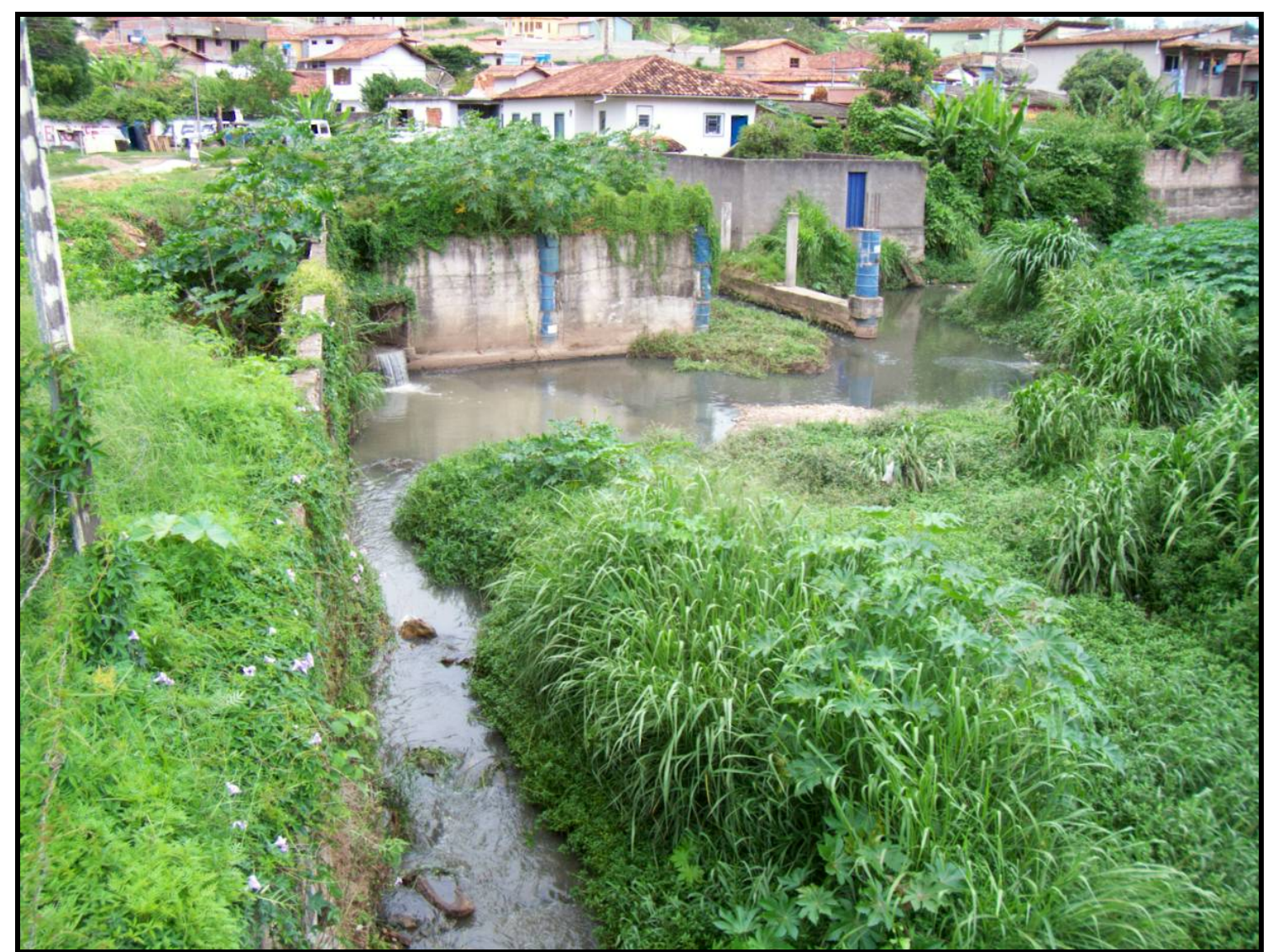

Foto 25: Esgoto a céu aberto e no fundo das residências, no bairro Rio Grande / jan. 07. 


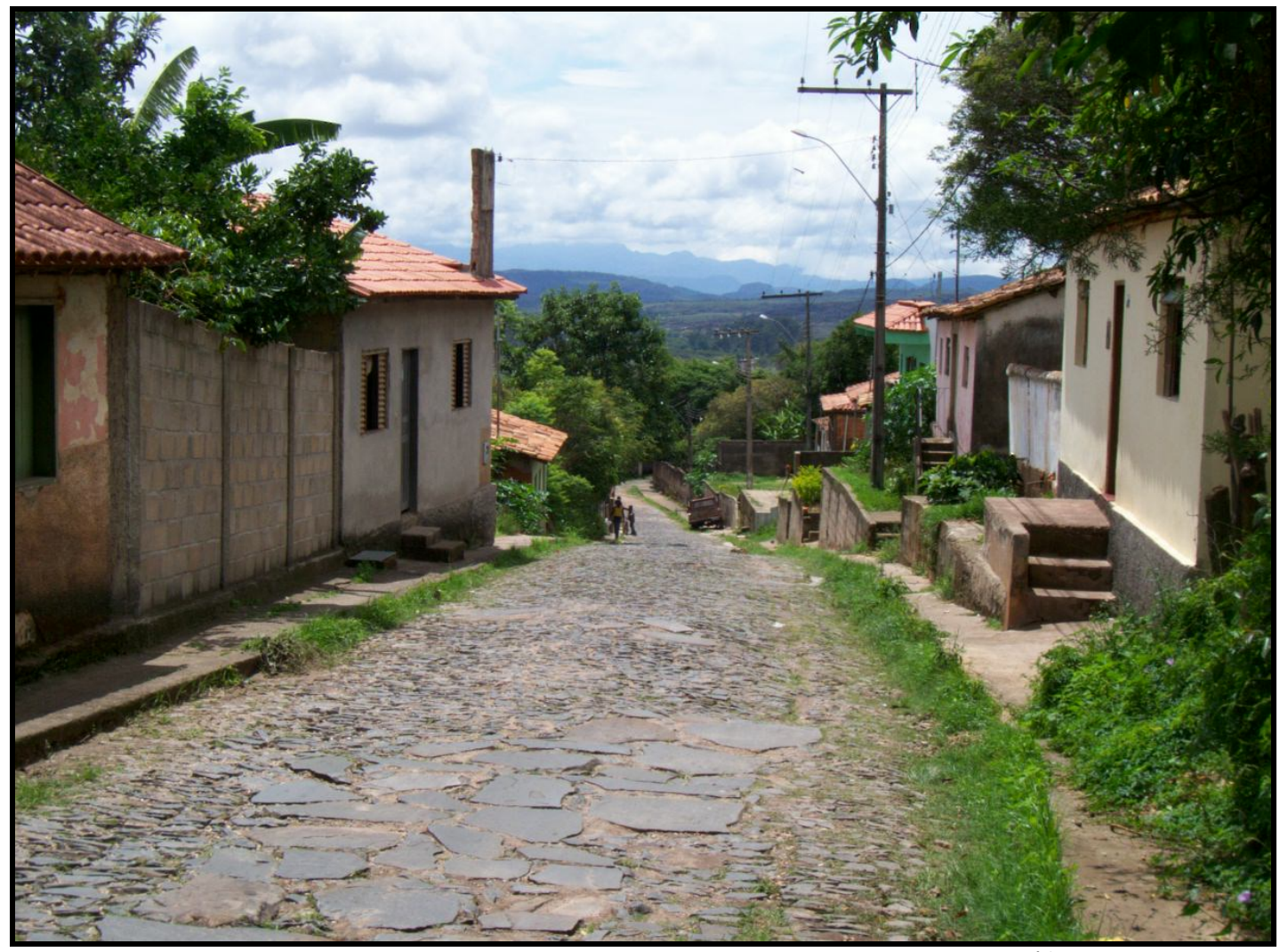

Fotos 26: Descuido com o tecido urbano, no bairro Palha. Fotos do autor / fev. 08.

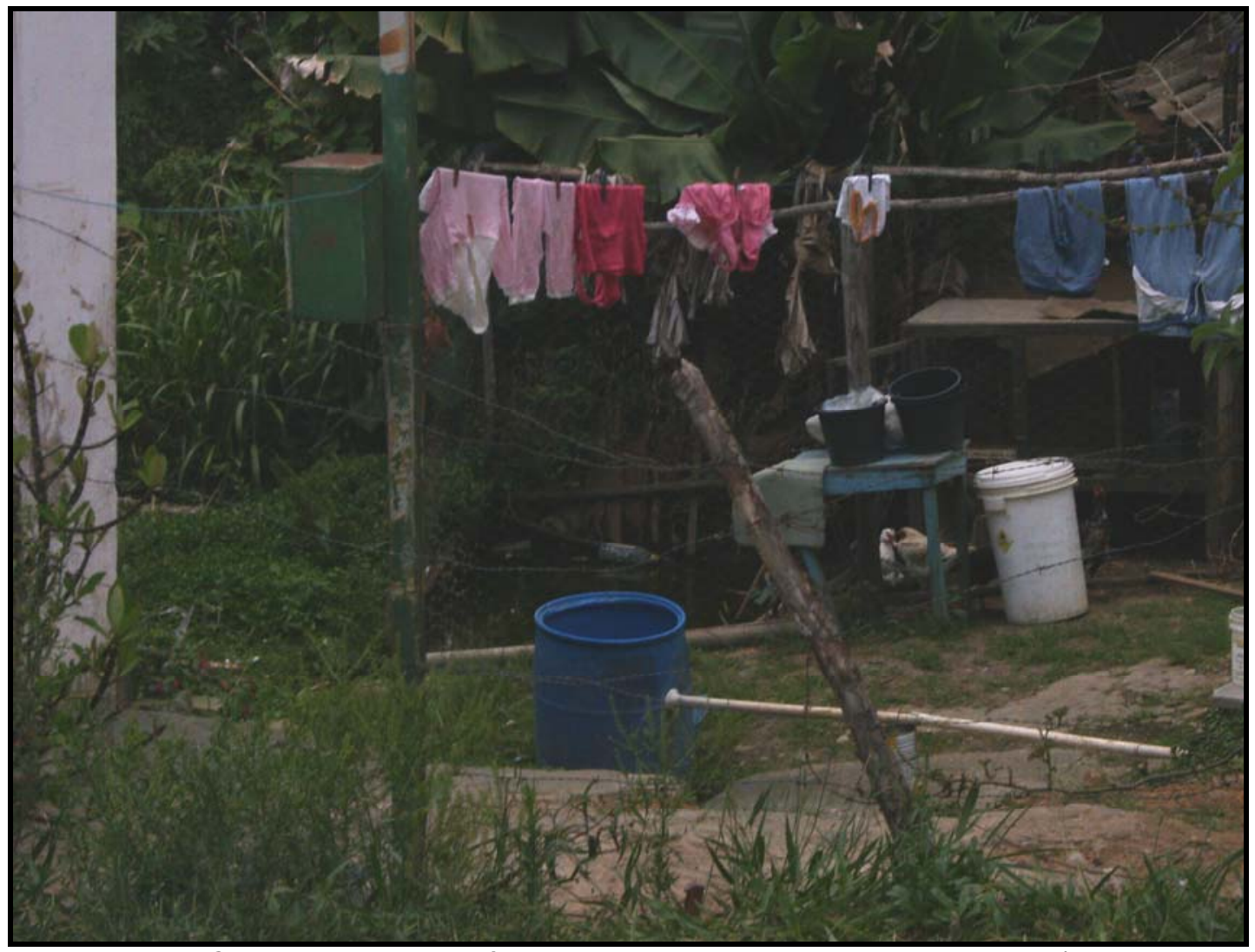

Foto 27: Condições de vida precária, no bairro Bela Vista. Foto de Luiza Almeida / set. 08. 
Segundo Campos Filho (1992, p. 47), atender ao direito mínimo do cidadão urbano, que é o habitar com dignidade, está se tornando importante reivindicação política dos movimentos sociais urbanos. Isso significa ter o cidadão uma casa, ainda que singela, com transporte para o trabalho, algum lazer, os serviços essenciais à saúde, como água potável, com a drenagem da água, tanto insalubre como a destruidora de sua moradia (enchentes), e os serviços necessários à sua segurança, como ruas bem iluminadas e transitáveis durante todo o ano.

Ao considerarmos a proposição de Campos Filho, aferimos que Diamantina apresenta um espaço urbano desigual e mutável; o Estado, juntamente com os agentes de mercado, frente aos grupos sociais segregados, constituem-se nos principais modeladores do espaço urbano. O Estado e o mercado buscam na valorização simbólica um adendo para a valorização econômica do espaço central da cidade, criando uma "cidade empreendimento de última geração" (ARANTES, 2002, p.16) com ênfase no retorno ao planejamento, que segundo a autora, não veio para corrigir o antiurbanismo anárquico. Ao contrário, esse novo planejamento veio para agravar ainda mais as problemáticas socioespaciais urbanas, desde que governantes e investidores passaram a desbravar a fronteira do poder e do dinheiro - no negócio das imagens. "O 'tudo é cultura' da era que parece ter sido inaugurado nos idos de 1960 teria pois se transformado de vez naquilo que venho chamando de culturalismo de mercado" (ARANTES, 2002, p. 16). O espaço urbano de Diamantina é produzido focalizando-se esculturas, praças, objetos arquitetônicos de alto valor simbólico incorporado, atraindo capitais e estruturando a obrigatoriedade de um trajeto pré-estabelecido, são zonas favorecidas que incorporam o capital cultural, na ilusão que forja não somente um esperado futuro promissor para uma classe determinada, mas precariza a situação urbana e de vida de pessoas menos esclarecidas e menos favorecidas social e espacialmente.

Quanto aos grupos sociais segregados, os últimos modeladores do espaço urbano, vivem as diferenças aos acessos aos bens e serviços produzidos socialmente. Corrêa (2005) considera marcante no espaço urbano a diferenciação no padrão das habitações, onde poucos possuem uma renda para pagar uma moradia decente (foto 28). Há uma grande sintonia da segregação, da fragmentação do território urbano, com a subnutrição, com o baixo nível de escolaridade, com o desemprego, com o sub-emprego e 
com o emprego mal-remunerado. Para Corrêa (2005, p. 30), esse grupo torna-se um agente modelador do espaço na produção de favelas (terrenos públicos ou privados), a despeito de outros agentes; vê-se uma luta pela sobrevivência frente às diversidades que encontram grupos recém chegados do campo ou provenientes de áreas urbanas reformuladas pelo mercado, que lutam pelo direito à cidade.

Como morar na periferia é, na maioria das cidades brasileiras, o destino dos pobres, eles estão condenados a não dispor de serviços sociais ou a utilizálos precariamente, ainda que pagando por eles preços extorsivos, é o mesmo que se dá com os transportes. O resultado de todos esses agravos é um espaço empobrecido e que também se empobrece: material, social, política, cultural e moralmente (...) A quem pode um candidato a cidadão recorrer para pedir que faça valer o seu direito ao entorno (...) ? A própria existência vivida mostra a cada qual que o espaço em que vivemos é, na realidade, um espaço sem cidadãos. (SANTOS, 2007, p. 65)

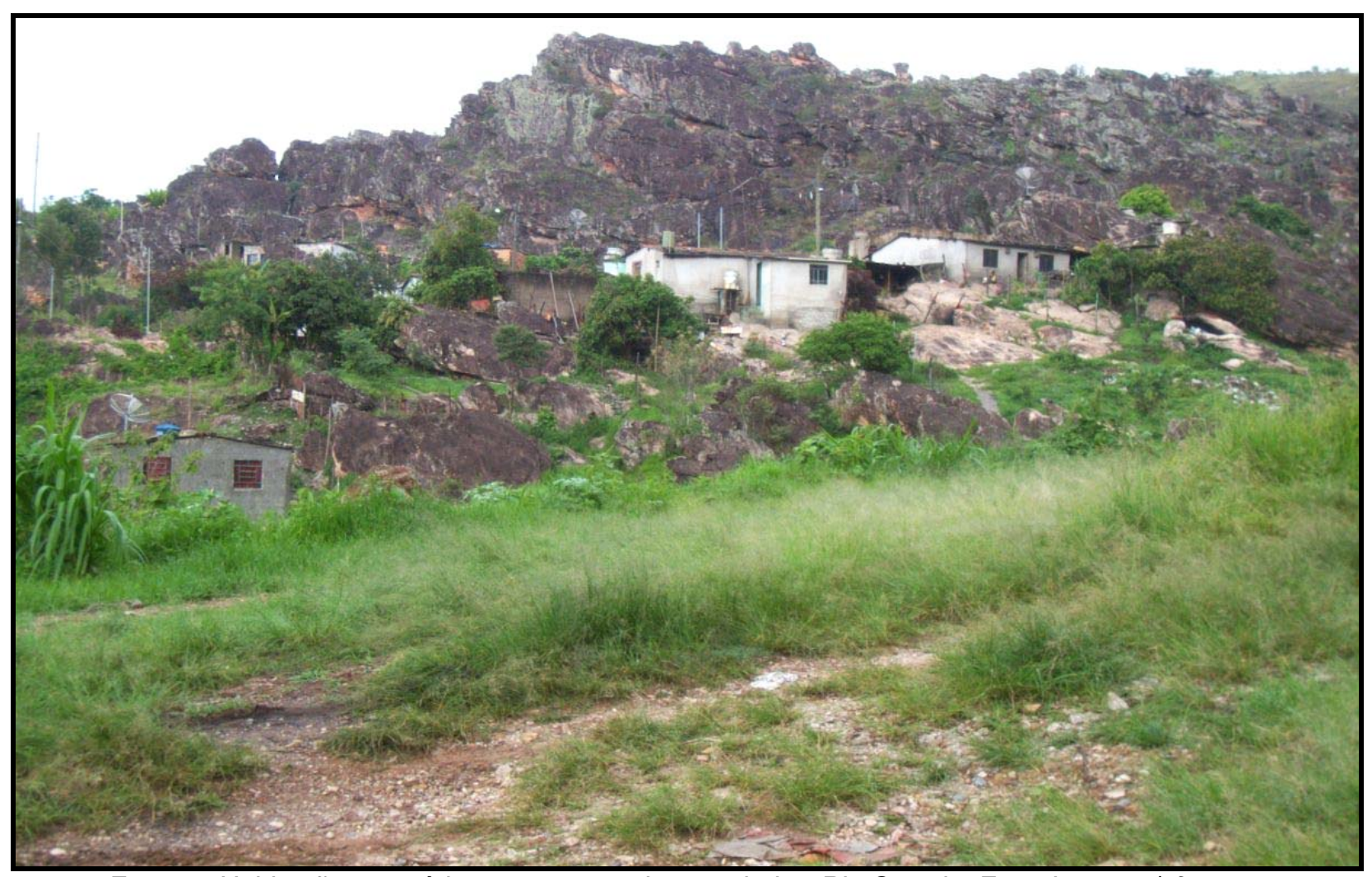

Foto 28: Habitações precárias, entre as pedras, no bairro Rio Grande. Foto do autor / fev. 08.

Os bairros Palha e Rio Grande, principalmente, estabelecidos em terrenos inadequados aos outros agentes de produção do espaço (como o da foto 28, acima), devido às encostas íngremes e áreas alagadiças, aos poucos e de forma incompleta recebem o insuficiente de infra-estrutura da municipalidade. Normalmente, a verba pública 
ou os investimentos só são destinados à periferia ou à parte do território urbano desprovido de capital fixo, sob a forma de assistencialismo, em caso de catástrofes naturais ou forte reivindicação popular, em lugares cujos habitantes organizam-se frente aos setores públicos. Conforme Carlos (2006), o urbano é, por excelência, o lugar das contradições, dos confrontos, das lutas pelo espaço e da imposição de classe (foto 29).

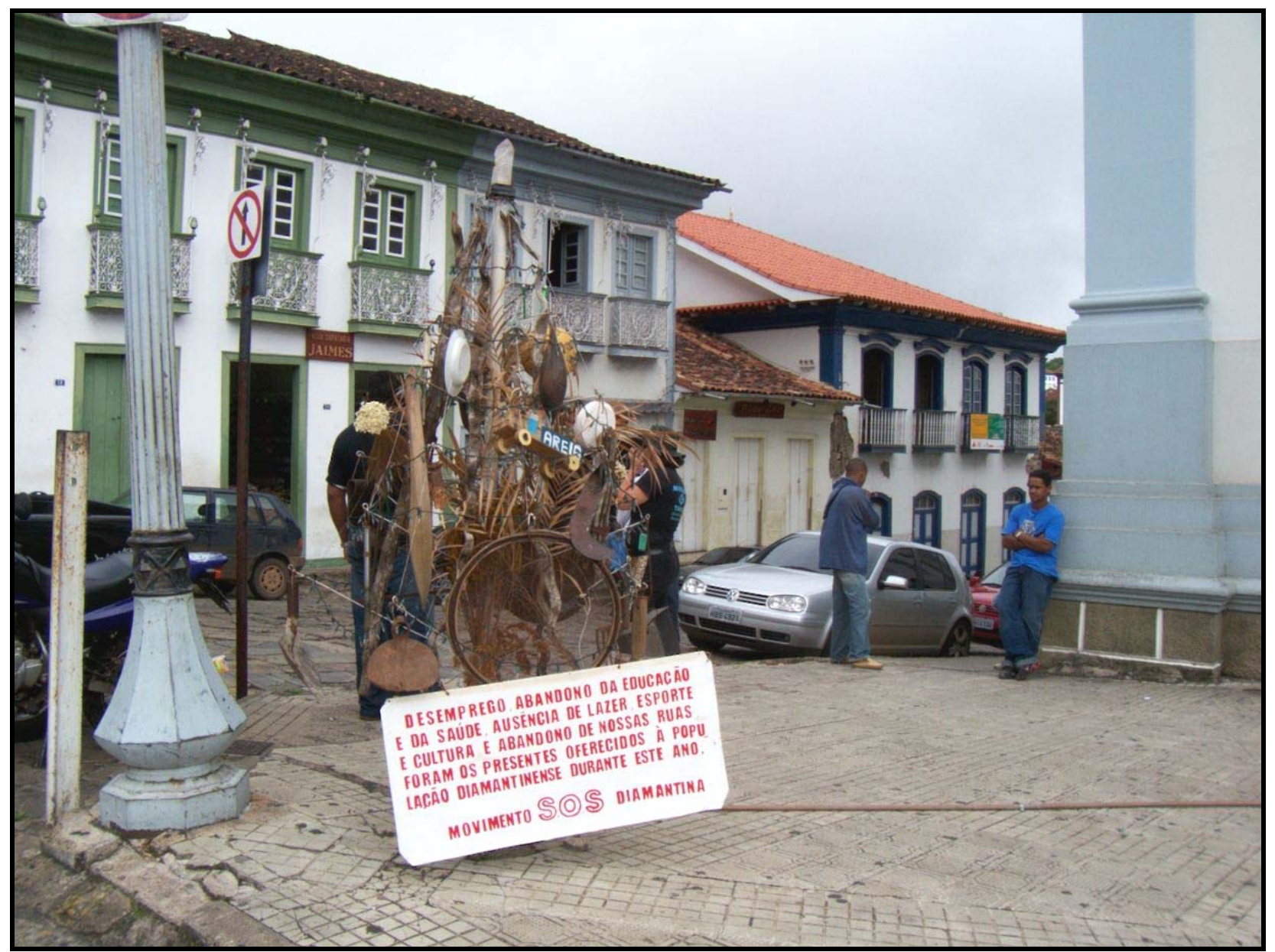

Foto 29: Reivindicação popular por melhores condições de vida, no centro de Diamantina. Foto do autor / jan.07.

Os problemas urbanos de Diamantina apontados neste capítulo agravam a situação de vida da população, vê-se que a ilusão de que o desenvolvimento da atividade turística favorece a melhoria das condições sociais, de forma coletiva, transforma-se em uma retórica que busca o apaziguamento dos ânimos sociais frente a um processo que segrega social e espacialmente. Segundo Campos Filho (1992), o conjunto dos problemas sociais urbanos vai empurrando o trabalhador de baixa renda para posições cada vez 
mais periféricas na estrutura urbana, muitas vezes não the restando outra possibilidade que a aquisição de terrenos na zona rural (uma inversão de fluxos populacionais, agora, da cidade para o campo). Esse processo de periferização física e social acaba por distanciar ainda mais a família pobre do emprego, do comércio melhor e mais barato e dos serviços públicos de melhor qualidade, da educação, saúde e lazer, que são gratuitos, ou seja, não são pagos pelos salários, isso, quando já existentes em seu lugar de morada.

Logo, o novo planejamento urbano estratégico assume uma política cultural que não diz respeito à totalidade da experiência social, mas na segmentação dos privilegiados. De acordo com Meneses (1999, p. 95), há uma visão concentradora de cultura que se consubstancia no centro histórico, por exemplo. O termo centro, de cara, induz à idéia da existência de uma periferia. Considerar a cultura localizada apenas no centro é se desconsiderar o que não é central, o que acontece em Diamantina, no nosso entender; a cultura que se cultiva no território que se mostra desprovido das condições dignas de sobrevivência é a da pobreza e a da miséria, o que faz por transformar o imaginário do residente em relação à sua cidade histórica. "A musealização da cidade e dos centros históricos, ocorre em lugar da 'culturalização' de todo espaço urbano; as ruas de lazer e outros enganosos paliativos aos desequilíbrios da vida contemporânea caem também nesta perspectiva" (MENESES, 1999, p. 95).

Planejadores, políticos e promotores culturais trabalham em conjunto para produzirem ou estabelecerem um consenso social sobre as estratégias culturalistas; assumem papel preponderante a mídia e a propaganda na veiculação local e internacional das vantagens oriundas do desenvolvimento turístico, onde aparecem como os principais benefícios oriundos da atividade, de acordo com as informações disseminadas, a geração "exorbitante" de empregos, a melhoria da qualidade de vida para a população local e o desenvolvimento do "capital" cultural para a população local.

O planejamento urbano estratégico, como instrumento de classe, que atua, objetivamente, nos lugares "especiais" da cidade (uma de suas limitações) não nos deixa crer na argumentação de uma vertente para a qual a cultura desceu de seu pedestal elitista, bem como saiu de seu confinamento populista, expandindo-se e infiltrando-se por todos os domínios relevantes nas arenas econômicas, sociais e políticas, reconstituindoas segundo as regras de novos formatos culturais, utilizados por sua vez, como recurso de 
valorização nos respectivos âmbitos (cultura para as massas?). Concordamos com Arantes (2002, p. 47), seu acesso ainda é elitizado e direcionado a uma classe específica.

Para colocarmos termo à dialética fragmentária de uma construção destrutiva que assola as cidades históricas, analisadas à luz da relação entre a valorização do espaço, a dominação do espaço e a representação do espaço, operacionalizadas por sujeitos sociais com distintas visões sociais de mundo, urge a transcendência de uma luta urbana que deve enfocar a cidade como um todo e o indivíduo total, onde os segregados unam-se em favor de uma causa comum. Para Milton Santos, em O espaço do cidadão, as ações que tem por base intelectual e ideológica comportamentos corporativos têm eficácia reduzida, ou nenhuma, na formulação da consciência social e como contribuição válida ao desenvolvimento social. Segundo Milton,

Marx, em A Ideologia Alemã, já lembrava o perigo de os indivíduos de uma mesma classe se tornarem inimigos na concorrência internamente travada entre eles próprios, em lugar de se organizarem para se exprimir eficazmente contra a classe dominante, cuja condução da sociedade impede que as classes dominadas busquem seu caminho via uma ação conseqüente. (SANTOS, 2007, p. 99)

É evidente a dualidade da "valorização" do centro histórico frente à "precarização" da periferia como fator de transformação da realidade e do imaginário do diamantinense, constituindo-se em uma questão de produção socioespacial capitalística. Nesse sentido, verificamos que o poder público colabora para a supervalorização de certas áreas, para o melhor êxito da especulação, para a maior anarquia das localizações e dos fluxos, para o empobrecimento cumulativo das populações. Em um território urbano onde a localização dos serviços essenciais é deixada ao bel sabor da lógica do mercado (ou da mercantilização de patrimônio), verifica-se uma tendência geral para que as desigualdades sociais aumentem. Ao empobrecimento pela economia, isto é, pelo mercado, junta-se o empobrecimento pela desorganização do território por inação do poder político.

Somos favoráveis à análise de Castells (1975) sobre o planejamento urbano, pois, pode definir-se, em geral, como a intervenção do sistema político sobre o sistema econômico-social, no nível de um conjunto socioespacial específico; intervenção encaminhada para regular o processo de reprodução da força de trabalho (consumo de 
bens e serviços) e o da reprodução dos meios de produção (produção de bens e serviços), superando as contradições postas no interesse geral da formação social cuja subsistência procura assegurar. Sabendo que a intervenção no espaço urbano está necessariamente sujeita à matriz social que a gera e a circunscreve, urge a implementação da gestão participativa nas cidades históricas do interior brasileiro, especialmente, nas cidades onde o turismo mostra-se incipiente, como é o caso de Diamantina (proposta já mencionada nos documentos internacionais apresentados no capítulo 2 da pesquisa, a qual daremos maior ênfase no tópico que se segue).

Pretendemos, neste capítulo, amarrar nosso objetivo de pesquisa e dar resposta ao nosso problema, onde buscamos entender como a "preservação" de patrimônio cultural reflete na organização socioespacial de Diamantina. Através de uma abordagem crítica, verificamos que o par dialético "preservação" / "mercantilização" favorece a produção de um território urbano dividido quando as ações do poder público voltam-se para o centro da cidade e negligenciam o processo de "precarização" vigente e ascendente na periferia, de acordo com nossa análise dos bairros Palha, Rio Grande e Bela Vista.

Fica-nos claro que, mais uma vez, o planejamento não chega à periferia, é feito das elites para as elites; o que temos é mais um modelo segregacionista de planejamento urbano, quando poderia se constituir em um potencial instrumento de melhoria da qualidade de vida de toda população diamantinense. Logo, lançamos um olhar geográfico sobre Diamantina reconhecendo a dialética da fragmentação articulada instaurada no território urbano, pois a especulação do centro histórico parece estar dependendo da "precarização" da periferia, mesmo constituindo-se o centro em um lugar primaz na vida de todo diamantinense, pois seu imaginário aponta para a transformação dos significados que esse espaço tem para si, como veremos a seguir. Nem tão articulado, nem tão somente fragmentado, a leitura geográfica do território urbano de Diamantina aponta-nos para a limitação do acesso público aos bens culturais e lugares coletivos; a cidade, de forma incipiente, é açambarcada pela lógica do turismo enquanto uma atividade que rebate, negligentemente (na falta do devido planejamento), sobre o espaço social. No limite, essa análise aponta-nos para o que denominamos dialética da construção destrutiva na consagração do Patrimônio Mundial (simultaneamente, símbolo de cultura e de mercadoria; cultura urbana enquanto valor de uso civilizatório que é minimizada pela 
mercantilização que a recria e a maximiza como valor de troca), baseado na leitura de David Harvey, Milton Santos e Antônio Carlos Robert Moraes, principalmente, que nos legam uma crítica marxista que apresenta com propriedade e coerência a idéia de um desenvolvimento desigual e combinado da sociedade, argumentando que o capital constrói, destrói e reconstrói os lugares à sua semelhança. Sobretudo a cidade histórica do interior, transforma-se, contemporaneamente, em função das funcionalidades do capital; mais do que isso, a necessidade de reprodução do capital busca nas singularidades e irreplicabilidades do urbano (Diamantina Patrimônio Mundial universal e excepcional) um adendo para a "valorização do espaço" agora metamorfoseado em "capital simbólico".

Assim, o planejamento torna-se um dos primeiros instrumentos favorecedores da transformação da cidade histórica em mercadoria, ao passo que deveria possibilitar uma maior articulação entre agentes públicos e sociedade civil para se pensar o direito de todos à cidade e a preservação dos bens culturais do mundo de forma social espacial e democraticamente integrada, verdadeiramente participativa, que por falta de vontade política não pode ser implementada. A fala do atual secretário de turismo de Diamantina corrobora nossa crítica, ao desconsiderar a importância da opinião do residente sobre as ações implementadas pelo Programa Monumenta, na cidade,

Acredito muito no Monumenta, dentro do que minha visão alcança, são as coisas que vejo acontecer. Aqui, há varias obras que estão acontecendo com o Monumenta. A igreja de São Francisco foi restaurada e vi coisas lá que nunca tinha visto. Anjos, pinturas, cimalhas; algumas coisas não concordo, como as luminárias que parecem de banheiro, acho que deveria ter outra solução. A cor da igreja foi questionada pela população, na realidade foi feita análise da cor original. Então as pessoas dizem: Por que não perguntaram a comunidade? Não, não temos que perguntar nada à comunidade, se deve voltar ao original, porque la foi feito uma restauração, o que se deve colocar é o que foi feito no original. ${ }^{163}$

\footnotetext{
${ }^{163}$ Entrevista do secretário de turismo de Diamantina, Walter Cardoso França Júnior, concedida ao autor em 13 de fevereiro de 2008.
} 


\subsection{Do imaginário do residente à urgência da gestão participativa do Patrimônio Mundial}

Afirmamos em nosso aporte teórico-metodológico que, como nossa análise é direcionada ao urbano, cabe considerar a proposta de Scarlato (2005), para quem há de se trabalhar a cidade não somente no plano de sua materialidade, mas também no da subjetividade; quer dizer, a sociedade não só produz, historicamente, formas espaciais, condições de sobrevivência, mas também reproduz, no seu imaginário, as representações simbólicas da cidade. Consideramos, assim, a concepção materialista histórica da cidade, ao longo do trabalho, para, agora, fecharmos com uma noção representativa da mesma, através da análise do imaginário do residente sobre seu espaço de vivência, sua percepção do espaço vivido.

A criação de um "capital simbólico" contribui para a "ultravaloração" econômica do espaço urbano e em conseqüência favorece a revaloração do mesmo para o residente, ou seja, a dialética do valor de uso e do valor de troca tem na valorização simbólica um adendo para se produzir marcos de distinção, novas mercadorias para a "indústria cultural" e também uma nova representação do patrimônio no imaginário do residente. Esse imaginário popular transformado, enquanto um "produto" das ações que rebatem sobre o território na ânsia da "turistificação" do lugar, é uma das conseqüências da dialética da construção destrutiva que opera, de forma particular, em Diamantina.

Jean-Paul Sartre, em O imaginário: psicologia fenomenológica da imaginação, deixa-nos subsídios para o entendimento de como se constitui o imaginário humano; uma abordagem que nos possibilita entender o mecanismo da representação do patrimônio para o diamantinense, o que julgamos também ser de grande importância para a pesquisa. A objetividade da análise de Sartre nos é valiosa por sintetizar uma teoria que complementa, em nosso entendimento, a argumentação posta até o momento (a qual está calcada em uma apreensão histórica e dialética da realidade). Uma vez que não aprofundaremos na teoria sobre a fenomenológica, o autor supre-nos de forma específica e pontual. Logo, se a valorização e a dominação do espaço produzido foram discutidas até o momento, resta-nos tecer comentários sobre a consciência e a representação desse espaço, como nos propomos no início desta pesquisa. 
Torna-se salutar considerarmos que os estados afetivos estão freqüentemente ligados às representações, conforme Sartre. Nesse sentido, a percepção, tal qual a imagem, pode se definir como a relação entre um objeto e uma consciência, onde o objeto torna-se síntese das percepções, sob a forma corporal e sensível, "a imagem é um objeto exterior, o campo hipnagógico faz parte - ou pelo menos é o que a pessoa acredita - da extensão real" (SARTRE, 1996, p. 119). Assim, a imagem é a consciência que visa a produzir seu objeto, "é constituída por um certo modo de julgar e de sentir". Essa proposição possibilita-nos afirmar que a posição do diamantinense em relação à sua cidade está estreitamente ligada ao processo mercantil em curso, percebido pelo habitante.

A cidade, nesse sentido, é constituída pela materialização da consciência, converte-se em um objeto da própria experiência (vivência, necessidades, desejos, angústias etc.) por meio dos vários aspectos em que ocorre sua apreensão por seus habitantes. De acordo com Pereira (2007), a experiência da cidade ocorre em diversas instâncias de relações as quais se manifestam pela cidade que vivemos, sentimos, temos e vemos. Tais aspectos revelam as formas pelas quais a cidade é apreendida por seus habitantes.

Logo, o processo mercantil que se instala em Diamantina, como afirmamos anteriormente, favorece a produção de uma cidade dual, uma vez que o centro histórico da cidade aparece no imaginário do residente, em primeiro lugar, como um espaço do turismo, seguido da representação imaginária de ser um espaço comercial e de serviços (gráfico 14). A imaginação do residente sobre o turismo no centro histórico é convertida dada a função psicológica e também empírica - percebida -, que "representa uma condição necessária da liberdade do homem empírico no meio do mundo (...) não poderia haver (...) uma intuição do nada, precisamente porque o nada não é coisa nenhuma e porque toda consciência (...) é consciência de alguma coisa" (SARTRE, 1996, p. 243). 


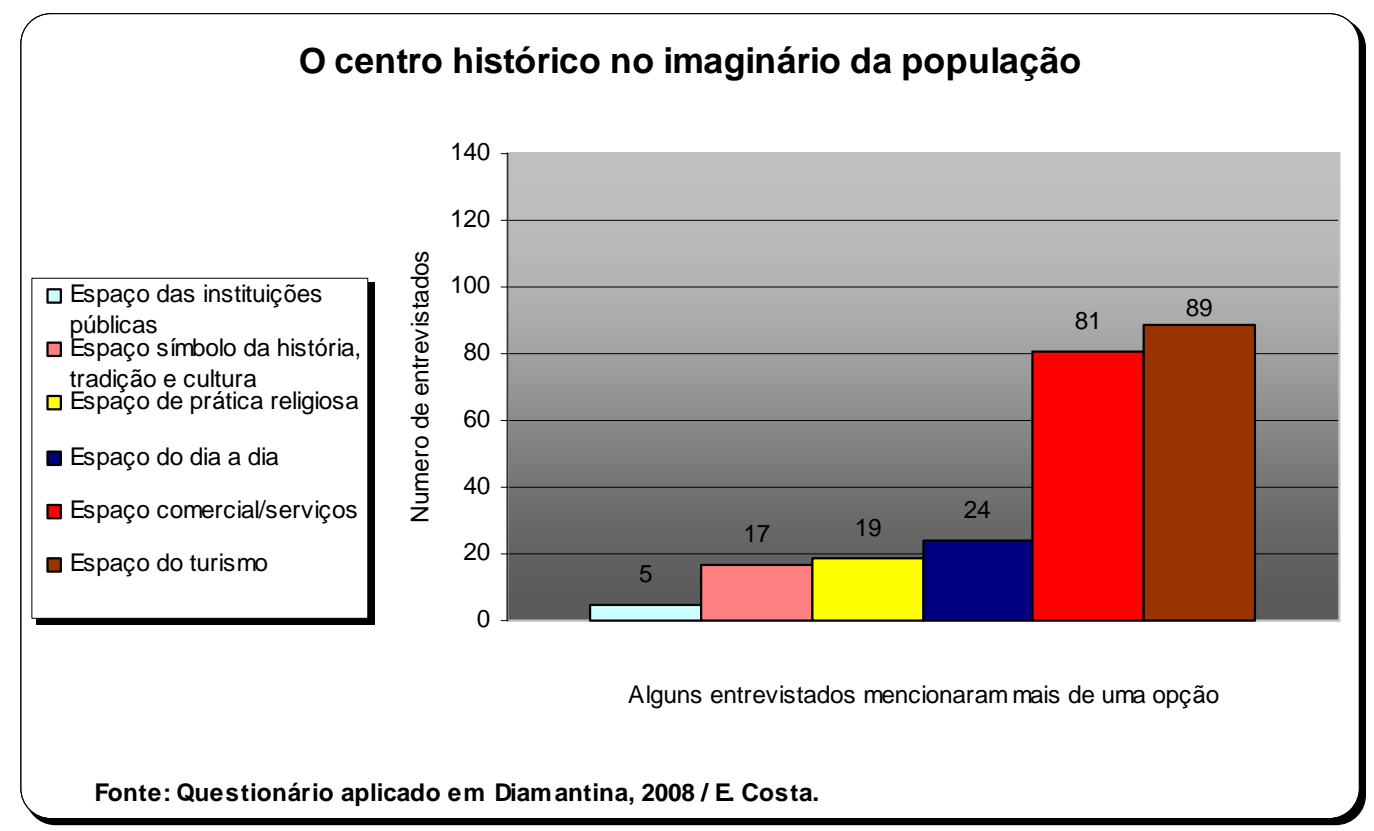

Gráfico 14

De acordo, ainda, com o gráfico 14, consideramos que, aos poucos, a população perde sua ligação afetiva com o núcleo tombado; dizemos aos poucos pois, ante a implantação do turismo que favorece a representação do centro como um espaço turístico (do forasteiro), de comércio e serviços, a população reconhece o centro histórico também como um espaço do dia a dia, dadas as funcionalidades diversas que ainda guarda, o que representa um fator positivo (a concentração do comércio e serviços no centro histórico não deve "acobertar" a "precarização" ascendente da periferia, muito menos significa que o residente esteja diretamente ligado ao mesmo. Ao não ser estabelecida uma política de educação patrimonial que vise a desenvolver no residente o sentimento de afetividade e de pertencimento ao lugar, o mesmo pode se constituir como um ponto de trânsito e de passagem e não o encontro com sua história e sua identidade).

Segundo Pereira (2007), a cidade que sentimos verifica-se pela capacidade do ambiente urbano motivar o despertar de emoções fortes, favoráveis à construção de um vínculo afetivo entre o habitante e a cidade. A satisfação em viver no lugar, o orgulho pelo pertencimento ao mesmo, a sensação de prazer e bem-estar proporcionados pelas condições ideais de um ambiente aprazível são sentimentos nobres que podem surgir da própria forma urbana que se constitui de atributos particulares e qualificados. O contrário também é válido; em ambiente em que se predomina o "stress ambiental" a irritação do humor e a desesperança refletem estados emocionais que proporcionam o distanciamento 
entre a cidade e seu habitante. Em Diamantina, a Vesperata é o evento que caracteriza, claramente, tal "stress ambiental" ao segregar espacial e socialmente o residente, dado seu caráter exclusivo mercantil; um evento que, revalorado, não remete mais o residente a um culto tradicional da cidade, mas a uma prática turística, como identificamos em campo.

Logo, notemos que apesar de concentrar oito igrejas e da realização anual de eventos atrativos diversos (Vesperatas, Inverno Cultural, carnaval, algumas festa religiosas etc.), a população pouco reconhece o centro histórico como um espaço de prática religiosa ou um espaço símbolo da história, tradição e cultura. Isso nos leva a indicar a urgência de uma gestão verdadeiramente participativa da cidade histórica, como propõe as cartas, recomendações e memorandos analisados no capítulo 2 desta pesquisa. Proposta que deve ir além, dessa maneira, dos documentos produzidos e da retórica sobre a implantação de planos diretores participativos.

De acordo com Scarlato (2005, p. 132) - ao analisar o centro antigo de São Paulo que perdeu suas antigas funcionalidades com a chegada do capitalismo monopolista multinacional -, "nunca é demais lembrar que pela lógica histórica, os centros antigos guardam a memória da cidade e, só por isso, já representam um espaço de significativo 'valor simbólico' para a mesma". Sem dúvida, a materialidade preservada ou a paisagem urbana histórica produzida, remete-nos ao valor simbólico que representa o patrimônio cultural para a sociedade. No entanto, no caso das cidades históricas do interior - apropriadas massivamente pelo turismo chamado cultural - a contradição entre o uso e a troca que as cercam vem favorecendo a sobreposição do valor econômico em detrimento ao seu valor simbólico tradicional que é metamorfoseado em prol da busca de singularidades e irreplicabilidades que o recriam como "capital simbólico" (HARVEY, 2005). O fluxo turístico em Diamantina, percebido pela população local, conforme o gráfico 15 , abaixo, ratifica nossa assertiva, uma vez que o turismo gera um movimento dialético que funde "velho" e o "novo", de forma acelerada pela urbanização turística, gerando novas paisagens e consumindo outras, trazendo à cena novos sujeitos sociais, eliminando ou marginalizando outros e redesenhando as formas de apropriação (e representação) do espaço urbano, conforme aponta Luchiari (2005). 


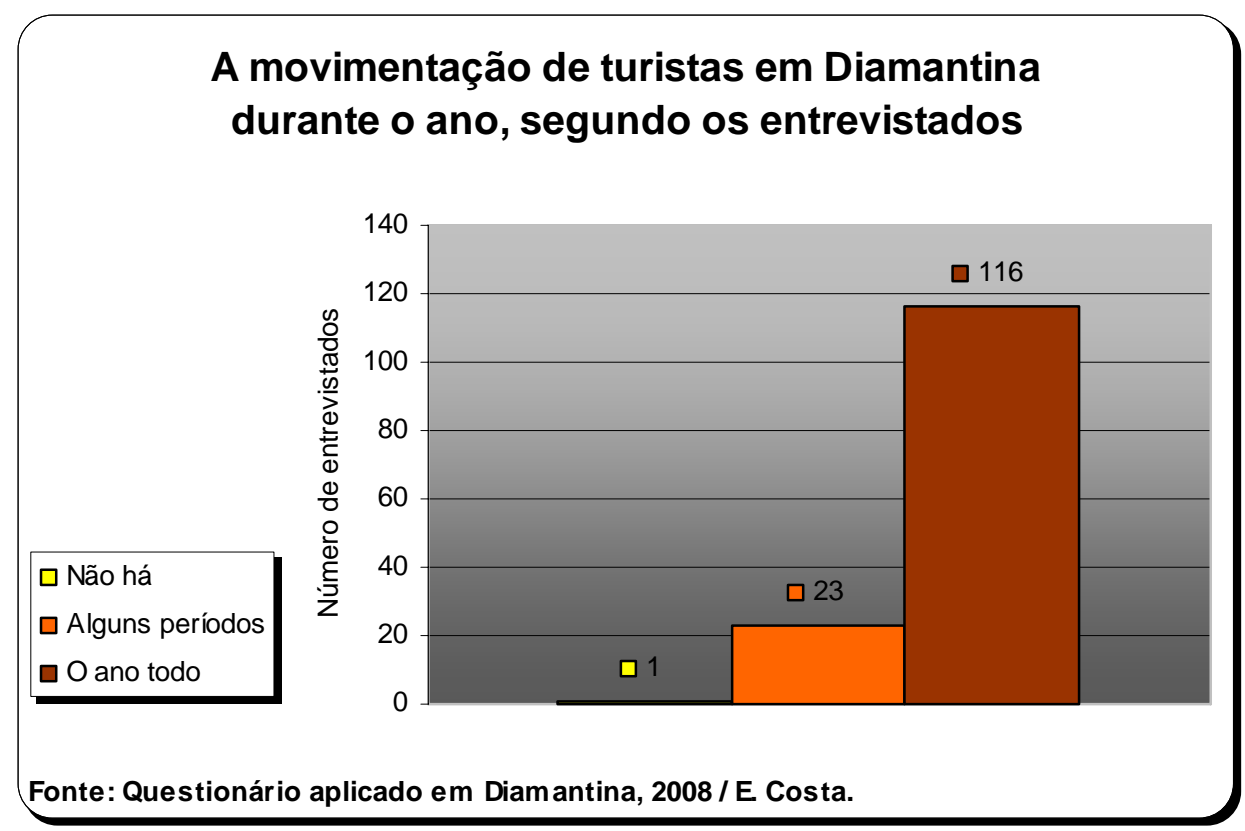

Gráfico 15

Meneses (1998, p. 325) também propõe que imagem, imaginário e imaginação são referentes à problemática do sentido, da significação. Envolvem fenômenos da produção, circulação, armazenamento, reciclagem e descarte de sentidos fundamentais na formulação e hierarquização de valores gerados por uma sociedade e indispensáveis em sua organização. Para Meneses, sentidos e valores são criados pela sociedade, são, assim, mutáveis, variáveis, de acordo com os processos históricos. Os valores não são imanentes aos objetos; nestes, "só há de intrínseco as propriedades físico-químicas dos materiais que os compõe". Logo, diversas percepções, no campo do patrimônio, se entrecruzam, visões de mundo dilaceradas, cuja variabilidade é estabelecida e aquilatada com a dinâmica dos meios de comunicação e os diversos conhecimentos/mentalidades que marcam cada fase histórica. "É no âmago das relações sociais e no quadro das estruturas sociais que se produzem sentidos e valores que constituem a imagem e o imaginário" (MENESES, 1998, p. 326).

Nesse contexto, podemos afirmar que os novos fluxos estabelecidos em Diamantina [até o ano de 1998, antecedente à conquista do título de Patrimônio Mundial, a cidade possuía 18 pousadas relacionadas na Prefeitura; em 2007, esse número atingiu a cifra de 42 pousadas (PREFEITURA MUNICIPAL, 2007)], que transformam os fenômenos da circulação, produção e promoção do centro histórico, fazem com que a população 
tolere o sistema social e econômico imposto; tolera por não perceber a lógica perversa que ronda os bens culturais do mundo. A governança urbana, em Diamantina, cria uma cidade mediada por um campo de forças em conflito de natureza econômica, política, cultural e social ao buscar na "valorização do espaço" a mercantilização da paisagem urbana histórica. O produto dessa coerção consentida (favorecida pela dialética entre a ilusão e a concretude do fenômeno - novos fluxos propiciados pelo turismo e identificados pelo residente) é a percepção positiva e a aceitação de uma atividade (gráfico 16) que surge sem o devido planejamento, que alija a grande maioria do processo de crescimento econômico estabelecido sem o esperado e desejado desenvolvimento social coletivo. "Assim, o imaginário representa a cada instante o sentido implícito do real" (SARTRE, 1996, p. 244).

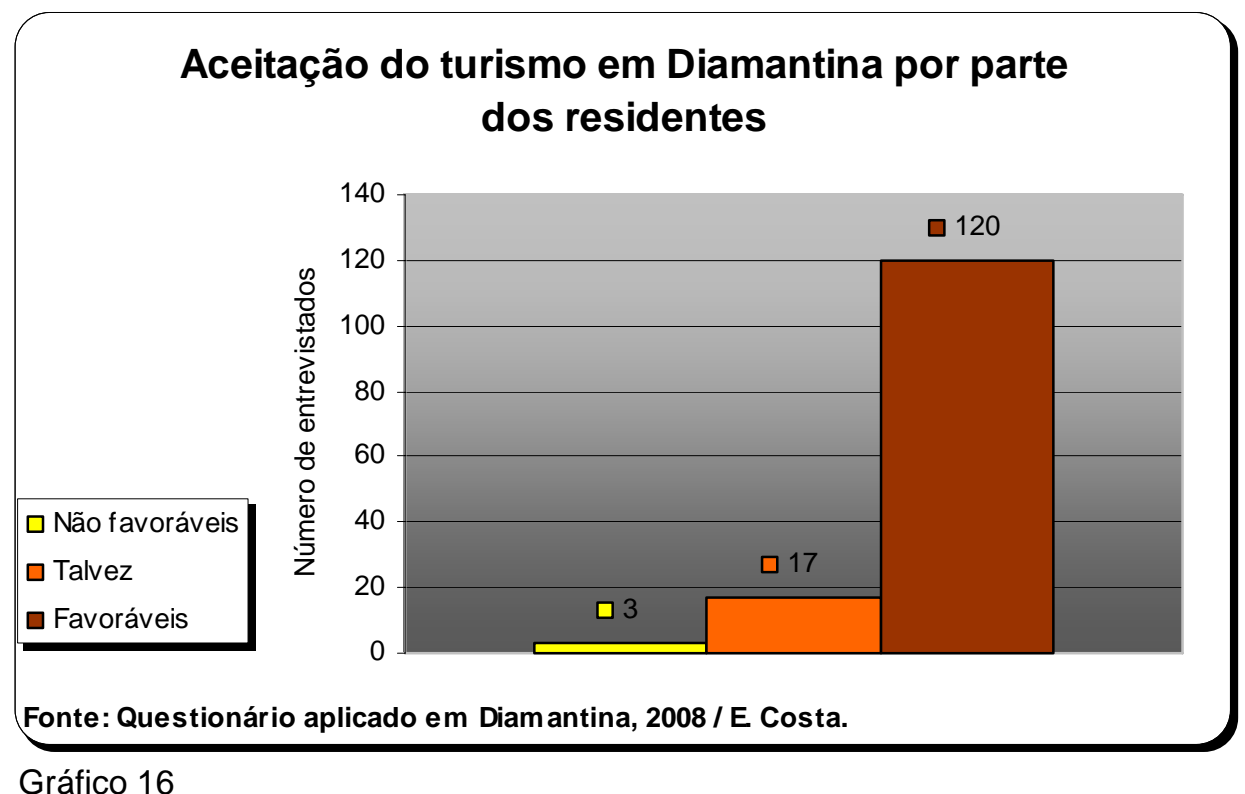

Nossa abordagem sobra a cidade histórica, que parte de sua produção material e chega à sua representação simbólica, ou seja, perpassando o campo da produção / valorização do espaço, dominação / política do espaço e consciência / representação do espaço, remete-nos ao entendimento de sua concepção enquanto produção cultural, pois toda ação humana que se efetiva em cultura material progride de aspirações, sentimentos, interesses, ideais e ideologias preconcebidas na própria consciência. Logo, a cidade histórica é fruto do espaço-tempo e da consciência de seus construtores e "reconstrutores", respectivamente, fruto da ânsia da conquista territorial 
pelos primeiros, no passado, e da seletividade do capital, propiciada pelos segundos, no momento atual.

A análise do imaginário da população residente em Diamantina aponta-nos para novos sentidos e valores produzidos no âmago de relações sociais mediadas pelo capital e no quadro de uma estrutura socioespacial que tem nos agentes hegemônicos (Estado e mercado) os principais organizadores do território urbano. A organização do território esboça a prática direta do homem no universo empírico e são suas representações que induzem e conformam as mesmas práticas, simultaneamente.

Esse imaginário leva-nos a considerar a cidade histórica como uma variante operacional (materialidade) da consciência da sociedade (representatividade). Assim, as problemáticas que a rondam serão equacionadas quando o foco das intervenções deslocarem-se das coisas para as relações sociais, quando se procurar examinar as coisas dentro do processo perverso de reprodução do capitalismo e no centro da sociedade, de forma ampla e democrática. O habitante não pode aparecer como um ser abstrato, fantasmagórico, sem densidade social; a análise do imaginário do residente, em Diamantina, aponta-nos para o estabelecimento de um sistema de valores que vem promovendo sua total alienação ao ser convencido pela retórica dos maiores interessados sobre a "certeza" de futuras benesses oriundas de uma nova atividade que dizem ser capaz de reverter diferenças criadas historicamente.

Logo, entendemos a cidade histórica como um campo de forças em permanente e simultâneo conflito de natureza ideológica, econômica, política, cultural e social, que "organiza" o território no sentido de mercantilizar a paisagem urbana histórica.

Assumimos, na pesquisa, uma postura crítica por verificarmos a prática na produção do espaço urbano em algumas cidades históricas mineiras - especialmente em Diamantina, Patrimônio Mundial - (sintetizada por planejamentos executados aos fragmentos e das elites para as elites), desfocada de seus habitantes locais. Nossa análise vem na perspectiva não de favorecer meros discursos ou enaltecer a retórica dos agentes públicos em voga, mas de incentivar práticas cuja preferência seja dada aos habitantes dessas cidades. Por assumirmos esta crítica e sabermos que na dialética da negação e da assimilação, que a crítica válida é a que introduz a nova afirmação (MORAES e COSTA, 1996), há de se frisar o possível caminho para a preservação dos bens culturais do mundo - através da gestão urbana participativa - uma afirmação já 
introduzida pela UNESCO através dos documentos relativos ao patrimônio cultural da humanidade; uma afirmação já posta, ou seja, não tratamos de algo novo, mas que se faz esquecida (ou desconhecida por desinteresse) pela governança urbana. Deixamos nossa indicação através da tradução das fontes internacionais, no intuito de esclarecer o caminho que deve ser seguido por essa governança urbana negligente. O gráfico 17 , abaixo, que retrata a insatisfação popular com a atual administração de Diamantina, atesta tal negligência.

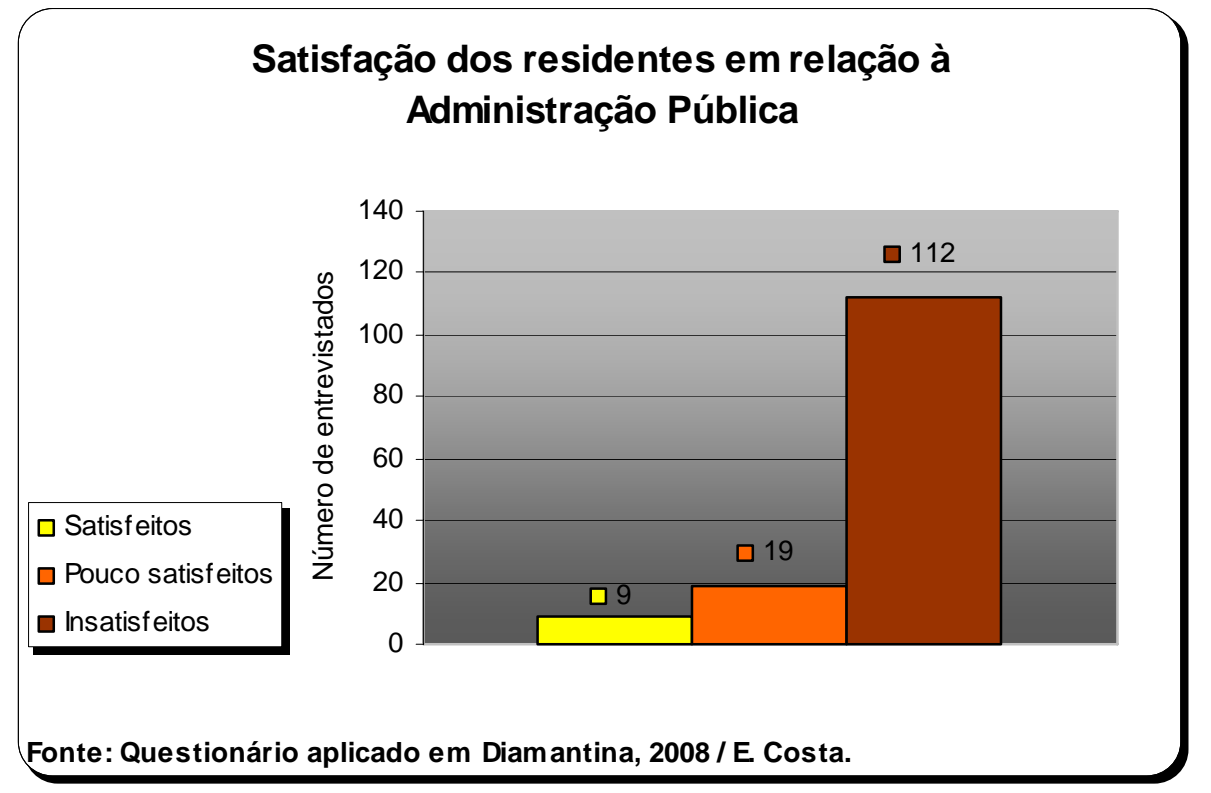

Gráfico 17

No Plans de gestion et protection, outils de conservation et de promotion des biens du patrimoine mondial, é bem clara a orientação de que cada bem proposto para inscrição na Lista do Patrimônio Mundial deve ter um plano de gestão ou um sistema de gestão documentado que especifique a forma como o valor universal excepcional do bem será preservado; "de préférence par des moyens participatifs (...) les conditions d'itégrité et/ou d'authenticité définies lors de l'inscription soient maintenues ou améliorées à l'avenir" (UNESCO, 2007b, p. 01). Em Diamantina, pouco a população tem sido chamada a participar da gestão de seu patrimônio consagrado como mundial.

O documento supracitado informa também que a proposta do sistema de gestão, para ser eficaz, deve ser concebido segundo o tipo, as características, o contexto e as necessidades do bem, da sociedade por ele envolvida, bem como seu contexto cultural. Esse Plano de Gestão proposto pela UNESCO, trás, ainda, que o fim principal 
objetivo de um sistema de gestão para um bem do patrimônio mundial é a proteção de seus valores patrimoniais e, em particular, de seu valor universal excepcional, mas também é importante que os objetivos de conservação sejam determinados em função e em harmonia com os outros problemas de desenvolvimento existentes e as necessidades legítimas das comunidades locais, para se assegurar a legitimidade dos conjuntos.

O documento não exclui o potencial para o desenvolvimento econômico local, porém deve estar atrelado ao desenvolvimento social, a partir de uma intervenção democrática. Prossegue afirmando que um sistema de gestão deve assegurar a preservação do bem, permitir a maior compreensão dos habitantes e do publico em geral sobre seu valor universal excepcional, bem como deve sensibilizar a população sobre a necessidade de proteção, dado o valor educativo do bem "et son potentiel pour le développement sociel et économique" (UNESCO, 2007b, p. 02).

O documento remete-nos à necessidade de uma abordagem humanista da cidade, menos tecnocrática; visão humanista defendida por Scarlato (2005, p. 132). Segundo o autor, de forma crítica radical, os primeiros são levados a pensar a cidade como lugar das realizações humanas, na construção de identidades e de uma sociabilidade integradora, os segundos, praticam uma intervenção que, em essência, concebe a cidade como um receptáculo de morar, circular e trabalhar, objetivamente (isso quando não atrelada, preponderantemente, aos ditames do capital especulativo, como nos apresenta o caso de Diamantina).

Outro significativo documento é o Mémorandum de Vienne, que trata da gestão da paisagem urbana histórica. Considera que a maior preocupação das intervenções materiais e funcionais - na cidade histórica - deve ser a de melhorar a qualidade de vida e eficiência da produção, a fim de elevar as condições de vida, de lazer e de trabalho do habitante local, sem comprometer os valores e as características do tecido urbano histórico.

É-nos de relevante importância a seguinte recomendação do Memorando de Viena. Considera que o planejamento urbano, a arquitetura contemporânea e a preservação da paisagem urbana histórica deverão evitar todas as formas de concepção pseudo-histórica, na medida onde constitui uma negação dos aspectos históricos e mesmo contemporâneos. A visão histórica não pode ser suplantada pelas 
outras, deve continuar legível, impedindo que a cultura seja apropriada pelos modos de intervenção como objetivo supremo. Essa postura da UNESCO evita a dialética da construção destrutiva que vem envolvendo os bens culturais do mundo, ou seja, o confronto à sua proposta, oriundo da "indústria cultural" por via do turismo internacional.

De acordo com a UNESCO (2005, p. 06), a elaboração do plano de gestão exige a participação de uma equipe interdisciplinar de profissionais, além da organização de uma consulta pública aprofundada, pois a arquitetura histórica e contemporânea constitui em atributos para as comunidades locais; devem servir para objetivos educativos, recreativos e mesmo turístico, porém garantindo o valor dos bens acima do mercado. Observamos em Diamantina o descompromisso com essa democratização do patrimônio cultural. A Convenção do Patrimônio Mundial (UNESCO, 1972), já fazia, na década de 1970, menção à importância de os Estados-parte esforçarem-se por todos os meios apropriados para o estabelecimento de programas de educação e de informação para se reforçar o conhecimento e o respeito dos povos pelo patrimônio cultural e natural do mundo.

Quando Diamantina é inscrita na Lista do Patrimônio Mundial e todos os esforços não são feitos para se estabelecerem tais programas ou para a promoção da democratização do patrimônio cultural, ou mesmo da implementação de uma gestão urbana participativa, a governança urbana descumpre um compromisso estabelecido quando da busca da chancela da UNESCO e perde uma oportunidade primaz de melhorar as condições de vida da população local a partir de seus verdadeiros valores intrínsecos, que podem e devem ser compartilhados mundialmente. O intento requer o planejamento da cidade histórica enquanto totalidade inserida no contexto global; requer, ainda, que se molde um homem novo para o estabelecimento de uma sociedade que não se faça fragmentada.

Por fim, não poderíamos deixar de fazer referência ao documento que consideramos, juntamente com Choay (2006, p. 223), o texto mais lúcido sobre os perigos inerentes às políticas de patrimônio atreladas ao capital que envolvem as cidades históricas do mundo, na atualidade, a Recomendation concenant la sauvegarde des ensembles historiques ou traditionnels et leur role dans la vie contemporaine ou Recomendação de Nairóbi. 
De acordo com a Recomendação, os conjuntos históricos ou tradicionais e seu ambiente devem ser considerados como constitutivos de um patrimônio universal insubstituível. Sua salvaguarda e sua integração na vida coletiva de nossa época é um dos deveres dos governos e cidadãos dos Estados, considerando os territórios sobre os quais estão situados os conjuntos. Os bens do patrimônio mundial deverão ser protegidos contra todo tipo de deterioração, em particular contra a que resulta do uso inapropriado, de transformações abusivas ou desprovidas de sensibilidade quanto à sua autenticidade e contra todas as formas de poluição. Considera, ainda, que ao vivermos em uma época onde a universalidade das técnicas de construção e das formas arquiteturais provocam uma uniformização dos estabelecimentos humanos, a preservação dos conjuntos históricos ou tradicionais pode contribuir para o aprofundamento dos valores culturais e sociais edificados em cada nação, e favorecer a conservação do patrimônio cultural mundial sobre o plano arquitetural.

A funcionalidade dos bens culturais deve estar diretamente ligada às necessidades sociais, culturais e econômicas dos habitantes locais, sem deixar que se perca as características do conjunto. Políticas de promoção cultural devem fazer dos conjuntos históricos lugares de atividades culturais e lhes dar uma função essencial no desenvolvimento cultural das comunidades envolvidas (UNESCO, 1976, p. 26). O caso da Vesperata de Diamantina não nos remete a essa recomendação do organismo internacional.

Amarra bem a nossa crítica a seguinte proposição da Recomendação de Nairóbi, quando verificamos que tal proposta pouco vem sendo implementada através de políticas públicas de patrimônio, no Brasil. Deve-se desenvolver a consciência da necessidade de salvaguarda dos bens culturais no ensino fundamental, médio, universitário e, ainda, através dos meios de comunicação, como jornais, rádio, televisão, cinema e exposições itinerantes. Essas ações podem promover vantagens não só estéticas e culturais, mas também sociais e econômicas, através de políticas claras e competentes bem conduzidas de salvaguarda dos conjuntos históricos e tradicionais. Todas informações sobre os conjuntos devem ser difundidas amplamente, junto a órgãos públicos e privados, nacionais, regionais, locais e entre a população, que deve saber porque e como seu lugar de vivência pode ser melhorado por meio de investimentos financeiros, ou da atividade turística. Verificamos, no capítulo 3.4.3, que o Programa 
Monumenta, em Diamantina, pouco tem desenvolvido uma política de patrimônio que favoreça a difusão de informações sobre as ações que se estabelecem no conjunto tombado.

As ações propostas pela Recomendação de Nairóbi, realmente, estão diretamente ligadas ao que vislumbramos para as cidades históricas brasileiras, de forma ampla. Considera também que se deve enraizar nos jovens a compreensão e o respeito para com as obras do passado e deixar claro a função desse patrimônio na vida contemporânea. Esses ensinamentos devem ser passados por amplos meios, como os audiovisuais e as visitas monitoras aos conjuntos históricos e tradicionais. Nesse contexto, podemos considerar que os professores do ensino fundamental e médio de geografia, história e sociologia, principalmente, podem assumir um papel fundamental na difusão do valor simbólico dos bens culturais do mundo, através de trabalhos de campo nas respectivas cidades históricas. A difusão dessa proposta pouco oneraria o Estado pela facilidade de acesso a esses lugares por parte dos residentes; urge o estabelecimento de um sério compromisso com nossa sociedade e com os territórios do patrimônio.

O documento fecha responsabilizando os Estados pelas políticas públicas de patrimônio que devem assegurar o melhor uso e a melhor proteção dos bens culturais do mundo. Os documentos citados ao final desta pesquisa deveriam ser adotados como "cartilha básica" da governança urbana das cidades históricas, de forma muito especial, de Diamantina. De uma forma geral, identificamos o estabelecimento de reformas sócioeconômicas e a busca de um crescimento que não respeita a autenticidade e a integridade das cidades históricas, nem sua paisagem urbana pretérita.

Frente ao descaso às recomendações da UNESCO, faz-se urgente a gestão participativa dos bens culturais do mundo. Torna-se indispensável que se elaborem estudos sociológicos, antropológicos, históricos, geográficos ou outros sobre as cidades históricas, mas que sejam ágeis e pragmáticos: a paisagem urbana histórica e as sociedades afetas não podem esperar muito.

De acordo com Yázigi (2006, p. 136), a melhor forma de viabilizar os interesses locais em causa própria consiste na criação de conselhos independentes do poder, mas revestidos de legitimidade formalizada. Cultura não se planeja, de acordo com o autor, mas os projetos podem ser virtuosos no sentido de alargar os interesses sociais da coletividade. 
Consideramos que a participação popular na gestão urbana da cidade histórica é mais que uma necessidade administrativa moderna ou uma opção ideológica, ela representa a busca da consciência do espaço, do ordenamento e da socialização do território, do pertencimento ao lugar e da transcendência a um planejamento que enfoque a cidade como um todo e o indivíduo total. O que se sugere é a implantação de um verdadeiro planejamento que busque preservar a paisagem urbana histórica e oferecer uma vida digna à população, nas cidades do interior; para o intento, as realidades locais devem ser o ponto de partida para o raciocínio dos administradores, e não apenas o lugar de ações desarticuladas e, por isso mesmo, ineficientes. A proposta é pelo fim da "dualidade" entre a "valorização" do centro histórico frente à "precarização" da periferia, onde a população local tenha a palavra final. Que outra saída teríamos para o processo em curso que consagra um Patrimônio Mundial que, aos poucos, contraditoriamente, deixa de ser local, quando açambarcado pela lógica do capital? Quem cuida melhor do que é seu que o próprio dono que sabe que é dono? 


\section{À guisa de uma conclusão: as contradições do processo de "preservação" I mercantilização do patrimônio cultural como produtos da "dialética da construção destrutiva"}

A abordagem histórico-dialética - método adotado nesta pesquisa - é, segundo Kosík (1976, p. 15), o pensamento crítico que se propõe a compreender a "coisa em si" e sistematicamente se pergunta como é possível chegar à compreensão da realidade. Por isso, é o oposto da sistematização doutrinária ou da romantização das representações comuns. Como não nos contentamos com os esquemas abstratos da realidade e suas simples representações do visível, buscamos "destruir a aparente independência do mundo dos contatos imediatos de cada dia" (KOSíK, 1976, p. 16).

Nesse sentido, a resposta ao nosso problema de pesquisa que é o de identificar como as ações de "preservação" de patrimônio cultural estão refletindo na organização socioespacial de Diamantina, se dá por meio de uma análise que desvenda o mundo real para além do mundo da aparência. Por isso, não nos atemos apenas à análise dos novos fluxos e das ações estabelecidas no centro histórico de Diamantina, fato dado que nos fornece a falsa ilusão de um território urbano preservado pela e para a coletividade, mas transcendemos essa porção central da cidade e encontramos, na periferia, o que representa a lógica contraditória e perversa da reprodução do capitalismo pela sua própria expansão, uma periferia em processo de intensa "precarização" fruto da seletividade do capital, como nos indica Harvey (2005).

Nesse movimento de destruição do aparente, que Kosík (1976) denomina "pseudoconcreticidade", não negamos a existência ou a objetividade do fenômeno que ronda o centro histórico de Diamantina, mas tentamos destruir sua pretensa independência demonstrando seu caráter derivado quando buscamos dar resposta às duas problemáticas que são o fio condutor desta pesquisa. Confirmamos que a inclusão da cidade na Lista do Patrimônio Mundial e a posterior implantação do Programa Monumenta (ações que representam a universalidade da prática patrimonial) perdem o papel principal de valorização cultural, memorial e identitária para se estabelecerem como processos que têm na "valorização do espaço" um adendo para a especulação econômica e imobiliária na cidade, apesar de a retórica dos agentes públicos remeterem-nos ao contrário. Confirmamos também que os dois "eventos" redundam em uma política de 
patrimônio que desvia a atenção pública e recursos de problemas mais amplos, sobretudo, fora do núcleo tombado, o que afeta as condições de vida da população local, transforma o imaginário popular em relação ao seu patrimônio e produz um território urbano, dialeticamente, fragmentado e articulado, quando a "valorização" do centro parece depender da "precarização" da periferia, esboçando uma cidade dual. A formação de uma cidade dual é o primeiro produto do que denominamos dialética da construção destrutiva que encerra os bens culturais do mundo.

A dialética não considera as configurações e os objetos fixados, como algo originário e independente, como também não considera o mundo das representações banais, não aceita sob o seu aspecto imediato; submete-os a um exame em que as formas reificadas do mundo objetivo e do mundo ideal se diluem, segundo Kosík (1976); perdem a sua fixidez, naturalidade e pretensa originalidade para se mostrarem como fenômenos derivados e mediatos, como sedimentos e produtos da práxis social da humanidade.

Nesse contexto, fica-nos claro que a "construção" do patrimônio cultural sempre teve um caráter identitário, espacial e político, dialética e universalmente. Primeiro, para afirmação dos "Estados-nações" enquanto símbolos da formação de seus territórios (caráter particularista de patrimônio), depois, no extremo de sua ampliação, na tentativa de se afirmar a diversidade cultural dos povos e a integração das nações, através do conceito de humanidade (caráter universalista do patrimônio).

Hoje, o patrimônio passa a ser procurado e encontrado em todo o mundo; adquire uma visibilidade e uma importância inigualáveis na história, englobando tudo o que é dotado de significado cultural irreplicável. Cultura revestida pela lógica da mercadoria, na sociedade contemporânea, fazendo com que o patrimônio, cada vez menos, represente o ideal de "Estado-nação" ou de diversidade cultural dos povos, perdendo, aos poucos, seu referencial de memória viva ao se tornar um produto em potencial do desenvolvimento turístico nos lugares; atividade que tem o poder de banalizar pela cenarização progressiva; isso denota o esvaziamento das práticas de patrimônio, nas cidades históricas. A mercantilização desenfreada dos bens culturais faz com que percam sua função primeira, que é a de esclarecimento, ligada ao valor cognitivo e afetivo, transformando-se num grande fetiche incorporado ao mundo do consumo e se tornando peça central da máquina reprodutiva do capitalismo. Em Diamantina, a prática de 
patrimônio adotada remete-nos à tendência contemporânea ao "esvaziamento" no campo da cultura. Assim, a minimização do valor simbólico e de uso para a maximização do "capital simbólico" que passa a representar o patrimônio para o diamantinense, como atestamos em nossas atividades de campo, é o segundo produto da dialética analisada. São antigas formas que, ao assumirem novas funções, sintetizam novos conteúdos para o habitante, dentro da vigente estrutura estabelecida pela reprodução do capitalismo e seletividade do capital, que impactua o território urbano.

Sabendo que as coisas não se mostram ao homem diretamente como são e como o homem não tem a faculdade de ver as coisas na sua essência, Kosík (1976) propõe que a humanidade faça um détour para conhecer as coisas e a sua estrutura. Como tal détour é o único caminho acessível para o homem chegar à verdade sobre os fenômenos - e tal caminho é nebuloso -, periodicamente, poupa-se do trabalho desse desvio e observa diretamente a essência das coisas. Isso significa a tendência à alienação total da humanidade perante os processos que rebatem sobre a cidade enquanto lugar da vida, da morada e das relações sociais. Segundo Kosík (1976, p. 22), para conhecer as coisas em si, o homem deve primeiro transformá-las em coisas para si; para conhecer as coisas como são independentemente de si, tem primeiro de submetê-las à própria práxis: para poder constatar como são elas quando não estão em contato consigo, tem primeiro de entrar em contato com elas. "O conhecimento não é contemplação (...) o homem só conhece a realidade na medida em que ele cria a realidade humana e se comporta antes de tudo como um ser prático".

Admitimos que a "pseudoalienação" dos agentes públicos em relação à perversidade do mercado e a alienação da população local em relação ao trato despendido à sua cidade e ao seu patrimônio (onde os primeiros - representantes da sociedade e quem deveria ser os defensores das causas coletivas -, contraditoriamente, favorecem a alienação dos segundos) sintetizam a idéia de que o homem, realmente, não se distancia das coisas e de suas estruturas para conhecê-las em essência. Logo, identificamos, em Diamantina, uma espécie de coerção consentida que simboliza a alienação do residente pela "pseudoalienação" da governança urbana, a qual atinge seus objetivos através da retórica das benesses coletivas advindas da mercantilização do espaço central da cidade. Assim, a simultaneidade entre a ilusão forjada e a pseudoconcretude do fenômeno - novos fluxos propiciados pelo turismo e vislumbrados 
pelo morador de Diamantina - promove a alienação do residente por meio de tal coerção consentida, um terceiro produto da dialética da construção destrutiva na consagração do Patrimônio Mundial.

Segundo Milton Santos, em O espaço do cidadão, o espaço tem sido utilizado como veículo do capital e instrumento da desigualdade social, mas uma função diametralmente oposta poderia ser-Ihe encontrada. Será impossível chegar a uma sociedade mais igualitária sem reformular a organização do seu espaço. No entanto, deve ser considerado que a dialética da construção destrutiva que envolve o patrimônio cultural, objetivamente, e a cidade histórica, de forma total, é um processo e também um resultado da operacionalização do capital sobre o espaço e sobre os lugares do patrimônio. Nesse contexto, a análise de Diamantina remete-nos à ambivalência do termo valorização; expressão chave para o patrimônio e para o próprio espaço. O termo que deveria propiciar-nos tranqüilidade, ao contrário, inquieta-nos por sua ambigüidade ao nos remeter a dois estilos de conservação sintetizadas, por um lado, pela valorização simbólica da cultura, por outro - a preponderante -, por sua valorização econômica; essa valorização inquieta-nos, também, por identificarmos o valor simbólico do patrimônio servir de adendo para a venda da cidade histórica, um valor de uso civilizatório. Temos desse processo resultante da operacionalização do capital sobre o espaço, o quarto produto da contradição "preservação" I mercantilização dos bens culturais de Diamantina, um planejamento que favorece o antiurbanismo anárquico, um planejamento feito das elites para as elites, um modelo segregacionista de planejamento urbano, quando poderia se constituir em um potencial instrumento de melhoria da qualidade de vida de toda população local e de ordenamento do território urbano enquanto totalidade.

O quinto e último produto identificado do processo contraditório e simultâneo de "preservação" / mercantilização operacionalizado em Diamantina é a tendência ao "fim" da cidade histórica, é o caso limite de uma crise que não ameaça apenas a paisagem urbana histórica, o figurino dessas cidades simbólicas do urbanismo barroco das Geraes, mas a instituição urbana em si; o processo mercantil em curso minimiza o significado da cidade histórica como embrião, sede e centro do processo civilizatório brasileiro; a lógica mercantil em tela minimiza a própria concepção de espaço como dimensão cultural da vida social, para se tornar palco de atuação do capital. 
Nesta perspectiva, buscamos olhar, criticamente, para o conteúdo que refuncionaliza o patrimônio e Ihe atribui novos valores que são retratados no imaginário do residente; tentamos identificar a segregação socioespacial evidente a partir da "valorização do espaço" no centro histórico, bem como desvendar os usos que cercam esse espaço central em favor da "precarização" da periferia.

Principalmente por estar em sua forma embrionária, em Diamantina, acreditamos que o processo contraditório de "preservação" / mercantilização de patrimônio para a atividade do turismo deve ser acompanhado - de perto e sob orientação - por seus verdadeiros donos, o habitante local. Deve-se promover, de forma equilibrada e coletiva, a valorização cultural e mesmo econômica dos lugares do patrimônio, desde que seja a vontade e a necessidade da maioria. Não buscamos santificar ou bestializar o mercado, muito menos o turismo, mas propor a busca de soluções socioespaciais democráticas através da gestão participativa dos bens culturais do mundo e da implementação de Políticas Públicas de Educação Patrimonial; as quais devem estar centradas, por meio das diversas instituições de ensino, nas crianças e nos adolescentes, os futuros guardiões do patrimônio cultural e natural do mundo. Para tanto são de suma referência as diretrizes das várias cartas patrimoniais editadas ao longo do século XX e no início deste século (as quais apresentamos ao longo desta pesquisa), como a Carta de Veneza (1964), a Carta de Quito (1967), a Convenção do Patrimônio Mundial (1972), a Declaração de Amsterdã (1975), a Recomendação de Nairóbi (1976) e o Memorando de Viena (2005).

Militamos não pelo fim da dinâmica econômica e turística nesses espaços, as quais podem sim, contribuir para melhoria das condições de vida da população local a partir de uma gestão verdadeiramente participativa, mas defendemos a permanência dos usos sociais tradicionais e contemporâneos, harmoniosamente, nesses espaços coletivos da história, da memória e da cultura, de forma a não se produzirem territórios urbanos fragmentados. Militamos pela "sobrevivência" da cidade histórica enquanto totalidade perpassada pela lógica capitalista de um mercado global e pela "perpetuação" de seus habitantes, ante um mundo que se mostra cada vez mais voraz.

Por fim, dessa forma, deixando de isolar os fatos e os fenômenos, como propõe o método dialético, devemos reintegrá-los em seu movimento: movimento interno, que provém deles mesmos, e movimento externo, que os envolve no devir universal. Os dois movimentos são inseparáveis (LEFEBVRE, 1975, p. 238). Só a partir de um 
instrumento que capte a ligação, a unidade e o movimento que engendra as ações contraditórias, que as opõe, que faça com que se choquem, que as supere, podemos superar a ilusão da realidade; esse instrumento é a busca do conhecimento que não se limita à contemplação. O homem só conhece a realidade quando cria a realidade humana e se comporta como um ser não-alienado, prático e revolucionário. Logo, a cidade histórica deve se estabelecer como o espaço de um homem desalienado, um espaço em que todos se unam para o trabalho e não se separem em classes antagônicas conflitantes; a cidade histórica só se estabelecerá como um espaço coletivo, de toda gente, quando a luta for pelo resgate de seu valor de uso civilizatório em detrimento ao seu valor de troca tão em voga.

Falta o discurso coerente da cidade, pois o discurso incoerente, fragmentado e analiticamente indigente, já existe. Os próprios intelectuais ainda buscam as variáveis adequadas para escrever essa pedagogia do urbano que codifique e difunda, em termos didáticos e de maneira simples, o emaranhado de situações e relações com que o mundo da cidade transforma o homem urbano em instrumento de trabalho e não mais em sujeito. Entretanto, todos os dados estão praticamente em nossas mãos, para tentar reverter a situação (...) Ficar prisioneiro do presente ou do passado é a melhor maneira para não fazer aquele passo adiante, sem o qual nenhum povo se encontra com o futuro. (SANTOS, 2007, p. 161, grifos nossos) 


\section{REFERÊNCIA BIBLIOGRÁFICA}

ABREU, Adilson Avansi. Análise Geomorfológica: Reflexão e Aplicação (Uma contribuição ao conhecimento das formas de relevo do Planalto de Diamantina - MG). São Paulo: DG/USP - Tese de Livre Docência - FFLCH, 1982.

ABREU, Adilson Avansi. O Planalto de Diamantina: Um setor da Serra do Espinhaço em MG. Instituto de Geografia USP, Revista Orientação, 1984.

ABREU, Maurício Almeida. A apropriação do território no Brasil Colonial. In: CASRO, I. E; GOMES, P. C; CORREAA, R. L. (orgs.). Explorações geográficas: percursos no fim do século. Rio de Janeiro: Editora Bertrand Brasil, 1997.

ABREU, Regina. A emergência do patrimônio genético e a nova configuração do campo do patrimônio. In: ABREU, R; CHAGAS, M. (org.). Memória e Patrimônio: ensaios contemporâneos. Rio de Janeiro. DP\&A, 2003.

AGNOLIN, Adone. Política Barroca: A arte da Dissimulação. In: TIRAPELI, P. (org.). Arte Sacra: barroco memória viva. 2. ed. São Paulo: EdUNESP, 2005.

ANDRADE, Rodrigo Melo Franco. Rodrigo e o SPHAN: coletânea de textos sobre patrimônio cultural. In: Secretaria do Patrimônio Histórico e Artístico Nacional. Rio de Janeiro, 1987.

ARANTES, Antônio A. As tramas da memória: antigas estruturas e processos culturais contemporâneos. In: Revista Crítica de Ciências Sociais, nº 32, 1991.

ARANTES, Otília B. Uma estratégia fatal: A cultura nas novas gestões urbanas. In: ARANTES, O; VAINER, C; MARICATO, E. (orgs.). A cidade do pensamento único. Desmanchando consensos. Rio de Janeiro: Editora Vozes, 2002.

ARANTES, Otília B. A virada cultural do sistema das artes. In: JINKINGS, I; NETO, A. (ed.). Margem esquerda: ensaios marxistas. São Paulo: Editora Boitempo, 2005.

ÁVILA, Afonso. Barroco Mineiro. Glossário de Arquitetura e Ornamentação. Belo Horizonte: Fundação João Pinheiro,1980.

AZEVEDO, Aroldo. Vilas e Cidades do Brasil Colonial. Ensaio de Geografia Urbana Retrospectiva. São Paulo: Boletim Paulista de Geografia n. 33., 1956.

BENKO, Georges. Geografia de lugar nenhum ou hiperglobalização. Breve exame do mundo pós-moderno. In: SANTOS, M; SOUZA, M; SILVEIRA, M. Território, Globalização e Fragmentação. São Paulo: Editora Hucitec, 2002.

BIANCARDI, Cleide S. C. Liturgia, arte e beleza: o patrimônio móvel das sacristias barrocas no Brasil. In: TIRAPELI, P. (org.). Arte Sacra: barroco memória viva. 2. ed. São Paulo:EdUNESP, 2005. 
BOSQUE, Joaquín Morel. O Patrimônio da Humanidade. In: YÁZIGI. E, CARLOS. A. F, CRUZ. R. C. A. (orgs). Turismo: Espaço, Paisagem e Cultura. São Paulo. Editora Hucitec, 1996.

CAMARGO, Haroldo Leitão. Patrimônio Histórico e Cultural. São Paulo. Ed. Aleph, 2002.

CAMPOS FILHO, Cândido Malta. Cidades brasileiras: seu controle ou o caos. São Paulo: Studio Nobel, 1992.

CARLOS, Ana Fani A. O lugar: mundialização e fragmentação. In: SANTOS, M; SOUZA, M; SCARLATO, F; ARROYO, M. (org.). O novo mapa do mundo: fim de século e globalização. São Paulo: Editora Hucitec, 1993.

CARLOS, Ana Fani A. A mundialização do espaço. In: MARTINS, J. S. (org.). Henri Lefebvre e o retorno à dialética. São Paulo: Editora Hucitec, 1996.

CARLOS, Ana Fani A. A segregação como fundamento da crise urbana. In: DAMIANI, A; CARLOS A. F; SEABRA, O. (org.). O espaço no fim do século: a nova raridade. São Paulo: Ed. Contexto, 1999.

CARLOS, Ana Fani A. Novas contradições do espaço. In: SILVA, J.B; DANTAS, E.W; (orgs.). Panorama da Geografia Brasileira. São Paulo: Annablume, 2006.

CASTELLS, Manuel. Problemas de investigação em sociologia urbana. Editora Presença, 1975.

CASTRO, Antônio Barros. A herança colonial no desenvolvimento brasileiro. A região das Minas - retrocesso e dispersão após a Crise. In: 7 Ensaios sobre a Economia Brasileira. São Paulo: Ed. Ferrense, Vol II, 1979.

CARDOSO, Jorge de Jesus. Patrimônio Ambiental Urbano e Requalificação: Contradições no Planejamento do Núcleo Histórico de Santos. São Paulo: DG/USP - Tese de Doutorado - FFLCH, 2007.

CHOAY, Françoise. A alegoria do patrimônio. São Paulo: Editora da UNESP, 2006.

CIFELLI, Gabrielle. Turismo, Patrimônio e Novas Territorialidades em Ouro Preto - MG. Campinas: UNICAMP/ Dissertação de Mestrado - Instituto de Geociências, 2005.

COELHO NETTO, J. Teixeira. A construção do sentido na arquitetura. São Paulo: Editora Perspectiva, 2007.

COLOMBO FILHO, Egydio. Sobre os objetos barrocos. In: TIRAPELI, P. (org.). Arte Sacra: barroco memória viva. 2. ed. São Paulo:EdUNESP, 2005.

CONH, Gabriel. Concepção oficial de cultura e processo cultural. In: IPHAN, Revista do Patrimônio, n 22, 1987.

CORRÊA, Roberto Lobato. Região e Organização Espacial. São Paulo: Ed. Ática, 2003. 
CORRÊA, Roberto Lobato. O Espaço Urbano. São Paulo: Editora Ática, 2005.

COSTA, Everaldo B. Município de Tiradentes (MG): reflexo presente de uma imagem pretérita. Rio Claro/SP: Anais do XVII Congresso de Iniciação Científica da UNESP, 2005.

COSTA, Everaldo B. Turismo e organização socioespacial no centro histórico de São João Del Rei - MG. São Paulo: Universidade de São Paulo: TGI, Departamento de Geografia (USP - FFLCH), 2007.

COSTA, Everaldo. B. Turismo, comércio e patrimônio em São João Del Rei - MG. In: Colóquio Internacional sobre o Comércio e a Cidade, n. 2, 2008, São Paulo. Anais do Colóquio (FAU / USP), CD, 2008.

COSTA, Everaldo B; CASTRO, Bernadete C. O processo de "banalização pela cenarização" em núcleos urbanos tombados: o caso de Tiradentes - MG. Belo Horizonte: Revista Geografias / IGC / UFMG, 2008a.

COSTA, Everaldo. B. O protagonismo do negro na formação socioespacial brasileira. In: Revista Política Democrática. Caderno de Debates. Ano I, $n^{\circ} 2$. Brasília, 2008b, p. 72-74.

CRUZ, Rita de C. A. Introdução à Geografia do Turismo. São Paulo: ROCA, 2003.

CRUZ, Rita de C. A. Políticas públicas de turismo no Brasil: território usado, território negligenciado. Santa Catarina: Editora da UFSC, Geosul (Revista do Departamento de Geociências), 2005.

CRUZ, Rita de C. A. Geografias do Turismo: de Lugares a Pseudo-lugares. São Paulo: ROCA, 2007.

CUNHA, Maria Clementina P. Patrimônio Histórico e Cidadania: uma discussão necessária In: Revista do Departamento do Patrimônio Histórico de São Paulo. O direito à memória: patrimônio histórico e cidadania. São Paulo:1992.

DUARTE, Nestor. A Ordem Privada e a Organização Política Nacional. São Paulo: Companhia Editora Nacional, 1995.

DEFFONTAINES, Pierre. Como se constituiu no Brasil a rede das cidades. Rio de Janeiro: Conselho Nacional de Geografia / IBGE, 1944.

FELÍCIO DOS SANTOS, Joaquim. Memórias do Distrito Diamantino da Comarca do Serro Frio (Província de Minas Gerais). São Paulo: Editora da Universidade de São Paulo, 1978.

FENELON, Déa. Políticas Culturais e Patrimônio Histórico. In: Revista do Departamento do Patrimônio Histórico de São Paulo. O direito à memória: patrimônio histórico e cidadania. São Paulo:1992. 
FRANCO, Afonso Arinos Melo. Desenvolvimento da Civilização Material no Brasil. Publicações do SPHAN (Serviço do Patrimônio Histórico e Artístico Nacional), 1944.

FREITAS, Cláudia Lamounier. Turismo, Política e Planejamento - Estudo do Circuito Turístico do Diamante no Vale do Jequitinhonha, em Minas Gerais. Belo Horizonte, IGC / UFMG, Tese de Doutorado, 2008.

FREYRE, Gilberto. Sobrados e Mucambos: decadência do patriarcado e desenvolvimento do urbano. 14 Ed - São Paulo: Global, 2003.

FUNARI, Pedro \& PELEGRINI, Sandra. Patrimônio Histórico e Cultural. São Paulo: Jorge Zahar Editora, 2006.

FURTADO, Celso. Formação Econômica do Brasil. São Paulo. Editora Nacional, 1974.

GEIGER, Pedro P. Evolução da Rede Urbana Brasileira. Rio de Janeiro: Centro Brasileiro de Pesquisas Pedagógicas / MEC, 1963.

GONÇALVES, José Reginaldo. O patrimônio como categoria de pensamento. In: REGINA, Abreu (org.). Memória e Patrimônio: ensaios contemporâneos. Rio de Janeiro. DP\&A, 2003.

GREGOLIN, Maria do Rosário; MONTANHEIRO, Fábio César. O fausto e a ostentação: a religião sob o signo barroco nas Minas Gerais do século XVIII. In: TIRAPELI, P. (org.). Arte Sacra: barroco memória viva. 2. ed. São Paulo: EdUNESP, 2005.

HAESBAERT, Rogério. O mito da desterritorialização: do fim dos territórios à multiterritorialidade. Rio de Janeiro: Bertrand Brasil, 2004.

HARVEY, David. A justiça social e a cidade. São Paulo: Editora Hucitec, 1980.

HARVEY, David. A produção capitalista do espaço. São Paulo: Annablume, 2005.

HIERNAUX NICOLAS, Daniel. Elementos para un Analisis Sociogeografico del Turismo. In: RODRIGUES, Adyr A. B. (org). Turismo e Geografia: Reflexões Teóricas e Enfoques Regionais. São Paulo: Hucitec, 2001.

HOLANDA, Sergio Buarque de. Raízes do Brasil. 26.ed. São Paulo: Companhia das Letras, 1995.

IANNI, Octavio. Enigmas da Modernidade-Mundo. Rio de Janeiro: Editora Civilização Brasileira, 2000.

KELLY, Dawn Lynn. O retrato socioambiental do Município de Diamantina: dados e ações. Diamantina: Monografia do Curso de Especialização em Avaliação de Impactos Ambientais da Universidade Federal do Vales do Jequitinhonha e Mucuri, 2006.

KHOURI, Omar. Os modernistas de São Paulo e a (re)descoberta do barroco. In: TIRAPELI, P. (org.). Arte Sacra: barroco memória viva. 2. ed. São Paulo: EdUNESP, 2005. 
KNAFOU, Remy. Turismo e Território. Por uma abordagem científica do turismo. In: RODRIGUES, Adyr A. B. (org). Turismo e Geografia: Reflexões Teóricas e Enfoques Regionais. São Paulo: Editora Hucitec, 2001.

KOSÍ́, Karel. Dialética do Concreto. Rio de Janeiro: Ed. Paz e Terra, 1976.

LAMAS, José M. Ressano G. Morfologia Urbana e Desenho da Cidade. Lisboa: Fundação Galouste Golbenkian - Junta Nacional de Investigação Científica e Tecnológica, s.d.

LEFEBVRE, Henri. Lógica formal / lógica dialética. Rio de Janeiro: Editora Civilização Brasileira, 1975.

LEFÈVRE, Renée; VASCONCELLOS, Sylvio. Minas: Cidades Barrocas. São Paulo: Companhia Editora Nacional. Editora da Universidade de São Paulo, 1968.

LE GOFF, Jacques. História e Memória. Tradução de Bernardo Leitão [et.al.]. - $5^{\circ}$ ed. Campinas, SP: Editora da Unicamp, 2003.

LEITE, Rogério Proença S. Contra-Usos da Cidade: Lugares e Espaço Público na Experiência Urbana Contemporânea. Campinas, SP: Editora da UNICAMP; Aracaju, SE: Editora da UFS, 2004.

LENCIONE, Sandra. Região e Geografia. São Paulo: Edusp, 1999.

MACHADO, Lourival Gomes. Barroco Mineiro. São Paulo: Editora Perspectiva, 1973.

MACHADO FILHO, Aires da Mata. Arraial do Tijuco Cidade de Diamantina. São Paulo: Editora da Universidade de São Paulo, 1980.

MARTINS, Lígia Márcia. As aparências enganam: divergências entre o materialismo histórico dialético e as abordagens qualitativas de pesquisa. GT Filosofia da Educação, $n^{\circ}$ 17, 2006.

MARTINS, Marcos Lobato. Os negócios de diamante e os homens de fortuna na Praça de Diamantina, Mg: 1870 - 1930. São Paulo: USP / Tese de Doutorado - FFLCH, DH, 2004.

MARX, Karl. O Capital: Crítica da Economia Política; Livro 1, vol 1. São Paulo: Difel, 1982.

MARX, Murillo. Cidade no Brasil em que termos? São Paulo: Studio Nobel, 1999.

MASSEY, Doreen. Um sentido global do lugar. In: ARANTES, Antônio (org). O Espaço da Diferença. São Paulo: Papirus, 2000.

MENESES, Ulpiano T. B. A paisagem como fato cultural. In: Yázigi, E. (org.). Turismo e Paisagem. São Paulo: Editora Contexto, 1996. 
MENESES, Ulpiano B. Patrimônio industrial e política cultural. Anais do $1^{\circ}$ Seminário Nacional de História e Energia. São Paulo, 1986.

MENESES, Ulpiano Bezerra. O patrimônio cultural entre o público e o privado. In: Revista do Departamento do Patrimônio Histórico de São Paulo. O direito à memória: patrimônio histórico e cidadania. São Paulo:1992.

MENESES, Ulpiano Bezerra. Os usos culturais da cultura: contribuição para uma abordagem críticas das práticas e políticas culturais. In: YAZIG, E; CARLOS, A. F; CRUZ, R. C. (orgs.). Turismo: Espaço, Paisagem e Cultura. São Paulo:Editora Hucitec, 1999.

MOHEN, Jean-Pierre. Les Sciences du Patrimoine: identifier, conserver, ressaurer. Paris. Éditions Odili Jacob, 1999.

MORAES, Antônio Carlos Robert. Geografia Crítica: A Valorização do Espaço. São Paulo. Editora HUCITEC, 1993.

MORAES, Antônio Carlos Robert. Ideologias Geográficas: Espaço, Cultura e Política no Brasil. São Paulo. Editora HUCITEC, 1996a.

MORAES, A. C. R; COSTA, W. M. A geografia e o processo de valorização do espaço. In: SANTOS, M. (org.). Novos rumos da geografia brasileira. Editora Hucitec, 1996.

MORAES, Antônio Carlos Robert. Capitalismo, Geografia e Meio Ambiente. São Paulo: Tese de Livre Docência. FFLCH/USP, 2000.

MORAES, Antônio Carlos Robert. Bases da formação territorial do Brasil - O território brasileiro no longo século XVI. São Paulo: Editora Hucitec, 2000a.

MORAES, Antônio Carlos Robert. Território e História no Brasil. São Paulo: Editora Hucitec, 2002.

MORAES, Antônio Carlos Robert. Meio Ambiente e Ciências Humanas. São Paulo. Editora Annablume, 2005.

MOTTA, Lia. A Apropriação do Patrimônio Urbano: Do Estético-Estilístico Nacional ao Consumo visual do Global. In: ARANTES, Antônio A. (org). O Espaço da Diferença. São Paulo: Papirus, 2000.

NIGRO, Cíntia. Territórios do Patrimônio. Tombamentos e participação social na cidade de São Paulo. São Paulo: USP/ Dissertação de Mestrado, FFLCH, 2001.

PEREIRA, Joelson Gonçalves. O patrimônio ambiental urbano de Corumbá - MS: identidade e planejamento. São Paulo: USP / Tese de Doutorado - FFLCH, DG, 2007.

PRADO JUNIOR, Caio. Formação do Brasil Contemporâneo. Brasiliense, 1969.

PRADO JUNIOR, Caio. História Econômica do Brasil. 29Edição. Brasiliense, 1983. 
REIS FILHO, Nestor Goulart. Contribuição ao Estudo da Evolução Urbana do Brasil. (1500/1720). São Paulo: Editora da Universidade de São Paulo, 1968.

REIS FILHO, Nestor Goulart. Espaço e Memória: conceitos e critérios de intervenção. In: Revista do Departamento do Patrimônio Histórico de São Paulo. O direito à memória: patrimônio histórico e cidadania. São Paulo:1992.

REIS FILHO, Nestor Goulart. Notas sobre o urbanismo barroco no Brasil. In: ÁVILA, Afonso (org.). Barroco Teoria e Análise. São Paulo: Editora Perspectiva, 1997.

REIS FILHO, Nestor Goulart. A urbanização e o urbanismo nas regiões das Minas. In: Seminário de Comemoração de Ouro Preto. Ouro Preto. Centro de Estudos do século XVIII, Escola de Minas, Universidade Federal de Ouro Preto, 1998.

SAID, Edward. Cultura e Imperialismo. São Paulo: Editora Companhia das Letras, 2006.

SAINT-HILAIRE, Auguste de. Viajem pelo Distrito dos Diamantes e Litoral do Brasil. Belo Horizonte: Ed. Itatiaia, São Paulo: EdUSP,1974.

SAINT-HILAIRE, Auguste de. Viagem às nascentes do Rio São Francisco. Belo Horizonte: Ed. Itatiaia, São Paulo: EdUSP,1975.

SANT'ANNA, Márcia. A face imaterial do patrimônio cultural: os novos instrumentos de reconhecimento e valorização. In: REGINA, Abreu (org.). Memória e Patrimônio: ensaios contemporâneos. Rio de Janeiro. DP\&A, 2003.

SANTOS, Milton. Espacio y Método. Barcelona (Espanha). GeoCrítica (Universidad de Barcelona), 1986.

SANTOS, Milton. Los espacios de la globalización. In: Anales de geografia de la Universidad Conplutense. Barcelona, 1993.

SANTOS, Milton. O retorno do território. In: SANTOS, M; SOUZA, M; SILVEIRA, M. Território, Globalização e Fragmentação. São Paulo: Editora Hucitec, 1994.

SANTOS, Milton. Técnica, espaço e tempo: globalização e meio técnico-científico informacional. São Paulo: Editora Hucitec, 1994a.

SANTOS, Milton. A Urbanização Brasileira. São Paulo: Editora Hucitec, 1994b.

SANTOS, Milton. Modo de produção técnico-científico e diferenciação espacial. Rio de Janeiro: Revista Território, IV, nº 6, UFRJ, 1999.

SANTOS, Milton. Por uma outra globalização: do pensamento único à consciência universal. Rio de Janeiro - São Paulo: Editora Record, 2000.

SANTOS, Milton. A natureza do espaço: técnica, tempo, razão e emoção. São Paulo: Editora da Universidade de São Paulo (Edusp), 2002. 
SANTOS, Milton. A aceleração contemporânea: tempo mundo e espaço mundo. In: SANTOS, M; SOUZA, M; SCARLATO, F; ARROYO, M. (orgs.). O novo mapa do mundo. Fim de século e globalização. São Paulo: Hucitec, 2002a.

SANTOS, Milton. Região: globalização e identidade. In: LIMA, Luiz (org.). Conhecimento e reconhecimento. Fortaleza: EDUCE, 2003.

SANTOS, Milton. Por uma geografia nova. São Paulo: EdUSP, 2004.

SANTOS, Milton. Pensando o Espaço do Homem. São Paulo: Editora da Universidade de São Paulo (Edusp), 2004a.

SANTOS, Milton. O espaço do cidadão. São Paulo: EdUSP, 2007.

SANTOS, Milton. Metamorfoses do espaço habitado. São Paulo: EdUSP, 2008.

SARTRE, Jean-Paul. O imaginário: psicologia fenomenológica da imaginação. São Paulo: Editora Ática, 1996.

SCARLATO, Francisco C. Ouro Preto. Cidade Histórica da Mineração no Sertão Brasileiro. In: Anales de Geografia de la Universidad Complutense. Servicio de Publicaciones de la Universidad Complutense. Madrid, 1996.

SCARLATO, Francisco C. Centro Antiguo e Memória: El reencuentro com la ciudade. In: BERTONCELLO, R; CARLOS, A. Processos Territoriales em Argentina y Brasil. Buenos Aires: Universidad de Buenos Aires, 2003.

SCARLATO, Francisco C. Revitalização do Centro Antigo: O Espaço da Memória de São Paulo. In: CARLOS, A. F. CARRERAS, C. Urbanização e Mundialização: estudos sobre a metrópole. São Paulo: Editora Contexto, 2005.

SCARLATO, Francisco C. População e Urbanização Brasileira. In: ROSS, J. (org.) Geografia do Brasil. São Paulo: Editora da Universidade de São Paulo (Edusp), 2005a.

SCARLATO, Francisco C . Geografia Regional do Brasil II - Região Sudeste. In: Notas do Curso. Faculdade de Filosofia Letras e Ciências Humanas / Departamento de Geografia / USP, 2008.

SCIFONI, Simone. Patrimônio Mundial: do ideal humanista à utopia de uma nova civilização. São Paulo. Revista Geousp - Espaço e Tempo, n 14, 2003.

SCIFONI, Simone. A construção do Patrimônio Natural. São Paulo: DG/USP - Tese de Doutorado - FFLCH, 2006.

SILVA, Fernando F. As Cidades Brasileiras e o Patrimônio Cultural da Humanidade. São Paulo: Editora da Universidade de São Paulo (Edusp), 2003. 
SILVEIRA, Maria Laura. Da Fetichização dos Lugares à Produção Local do Turismo. In: RODRIGUES, Adyr Balastreri. (org). Turismo. Modernidade. Globalização. São Paulo. Editora Hucitec, 1997.

SOUZA, José Moreira. Cidade: Momentos e Processos. Serro e Diamantina na formação do Norte Mineiro no século XIX. São Paulo: Editora Marco Zero, 1993.

TADDEI NETO, Pedro. Preservação sustentada de sítios históricos: A experiência do Programa Monumenta. In: Políticas Culturais para o desenvolvimento. UNESCO BRASIL, 2003.

TELLES, Augusto Carlos Silva. Alguns aspectos da arquitetura na segunda metade do século XVIII no Brasil. In: ÁVILA, Afonso (org.). Barroco Teoria e Análise. São Paulo: Editora Perspectiva, 1997.

TELLES, Augusto C. S. Preservação dos Bens Culturais Ontem e Hoje; e Amanha? In: GUTIERREZ, Ângela e TELLES, Augusto C (orgs.). O Território do Barroco no século XXI. Belo Horizonte. Instituto Cultural Flavio Gutierrez. Bureal Cultural, 2000.

THOMPSON, John B. Ideologia e cultura moderna: teoria social crítica na era dos meios de comunicação de massa. Rio de Janeiro, Ed. Vozes, 1995.

TORRÃO FILHO, Amílcar. Imagens de pitoresca confusão: a cidade colonial na América Portuguesa. In: Revista USP / Dossiê Brasil Colônia. São Paulo: CCS / USP, 2003.

TOZI, Desirée Ramos. Primavera de Estações: o Programa Monumenta e as Políticas Públicas de Preservação de Patrimônio Cultural na região do bairro da Luz / São Paulo. São Paulo: DH / USP, Dissertação de Mestrado - FFLCH, 2007.

VALENÇA, Márcio Moraes. Cidades ingovernáveis? Ensaio sobre o pensamento harveyano acerca da urbanização do capital. In: SILVA, J; LIMA, L; ELIAS, D. (org.). Panorama da Geografia Brasileira. São Paulo: Annablume, 2006.

VASCONCELLOS, Sylvio. A arquitetura colonial mineira. In: ÁVILA, Afonso (org.). Barroco Teoria e Análise. São Paulo: Editora Perspectiva, 1997.

YÁZIGI, Eduardo Abdo. Acertos metodológicos: relativismo cultural e turismo. In: SILVA, J; LIMA, L; ELIAS, D. (org.). Panorama da Geografia Brasileira. São Paulo: Annablume, 2006.

ZEMELLA, Mafalda P. O Abastecimento da Capitania das Minas Gerais no Século XVIII. São Paulo: Ed. Hucitec, 1990.

ZEVI, Bruno. Saber ver a arquitetura. São Paulo: Editora Martins Fontes, 1978. 


\section{DOCUMENTOS INTERNACIONAIS}

UNESCO. La Charte de Venise - Charte Internationale Sur la Conservation et la Restauration des Monumentos et des Sites. Paris, Siège de l'UNESCO, 1965.

UNESCO. Convention concernant La Protection Du Patrimoine Mondial Culturel Et Naturel. Adoptée par la Conférence générale à sa dix-septième sessiona. Paris, Siège de l'UNESCO, 1972.

UNESCO. Recomendation concenant la sauvegarde des ensembles historiques ou traditionnels et leur role dans la vie contemporaine. Actes de la Conférence générale Dix-neuvième session. Paris, 1976.

UNESCO. Adoption de la Déclaration sur la conservation des paysages urbains historiques. Le patrimoine mondial et l'architecture contemporaine - Gestion du paysage urbain historique. Paris, Siège de I'UNESCO, 2005.

UNESCO. Discussion sur la valeur universelle exceptionnelle. Paris, 2007.

UNESCO. Liste des Etats parties la Convention du patrimoine mondial, Répartition des biens du patrimoine mondial dans les Etats parties et Composition du Comitê du patrimoine mondial depuis 1976. Paris, Siège de l'UNESCO, 2007a.

UNESCO. Plans de gestion et protection, outils de conservation et de promotion des biens du patrimoine mondial. Paris, Siège de l'UNESCO, 2007b.

UNESCO. Rapport sur l'élaboration d'une recommandation révisée sur a consevation des paysages urbains historiques. Paris, Siège de l'UNESCO, 2007c. 


\section{DOCUMENTOS NACIONAIS}

BRASIL. Projeto Conjunto Arquitetônico e Urbanístico da Cidade de Diamantina. Perfil do Projeto / Caderno 2/5. Monumenta / BID / República Federativa do Brasil, 2002.

BRASIL. Parecer Técnico do IPHAN/Monumenta sobre a Carta Consulta do Projeto Diamantina. Ministério da Cultura, 2001.

BRASIL. Regulamento Operativo. Programa de Preservação do Patrimônio Histórico Urbano. Ministério da Cultura, 2006.

Fundação João Pinheiro. Plano de Desenvolvimento Integrado do Turismo Sustentável. Pólo Turístico do Vale do Jequitinhonha. Belo Horizonte, 2004.

MONUMENTA. Planilha de Financiamento de Imóveis Privados. Diamantina, 2008.

IPHAN. Proposta de Inscrição de Diamantina na Lista de Patrimônio Cultural da Humanidade. Diamantina, 1998.

PREFEITURA MUNICIPAL. Plano Diretor de Diamantina. Diamantina, 1999.

PREFEITURA MUNICIPAL. Carta Consulta Projeto Diamantina. Diamantina, 2001.

PREFIETURA MUNICIPAL. Relação de contribuintes por atividades. Diamantina, 2007.

\section{SITES CONSULTADOS}

www.internationalicomos.org/e statut.htm - consultado em 03 de março de 2008.

www.iccron.org - consultado em 03 de março de 2008.

whc.unesco.org - site internacional da UNESCO, consultado nos meses de janeiro, fevereiro, março e abril de 2008, onde tivemos acesso aos documentos internacionais supramencionados.

www.cvc.com.br - consultado em 09 de setembro de 2008.

www.circuitodosdiamantes.tur.br 


\section{ANEXO 1 \\ UNIVERSIDADE DE SÃO PAULO \\ FACULDADE DE FILOSOFIA LETRAS E CIÊNCIAS HUMANAS \\ DEPARTAMENTO DE GEOGRAFIA \\ PROGRAMA DE PÓS-GRADUAÇÃO EM GEOGRAFIA HUMANA \\ QUESTIONÁRIO: TRABALHO DE CAMPO EM DIAMANTINA - MG}

Nome:

Idade:

Bairro:

1 - Trabalha? __ Sim _ Não Profissão:

2 - Natural de Diamantina? __ Sim _ Não. Mora a ___ anos na cidade, vindo de

3 - Morou no Centro Histórico?__ Sim _ _ Não. Conhece alguém que já morou no centro histórico e mudou-se? __ Sim

__ Não. Qual a causa, no caso de mudança?

4 - Vai __ dias por semana ao centro histórico, com a finalidade de

5 - Quais as principais festividades realizadas no centro histórico durante 0 ano? Participa de quais?

6 - Há algum evento voltado especificamente para a atração turística?

O residente tem acesso livre a estas atividades? __ Sim_ Não __ Algumas. Por que é difícil o acesso a estas atividades?

7 - Vê o centro histórico como: __ espaço das práticas religiosas _ espaço comercial/serviços _ espaço do dia a dia

_ espaço das instituições públicas _ _ espaço do turismo _ espaço símbolo da história, tradição e cultura.

8 - Já ouviu falar do __ Prog. Monumenta __IPHAN.

9 - Sabe do que se trata o Monumenta? _ Sim _ Não _ Tem uma noção. O que é o Monumenta? Considera-o positivo para a cidade?

10 - Sabe do que se trata o IPHAN?

11 - O IPHAN é atuante na cidade?

12 - Considera o bairro em que mora dotado de boa infra-estrutura? _ Sim _ Não _ Pouca.

13 - O que falta no bairro?

14 - Considera o centro histórico dotado de boa infra-estrutura? __ Sim _ Não _ Pouca.

15 - Considera o centro histórico bem preservado (conservado do ponto de vista arquitetônico)? __ Sim _ _ Não _ _ Pouco.

16 - O que falta no centro histórico?

17 - Conhece a história da cidade? __ Sim _ _ Não __Pouco.

18 - É grande a movimentação de turistas na cidade por todo o ano? _ Sim _ Não _ Alguns períodos.

19 - É favorável ao desenvolvimento turístico na cidade? _ Sim _ Não _ Talvez. Por que?

20 - A presença do turista incomoda? _ Sim _Não__ Pouco. Por que?

21 - A administração atual é positiva? _ Sim _ Não _ Pouco. Por que?

22 - O que falta para Diamantina ser uma cidade melhor? 